\title{
Investigations of the \\ New Madrid, Missouri, \\ Earthquake Region
}

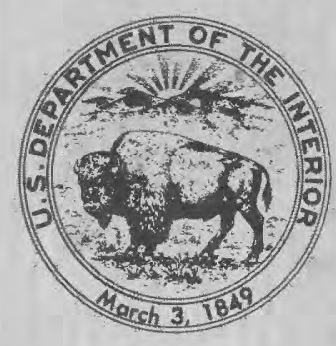

GEOLOGICAL SURVEY PROFESSIONAL PAPER 1236

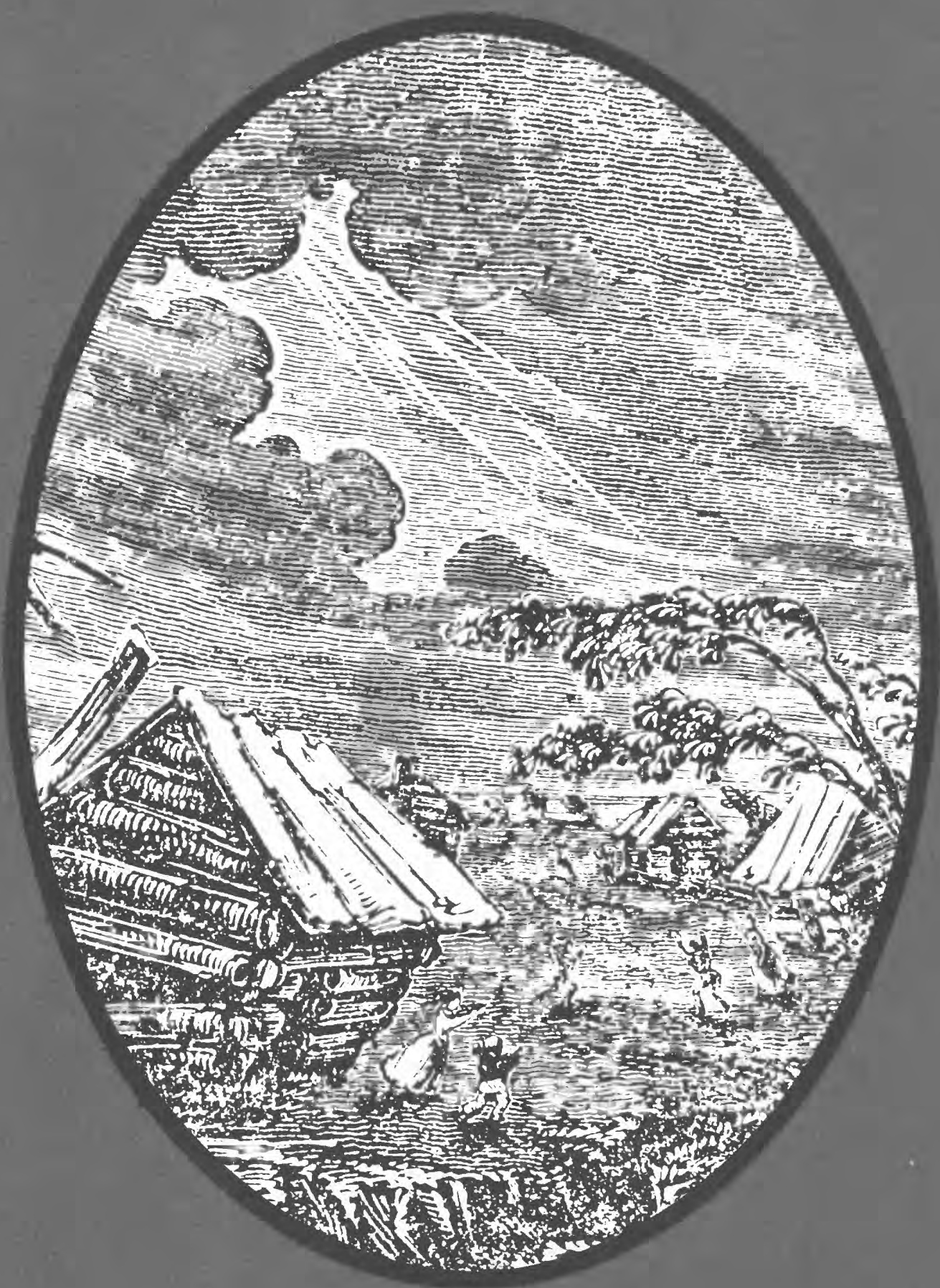





\title{
Investigations Of The New Madrid, Missouri, Earthquake Region
}

\author{
Edited by F. A. MCKEOWN and L. C. PAKISER
}

A. Overview and discussion, by F. A. Mckeown

B. Damaging earthquakes of the central Mississippi valley, by O. W. Nuttli

C. Present-day seismicity and identification of active faults in the New Madrid seismic zone, by William Stauder

D. Microearthquakes and faulting in the area of New Madrid, Missouri - Reelfoot Lake, Tennessee, by D. O'Connell, C. G. Bufe, and M. D. Zoback

E. Magnetic basement in the upper Mississippi embayment region - A preliminary report, by T. G. Hildenbrand, M. F. Kane, and J. D. Hendricks

F. Tectonic features of the New Madrid seismic zone from seismic reflection profiles, by R. M. Hamilton, and M. D. Zoback

G. A crustal structure study of the Northern Mississippi embayment, by C. B. Austin, and G. R. Keller

H. Style and significance of surface deformation in the vicinity of New Madrid, Missouri, by D. P. Russ

I. Configuration and deformation of the Paleozoic bedrock surface in the New Madrid seismic zone, by A. J. Crone, and S. R. Brockman

J. High resolution seismic reflection surveying on Reelfoot scarp, northwestern Tennessee, by J.L. Sexton, Frey, and Malicki

K. Stratigraphy and structure of sediments above the Newport pluton of northeastern Arkansas, by E. E. Glick

L. The northeastern extension of the New Madrid seismic zone, by L. W. Braile, W. J. Hinze, G. R. Keller, E. G. Lidiak

M. Heat flow in the upper Mississippi embayment, by C. A. Swanberg, B. J. Mitchell, R. L. Lohse, and D. D. Blackwell

N. Radon emanation in the New Madrid seismic zone, by S. R. Steele, W. C. Hood, J. L. Sexton

GEOLOGICAL SURVEY PROFESIONAL PAPER 1236

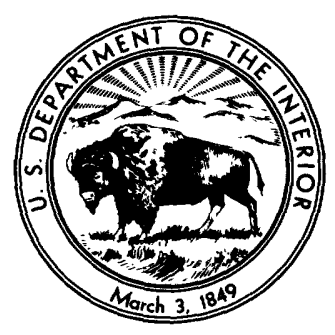




\section{UNITED STATES DEPARTMENT OF THE INTERIOR}

JAMES G. WATT, Secretary

\section{GEOLOGICAL SURVEY}

Dallas L. Peck, Director

First Printing 1982

Second Printing 1983

Library of Congress Cataloging in Publication Data

Main entry under title:

Investigations of the New Madrid, Missouri. Earthquake Region.

(Geological Survey Professional Paper 1236)

Bibliography: $201 \mathrm{p}$.

1. Earthquakes-Missouri-New Madrid region.

I. McKeown, Francis A. II. Pakiser, L. C. (Louis Charles), 1919- . III. United States. Geological Survey. IV. Series. $\begin{array}{llll}\text { QE535.2.U6I58 } & 551.2^{\prime} 2^{\prime} 09778985 & 81-607888 & \text { AACR2 }\end{array}$

For sale by the Superintendent of Documents, U.S. Government Printing Office Washington, D.C. 20402 


\section{PREFACE}

The sequence of earthquakes during 1811-12 in the New Madrid region has been a seismological enigma, and the potential damage and loss of life that a repetition of these earthquakes might cause has been ignored by most people. The earthquakes have been an enigma because they occurred in a part of the country generally described as the stable interior of a continent. The potential hazards of a repetition of them are commonly not realized because much of the country was undeveloped and unsettled in 1811-12; consequently, the earthquakes did not cause the massive amount of damage possible should a similar sequence occur in the near future.

However, recent increased public, Federal, and State awareness of the potential earthquake hazard in the New Madrid, Mo., and contiguous regions has prompted initiation of a variety of geological, geophysical, and geochemical studies at a scale never before attempted in the Central United States. Prior to about 1973, most investigations related to earthquakes in the region were made by faculty and students of St. Louis University using only small financial resources. In 1973, new regional gravity and aeromagnetic surveys were started by the USGS (U.S. Geological Survey). In 1974, the USGS funded St. Louis University to establish a seismographic network to record and locate small earthquakes in the New Madrid region, and about a year later the USGS started geologic investigations

In 1976, the NRC (Nuclear Regulatory Commission) funded a six-State cooperative project involving both State and university communities as principal investigators. The principal objective of the cooperative project is to conduct investigations that will contribute to the seismic-hazard assessment of nuclear power plants that might be affected by a large earthquake in the New Madrid region.

Because a wealth of data has been acquired in the past few years, it seems propitious and timely to publish a collection of this information, rather than having it dispersed in many journals. The intent of this Professional Paper, therefore, is to publish, in one volume, reports of both the USGS and other investigations that represent the present state of knowledge of the seismicity and geology of the New Madrid region. Some of the results of earthquake investigations in the New Madrid region have provided valuable information for other geologic interests. For example, the inferred rift described in this volume, and reports that preceded the present study, is of interest to petroleum companies because of the possibility that thick sections of sedimentary rocks may occur within the rift. Plutons inferred in the subsurface and chemical and mineralogical data from igneous rocks penetrated by drill holes suggest the possibility of mineralization more widespread than outcrops indicate.

We believe that the studies reported in this volume are major advances toward understanding the nature of earthquakes and earthquake hazards in the Midcontinent region. Earthquake investigations in this region have in the past been assigned a low priority as compared with those in the West. Now at last, as indicated by the following papers, the importance of potentially destructive earthquakes in a region of high population density has been acknowledged and a much higher priority has been assigned to the study of earthquakes in this region.

We also believe that advances which have been and are continuing to be made in the New Madrid region are due as much to the manner in which the investigators have cooperated and shared their knowledge as to the talents of individual investigators. Most complex geological problems require a multidisciplinary approach for their efficient and rational resolution. The results of the investigations of the New Madrid region are a good example of an integrated multidisciplinary effort to resolve a long-standing, complex geological and seismological problem. 


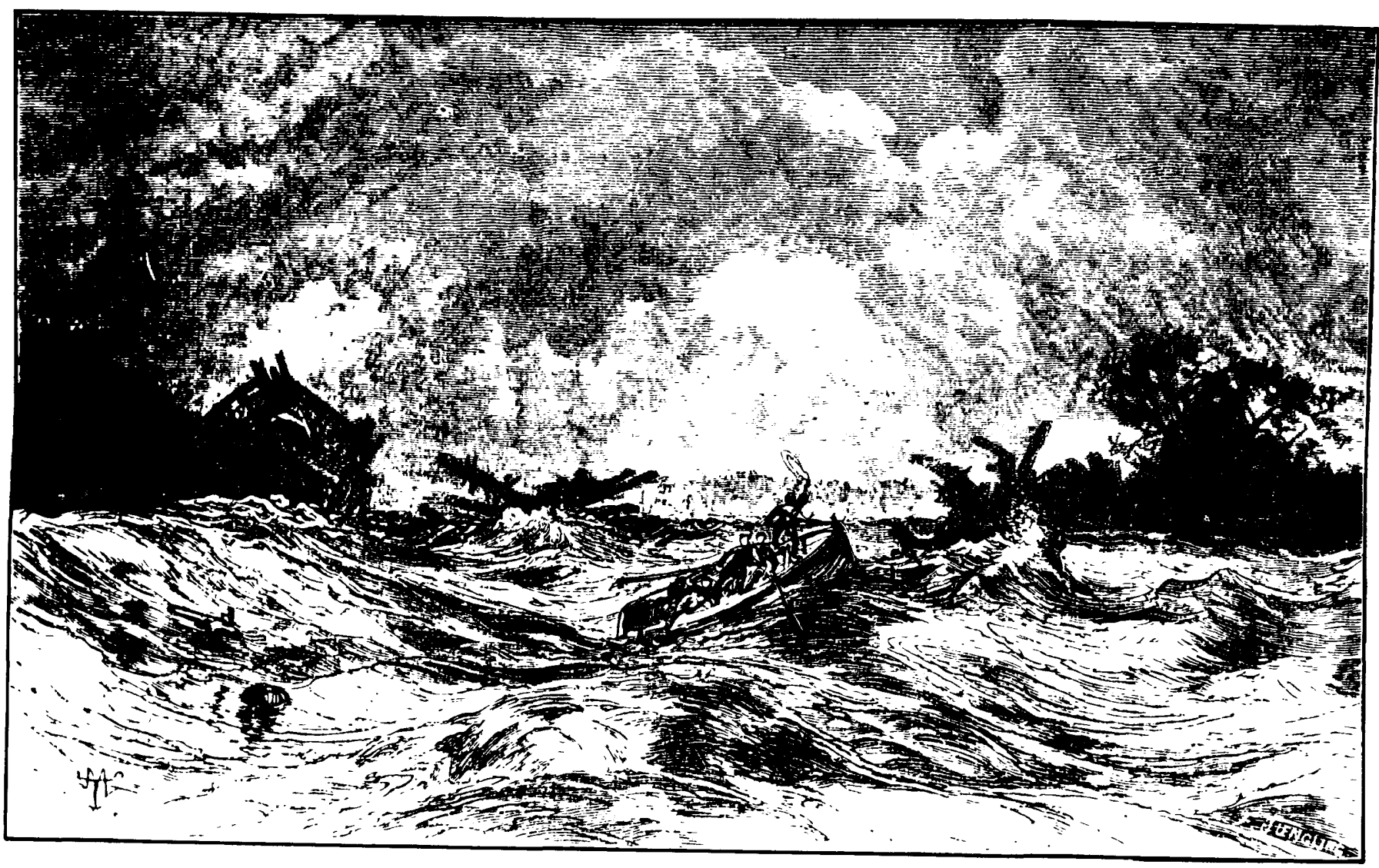

Wood cut of scene of the great earthquake in the West (p.220 in Our First Century: One Hundred Great and Memorable Events, 1877). Published with permission of Historical Society of Missouri, Columbia. 


\section{CONTENTS}

(A) Overview and discussion, by F. A. Mckeown $\ldots \ldots \ldots \ldots \ldots \ldots \ldots \ldots \ldots \ldots \ldots$

(B) Damaging earthquakes of the central Mississippi valley, by 0. W. Nuttli $\ldots \ldots \ldots \ldots$

(C) Present-day seismicity and identification of active faults in the New Madrid seismic zone,

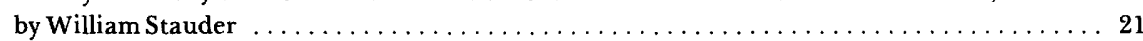

(D) Microearthquakes and faulting in the area of New Madrid, Missouri-- Reelfoot Lake, Tennessee,

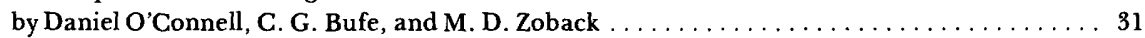

(E) Magnetic basement in the upper Mississippi embayment region-- A preliminary report,

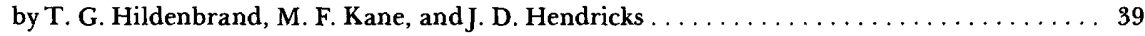

(F) Tectonic features of the New Madrid seismic zone from seismic-reflection profiles,

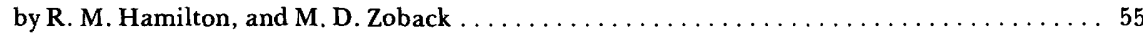

(G) A crustal structure study of the Mississippi embayment, by C. B. Austin and G. R. Keller . . . . 83

(H) Style and significance of surface deformation in the vicintiy of New Madrid, Missouri, by D. P. Russ . 95

(I) Configuration and deformation of the Paleozoic bedrock surface in the New Madrid seismic zone,

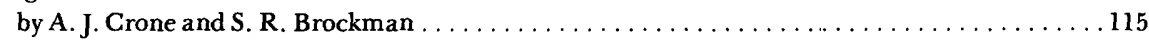

(J) High-resolution seismic-reflection surveying on Reelfoot scarp, northwestern Tennessee, by J. L. Sexton, E. P. Frey, and Dave Malicki $\ldots \ldots \ldots \ldots \ldots \ldots \ldots \ldots \ldots \ldots \ldots \ldots \ldots \ldots$

(K) Stratigraphy and structure of Post-Paleozoic sediments above the Newport pluton of northeastern

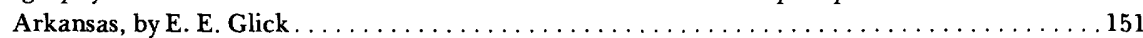

(L) The northeastern extension of the New Madrid fault seismic zone, by L. W. Braile, W. J. Hinze,

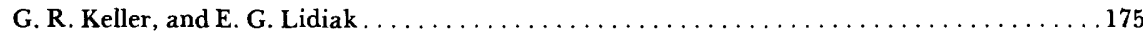

(M) Heat flow in the upper Mississippi embayment, by C. A. Swanberg, B. J. Mitchell, R. L. Lohse, D. D. Blackwell

(N) Radon emanation in the New Madrid seismic zone, by S. R. Steele, W. C. Hood, and J. L. Sexton . . 191 



\section{Overview and Discussion}

By F. A. MCKEOWN

INVESTIGATIONS OF THE NEW MADRID, MISSOURI, EARTHQUAKE REGION

GEOLOGICAL SURVEY PROFESIONAL PAPER 1236-A 


\section{CONTENTS}

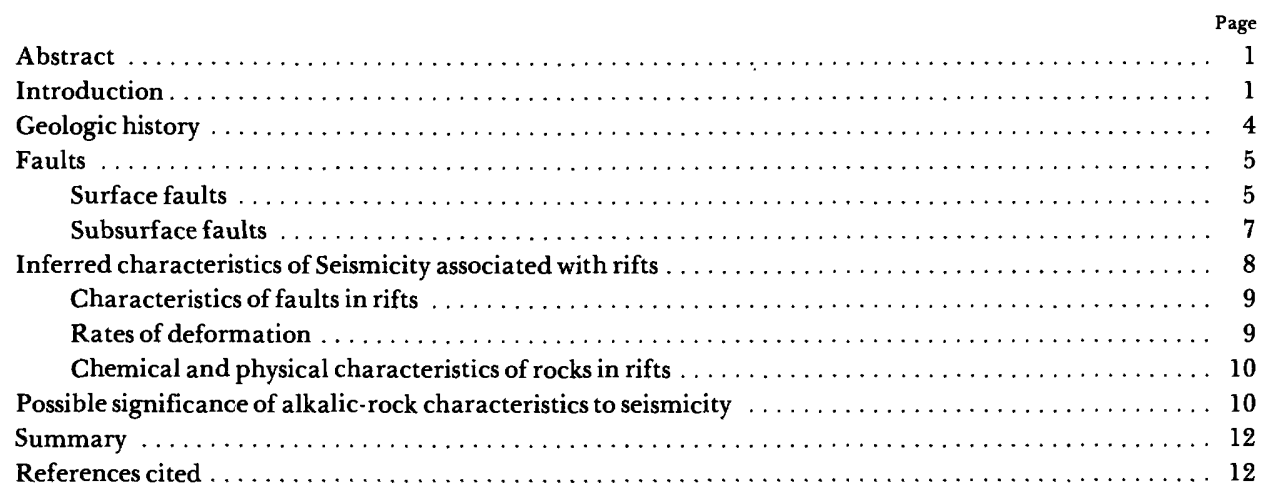

\section{ILLUSTRATIONS}

FIGURE 1. Modified Mercalli intensity isoseismal zones for the San Francisco (1906) and the New Madrid (December 16, 1811) earthquakes superim-

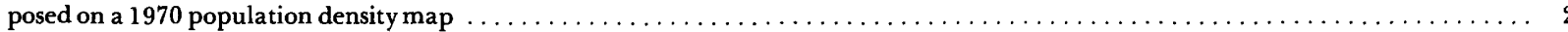

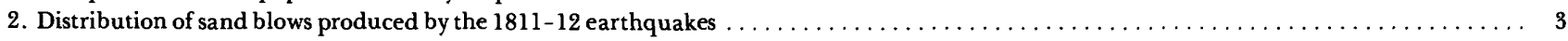

3. Generalized fault map of the New Madrid region showing plutons, approximate rift boundaries, and epicenters of earthquakes detected from

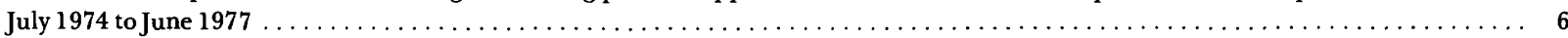

4. Graph showing rate of deposition of sediments during subsidence of embayment based upon thickness of sediments deposited during indicated periods of geologic time but not the loss of record of deposition at diastems and unconformities 


\title{
INVESTIGATIONS OF THE NEW MADRID EARTHQUAKE REGION
}

\section{OVERVIEW AND DISCUSSION}

\author{
By F.A. MCKEOwN
}

\begin{abstract}
The 1811-12 sequence of earthquakes commonly referred to as the New Madrid earthquake was felt and produced damaging intensities at far greater distances than any other historical earthquake in the conterminous United States. This fact and the current population within the Modified Mercalli intensity VII isoseismal of the 1811-12 sequence force the conclusion that, should the sequence be repeated today, widespread destruction of property and loss of life would very likely occurred. Magnitude-frequency studies and sand-blow relationships indicate a recurrence interval of 600-700 years for large earthquakes in the New Madrid region. The geological structures on which the earthquakes occurred and the forces that drove them have been an enigma. However, since seismological, geological, and geophysical studies were started in 1974, enough information has been acquired to propose reasonable explanations of the locations of the earthquakes, but the driving forces are still unexplained. In addition to the great distances at which the New Madrid earthquakes were felt and caused damage, another preeminent characteristic of them was the great number of large aftershocks and the long period over which they occurred.
\end{abstract}

Earthquakes in the New Madrid region occur in a geologically complex environment. Geophysical and petrologic data indicate that intracontinental rifting occurred in late Precambrian or Early Cambrian time. This tectonic event was followed by deposition of clastic and carbonate sediments during the Paleozoic and uplift to form the Pascola arch in the late Paleozoic or Mesozoic. During the emergence of the Pascola arch, more than $2.5 \mathrm{~km}$ of sediments were eroded. Subsidence of the region started in Late Cretaceous time and probably continued until at least the beginning of the Holocene, resulting in formation of the present-day southward-plunging syncline in the Mississippi Embayment. Mapping in the region is too incomplete to make comprehensive tectonic analyses from the distribution and character of faults exposed at the surface. Recent seismic-reflection profiling shows a number of faults in the subsurface, some of which coincide with epicentral trends, particularly in the axial region of the rift. In addition to the evidence of faults in the profiles, a gross perspective of the characteristics of the subsurface structure and rocks may be had by assuming that the buried rift is analogous to well-exposed rifts in east Africa. Interpretation of geophysical data, drill-hole information, and outcrops in the Magnet Cove area of Arkansas show that a number of mafic intrusive masses occur along the boundaries of the rift and that several occur along the axis of the rift. All available information shows that the plutons comprise complexes of mafic to felsic alkalic rocks. Most of the seismic activity in the region occurs within the inferred boundaries of the rift, particularly along the axis and where apparent crosscutting structures occur in the vicinity of New Madrid, Mo. Despite the present seismicity, which indicates deformation at depth, rates of deformation by faulting or uplift at the surface and at shallow depths are more than an order of magnitude less than rates of deformation in the seismically active areas of Western United States. This profound difference may be part of the explanation for the apparent lack of surface rupturing that would be expected for some of the New Madrid earthquakes. The importance of recognizing that earthquakes are associated with rifts, regardless of their age and the current state of stress on them, is that rifts are major breaks in the Earth's crust which have properties more favorable for the occurrence of earthquakes than adjacent, less faulted parts of the crust. Given the facts that rifts are highly faulted and are associated with an abundance of alkalic rocks that had a high content of volatiles, range from mafic to felsic, and have a wide variation in physical properties, a qualitative physical explanation of earthquakes occurring in rifts is proposed. In brief, the explanation is that the high volatile content has resulted in rocks that have higher porosity and probably higher pore pressure within or associated with a rift in comparison to most rocks adjacent to a rift. This condition, in addition to the abundance of faults, is conducive to the generation of earthquakes. Also, the contrasts in physical properties of the rocks provide conditions for stress amplification and therefore local control of the distribution of earthquakes.

\section{INTRODUCTION}

Comparison of any isoseismal map (for example, Nuttli, 1973a; Stearns and Wilson, 1972) of the principal shocks of the New Madrid sequence of earthquakes with a current population map of the United States makes one realize that such a series of earthquakes today would be likely to cause very widespread destruction of property and loss of life. Figure 1 shows the isoseismal map of Nuttli (1973a) superimposed on a population density map. The intensity contours to the west of the epicentral area, for which no data are available, have been arbitrarily made symmetrical to those east of the epicentral area. According to the 1975 census information (M. McGrath, written commun., 1980), the population within the Modified Mercalli intensity VII or greater zone, which corresponds with damage threshold, for the New Madrid sequence is about 12.6 million people. In contrast, the 1975 population within the intensity VII zone for the 1906 San Francisco earthquake is only about 4.0 million people. This comparison must be tempered with the fact that earthquakes occur more frequently on the San Andreas fault in California, on which the 1906 earthquake occurred, than in the New Madrid region. New Madrid-type earthquakes may only occur every several thousands of years. If so, the short-term probability of much damage and loss of life is very low. The best estimates, however, of the recurrence interval for large $\left(\mathrm{m}_{\mathrm{b}} \geqq 6.2\right)$ earthquakes in the New Madrid region is on the order of every 


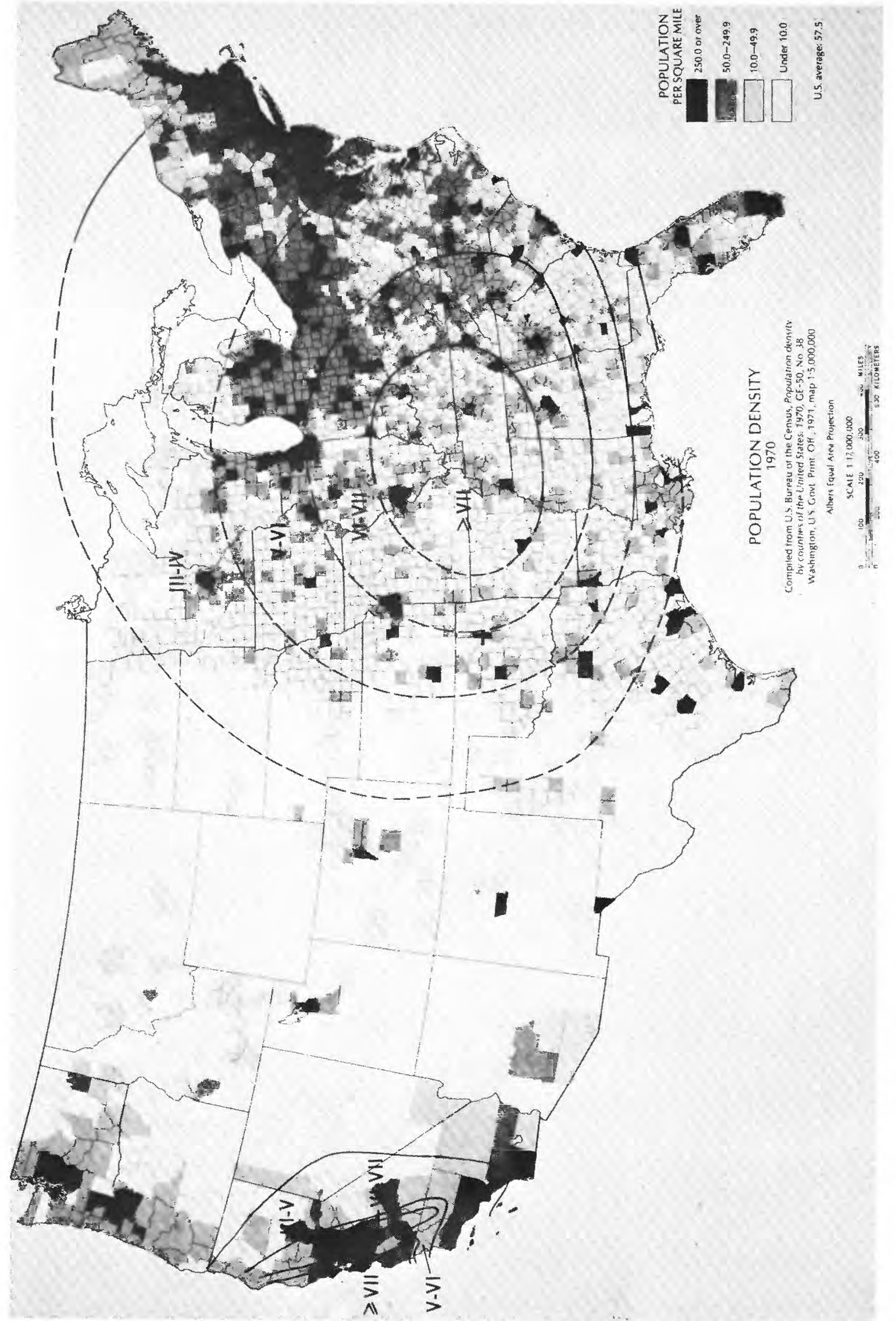


600-700 years (Nuttli, 1974; Russ, 1979; Russ, this volume) compared with about 100 years for large earthquakes on the San Andreas fault. The 500- to 600-year difference in recurrence intervals for an exposure time of 100 years reduces the probability of exceeding a given level of ground motion by a factor of two to three (K. Shedlock, oral commun., 1980).

Another disturbing aspect of earthquakes in the New Madrid region is that their causes and the geologic structures on which they occur are not understood. Furthermore, much of the knowledge available from study of earthquakes in Western United States does not seem applicable to study of earthquakes in the New Madrid region. One case of inapplicability is the profound difference between rates of tectonic deformation in seismically active regions of Western United States and rates of deformation in the New Madrid region. For example, the rate of movement in historic time along the San Andreas fault zone is $2-3 \mathrm{~cm}$ per year. In contrast, the rate of movement during the last 100 m.y.(million years) across a fault zone that appears to be associated with some earthquakes in the New Madrid region is less than $0.008 \mathrm{~mm}$ per year. Most areas of high seismicity and large earthquakes around the world are found where movement between oceanic and continental plates is occurring, and rational explanations can, therefore, be given for the occurrence of the earthquakes. Within continental plates of the United States, the cause of localization and the crustal or mantle driving forces of earthquakes are still largely an enigma. However, seismologic, geophysical, and geologic data acquired since about 1974 have begun to provide earth scientists with enough information to advance reasonable explanations of at least the localization of earthquakes in the New Madrid region. Explanation of the driving forces however, is speculative.

The history of earthquakes in the New Madrid region has been adequately described by a number of investigators. (See, for example, Fuller, 1912; Nuttli, 1973a.)

Fuller's account is the most descriptive and best documented. It has served as the basic document for subsequent investigators' studies of the New Madrid region. Restating much of the detail that is already in the literature is unnecessary. A very brief description of some of the effects is appropriate, however, and emphasis on the effects and features of the New Madrid sequence of earthquakes that now appear to be more significant than early investigators recognized is warranted.

According to Fuller's account, three major shocks occurred: December 16, 1811; January 23, 1812; and February 7, 1812 (Fuller, 1912). Nuttli (1973a) provided evidence from a study of intensity information which indicates that the first shock was located about $100 \mathrm{~km}$ southwest of New Madrid near Marked Tree, Ark. This location is supported in part by the distribution of sand blows (Heyl and McKeown, 1978), as indicated on figure 2. The last large shock, on February 7, 1812, is presumed to have been in the vicinity of New Madrid. This shock is reported by Nuttli to have been the largest of the three principal shocks. Sand blows, however, are not nearly as abun-

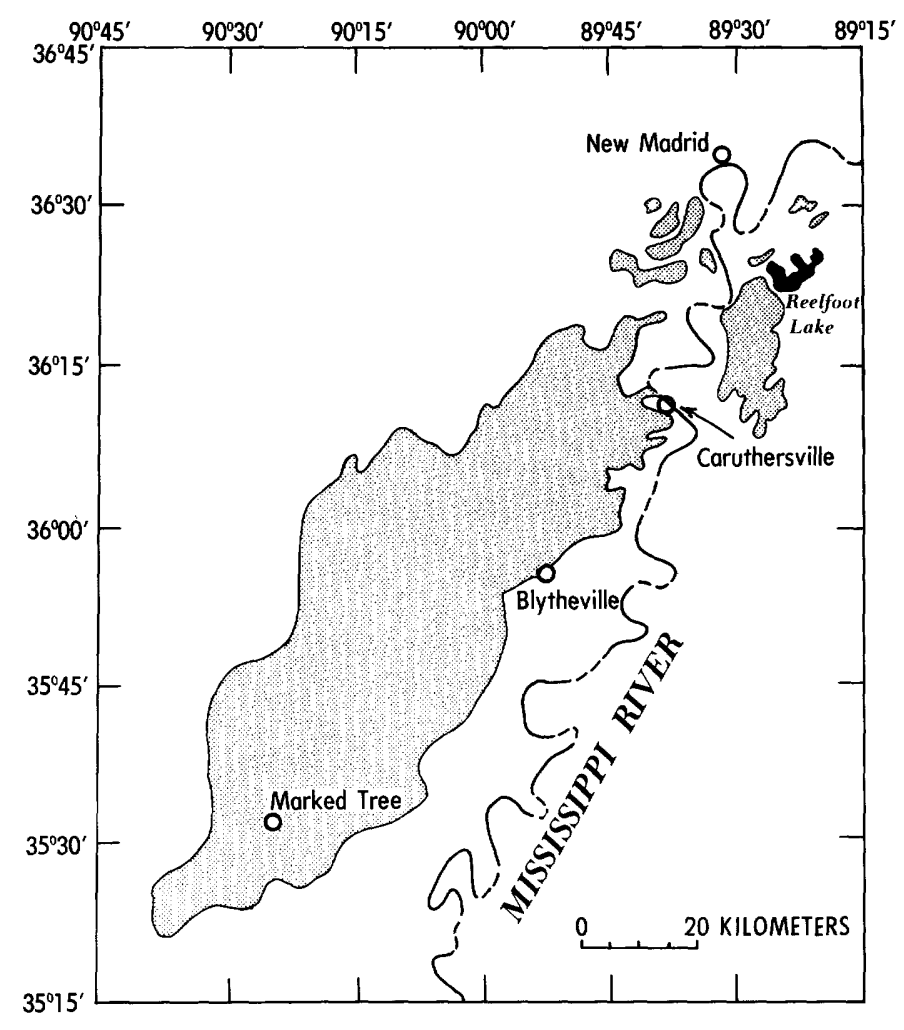

Figure 2. Distribution of sand blows produced by the 1811-12 earthquakes

dant or as large in the vicinity of New Madrid as they are to the southwest. During the time between the three principal shocks, many other smaller shocks occurred, some of which were felt in places as distant as Washington, D.C.; Baltimore; and other cities along the East Coast. It seems likely, therefore, that all of the large and most of the smaller shocks occurred under the area of most abundant sand blows. Most of the current seismicity, as detected by the St. Louis University network which has been in operation since 1974, is also largely confined to the area of sand blows. This may be further confirmation of the source zones of the 1811-12 sequence.

Three facts are preeminent about the New Madrid sequence of shocks: (1) the great distances at which they were felt and caused damage, (2) the great number of shocks that apparently were of large size (as indicated by reports of effects and the great distances at which they were felt), and (3) the long period of time over which they occurred.

The great distance at which earthquakes were felt and caused damages has been explained by low attenuation of seismic waves (for example, Nuttli, 1973b; Evernden, 1975). The reason for low attenuation in regions of Central and Eastern United States has not been explained rigorously by physical models but is well recognized and makes estimation of the size of earthquakes in these regions a subject of controversy.

The large number and long aftershock sequence of large shocks seem well documented, but no explanations have been offered in the literature for these effects. Not only did many 
relatively large shocks occur for several months in the New Madrid area, but the seismic activity apparently migrated northward and continued for at least 2 years. For example, small shocks were felt almost daily at Saline Mines, formerly called United States Saline, Ill., for 2 years (Fuller, 1912). Some of the most severe of these shocks were felt in Kaskaskia, Ill., and along the Wabash River. Whether these shocks were related to the shocks near and south of New Madrid cannot be proved. No similar long sequence in southern Illinois has occurred, however, since the United States Saline shocks in 1812-14.

The detailed accounts of historic seismicity (Nuttli, this volume) and present day seismicity (Stauder, this volume) provide more precise descriptions of the effects, size, and distribution of earthquakes in the New Madrid region than earlier reports. Their work indicates that damaging earthquakes in the region are commmon. That more damage was not caused by the pre- 1900 shocks is probably attributable to the fact that much of the region did not have large towns or cities close to the epicentral areas. Even today the areas of most intense seismic activity are rural. However, the increasing size and number of moderate-sized cities such as Memphis, Tenn., Little Rock, Ark., and Paducah, Ky., and of towns serving farming communities such as Sikeston, Mo., Dexter, Mo., Paragould, Ark. and Forrest City, Ark., make the potential damage much greater than it was 50-150 year ago.

The recording and analysis of present-day seismicity, as reported by Stauder, have provided, for the first time, an indication of specific zones of seismic activity which are presumably related to specific fault zones. More detailed locations of zones are given in the study of seismicity in the New Madrid, Mo.-Reelfoot Lake, Tenn., area conducted by O'Connell and others (this volume). Their results are based on data from a net of 19 seismometers spaced less than $5 \mathrm{~km}$ apart. The results indicate that the seismicity is occurring on several short north- and northwest-striking fault zones. The geologic characteristics of the zones of seismicity and their extent, however, must be resolved by a variety of earth science disciplines.

The first subsurface information indicating that the seismic activity is associated with a rift about $70 \mathrm{~km}$ wide and more than $200 \mathrm{~km}$ long is provided by the gravity and aeromagnetic studies of Hildenbrand and others (1977), and Hildenbrand and others (this volume). The extent of the rift to the southwest is not yet known. A northeastern extension of it to the Wabash Valley is postulated by Braile and others (this volume). The deep-crustal and upper- mantle properties of the rift have been described by Austin and Keller (this volume); their model of the structure is consistent with models of other intraplate rifts throughout the world. Swanberg and others (this volume) identified a thermal anomaly in the New Madrid region, but the limited spatial extent of the anomaly indicates that it is not related to an upper-mantle source as might be expected in an active rift zone. The lack of evidence of active rifting is one of several enigmas that compound the difficulty in explaining the driving forces of the earthquakes.

Studies of deformation are reported in this volume. Russ demonstrated, using geomorphic methods, that an elongate composite uplift of the surface occurs over the zone of most frequent seismic activity in the vicinity of New Madrid, Mo. Most of the uplift, known as the Lake County uplift, is younger than 6000 years B.P. and parts of it formed between 200 and 2000 years B.P. Crone and Brockman (this volume), using results of seismic-reflection profiling as reported by Hamilton and Zoback (this volume), determined that the deformation of the buried Paleozoic surface in the Lake County uplift area is concordant with the surface uplift. No serious efforts have yet been made to attempt prediction of earthquakes in the New Madrid region. However, the study of radon-isotope emanation by Steele and others (this volume) is a first step in assessing the usefulness of the emanation method for predicting earthquakes.

The reader may find some differences in interpretation of the same or similar data among the various investigators who have contributed to this volume. This is to be expected when the geologic complexity and imperfect knowledge of the region are considered.

In the following parts of this introductory chapter, an attempt will be made to integrate much of the recent earthscience information reported in subsequent chapters with earlier information and to present a generalized description of the tectonic environment of New Madrid seismicity. In addition, the implications of earthquake source zones associated with intraplate rifts will be discussed.

\section{GEOLOGIC HISTORY}

The geologic history of the New Madrid region or parts of it has been described by a number of investigators from a variety of perspectives. (See, for examples, Fuller, 1912; Stearns and Marcher, 1962; Caplan, 1954; Grohskopf, 1955; Ervin and McGinnis, 1955; and Heyl and Brock, 1961.) Until the past few years when studies related to earthquakes were started by a number of investigators, most previous work, except that of Fuller, was related to mineral deposits in the Ozark Mountains, southern Illinois, and western Kentucky; water resources in the Mississippi Valley; and flood control in the valley. The monumental work on the Mississippi Valley by Fisk (1944) and later mapping of the upper part of the valley by Saucier $(1964,1974)$ and Smith and Saucier (1971) give details of the Quaternary history of the embayment. More recently, Russ (this volume) has started detailed studies of river terraces and geomorphic features to search for evidence of Holocene regional deformation.

On cursory examination, the geology (fig. 3) of the central and lower Mississippi Valley area appears relatively simple. Actually it has been and still is an area with very active and 
complex geological processes that probably started as early as the late Precambrian and have continued intermittently to the present. Knowledge of Precambrian events is inferred mostly from rocks in the St. Francois Mountains of the Ozark uplift, where thick extensive subalkaline to peralkaline rhyolitic tuffs were deposited about $1.2 \mathrm{~b} . \mathrm{y}$. (billion years) ago (Anderson, 1970; Bickford and Mose, 1975; Kisvarsanyi, 1976; and Kisvarsanyi, 1980). Alkaline granites were emplaced about the same time. Precambrian igneous activity ended in the area with intrusion of gabbro and diabase dikes. This igneous activity is believed to have been accompanied by epeirogenic uplift and the formation of the "Reelfoot Rift" (Ervin and McGinnis, 1975).

The area of the present Mississippi Embayment subsided in early Paleozoic time, and a basin called the Reelfoot Basin (Schwalb, 1971) formed with a center of deposition in the vicinity of western Kentucky and southeastern Missouri. Clastics followed by carbonates were deposited in Middle and Late Cambrian time. By Silurian time the center of deposition of the Reelfoot Basin had migrated northward and merged with the southward-migrating Illinois Basin. Late Paleozoic and Mesozoic uplift of the Reelfoot Basin resulted in formation and later erosion of the Pascola arch between the Ozark Dome and Nashville Dome. The uplift apparently continued until Late Cretaceous time as no younger Mesozoic sediments have been found, and the arch apparently was emergent until the Early Cretaceous. On the basis of reconstruction of the stratigraphic section, Stearns and Marcher (1962) estimated that at least $2.5 \mathrm{~km}$ and as much as $4.5 \mathrm{~km}$ of rocks were eroded from the arch before subsidence started in the Late Cretaceous. This subsidence and accompanying deposition of predominantly clastic rocks continued into the Pleistocene and probably the Holocene. Subsidence may have been occurring about 6000 years B.P. when the Mississippi and Ohio River systems changed from a braided to a meandering system in the northern part of the Mississippi Embayment (Saucier, 1974). Certainly much of the alluvium that fills the eastern lowlands of the Mississippi Valley was deposited during the interval from about 20,000 to 6000 years B.P. (Saucier, 1974). Interpretation of this deposition being related to subsidence becomes a problem beyond the scope of this paper, however, because it requires detailed consideration of climatic changes and of the effect of sea-level changes on stream gradients and loads. A rough comparison of rates of deposition since Late Cretaceous time is shown in figure 4.

Deposition of sediments, largely of marine origin (Stearns, 1957), in the Mississippi Embayment was clearly most rapid during the early Tertiary, which presumably indicates the greatest rate of subsidence. The high rate of deposition of continental sediments calculated for the Quaternary Period may indicate an increase in subsidence, but, as stated above, sealevel and other changes may have had major effects on rates and amount of deposition of alluvium in the valley of the Mississippi and Ohio rivers.

\section{FAULTS}

This discussion of faults is separated from geologic history because of their direct importance to earthquakes (fig. 3). The fundamental questions to be answered in any study of the location and cause of earthquakes in a particular region are (1) where are the seismically active faults, and (2) what is the past and present rate of movement of them. Extensions of the questions include consideration of the structural regime in which the faults occur, their length, and their mode of displacement.

\section{SURFACE FAULTS}

The amount and history of faulting are not well known because of cover by Quaternary sediments and because detailed geologic mapping has not been done in much of the area. The faults shown in the generalized map of the region (fig. 3) are inadequate for comprehensive tectonic analysis. Even more detailed compilations have limitations. As Heyl and McKeown (1978) stated, for a more detailed map than is shown in figure 3, most of the eastern Ozark Mountains, most of western Tennessee, and most of southwestern Illinois have not been mapped in detail, whereas western Kentucky and the Fluorspar district of southern Illinois have been. Comparison of the geologic structure among the areas is, therefore, not justified. The New Madrid fault zone of Heyl and Brock (1961) is suggested in part on the basis of the zone of northeasttrending faults in southeastern Illinois. The trend, distribution, and abundance of faulting in southwestern Illinois, however, are not known owing to lack of enough detailed mapping.

Some gross inferences of major structural trends can be made, particularly from a regional perspective. Major faults such as the Palmer and Sims Mountain faults in the Precambrian and Paleozoic rocks of the St. Francois Mountains trend predominantly west and northwest. The largest fault or fault zone in the northeastern part of the Ozark uplift is the Ste. Genevieve fault zone, which is part of the 38th parallel lineament of Heyl (1972). The fault apparently had post-Devonian movement and possibly post-Mississippian movement on it. In contrast to the northwest strike of major faults, the trend of diabase dikes in the St. Francois Mountains is predominantly north (Gibbons, 1972). As noted by McKeown (1978), this trend is coincident with the strike of most nodal planes in focal-mechanism solutions of Street and others (1974). Whether or not this coincidence in trends is causally related is controversial, but the trend of diabase dikes is certainly indicative of a structural grain related to major deep-seated crustal stresses during the late Precambrian.

The northeast-trending faults in southern Illinois and western Kentucky offset Mississippian and Pennsylvanian rocks. They form a broad zone but, as mentioned above, their western extent is unknown. Displacement on them is as much as about $150 \mathrm{~m}$, but none of the faults appears to be a major 


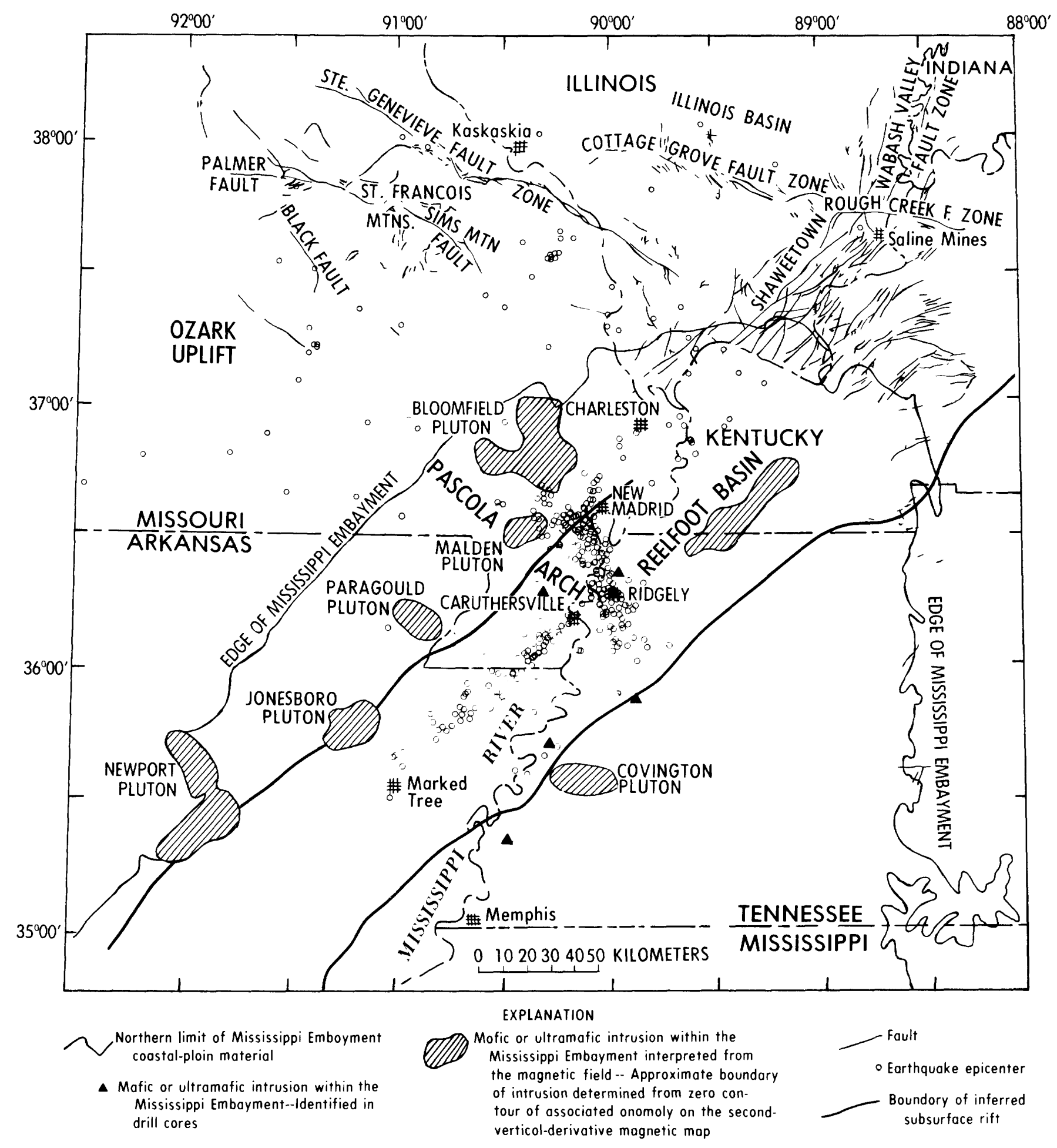

FIGURE 3.--Generalized fault map of the New Madrid region showing plutons, approximate rift boundaries, and epicenters of earthquakes detected from July 1974 to June 1977 .

structural feature. As noted by Heyl and McKeown (1978), they appear to be tensional faults related to anticlines, and some of them in the Wabash Valley fault system may ter- minate at shallow depths (Bristol, 1975). More recent interpretations of drill-hole data by Bristol and Treworgy (1979) show that the major faults in the system probably extend to 


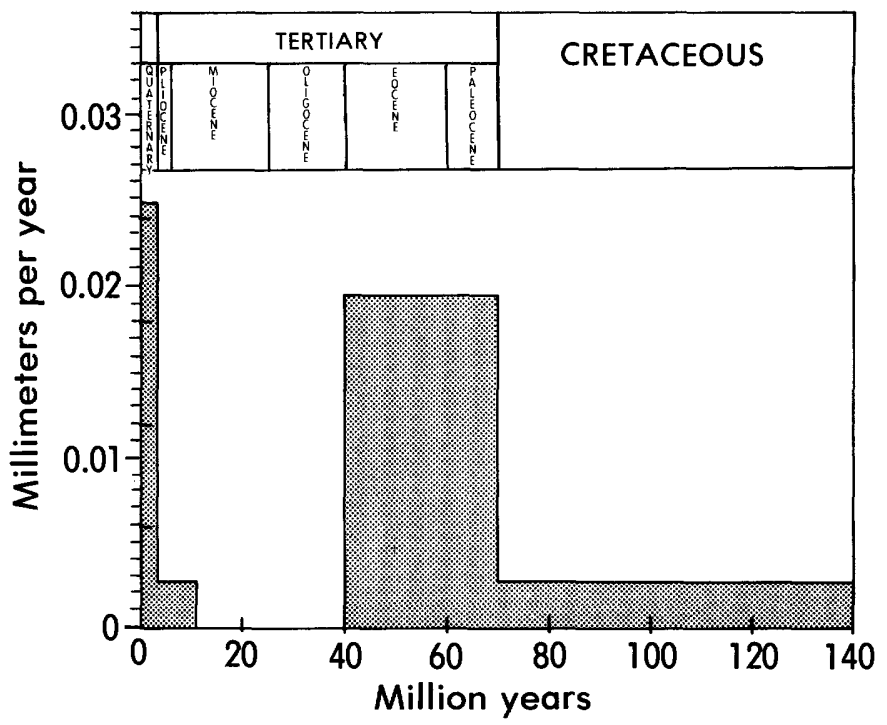

FIGURE 4. Graph showing rate of deposition of sediments during subsidence of embayment based upon thickness of sediments deposited during indicated periods of geologic time but not the loss of record of deposition at diastems and unconformities

basement, which is $3.6-4.3 \mathrm{~km}$ below sea level. They also show, as Bristol did earlier, that some faults die out with depth.

Most of the youngest faults strike northeast and offset Tertiary gravels (Lafayette Formation of former usage), whose age is controversial. These gravels are generally considered to be Pliocene (Potter, 1955), but some evidence suggests a Miocene age (W. W. Olive, written commun., 1978). Recently, Russ (1979) reported more than $3 \mathrm{~m}$ of offset of strata in Holocene alluvium near the base of a scarp on the west side of Reelfoot Lake. The tectonic significance of this fault is not clear, however, and the reader is referred to Russ for details.

\section{SUBSURFACE FAULTS}

Recent exploration of the New Madrid region by gravity, magnetic, and seismic-reflection-profile methods has tremendously advanced knowledge of the tectonic framework of the region. The first significant information on deeply buried geologic structure has resulted from the gravity and aeromagnetic surveys started under the leadership of Martin Kane, of the USGS, in 1973. Maps (Hildenbrand and others, 1977) and reports (Hildenbrand and others, this volume) show and describe a major subsurface rift extending from the vicinity of New Madrid, Mo., southwestward at least as far as the latitude of Memphis, Tenn. The northeastern extent is not known. By analogy with rifts in other parts of the world, particularly east Africa, an abundance of faults may be inferred within the rift. Available reflection profiles, however, do not show an abundance of faults that offset post-Paleozoic rocks (Zoback, 1979; Zoback and others, 1980; Hamilton and Zoback, this volume). Very few reflections from below the surface of the Paleozoic rocks occur in these profiles, however, and so the amount of faulting in Paleozoic rocks is not well known. Only two of the profiles have reflections below the Paleozoic surface. These profiles were obtained along lines in the southern part of the current zone of seismicity and cross the zone in two places. Zoback and others (1980) interpreted the profiles as showing a fault zone with a vertical offset of about $1 \mathrm{~km}$ in rocks of Paleozoic age. In addition, they interpreted several small faults that offset the Paleozoic surface with a cumulative vertical displacement of about $50 \mathrm{~m}$ over a distance of $9 \mathrm{~km}$. The zone of small faults overlies the large fault zone, and both zones are coincident with the northeast-trending zone of seismicity. Because of the differences in the character of the seismic signature of the deep reflectors on both sides of the inferred large vertical offset and the relatively small vertical displacement of the Paleozoic surface, an interpretation of some lateral movement across the zone is permissible. Such an interpretation is compatible with focal- mechanism studies of Hermann and Canas (1978). No unambiguous geologic evidence of lateral movement is known; however, large (tens of kilometers) movement can be precluded from stratigraphic relationships in the Pascola arch area. Some investigators (Grohskopf, 1955; Marcher and Stearns, 1962) have constructed pre-Cretaceous subsurface geologic maps of the area. The drill-hole control for these maps is poor, but it is adequate to define the gross distribution of Paleozoic rock units. The continuity of the units across the inferred rift does not suggest lateral movement.

Many small faults that offset the Paleozoic surface and rocks of Paleocene and Eocene age occur locally in the Reelfoot Lake area. Most of the faults cannot be correlated from one profile line to another. A notable exception is the Cottonwood Grove fault, defined and described by Zoback and others (1980). This fault and subparallel faults are part of a small northeasttrending fault system that appears to be on a projection of the zone of seismicity along the axis of the rift. The system is about $3 \mathrm{~km}$ wide and $12 \mathrm{~km}$ long. However, neither epicenters nor nodal planes of seismic events in the vicinity of the fault system parallel the northeast trend of the system. Any relation between structural and seismic trends is at best equivocal.

Prior to the inferred delineations of subsurface faults from the reflection-profile data, the trends of epicenters reported by Stauder and others (1976) and Stauder and others (this volume) indicated the direction of seismically active faults or fault zones. The longest trend extends for about $100 \mathrm{~km}$ from Marked Tree, Ark., to about Caruthersville, Mo. Whether the epicenters that define this trend are all related to a single long fault or a zone of subparallel short faults along the axis of the rift cannot be determined from any available data. The fact that this trend is the longest, is along the axis of the rift, and is coincident with the linear zone of sand blows caused by earthquakes in the New Madrid sequence of 1811-12 suggests that it is related to a fault zone with the potential of having the largest earthquakes in the region. This trend is not, however, indicative of the structural complexity in the region. The 
seismological and geophysical data northeast of Caruthersville in the vicinity of Reelfoot Lake provide insight into some of this complexity. The trend of epicenters (Stauder and others, this volume) indicates a north-northwest structural zone that extends from near Dyersburg, Tenn., to near New Madrid, Mo., where it bifurcates into an east-west branch and a northeast branch. The branches occur approximately on edges of the Bloomfield pluton (Hildenbrand and others, this volume). Some of the more recent locations of earthquakes between Dyersburg and New Madrid suggest that the north-northwest zone may comprise an en echelon northwest- trending zone of faults. Recent work by O'Connell and others (this volume) shows northwest and north trends in seismic data acquired from a portable network of 19 stations in the area.

In summary, even though more geophysical, seismological, and geologic data are available for the area of currently most frequent seismic activity than for any other area in the region, exact delineations of seismogenic faults cannot yet be made. The reader is referred to references cited earlier in this section for more detailed information on subsurface structure as inferred from geophysical and seismological data. Many of these data indicate the presence of many relatively small bodies of intrusive rocks. As these bodies of rock appear to have some relation to the location of some seismic activity and are probably genetically related to repeated faulting and minor doming, they may be of considerable significance to understanding the seismic activity. Details of the relation of structure to intrusive masses are given in Zoback and others (1980) and Hamilton and Zoback (this volume).

\section{INFERRED CHARACTERISTICS OF SEISMICITY ASSOCIATED WITH RIFTS}

As the available evidence strongly indicates that the seismicity in the New Madrid region is associated with an ancient intraplate rift, a brief review of the evidence and an analysis of the possible significance of the rift to characteristics of seismicity are appropriate. It is unnecessary here to review the possible causes and timing of the rift and its relation to other possible rifts and tectonic events in Central and Eastern United States. An excellent overview of these topics has been given by Hinze and others (1980). In addition, the reader is referred to Burke and Dewey (1973), Ervin and McGinnis (1975), Hoffman and others (1974), Lidiak and Zietz (1976), and Rankin (1975) for extensive discussion on and inferences about the location and development of rifts. Perhaps more relevant to discussion of the relation of seismicity to rifts are the data and concepts given by Kumarapeli and Saull (1966). They argued convincingly that the St. Lawrence Valley is a rift zone initiated in the Mesozoic Era that may extend to the midcontinent region. Further, they attributed current seismicity to the rift system. In a later paper, however, Kumarapeli (1976) modified some of the concepts presented in 1966. One of the chief criticisms of the 1966 paper was that the St. Lawrence rift system is not currently an active extensional feature (Voight, 1969). Results of in situ stress measurements presented by Voight indicate that the region is under high horizontal compressive stress. This observation of the current state of stress does not invalidate the importance of Kumarapeli's concepts of the distribution and ages of the St. Lawrence rift system, or of the mineral assemblages and seismicity associated with it.

That the rifts tend to be located along old structural elements is widely recognized. (See Sykes, 1979, for a review of evidence of reactivation of rifts.) It is significant to note that the east coastal area of the United States, which was involved with continental rifting in the Mesozoic, is today under compression (Zoback and Zoback, 1980). Therefore, arguments about whether a rift is currently in a state of compression or extension are not necessarily relevant to explanations of why earthquakes occur in rifts. What is relevant is that rifts are major breaks in the crust that have properties more favorable for the occurrence of earthquakes than adjacent less broken parts of the crust.

Recognition of young or old rifts is of value to earthquake studies because it helps to differentiate faults in a region that extends to hypocentral depths of earthquakes from faults that may or do not extend to depths of more than a few kilometers. Recognition of rifts and an association of earthquakes with rifts are important steps in attempts to understand the location of earthquakes within continental plates. However, in concert with this knowledge, efforts must be made to explain physically why earthquakes are more likely to occur in rifts than in adjacent areas. Rigorous physical explanations cannot be given yet, but several qualitative geologic explanations will be given in subsequent paragraphs. Explanation of earthquakes occurring in rifts may not only provide a basis as to why earthquakes occur where they do but also provide a possible basis to estimate limits both on location and on source dimensions of earthquakes in rifts. Explanations of earthquakes associated with plate boundaries in Western United States, particularly California, can be made; and these, along with empirical data, are used to estimate source dimensions, size of earthquakes, zones of potential seismic activity, and so forth. The tectonic environment of intraplate earthquakes in Central and Eastern United States, however, is poorly known, and some knowledge commonly used to describe and evaluate earthquakes in Western United States does not appear to be relevant to studies of earthquakes in Central and Eastern United States. Discussion of earthquake sources and dimensions in this chapter, therefore, will be limited to the tectonic regime of the New Madrid region and comparison with similar regimes elsewhere in the world. The features of the regime that need to be considered as a basis for estimating limits on earthquake source dimensions and their physical characteristics are (1) abundance, dimensions, and mode of displacement of faults in and adjacent to intraplate rifts; (2) 
rates and kind of deformation occurring now or in the recent past; and (3) physical characteristics and distribution of rocks in rifts.

\section{CHARACTERISTICS OF FAULTS IN RIFTS}

The abundance of, dimensions of, and mode of displacement on faults in the buried rift of the New Madrid region may never be known in detail but may be postulated by analogy with exposed rifts. According to interpretations of the aeromagnetic and gravity data presented in this volume, major rifting occurred in the late Precambrian or Early Cambrian. As delimited by offsets of the aeromagnetic basement, the rift is about $70 \mathrm{~km}$ wide and more than $200 \mathrm{~km}$ long. Relief on the aeromagnetic basement is about $2 \mathrm{~km}$. The bounding fault zones have not been observed on the seismic-reflection profiles; however, the profile lines did not extend far enough towards the boundaries of the rift to detect the zones for certain. An axial zone of faults and probably intrusives has been identified in reflection profiles southwest of Blytheville, Ark. (Zoback and others, 1980). The northeastern and southwestern extent of the zone is not known from available geophysical data. As a northeastern trend of seismicity that extends from Marked Tree, Ark., to about Caruthersville, Mo., seems to be associated with the axial zone, the zone may extend equally as far. Reflection-profile data show faults of the Paleozoic surface, but they are not particularly abundant and offsets are small. For example, a cumulative offset of the Paleozoic surface of only 50 $m$ occurs within a distance of about $9 \mathrm{~km}$ across the axial zone.

Studies of exposed active or recently active rifts in east Africa (for example, Baker and others, 1972; Bailey, 1974; Barberi and others, 1974; and King, 1970) provide examples of the characteristics of faults and igneous rocks in rifts that may be similar to the rift in the New Madrid region. These studies also show, however, that rifts are quite complex and are varied enough so that generalizations could be misleading. Nevertheless, it is reasonable to cite features of the East African rifts as models for the New Madrid region. Where exposures are good, detailed mapping shows an abundance of faults within rifts (for example, Baker and others, 1972, figs. 11 and 12). King (1970, p. 203) noted for the East African Rift System the "...extraordinary intensity of faulting (ranging from Tertiary to Recent) within their limits and the almost complete absence of faults outside." The rift in the New Madrid region, therefore, may have an abundance of faults at a depth below the top of the aeromagnetic basement, which presumably represents Precambrian or Lower Cambrian igneous rocks, that would have been involved in rifting. By analogy, if east African-rift-type faults are present, they will typically be segmented, intersecting, and en echelon; their lengths will commonly range from a few to about $15 \mathrm{~km}$. In addition, King (1970) has observed that the tectonic and igneous activity migrates with time towards the center of rifts. It is reasonable to expect, therefore, that the axial zone of a rift may be the most disrupted and long-lasting zone of weakness. If so, it is not surprising that some of the current seismicity in the New Madrid region is along an inferred axial zone of the rift.

Rifts are the result of extensional tectonics. Causes of the extension are controversial, and the reader is referred to Bailey (1974) for review of some of the controversy. It is not controversial that faults within an active rift predominantly have normal dip-slip displacement. As mentioned earlier in this chapter, however, the mode of displacement of faults initially formed in a rift may change in accordance with changes in the state of stress. The strike-slip and reverse fault mechanisms reported by Herrman and Canas (1978) for modern earthquakes in the New Madrid region reflect the current state of stress on faults in an ancient rift.

\section{RATES OF DEFORMATION}

As was briefly stated in the introduction to this chapter, the rate of movement on faults in the New Madrid region is profoundly less than the rate of movement on faults in an active plate boundary system or the rate of movement of oceanic rifts. A wide range in rate of fault slip can be calculated in the New Madrid region, but the rates are all low relative to plateboundary motion. If the 50-m cumulative vertical displacement of the Paleozoic surface across a width of $9 \mathrm{~km}$, reported by Zoback and others (1980), is assumed to have occurred in the last $50 \mathrm{~m} . \mathrm{y}$., the rate of displacement is $0.001 \mathrm{~mm} / \mathrm{yr}$. Another example is the $80-\mathrm{m}$ vertical displacement on the Cottonwood Grove fault, reported by Zoback and others (1980). The total offset on this fault likely occurred in the last $50 \mathrm{~m}$.y. However, even if it is assumed to have occurred in the last 10 m.y., the rate is only $0.008 \mathrm{~mm} / \mathrm{yr}$. The largest rate of displacement may be deduced from the work of Russ (1979). He reported at least a 3-m vertical offset of alluvium exposed in a trench near Reelfoot Lake in the last 2,000 years. This is a rate of $1.5 \mathrm{~mm} / \mathrm{yr}$. All of these calculated rates of displacement are more than an order of magnitude smaller than the 2-3 $\mathrm{cm} / \mathrm{yr}$ horizontal movement measured along the San Andreas fault. Another comparison of rates of fault slip can be made using information from the Basin and Range province provided by R. C. Bucknam (oral commun., 1980). Rates of structural relief that may be presumed to have occurred on faults range from 0.2 to $0.4 \mathrm{~mm} /$ year in a time range of $10^{5}-10^{7}$ years. On a shorter time scale, movement on the Wasatch fault ranges from 1.1 to $1.7 \mathrm{~mm} / \mathrm{yr}$ during the last $10^{4}$ years.

Deformation by warping (uplift or subsidence) of large areas of the land surface, however, is also an order of magnitude different for the New Madrid region when compared with the southern California uplift. Russ reports a 10-m vertical displacement of the Lake County uplift area in the last 6,000 years, which is $1.6 \mathrm{~mm} / \mathrm{yr}$. Most of the uplift could have occurred in the last 2000 years, which would be a maximum rate of $4.8 \mathrm{~mm} / \mathrm{yr}$. In contrast, uplift and subsidence rates of the southern California uplift are on the order of $1-3 \mathrm{~cm} / \mathrm{yr}$ 
(Castle and others, 1976).

Another comparison of rate of tectonic deformation within rift zones is given by Bailey (1974) and Baker and others (1972). Bailey, citing other authors, reported extension rates of 0.1 and $0.5 \mathrm{~mm} / \mathrm{yr}$ for the Rhine and Kenya rifts, respectively. Similarly, Baker and others reported maximum extension rates of $0.4-1 \mathrm{~mm} / \mathrm{yr}$ for rifts in Ethiopia, Kenya, Turkana, and Tanzania. As emphasized by Bailey, the rate of extension of intracontinental rifts is more than an order of magnitude less than the rate of extension of oceanic rifts, which suggests that they are fundamentally different structures.

In view of the above examples of rates of various kinds of tectonic deformation, it is not surprising that surficial evidence of deformation associated with historic earthquakes in the New Madrid region is lacking.

A deduction from the above data may be that the large earthquakes (the 1811-12 sequence) were deeper than postulated on the basis of attenuation studies (Nuttli, 1973b) or that the source dimensions are smaller (Evernden, 1975). Either circumstance would very likely preclude rupturing of the surface or even offset of deeply buried Paleozoic rocks and explain the lack of surface rupturing during the 1811-12 sequence of earthquakes.

\section{CHEMICAL AND PHYSICAL GHARACTERISTICS OF ROGKS IN RIFTS}

The great abundance of alkalic rocks in or associated with rifts is well documented. The fact that assemblages of these rocks have unique chemical and physical characteristics and originate in the upper mantle or lower crust makes any zone that has an abundance of them of particular interest to a variety of earth-science specialists. Interests include questions related to the fields of economic geology and mineralogy and, of importance to this discussion, the possible effect that assemblages of alkalic rocks may have on the location of earthquakes. The abundance of such rocks in or associated with the rift in the New Madrid region can only be inferred. As all outcrops and samples of rock from drill holes immediately adjacent to or within the Reelfoot rift are alkalic, it is reasonable to infer that an abundance of such rocks occur in the subsurface. The best known occurrences of alkalic suites of rock in the region occur at Magnet Cove, Ark. (Erickson and Blade, 1963), and in the Little Rock, Ark., bauxite district (Gordon and others, 1958). Earlier Williams (1891) described all of the known occurrences of igneous rocks in Arkansas, all of which are alkalic. These alkalic rocks occur in petrologically complex plutons that are part of the northwest side of the Reelfoot rift; they range from felsic to mafic varieties of alkalic rocks. The Magnet Cove Complex includes carbonatite, which is common in areas of rifting. Exploration drill holes for oil in Tennesse and Missouri have penetrated syenite, lamprophyre, and mica peridotite (Kidwell, 1951). Syenite was penetrated by a drill hole over the
Covington pluton about $80 \mathrm{~km}$ north of Memphis, Tenn. Lamprophyre and mica peridotite were penetrated in drill holes in southwestern Tennessee and southeastern Missouri. As noted by Hildenbrand and others (this volume), these occurrences of alkalic rocks range from Permian to Cretaceous in age. Interpretations of seismic-reflection profiles (Zoback and others, 1980; Glick, this volume) suggest Tertiary intrusive activity. This range in age of alkalic intrusive rocks along the boundaries of a Precambrian or Early Cambrian rift is indicative of renewed rift tectonics.

The characteristics of alkalic rocks that may affect the location of seismicity are their origin in the upper mantle or lower crust; their original, very high content of volatiles; and their wide range in mineralogic composition. Convincing arguments and data support the view that alkalic rocks are derived from the upper mantle or lower crust (for example, Bailey, 1974). Bailey also stated (p. 155), "Abnormal enrichment in volatiles and alkalies is the keynote of rift magnetism." The wide range in mineralogic composition is well documented in the study of the Magnet Cove area by Erickson and Blade (1963); it requires the interpretation that the elastic moduli and density of the rocks also range widely. These characteristics, as they may relate to earthquakes, are discussed in the next section.

\section{POSSIBLE SIGNIFICANCE OF ALKALIC-ROCK CHARACTERISTICS TO SEISMICITY}

In addition to the fact that alkalic rocks have deep-seated origins and therefore must have penetrated through deep fractures in the crust to reach shallow crustal levels, they prompt suggesting a speculative hypothesis that is relevant to seismicity in rifts. Briefly, the hypothesis presented in this section is that the volatile content of rocks in the rift of the New Madrid region was or is still high enough to make them particularly weak because of increased porosity and (or) high pore pressure compared with rocks not associated with the rift. Furthermore, the large contrasts in rock types, ranging from very dense mafic rock to much less dense felsic rock, provide differences in elastic moduli that may cause local concentrations of stress. Arguments to support this hypothesis rest principally on the assumption that a variety of alkalic rocks are present in the rift, as available evidence previously given indicates, and that extrapolation of the amount of volatiles and their effects on the strength of materials are as given in the literature.

The volatile content of alkalic rocks, particularly those that never reached the surface, is difficult to document. Roedder (1965) noted in his study of $\mathrm{CO}_{2}$ inclusions in olivine-bearing nodules that the volume percent of $\mathrm{CO}_{2}$ ranged widely, from a few parts $\mathrm{CO}_{2}$ per trillion of rock to as much as 3 percent in individual grains of olivine. Studies of phase relationships of compounds in the mantle and lower crust provide some insight 
into the limits of the volatile content of magmas and rocks. As mantle magma cannot dissolve more than 5 percent $\mathrm{CO}_{2}$ at depths above $80 \mathrm{~km}$ but may contain 40 percent $\mathrm{CO}_{2}$ below 80 $\mathrm{km}$, a large amount of $\mathrm{CO}_{2}$ is presumably exsolved as the magma ascends. This potentially large exsolution of $\mathrm{CO}_{2}$ may be an explanation of the explosive emplacement of kimberlites (Wyllie and Huang, 1976). The many occurrences of diatremes (Heyl and McKeown, 1978) are evidence that exsolution of $\mathrm{CO}_{2}$ has occurred on a large scale in the New Madrid region. A further argument that the alkalic rocks in the region contained a high volatile content is that $\mathrm{CO}_{2}$ and $\mathrm{H}_{2} \mathrm{O}$ must be present to explain alkalic magmas (Wyllie, 1978).

The best quantitative information on the volatile content of alkalic rocks similar to those penetrated by drill holes in the New Madrid region is in the studies of the Magnet Cove area, Ark., by Erickson and Blade (1963). In table 46 of their report, the computed values of volatiles in Magnet Cove rocks and average igneous rocks are as follows:

\begin{tabular}{|c|c|}
\hline $\begin{array}{l}\text { Rocks of Magret Cove Complex } \\
\text { (percent) }\end{array}$ & $\begin{array}{c}\text { Average igneous rocks } \\
\text { (percent) }\end{array}$ \\
\hline $\mathrm{CO}_{2} \ldots \ldots \ldots 2.3$ & 0.10 \\
\hline C1 $\ldots \ldots \ldots \ldots .14$ & .05 \\
\hline $\mathrm{F} 1 \ldots \ldots \ldots \ldots$ & .03 \\
\hline$S+3 \ldots \ldots \ldots \ldots$ & - \\
\hline $\mathrm{S} \ldots \ldots \ldots \ldots \ldots$ & .05 \\
\hline Total ....3.32 & 0.23 \\
\hline
\end{tabular}

They also calculated that the end fraction of magma, which was 9 percent of the original Magnet Cove magma, contained more than 10 percent $\mathrm{CO}_{2}$. It is assumed that this excess $\mathrm{CO}_{2}$ combined with $\mathrm{Ca} \mathrm{O}$ to form carbonatite bodies. As the exact quantities of compounds and elements in the end fraction of magma are not known, it is impossible to compare excesses and deficiencies in them with stoichiometric calculations. Considering the generally known fact that all volcanic activity includes discharges of large amounts of volatiles, it is reasonable to assume that an excess of those that do not combine to form crystalline products is present in all magmas. This is not to say that all excess volatiles remain trapped in the solidified magmas of intrusive and extrusive bodies of igneous rock. But it is certainly reasonable to assume that rocks derived from highly volatile magma will have a greater residual uncombined, trapped volatile content than rock derived from magma with a low volatile content.

The above information and arguments are given simply to support the concept that even though no quantitative information on the porosity or volatile content of deeply buried alkalic igneous rocks in the region is available, the probability is high that they should still contain more volatiles or have higher porosity than adjacent metamorphic or granitic rocks whose source zones are at much shallower crustal depths than those of alkalic rocks and that did not evolve from a magma with an extremely high content of volatiles.

Given the preceding hypotheses about the physical characteristics of deeply buried rocks in the rift zone in the New Madrid region, one can conclude that (1) trapped volatiles in phenocrysts, miarolitic cavities, or other bubbles are likely to be under high pressure; and (2) whether or not the volatiles have reacted with minerals or escaped through fractures or other permeable channels, the alkalic rocks are likely to have a higher porosity than adjacent country rock.

The first conclusion is based on the supposition that the magma, which persumably starts exsolving $\mathrm{CO}_{2}$ at a depth of about $80 \mathrm{~km}$ would trap ( $25 \mathrm{~kb}$ ), $\mathrm{CO}_{2}$ or other volatiles at high pressure as crystallization of the magma occurs during its upward ascent. This process, therefore, would result in a rock having high pore pressure, an environment conducive to generation of earthquakes.

The second conclusion permits suggesting a similar environment but one in which the pore pressure would not be greater than the lithostatic load, or the hydrostatic load if the pores were interconnected to a hydrologic system. As demonstrated by Hubbert and Rubey (1959) and suggested earlier by Yoder (1955), pressure in rocks with very low permeability and with pores essentially isolated approximates the weight of the overburden. Similar to the environment derived from the first conclusion, this environment of high, though not abnormal, pore pressure would be conducive to generation of earthquakes. The normal stress across any shear plane in rocks in either environment would be reduced by the pore pressure (Hubbert and Rubey, 1959).

Pore-pressure effect, as hypothesized above, may be the largest factor contributing to the localization of earthquakes in the New Madrid region, but porosity alone could contribute to weakening of the rock, particularly if the porosity is greater than a few percent. Experiments to determine the empirical relationship of the stress required to cause brittle fracture of rocks as a function of porosity have been made by Dunn and others (1973) on sandstone and quartzite. Hoshino (1974) reported results of similar experiments on argillaceous and arenaceous rocks. Prior to the experiments on rocks, experiments on the properties of ceramics had determined a relationship of strength to porosity (for example, Ryshkewitch, 1953; Coble and Kingery, 1956; Knudsen, 1959; and Friedman, 1976). The empirical data from these experiments for both rocks and ceramics indicate large changes in strength for small changes in porosity at low values of porosity. As examples of the range in percentage change in strength as a function of porosity, data from Hoshino (1974) and Dunn and others (1973) are cited. Hoshino (1974) determined about a 10 percent reduction in compressive strength of argillaceous rocks for a change in porosity from 1 to 5 percent at a confirming pressure of 100 bars. Data on sandstone and quartzite, reported by Dunn and others (1973), show a 60 percent reduction in compressive strength for a change in porosity from 1 to 5 percent at a confining pressure of 1000 bars. According to the experimental data on rocks, at higher confining pressures the reductions in strength are larger. These relatively large 
changes in strength of rocks as a function of porosity indicate that the small difference in porosity inferred from the petrologic characteristics and origin of alkalic rocks compared to other igneous types of rocks may be very significant to the interpretation of the relationship of seismicity to type of ig. neous rock.

The actual porosity of rocks at the depths of earthquakes in the New Madrid region is of course unknown and may never be known. Some insight on the porosities can be gained from measured porosities of igneous rocks reported in the literature. Farbeov and Levykin (1971) noted that the differences in elasticity among some rocks could not be explained by differences in mineral computations. The relatively low elasticity of some ultrabasic xenoliths was due to microporosity of as much as 5 percent. Measurement of intragranular porosity calculated from bulk and grain densities of a variety of syenites ranges from 0.6 to 0.9 percent (Wuerker, 1956). Additional perspective on the range in porosities of igneous rocks can be gained from some of the abundant physical-property measurements of igneous rocks at the NTS (Nevada Test Site), even though these rocks are not alkalic. Porosities of quartz monzonite and granodiorite from the Climax stock at the NTS average 0.71 percent, 1.08 percent, and 1.55 percent for finegrained quartz monzonite, medium-grained quartz monzonite, and granodiorite respectively (Maldonado, 1977). It should be noted, perhaps emphasized, that the porosities cited above are for a type of rock that probably did not have as high a volatile content as alkalic rocks. Alkalic rocks that have higher volatile content and that were emplaced under extensional tectonic conditions of a rift may certainly be expected to have a total in situ porosity higher than that of the intrusive rocks at NTS and rocks of similar composition elsewhere. A higher porosity of only a few percent would result in alkalic rocks in a rift being significantly weaker than nonalkalic rocks outside of a rift.

The concept of stress amplification around masses of rock surrounded by other rocks with different elastic moduli has been proposed by Kane (1977), Long (1976), and McKeown (1978). In the author's opinion, this concept must be considered as an explanation for local control on the distribution of earthquakes in the New Madrid region because of the divergence in trends of epicenters near the Bloomfield pluton. Geophysical, outcrop, and drill-hole information strongly indicates an abundance of mafic intrusive masses ranging in size probably from a few tens of meters to several tens of kilometers in their greatest horizontal dimensions. That intrusives having different elastic moduli than the host rock cause stress concentrations is well documented (for example, Oudenhoven and others, 1972). It seems reasonable to expect that some if not all of the intrusive masses in and associated with the rift will cause local perturbations and concentrations in the regional stress field and, therefore, have an effect on the location of earthquakes.

\section{SUMMARY}

The environment of the source zones of earthquakes in or associated with the rift in the New Madrid region can be summarized as follows:

1. A large number of faults are likely present, such as those mapped in rifts of east Africa. Individual faults probably have lengths less than $15 \mathrm{~km}$.

2. The felsic-to-mafic range in composition of igneous rocks results in large contrasts in density and elastic module.

3. The pore pressure and (or) porosity is likely to be higher in rocks within or immedately adjacent to the rift than elsewhere in the region.

4. As the alkalic rocks originated in the lower crust or upper mantle, some faults must extend essentially through the crust.

The above four factors suggest that earthquakes in the rift may have the following characteristics:

1. Source dimensions should be less than $15 \mathrm{~km}$ in length.

2. Multiple rupturing may occur because of close spacing and interconnection of faults.

3. Local control of the distribution of earthquakes should occur because of stress concentrations around bodies of rock that have grossly different physical properties, as postulated by Long (1976), Kane (1977), and McKeown (1978).

4. Because of the high pore pressure and (or) porosity, rupturing may occur on relatively low stress levels.

5. As some faults may extend through the crust, some earthquakes may have deep hypocenters.

\section{REFERENCES CITED}

Anderson, R. E., 1970, Ash-flow tuffs of Precambrian age in southeast Missouri (Contribution to Precambrian Geology, no. 2): Missouri Geological Survey and Water Resources Report of Investigations 46, $50 \mathrm{p}$.

Baker, B. H., Mohr, P. A., and Williams, L. A. J., 1972, Geology of the eastern rift system of Africa: Geological Society of America Special Paper 136, $67 \mathrm{p}$.

Barberi, F., Bonatti, E., Marinelli, G., and Varet, J., 1974, Transverse tectonics during the split of a continent $\rightarrow$ Data from the afar rift: Tectonophysics, v. 23, p. 17-29.

Bailey, D. K., 1974, Continental rifting and alkaline magnetism, in Sorensen, H., ed., The alkaline rocks: New York, N.Y., John Wiley and Sons, p. 148-159.

Bickford, M. E., and Mose, D. G., 1975, Geochronology of Precambrian rocks in the St. Francois Mountains, southeastern Missouri: Geological Society of America Special Paper 165, 48 p.

Bristol, H. M., 1975, Structural geology and oil production of northern Gallatin County and southernmost White County, Illinois: Illinois State Geological Survey, Illinois Petroleum 105, 20 p.

Bristol, H. M., and Treworgy, J. D., 1979, The Wabash Valley fault system in southeastern Illinois: Illinois State Geological Survey Circular 509, $19 \mathrm{p}$. 
Burke, Kevin, and Dewey, J. F., 1973, Plume-generated triple junctionsKey indicators in applying plate tectonics to old rocks: Journal of Geology, v. 81, p. 406-433.

Caplan, W. M., 1954, Subsurface geology and related oil and gas possibilities of northeastern Arkansas: Arkansas Resources and Development Commission, Division of Geology Bulletin 20, $124 \mathrm{p}$.

Castle, R. O., Church, J. P., and Elliott, M. R., 1976, Aseismic uplift in southern California: Science, v. 192, p. 251-253.

Coble, R. L., and Kingery, W. D., 1956, Effect of porosity on physical properties of sintered alumina: American Ceramic Society Journal, v. 39, p. $377-385$.

Dunn, P. E., LeFountain, L. T., and Jackson, R. E., 1973, Porosity dependence and mechanism of brittle fracture in sandstones: Journal of Geophysical Research, v. 78, p. 2403-2417.

Erickson, R. L., and Blade, L. V., 1963, Geochemistry and petrology of the alkalic igneous complex at Magnet Cove, Arkansas: U.S. Geological Survey Professional Paper 425, 95 p.

Ervin, C. P., and McGinnis, L. D., 1975, Reelfoot rift--Reactivated precursor to the Mississippi Embayment: Geological Society of America Bulletin, v. 86, p. 1287-1295.

Evernden, J. F., 1975, Seismic intensities, "size" of earthquakes and related parameters: Seismological Society of America Bulletin, v. 65, p. $1287-1313$.

Fabareov, A. I., and Levykin, A. I., 1971, Elastic properties of Kamchatka rocks at pressures up to $30 \mathrm{~kb}$ in connection with problems of deepseated structures of volcanic areas-- Preliminary results: Volcanology Bulletin, v. 35, p. 183-197.

Fisk, H. N., 1944, Geological investigation of the alluvial valley of the lower Mississippi River: Vicksburg, U.S. Corps of Engineers Mississippi River Commission, $78 \mathrm{p}$.

Friedman, M., 1976, Porosity, permeability and rock mechanics-A review: Symposium on Rock Mechanics, 17th, Proceedings, Snowbird, Utah, p. 1-16.

Fuller, M. L., 1912, The New Madrid earthquake: U.S. Geological Survey Bulletin 494, $119 \mathrm{p}$.

Gibbons, J. F., III, 1972, Tectonics of the eastern Ozarks area, southeastern Missouri: Syracuse University Ph. D. thesis, $70 \mathrm{p}$.

Gordon, M., Jr., Tracey, T. I., Jr., and Ellis, M. W., 1958, Geology of the Arkansas bauxite region: U.S. Geological Survey Professional Paper $299,268 \mathrm{p}$.

Grohskopf, J. G., 1955, Subsurface geology of the Mississippi Embayment of southeastern Missouri: Missouri Geological Survey and Water Resources, v. 37, ser. 5, 133 p.

Herrmann, R. B., and Canas, J., 1978, Focal mechanism studies in the New Madrid seismic zone: Seismological Society of America Bulletin, v. 68, no, 4, p. 1095-1102.

Heyl, A. V., Jr., 1972, The 38th parallel lineament and its relationship to ore deposits: Economic Geology, v. 67, p. 879-894

Heyl, A. V., Jr., and Brock, M. R., 1961, Structural framework of the Illinois - Kentucky mining district and its relation to mineral deposits, in Short papers in the geologic and hydrologic sciences: U.S. Geological Survey Professional Paper 424-D, p. D3-D6.

Heyl, A. V., and McKeown, F. A., 1978, Preliminary seismotectonic map of central Mississippi Valley and environs: U.S. Geological Survey Miscellaneous Field Studies Map MF-1011.

Hildenbrand, T. G., Kane, M. F., and Stauder, William, 1977, Magnetic and gravity anomalies in the northern Mississippi Embayment and their spatial relation to seismicity: U.S. Geological Survey Miscellaneous Field Studies Map MF-914.

Hinze, W. J., Braile, L. W., Keller, G. R., and Lidiak, E. G., 1980, Models for Midcontinent tectonism: National Academy of Science Monograph on Continental Tectonics [in press].
Hoffman, P., Dewey, J. F., and Burke, K., 1974, Aulacogens and their genetic relation to geosynclines with a Proterozoic example from Great Slave Lake, Canada, in Dott, R. H., Jr., and Shaver, R. H., eds. Modern and ancient geosynclinal sedimentation: Society of Economic Paleontologists and Mineralogists Special Publication 19, p. 38-55.

Hoshino, K., 1974, Effect of porosity on the strength of clastic sedimentary rocks, in Advances in rock mechanics: International Congress on Rock Mechan ics, 3d, Proceedings, v. 2A, p. 511-516.

Hubbert, M. K., and Rubey, W. W., 1959, Role of fluid pressure in mechanics of overthrust faulting: Geological Society of America Bulletin, v. 70, p. 115-166.

Kane, M. F., 1977, Correlation of major eastern earthquake centers with mafic/ultramafic basement masses: U.S. Geological Survey Professional Paper 1028-0, p. 199-204.

Kidwell, A. L., 1951, Mesozoic igneous activity in the northern gulf coastal plain: Transactions Gulf Coast Association of Geological Societies, Annual Meeting, 1st, New Orleans, La., p. 182-199.

King, B. C., 1970, Vulcanicity and rift tectonics in East Africa, in Clifford, T. N., and Gass, I. G., eds., African magmatism and tectonics: Darien, Conn., Hafner Publishing Co., p. 263-283.

Kisvarsanyi, E. B., 1980, Granitic ring complexes and pre-Cambrian hotspot activity in the St. Francois Terrane, Midcontinent region, United States: Geology, v. 8, p. 43-47.

Kisvarsanyi, Geza, 1976, Precambrian metallogenics in the St. Francois Mountains igneous province, southeastern Missouri, in Kisvarsanyi, E. B., ed., Studies in Precambrian geology: Missouri Department of Natural Resources Report of Investigations 61, p. 60-76.

Knudsen, F. P., 1959, Dependence of mechanical strength of brittle polycrystalline specimens on porosity and grain size: American Ceramic Society Journal, p. 376-387.

Kumarapeli, P. S., 1976, The St. Lawrence rift system, related metallogeny, and plate tectonic models of Appalachian evolution: Geological Association of Canada Special Paper 14, p. 301-320.

Kumarapeli, P. S., and Saull, V. A., 1966, The St. Lawrence Valley system - A North American equivalent of the east African rift system: Canadian Journal of Earth Sciences, v. 3, p. 639-658.

Lidiak, E. G., and Zietz, Isidore, 1976, Interpretation of aeromagnetic anomalies between latitudes $37 \mathrm{~N}$. and $38 \mathrm{~N}$. in Eastern and Central United States: Geological Society of America Special Paper 167, $37 \mathrm{p}$.

Long, L. T. 1976 Speculations concerning southeastern earthquakes, mafic intrusions, gravity anomalies, and stress amplifications: Earthquake Notes, v. 47, p. 29-35.

Maldonado, Florian, 1977, Summary of the geology and physical properties of the Climax Stock, Nevada Test Site: U.S. Geological Survey Open File Report 77-356, 25 p.

Marcher, M. V., and Stearns, R. B., 1962, Tuscaloosa Formation in Tennessee: Geological Society of America Bulletin, v. 73, p. 1365-1386.

Mckeown, F. A., 1978, Hypothesis-- Many earthquakes in the Central and Southeastern United States are causally related to mafic intrusive bodies: U.S. Geological Survey Journal of Research, v. 6, no. 1, p. 41-50.

Nuttli, O. W., 1973a, The Mississippi Valley earthquakes of 1811 and 1812 - Intensities, ground motion, and magnitudes: Seismological Society of America Bulletin, v. 63, p. 227-248.

$1973 \mathrm{~b}$, Seismic wave attenuation and magnitude relations for eastern North America: Journal of Geophysical Research, v. 78, p. 876-885.

1974, Magnitude-recurrence relation for central Mississippi Valley earthquakes: Seismological Society of America Bulletin, v. 64, p 1189-1207.

Oudenhoven, M. S., Babcock, C. O., and Blake, Wilson, 1972, A Method for the prediction of stresses in an isotropic inclusion or orebody of irregular shape: U.S. Bureau of Mines Report of Investigations 7645, $36 \mathrm{p}$ 
Potter, P. E., 1955, The petrology and origin of the Lafayette Gravel: Journal of Geology, v. 63, no. 2, p. 115-132.

Rankin, D. W., 1975, The Continental margin of eastern North America in the southern Appalachians-- The opening and closing of the ProtoAtlantic Ocean: American Journal of Science, v. 275-A, p. 298-336.

Roedder, E., 1965, Liquid $\mathrm{CO}_{2}$ inclusions in olivine-bearing nodules and phenocrysts from basalts: American Mineralogist, v. 50, p. 1746-1782.

Russ, D. P., 1979, Late Holocene faulting and earthquake recurrence in the Reelfoot Lake area, northwestern Tennessee: Geological Society of America Bulletin, v. 90, pt. 1, p. 1013-1018.

Ryshkewitch E., 1953 Compression strength of porous sintered alumina and zirconia: American Ceramic Society Journal, p. 65-68.

Saucier, R. T., 1964, Geological investigations of the St. Francis basin, lower Mississippi Valley: U.S. Army Corps of Engineers, Waterways Experiment Station Technical Report 3-659.

1974, Quaternary geology of the lower Mississippi Valley: Arkansas Archeological Survey, Publications on Archeology, Research Series 6, $26 \mathrm{p}$.

Schwalb, H. R., 1971, The northern Mississippi Embayment--A latent Paleozoic oil province, in Proceedings of Symposium on Future Petroleum Potential of NPC region 9 (Illinois basin, Cincinnati arch, and northern part of Mississippi Embayment): Illinois State Geological Survey, Illinois Petroleum 95, p. 44-49.

Smith, F. L., and Saucier, R. T., 1971, Geological investigation of the western lowlands area, lower Mississippi Valley: U.S. Army Corps of Engineers, Waterways Experiment Station Technical Report S-71-5.

Stearns, R. G., 1957, Cretaceous, Paleocene, and Lower Eocene geologic history of the northern Mississippi Embayment: Geological Society of America Bulletin, v. 68, p. 1077-1100.

Stearns, R. G., and Marcher, M. V., 1962, Late Cretaceous and subsequent structural development of the northern Mississippi Embayment area: Geological Society of America Bulletin, v. 73, p. 1387-1394.

Stearns, R. G., and Wilson, C. W., Jr., 1972, Relationships of earthquakes and geology in west Tennessee and adjacent areas: Report for Tennessee Valley Authority, Office Tributary Area Development Research Paper, Nashville, Tenn., Vanderbilt Univ., 344 p.

Street, R. L., Herrmann, R. B., and Nuttli, O. W., 1974, Earthquake mechanics in the Central United States: Science, v. 184, p. 1285-1287.
Stauder, William, Kramer, M., Fischer, G., Schaefer, Stephen, and, Morrissey, S. T., 1976, Seismic characteristics of southeast Missouri as indicated by a regional telemetered microearthquake array: Seismological Society of America Bulletin, v. 66, no. 6, p. 1953-1964.

Sykes, L. R., 1979, Intraplate seismicity, reactivation of preexisting zones of weakness, alkaline microzonatism, and other tectonism post-dating continental fragmentation: Geophysics and Space Physics Review, v. 16, p. 621-688.

U.S. Geological Survey, 1974, National Atlas of the United States of America: Washington, D.C., sheet 418.

Voight, Barry, 1969, Evolution of North Atlantic Ocean-Relevance of rock-pressure measurements, in Kay, M., ed., North Atlantic geology and continental drift: American Association of Petroleum Geology Memoirs 12, p. 955-962.

Williams, J. F., 1891, The igneous rocks of Arkansas: Arkansas Geological Survey Annual Report 1890, v. 2, 391 p.

Wuerker, R. G., 1956, Annotated tables of strength and elastic properties of rocks: American Institute of Mining and Petroleum Engineers, December, p. 12, table 5.

Wyllie, P. J., and Huang, Wuu-Liang, 1976, Carbonation and melting reactions in the system $\mathrm{CaO}-\mathrm{MgO}-\mathrm{SiO}_{2}-\mathrm{CO}_{2}$ at mantle pressures with geophysical and petrological applications: Contributions to Mineralogy and Petrology, v. 54, p. 79-107.

Wyllie, P. J., 1978, Mantle fluid compositions buffered in peridotite $\mathrm{CO}_{2}-\mathrm{H}_{2} \mathrm{O}$ by carbonates, amphibole, and phlogopite: Journal of Geology, v. 86, p. 687-713.

Yoder, H. S., Jr., 1955, Role of water in metamorphism, in Poldervaart, Arie, ed., Crust of the earth: Geological Society of America Special Paper 62, p. 505-523.

Zoback, M. D., 1979, Recurrent faulting in the vicinity of Reelfoot Lake, northwestern Tennessee: Geological Society of America Bulletin, v. 90, pt. 1, p. 1019-1024

Zoback, M. D., Hamilton, R. M., Crone, A. J., Russ, D. P., McKeown, F. A., and Brockman, S. R., 1980, Recurrent intraplate tectonism in the New Madrid seismic zone: Science, v. 209, no. 4460, p. 971-976.

Zoback, M. L., and Zoback, M. D., 1980, State of stress in the conterminous United States: Journal of Geophysical Research, v. 85, p. 6113-6156. 


\section{Damaging Earthquakes of the Central Mississippi Valley}

By O. W. NUTTLI

INVESTIGATIONS OF THE NEW MADRID, MISSOURI, EARTHQUAKE REGION

GEOLOGICAL SURVEY PROFESSIONAL PAPER 1236 -B 


\section{CONTENTS}

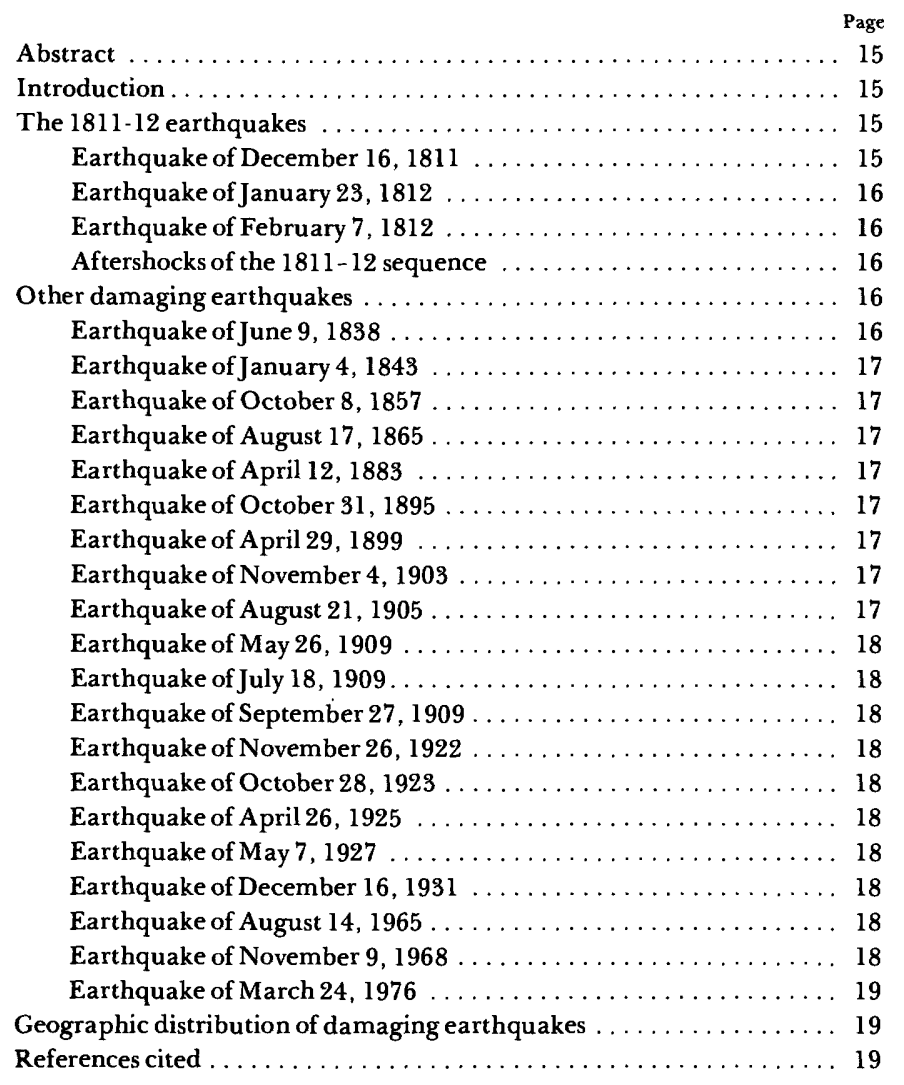

\section{ILLUSTRATIONS}

FIGURE 1. Magnitude-recurrence curves for 3-month interval of New Madrid earthquakes in 1811-12 and for 41-year interval of southern California

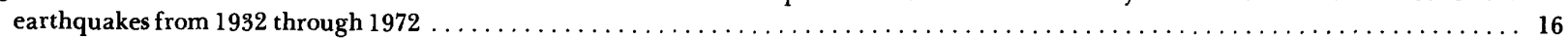

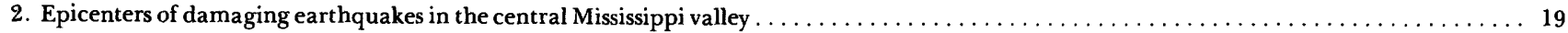




\title{
INVESTIGATIONS OF THE NEW MADRID EARTHQUAKE REGION
}

\section{DAMAGING EARTHQUAKES OF THE CENTRAL MISSISSIPPI VALLEY}

\author{
By OTto W. NUTTLI ${ }^{1}$
}

\section{ABSTRACT}

The history of damaging earthquakes in the central Mississippi valley began on December 16, 1811, with the initiation of the great series of earthquakes of the winter of 1811-12. Three major earthquakes, plus 203 damaging aftershocks, occurred in the 3-month interval from December 16, 1811 , through March 15, 1812. The body-wave magnitudes of the major earthquakes were $7.35,7.2$, and 7.5 . The body-wave magnitudes of the damaging aftershocks ranged from 5.0 to 6.7 .

Since 1812, 20 damaging earthquakes have occurred in the central Mississippi valley of epicentral intensity VI-VII to IX and of body-wave magnitude 5.0 to 6.2 . This seismic activity is greater than that of any other region in the Central or Eastern United States.

The three major earthquakes of 1811-12 occurred in the central portion of the New Madrid fault zone. All 20 later damaging Earthquakes occurred at the two ends of the fault zone, suggesting that the 1811-12 series released the accumulated stress in the central part. Microearthquakes have occurred, however, in large numbers in the central portion.

\section{INTRODUCTION}

Much has been written about the great series of earthquakes that occurred in the central Mississippi valley in the winter of 1811-1812. But it is not as well known that, since that time, the region has experienced 20 damaging earthquakes; that is, earthquakes of epicentral intensity greater than VI. On the basis of these earthquakes alone, the region would be considered to be the most seismically active area of the Central and Eastern United States. This paper will give a brief account of each of the earthquakes, including location, epicentral intensity, magnitude, and a description of the damage.

\section{THE 1811-12 EARTHQUAKES}

Little information exists about the seismicity of the central Mississippi valley prior to the nineteenth century. Five earthquakes are known to have occurred between 1776 and 1804 (Coffman and von Hake, 1973), but it is likely that many were not reported during that time interval. The seismic history of the region actually began with the activity that took place in the winter of 1811-12.

\footnotetext{
' Department of Earth and Atmospheric Sciences Saint Louis University, St. Louis, Mo. 63156.
}

\section{EARTHQUAKE OF DECEMBER 16, 1811}

At 2:15 a.m. (local time) the entire Central United States and much of the Eastern United States was shaken by a major earthquake, the first of a series of events that continued strongly through the spring of 1812 and to a lesser degree for more than 5 years after that. Fuller (1912) gave a description of these earthquakes, particularly of their physiographic effects, some of which were still visible upon his inspection of the area almost 100 years after the occurrence of the Earthquakes. Nuttli (1973a) prepared an isoseismal map, based on contemporary newspaper reports, and gave the epicentral intensity and body-wave magnitude as X-XI and 7.2, respectively. In subsequent studies (Gupta and Nuttli, 1976; Nuttli and others, 1979), Nuttli revised the value of epicentral intensity upwards to XI and of the body-wave magnitude to 7.35.

Copies of the newspaper reports on the effects of the earthquake are contained in Nuttli (1973a). The earthquake was noteworthy for the large damage area (radius of approximately $600-700 \mathrm{~km})$ and the large felt area $\left(5,000,000 \mathrm{~km}^{2}\right)$. These large areas are a consequence of both the low attenuation of highfrequency wave energy in the Central United States (Nuttli, 1973b, 1978) and the size of the earthquake. Practically speaking, the upper limit of the body-wave-magnitude, $\mathrm{m}_{\mathrm{b}}$, scale is about 7.5. The greatest earthquakes occurring anywhere in the world will not have $\mathrm{m}_{\mathrm{b}}$ values exceeding 7.5. Thus this earthquake was near the upper limit of the bodywave-magnitude scale. However, although it was a very large earthquake, the implication is not that it was the greatest to occur in the world. Unlike the body- and surface-wavemagnitude scales, the seismic-moment scale does not get saturated and thus is a better measure of the strength of great earthquakes. Herrmann and others (1978) estimated the total seismic moment for the three 1811-12 earthquakes to be $6 \times 10^{27}$ dyne-cm. By comparison, the moment of the $1906 \mathrm{San}$ Francisco earthquake has been estimated both by Thatcher (1975) and by Sieh (1977) to be $4 \times 10^{27}$ dyne-cm. The 1952 Kamchatka earthquake had a moment of $350 \times 10^{27}$ dyne-cm; and the 1960 Chilean earthquake, the greatest in the last two centuries, had a moment of $2000 \times 10^{27}$ dyne-cm (Kanamori, 1977). 
From a description of the damage accounts of the earthquake, Nuttli (1973a) found the epicenter to be southwest of the town of New Madrid, Mo. Although a precise epicenter could not be determined, it almost certainly lies on the southwest branch of the New Madrid fault zone, as delineated by microearthquakes (Stauder and others, 1976). Tentative coordinates of lat $36^{\circ} \mathrm{N}$., long $90^{\circ} \mathrm{W}$. were assigned by Nuttli (1973a).

\section{EARTHQUAKE OF JANUARY 23, 1812}

The December 16, 1811, earthquake was followed by a series of aftershocks, some of which were large, destructive events. The aftershock series was interrupted by the occurrence of a second major earthquake at 9 a.m. (local time) on January 23,1812 . This earthquake also was felt as far away as the Atlantic and gulf coasts. The revised value of epicentral intensity is X-XI (Gupta and Nuttli, 1976) and of body-wave magnitude is 7.2 (Nuttli and others, 1979). The felt area was approximately $5,000,000 \mathrm{~km}^{2}$. The epicenter probably was at the northern end of southwest branch of the New Madrid fault zone. Its epicentral coordinates thus would be lat $36.3^{\circ} \mathrm{N}$., long $89.6^{\circ} \mathrm{W}$. (Nuttli, 1973a).

\section{EARTHQUAKE OF FEBRUARY 7, 1812}

The largest of the so-called New Madrid earthquakes occurred on February 7,1812 , at 3:45 a.m. (local time). It completely destroyed the town of New Madrid, which was apparently near the epicenter. Nuttli (1973b) assigned epicentral coordinates of lat $36.5^{\circ} \mathrm{N}$., long $89.6^{\circ} \mathrm{W}$. Newspaper and other reports of the 1811-12 earthquakes often did not distinguish among the events, so there were too few reliable data to construct isoseismal maps for this or the January 23 earthquake. The revised value of epicentral intensity is XII (Gupta and Nuttli, 1976) and of body-wave magnitude is 7.5 (Nuttli and others, 1979). The felt area was at least 5,000,000 $\mathrm{km}^{2}$.

\section{AFTERSHOCKS OF THE 1811-1812 SEQUENCE}

The aftershock activity of the 1811-1812 earthquakes was noteworthy. Contemporary observers remarked that the earth seemed to be in a continuous state of unrest during the entire winter of 1811-1812. One particularly astute observer, Jared Brooks' of Louisville, Ky., set up horizontal pendulums and vertical mass-spring systems to detect and measure the size of the movement produced by the earthquakes. He also classified them as to their degree of violence at Louisville, some 400-500 km from the epicenter. Fuller (1912) reproduced Brooks' classification of earthquake intensities, from which Nuttli (1973a) was able to assign body-wave magnitudes for the earthquakes reported by Brooks from December 16, 1811, through March 15,1812 . There were 62 damaging aftershocks from December 16 to January 23, 30 from January 23 to February 7 , and 111 from February 7 through March 15.
A plot comparing the cumulative number of earthquakes in the New Madrid area and in southern California as a function of their magnitude $\left(\mathrm{m}_{\mathrm{b}}\right.$ for the Mississippi valley, $\mathrm{M}_{\mathrm{L}}$ for southern California) was prepared (fig. 1). The two straightline curves are almost coincident, which indicates that the number and the magnitude of earthquakes that occurred in the New Madrid fault zone in 3 months equaled that which occurred in southern California in 41 years. This is a remarkable phenomenon, which further attests to the large energy release accompanying the 1811-12 earthquakes.

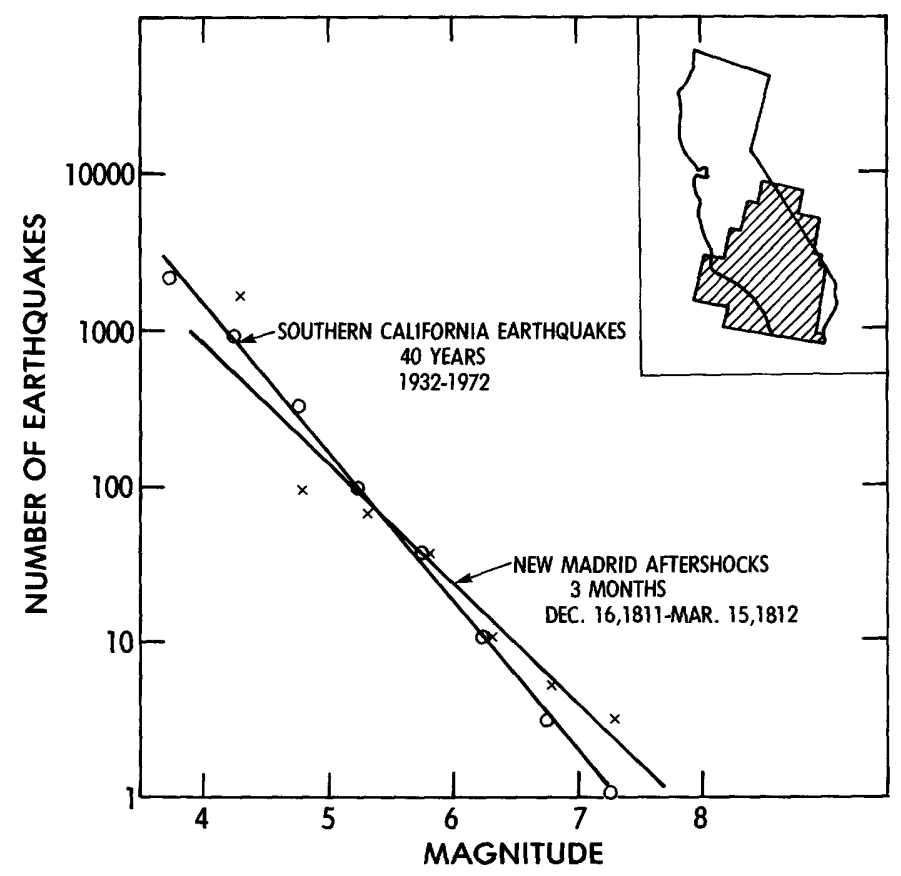

FIGURE 1.-Magnitude-recurrence curves for 3-month interval of New Madrid earthquakes in 1811-12 and for 41-year interval of southern California earthquakes from 1932 through 1972. Crosshatched area of index map shows southern California source area considered. Crosses refer to New Madrid data $\left(\mathrm{m}_{\mathrm{b}}\right)$, circles to southern California data $\left(M_{L}\right)$ (Hileman and others, 1973).

\section{OTHER DAMAGING EARTHQUAKES}

Although activity subsequent to the 1811-12 earthquakes does not compare in strengh or in number to those events, it nevertheless is large enough on its own to justify the classification of the region as a seismically active one. A description of the 20 damaging earthquakes follows.

\section{EARTHQUAKE OF JUNE 9, 1838}

The earthquake of June 9, 1838, had its epicenter in southcentral Illinois, about $100 \mathrm{~km}$ east of St. Louis. Nuttli (1974) gave the coordinates as lat $38.5^{\circ} \mathrm{N}$., long $89^{\circ} \mathrm{W}$., the epicentral intensity as VII-VIII, the felt area as $500,000 \mathrm{~km}^{2}$, and the body-wave magnitude as 5.7. Part of a chimney was thrown down in St. Louis (Coffman and von Hake, 1973). 


\section{EARTHQUAKE OF JANUARY 4, 1843}

Nuttli (1974) prepared an isoseismal map of the January 4 , 1843 , earthquake on the basis of contemporary newspaper accounts. The earthquake occurred at 8:45 p.m. (local time) and was felt over an area of $1,500,000 \mathrm{~km}^{2}$. The epicentral intensity was estimated to be VIII, and the body-wave magnitude 6.0. The epicenter was placed at approximately lat $35.5^{\circ} \mathrm{N}$., long $90.5^{\circ} \mathrm{W}$., at the center of the intensity-VII isoseism. This location is compatible with the observations that at Memphis the shocks appeared to come from the northwest and that at Helena, Ark., where some chimneys were thrown down, the shock was more severe to the north. Chimneys also were thrown down at Mills Point, Tenn. Coffman and von Hake (1973) reported that walls were cracked, chimneys fell, and windows were broken in Memphis and that one chimney fell in St. Louis.

\section{EARTHQUAKE OF OCTOBER 8, 1857}

The epicenter of the October 8, 1857, earthquake was near that of the June 9,1838 , event. Nuttli (1974) gave the epicentral coordinates as lat $38.7^{\circ} \mathrm{N}$., long $89.2^{\circ} \mathrm{W}$., with a felt area of $200,000 \mathrm{~km}^{2}$, an epicentral intensity of VII, and a bodywave magnitude of 5.4. He also gave an isoseismal map for the earthquake. At Centralia, Ill., near the epicenter, chimneys were demolished. At Belleville, Ill., to the west, some plaster fell and bricks were dislodged from an old chimney. Coffman and von Hake (1973) reported that plaster fell and bricks were dislocated at St. Louis, about $100 \mathrm{~km}$ west of the epicenter.

\section{EARTHQUAKE OF AUGUST 17, 1865}

From newspaper accounts of the August 17, 1865, earthquake, Nuttli (1974) placed the epicenter north of Memphis at lat $35.5^{\circ} \mathrm{N}$., long $90.5^{\circ} \mathrm{W}$. Its felt area was $250,000 \mathrm{~km}^{2}$, epicentral intensity VII, and body-wave magnitude 5.3. Damage at Memphis consisted of bricks knocked out of parapet walls, tops knocked off chimneys, and broken windows. Coffman and von Hake (1973) reported that objects fell from shelves and chimneys were damaged at New Madrid, Mo.

\section{EARTHQUAKE OF APRIL 12, 1883}

The effects of the earthquake of April 12, 1883, were confined to the epicentral region near Cairo, Ill., where one old frame house was reported shaken down (Coffman and von Hake, 1973). Nuttli (1979) gave its epicentral coordinates as lat $37.0^{\circ} \mathrm{N}$., long $89.2^{\circ} \mathrm{W}$., its epicentral intensity as VI-VII, and its body-wave magnitude as 4.0 .

\section{EARTHQUAKE OF OCTOBER 31, 1895}

The October 31, 1895, earthquake was the largest to occur in the central Mississippi valley after 1812. Newspaper coverage was unusually thorough, allowing Nuttli (1974) to construct a fairly detailed isoseismal map. The earthquake was felt as far away as the gulf and Atlantic coasts. The felt area was $2,500,000 \mathrm{~km}^{2}$. The epicenter was near the town of Charleston, Mo., with coordinates of lat $37.0^{\circ} \mathrm{N}$., long $89.4^{\circ}$ W. Epicentral intensity was IX and body-wave magnitude 6.2. Coffman and von Hake (1973) reported that near Charleston $16 \mathrm{~m}^{2}$ of ground sank and a lake was formed. At Cairo, Ill., church steeples were twisted and chimneys were cracked and demolished. Near Bertrand, Mo., hundreds of mounds of sand were piled up, ranging from $30 \mathrm{~cm}$ to $3 \mathrm{~m}$ in diameter.

\section{EARTHQUAKE OF APRIL 29, 1899}

On the evening of April 29, 1899, southwestern Indiana and southeastern Illinois were shaken by an earthquake. The epicentral coordinates were lat $38.8^{\circ} \mathrm{N}$., long $87.0^{\circ} \mathrm{W}$, the felt area was $100,000 \mathrm{~km}^{2}$, the epicentral intensity VI-VII, and the body-wave magnitude 5.0 (Nuttli, 1979). Coffman and von Hake (1973) stated that the earthquake was strongest at Jeffersonville and Shelbyville, Ind., and that a few chimneys were thrown down and brick walls cracked at Vincennes, Ind.

\section{EARTHQUAKE OF NOVEMBER 4, 1903}

The earthquake of November 4, 1903, was unusual in that it was accompanied by a foreshock and two aftershocks (Coffman and von Hake, 1973). Building walls were cracked at New Madrid, Mo., and Cairo, Ill., and chimneys fell at Cape Girardeau, Mo. Nuttli (1979) gave the epicentral coordinates as lat $36.9^{\circ} \mathrm{N}$., long $89.3^{\circ} \mathrm{W}$., the felt area as $340,000 \mathrm{~km}^{2}$, the epicentral intensity as VII, and the body-wave magnitude as 5.3 .

\section{EARTHQUAKE OF AUGUST 21, 1905}

The August 21, 1905, earthquake had epicentral coordinates of lat $36.8^{\circ} \mathrm{N}$., long $89.6^{\circ} \mathrm{W}$., a felt area of 325,000 $\mathrm{km}^{2}$, an epicentral intensity of VI-VII, and a body-wave magnitude of 5.0 (Nuttli, 1979). Coffman and von Hake (1973) reported that chimneys were thrown down and a wall cracked at Sikeston, Mo.

\section{EARTHQUAKE OF MAY 26, 1909}

The earthquake of May 26, 1909, occurred in northern Illinois. Its epicentral coordinates were lat $42.5^{\circ} \mathrm{N}$., long $89.0^{\circ} \mathrm{W}$., its felt area $800,000 \mathrm{~km}^{2}$, its epicentral intensity VII, and its body-wave magnitude 5.3 (Nuttli, 1979). Docekal (1970) reported that damage was centered at Aurora, Ill., where many chimneys fell and a stove was overturned. He also reported that chimneys fell in Waukegan, Ill., and in the suburbs of Chicago. Brick walls cracked at Bloomington, Ill., sidewalks at Freeport, Ill., and an old building at Platteville, Wis. Houses were thrown out of plumb in Beloit, Wis. 


\section{EARTHQUAKE OF JULY 18, 1909}

Central Illinois was shaken by an earthquake on the evening of July 18, 1909. Coffman and von Hake (1973) reported that many chimneys were thrown down at Petersburg, Ill., Hannibal, Mo., and Davenport, Iowa. More than 20 windows broke, brick was pushed out over the doorway arches, and plaster cracked near Petersburg, Ill. Nuttli (1979) gave the epicentral coordinates as lat $40.2^{\circ} \mathrm{N}$., long $90.0^{\circ} \mathrm{W}$., the felt area as $100,000 \mathrm{~km}^{2}$, the epicentral intensity as VII, and the body-wave magnitude as 5.3 .

\section{EARTHQUAKE OF SEPTEMBER 27, 1909}

The epicentral coordinates of the September 27, 1909, earthquake were lat $39.5^{\circ} \mathrm{N}$., long $87.4^{\circ} \mathrm{W}$. (Nuttli, 1979). The felt area was $250,000 \mathrm{~km}^{2}$, the epicentral intensity VII, and the body-wave magnitude 5.3. Docekal (1970) reported that Terre Haute, Ind., suffered two downed chimneys, cracked plaster, and severed light connections. A few windows were broken and chimneys thrown down in Covington, Ind.

\section{EARTHQUAKE OF NOVEMBER 26, 1922}

Docekal (1970) reported that the earthquake which occurred on the evening of November 26, 1922, broke windows and overturned chimneys at Eldorado, Ill. Its epicentral coordinates were lat $37.5^{\circ} \mathrm{N}$., long $88.5^{\circ} \mathrm{W}$., its felt area 130,000 $\mathrm{km}$, its epicentral intensity VI-VII, and its body-wave magnitude 5.0 (Nuttli, 1979).

\section{EARTHQUAKE OF OCTOBER 28, 1923}

The earthquake of October 28, 1923, occurred near the southern limit of the New Madrid fault zone. At Marked Tree, Ark., windows were shattered, several old chimneys were razed, and walls were cracked (Coffman and von Hake, 1973). The epicentral coordinates were lat $35.5^{\circ} \mathrm{N}$., long $90.4^{\circ} \mathrm{W}$., the felt area $120,000 \mathrm{~km}^{2}$ the epicentral intensity VII, and the body-wave magnitude 5.3 (Nuttli, 1979).

\section{EARTHQUAKE OF APRIL 26, 1923}

On the evening of April 26, 1925, an earthquake in the Wabash valley near Princeton, Ind., caused chimneys to fall (Docekal, 1970). The epicentral coordinates were lat $38.3^{\circ}$ $\mathrm{N}$., long $87.6^{\circ} \mathrm{W}$., the felt area $250,000 \mathrm{~km}^{2}$, the epicentral intensity VI-VII, and the body-wave magnitude 5.0 (Nuttli, 1979).

\section{EARTHQUAKE OF MAY 7, 1927}

The earthquake of May 7, 1927, had epicentral coordinates of lat $35.7^{\circ} \mathrm{N}$., long $90.6^{\circ} \mathrm{W}$., a felt area of $300,000 \mathrm{~km}^{2}$, an epicentral intensity of VII, and a body-wave magnitude of 5.3 (Nuttli, 1979). Chimneys fell at North Jonesboro, Ark. (Coff- man and von Hake, 1973). Docekal (1970) reported broken windows and dishes at Memphis.

\section{EARTHQUAKE OF DECEMBER 16, 1931}

The December 16, 1931, earthquake occurred in northern Mississippi and was felt over an area of $220,000 \mathrm{~km}^{2}$. The epicentral coordinates were lat $34.1^{\circ} \mathrm{N}$., long $89.8^{\circ} \mathrm{W}$., its epicentral intensity VI-VII, and its body-wave magnitude 5.0 (Nuttli, 1979). Chimneys were thrown down, and walls and foundations cracked in Charleston, Miss. (Coffman and von Hake, 1973). Chimneys also were damaged at Tillahota and Water Valley, Miss. , and buildings were damaged and plaster fell at Belzoni, Miss.

\section{EARTHQUAKE OF AUGUST 14, 1965}

The earthquake of August 14, 1965, is an example of a small-magnitude event that can produce damage because of shallow focal depth. Herrmann (1979), from a study of the spectra of Rayleigh waves, determined the focal depth to be only $1.5 \mathrm{~km}$. Herrmann and Nuttli (1975) showed that for such shallow focal depths the high-frequency, fundamentalmode surface waves are strongly excited, by one or two orders of magnitude more than for depths of $5 \mathrm{~km}$ or greater. Their attenuation is large, because it is controlled by the anelastic properties of the surficial layer. Thus their damage is confined to a small epicentral area, in contrast to the more normal Central and Eastern U.S. earthquakes which have relatively large damage and felt areas. Their magnitude is determined by the excitation of the higher mode waves, which does not vary with depth in the crust.

The epicentral coordinates were lat $37.1^{\circ} \mathrm{N}$., long $89.2^{\circ}$ W., the felt area was $700 \mathrm{~km}^{2}$, the epicentral intensity VII, and the body-wave magnitude 3.8 (Nuttli, 1979). Chimneys were knocked down, walls cracked, water muddied, and groceries shaken from shelves at Tamms, Ill. (Coffman and von Hake, 1973). In epicentral location and damage effects, it is similar to the earthquake of April 12, 1883, which had a very shallow focal depth.

\section{EARTHQUAKE OF NOVEMBER 9, 1968}

The earthquake of November 9, 1968, was the largest in the central Mississippi valley after 1895 . Its epicentral coordinates were lat $38.0^{\circ} \mathrm{N}$., long $88.5^{\circ} \mathrm{W}$. It was felt over an area of $1,600,000 \mathrm{~km}^{2}$, had an epicentral intensity of VII, and had a body-wave magnitude of 5.5 (Nuttli, 1979). In the epicentral area there were downed chimneys, cracks in foundations, overturned tombstones, and a few instances of collapsed parapets. In south-central Illinois bricks were thrown from chimneys, windows were broken, television aerials were toppled, and plaster broke and fell. Moderate damage to chimneys also occurred in southwestern Indiana, northwestern Kentucky, and at Herrmann, St. Charles, Sikeston, and St. Louis, 
Mo. (Coffman and von Hake, 1973).

\section{EARTHQUAKE OF MARCH 24, 1976}

The earthquake of March 24, 1976, occurred during the early evening hours (local time). Its epicentral coordinates were lat $35.59^{\circ} \mathrm{N}$., long $90.48^{\circ} \mathrm{W}$., and its body-wave magnitude 5.0 (Simon and others, 1978). The epicentral intensity was VI, so strictly speaking this earthquake should not be included in the present list of damaging events. However, its body-wave magnitude of 5.0 usually corresponds to an epicentral intensity of VI-VII. Furthermore, the felt area of $280,000 \mathrm{~km}^{2}$ and the character of the damage argue in support of including it in the present list.

Simon and others (1978) reported telephone lines downed and a power blackout in Jonesboro, Ark.; broken windows in Paragould and Walnut Ridge, Ark.; cracked masonry in Tupelo, Miss.; roof damage and fallen ceiling tiles in Decatur, Ark.; and damaged telephone circuits in Union City, Tenn.

The earthquake triggered strong-motion accelerographs at seven sites in Mississippi, Missouri, and Tennessee, at distances of $100-150 \mathrm{~km}$. The maximum recorded acceleration was $0.041 \mathrm{~g}$, at a distance of $100 \mathrm{~km}$ (Herrmann, 1977).

\section{GEOGRAPHIC DISTRIBUTION OF DAMAGING EARTHQUAKES}

The three major earthquakes of 1811-12 plus 11 of the 20 other damaging earthquakes are associated with the New Madrid fault zone, which extends from about lat $35.5^{\circ} \mathrm{N}$. to $37.0^{\circ} \mathrm{N}$., and long $90.5^{\circ} \mathrm{W}$. to $89.5^{\circ} \mathrm{W}$. (fig. 2).

The three main earthquakes occurred in the center of the region whereas all the damaging earthquakes subsequent to those occurred at the southern and northern edges of the fault zone (fig. 2). The great 1811-12 sequence appears to have released much of the strain energy in the central region, but not at the ends of the fault zone. Microearthquake studies (Stauder and others, 1976), however, indicate a concentration of small earthquakes in the vicinity of the epicenters of the January 23 and February 7,1812 , earthquakes. Thus the whole New Madrid fault zone must be considered to have the potential for producing damaging earthquakes.

Five of the damaging earthquakes can be associated with the Wabash valley fault zone of southeastern Illinois and southwestern Indiana. The two earthquakes near lat $38.5^{\circ} \mathrm{N}$. and long $89^{\circ} \mathrm{W}$. may be associated with the Centralia fault, although no evidence exists except for proximity of the epicenters to the fault. The same is true of an association of the epicenter of the earthquake at the Illinois-Wisconsin border with the Sandwich fault. The Illinois earthquake of 1909 , with epicenter near lat $40^{\circ} \mathrm{N}$., long $90^{\circ} \mathrm{W}$., remains an enigma. The Mississippi earthquake near lat $34^{\circ} \mathrm{N}$., long $90^{\circ} \mathrm{W}$., could possibly be associated with the buried Ouachita moun- tain front, as minor seismic activity has occurred along that front in Arkansas and Oklahoma.

On the basis of the available historical record, which is short compared to the time scale of the geologic processes related to earthquake activity, we can conclude that most of the future damaging earthquakes in the central Mississippi valley will have their epicenters in the New Madrid and the Wabash valley fault zones. However, we cannot exclude the possibility that a damaging earthquake could occur anywhere in the central Mississippi valley.

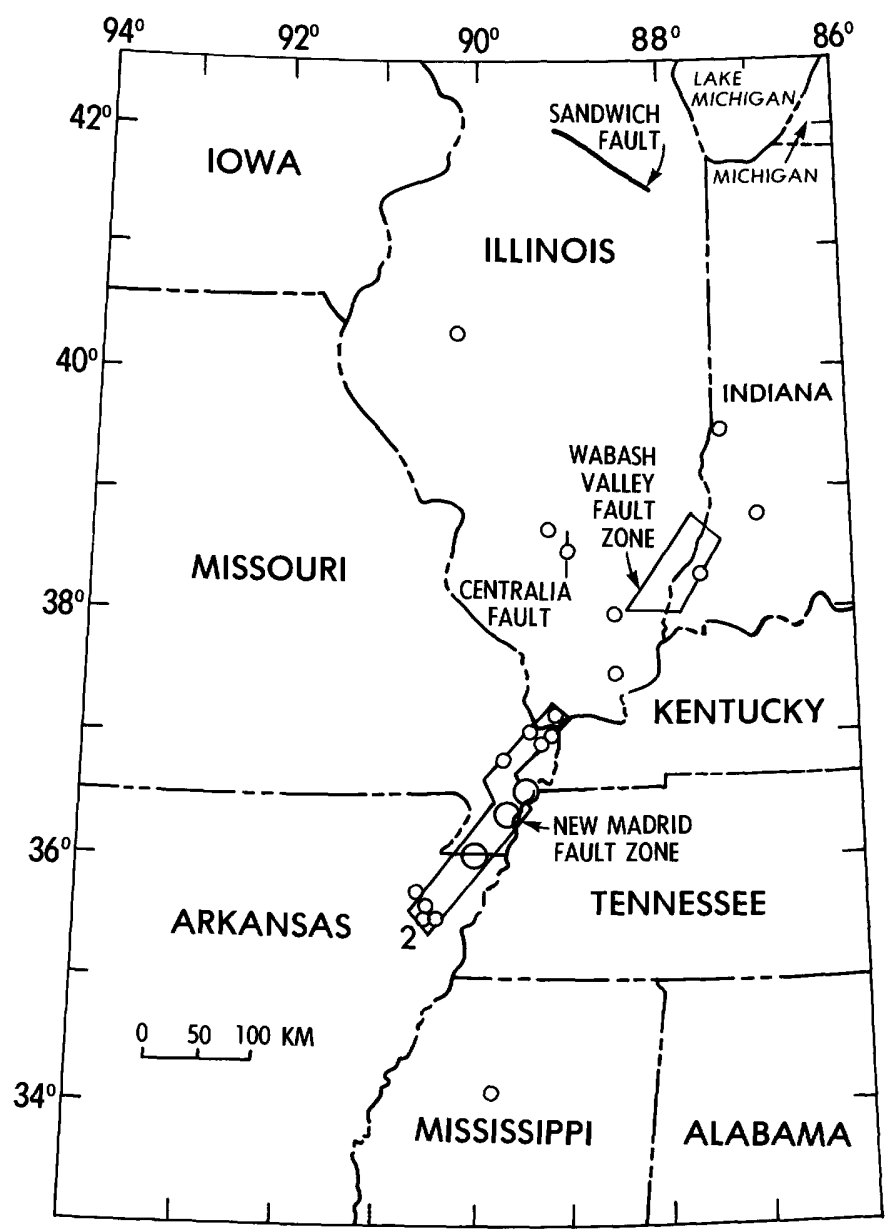

FIGURE 2. - Epicenters of damaging earthquakes in the central Mississippi valley. Large circles refer to epicenters of the three major earthquakes of 1811-12. Epicenters of the 203 damaging aftershocks are not plotted. Small circles refer to damaging earthquakes subsequent to 1812 . The number 2 indicates two earthquakes with the same epicenter.

\section{REFERENCES CITED}

Coffman, J.L. and von Hake, C.A., eds., 1973, Earthquake history of the United States-Revised edition (through 1971): U.S. Environmental Data Service Publication 41-1, 208 p.

Docekal, Jerry, 1970, Earthquakes of the stable interior, with emphasis on the Midcontinent, v. 2, Catalogue: University of Nebraska Ph. D. dissertation, $332 \mathrm{p}$. 
Fuller, M. L., 1912, The New Madrid earthquake: U.S. Geological Survey Bulletin 494,119 p.

Gupta, I. N., and Nuttli, O. W., 1976, Spatial attenuation of intensities for central U.S. earthquakes: Seismological Society of America Bulletin, v. 66 , no. 3, p. 743-751.

Herrmann, R. B., 1977, Analysis of strong motion data from the New Madrid seismic zone-1 1975-1976: Saint Louis University, Department of Earth and Atmospheric Sciences, 144 p.

1979, Surface wave focal mechanisms for eastern North American earthquakes with tectonic implications: Journal of Geophysical Research, v. 84, p. 3543-3552.

Herrmann, R. B., and Nuttli, O. W., 1975, Ground-motion modelling at regional distances for earthquakes in a continental interior, II, Effect of focal depths, azimuth and attenuation: Earthquake Engineering and Structural Dynamics, v. 4, no. 1, p. 59-72.

Herrmann, R. B., Cheng, S. H., Nuttli, O. W., 1978, Archeoseismology applied to the New Madrid earthquakes of 1811-12: Seismological Society of America Bulletin, v. 68, no. 6, p. 1751-1759.

Hileman, J. A., Allen, C. R., and Nordquist, J. M., 1973, Seismicity of the southern California region, 1 January 1932 to 31 December 1972: California Institute of Technology, Seismological Laboratory, 83 p., 404 tables.

Kanamori, H., 1977, The energy release of great earthquakes: Journal of Geophysical Research, v. 82, p. 2981-2987.

Nuttli, O. W., 1973a, The Mississippi Valley earthquakes of 1811 and 1812; intensities, ground motion and magnitudes: Seismological Society of America Bulletin, v. 63, no. 1, p. 227-248. 1973b, Seismic wave attenaation and magnitude relations for eastern North America: Journal of Geophysical Research, v. 78, no. 5, p. 876-885.

1974, Magnitude-recurrence relation for central Mississippi Valley earthquakes: Seismological Society of America Bulletin, v. 64, no. 4, p. $1189-1207$.

1978, A time-domain study of the attenuation of $10-\mathrm{Hz}$ waves in the New Madrid seismic zone: Seismological Society of American Bulletin, v. 68 , no. 2 , p. $343-355$.

Nuttli, O. W., 1979, The seismicity of the Central United States, in Geology in the siting of nuclear power plants: Geological Society of America, Reviews in Engineering Geology, v. 4, p. 67-93.

Nuttli, O. W., Bollinger, G. A., and Griffiths, D. W., 1979, On the relation between MM intensity and body-wave magnitude: Seismological Society of America Bulletin, v. 69 no. 3, p. 893-909.

Sieh, K. E., 1977, A study of Holocene displacement history along the south-central reach of the San Andreas fault: Stanford University Ph. D. dissertation, $219 \mathrm{p}$.

Simon, R. B., Stover, C. W., Person, W. J., and Minsch, J. H., 1978, Earthquakes in the United States, January-March 1976: U.S. Geological Survey Circular 776-A, p. A18-A20.

Stauder, William, Kramer, Mark, Fischer, Gerard, Schaefer, Stephen, and Morrissey, S. T., 1976, Seismic characteristics of southeast Missouri as indicated by a regional telemetered microearthquake array: Seismological Society of America Bulletin, v. 66, no. 6, p. 1953-1964.

Thatcher, W., 1975, Strain accumulation and release mechanism of the 1906 San Francisco earthquake: Journal of Geophysical Research, v. 80 , no. 35 , p. $4862-4880$. 


\section{Present-Day Seismicity and Identification of Active Faults in the New Madrid Seismic Zone}

By WILLIAM STAUDER

INVESTIGATIONS OF THE NEW MADRID, MISSOURI, EARTHQUAKE REGION

GEOLOGICAL SURVEY PROFESIONAL PAPER 1236 -C 


\section{CONTENTS}

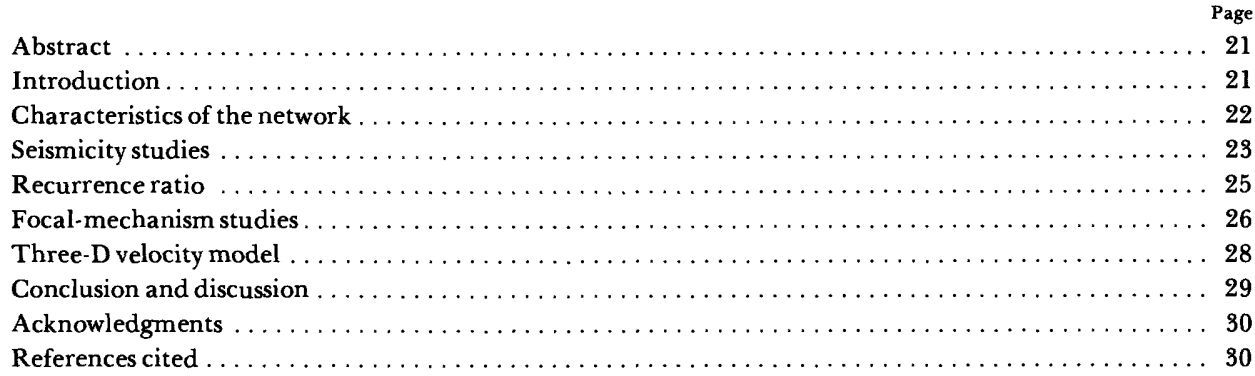

\section{ILLUSTRATIONS}

FIGURE 1. Epicenters of 488 earthquakes of magnitude $\mathrm{m}_{\mathrm{b}} 3$ occurring in the central Mississippi Valley from 1811 to mid-1974.

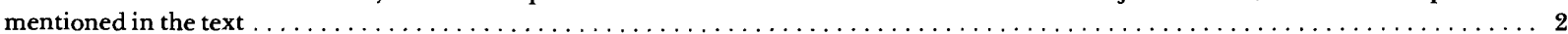

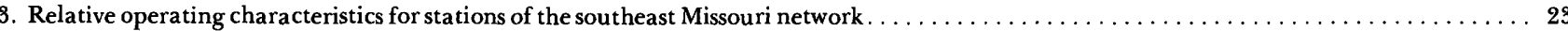

4. Epicenters of 731 earthquakes located in the southeast Missouri region in the 4-year period, $1 \mathrm{July} 1974$ to $30 \mathrm{June} 1978$........... 23

5. Epicenters of 626 earthquakes located within $1^{\circ} 30^{\prime} \times 1^{\circ} 30^{\prime}$ area of the network from 1 July 1974 to $30 \mathrm{June} 1978 \ldots \ldots 24$

6. Epicenters of earthquakes located in the $30^{\prime} \times 30^{\prime}$ region from New Madrid, Mo., to Ridgley, Tenn., near the station GRT (Gratio, Tenn.) . . 24

7. Cumulative number of earthquakes, Nc vs. $\mathrm{m}_{\mathrm{b}}$, for earthquakes occurring within the network during the 4-year period from 1 July 1974 to

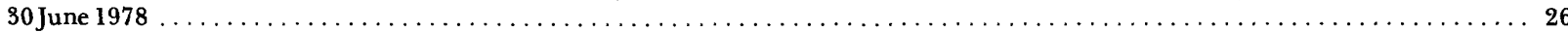

8. Focal-mechanism diagrams of the five earthquakes identified in Table 3 for which focal mechanisms have been determined by Herrmann and

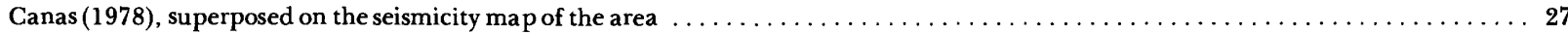

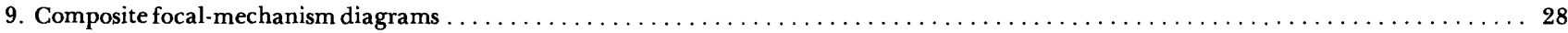

10. Model derived from an inversion using blocks having lateral dimensions of $30 \mathrm{~km}$ and thicknesses given in table $3 \ldots \ldots . \ldots . \ldots . \ldots$

\section{TABLES}

TABLE 1. Number of earthquakes during each quarter, Qi, versus $\mathbf{m}_{\mathbf{b}}$ located within the $1.5^{\circ} \times 1.5^{\circ}$ area of the network during the 4 -year period 1 July 1974 to 30 June 1978

2. Earthquake source parameters.

3. Initial model parameters for the crust and upper mantle beneath the New Madrid seismic zone 


\title{
PRESENT-DAY SEISMICITY AND IDENTIFICATION OF ACTIVE FAULTS IN THE NEW MADRID SEISMIC ZONE
}

\author{
By WILLIAM STAUDER ${ }^{1}$
}

\begin{abstract}
A regional seismic network was established in the New Madrid seismic zone in the summer of 1974 in order to study the seismicity of the region in detail. During the first 4 years of operation of the network, 731 earthquakes were located. These earthquakes are reported in quarterly bulletins, entitled Southeastern Missouri Regional Seismic Network Quarterly Bulletin.

The main features of the seismicity include a diffuse seismic activity over the regional area. Within the network are northeast-southwest trends of faulting, varying in length from $25 \mathrm{~km}$ to $120 \mathrm{~km}$, and extending from approximately Cairo, Ill., into northeastern Arkansas. There is a major offset in these trends in the region between New Madrid, Mo., and Ridgley, Tenn. The region of offset is that of greatest seismic activity and is the feature least well defined at the present time. The $b$ value, determined by the recurrence relation of $N_{c}$ vs. $m_{b}$ for low-magnitude earthquakes, is 0.78 .

Focal-mechanism studies indicate right-lateral, predominantly strike-slip motion on the major seismic trend extending from Ridgley, Tenn., into northeast Arkansas. A composite focal mechanism indicates reverse motion on a transverse trend extending from Ridgley southeastward into Tennessee. Application of the stochastic inversion procedures of Aki and others (1976, 1977 ) to the relative residuals of teleseismic $P$ waves yields a threedimensional velocity model in which a 5 percent decrease in velocity is found to exist in the region of the crust and upper mantle directly beneath the region of greatest seismic activity. The low-velocity zone extends at least 150 $\mathrm{km}$ into the upper mantle.
\end{abstract}

\section{INTRODUCTION}

In the preceding paper Nuttli has given a brief account of the larger earthquakes that have occurred in the central Mississippi valley, beginning with the three devastating earthquakes of the winter of 1811-12 and then considering 20 other damaging earthquakes that have occurred in the region from that date down to the present time. These 23 earthquakes are not isolated events, but a part of a continuing pattern of seismic activity. Yet while the region of southeast Missouri in particular has been recognized as one of potentially hazardous earthquakes, little has been known until recently of the seismotectonic character of the region. This paper briefly presents

'Department of Earth and Atmospheric Sciences, Saint Louis University, St. Louis, Mo. 63156. the seismic history of the region and then reviews what has been learned of its present-day seismic activity through the operation of a regional microearthquake array.

In addition to his paper in this volume, Nuttli (1979) recently completed another study dealing with the seismicity of the Central United States. He has drawn together into a single paper all that he could discover from published and unpublished sources about the seismic history of the Central States. The result includes a listing of 1,128 earthquakes and a consideration of the inferences that can be drawn from the distribution and magnitudes of these events. The study is based on intensity data. Through a relationship established between intensity and magnitude (Nuttli, 1974), however, Nuttli has attempted to include all known earthquakes of $m_{b} \geq 3.0$.

The central Mississippi valley region is bounded by lat $35^{\circ}$ and $39^{\circ} \mathrm{N}$. and by long $87^{\circ} 30^{\prime}$ and $91^{\circ} 30^{\prime} \mathrm{W}$. Nuttli's catalogue, which excludes aftershocks of the 1811-12 earthquakes, contains 488 earthquakes occurring within this $4^{\circ} \times 4^{\circ}$ region from the year 1811 to mid-1974. The epicenters of these events are shown in figure 1 , which indicates not only the presence of a few isolated larger or damaging events, but also the existence of a regular, more or less continuous seismic activity of lesser magnitude. A concentration of these events is found in the southeast Missouri region, extending along the Mississippi River from Cairo to Memphis, but earthquakes as large as $\mathrm{mb}_{\mathrm{b}}$ $=5$ are apt to occur almost anywhere throughout the region.

While Nuttli's study has enhanced the knowledge of the seismic history of the region, thus emphasizing the potential seismic hazard present there, it leaves questions about the detail of the seismotectonic activity of the region unanswered. Knowledge of faults is rudimentary at best, and prior to 1974 no active faults had been mapped in the area. In order to study the seismicity of the region in detail, then, a microearthquake network was established in the New Madrid seismic zone in the summer of 1974 . The network has now been in operation con. 


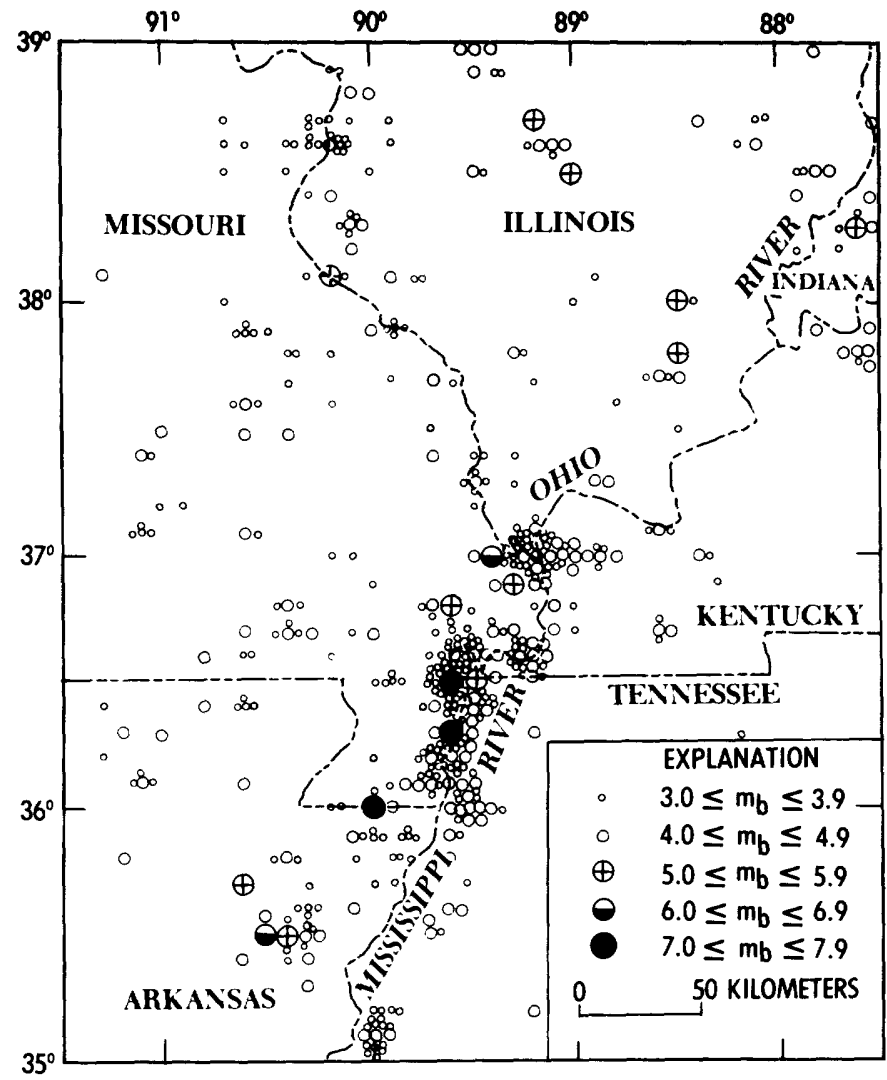

FIGURE 1.--Epicenters of 488 earthquakes of magnitude $m_{b}=3$ occurring in the central Mississippi valley from 1811 to mid-1974.

tinuously since that date. The remainder of this paper will be devoted to updating an earlier report on the network (Stauder and others, 1976) and to presenting the findings that have resulted from its operation.

\section{CHARACTERISTICS OF THE NETWORK}

The configuration of the microearthquake network is shown in figure 2 . The network itself consists of 16 stations. The instrumentation is of the standard design developed and supplied by the U.S. Geological Survey for regional microearthquake networks. Each remote station consists of a single package containing a short-period seismometer, a preamplifier/VCO, and a telemetry package. Signals are telemetered by radio link to a collection point, where they are retransmitted via phone line to the Seismic Data Center in the Department of Earth and Atmospheric Sciences of Saint Louis University. Recording is by Develocorder by monitor pen-andink recorders, and by slow-speed 16-channel magnetic tape recorders.
The selection of station sites was guided by an effort to cover the entire southeast Missouri region. In addition, the desirability of locating stations on the more competent rock on the edges of the Mississippi Embayment to the west and on the higher ground above the banks of the river to the east, off the seismically noisy Quaternary sediments of the alluvial plain, was considered. As a consequence the aperture of the network is relatively large; it is $120 \mathrm{~km}$ in width and $240 \mathrm{~km}$ in length, and has a station spacing of approximately $50 \mathrm{~km}$.

Before installation, each station was calibrated by placing the seismometer package on a precision, Geo-Techmanufactured shake table. The relative operating characteristic so obtained for a typical station is indicated in figure 3 . The maximum gain at $10 \mathrm{~Hz}$ for traces displayed on the Develocorder screen for stations on the Paleozoic carbonate rocks bordering the embayment is $1500 \mathrm{k}$. For stations located within the embayment, the gain at $10 \mathrm{~Hz}$ is $100-200 \mathrm{k}$. The network was designed to have a location capability for events occurring within the network down to a threshold of $m_{b}=1$.

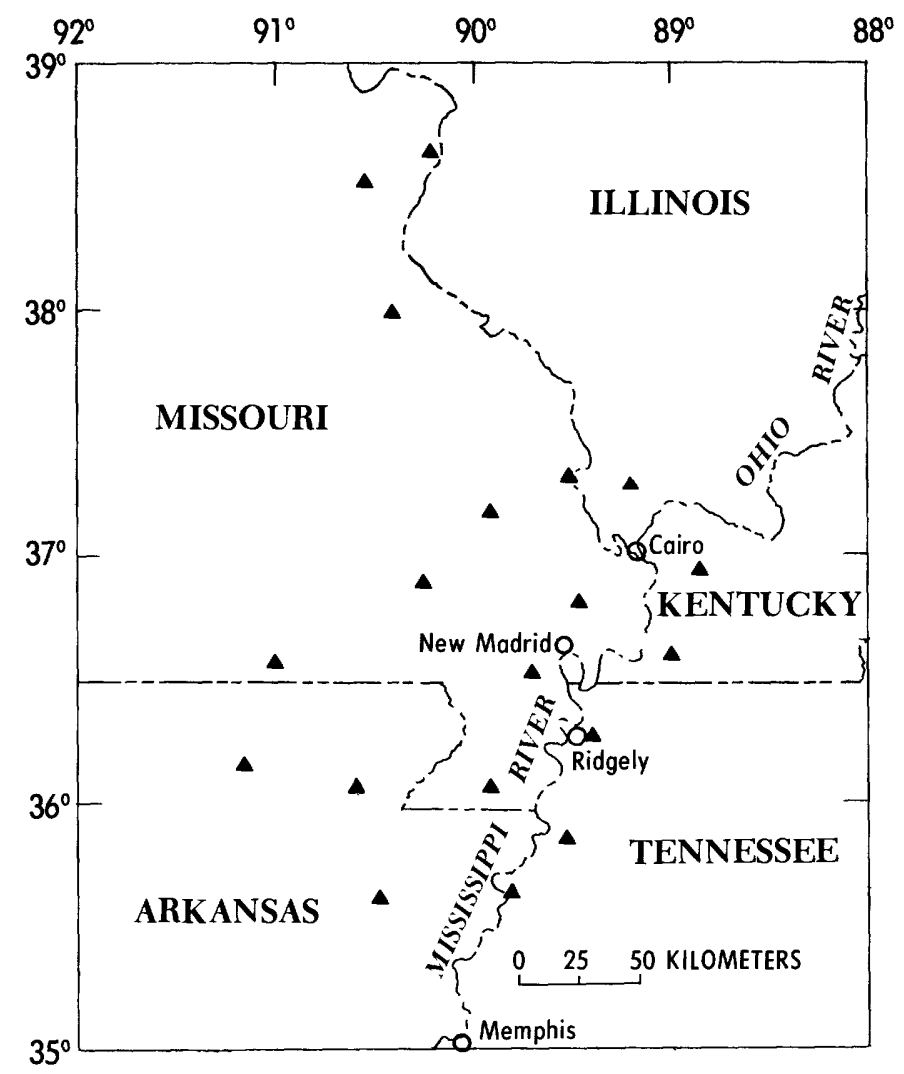

FIGURE 2. - Location of the Saint Louis University microearthquake network stations (triangles) in southeast Missouri and adjacent areas, and index map of cities mentioned in the text. 


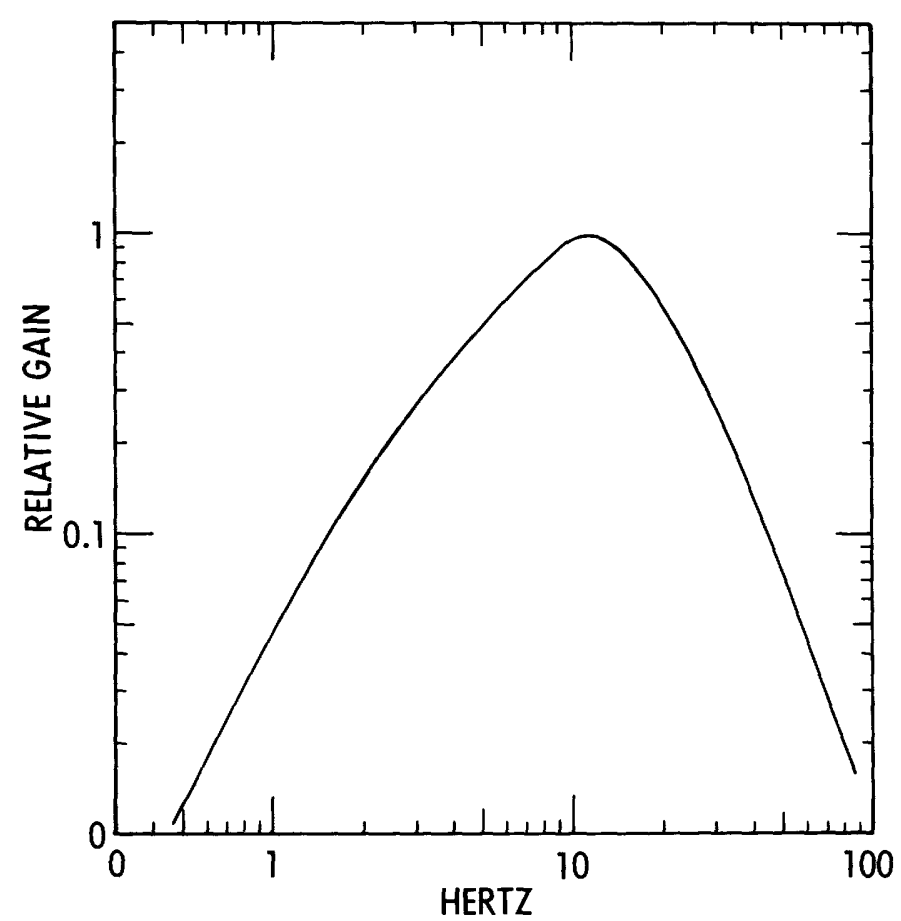

FIGURE 3.-- Relative operating characteristics for stations of the southeast Missouri network, as recorded on Develocorder.

\section{SEISMICITY STUDIES}

Figure 4 presents the epicenter locations for the period 1 July 1974 to 30 June 1978, the first 4 years of operation of the network. Epicenters have been located by means of the HYPO 71 program (Lee and Lahr, 1972) with adaptations to local crustal models. A network bulletin, the Southeastern Missouri Regional Seismic Network Quarterly Bulletin, lists the events located during each 3-month period. During the four-year period in question, 731 events were located.

Two observations can be made on examination of the distribution of epicenters in figure 4: first, epicenters are concentrated in the New Madrid region. In fact, 626 or approximately 85 percent of the events occur in this region of southeast Missouri, within the dimensions of the array. But second, epicenters are generally dispersed throughout the map area $\mathbf{D}$. More than 100 , or 15 percent of the events, occur outside the array. This latter feature is important for understanding the overall seismicity of the region. Earthquakes may occur almost anywhere throughout the region. Indeed, some of the larger, more recent events in Nuttli's catalogue (Nuttli, 1979) include the Centerville, Mo., earthquake $\left(\mathrm{m}_{\mathrm{b}}=4.9\right)$ of 16 October 1965 and the southeast Illinois earthquake $\left(\mathrm{m}_{\mathrm{b}}=5.5\right)$ of 9 November 1968, which occurred in the Ozark uplift region and in the Illinois basin, respectively. Nuttli estimates the maximum magnitude for these regions to be $\mathrm{m}_{b}=6.0$ in the St. Francois zone and $\mathrm{m}_{\mathrm{b}}=6.5$ in the Wabash valley zone.

Figure 5 presents the epicenter locations occurring inside a $1^{\circ} 30^{\prime} \times 1^{\circ} 30^{\prime}$ region within the array. As noted previously, 626 earthquakes were located within this region during the first 4 years of operation of the array. The spatial distribution of epicenters indicated on the figure has been noted in a previous publication (Stauder and others, 1976) and in the quarterly network bulletins. The pattern is coming to be a familiar one referred to by other authors in publications on the area. The familiarity of the pattern should not, however, detract from the recognition of its significance. While as yet incomplete, and hence in need of further documentation, the distribution of epicenters in figure 5 has identified the active seismic features of the New Madrid seismic zone and is providing a mapping of the active faults for the first time.

The features of figure 5 , worthy of comment, are as follows:

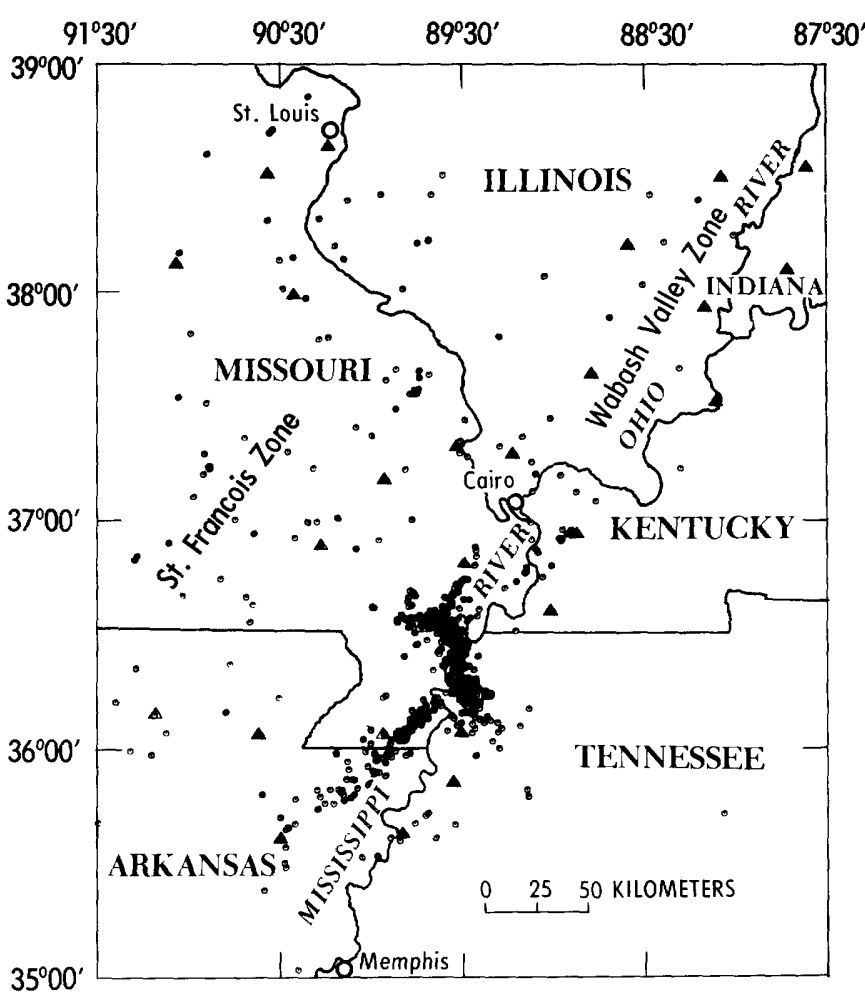

Figure 4.-- Epicenters of 731 earthquakes located in the southeast Missouri region in the 4 -year period, 1 July 1974 to 30 June 1978 . Triangles, station locations; dots, locations of epicenters. 


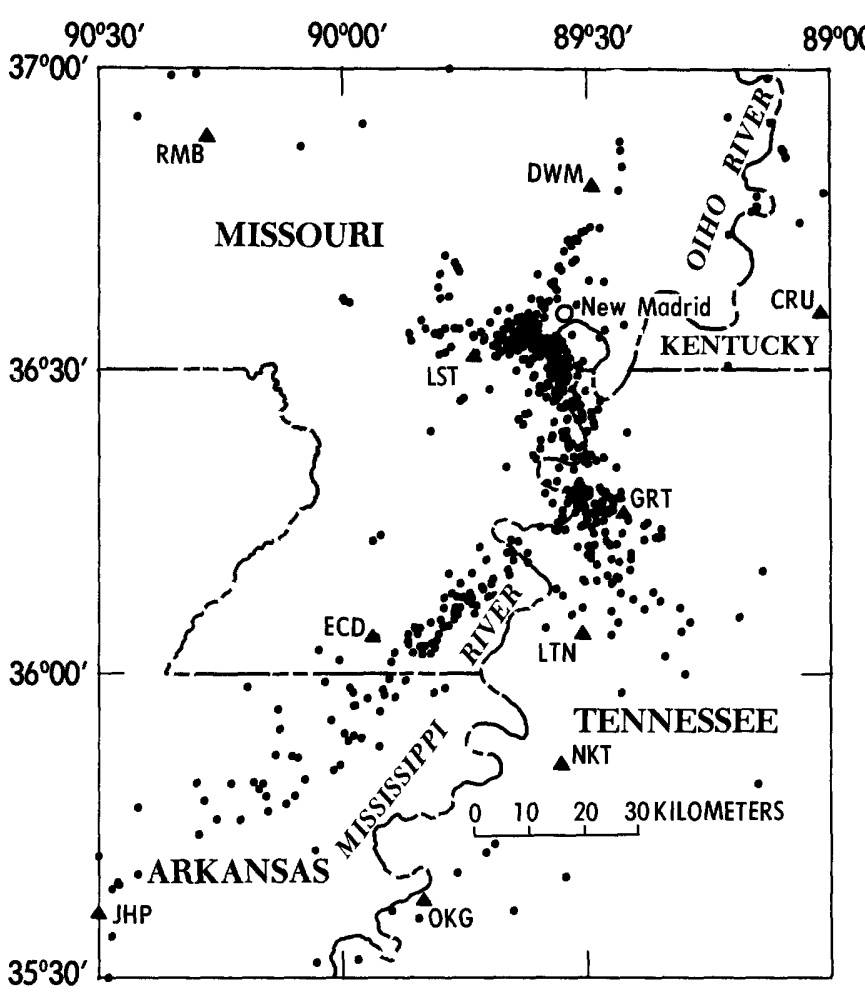

Figure 5. - Epicenters of 626 earthquakes located within $1^{\circ} 30^{\prime} \times 1^{\circ} 30^{\prime}$ area of the network from July 1974 to 30 June 1978. Triangles, station locations; dots, locations of epicenters. Station code: RMB, Rombauer, Mo.; DWM, Dogwood, Mo.; LST, Lone Star, Mo.; ECO, Elk Chute Ditch, Mo.; CRU, Crutchfield, Ky.; GRT, Gratio, Tenn.; LTN, Lennox, Tenn.; NKT, Nankipoo, Tenn.; OKG, Oak Grove, Tenn.; JHP, Judd Hill Plantation, Ark. Ridgley, Tenn., is located just west of the station GRT.

1. A major linear seismic trend about $120 \mathrm{~km}$ in length extends in a northeast-southwest direction from Ridgley, Tenn., near the station GRT, into north-eastern Arkansas.

2. To the north a lesser, parallel trend about $40 \mathrm{~km}$ in length extends from the station DWM toward the station LST.

3. A region of increased seismic activity, though as yet not well defined, exists in the offset region between the two trends just mentioned, extending from the New Madrid bend of the Mississippi River to the station GRT.

4. An apparent east-west trend extends from the New Madrid bend westward past the station LST.

5. Another, less active zone, parallel to the one mentioned in item 1 above and about $40 \mathrm{~km}$ to the east, passes through the line of the stations NKT- OKG.

6. A northwest-southeast trend extends from the Mississippi River, near GRT, into Tennessee.
7. A gap in the seismicity separates the trend just noted from the northern extremity of the principal northeast-southwest trend of item 1.

8. The earthquake activity terminates abruptly at either end, north and south, of the trends indicated, implying that the seismic regime of southeast Missouri is selfcontained within the latitude limits of $35^{\circ} 00^{\prime} \mathrm{N}$. and $37^{\circ} 00^{\prime} \mathrm{N}$.

While not noted on figure 5 , the region of offset between New Madrid and the station GRT (near Ridgley, Tenn.) is marked by a greater than average microearthquake activity. Each quarter, 40-80 earthquakes are detected at the stations GRT and LST that are not large enough to record at other stations, or at a sufficient number of stations to permit location. Nevertheless, their detection and number, even without location, indicate a high level of seismic activity in the offset region and direct attention to this region as one which merits further study.

Figure 6 presents the earthquake activity of this New Madrid-Ridgley region on a $30^{\prime} \times 30^{\prime}$ map. While some patterns might be pointed out (a general north-south distribu-

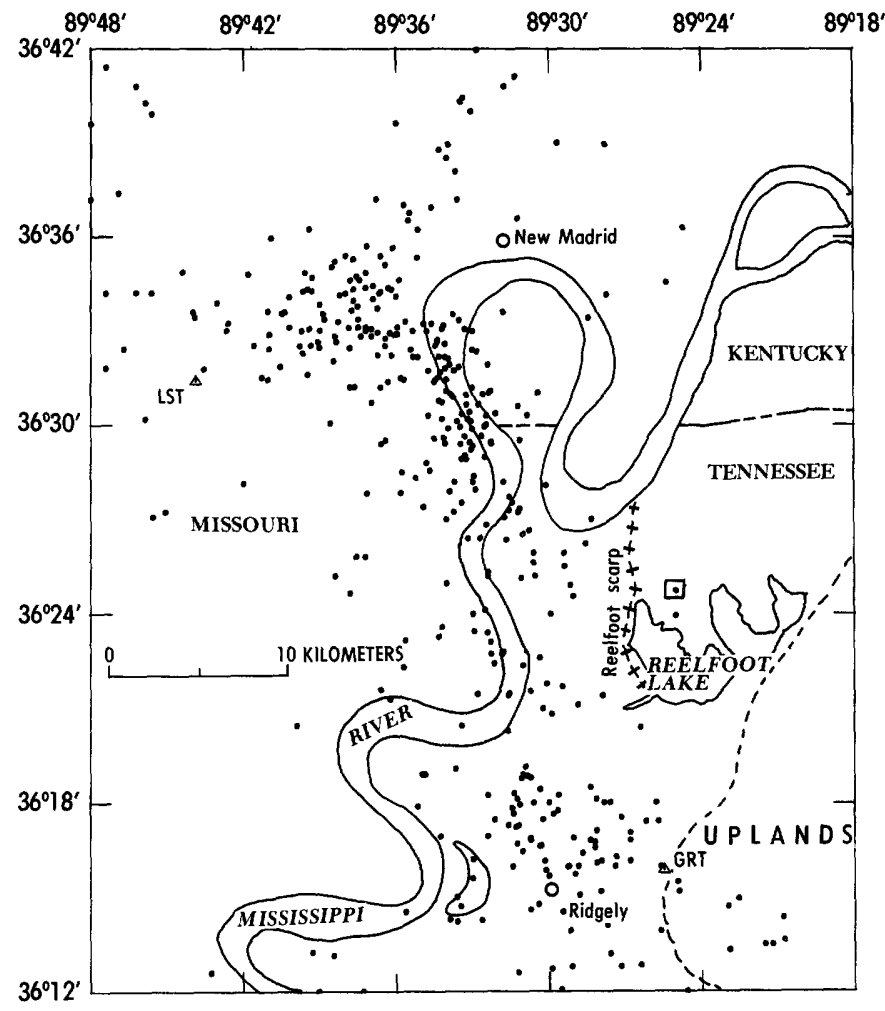

FIGURE 6. --Epicenters of earthquakes located in the $30^{\circ} \times 30^{\circ}$ region from New Madrid, Mo., to Ridgley, Tenn., near the station GRT (Gratio, Tenn.). Triangles, station locations; dots, locations of epicenters; square, location of USGS explosion; dashed line, edge of alluval plain. 
tion? or a series of echelon northwest-southeast trends?), the dispersion of the epicenters does not allow the identification of any distinct features at this time.

Two factors affect the interpretation of the distribution of the epicenters indicated in the figure. First, there is the accuracy of epicenter location. The standard deviation in the positiion of the epicenters is of the order of 0.5-1 km (see quarterly bulletins). Second, the station spacing of the array does not permit accuracy in the determination of the depth of focus of the earthquakes. Depth is routinely fixed at $5 \mathrm{~km}$ or at 10 $\mathrm{km}$. Even if the depth of focus is allowed to be determined freely by the HYPO 71 program, the resultant value is no better, statistically, than the fixed-depth solutions. While the pattern of epicenters in figure 6 is somewhat diffuse, it is not different from what might be expected for foci distributed on a dipping fault or on a system of dipping faults.

An understanding of the seismic activity in this offset region depends, then, upon an improvement in the capability of determining the location and depth of focus of the numerous small earthquakes that occur here. For this purpose the number of stations in the network is presently being increased and the station separation improved from approximately $50 \mathrm{~km}$ to $10-15 \mathrm{~km}$ throughout the region of seismic activity shown in figure 6 .

Some further information about the recent faulting and the seismicity of this region is known. Russ (1979) has conducted a trenching experiment across the Reelfoot scarp just west of Reelfoot Lake and has found evidence of three earthquakes near the trench site strong enough to liquefy sediments and generate surface faulting in the last 2,000 years. Zoback (1979) has reported the results of $32 \mathrm{~km}$ of seismic-reflection profiling in this same vicinity. This profiling has revealed numerous faults involving vertical motion in late Cenozoic and Cretaceous time; coincidence of surficial indicators of faulting with several of the subsurface offsets implies that Holocene activity probably has occurred as well. Jordan and others (1978) have reported results from a Vibroseis survey conducted in the vicinity of this same scarp and from a 4-week field study conducted using a dense micronet of temporary seismic stations deployed in the Reelfoot Lake area. Each of these projects was sponsored by the U.S. Geological Survey. The latter study included a calibration explosion detonated at the point indicated on the map of figure 6 . Signals from this explosion were detected by the Saint Louis University network, and the event was located as if it were an earthquake. With no prior knowledge of the location of the event itself, the computer solution yielded an epicenter distant $390 \mathrm{~m}$ to the east of the shot point for a solution constrained to 0 focal depth. An epicenter $75 \mathrm{~m}$ to the west of the shot point was obtained for a focus restrained to $5-\mathrm{km}$ depth, one $750 \mathrm{~m}$ to the south for a $10-\mathrm{km}$ focal depth, and one $550 \mathrm{~m}$ south for a freely determined depth of $8.6 \mathrm{~km}$. These calculations give empirical evidence of the accuracy of epicenter determination, noted above, of 0.5 to $1.0 \mathrm{~km}$. Finally, independent of the USGS group, a second micronet field experiment was conducted by Saint Louis University personnel during the spring of 1978 in the vicinity of Ridgley, Tenn. (Nicholson and Singh, 1979).

\section{RECURRENCE RATIO}

Table 1 lists the frequency of occurrence of the earthquakes that have been located during the 4-year period from 1 July 1974 to 30 June 1978 and whose epicenters lie within the $1^{\circ} 30^{\prime} \times 1^{\circ} 30^{\prime}$ area of the network, as listed in the quarterly bulletins. The table gives the number of earthquakes by halfmagnitude units and by each of the 16 quarters of network operation.

The bottom line of the table, which gives the total number of earthquakes located each quarter, indicates a variation in the rate of occurrence of the smaller earthquakes in the region. Over the 4-year period in question, the number of earthquakes located per quarter varies from a low of 23 to a high of 65 .

TABLE 1. - Number of earthquakes during each quarter, $Q_{a}$, vs. $m_{b}$ located within the $1.5^{\circ} x 1.5^{\circ}$ area of the network during the $4-y e a r$ period from 1 July 1974 to 3 June 1978

[ $N$, total number per $\mathrm{m}_{\mathrm{b}}$ range; $\mathrm{N}_{\mathrm{c}}$, cumulation number of events in the given $\mathrm{m}_{\mathrm{b}}$ range]

\begin{tabular}{|c|c|c|c|c|c|c|c|c|c|c|c|c|c|c|c|c|c|c|}
\hline $\mathrm{m}_{\mathrm{b}}$ & Q1 & Q2, & Q3 & Q4 & Q5 & Q6 & Q7 & Q8 & Q9 & Q10 & Q11 & Q12 & Q13 & Q14 & Q15 & Q16 & $\mathrm{N}$ & ${ }_{62 G}$ \\
\hline $\begin{array}{l}0.0-0.4 \\
0.5-0.9\end{array}$ & $\begin{array}{r}4 \\
26\end{array}$ & $\begin{array}{r}2 \\
18\end{array}$ & $\begin{array}{l}0 \\
9\end{array}$ & $\begin{array}{r}1 \\
10\end{array}$ & $\begin{array}{r}0 \\
12\end{array}$ & $\begin{array}{r}0 \\
21\end{array}$ & $\begin{array}{r}0 \\
14\end{array}$ & $\begin{array}{l}1 \\
9\end{array}$ & $\begin{array}{r}0 \\
10\end{array}$ & $8^{0}$ & $0^{0}$ & $3^{0}$ & $\begin{array}{l}0 \\
4\end{array}$ & $\begin{array}{l}0 \\
6\end{array}$ & $\begin{array}{l}0 \\
6\end{array}$ & $\begin{array}{r}0 \\
13\end{array}$ & $\begin{array}{r}4 \\
163\end{array}$ & $\begin{array}{l}626 \\
618\end{array}$ \\
\hline $1.0-1.4$ & 20 & 22 & 19 & 13 & 13 & 21 & 17 & 21 & 15 & 17 & 19 & 20 & 12 & 10 & 15 & 30 & 284 & 455 \\
\hline $1.5-1.9$ & 6 & 3 & 7 & 5 & 6 & 6 & 8 & 7 & 7 & 4 & 6 & 4 & 8 & 3 & 7 & 2 & 89 & 171 \\
\hline $2.0-2.4$ & 6 & 5 & 5 & 8 & 3 & 4 & 1 & 2 & 3 & 1 & 2 & 2 & 1 & 8 & 1 & 1 & 53 & 82 \\
\hline $2.5-2.9$ & 2 & 2 & 0 & 0 & 2 & 1 & 0 & 0 & 0 & 0 & 2 & 0 & 0 & 1 & 2 & 5 & 17 & 29 \\
\hline $3.0-3.4$ & 0 & 1 & 1 & 1 & 1 & 0 & 0 & 1 & 0 & 0 & 0 & 0 & 0 & 1 & 0 & 1 & 7 & 12 \\
\hline $3.5-3.9$ & 1 & 0 & 0 & 0 & 0 & 0 & 0 & 0 & 1 & 0 & 0 & 0 & 0 & 0 & 0 & 0 & 2 & 5 \\
\hline $4.0-4.4$ & 0 & 0 & 0 & 1 & 0 & 0 & 0 & 0 & 0 & 0 & 0 & 0 & 0 & 0 & 0 & 0 & 1 & 3 \\
\hline $4.5-4.9$ & 0 & 0 & 0 & 0 & 0 & 0 & 1 & 0 & 0 & 0 & 0 & 0 & 0 & 0 & 0 & 0 & 1 & 2 \\
\hline $5.0-5.5$ & 0 & 0 & 0 & 0 & 0 & 0 & 1 & 0 & 0 & 0 & 0 & 0 & 0 & 0 & 0 & 0 & 1 & 1 \\
\hline Total--- & 65 & 53 & 41 & 39 & 37 & 53 & 42 & 41 & 36 & 30 & 29 & 29 & 25 & 23 & 31 & 52 & 626 & \\
\hline
\end{tabular}


The last column of the table gives the cumulative frequency of earthquake occurrence by half-magnitude units. The same information is given in figure 7 in a semilogarithmic plot of $N_{C}$ vs. $m_{b}$. Examination of this figure shows, first, that the sensitivity of the network does indeed extend down to a location capability of $m_{b}=1$. Second, during the 4-year period some 500 events occurred having $m_{b} \geq 1$, while three events occurred having $m_{b} \geq 4$. These frequencies are similar to those found by Nuttli (1979) using the data from his historical catalogue of earthquakes for the New Madrid region.

The recurrence relation obtained by determining the leastsquares best fit to a straight line for the points for which $1 \leq \mathrm{m}_{\mathrm{b}} \leq 3.5$ is

$$
\log \mathrm{N}_{\mathrm{C}}=3.437 \pm 0.032-(0.783 \pm 0.013) \mathrm{mb}_{\mathrm{b}}
$$

It should be noted, however, that the $b$ value, $b=0.783$, of this relation is dependent on a magnitude scale developed for small local earthquakes and may not be applicable to larger earthquakes. Although the values of $N_{C}$ vs. $m_{b}$ seem to depart from the straight line at the lower end of the curve, this is attributable to a pair of earthquakes. These two earthquakes had $\mathrm{m}_{\mathrm{b}}=5.0$ and $\mathrm{m}_{\mathrm{b}}=4.5$; they occurred near the southern extremity of the active zone on 25 March 1976, during the seventh quarter of network operation. The period of observation has not been sufficiently long to establish the frequency of occurrence of events of this magnitude.

\section{FOCAL-MECHANISM STUDIES}

Using the data both from long-period surface waves and from P-wave first motion, Herrmann and Canas (1978) have determined the focal-mechanism solutions for five earthquakes that occurred within the region of the network. Table 2 lists the date of occurrence, location, origin time, and $\mathrm{m}_{\mathrm{b}}$ for each event, together with the orientation of the tension and compression axes of the focal mechanism.

The relation of all five earthquakes to the linear seismic trends identified above is indicated in figure 8 , in which the lower hemisphere focal-mechanism symbols are superimposed on the seismicity map of figure 5 . The solid quadrants of the mechanism diagrams correspond to a compression first motion of the $P$ wave, the open quadrants to a rarefaction first motion. Given that events 1 and 2 occurred prior to the installation of the network, at a time when location accuracy of the earthquakes in the region was probably not better than $6^{\prime}$, the correspondence between the focal mechanisms and the linear seismic trends is quite satisfactory.

The occurrence of events 1 and 3 near a point of convergence of three seismic trends makes it difficult to relate the

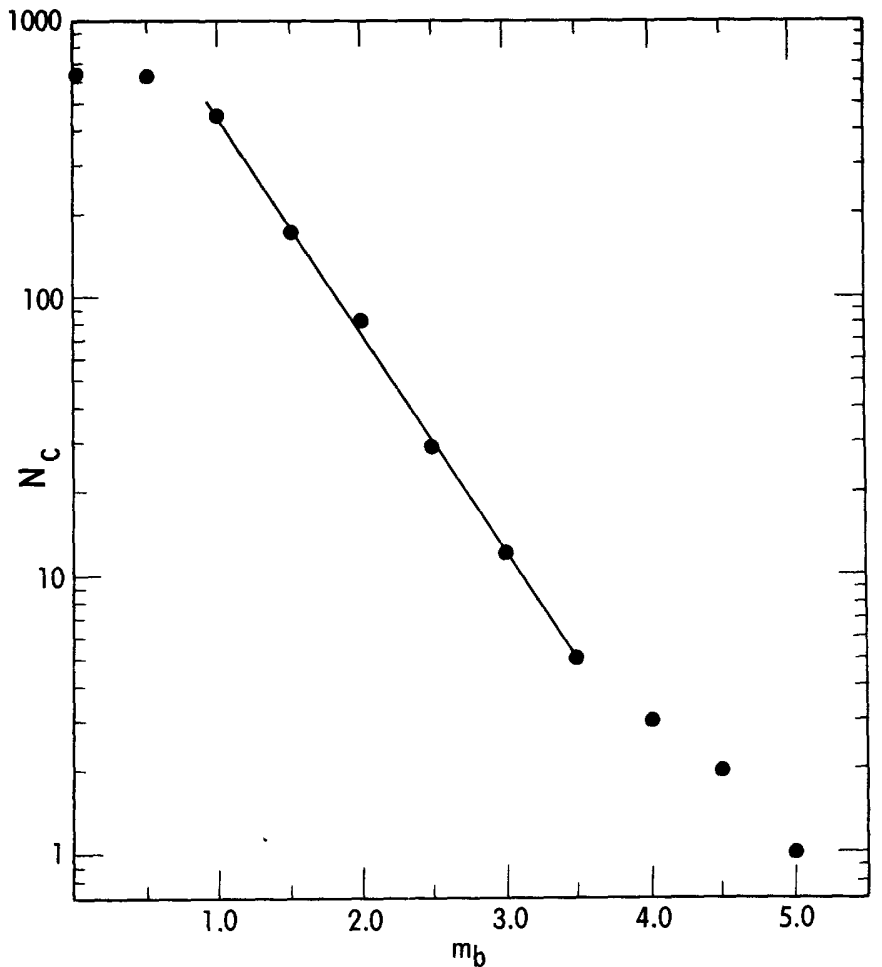

Figure 7.-Cumulative number of earthquakes, $N_{c}$ vs. $m_{b}$, for earthquakes occurring within the network during the 4-year period from 1 July 1974 to 30 June 1978.

nodal planes unambiguously to the fault motion at the source for these two earthquakes. The most likely identfication would seem to be a selection of the nodal plane striking east-west like the fault plane. In this case the mechanism diagrams indicate predominantly left-lateral strike-slip faulting along a fault dipping steeply to the south. The solutions for the two events are quite similar to one another.

Earthquakes 2, 4, and 5 occurred along the 120-km-long northeast- southwest seismic trend, which extends from near Ridgley, Tenn., into northeastern Arkansas. The first two of these earthquakes have almost identical focal mechanisms. On the basis of the seismicity pattern, the nodal plane striking northeast would be the fault plane. Earthquake number 5, which is an aftershock of earthquake number 4 , differs in its focal mechanism from that of the main event in the direction of dip of the northeast-trending nodal plane. An interpretation of right-lateral motion on a northeast-trending fault is common, however, to all three of these events occurring on this same seismicity trend. 


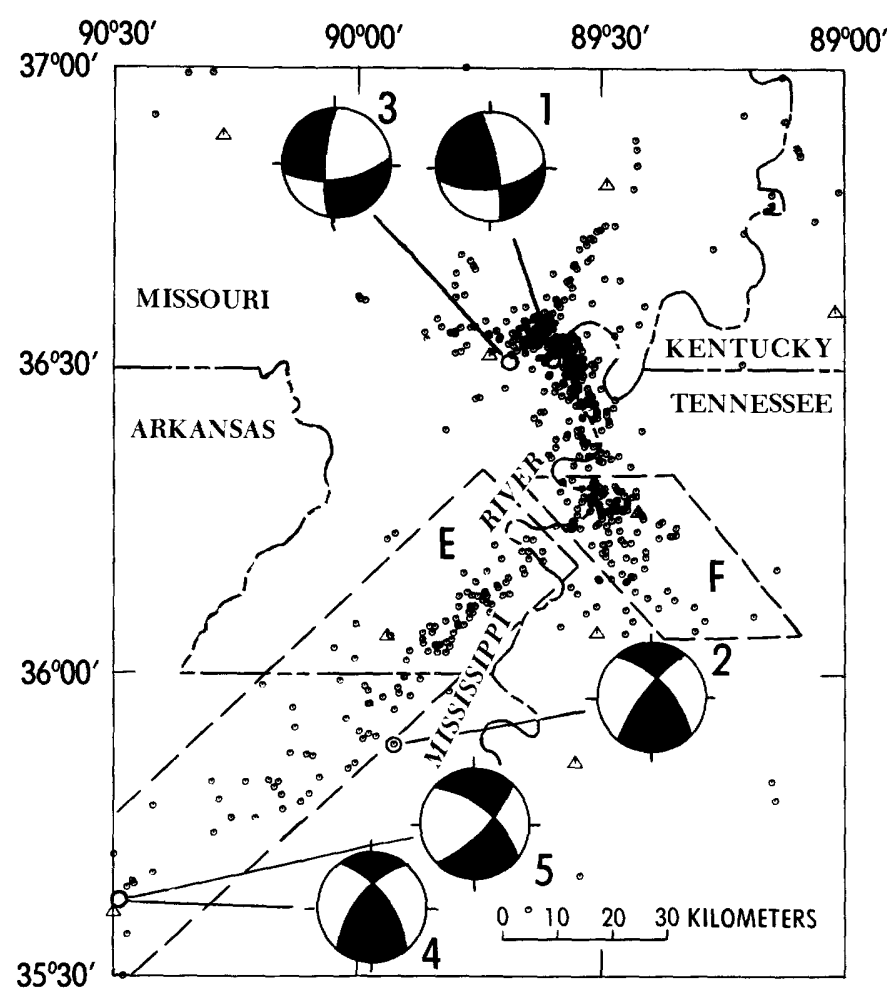

FIGURE 8. --Focal-mechanism diagrams (beach balls) of the five earthquakes (circles) identified in table 3 for which focal mechanisms have been determined by Herrmann and Canas (1978), superposed on the seismicity map of the area. Mechanism diagrams represent lower half of focal sphere; solid quadrants correspond to a compression first motion of the $\mathbf{P}$ wave, open quadrants to a rarefaction first motion. Triangles, station locations; dots, locations of epicenters. Dashed lines enclose zones $\mathrm{E}$ and $\mathrm{F}$, used for composite focal-mechanism solutions in figure 9

Herrmann and Canas (1978) included a determination of composite focal mechanisms in their study. For this they first delineated six possible linear segments or zones within the seis- micity pattern indicated in figure 5 . The first four of these zones were in the region north of the station GRT. The fifth segment, which they designated zone E, corresponds to the northeast- striking Tennessee-Arkansas trend. The sixth segment, their zone F, corresponds to the northwest-striking trend extending from GRT into Tennessee. Each of these latter zones is shown in figure 8. In the determination of the composite focal mechanisms, only stations with clear unambiguous directions of first motion were used. For the four northern zones, either because of the small number of usable data for each zone or because of the lack of definition of quadrants of compression and rarefaction first motion, the composite focal mechanisms that resulted were not satisfactory. More data are required, or a more appropriate definition of zones.

For zones $\mathrm{E}$ and $\mathrm{F}$, however, composite solutions were indicated that can be interpreted without too much difficulty. The composite solutions for these two zones are given in figures $9 \mathrm{~A}$ and $9 \mathrm{~B}$. For zone $\mathrm{E}$, as is evident in figure $9 \mathrm{~A}$, the composite solution may be either a simple vertical strike-slip mechanism or an oblique fault that has a significant component of right-lateral motion along a northeast-striking fault. This composite solution is in agreement with the combined surface wave-body wave focal-mechanism solutions by Herrmann and Canas (1978) for the three individual events along this trend, as discussed previously.

The correspondence between the individual focal mechanism of the three larger events and the composite focal mechanism obtained for events distributed along the entire length of the zone supports the hypothesis that this trend identifies a single fault feature that is active along its entire length.

The data of zone $\mathrm{F}$, in figure $9 \mathrm{~B}$, are interpreted as a northwest-trending reverse fault which agrees with the northwestsoutheast seismicity trend. The agreement between the composite focal-mechanism solution and the trend in seismicity identified visually by inspection of figure 5 would seem to confirm that the trend corresponds to a physical feature in the crust. The reverse motion on this presumed fault is consistent with strike-slip motion on the northeast trends.

TABLE 2. -- Earthquake source parameters

[OT, origin time (BMT); h, focal depth; Tr, trend; Pl, plunge]

\begin{tabular}{|c|c|c|c|c|c|c|c|c|c|c|c|c|}
\hline \multirow{3}{*}{ Event } & \multirow{2}{*}{\multicolumn{2}{|c|}{ Date }} & \multirow{3}{*}{$\frac{\text { Lat }{ }^{\circ} \mathrm{N}}{36.5}$} & \multirow{3}{*}{$\frac{\text { Long }{ }^{\circ} \mathrm{W}}{89.5}$} & \multirow{2}{*}{\multicolumn{2}{|c|}{ OT }} & \multirow{3}{*}{$\frac{\mathrm{m}_{\mathrm{b}}}{4.3}$} & \multirow{3}{*}{$\frac{\mathrm{h}(\mathrm{km})}{8}$} & \multirow{2}{*}{\multicolumn{2}{|c|}{$\operatorname{Tr} \frac{\mathrm{T} \text {-axis }}{\mathrm{P} 1}$}} & \multicolumn{2}{|c|}{ P-axis } \\
\hline & & & & & & & & & & & $\operatorname{Tr} \quad \mathrm{P}$ & \\
\hline & 2 & Feb 1962 & & & 06 & 43 & & & 301 & 28 & 43 & 19 \\
\hline 2 & 17 & Nov 1970 & 35.9 & 89.9 & 02 & 13 & 4.4 & 16 & 176 & 32 & 272 & 9 \\
\hline 3 & 13 & Jun 1975 & 36.5 & 89.7 & 22 & 40 & 4.2 & 9 & 313 & 8 & 49 & 34 \\
\hline 4 & 25 & Mar 1976 & 35.6 & 90.5 & 00 & 41 & 5.0 & 12 & 181 & 38 & 272 & 1 \\
\hline 5 & 25 & Mar 1976 & 35.6 & 90.5 & 01 & 00 & 4.5 & 16 & 174 & 13 & 271 & 28 \\
\hline
\end{tabular}



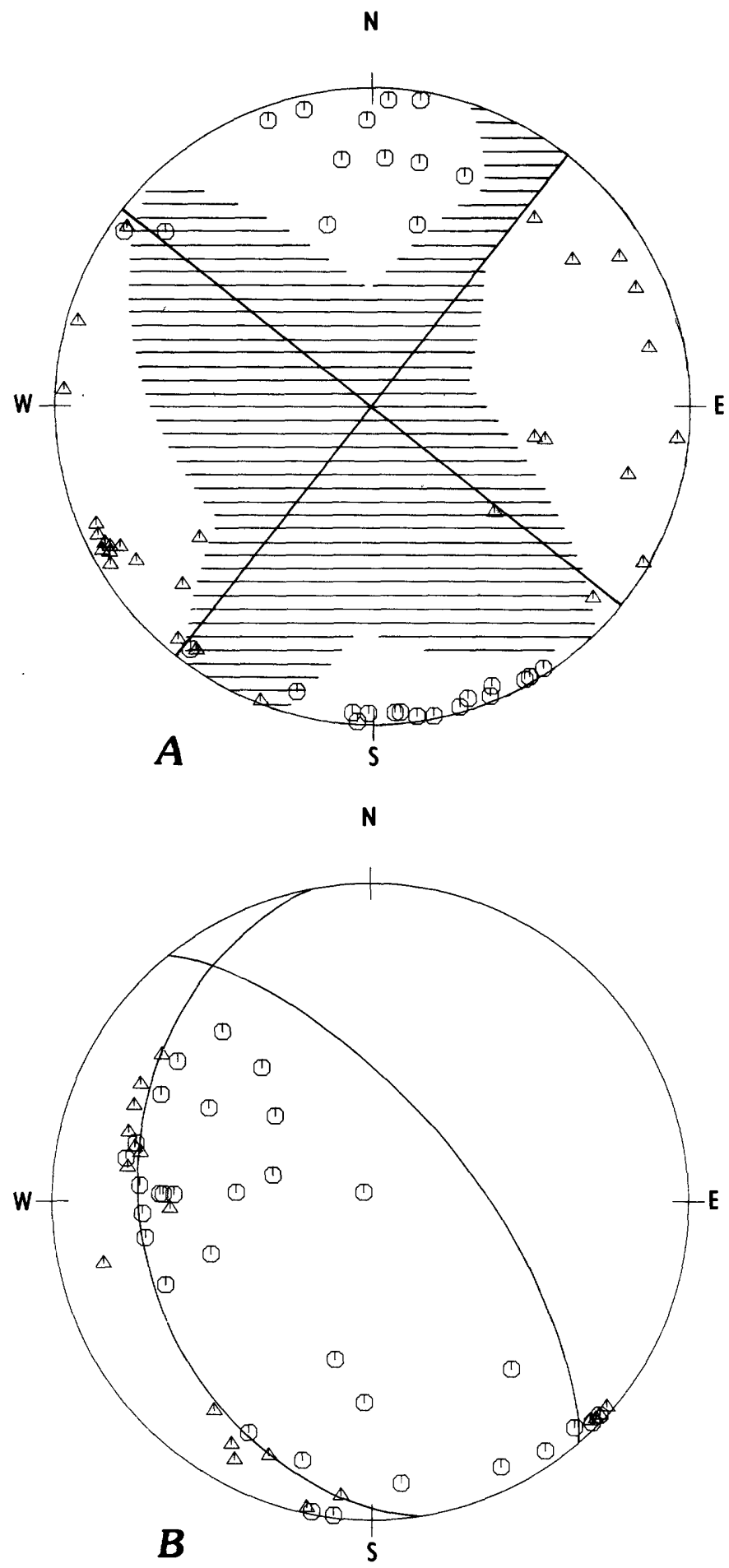

Figure 9. - Composite focal-mechanism diagrams. Circles, compression first motions of $P$ waves; triangles, rarefaction first motions. $A$, for Zone E, from Ridgley, Tenn., into northeastern Arkansas; $B$, for Zone F, from Ridgley southeastward into Tennessee.

\section{THREE-D VELOCITY MODEL}

Although the stations of the New Madrid network were designed to record seismic waves from local earthquakes and, hence, have a peak response at about $10 \mathrm{~Hz}$, the stations do operate at sufficiently high magnification that teleseimic $P$ waves for larger earthquakes are well recorded. Travel-time residuals relative to a selected reference station of the network varied over a range of about 1.5 seconds, from -0.5 seconds to +1.0 seconds, and a number of stations were found to be azimuth-dependent. This suggests a three-dimensional velocity structure in the crust and possibly in the upper mantle under the network.

Aki and others $(1976,1977)$ developed stochastic and generalized inversion procedures, using observations of this nature, for inferring lateral velocity changes within each of several layers. The procedures begin by assuming a simple plane-layered model, each layer of which is characterized by a constant velocity and is divided into a number of blocks, the number and size of which are determined by the area covered by the seismographic network and by the density of the stations. The method is restricted to obtaining velocity perturbations within individual layers; independent data are required to determine the average velocities in each layer.

Mitchell and others (1977) have applied the method of Aki and others to determine the three-dimensional velocity structure beneath the New Madrid network. Since the aperture of the network is moderately large and the station density is not great, blocks of relatively large lateral dimensions had to be used. A number of configurations were tried. The best results were found using a four-layer model consisting of blocks in each layer that are $30 \mathrm{~km}$ in horizontal dimension, cover the area of figure 5 , and extend northward another $70 \mathrm{~km}$ in a five by eight configuration.

The starting model was taken from Nuttli and others (1969) and is given in table 3. The resultant model is shown in figure 10. Positive numbers (percentages) indicate velocities that are less than the mean velocity in each layer and vice versa. The variation between highest and lowest values within each layer amounts to about 5 percent. The standard errors for this inversion are consistently between 0.2 and 0.3 for every block. The resolution was found to be poor for the crustal layers but good for both mantle layers.

The most interesting result of this inversion is the indication that a zone of low velocity exists below the region of most intensive seismic activity and that this zone extends from near the surface to depths of at least $150 \mathrm{~km}$. The velocities, as noted above, are about 5 percent lower than the velocities in the surrounding rock for each layer. The low-velocity zone appears to dip to the west and to become broader and more diffuse with increasing depth in the mantle. 
TABLE 3. -- Initial model parameters for the crust and upper mantle beneath the New Madrid seismic zone [From Nuttli and others, 1969]

\begin{tabular}{ccc}
\hline Layer & $\begin{array}{c}\text { Thickness } \\
(\mathrm{km})\end{array}$ & $\begin{array}{c}\text { P-wave velocity } \\
(\mathrm{km} / \mathrm{sec})\end{array}$ \\
\hline 1 & 20 & 6.15 \\
2 & 20 & 6.70 \\
3 & 57 & 8.18 \\
4 & 57 & 8.37 \\
\hline
\end{tabular}

\begin{tabular}{|c|c|}
\hline 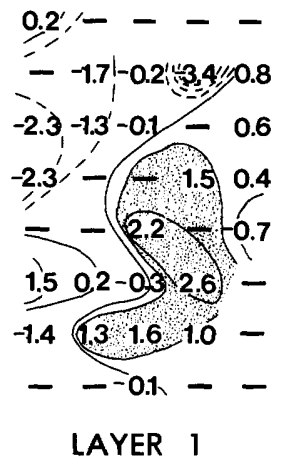 & 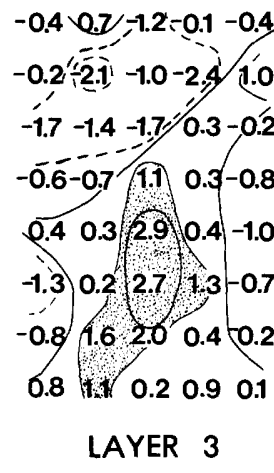 \\
\hline 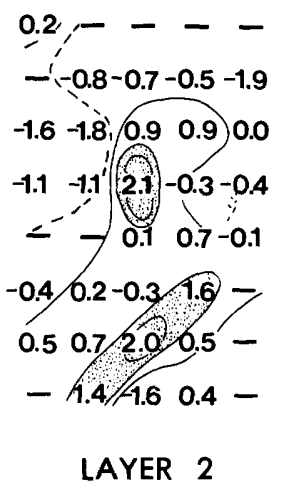 & 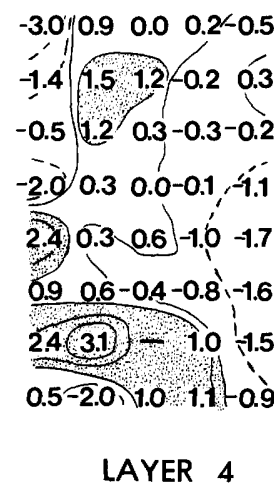 \\
\hline
\end{tabular}

FIGURE 10. - Model derived from an inversion using blocks having lateral dimensions of $30 \mathrm{~km}$ and thicknesses given in table 3 . The numbers are percent velocity perturbations from the average layer velocity; positive values (and solid contours) indicate lower than average velocities; negative numbers (and dashed contours) indicate higher than average velocities. Dashes indicate blocks for which no values are obtainable. Contours are drawn at 1 percent intervals. Shaded areas denote velocities that are more than 1 percent than average (from Mitchell and others, 1977).

\section{CONCLUSION AND DISCUSSION}

The operation of the microearthquake network in the New Madrid seismic zone has made it possible for the first time to map linear trends in the New Madrid seismic zone. Presumably these correspond to active faults in the region. The main features of the seismicity indicate two principal northeast- southwest-trending zones extending from Cairo, III., into northeastern Arkansas. These two zones are offset from one another in the region between New Madrid, Mo., and Ridgley, Tenn. The $b$ value, determined by a plot of $N_{C}$ vs. $m_{b}$ for 626 earthquakes that have occurred in the region over a 4-year period and using the scale developed for smallmagnitude local earthquakes, is 0.78 .

While the strikes of the linear features are fairly well determined, the density of stations of the network has not been appropriate to the present time to determine accurately the depth of focus of events that are located. Hence, threedimensional mapping of foci along the seismically active zones has not been possible. This stage of the seismicity studies will be pursued as soon as data are available from additional stations of the network that are presently being installed. A region of particular interest in this regard is between New Madrid, Mo., and Ridgley, Tenn. This is the region of greatest seismic activity and the one whose features are least resolved by the distribution of epicenters determined thus far.

The most prominent single feature is the northeast-southwest seismic trend extending from Ridgley, Tenn., into northeastern Arkansas. Individual focal-mechanism solutions for three earthquakes located two at the southern extremity and one in the middle of this trend; along with a composite focalmechanism solution from P-wave first motion for earthquakes occurring along the whole extent of this feature, these individual focal-mechanism solutions indicate uniform rightlateral, predominantly strike-slip motion. The dip of the fault is probably to the northwest, though verification of this conclusion awaits the study of additional events and the evidence which will be forthcoming relative to depth of focus of events occurring on this trend.

A composite focal mechanism for earthquakes occurring on a northwest-southeast trend extending from Ridgley, Tenn., into the interior of the State affirms a visual identification of this trend on the seismicity map and indicates that the motion on the fault is reverse in character. 
Finally, three-dimensional modeling, using data from the relative residuals of teleseismic $P$ waves and applying the inversion procedures of Aki and others (1976, 1977), indicates the existence of a low-velocity zone under the region of greatest seismic activity. This zone extends at least $150 \mathrm{~km}$ into the upper mantle. A question arises, naturally, concerning the nature of this zone and its possible relationship to the seismic activity that occurs in the crust above it. Mitchell and others (1977) remarked that a generic relationship may possibly exist between the low-velocity material in the lithosphere of this region and the occurrence of earthquakes there. If so, this discovery bears an important practical implication concerning the determination of earthquake risk in the Central and Eastern United States, and perhaps in seismic regions more generally.

\section{ACKNOWLEDGMENTS}

The research reported in this paper was supported by the Department of the Interior, U.S. Geological Survey, under Contracts 14-08-0001-14555, 15867, and 16708. The substance of the paper is drawn from the previously published papers of Stauder and others (1976), Herrmann and Canas (1978), and Mitchell and others (1977).

\section{REFERENCES CITED}

Aki, K., Christoffersson, A., and Husebye, E. S., 1976, Three-dimensional seismic structure of the lithosphere under Montana LASA: Seismological Society of America Bulletin, v. 66, p. 501-524.
1977, Determination of the three-dimensional seismic structure of the lithosphere: Journal of Geophysical Research, v. 82, p. 277-296. Herrmann, R.B., and Canas, J., 1978, Focal mechanism studies in the New Madrid seismic zone: Seismological Society of America Bulletin, v. 68 , p. 1095-1102.

Jordan, D., O'Connell, D., Coakley, J., Zoback, M. D., and Bufe, C. G., 1978, Microearthquakes near Reelfoot Lake, Tennessee (abs.): American Geophysical Union, 4th Annual Midwest Meeting, Program and Abstracts, Saint Louis University, p. 11.

Lee, W. K., and Lahr, J. C., 1972, HYPO71, a computer program for determining hypocenters: U.S. Geological Survey Open-file report, 100 p.

Mitchell, B. J., Cheng, C. C., and Stauder, William, 1977, A three dimensional velocity model of the lithosphere beneath the New Madrid seismic zone: Seismological Society of America Bulletin, v. 67, p. 1061-1074.

Nicholson, C., and Singh, S., 1979, A detailed microearthquake study of the New Madrid fault system's western Tennessee segment (abs.): Earthquake Notes, v. 49, p. 19.

Nuttli, O. W., 1974, Magnitude-recurrence relation for central Mississippi Valley earthquakes: Seismological Society of America Bulletin, v. 64, p. 1189-1207.

Nuttli, O. W., 1979, The seismicity of the Central United States, in geology in the siting of nuclear power plants: Geological Society of America, Reviews in Engineering Geology, v. 4, p. 67-93.

Nuttli, O. W., Stauder, William, and Kisslinger, C., 1969, Travel time tables for earthquakes in the Central United States: Earthquake Notes, v. 40 , p. $19-28$.

Russ, D. P., 1979 Late Holocene faulting and earthquake recurrence in the Reelfoot Lake area, northwestern Tennessee: Geological Society of America Bulletin, v. 90, pt. 1, p. 1013-1018.

Stauder, William, Kramer, M., Fischer, G., Schaeffer, S., and Morrissey, S. T., 1976, Seismic characteristics of southeast Missouri as indicated by a regional telemetered microearthquake array: Seismological Society of America Bulletin, v. 66, p. 1953-1964.

Zoback. M. D., 1979, Reactivation of Late Cretaceous faulting in the vicinity of Reelfoot Lake, northwestern Tennessee: Geological Society of America Bulletin, v. 90, no. pt. 1, p. 1019-1024. 


\section{Microearthquakes and Faulting in the Area of New Madrid, Missouri- Reelfoot Lake, Tennessee}

By DANIEL R. O'CONNELL, C. G. BUFE, and M. D. ZOBACK

INVESTIGATIONS OF THE NEW MADRID, MISSOURI, EARTHQUAKE REGION

GEOLOGICAL SURVEY PROFESSIONAL PAPER 1236 -D 


\section{CONTENTS}

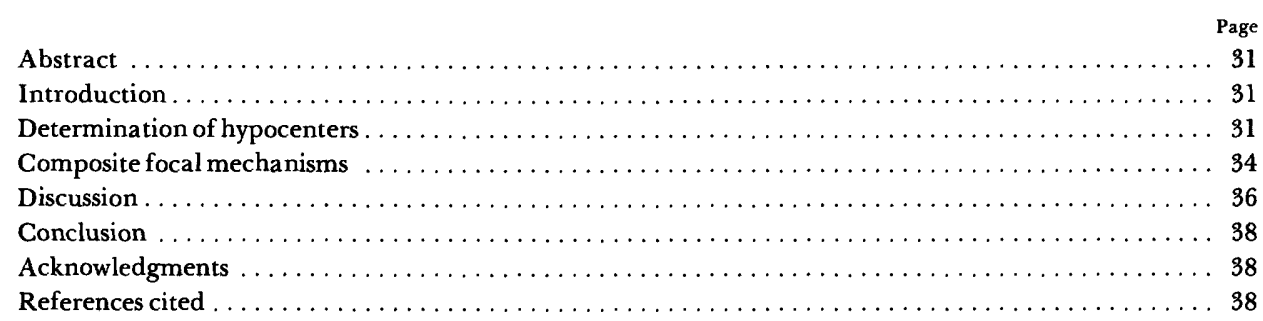

\section{ILLUSTRATIONS}

FIGURE 1. Map of nothern Mississippi Embayment region showing earthquake epicenters, plutons and rift boundaries, and faults ............ 32 2. Seismicity near Reelfoot Lake, Tenn., for the period from March 20, 1978, to May 7, 1978, and distribution of seismic stations used in this

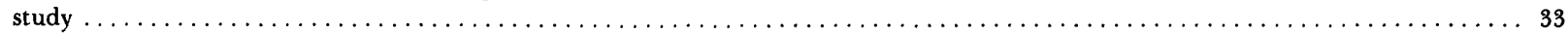

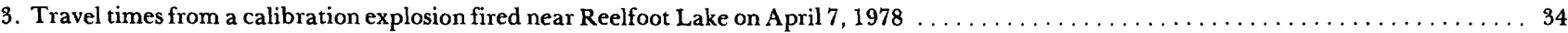

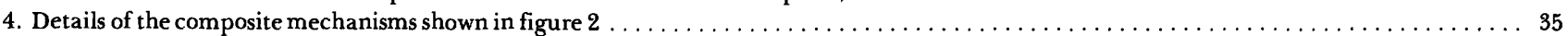

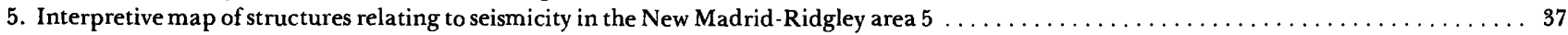

\section{TABLES}

TABLE 1. Hypocenter data for the USGS array, March-April 1978 


\title{
MICROEARTHQUAKES AND FAULTING IN THE AREA OF NEW MADRID, MISSOURI-REELFOOT LAKE, TENNESSEE
}

\author{
By Daniel R. O'Connell, Charles G. Bufe, and Mark D. Zoback
}

\begin{abstract}
A part of an ongoing investigation of the tectonic setting of the 1811-12 New Madrid earthquakes, the U.S. Geological Survey operated a dense network of 20 portable seismographs in the vicinity of Reelfoot Lake, Tenn., during a 6-week period in March-May 1978. Using readings from these instruments and from the Gratio Station of Saint Louis University, 23 earthquakes with magnitudes between -1 and +3 were located relative to a calibration shot fired near the lake. Most of the epicenters lie to the west of Reelfoot Lake in an 8-km-wide, north-northwest- trending strip extending from Ridgely, Tenn., to New Madrid, Mo.; focal depths range from 3 to 18 $\mathrm{km}$ and have a median depth of $7 \mathrm{~km}$. Composite focal mechanisms are varied, with the compressional axis shifting from east-west near Ridgely to northeast-southwest near New Madrid. The northeasterly compression may result from the left-stepping offset of the northeast-striking, right-lateral fault system near New Madrid.
\end{abstract}

\section{INTRODUCTION}

The southeastern Missouri earthquakes of 1811-12 were felt over a wide area of the Central and Eastern United States, Major deformation was induced in the surficial blanket of unconsolidated sediments in the epicentral region, but little is known of the orientation or sense of movement of the basement faults that produced these earthquakes.

The New Madrid seismic zone encompasses northeastern Arkansas, southeastern Missouri, southwestern Kentucky, and western Tennessee. Earthquakes in this region (fig. 1) are concentrated along three principal zones: (1) a 100-km-long linear zone that extends northeast from Marked Tree, Ark., to Caruthersville, Mo., approximately along the center of the rift structure defined by Hildenbrand and others (1977); (2) a zone of relatively more intense activity that extends from near Ridgely northward to west of New Madrid; and (3) a relatively short, northeast-trending zone that passes west of New Madrid. A recent microearthquake study (Herrmann and Canas, 1978) indicates a short east-west trend of seismicity starting just south of New Madrid and extending to the west. Two of the large 1811-12 earthquakes may have occurred in the northeast-trending zone along the rift axis, but the third and largest earthquake (February 7, 1812) probably occurred near New Madrid (Nuttli, 1973).

Hermann and Canas (1978) obtained both single-event and composite focal-plane mechanisms for earthquakes along the center of the rift southwest of New Madrid. These show primarily right- lateral strike-slip motion on a northeaststriking fault plane and thus correlate well with the axis of the rift structure. It is clear, however, that the zone of seismicity extending from near Ridgely to west of New Madrid is geologically and seismologically more complex.

Three of the linear zones of seismicity intersect immediately west of New Madrid. Efforts to obtain coherant composite focal mechanisms for microearthquakes in this zone, as well as in the zone of seismicity extending to Ridgely, have been largely unsuccessful owing to the complex distribution of $\mathbf{P}$-wave first motions (Herrmann and Canas, 1978) and sparse station density.

In an effort to reduce the uncertainty in hypocenter locations and determine the focal mechanisms for earthquakes in the zone extending from near Ridgely to New Madrid, the U.S. Geological Survey operated a dense network of 20 shortperiod seismic stations from March 20, 1978, to May 7, 1978, within the regional seismic network of Saint Louis University. Our objective was to study the processes related to currently active faulting in the New Madrid epicentral region by examining the distribution and focal mechanisms of microearthquakes occurring there today.

\section{DETERMINATION OF HYPOCENTERS}

Seismic data were recorded by 12 three-component, 5-day analog-magnetic-tape systems and 8 vertical-component smoked-drum seismographs. Station distribution is shown in figure 2. $P$ and $S$ arrivals were read from playbacks to 0.01 second, but the arrival-time uncertainty is often larger due to unclear onsets in the presence of variable, high-amplitude 


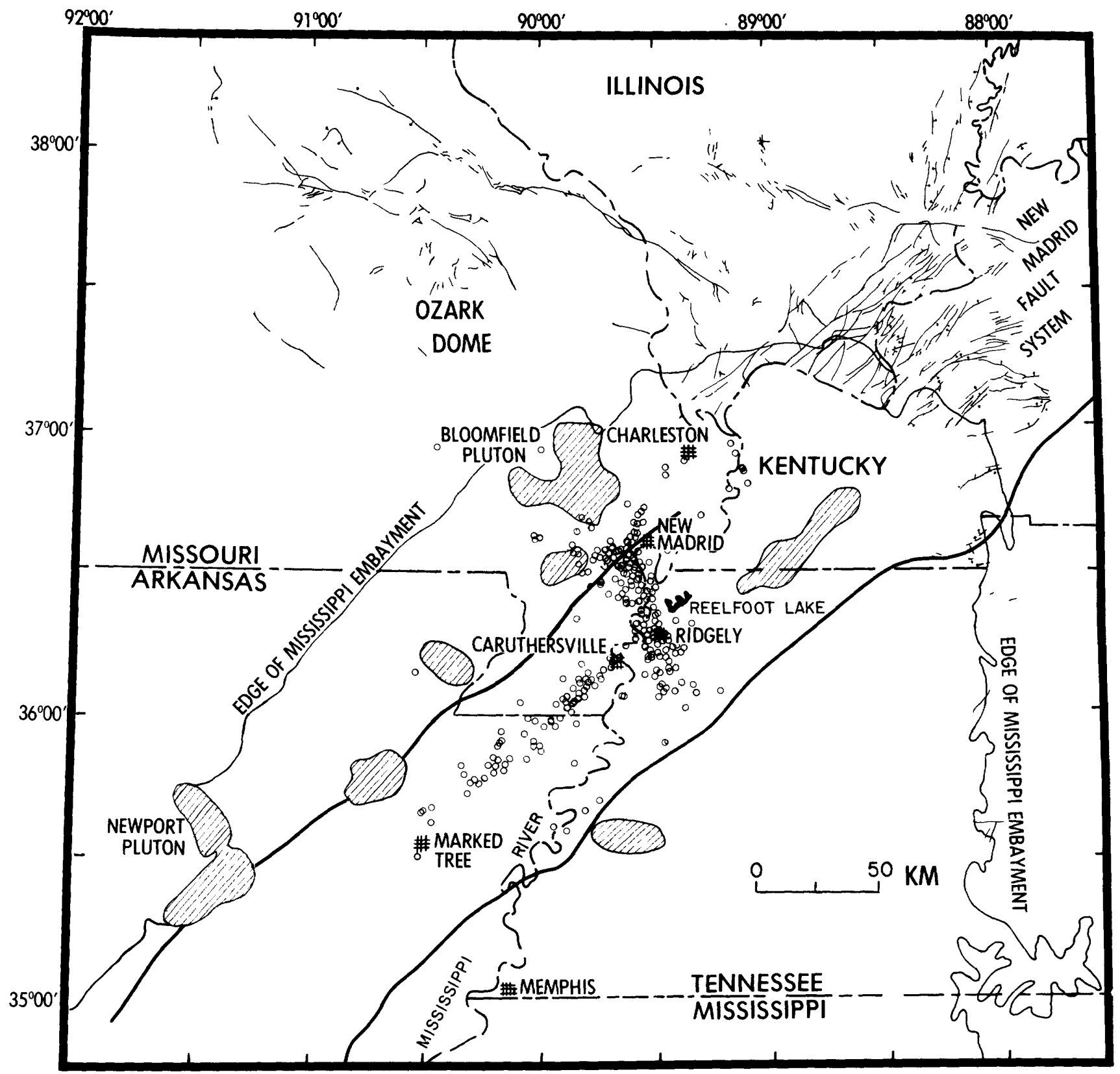

FIGURE 1. - Map of northern Mississippi Embayment region showing earthquake epicenters (open circles) (Stauder and others, 1979), plutons (line pattern) and rift boundaries (heavy solid lines) (Hildenbrand, 1979), and faults (fine solid lines) (Heyl and McKeown, 1978). Modified from oback and others (1980).

background noise. Hypocentral coordinates, origin time, depth, and first-motion plots were determined using the HYPOELLIPSE location program (Lahr, 1979). The earthquakes were located using a crustal model in which velocity increases linearly with depth. The velocity- depth relation is based on travel times (fig. 3) for a calibration explosion near Reelfoot Lake (location of calibration shot shown in fig. 2). Station corrections are based on residuals from the calibration shot, but have been modified slightly to reduce average station residuals. Coordinates of the shot point and its location as determined by the above model are listed in table 1 .

We located 23 earthquakes with magnitudes ranging from about -1 to 3. Magnitudes were determined from coda-length (T), using the relationship, $M=2.54 \log (T)-2.25$. The calculated depths range from 4 to $18 \mathrm{~km}$ and have a median depth of $7 \mathrm{~km}$ (table 1). The earthquake locations and composite focal-mechanism solutions for four groups of earthquakes are shown in figure 2. 


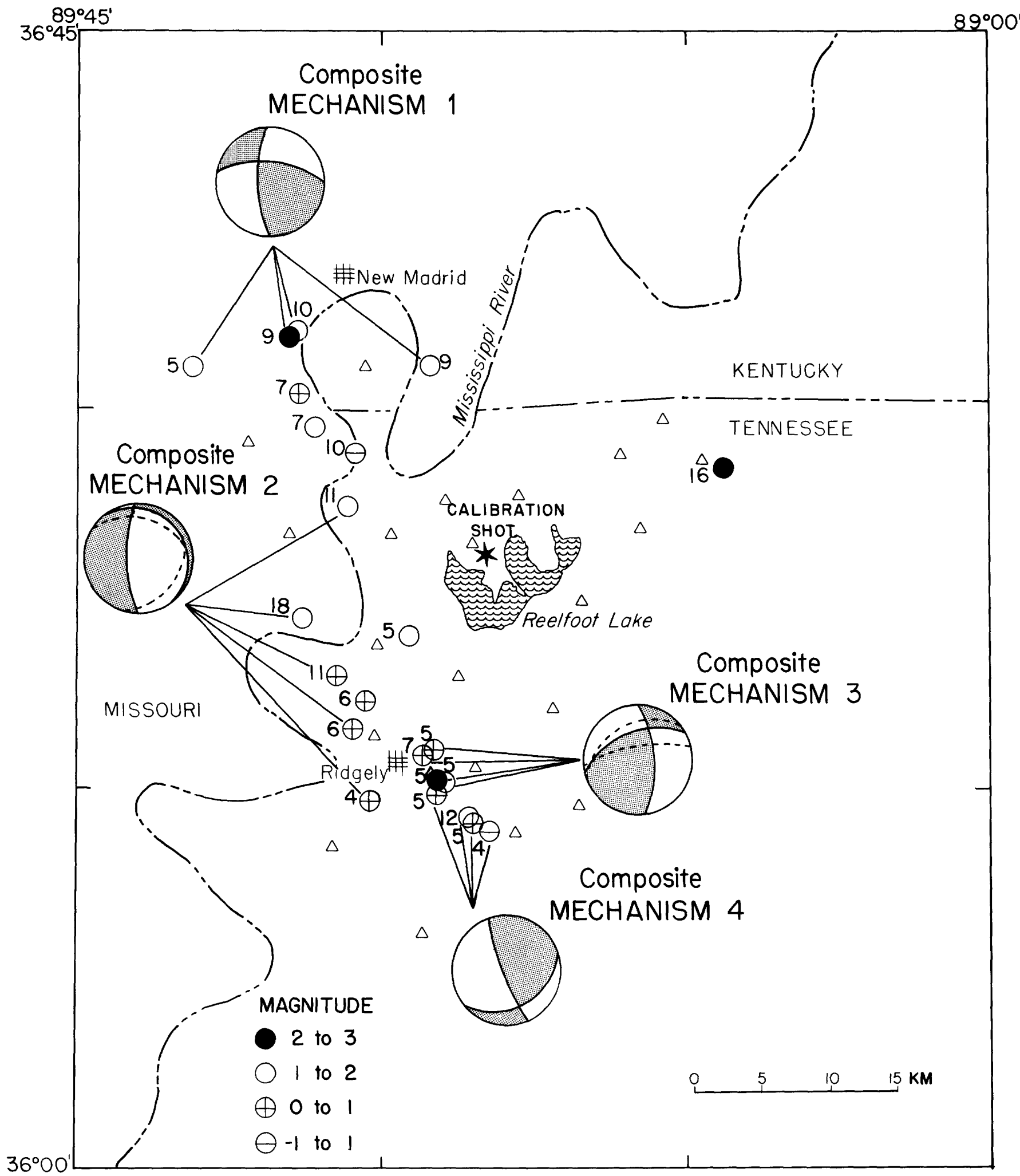

Figure 2.--Seismicity near Reelfoot Lake, Tenn., for the period from March 20, 1978, to May 7, 1978, and distribution of seismic stations used in this study. Open triangles represent temporary seismic stations operated between March and May. Star is the calibration-shot site. Numbers indicate depth in kilometers. Composite focal mechanisms are shown for four groups of events. Shaded areas on the spheres represent zones of compressional first motion; dashed lines in spheres indicate limits of position of the nodal planes. Details of the composite focal mechanisms are shown in figure 4. 
TABLE 1, - Hypocenter data for the USGS array, March-April 1978

[MAG, magnitude; NO, number of $P$ and $S$ readings used in locating the earthquake; GAP, largest azimuthal separation in degrees between stations, in degrees; DMIN, Distance in kilometers to the third-closest station; RMS, root mean square of $\mathbf{P}$ and $S$ time residuals in seconds; ERH, standard error of the epicenter in kilometers; ERZ, standard eror of the focal depth in kilometers; QS, solution quality of the hypocenter: A, excellent, B, good; C, average; D, bad; and MEC, composite focal mechanism number that includes this event; leaders (---) indicate no data. Location of the USGS calibration shot is $36^{\circ} 24.7 I^{\prime} \mathrm{N}$., $89^{\circ} 25.23^{\prime}$ 'W., depth $0.02 \mathrm{~km}$; shot occurred on April 7, 1978, at 7:35:37.11]

\begin{tabular}{|c|c|c|c|c|c|c|c|c|c|c|c|c|c|c|c|c|c|}
\hline Date & $\begin{array}{l}\text { Ori } \\
h\end{array}$ & $\begin{array}{l}\text { gin } \\
\text { min }\end{array}$ & $\begin{array}{r}\text { time } \\
s\end{array}$ & $\begin{array}{l}\text { Lat } \\
\text { degree }\end{array}$ & $\stackrel{\mathrm{N} .}{\mathrm{min}}$ & $\begin{array}{l}\text { Long } \\
\text { degree }\end{array}$ & $\begin{array}{l}\text { w. } \\
\text { min }\end{array}$ & $\begin{array}{c}\text { Depth } \\
\text { km }\end{array}$ & MAG & NO & GAP & DMIN & RMS & ERH & ERZ & QS & MEC \\
\hline \multicolumn{18}{|c|}{ Free solution for the USGS calibration shot } \\
\hline $04 / 07 / 78$ & 7 & 35 & 37.61 & 36 & 24.72 & 89 & 25.31 & 0.00 & 0.38 & 17 & 49 & 4.9 & 0.13 & 0.5 & 6.1 & B- & -- \\
\hline \multicolumn{18}{|c|}{ Hypocentral data } \\
\hline $03 / 21 / 78$ & 10 & 10 & 29.74 & 36 & 31.74 & 89 & 27.64 & 9 & 1.4 & 9 & 255 & 16.0 & 0.08 & 1.3 & 2.2 & C & $l$ \\
\hline $03 / 21 / 78$ & 15 & 54 & 29.51 & 36 & 13.60 & 89 & 25.33 & 5 & .1 & 7 & 225 & 10.4 & .06 & 1.5 & 3.4 & $\mathrm{C}$ & 4 \\
\hline $03 / 22 / 78$ & 11 & 45 & 21.17 & 36 & 13.76 & 89 & 25.79 & 12 & 1.3 & 12 & 154 & 8.9 & .19 & 1.9 & 3.4 & $\mathrm{C}$ & 4 \\
\hline $03 / 27 / 78$ & 8 & 18 & 16.78 & 36 & 26.02 & 89 & 31.95 & 11 & 1.2 & 18 & 112 & 10.2 & .13 & .9 & 1.4 & B & 2 \\
\hline $03 / 30 / 78$ & 7 & 33 & 12.45 & 36 & 31.66 & 89 & 39.42 & 5 & 1.4 & 14 & 310 & 23.0 & .13 & 2.1 & 1.4 & D & 1 \\
\hline $03 / 30 / 78$ & 23 & 2 & 38.03 & 36 & 15.24 & 89 & 27.22 & 5 & 3.0 & 20 & 122 & 5.5 & .14 & .9 & .9 & B & 3 \\
\hline $03 / 31 / 78$ & 6 & 25 & 22.97 & 36 & 32.90 & 89 & 34.13 & 10 & 1.7 & 30 & 259 & 15.9 & .16 & 1.1 & 1.3 & $\mathrm{C}$ & 1 \\
\hline $04 / 01 / 78$ & 23 & 34 & 18.03 & 36 & 32.75 & 89 & 33.66 & 9 & 2.1 & 19 & 270 & 16.6 & .17 & 1.6 & 2.0 & $\mathrm{C}$ & 1 \\
\hline $04 / 05 / 78$ & 15 & 43 & 33.48 & 36 & 21.73 & 89 & 33.98 & 18 & 1.3 & 14 & 209 & 14.0 & .15 & 2.1 & 1.8 & D & 2 \\
\hline $04 / 07 / 78$ & 5 & 56 & 5.95 & 36 & 15.07 & 89 & 26.95 & 5 & 1.4 & 19 & 120 & 6.0 & .05 & .3 & .4 & B & 3 \\
\hline $04 / 10 / 78$ & 7 & 40 & 16.89 & 36 & 29.12 & 89 & 33.47 & 7 & 1.2 & 15 & 186 & 13.9 & .13 & 1.0 & 2.1 & $\mathrm{C}$ & -- \\
\hline $04 / 16 / 78$ & 1 & 57 & 31.06 & 36 & 19.37 & 89 & 32.06 & 11 & .9 & 23 & 158 & 9.0 & .14 & 1.0 & 1.0 & $\mathrm{C}$ & 2 \\
\hline $04 / 20 / 78$ & 4 & 20 & 24.57 & 36 & 14.22 & 89 & 30.61 & 4 & .6 & 10 & 151 & 5.6 & .07 & 1.3 & 1.3 & C & 2 \\
\hline $04 / 20 / 78$ & 6 & 32 & 16.73 & 36 & 18.22 & 89 & 30.89 & 6 & .4 & 25 & 146 & 7.6 & .11 & .5 & 1.0 & B & -- \\
\hline $04 / 23 / 78$ & 20 & 26 & 56.36 & 36 & 30.41 & 89 & 34.18 & 7 & .8 & 12 & 235 & 13.5 & .06 & .8 & 1.2 & C & -- \\
\hline $04 / 29 / 78$ & 10 & 22 & 11.64 & 36 & 16.32 & 89 & 27.35 & 5 & .8 & 20 & 70 & 4.4 & .06 & .2 & .4 & A & 3 \\
\hline $04 / 29 / 78$ & 15 & 26 & 16.95 & 36 & 27.66 & 89 & 13.21 & 16 & 2.4 & 9 & 290 & 14.0 & .14 & 6.0 & 2.2 & D & - \\
\hline $04 / 30 / 78$ & 8 & 32 & 30.20 & 36 & 16.14 & 89 & 27.91 & 7 & .2 & 14 & 71 & 6.6 & .10 & .6 & 1.2 & A & 3 \\
\hline $05 / 03 / 78$ & 3 & 37 & 48.96 & 36 & 20.98 & 89 & 28.26 & 5 & 1.0 & 16 & 173 & 10.4 & .11 & .8 & 1.5 & B & -- \\
\hline $05 / 04 / 78$ & 23 & 29 & 14.59 & 36 & 14.72 & 89 & 27.14 & 5 & .6 & 14 & 160 & 8.2 & .07 & .4 & 1.0 & B & 4 \\
\hline $05 / 05 / 78$ & 4 & 1 & 54.88 & 36 & 28.09 & 89 & 31.24 & 10 & -1.2 & 9 & 214 & 12.5 & .05 & 1.0 & 1.2 & C & -- \\
\hline $05 / 05 / 78$ & 7 & 13 & 13.29 & 36 & 13.15 & 89 & 24.75 & 4 & -.5 & 6 & 285 & 11.7 & .13 & 9.1 & 11.8 & D & 4 \\
\hline $05 / 05 / 89$ & 23 & 50 & 45.45 & 36 & 17.18 & 89 & 31.40 & 6 & .5 & 11 & 194 & 9.0 & .15 & 3.5 & 5.7 & D & 2 \\
\hline
\end{tabular}

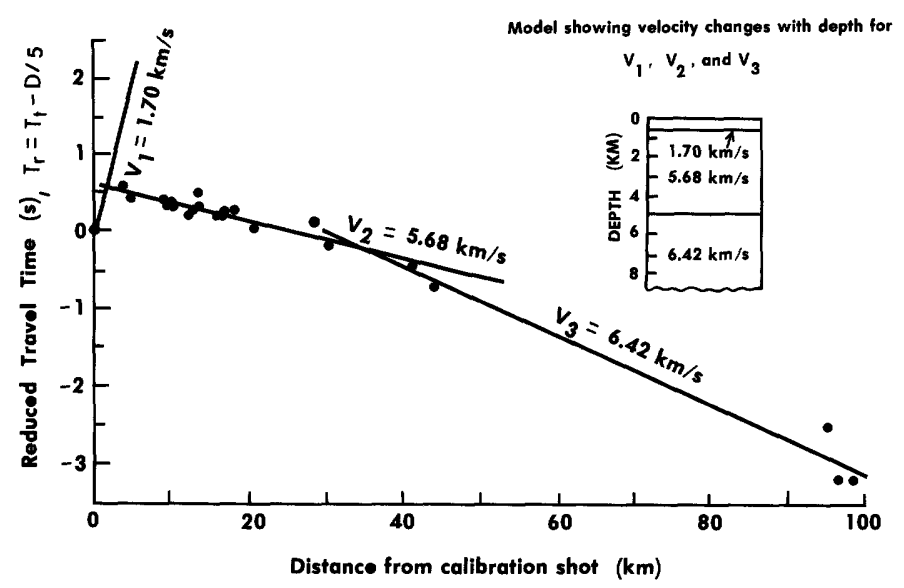

Figure 3. - Travel times from a calibration explosion fired near Reelfoot Lake on April 7, 1978. Layered-model interpretation of the travel-time data is shown. The $1.70 \mathrm{~km} / \mathrm{s}$ surface-layer velocity $\left(V_{1}\right)$ is based on well logs and reflection data. Earthquakes were located using the velocitydepth relation $\mathrm{V}=5.6+0.1 \mathrm{Z}$, where $\mathrm{Z}$ represents depth in kilometers.

\section{COMPOSITE FOCAL MECHANISMS}

The absence of sufficent first motions to obtain a unique focal mechanism for any one event forced us to use composite focal mechanisms. Only those records having unambiguous first motions were used. The first-motion data were plotted on a lower hemisphere, equal-area projection. The composite focal-mechanism solutions are shown in figure 4 , and the solution parameters are given in table 2 . The events used in each composite focal-mechanism solution have corresponding mechanism numbers in table 1 .

Initially we attempted to obtain a composite focal mechanism using all the earthquakes located. It was impossible to obtain a focal-mechanism solution without numerous contradictory points. We therefore attempted a composite solution using various groups of adjacent events. It is important to approach composite fault-plane solutions with caution because they are not unique. However, each of the composite focal-mechanism solutions in figure 4 contains only events that can be located on a plane nearly parallel to one of the nodal planes. All of the mechanisms are composed of four or more events, and no event in any mechanism was farther than $7 \mathrm{~km}$ from the nearest of the other events used in the same mechanism. Although several other combinations of events are possible, the four composite mechanisms shown in figure 4 are the most reasonable using the criteria described above. The three events located between those in mechanism 1 and 2 cannot be composited and were not included in either mechanism because of contradictory first motions. For the same reason the two events north of Ridgely (with depths of 4 and $6 \mathrm{~km}$ ) were not used in either mechanism 2 or 4 . 

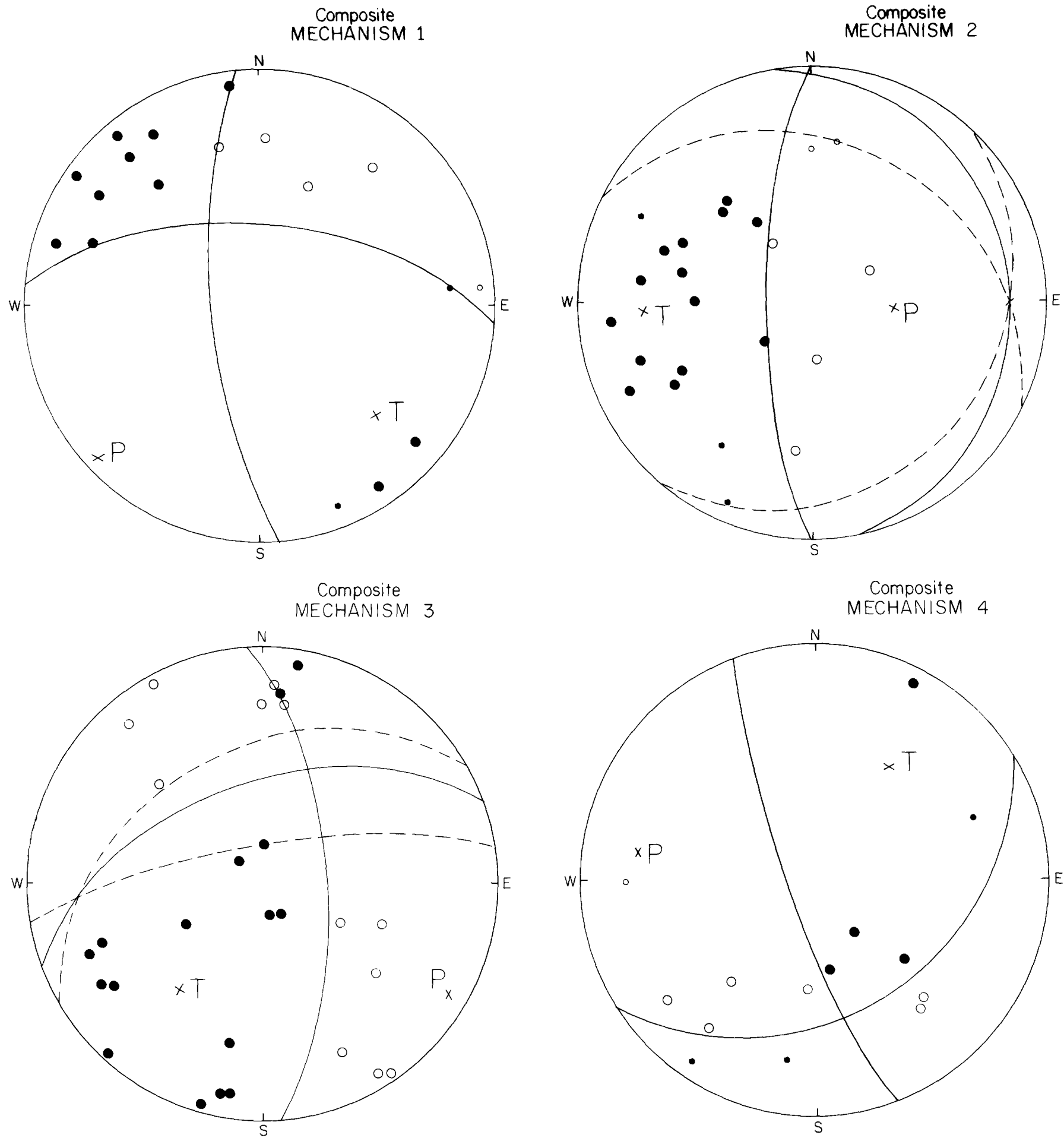

Figure 4. - Details of the composite mechanisms shown in figure 2. Closed circles are compressional arrivals, open circles are dilatational arrivals, and the smaller circles are weak arrivals. These are lower hemisphere equal-area projections. Solid lines are the nodal planes. Dashed lines delineate the limits of position of a nodal plane. $\mathrm{P}$ is the position of the compressional axis, and $\mathrm{T}$ is the position of the tensional axis.

Mechanism 1 contains tightly constrained nodal planes and $\mathbf{P}$ - and $\mathrm{T}$-axes. The orientations (azimuth, plunge) of the $\mathbf{P}$ and $\mathrm{T}$-axes are $\left(227^{\circ}, 6^{\circ}\right)$ and $\left(133^{\circ}, 33^{\circ}\right)$ respectively. The $\mathrm{N}$. $80^{\circ} \mathrm{W} ., 62^{\circ} \mathrm{N}$. nodal plane is designated as the fault plane, because the events in mechanism 1 lie on or near a plane that has this orientation. Components of inferred slip on this plane consist of left-lateral strike-slip and thrust with the north side up. Mechanism 1 is similar to the focal-mechanism solutions 
TABLE 2. - Focal-mechanism parameters

$[*$, all values reported in degrees represent an approximation of the orientation of the nodal plane, $\mathrm{P}$-axis, or $\mathrm{T}$-axis. The variability is described in the te $x t]$

\begin{tabular}{|c|c|c|c|c|c|c|}
\hline \multirow{2}{*}{$\begin{array}{l}\text { Composite } \\
\text { mechanism }\end{array}$} & \multicolumn{2}{|c|}{ Nodal Planes } & \multicolumn{2}{|c|}{ Pressure axis } & \multicolumn{2}{|c|}{ Tension axis } \\
\hline & Strike Dip & Strike Dip & Trend & Plunge & Trend & Plunge \\
\hline 1 & N. $5 \mathrm{~W}$. & N. 86 W. 62 N. & 227 & 6 & 133 & 33 \\
\hline 2 & N. $0 \mathrm{~W}$. & N. 30 W. 16 E.* & 94 & $61 *$ & 267 & $29 *$ \\
\hline 3 & N. $4 \mathrm{~W}$. & N. 70 E. $54 \mathrm{NW}$ ** & 120 & $8^{*}$ & 218 & $42 *$ \\
\hline 4 & N. 20 W. $80 \mathrm{Sw} . *$ & N. 58 E. 40 SE.* & 278 & $24 *$ & $34 *$ & $42 *$ \\
\hline
\end{tabular}

for the two earthquakes that Herrmann and Canas (1978) located south and southwest of New Madrid.

The events in mechanism 2 yield a solution that has one well-constrained nodal plane trending north and dipping steeply to the west. It is assumed to be the fault plane because it coincides with the locations of the events in the group. The indicated motion is down on the west side. A second nodal plane is poorly constrained; its possible strike and dip range from N. $65^{\circ} \mathrm{W}$. $\left(31^{\circ} \mathrm{NE}\right.$.) to N. $42^{\circ} \mathrm{E}$. $\left(21^{\circ} \mathrm{SE}\right.$.). The orientation of $\mathrm{P}$ varies from $\left(80^{\circ}, 44^{\circ}\right)$ to $\left(114^{\circ}, 39^{\circ}\right)$, and $\mathrm{T}$ varies from $\left(286^{\circ}, 44^{\circ}\right)$ to $\left(388^{\circ}, 40^{\circ}\right)$.

Mechanism 3 contains one tightly constrained nodal plane striking $\mathrm{N} .4^{\circ} \mathrm{W}$. and a second nodal plane that is not well constrained (a range of orientation of about $22^{\circ}$ is possible). The orientation of $P$ varies from $\left(111^{\circ}, 14^{\circ}\right)$, to $\left(131^{\circ},-4^{\circ}\right)$, and $\mathrm{T}$ varies from $\left(220^{\circ}, 55^{\circ}\right)$ to $\left(220^{\circ}, 28^{\circ}\right)$. Although the selection of the fault plane is slightly ambiguous, the choice of the north-striking nodal plane is the more reasonable, and the indicated motion on this plane has components of thrust (east side up) and left-lateral strike-slip.

Each nodal plane in mechanism 4 can vary over a range of $\pm 12^{\circ}$. This variation alters the nature of the solution very little, with the result that the $\mathrm{P}$ - and $\mathrm{T}$-axes change by less than $5^{\circ}$. The orientation of $\mathrm{P}$ varies from $\left(279^{\circ}, 21^{\circ}\right)$ to $\left(285^{\circ}\right.$, $\left.18^{\circ}\right)$, and $\mathrm{T}$ varies from $\left(30^{\circ}, 38^{\circ}\right)$ to $\left(34^{\circ}, 40^{\circ}\right)$. The steeply dipping nodal plane trending $\mathrm{N} .20^{\circ} \mathrm{W}$. is assumed to be the correct fault plane because it contains both the shallow and deep events and matches the trend of seismicity of the events. The indicated motion has components of thrust (southwest side up) and left-lateral strike-slip.

One of the clearest trends of the seismicity pattern is north to northwest through Ridgely; it includes the composite events that led to mechanisms 2, 3, and 4. It was not possible to combine any events used in mechanism 3 with the events used in mechanism 4 without producing one or more points of contradiction (and vice versa). Also, none of the events used in mechanism 3 was compatible with those in mechanism 2 .

\section{DISCUSSION}

Figure 5 is an interpretative structure map of this region that presents various types of data. We suggest that deformation in this region generally results from right-lateral strike- slip motion on two northeast-southwest-striking faults. The major fault is located southwest of Ridgely and trends down the center of the basement rift; the second fault is located north of New Madrid and trends northeast toward Charleston, Mo. The area between New Madrid and Ridgely is a zone of complex deformation in which both lateral and vertical motion occur on a variety of fault planes.

Figure 5 presents faults interpreted on the basis of the earthquakes discussed above, seismic-reflection profiling (Zoback and others, 1980), and the focal-mechanism studies of Herrmann (1979) and Herrmann and Canas (1978). In terms of the interpretation just discussed, note that mechanism 1, with its left-lateral strike-slip component of motion, appears to be a conjugate fault to the right-lateral, northeast-trending fault north of New Madrid. Similarly, mechanisms 3 and 4 seem to define subparallel, left-lateral faults conjugate to the major rift fault. Figure 5 also compares these faults with local topographic features described by Stearns (1979). The Tiptonville dome lies between the Reelfoot Fault and the surface projection of the fault plane defined by mechanism 2 . Thus, this uplift may result from vertical movements on these two faults. Stearns (1979) has estimated that Tiptonville dome has been uplifted about $6 \mathrm{~km}$ in the last 1400 years. The topographic high known as the Ridgely Ridge also may reflect vertical fault motion, as it lies on the upthrown block between the Ridgely and Cottonwood Grove faults.

The focal mechanisms of Herrmann and Canas (1978) and the surface-wave focal mechanisms of Herrmann (1979) indicate that the New Madrid seismic zone is located in an area of regional east-west to northeast-southwest compression. The orientations of the $\mathbf{P}$-axes of our composite focal mechanisms southwest are generally consistent with relative east-west or northeast- southwest compression. Composite focal mechanism 1 indicates northeasterly compression near New Madrid, which is in agreement with the focal mechanisms of two earthquakes located just south and southwest of New Madrid by Herrmann and Canas (1978). Composite focal mechanisms 3 and 4 are indicative of relative east-west compression near Ridgely, and earthquakes located along the 100-km-long rift southeast of Ridgely all have focal-plane solutions that indicate east-west compression (Herrmann, 1979). This suggests that from Ridgely to the southwest the maximum compressive stress is fairly uniform and oriented nearly east-west. In the area north of New Madrid, east-west compression is also indicated. Both the south-central Illinois 


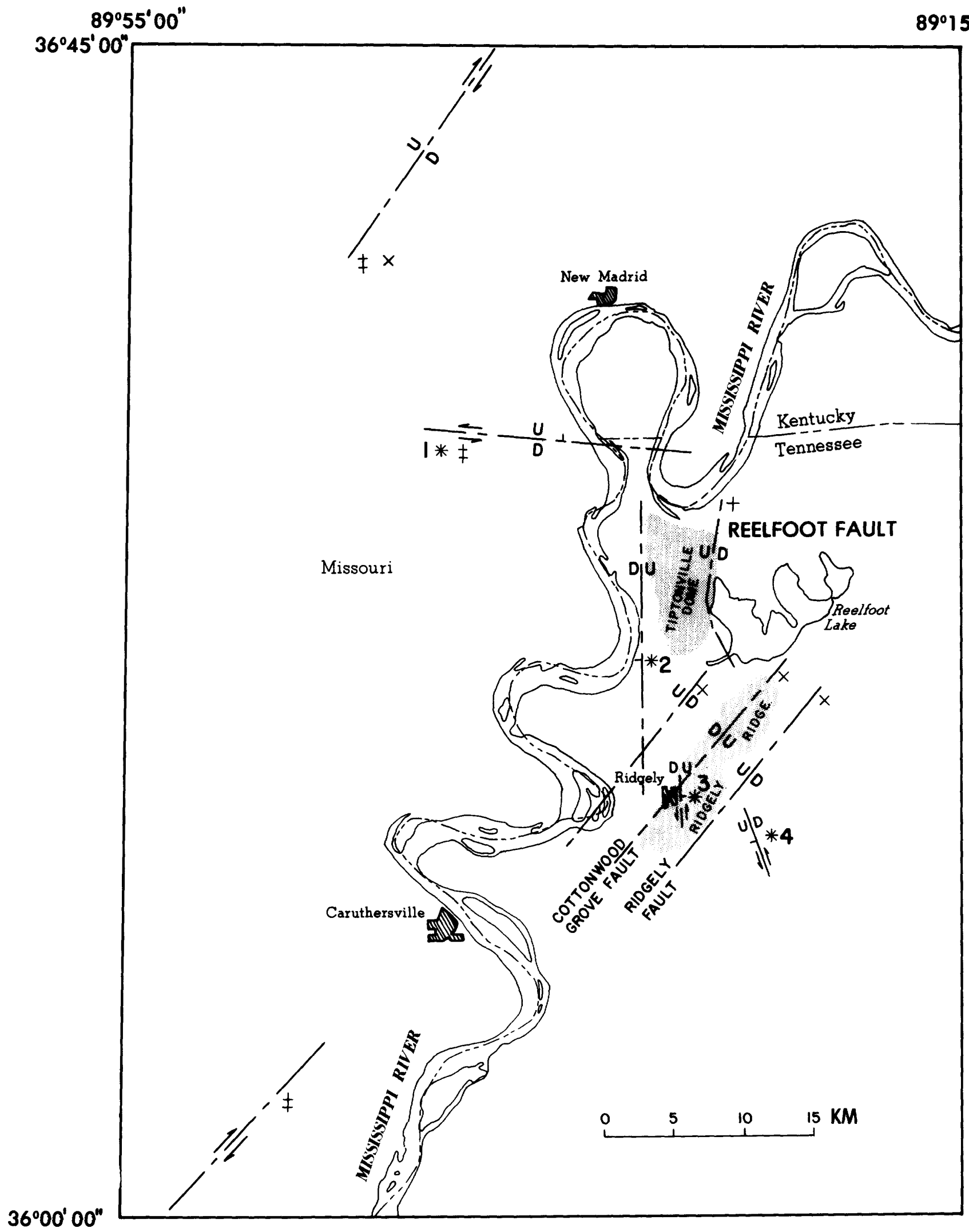

Figure 5. -- Interpretive map of structures relating to seismicity in the New Madrid-Ridgely area. Long dashed lines represent faults inferred from focal-plane solutions, and long and short dashed lines represent faults inferred from seismic-reflection profiles; U, upthrown side; D, downthrown side; arrows indicate relative motion. A short dash perpendicular to the line indicates the direction of dip. Surface projections of the designated fault planes: *, from mechanisms 1,2,3, and 4; $\neq$, inferred from Herrmann and Canas (1978); X, inferred from the seismic-reflection profiles of Zoback and others (1980) and; + , inferred from the seismic-relection profiles of Zoback (1979). 
earthquake of November 9, 1968 (Stauder and Nuttli, 1970), and composite focal mechanisms from earthquakes just north of New Madrid (Herrmann and Canas, 1978) indicate eastwest compression. Thus, it appears that the northeastsouthwest compressive-stress direction near New Madrid is a localized change in the stress field resulting from the leftstepping offset of the major northeast- trending, right lateral strike-slip fault system.

\section{CONCLUSION}

This work demonstrates that the seismicity in the New Madrid-Reelfoot Lake region is quite complex and is the result of the interaction of several major structures. The seismicity will be understood only through gathering precise information about those structures. Our report is a preliminary step in that direction, and future work will surely clarify both the structures and processes we describe.

\section{ACKNOWLEDGMENTS}

We thank Dan Jordan, Christi Scofield, and John Coakley of the U.S. Geological Survey for their efforts in data gathering and analysis. Our colleagues at Saint Louis University graciously provided copies of seismograms from their Gratio, Tenn., Station on a timely basis and were very supportive of our study.

\section{REFERENCES CITED}

Herrmann, R. B., 1979, Surface wave focal mechanisms for eastern North American earthquakes with tectonic implications: Journal of Geophysical Research, v. 84, no. 37, p. 3543-3552.

Herrmann, R. B., and Canas, J. A., 1978, Focal mechanism studies in the New Madrid seismic zone: Seismological Society of America Bulletin, v. 68 , no. 4 , p. $1095-1102$.

Heyl, A. V., and McKeown, F. A., 1978, Preliminary seismotectonic map of central Mississippi Valley and environs: U.S. Geological Survey Miscellaneous Field Studies Map MF-1011.

Hildenbrand, T. G., Kane, M. F., and Stauder, William, 1977, Magnetic and gravity anomalies in the northern Mississippi Embayment and their spatial relation to seismicity: U.S. Geological Survey Miscellaneous Field Studies Map MF-914.

Lahr, J. C., 1979, HYPOELLIPSE-- A computer program for determining local earthquake hypocentral parameters, magnitude, and first motion pattern: U.S. Geological Survey Open-File Report 79-431, 57 p.

Nuttli, O. W., 1973, The Mississippi Valley earthquakes of 181112--Intensities, ground motion and magnitude: Seismological Society of America Bulletin, v. 63, p. 227-248.

Stauder, William, and Nuttli, O. W., 1979, Seismic studies--South central Illinois earthquakes of November 9, 1968: Seismological Society of America Bulletin, v. 54, p. 1257-1269.

Stauder, William, and others, 1979, Central Mississippi Valley Earthquake Bulletin: Saint Louis University, 19 p.

Stearns, R. G., 1979, Recent vertical movement of the land surface in the Lake County uplift and Reelfoot Basin areas, Tennessee, Missouri, and Kentucky: U.S. Nuclear Regulatory Commission NUREG/CR-0874, $37 \mathrm{p}$.

Zoback, M. D., Hamilton, R. M., Crone, A. J., Russ, D. P., McKeown, F.A., and Brockman, S. R., 1980, Recurrent intraplate tectonism in the New Madrid seismic zone: Science, v. 209, p. 971-976. 


\section{Magnetic Basement in the Upper Mississippi Embayment Region- A Preliminary Report}

By T. G. HILDENBRAND, M. F. KANE, and J. D. HENDRICKS

INVESTIGATIONS OF THE NEW MADRID, MISSOURI, EARTHQUAKE REGION

GE OLOGICAL SURVEY PROFESSIONAL PAPER $1236-$ E 


\section{CONTENTS}

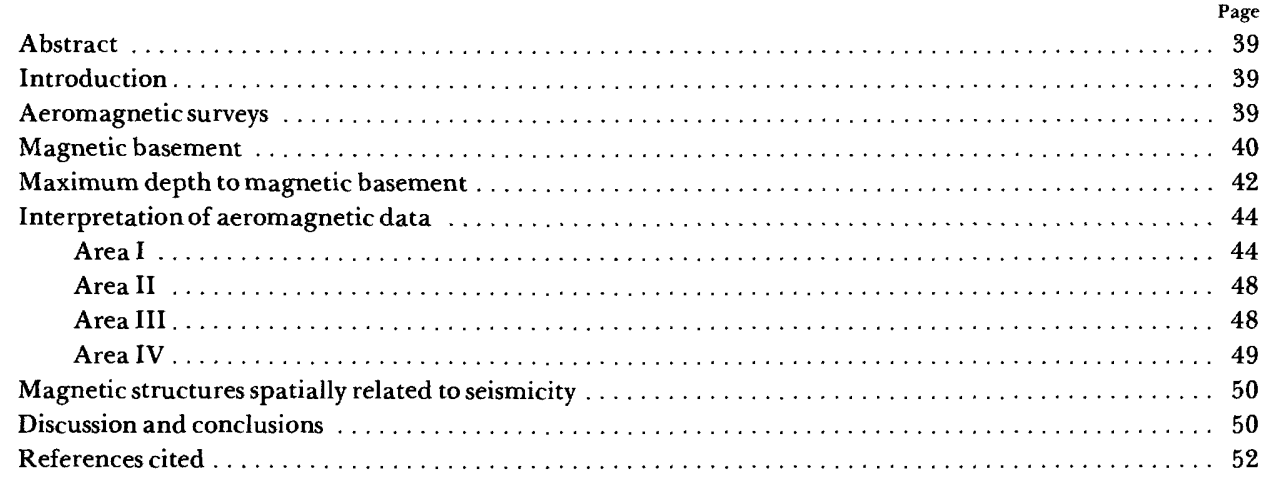

\section{ILLUSTRATIONS}

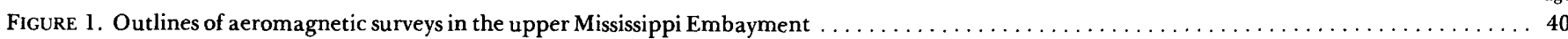

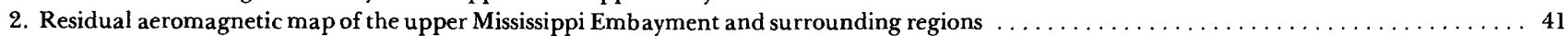

3. Gray-shaded aeromagnetic map showing interpreted lineaments and anomalies related to igneous intrusions . . . . . . . . . . . . . 42

4. Seismotectonic map showing inferred magnetic structures in the northern Mississippi Embayment and surrounding regions . . . . . . . . . . 43

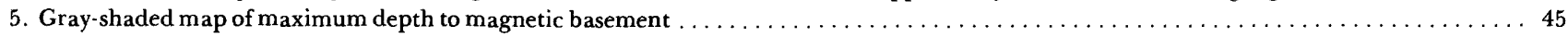

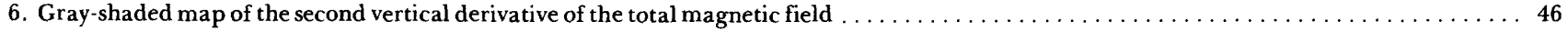

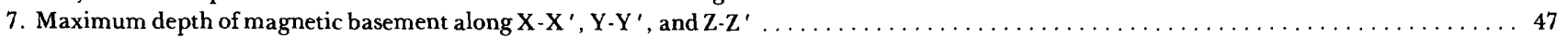




\title{
MAGNETIC BASEMENT IN THE UPPER MISSISSIPPI EMBAYMENT REGION-A PRELIMINARY REPORT
}

\author{
By T. G. Hildenbrand, M. F. KANE, and J. D. HENDRicks
}

\section{ABSTRACT}

Analysis of aeromagnetic data from the upper Mississippi Embayment region indicates a prominent northeast-trending graben that developed on the Precambrian surface and has structural relief of $1.6-2.6 \mathrm{~km}$. This graben, probably associated with a pre-Late Cambrian rift, may have developed along a boundary or suture separating contrasting basement-rock types. The graben formed where tensional stresses caused the crust to fail by brittle fracture and shear. Subsequent crustal thinning and partial melting of the crust led to plutonism and possibly volcanism. Mafic or ultramafic plutons intruded along both rift- border and rift-axial faults. However, this magmatism occurred hundreds of millions of years after formation of the structural graben. The available magnetic data suggest that the rift zone terminates northward in western Kentucky and southern Illinois, a region characterized by intense Paleozoic igneous activity and faulting.

Our interpretation of the geophysical data requires the upper Mississippi Embayment region to have experienced a long and complex tectonic history. The location of this ancient rift axis is presently one of the most active seismic regions in the United States. Geometries of some of the interpreted magnetic structures suggest that they are tectonic stress guides and that they determine the occurrence of release of present-day seismic energy.

\section{INTRODUCTION}

In 1974 aeromagnetic surveys were initiated by the U.S. Geological Survey in the upper Mississippi Embayment and surrounding regions. The purpose of these surveys is to delineate major geologic or tectonic features that may be responsible for the generation or control of seismic energy. To date, analysis of the magnetic data has been primarily qualitative, although some quantitative aspects of the data have been considered.

The qualitative approach has included close inspection of the aeromagnetic map and related filtered maps and subjective conclusions about the anomalous behavior of the magnetic signatures that were reached on the basis of contour closures and localized changes of gradients. A map of the magnetic second vertical derivative has been compiled to facilitate the identification of magnetic sources. Quantitative aspects of the magnetic interpretations have involved calculating the geometry of major geophysical structures. For this purpose, a generalized map of maximum depth to magnetic basement has been constructed using depth estimates determined from the horizontal extent of the steepest gradient (Vacquier and others, 1951).

Prominent structures inferred from the analyses of the magnetic data include (1) mafic-ultramafic plutonic masses of large areal extent; (2) a northeast-trending, parallel-sided depression of crystalline basement interpreted as a late Precambrian-early Paleozoic graben, probably associated with a continental rift; (3) several magnetic lineaments indicating lithologic contrasts in basement, probably along deep-seated fault zones; and (4) a block-faulted region characterized by appreciable vertical and lateral offsets. Geometries of some of these structures suggest that they are tectonic stress guides and that they determine the occurrence of release of seismic energy.

\section{AEROMAGNETIC SURVEYS}

The map of the residual total magnetic intensity was compiled from a synthesis of data acquired from several aeromagnetic surveys (fig. 1). These surveys, encompassing a total area of about $126,000 \mathrm{~km}^{2}$, were flown at elevations ranging from $900 \mathrm{ft}(0.27 \mathrm{~km})$ to $2,000 \mathrm{ft}(0.61 \mathrm{~km})$ barometric and with flight-line spacings of $0.5 \mathrm{mi}(0.85 \mathrm{~km})$ or $1 \mathrm{mi}(1.61 \mathrm{~km})$. Flight-line directions were east-west. All surveys were corrected for the diurnal variations of the Earth's field and for changes in flight elevation. The residual aeromagnetic field was obtained by removing the international geomagnetic reference field after updating to the years in which the surveys were flown.

To merge the various surveys, an elevation of $1,000 \mathrm{ft}(0.305$ $\mathrm{km}$ ) barometric was selected as the reduction datum level. Surveys flown above or below this datum level were analytically continued upward or downward so that the data are compatible. The surveys were merged utilizing one-dimensional splining techniques described by Bhattacharyya and others (1979). 


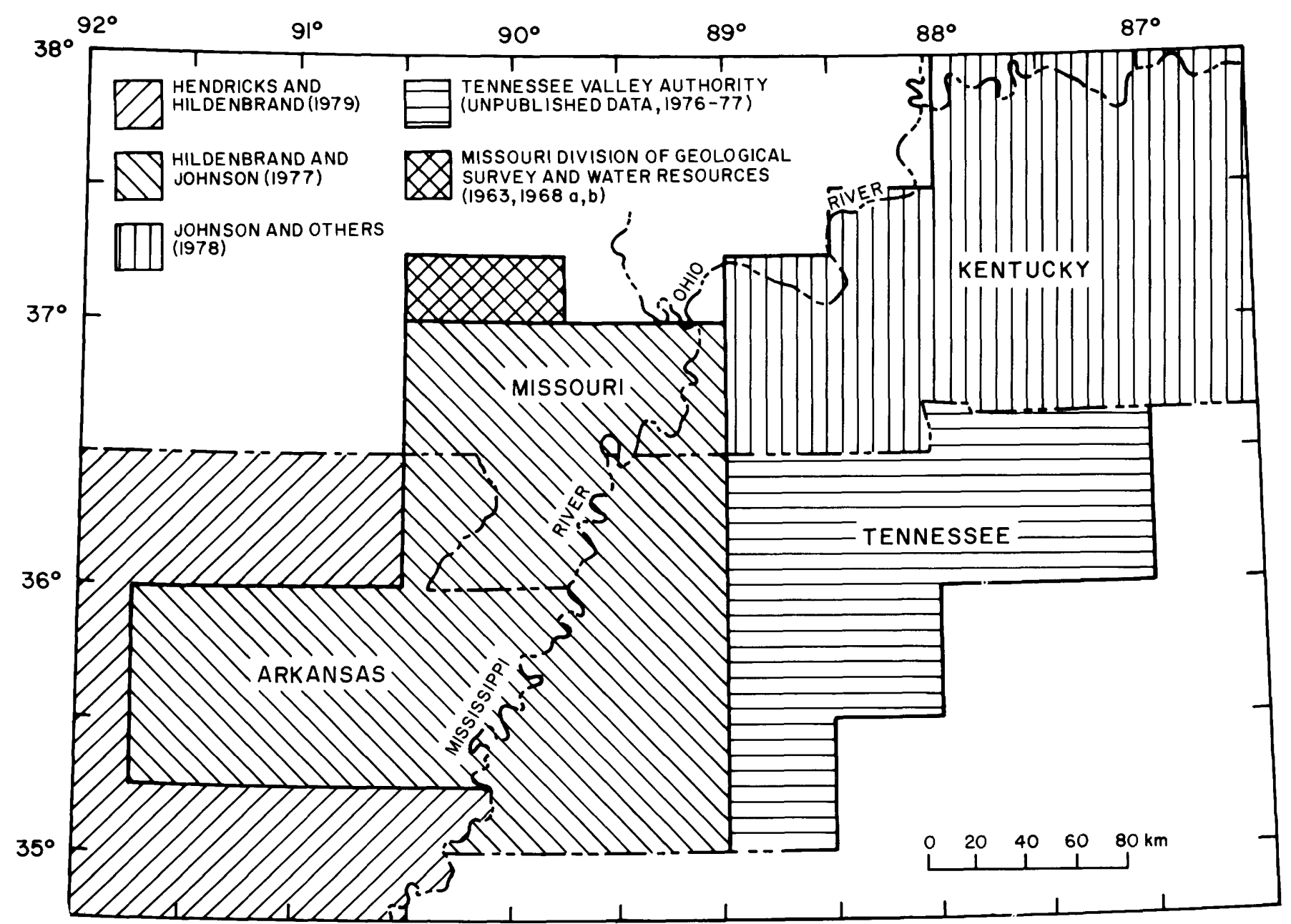

FigurE 1.-- Outlines of aeromagnetic surveys in the upper Mississippi Embayment.

\section{MAGNETIC BASEMENT}

The resulting residual aeromagnetic map (figs. 2,3) reflects structure and lithologic contrasts in the rocks of magnetic basement. Magnetic basement is defined as any lithologic unit having a susceptibility or remanent magnetization of sufficient magnitude to produce distortion in the magnetic field. In the Mississippi Embayment region, magnetic basement is interpreted as Precambrian crystalline rocks together with any igneous rocks of younger age. Phanerozoic sedimentary units observed in this region generally lack magnetic properties and, therefore, produce little or no effect on the magnetic field. On the other hand, Precambrian basement has a substantial effect on the magnetic field. Precambrian volcanic and related epizonal intrusive rocks represented in outcrops in the St. Francois Mountains (fig. 4) have average magnetic susceptibilities ranging from 0.6 to $2.4 \times 10^{-3} \mathrm{cgs}$ (Phelan, 1969).

Because of the thick sequence of sedimentary strata, the structure and geology of Precambrian basement are known largely from the effects of Precambrian structures on younger rocks, from drill records, and from geophysical surveys. In general, the buried Precambrian surface is undulating. It rises on the west toward the crest of the Ozark uplift (fig. 4) and descends deeply to the north and south beneath the Illinois Basin and Mississippi Embayment, respectively. Localized Precambrian structural deformations such as faults and folds can be observed by their effect on the total magnetic field intensity. For example, a linear and steep magnetic gradient may reflect the juxtaposition of different rock types along a buried fault or contact. Folded and tilted structures may be represented as regions of either low or high magnetic intensity, depending on the depth to the anomaly-producing rocks constituting magnetic basement.

Highly magnetic Phanerozoic dikes, diatremes, and plugs intrude Precambrian basement and younger formations along numerous faults within the Mississippi Embayment and surrounding regions. For instance, fracturing associated with the Ste. Genevieve fault (fig. 4) may have accommodated emplacement of intrusions in Early to Middle Devonian time (Zartman and others, 1967). In the Illinois-Kentucky 


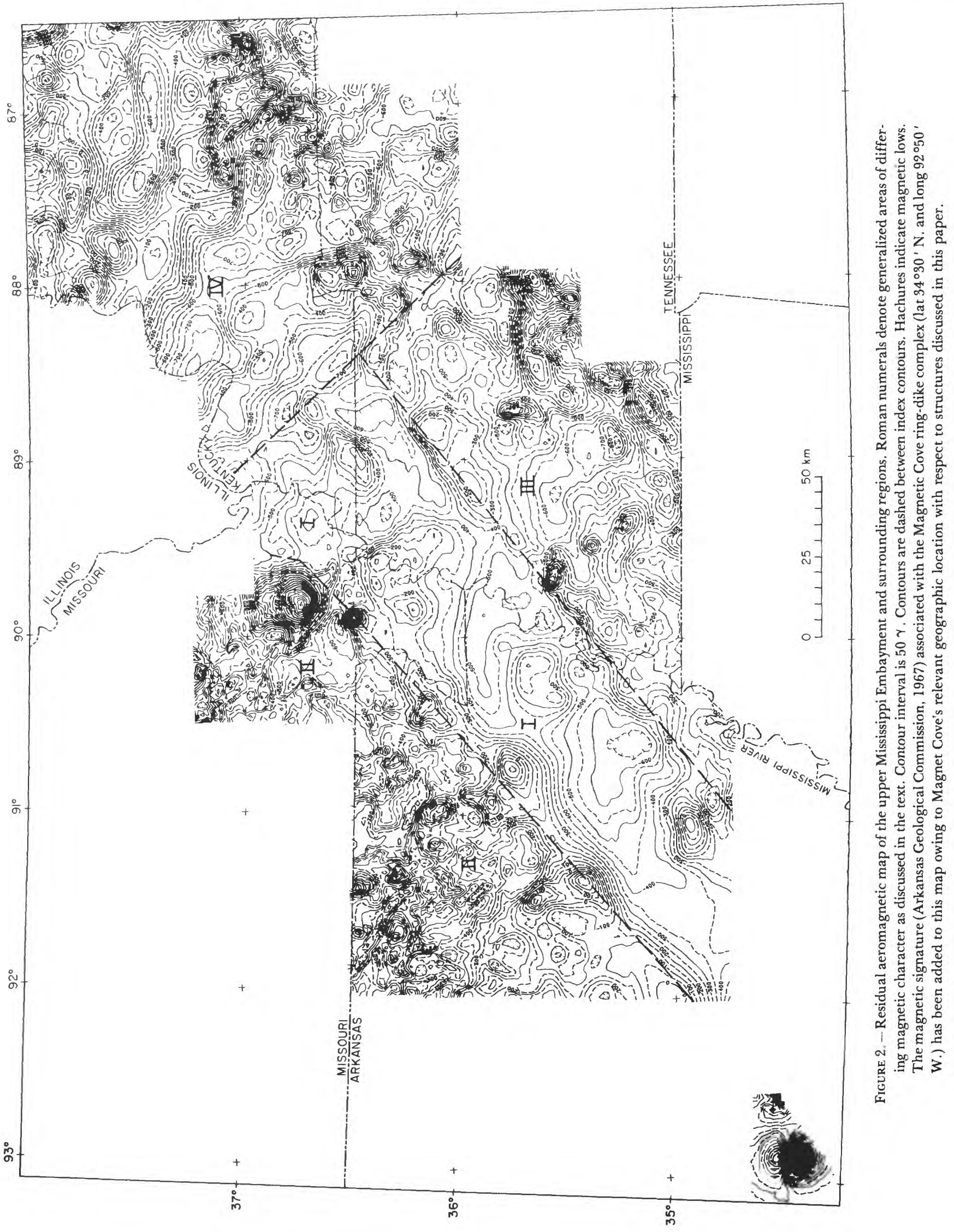




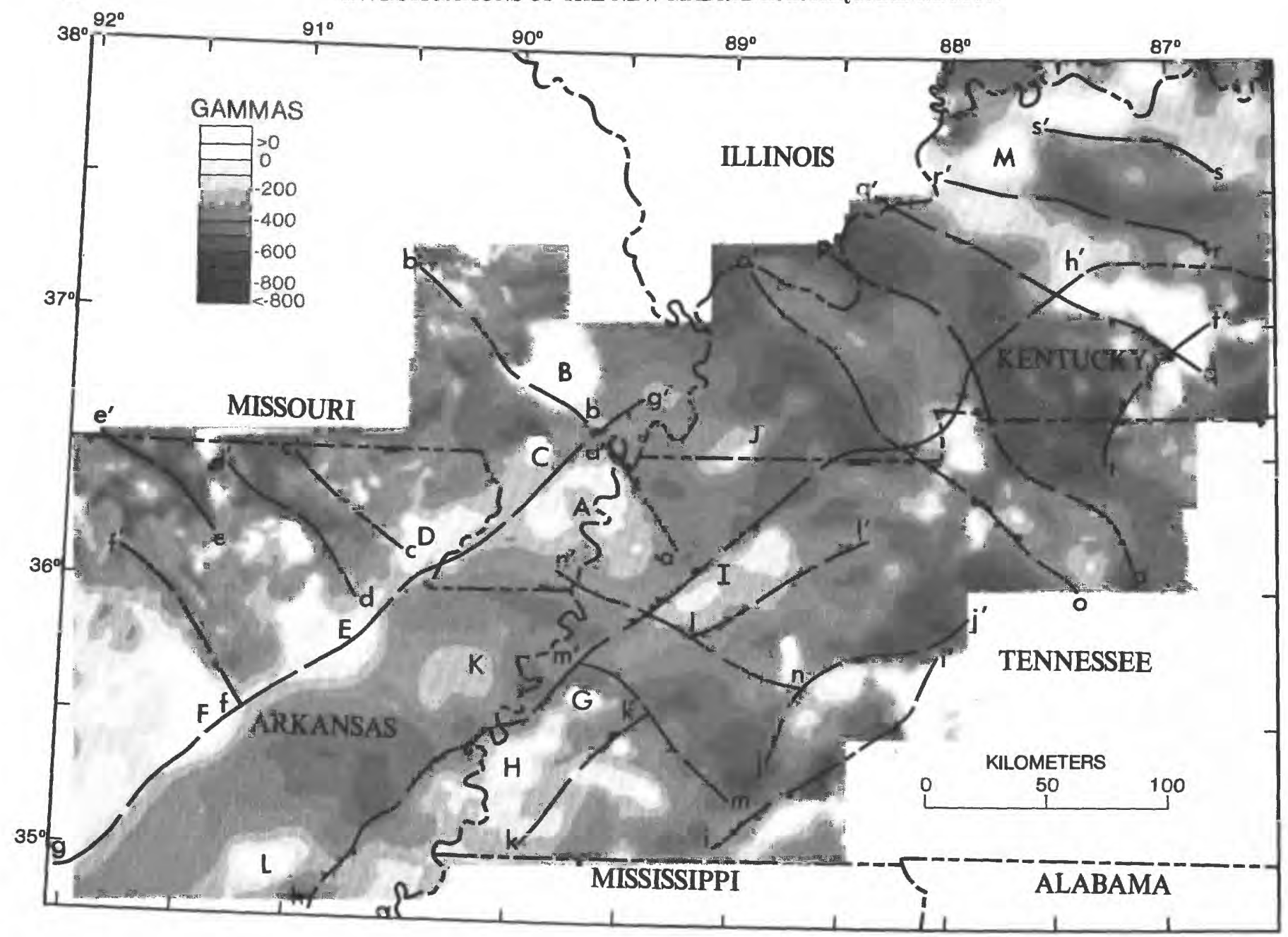

Figure 3.-Gray-shaded aeromagnetic map showing interpreted lineaments and anomalies related to igneous intrusions. Upper case letters denote locations of magnetic anomalies associated with highly magnetic intrusions. Dashed lines with lower case letters designate interpreted magnetic lineaments indicating structural or lithologic boundaries.

fluorspar district near lat $37^{\circ} 30^{\prime} \mathrm{N}$. and long $88^{\circ} 15^{\prime} \mathrm{W}$. (fig. 4), kimberlite dikes and diatremes intruded during Late Pennsylvanian and Permian time are restricted to northwesttrending fractures (Watson, 1967). Lamprophyric dikes have been encountered in drill holes (fig. 4) in rocks of Cambrian and Ordovician age on the Pascola arch (Kidwell, 1951; Grohskopf, 1955), a structure of major folding and faulting. Late Cretaceous lamprophyres, syenites, and nepheline syenites (Moody, 1949; Kidwell, 1951) have been detected in wells in southwest Tennessee. Bond and others (1971) suggested that these intrusions were emplaced along faults over a large area paralleling the Mississippi River in southwest Tennessee. In central Arkansas, the Magnet Cove ring dike complex (Erickson and Blade, 1963) and the syenite bodies near Little Rock (Gordon and others, 1958) may be alined along a zone of weakness associated with the Ouachita orogeny.

These alkalic intrusions are highly magnetic and produce intense anomalies. The Magnet Cove Complex is represented by a circular anomaly of $8,500 \gamma$ near lat $34^{\circ} 30^{\prime} \mathrm{N}$. and long $93^{\circ} \mathrm{W}$. (fig. 2). Large-amplitude and circular or elongated magnetic highs associated with inferred mafic or ultramafic intrusions will be considered here as reflecting magnetic basement. In those regions not intruded by Phanerozoic mafic rocks, magnetic basement will be assigned to the anomalyproducing Precambrian igneous or metamorphic basement.

\section{MAXIMUM DEPTH TO MAGNETIC BASEMENT}

An interpretational method developed by Vacquier and others (1951) has been employed to estimate the maximum depth to magnetic basement. In this method, an observed anomaly is compared with theoretical anomalies produced by vertical prisms of various dimensions and by different orientations of the Earth's ambient field. One generally assumes that the magnetic source is uniformly polarized in the same direction as the Earth's present field. When the areal shape of a the- 


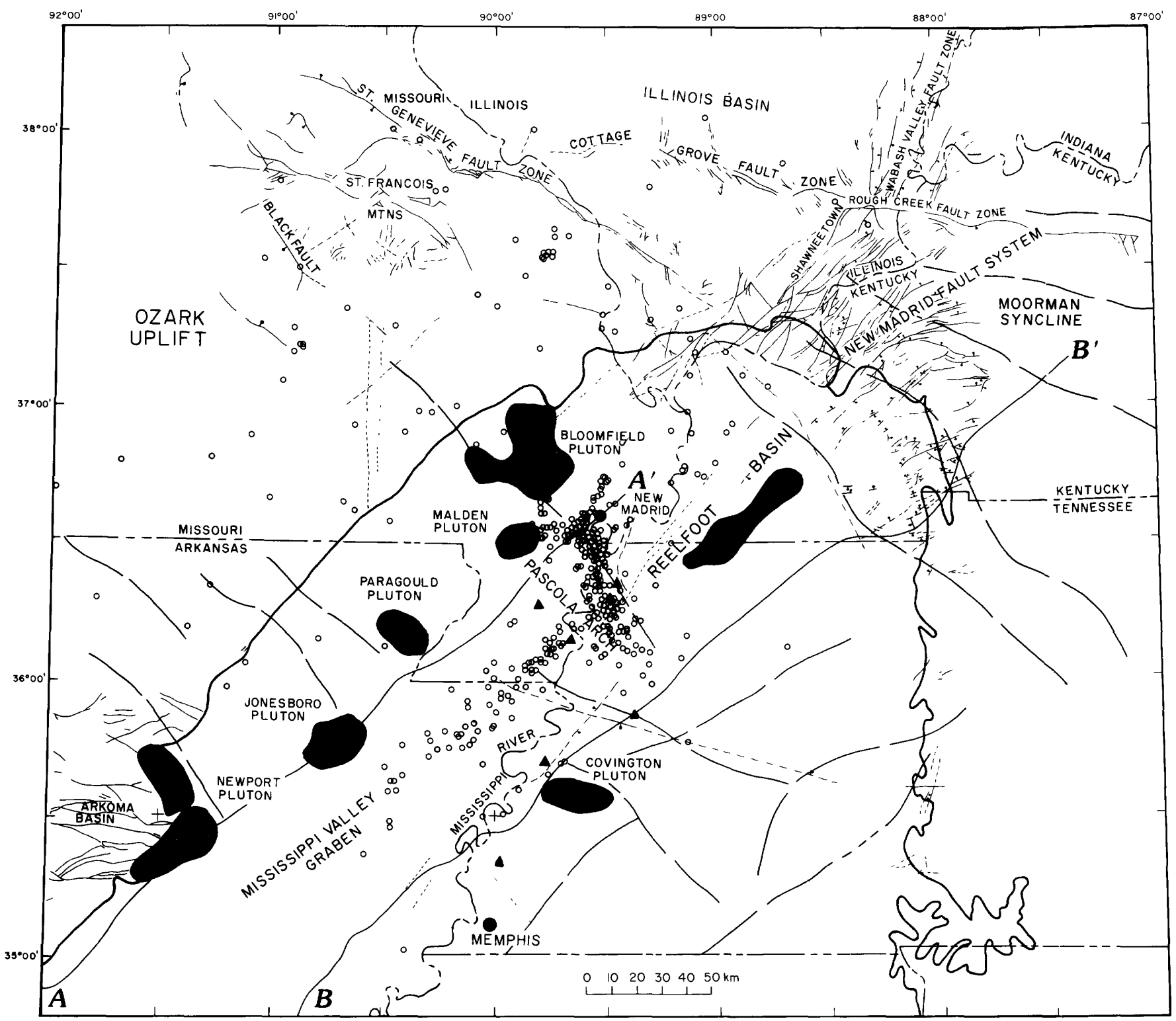

EXPLANATION

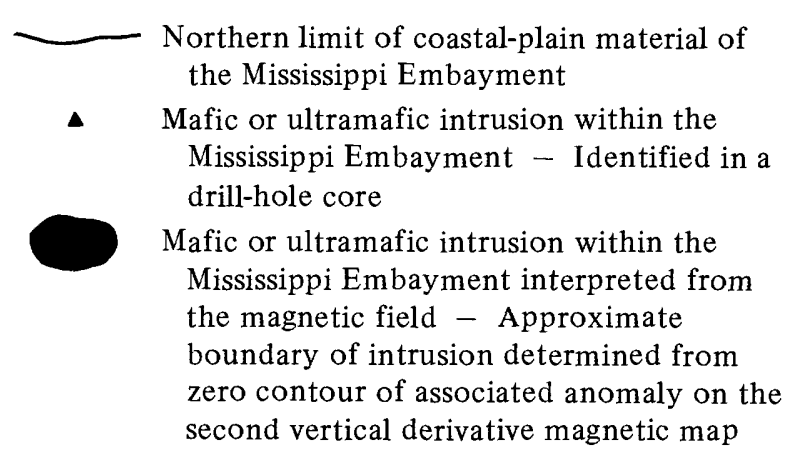

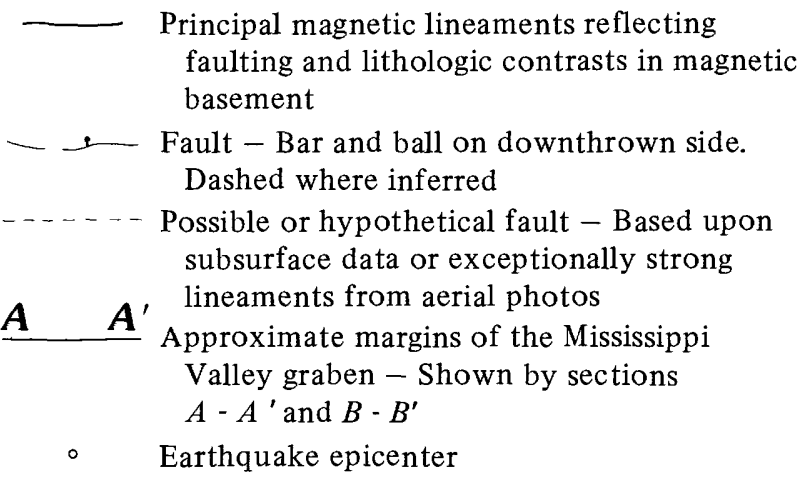

FIGURE 4.--Seismotectonic map showing inferred magnetic structures in the northern Mississippi Embayment and surrounding regions. This map has been modified from the "Tectonic Map of the United States" (Cohee and others, 1962) and the seismotectonic map of the Mississippi valley (Heyl and McKeown, 1978). It is provided as a reference for the accompanying magnetic maps, not as a revision of the sources mentioned. Epicenters of earthquakes detected by the southeast Missouri regional seismic network from July 1974 to June 1977 (W. Stauder, R. Herrman, R. Perry, S. Singh, M. Woods, and S. Morrissey, written commun., 1974-77) and major structures indicated in the magnetic field have been added to the map. 
oretical anomaly closely matches that of the observed anomaly, maximum depth to the magnetic source is determined by comparing lengths of horizontal gradients associated with the two anomalies. The method yields maximum depths to magnetic sources because the theoretical models used in the curve-matching process are assumed to have vertical sides. In real geologic situations, the causative body generally has sloping sides; and, therefore, its actual depth of burial is more shallow than the computed depth. The estimated average error of depth to a magnetic rock body is 10 percent (Vacquier and others, 1951).

The accuracy of depth estimates greatly depends on the validity of the geometric and magnetization assumptions. If these assumptions are reasonably valid, the method yields suitable depth estimates. Large errors occur, however, when the magnetic source is characterized by gently dipping sides, or nonuniform magnetization. The probable error associated with computed depths to magnetic basement underlying the Mississippi Embayment is difficult to assess owing to sparse drill-hole information. The depth estimates reported here must, therefore, be regarded as generalized. The computed depths are, however, in excellent agreement in those regions where depth to Precambrian basement is known. Four hundred and fifty estimates of maximum depth to magnetic basement have been determined by analyzing the anomalies of figure 2. The resulting generalized map of depth to magnetic basement is shown in figure 5 .

\section{INTERPRETATION OF AEROMAGNETIC DATA}

The second vertical derivative map (fig. 6) and generalized map of maximum depth to magnetic basement (fig. 5) are used in addition to the residual aeromagnetic map (fig. 2) in delineating and describing magnetic structures in the Mississippi Embayment and surrounding regions. Derivative maps resolve or sharpen anomalies of small areal extent. The zero contours of the second derivative map of the totalmagnetic-field anomalies can be used to outline the approximate boundaries of causative bodies (Vacquier and others, 1951).

Close inspection of the magnetic data reveals four generalized areas, shown in figure 2 , which contain different magnetic patterns. Area $I$ is characterized by a prominent, northeasttrending, grabenlike feature. Gradients and intense anomalies of small areal extent trend predominantly northwest in Area II and northeast in Area III. The magnetic pattern within Area IV contains pronounced northwest-trending magnetic features. The following discussions of the resulting interpretations of the magnetic data are separated into individual sections dealing with the various lithologic contrasts and structures indicated within each area.

\section{AREA I}

The most striking magnetic feature within the surveyed area is the broad zone of subdued magnetic expression within Area I. This zone has been interpreted by Hildenbrand and others (1977) as an expression of graben, probably associated with a rift that has been active since late Precambrian or early Paleozoic time. The graben, producing the quiet magnetic zone, trends between lat N. $45^{\circ} \mathrm{E}$. and long N. $50^{\circ} \mathrm{E}$. and has a width of approximately $70 \mathrm{~km}$. The average maximum depth to magnetic basement is $4.3 \mathrm{~km}$ within Area I (fig. 5).

The aeromagnetic and derivative maps delineate probable mafic intrusions in four localized regions in the graben. One circular magnetic anomaly (A, fig. 3) within the graben indicates as many as eight dikelike bodies (fig. 6), which is suggestive of a ring-dike complex. Four wells (fig. 4) within the areal extent of this magnetic high have encountered mica peridotite sills within rocks of Cambrian to Ordovician age. Peridotite from one of these wells, in Lake County, Tenn., has been dated at 267 m.y. (Permian) by the K-Ar method (Zartman, 1977). This magnetic high is geographically located over the crest of the late Paleozoic Pascola arch. The correspondence in age and location of the eight intrusive bodies and the arch suggests that they intruded along faults evolved during regional tectonism which formed the Pascola arch.

Three inferred mafic intrusions, represented by magnetic highs J, K, and L in figure 3, were emplaced in the center of the graben floor. The geographic relationship between intrusive emplacement and graben axis suggests that faults which formed during rifting provided channelways for magma. The ages and compositions of these intrusions are not known. The derivative (fig. 6) and depth-to-magneticbasement (fig. 5) maps do, however, reveal the shapes and depth of burial, respectively. Anomaly $\mathrm{J}$, located primarily in western Kentucky, is elongate along the axis of the graben. The associated source is delineated as a series of mafic dikes, sills, and plugs which intruded along $60 \mathrm{~km}$ of deep-seated faults that parallel the graben's axis. These inferred igneous bodies, lying at depths of about $3 \mathrm{~km}$, produce a structural high in magnetic basement and may, therefore, penetrate Phanerozoic sedimentary strata. The second vertical derivative of anomaly $\mathrm{K}$ reveals a circular pattern of emplacement of basic rocks. This anomaly may reflect a ring-dike complex lying at a depth of about $4.8 \mathrm{~km}$. Anomaly $\mathrm{L}$ is interpreted as a deeply buried $(4.7 \mathrm{~km})$ plutonic mass approximately $12 \mathrm{~km}$ in diameter.

A prominent magnetic gradient denoted as lineament a-a on figure 3 flanks anomaly A to the northeast. Although there are no associated surface faults, a linear trend of contemporary earthquake epicenters (fig. 4) is nearly alined with this gradient. The gradient presumably reflects faulting and will be discussed later in more detail.

Maximum depth of magnetic basement along profiles (X-X', Y-Y', and Z-Z', fig. 5) is shown in Figure 7. Magnetic 


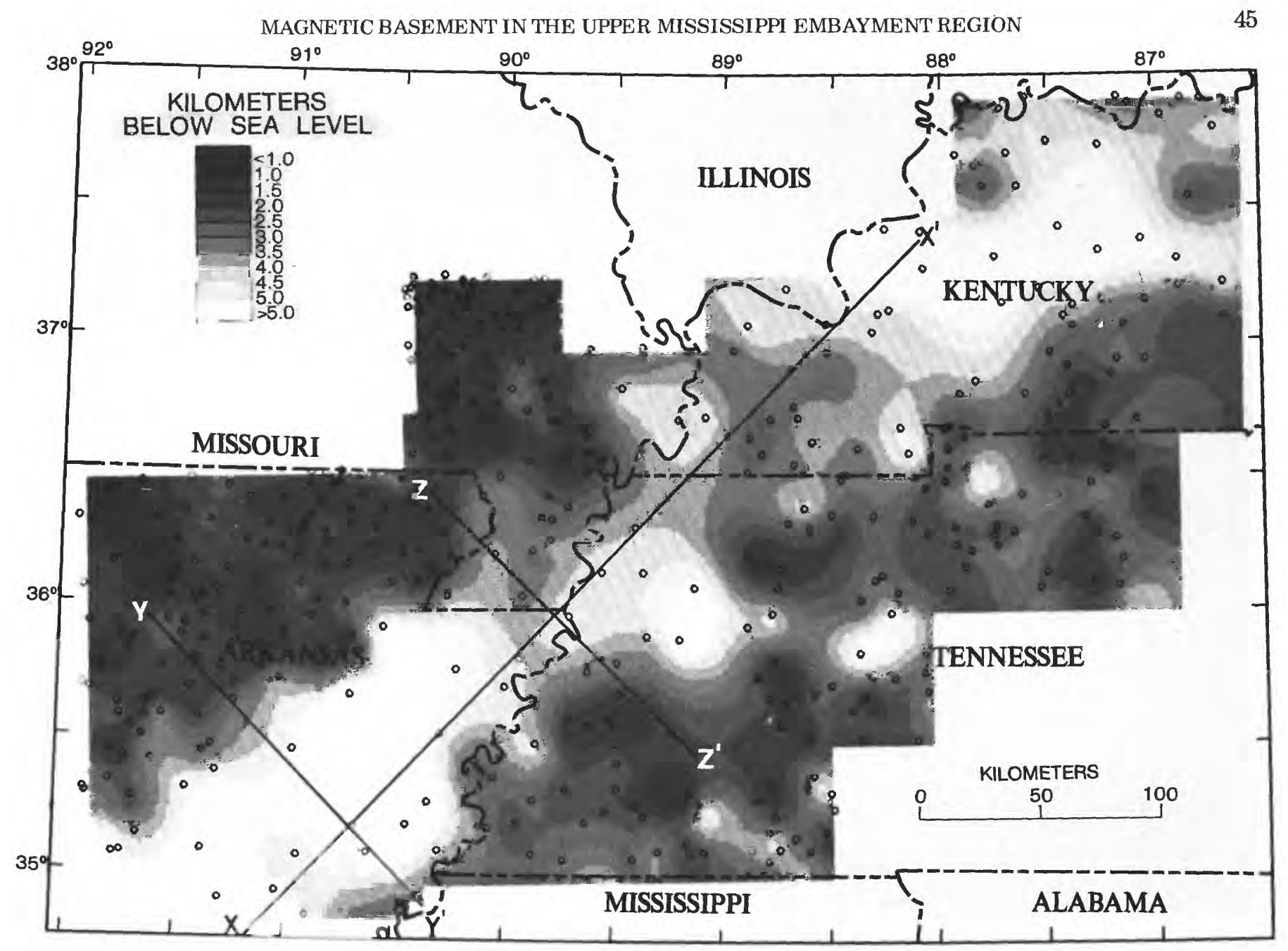

Figure 5. - Gray-shaded map of maximum depth to magnetic basement. Open circles denote locations of generalized depth estimates. Depths along profiles $\mathrm{X}-\mathrm{X}^{\prime}, \mathrm{Y}-\mathrm{Y}^{\prime}$, and $\mathrm{Z}-\mathrm{Z}^{\prime}$ are shown in figure 7.

basement along profile $\mathrm{X}-\mathrm{X}$, approximately oriented along the axis of the graben, appears to rise gently from $5.2 \mathrm{~km}$ at point $\mathrm{X}$ (on the southwest) to about $4 \mathrm{~km}$ at the crest of the Pascola arch (P). This $1.2 \mathrm{~km}$ of relief in magnetic basement may be related to uplift of the Pascola arch. Northeast of the Pascola arch, magnetic basement ascends to about $3 \mathrm{~km}$. This probably reflects, however, shallow igneous bodies rather than regional Precambrian basement. Basement then descends deeply into the Moorman syncline within Area IV. Depth profiles $Y-Y^{\prime}$ and $Z-Z^{\prime}$, oriented perpendicular to the graben, depict the pronounced depression of magnetic basement of this feature. Basement noticeably deepens near the southeast margin of the graben. The implied relief of $1 \mathrm{~km}$ within the basin indicates a greater vertical displacement on faults paralleling the axis of the graben.

The margins of the graben (g-g' and $h-h^{\prime}$, fig. 3) are characterized by a series of pronounced magnetic highs (B through
G, fig. 3). These anomalies are presumably caused by shallow mafic or ultramafic intrusions. The range in amplitudes is from 100 to $1100 \gamma$, and the sources are at depths of between 1.3 and $2.1 \mathrm{~km}$. The locations and shapes of these highly magnetic plutons (Hildenbrand and others, 1977) are shown in figure 4. Less prominent magnetic highs ( $\mathrm{H}$ and $\mathrm{I}$, fig. 3) bordering the southeast margin of the graben are also believed to represent shallow igneous intrusions. This interpretation is supported by drill-hole information that reveals the presence of lamprophyric and syenitic dikes and sills (fig. 4) within the vicinity of these elongated magnetic highs. Although there is no surface expression of faults, the plutons, dikes, and sills must have intruded along northeast-trending faults that border the graben. The presence of these faults supports the hypothesis that Area $I$ is underlain by a graben. The faults probably formed during the initial phases of rifting in late Precambrian or early Paleozoic time. On the other hand, drill-hole information and recent magnetic interpretations 


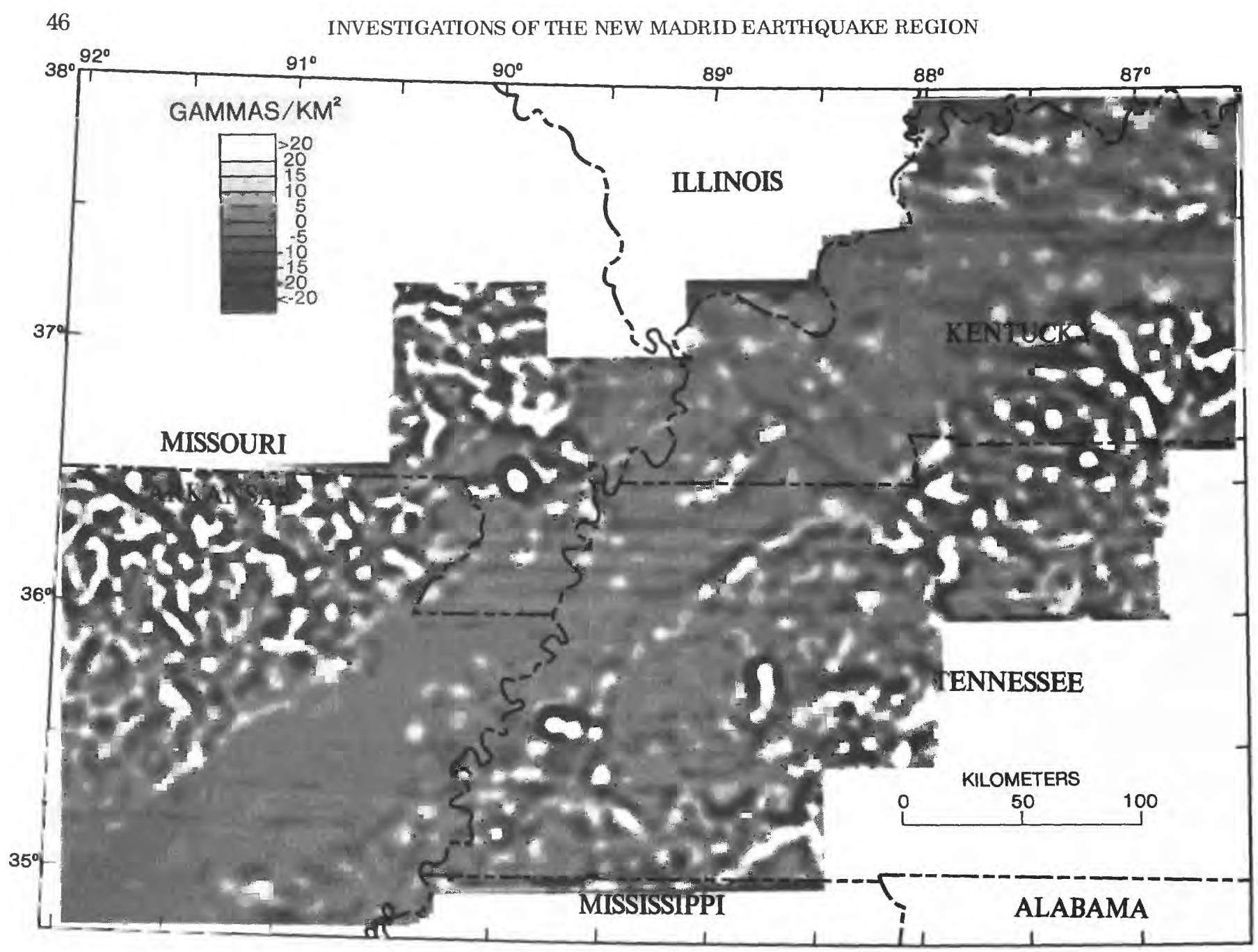

Figure 6. - Gray-shaded map of the second vertical derivative of the total magnetic field.

suggest that the large mafic or ultramafic masses were emplaced along graben-border faults subsequent to early Mesozoic time. The Pure Oil Company McGregor well, located near the Covington pluton (fig. 4), encountered syenite directly beneath Upper Cretaceous sedimentary rocks (Caplan, 1954).

The absence of stratigraphic or radiometric ages for the remaining plutons required development of an interpretation method utilizing the magnetic field intensity to obain approximate ages of these plutons (Hildenbrand, 1978). In this method, the age of a pluton is estimated by calculating the direction of remanent magnetization and comparing the corresponding paleomagnetic pole position with the polar wandering path for North America (Van Alstine, 1978). Remanent direction is obained by first calculating the total magnetization direction from the moments of the anomaly and then subtracting an induced component in the direction of the Earth's field. Because the magnitude of the induced component cannot be determined, the remanent direction is estimated within a range of possible values. If appreciable care is taken in isolating the anomaly and removing noise, this method indicates age accurate to, perhaps, part of a geologic era, although geologic periods cannot be resolved.

Owing to appreciable noise effects associated with neighboring magnetic sources, age determinations were not obtained for the Newport, Jonesboro, or Malden plutons (fig. 4), expressed as anomalies F, E, and $\mathrm{C}$ in figure 3, respectively. The computed ages of the Bloomfield, Paragould, and Covington plutons (fig. 4), represented by anomalies B, D, and G in figure 3, respectively, are post-early Mesozoic. This igneous period suggests reactivation of the rift, in the sense that faults bordering the graben provided channelways for the magma. The absence of major volcanism within the northern Mississippi Embayment indicates that magna ascended only to a depth at which the magmatic pressure balanced the lithostatic pressure.

The nepheline syenite bodies in western Tennessee (Kidwell, 1951; Moody, 1949) may have formed as the magma cooled by fractionation and differentiation of the more basic 

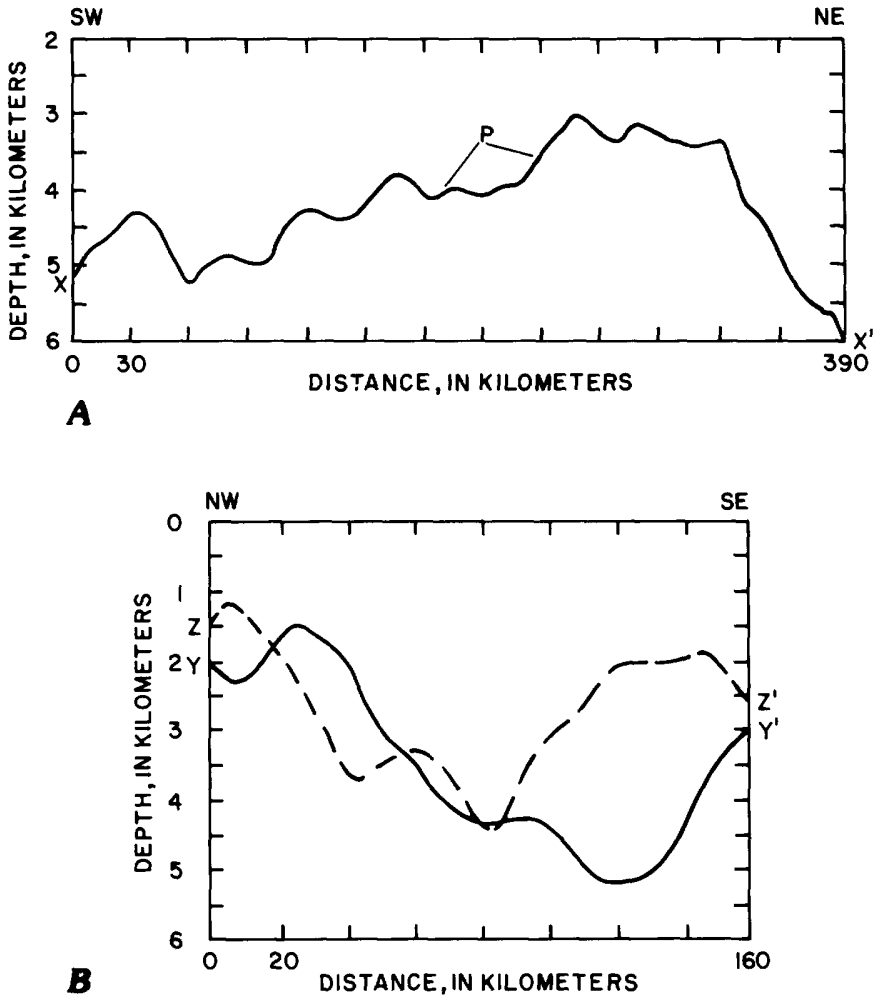

FigurE 7.--Maximum depth of magnetic basement along $X-X^{\prime}, Y^{\prime}-Y^{\prime}$, and $Z-Z^{\prime}$. Profiles shown in figure 5. A, parallel to graben axis; B, perpendicular to graben axis.

parent. Gravity modeling (Hildenbrand and others, 1977) of the Covington anomaly ( $\mathrm{G}$, fig. 3 ) indicates that the associated pluton is very dense (contrast of $+0.22 \mathrm{~g} / \mathrm{cm}^{3}$ ). The average density of nepheline syenite is $2.52 \mathrm{~g} / \mathrm{cm}^{3}$ (Thoenen and others, 1945), suggesting a density contrast of $-0.08 \mathrm{~g} / \mathrm{cm}^{3}$ for an assumed density of $2.6 \mathrm{~g} / \mathrm{cm}^{3}$ for the host rock. The discrepancy between the observed and computed density contrasts $\left(-0.08\right.$ vs. $\left.+0.22 \mathrm{~g} / \mathrm{cm}^{3}\right)$ implies that only the upper top of the pluton is syenite. The middle and lower sections of the intrusions must consist of denser rocks such as mafic or ultramafic alkalic masses similar to those exposed at the Magnet Cove Complex in central Arkansas.

The Magnet Cove ring-dike complex produces a pronounced magnetic high at lat $34^{\circ} 30^{\prime} \mathrm{N}$. and long $92^{\circ} 50^{\prime} \mathrm{W}$. (fig. 2 ), along the projection of the northwest margin (g-g', fig. 3) of the graben. This igneous complex, of Late Cretaceous age (Scharon and Hsu, 1969) may also have been emplaced along faults flanking the graben. The Magnet Cove Complex consists of alkalic rocks that include nepheline syenite, ijolite, jacupirangite, pyroxenite, and trachyte (Erickson and Blade, 1963). The more mafic components produce the large magnetic amplitude of $8500 \gamma$ associated with the complex. This amplitude is approximately an order of magnitude greater than those corresponding to the intrusive plutons situated along the margins of the graben. Most of these plutons are embedded entirely within Precambrian basement, whereas the Magnet Cove Complex intrudes Paleozoic rocks. Difference in depth of emplacement can, however, only partially explain the appreciable contrast in magnetic intensities. An obvious explanation for this is that the original melt composition of Magnet Cove was different from that of the other bordering plutonic masses. Magnetic Cove rocks developed from magma rich in the iron-titanium-oxygen compounds. In addition, the fine-grained alkalic rocks belonging to the Magnet Cove extrusive suite cooled faster than the intrusive alkalic rocks associated with the plutons. In general, fine-grained materials formed by rapid cooling have higher susceptibilities than coarse-grained crystals (Grant and West, 1965). The suggested difference in cooling rates may account, in part, for the substantial contrast between the magnetic amplitude of Magnet Cove and amplitudes of the buried plutons.

The proposed graben is clearly defined at the southern boundary of the surveyed area and probably extends somewhat farther southwest beyond the limits of the data. The northern terminus of the graben is difficult to determine owing to strong northwest-trending magnetic features that lie approximately normal to the graben's axis. These magnetic features mask the more subdued magnetic gradients associated with the graben. Consequently, the northwest margin of the graben, which is presently shown to end near the Bloomfield pluton (fig. 4), may extend farther northeast into Kentucky and Indiana. The derivative map (fig. 6), however, suggests that the trend of this boundary changes from northeast to north. A gradient transition with a northerly trend flanks the Bloomfield anomaly on its eastern side. Additional magnetic data north of the surveyed area will aid in defining the northern limits of the graben.

These magnetic structures indicate that Area I is underlain by a graben, probably associated with a rift. A graben is defined as an elongate depression of crustal rocks bordered by faults. The depth-to-magnetic-basement map clearly shows a crustal depression within Area I. The linear trend of igneous intrusions that border this depression strongly suggests the presence of faults that formed in conjunction with the graben. A rift can be defined as a large graben; generally in a rift, however, secondary faulting occurs along the floor, producing a series of smaller scale horsts and grabens. Magnetic basement along profiles perpendicular to the graben's axis (fig. 7) suggests that secondary faulting occurred within the graben floor. The area of principal seismicity in the upper Mississippi Embayment (fig. 4) lies within the graben structure and, thus, reveals the presence of active fault zones associated with this structure. These observations have prompted us to interpret this feature as an expression of an ancient rift. 


\section{AREA II}

The magnetic signature within Area II is characterized by intense anomalies of relatively small areal extent; it is similar to the magnetic signature of the St. Francois Mountains (U.S. Geological Survey, 1978). Unmetamorphosed volcanic and related epizonal intrusive rocks of late Precambrian age (Kisvarsanyi, 1974) make up the majority of the St. Francois region. However, included in the St. Francois Mountains Intrusive Suite (Kisvarsanyi, 1976) are highly magnetic mafic rocks such as pyroxene gabbro, hornblende diorite, olivine gabbro, and troctolite. An average susceptibility of $0.0024 \mathrm{cgs}$ units has been determined for diabasic rocks in the St. Francois Mountains, although susceptibilities as high as $0.014 \mathrm{cgs}$ units may be associated with some mafic intrusions (Phelan, 1969).

Magnetic basement within Area II is interpreted as containing rocks similar to those encountered in the nearby St. Francois terrane. These rocks, formed about $1.5 \mathrm{~b}$.y. ago (Bickford and Mose, 1975), predominantly include rhyolitic ash-flow tuffs, intrusive granites, and diabasic and basaltic dikes and sills. The mafic plutonic rocks presumably produce the observed intense highs of small areal extent (fig. 2). Precambrian basement (fig. 5) underlying Area II appears to be eroded into isolated hills and knobs. Drill-hole information indicates that the Paleozoic sedimentary rocks within Area II are relatively flat lying. The development of relief on Precambrian basement must, therefore, have occurred prior to the deposition of the oldest Paleozoic sedimentary unit. Similar erosional features are observed in the St. Francois Mountains and other Precambrian outcrops in southeast Missouri.

Five prominent northwest-trending magnetic lineaments (b-b' through f-f', fig. 3) are also present within magnetic basement underlying Area II. Four of these lineaments appear to terminate near the northwest boundary of the graben (g-g', fig. 3) in Area I. The northwest-trending magnetic features may represent deep- seated fracture systems in an older crustal terrane along which highly magnetic igneous material intruded. These mafic intrusions are probably similar in age ( 1.5 b.y.) and composition to those observed in the St. Francois terrane.

Magnetic lineament b-b' (fig. 3) trends N. $52^{\circ} \mathrm{W}$. along the southern boundary of the Bloomfield anomaly (B, fig. 3) to the edge of the surveyed area. If extended about $50 \mathrm{~km}$ to the northwest, the lineament alines with the Black fault (fig. 4) and may delineate the extension of this fault into the embayment. This interpreted fault may have also provided a channelway for magma which formed the Bloomfield pluton (fig. 4).

Magnetic basement (fig. 5) is relatively shallow within Area II, where computed depths of less than $2 \mathrm{~km}$ are common. More significantly, magnetic basement often rises to a kilometer or less below sea level, a depth suitable for mining ore deposits. The St. Francois Mountains are well known for ore deposits of iron-copper-cobalt, iron-apatite-rare earth, tungsten-lead-silver, and manganese (G. Kisvarsanyi, 1976). Within the southeast portion of Area II, magnetic basement descends to depths greater than $2 \mathrm{~km}$. The eastern terminus of the Arkoma basin (fig. 4) is located in this region and probably causes a deepening of the basement surface.

\section{AREA III}

Magnetic highs of small areal extent are observed in the vicinity of the southern and eastern boundaries of Area III. The average depth of the associated magnetic sources is 2.5 $\mathrm{km}$. This $2.5-\mathrm{km}$ depth is approximately $1 \mathrm{~km}$ deeper than that of the inferred Precambrian mafic intrusions located within Area II. Magnetic signatures of Areas II and III became comparable after compensating for the difference in emplacement depth. The high-frequency anomalies extensively distributed east of the graben are, therefore, interpreted as Precambrian mafic dikelike or sill-like bodies analogous to those west of the graben. An area characterized by nondescript magnetic signatures lies between the southeast margin of graben $\mathrm{h}$ - $\mathrm{h}^{\prime}$ (fig. 3) and the regions of Area III intruded by mafic masses. Magnetic basement within this relatively quiet magnetic zone evidently lacks highly magnetic mafic intrusions.

Distinct magnetic lineaments within Area III $\left(j-j^{\prime}\right.$ through n-n', fig. 3) strike predominantly northeast. The hypothesis that the Mississippi Embayment contains a tensional structure, namely a rift, is further supported by the correlation in trends of these lineaments and the margins of the graben. As stated previously, magnetic lineaments west of the graben are strongly oriented to the northwest. This contrast in the direction of magnetic lineaments on either side of the graben suggests that the magnetic basements flanking the graben underwent different tectonic evolutions.

Magnetic basement underlying Area III may also be younger than that within Area II. A well in St. Francois County, Ark., lat $35^{\circ} \mathrm{N}$. and long $91^{\circ} \mathrm{W}$. (Howard Schwalb, written commun., 1979), and one in Giles County, Tenn., lat $35^{\circ} 45^{\prime} \mathrm{N}$. and long $87^{\circ} \mathrm{W}$. (Wasserburg and others, 1962), have encountered granites dated at about 1.1 b.y. old by the K-Ar method. Granite from a well in north-central Mississippi has been dated as 0.79 b.y. by the K-Ar method. This latter granite, however, may be metamorphosed and, thus, somewhat older (Riggs, 1976). The indicated differences in age and structural trends in magnetic basements on either side of the graben suggest that the graben developed along a juxtaposition of contrasting lithologic basements. The age of basement rock east of the graben prompts comparison with Grenville terrane. According to Baer (1976), a Grenville event involved reactivation of an ancient crust by continental collision 1.0 to 1.1 b.y. ago. Metamorphism associated with the Grenville orogeny occurred over much of the eastern part of the continent (Lidiak and others, 1966). The extension of the Grenville Front into western Tennessee (Area III) will, 
however, require closer examination when additional data become available.

Magnetic lineaments e-e', k-k', and n-n' (fig. 3) flank magnetic highs associated with mafic intrusions. These lineaments may, therefore, reflect boundaries between different basement-rock types. Because of the intense highs lying along lineament $j-j^{\prime}$, the associated structure is delineated as a deepseated fault along which dikelike and sill-like masses intruded. Lineament $\mathrm{m}-\mathrm{m}^{\prime}$ parallels a hypothetical fault shown in figure 4. Owing to the proximity of the Pascola arch, the interpreted fault may represent partial decoupling associated with the late Paleozoic tectonism that formed the arch.

Substantial structural relief in magnetic basement is noticeable within Area III (fig. 5). Near its northern boundary, the basement appears to deepen along a troughlike feature trending east-west at an average depth of $3.9 \mathrm{~km}$ along lat $36^{\circ} \mathrm{N}$. This feature is flanked to the south by an east-westtrending basement high lying at an average depth of about 2.2 $\mathrm{km}$. The tectonic evolution of these two basement features is difficult to formulate because they trend obliquely to magnetic lineaments (fig. 3) and known Phanerozoic structures in the embayment (fig. 4). On the other hand, the Moorman syncline (fig 4) underlying Area IV is described as an eastwest-trending trough of early Paleozoic age. The upwarp and adjacent basin may, therefore, represent Phanerozoic readjustments to tectonic forces analogous to those that formed the Moorman syncline but unrelated to those associated with the formation of the northeast-trending graben within Area I.

\section{AREA IV}

Regional structures and lithologies of magnetic basement underlying most of Area IV were previously studied by Lidiak and Zietz (1976). Their major observation pertaining to this region, characterized by strongly oriented west-northwest lineaments (fig. 3), concerns the good correspondence between surface faults and magnetic lineaments. Excellent correlation exists between magnetic anomalies and the surface faults associated with the Rough Creek fault zone, which, in turn, coincide with magnetic lineament s-s '. Lineament o-o' alines with the buried extension (fig. 4) of the Ste. Genevieve fault in western Kentucky (Freeman, 1950). Also, strong gravity gradients alining with the Ste. Genevieve fault in Illinois appear to extend into western Kentucky along lineament o-o' (Hildenbrand and others, 1977). Lidiak and Zietz (1976) have, however, interpreted a magnetic lineament, approximately coinciding with lineament $\mathrm{p}-\mathrm{p}^{\prime}$, as an expression of the southern part of the Ste. Genevieve fault. Because the southeast projection of the fault lies between lineaments $o-o^{\prime}$ and $p-p^{\prime}$, it is difficult to assess which lineament represents the buried extension of the fault in western Kentucky. The Ste. Genevieve fault may bifurcate into two faults expressed as lineaments $0-o^{\prime}$ and $p-p^{\prime}$. Nevertheless, the correlation of magnetic lineaments and major fault zones suggests that the faults are basement controlled and are related to
Precambrian structural trends (Lidiak and Zietz, 1976).

Alternating magnetic highs and lows of Area II are bounded by the five magnetic lineaments oriented to the westnorthwest (fig. 3). This magnetic pattern may in part, reflect block faulting. For instance, the magnetic high situated between lineaments $0-0^{\prime}$ and $\mathrm{p}-\mathrm{p}^{\prime}$ may represent an uplifted block. Depths to magnetic basement, to some degree, support this hypothesis. Because substantial distortion in the southeast margin of the graben (h- $h^{\prime}$, fig. 3) occurs in the region between lineaments o-o' and p-p', this uplifted block may have also experienced lateral movement to the southeast. The resulting sense of movement would have been right-lateral along faults expressed as lineaments $0-\mathrm{o}^{\prime}$ and left-lateral along lineament $p-p$ '. The estimated amount of offset is about 12 $\mathrm{km}$. A depression in magnetic basement located between lineaments $p-p$ 'and s-s' apparently reflects the geographic extent of the Moorman syncline. A series of prominent northwest-trending magnetic highs bounded by lineaments $q-q^{\prime}$ and $r-r^{\prime}$ lie within this downfaulted block. Syenite to peridotite dikes and sills of varying composition, together with explosion breccias (Clegg and Bradbury, 1956; Koeing, 1956; Heyl and others, 1965), underlie this magnetic feature in the vicinity of the Kentucky-Illinois State boundary. Hicks dome, a structural feature of the Kentucky-Illinois fluorspar mineral district near lat $37^{\circ} 30^{\prime} \mathrm{N}$. and long $88^{\circ} 15^{\prime} \mathrm{W}$., is located a small distance beyond the surveyed area and along a northwest projection of this series of magnetic highs. This dome is an alkalic cryptovolcanic structure that consists of mineralized breccia and kimberlite dikes (Heyl and others, 1965). Kimberlite and peridotite dike rocks encountered within these regions have been dated as approximately $260 \mathrm{~m} . \mathrm{y}$. (Permian) by the Rb-Sr and K-Ar methods (Zartman, 1977). This northwest-trending magnetic feature evidently represents a region intruded by mafic igneous bodies that produce a lithologic contrast in magnetic basement.

An intense circular magnetic high (M, fig. 3) is interpreted as a large plutonic mass: the Madisonville pluton which lies within the Moorman syncline. The approximate age of the Madisonville pluton has been determined using the total-field dating method referred to previously. The resulting early Paleozoic age obtained for this feature coincides with the estimated time of formation of the Moorman syncline. An early Paleozoic igneous event apparently accompanied crustal warping, from which the Moorman syncline evolved.

The geographic extent of the graben, clearly defined in Area $I$, is somewhat ambiguous within Area IV. Westnorthwest-trending magnetic features characterizing Area IV (fig. 3) appear to mask the more subdued gradients related to the rift. The close correspondence in trend of the New Madrid fault system and the axis of the graben provides indirect evidence that the graben continues somewhat farther to the northeast. This fault system is described by Heyl and McKeown (1978) as a complex zone of horsts and grabens having an appreciable width (more than $60 \mathrm{~km}$ ). The northeast- 
trending faults associated with the New Madrid system may reflect the presence of the rift in northwest Kentucky and southeast Illinois. The derivative map (fig.3) suggests that the southeast margin of the graben (h- $h^{\prime}$, fig. 3) extends northeastward across perpendicular-trending features and then bends easterly where it merges with lineament $r-r^{\prime}$. The implied easterly trend of the graben's margin occurs geographically near the eastern boundary of the New Madrid fault system. Faults in this area also curve to the east in western Kentucky. As previously discussed, a marked change on the trend of the northwest margin of the graben is also indicated on the derivative map near the Bloomfield anomaly. The implied widening of the graben boundaries in the northern regions of the surveyed area may reflect a transition from a rift structure to a block-faulted region. In other words, the intense faulting and igneous activity within Area IV may represent structural features that formed within the northern terminus of the inferred rift zone. Without detailed analyses of additional magnetic data north of the surveyed area, the authors cannot firmly conclude that the northern terminus of the graben lies within the surveyed area, although this is suggested by interpretations of the available data.

\section{MAGNETIC STRUCTURES SPATIALLY RELATED TO SEISMICITY}

The graben structure noticeably contains the area of principal seismicity (fig. 4) in the upper Mississippi Embayment. Also, the epicentral line of the 1811-12 New Madrid earthquake series (Fuller, 1912) lies within the geographic limits of the graben. In particular, the present-day seismicity pattern suggests the existence of linear active zones (Stauder and others, 1976; Herrmann and Canas, 1978). A linear trend of epicenters strikes northeast along the graben's axis. Inferred vertical displacements, associated with deep-seated faults paralleling the graben's axis, are consistent with crustal fracturing of known rifts. The close correspondence between the interpreted fault zone and the linear northeast trend of present-day seismicity suggests that the associated rift is presently active. The axial seismicity pattern of known spreading rifts (Sykes, 1967) is very similar to that of the proposed rift. On the other hand, focal-mechanism studies by Herrmann and Canas (1978) revealed significant components of right-lateral motion occurring along the northeast-trending seismicity zone. This sense of movement is incompatible with that of extensional features such as rifts. Another explanation for right-lateral faulting along the graben's axis may be that past rifting activity resulted in highly fractured and folded crustal material within this region. The axis may represent a zone of crustal weakness along which strain, produced by tectonic forces different from that which formed the graben, is being relieved (Hildenbrand and others, 1977). Detailed investigations pertaining to the dynamics of rifting in the embayment, as well as additional numerical ground-motion studies, are needed to better understand the relationship between the graben's axis and contemporary faulting.

Seismicity trends change abruptly from northeast to slightly west of north at the intersection of the graben with the Pascola arch. This trend change may be intimately related to inferred igneous masses emplaced along the axis of the graben (fig. 4). These intrusions, if present, may have cemented the associated faults in such a manner as to influence the distribution of stress. Strain related to present-day earthquakes would then follow structural features of less resistance, such as the juncture of the Pascola arch and the graben. The resulting northnorthwest seismicity trend roughly coincides with the interpreted fault expressed as lineament $a-a^{\prime}$ in figure 3 . The magnetic low flanking this fault suggests that the fault is downthrown to the north.

Another change in direction of seismicity occurs near the Bloomfield pluton. Along the edge of the pluton, linear seismic zones corresponding to active faults appear to strike both in a westerly and northeasterly direction. The northeast component of seismicity may follow border faults associated with the graben's margin. Apparently, the Bloomfield pluton influences the distribution of stress in this region. Strong correlations between stress accumulation and mafic or ultramafic intrusions in the eastern United States have been previously discussed by Kane (1977), Long (1976), and McKeown (1975). Kane (1977) observed that extensive magnetic highs are present in or near seven major eastern North American earthquake areas as defined by Hadley and Devine (1974). He suggested that stresses are concentrated around the periphery of plutonic masses in much the same manner as stress concentrations occur near holes in plates under stress. The precise nature of the relationship between igneous intrusions and faulting in the embayment certainly requires closer examination.

Earthquakes are much less frequent southeast of the graben than northwest of it. This may indicate that active uplift or subsidence is presently occurring in the Ozarks and that the region east of the graben has essentially readjusted to presentday tectonic forces.

\section{DISCUSSION AND CONCLUSIONS}

Interpretation of the aeromagnetic data suggests a complex tectonic evolution of the upper Mississippi Embayment region. A major tectonic event involving the development of a large graben or rift zone occurred in late Precambrian or early Paleozoic time. The average maximum depth to magnetic basement is $4.3 \mathrm{~km}$ within the graben and $1.7 \mathrm{~km}$ and $2.7 \mathrm{~km}$ within the regions flanking the graben to the northwest and southeast, respectively. The suggested $1.6-2.6 \mathrm{~km}$ of relief between basement inside and outside the graben does not, however, fully account for the contrast in magnetic signatures. Magnetic data within those regions flanking the graben were continued upward the appropriate distance to compensate for 
the depression of basement associated with the graben. Magnetic signatures of the graben feature remained inherently different from those outside the graben. This difference diminished when data outside the graben were continued upward an additional kilometer or more. This simple exercise indicates that an intrinsic contrast exists in basement-rock type. Magnetic basement flanking the graben to the northwest may consist of metamorphic and granitic rocks intruded by mafic plutonic rocks. A somewhat similar composition is proposed for basement lying southeast of the graben. The widespread distribution of bodies of mafic rock within these two regions flanking the graben generates intense magnetic anomalies of small areal extent. Sparse distribution of similar mafic bodies within the graben may account for the observed contrast in magnetic signatures. Another explanation for this contrast in magnetic signatures is that magnetic properties of basement related to the graben have been appreciably reduced due to extensive fracturing or shearing. Whatever the precise cause, this feature is obviously of tectonic origin and must be intimately related to the formation of the Mississippi Embayment.

Available geologic information suggests that the sedimentary graben-fill is pre-Late Cambrian in age (E. Glick, oral commun., 1979). Development of the graben must have, therefore, occurred prior to Late Cambrian time. The 1.2- to 1.5-b.y.-old volcanic and shallow intrusive rocks related to the Central Province give evidence of a thermotectonic event during which continental rifting in central North America may have taken place. The extensive terrane of volcanic and shallow intrusive rocks associated with the Central Province extends from Michigan and Ohio to as far southwest as Arizona (Seyfert and Sirkin, 1973). Formation of the Oklahoma aulacogen (Wickham, 1978) also demonstrates late Precambrian to early Paleozoic rifting in the midcontinent. Suggested temporal limits associated with the evolution of the graben span a considerable period of geologic time, ranging from 0.55 to $1.5 \mathrm{~b} . \mathrm{y}$.

Moreover, magnetic basements flanking the graben may have differing tectonic histories. The magnetic basement northwest of the graben is thought to contain $\leq 1.5$-b.y.-old mafic intrusions analogous to those emplaced in the St. Francois Mountains. Apparently, these intrusive rocks were emplaced on or near an old crustal surface and represent part of the Central Province intrusive suite. On the basis of magnetic trends and drill-hole information, magnetic basement southeast of the graben is interpreted as being different in lithology and age than that northwest of the graben. We suggest that 1.1-b.y.-old basement, possibly Grenville-age rocks, flanks the graben to the southeast. The graben associated with inferred rifting may have, therefore, developed along a boundary separating different basement-rock types.

The proposed hypothesis, that the Mississippi Embayment is the site of a continental rift, is compatible with earlier interpretations made by Kumarapeli and Saul (1966), Heyl (in
White, 1967, p. 382), Burke and Dewey (1973), and Ervin and McGinnis (1975). In the model derived by Ervin and McGinnis, the rift evolved in late Precambrian time by the emplacement of high-density magma into the crust, associated uplift, and subsequent isostatic subsidence and trough formation. The present study, however, indicates that the graben, herein called the Mississippi Valley graben, is not as extensively intruded by mafic masses as those regions flanking the graben. In addition, if uplift occurred during the initial phases of rifting, the volcanic rocks of the St. Francois Mountains would have been extensively eroded, but this is not observed. A different model for the evolution of the Mississippi Valley graben is postulated herein on the basis of the new structural information derived from the interpretation of the magnetic data.

In the proposed model, the lithologic boundary, separating the Grenville Province and the Central Province, represented a zone of crustal weakness along which the rift evolved in late Precambrian or early Paleozoic time. Tensional stresses, acting along the boundary separating different basement-rock types, caused the crust to fail by brittle fracture and shearing. This model for rift basin evolution has been proposed by Salveson (1978). In this model, a rift zone forms from extension and not from initial uplift and subsequent subsidence due to isostatic adjustment. Fracturing by normal faulting or block faulting probably led to crustal thinning. Anomalous mass exess underlying the embayment is suggested in gravity interpretations by Cordell (1977) and Ervin and McGinnis (1975). The sparsity of mafic intrusions lying within the rift zone and the lack of any evidence for major volcanism in the embayment indicate that the raising of the mantle and associated partial melting of the crust did not provide a source of plutonism or volcanism within the shallow regions of the crust during the initial phases of rifting. The Tanganyika and Jordan depressions are examples of other rifts that have no associated volcanism.

The post-rifting phase included thick accumulation of Paleozoic sediments within the rift zone (Ervin and McGinnis, 1975) and emplacement of alkalic intrusions both within the rift zone and along its margins. Paleozoic sediments exceeding $4.5 \mathrm{~km}$ in thickness (Bond and others, 1971) may have been deposited in the Reelfoot basin (fig. 4). Age determinations of kimberlite and peridotite dikes and sills, encountered in wells in the vicinity of the Kentucky-Illinois fluorspar district and of the crest of the Pascola arch, suggest that Late Pennsylvanian and Permian igneous events occurred within the rift zone. A belt of interpreted mafic intrusions, lying within the rift zone and trending perpendicular to its axis in western Kentucky, may indicate the presence of a transverse shear zone that provided a channelway for magma. Inferred dikes, sills, and large plutons of post-middle Mesozoic age intruded the border faults of the rift zone. The extensive distribution of igneous bodies along the margins of the rift zone suggests that the anomalous mantle material in the lower crust solidified by post-middle Mesozoic time and, thus, represented an obstruc- 
tion for raising magma. The rift-border faults would then have provided better channelways for the ascending magma than the rift-axial faults. The geographic locations of these magmatic intrusions strongly suggest that the associated igneous events are intimately related to the rift zone. The igneous intrusions may reflect reactivation of the rift or simply tectonic events unrelated to rifting but associated with magma emanating from pre-existing deep-seated faults within the rift zone.

The geographic extent of rifting has yet to be determined. The available magnetic data indicate that the northern terminus of the rift zone lies within western Kentucky and southern Illinois. In this region, characterized by intense igneous activity and faulting, the margins of the rift zone appear to widen substantially. The rift zone is clearly defined at the southern boundary of the surveyed area and must, therefore, extend somewhat farther southwest. Continuation of the rift zone may be supported by the existence of alkalic intrusions in southeast Arkansas that include the Magnet Cove ring-dike complex and syenite bodies near Little Rock. If projected to the southwest, the rift intersects the Ouachita Foldbelt, where it bends beneath the embayment. The late Precambrian to early Paleozoic Oklahoma aulacogen also extends into a craton at a high angle from a bend in the Ouachita Foldbelt. The strong correlation in structural configuration and age of these two rifts suggests that they had a common origin. Additional magnetic data north and south of the present area of coverage will be helpful in delineating the geographic extent of the rift zone and in better understanding continental rifting in the embayment.

Pertinent research areas for future consideration include (1) delineating the total extent of rifting, (2) determining the relationship between seismicity and rift-related features that include deep-seated faults and plutonic masses, (3) developing a detailed model describing the evolution of the rift zone, (4) understanding the relation between infra-sedimentary plutonism and tectonic structures, (5) delineating the lithologies and structures of Precambrian basement, and (6) investigating the possible dynamics of continental rifting in the embayment. The magnetic interpretations presented here will certainly be refined or modified when more detailed quantitative analyses are carried out and additional geophysical and geologic data are acquired. The results indicate that the Mississippi Embayment region experienced a complex tectonic history. Further studies will be very helpful in understanding intra-cratonic tectonics.

\section{REFERENCES CITED}

Arkansas Geological Commission, 1967, Aeromagnetic survey of northwestern Arkansas: scale 1:100,000.

Baer, A. J., 1976, The Grenville Province in Helikian times--A possible model of evolution: Philosophical Transactions of the Royal Society of London, A., v. 280, p. 449-515.
Bhattacharyya, B. K., Sweeney, R. E., and Godson, R. H., 1979, Integration of aeromagnetic data acquired at different times with varying elevations and line spacing: Geophysics, v. 44, no. 4, p. 742-752.

Bickford, M. E., and Mose, D. G., 1975, Geochronology of Precambrian rocks in the St. Francois Mountains, southeastern Missouri: Geological Society of America Special Paper 165, 48 p.

Bond, D. C., and others, 1971, Possible future petroleum potential of region 9-Illinois Basin, Cincinnati arch, and northern Mississippi embayment: American Association of Petroleum Geologists Memoir 15, v. 2, p. 1165-1218.

Burke, K., and Dewey, J. F., 1973, Plume-generated triple junctions-- Key indicators in applying tectonics to old rocks: Journal of Geology, v. 81, p. 406-433.

Caplan, W. M., 1954, Subsurface geology and related oil and gas possibilities of northeastern Arkansas: Arkansas Resources and Development Commission, Division of Geology Bulletin 20, $124 \mathrm{p}$.

Clegg, K. E., and Bradbury, J. C., 1956, Igneous intrusive rocks in lllinois and their economic significance: Illinois State Geological Survey Report of lnvestigations 197, $19 \mathrm{p}$.

Cohee, G. V., and others, 1962, Tectonic map of the United States: U.S. Geological Survey and American Association of Petroleum Geologists, scale $1: 2,500,000$.

Cordell, Lindrith, 1977, Regional positive gravity anomaly over the Mississippi embayment: Geophysical Research Letters, v. 4, p. 285-287.

Erickson, R. L., and Blade, L. V., 1963, Geochemistry and petrology of the alkalic igneous complex at Magnet Cove, Arkansas: U.S. Geological Survey Professional Paper 425, $95 \mathrm{p}$.

Ervin, C. P., and McGinnis, L. D., 1975, Reelfoot rift--Reactivated precursor to the Mississippi embayment: Geological Society of America Bulletin, v. 86, p. 1287-1295.

Freeman, L. B., 1950, Paleozoic structure and stratigraphy of the Jackson Purchase region, Kentucky: Kentucky Geological Survey Bulletin, ser. 9, no. 4, p. 12-36.

Fuller, M. L., 1912, The New Madrid earthquake: U.S. Geological Survey Bulletin 494, $119 \mathrm{p}$

Gordon, M., Jr., Tracey, J. I., Jr., and Ellis, M. W., 1958, Geology of the Arkansas bauxite region: U.S. Geological Survey Professional Paper $229,268 \mathrm{p}$.

Grant, F. S., and West, G. F., 1965, Interpretation theory in applied geophysics: New York, McGraw-Hill Book Company, 583 p.

Grohskopf, J. G., 1955, Subsurface geology of the Mississippi embayment of southeast Missouri: Missouri Division of Geological Survey and Water Resources, v. 37, 2nd ser., 133 p.

Hadley, J. B., and Devine, J. F., 1974, Seismotectonic map of the eastern United States: U.S. Geological Survey Miscellaneous Field Studies Map MF-620.

Hendricks, J. D., and Hildenbrand, T. G., 1979, Total field aeromagnetic map of northeast Arkansas: U.S. Geological Survey Open-File Report 79-1208, scale 1:250,000.

Herrmann, R. B., and Canas, J., 1978, Focal mechanism studies in the New Madrid seismic zone: Seismological Society of American Bulletin, v. 68, no. 4, p. 1095-1102.

Heyl, A. V., Jr., Brock, M. R., Jolly, J. L., and Wells, C. E., 1965, Regional structure of the southeast Missouri and Illinois-Kentucky mineral districts: U.S. Geological Survey Bulletin 1202-B, 20 p.

Heyl, A. V., and McKeown, F. A., 1978, Preliminary seismotectonic map of central Mississippi valley and environs: U.S. Geological Survey Miscellaneous Field Studies Map MF-1011.

Hildenbrand, T. G., 1978, Approximate ages of igneous intrusions in the upper Mississippi embayment utilizing the total magnetic field anomalies: American Geophysical Union 1978 Midwest Meeting, Abstracts, p. 6. 
Hildenbrand, T. G., and Johnson, R. W., 1977, Aeromagnetic map of the northern Mississippi embayment: U.S. Geological Survey Open-File Report 77-229.

Hildenbrand, T. G., Kane, M. F., and Stauder, William, 1977, Magnetic and gravity anomalies in the northern Mississippi embayment and their spatial relation to seismicity: U.S. Geological Survey Miscellaneous Field Studies Map MF-914.

Johnson, R. W., Jr., Haygood, C., and Kunselman, P. M., 1978, Residual total intensity aeromagnetic map of Kentucky, western sheet: University of Kentucky, Kentucky Geological Survey.

Kane, M. F., 1977, Correlation of major eastern earthquake centers with mafic/ultramafic basement masses, in Rankin, D. W., ed., Studies related to the Charleston, South Carolina, earthquake of 1886--A preliminary report: U.S. Geological Survey Professional Paper 1028-O, p. 199-204.

Kidwell, A.L., 1951, Mesozoic igneous activity in the northern Gulf Coast Plain: Gulf Coast Association of Geological Societies, lst Annual Meeting, Transactions, p. 182-199.

Kisvarsanyi, E. B., 1974, Operation basement: Buried Precambrian rocks of Missouri-Their petrography and structure: American Association of Petroleum Geologists Bulletin, v. 58, no. 4, p. 674-684.

Kisvarsanyi, G., 1976, Precambrian metallogeneses in the St. Francois Mountains igneous province, southeast Missouri (Contribution to Precambrian Geology, no. 6): Missouri Department of Natural Resources, Geological Survey Report of Investigations 61, 190 p.

Koeing, J. B., 1956, The petrography of certain igneous dikes of Kentucky: Kentucky Geological Survey Bulletin, ser. 9, no. 21, 27 p.

Kumarapeli, P. S., and Saull, V. A., 1966, The St. Lawrence valley system - A North American equivalent of the East African rift system: Canadian Journal of Earth Science, v. 3, p. 639- 658.

Lidiak, E. G., Marvin, R. F., Thomas, H. H., and Bass, M. N., 1966, Geochronology of the midcontinent region, United States, Part 4, Eastern area: Journal of Geophysical Research, v. 71, p. 5427-5438.

Lidiak, E. G., and Zietz, Isidore, 1976, Interpretation of aeromagnetic anomalies between latitudes $37^{\circ} \mathrm{N}$. and $38^{\circ} \mathrm{N}$. in eastern and central United States: Geological Society of America Special Paper 167, 37 p.

Long, L. T., 1976, Speculations concerning southeastern earthquakes, mafic intrusions, gravity anomalies, and stress amplifications: Earth quake Notes, v. 47, p. 29-35.

McKeown, F. A., 1975, Hypothesis-Mafic intrusions and their contact zones are source zones of many earthquakes in central and southeastern United States: Earthquake Notes, v. 46, p. 53.

Missouri Division of Geological Survey and Water Resources, 1963, Aeromagnetic contour map of the Advance $15^{\prime}$ quadrangle: scale $1: 250,000$.

1968a, Aeromagnetic contour map of the Greenville 15' quadrangle: scale $1: 250,000$.

$1968 \mathrm{~b}$, Aeromagnetic contour map of the Zalma 15' quadrangle: scale $1: 250,000$

Moody, C. L., 1949, Mesozoic igneous rocks of the northern Gulf Coastal Plain: American Association of Petroleum Geologists Bulletin, v. 33, p. $1410-1428$.

Phelan, M., 1969, Crustal structure in the central Mississippi valley earthquake zone: St. Louis, Missouri, Washington University Ph.D. dissertation, $166 \mathrm{p}$
Riggs, K. A., 1976, Subsurface Precambrian granite, Lafayette County, Mississippi: American Association of Petroleum Geologists Bulletin, v. 60, p. 455-457.

Salveson, J. O., 1978, Variations in the geology of rift basins-- A tectonic model: International Symposium on the Rio Grande rift, Santa Fe, New Mexico, 1978, p. 82.

Scharon, L., and Hsu, I., 1969, Paleomagnetic investigations of some Arkansas alkalic igneous rocks: Journal of Geophysical Research, v. 74, no. 10, p. 2774-2779.

Seyfert, C. K., and Sirkin, L. A., 1973, Earth history and plate tectonics: New York, Harper and Row, $504 \mathrm{p}$.

Stauder, William, Kramer, M., Fischer, G., Schaeffer, S., and Morrissey, S. T., 1976, Seismic characteristics of southeast Missouri as indicated by a regional telemetered micro-earthquake array: Seismological Society of America Bulletin, v. 66, no. 6, p. 1953-1964.

Sykes, L. R., 1967, Mechanism of earthquakes and nature of faulting on the mid-oceanic ridges: Journal of Geophysical Research, v. 72, no. 8, p. 2131-2153.

Thoenen, J. R., Malamphy, M. C., and Vallely. J. L., 1945, Geophysical survey of Arkansas bauxite region: U.S. Bureau of Mines Report of Investigations $3791,49 \mathrm{p}$.

U.S. Geological Survey, 1978, Aeromagnetic form-line contour map of the east part of the Rolla, Missouri, $1^{\circ} \times 2^{\circ}$ quadrangle: U.S. Geological Survey Open-File Report 78-330.

Vacquier, V., Steenland, N. C., Henderson, R. G., and Zietz, Isidore, 1951, Interpretation of aeromagnetic maps: Geological Society of America Memoir 47, $151 \mathrm{p}$.

Van Alstine, D. R., 1978, A new technique for contracting apparent polar wander paths and the revised Phanerozoic path for North America: Geology, v. 6, p. 137-139.

Wasserburg, G. J., Wetherill, G. W., Silver, L. T., and Flawn, P. T., 1962, A study of ages of the Precambrian of Texas: Journal of Geophysical Research, v. 67, p. 4021-4047.

Watson, K. D., 1967, Kimberlites of eastern North America, in Wyllie, P. J., ed., Ultramafic and related rocks: New York, John Wiley and Sons, Inc., p. 312-323.

White, P. E., 1967, Outline of thermal and mineral waters as related to origin of Mississippi Valley ore deposits, with discussion, in Brown, J. S., ed., Genesis of stratiform lead- zinc-barite-fluorite deposits (Mississippi Valley type deposits) -- A symposium, New York, 1966: Economic Geology Monograph 3, p. 382.

Wickham, John, 1978, The southern Oklahoma aulacogen, in Field guide to structure and stratigraphy at the Ouachita Mountains and the Arkoma Basin: American Association of Petroleum Geologists 1978 Annual Meeting, p. 2-33.

Zartman, R. E., 1977, Geochronology of some alkalic rock provinces in eastern and central United States: Earth and Planetary Science Letters Annual Review, v. 5, p. 257-286.

Zartman, R. E., Brock, M. R., Heyl, A. V., and Thomas, H. H., 1967, K-Ar and $\mathrm{Rb}-\mathrm{Sr}$ ages of some alkalic intrusive rocks from the central and eastern United States: American Journal of Science, v. 265, p. 848-870. 



\section{Tectonic Features of the New Madrid Seismic Zone From Seismic-Reflection Profiles}

By R. M. HAMILTON and M. D. ZOBACK

INVESTIGATIONS OF THE NEW MADRID, MISSOURI, EARTHQUAKE REGION GEOLOGICAL SURVEY PROFESSIONAL PAPER 1236 -F 


\section{CONTENTS}

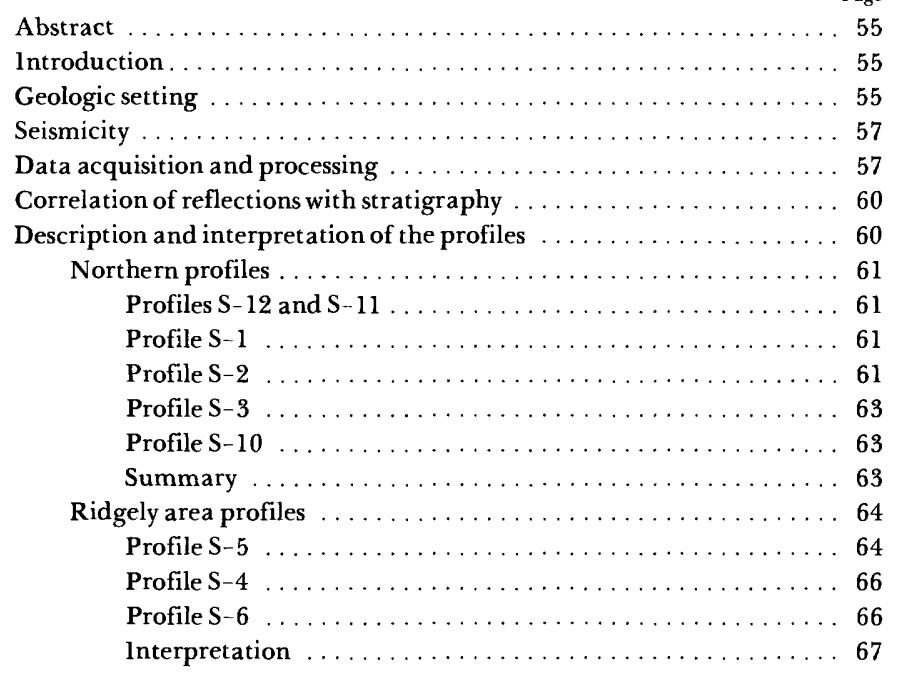

Description and interpretation of the profiles - Continued $\ldots \ldots \ldots \ldots$ Page

Caruthersville area profiles $\ldots \ldots \ldots \ldots \ldots \ldots \ldots \ldots \ldots \ldots \ldots$

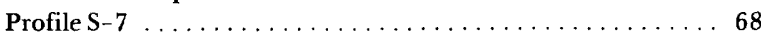

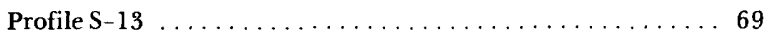

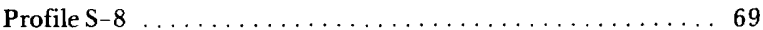

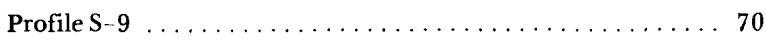

Deep-resolution profiles $\ldots \ldots \ldots \ldots \ldots \ldots \ldots \ldots \ldots \ldots$

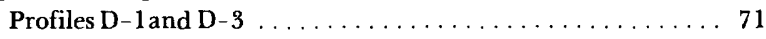

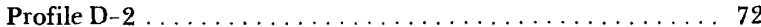

Nature of geologic structure and faulting in the region of the embayment

lllinois-Kentucky mineral district . . . . . . . . . . . 73

Cottage Grove-Shawneetown-Rough Creek fault zone . . . . . . 73

Wabash Valley fault zone $\ldots \ldots \ldots \ldots \ldots \ldots \ldots \ldots \ldots$

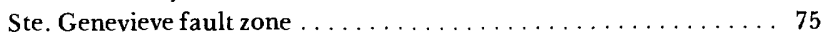

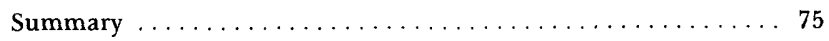

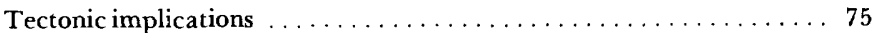

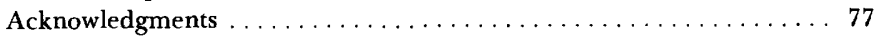

References cited . . . . . . . . . . . . . . . . . . . . . . . . 77

\section{ILLUSTRATIONS}

FiguRE 1. Relationship of earthquake epicenters, plutons, rift boundaries, faults, and major geologic features in the northern

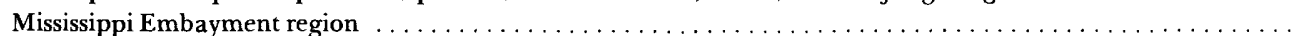

2. Locations of the seismic-reflection profiles, principal faults inferred from the data, rift boundaries, and research well ............ 58

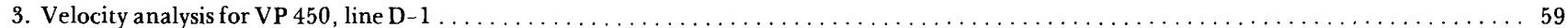

4. Correlation of stratigraphic units with a synthetic seismogram based on logs from the research well and part of nearby reflection profile $\mathrm{S}-10 \ldots 60$

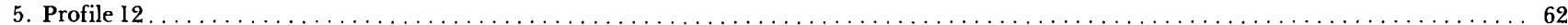

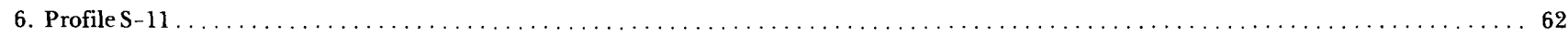

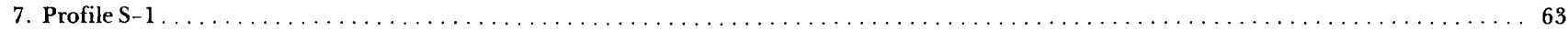

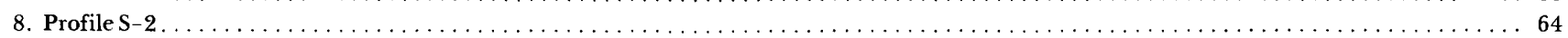

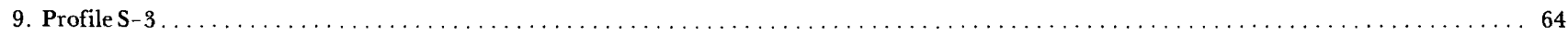

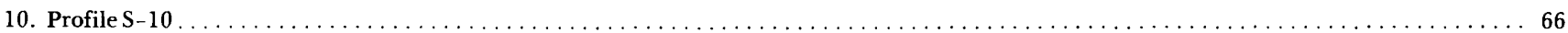

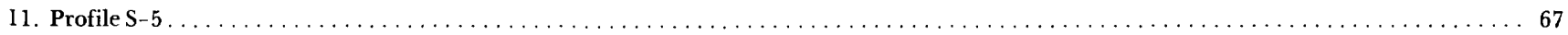

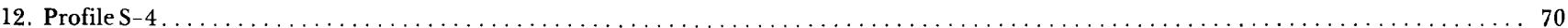

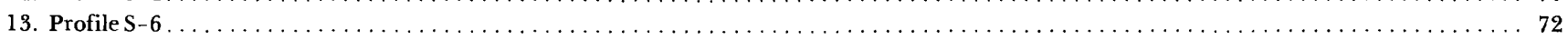

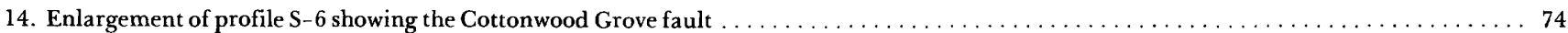

15. Spatial relationship of faults and an igneous intrusive mass to topographic ridges and Bouguer gravity anomalies in the

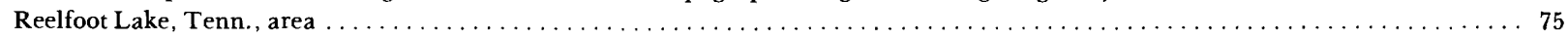

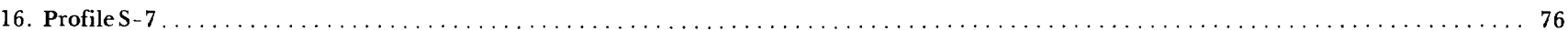

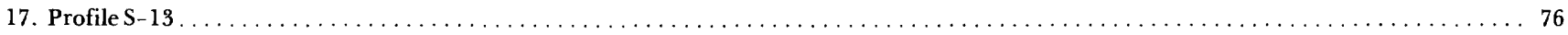

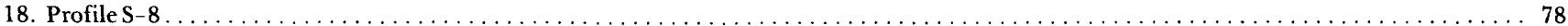

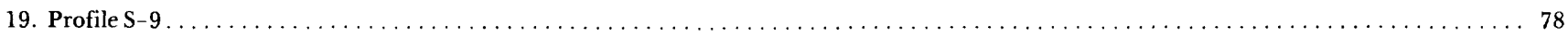

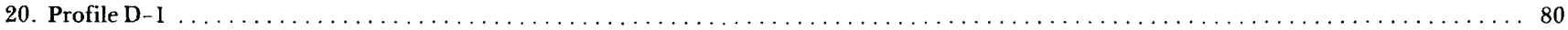

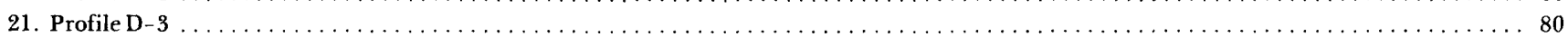

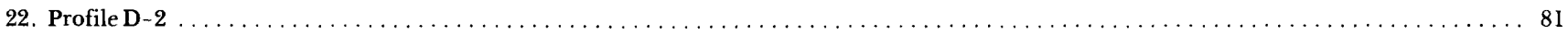




\title{
TECTONIC FEATURES OF THE NEW MADRID SEISMIC ZONE FROM SEISMIC-REFLECTION PROFILES
}

\author{
By R. M. Hamilton and M. D. Zoback
}

\begin{abstract}
Over $250 \mathrm{~km}$ of multichannel, common-depth-point seismic-reflection profiles in the New Madrid, Mo., seismic region show that the modern seismicity of the New Madrid area is associated with reactivated geologic features of ancient origin. The main seismic zone, which extends over 100 $\mathrm{km}$ in a northeasterly direction from near Marked Tree, Ark., to Caruthersville, Mo., is associated with a zone of arched and faulted Paleozoic rocks and minor faulting of overlying Upper Cretaceous and Tertiary rocks. Vertical offset of the Paleozoic rocks is about $1 \mathrm{~km}$. These zones of faulting and seismicity lie along the axis of a northeast-striking basement rift of late Precambrian or early Paleozoic age. In the southern part of the diffuse zone of seismicity that extends northward from the Ridgely, Tenn., area to the vicinity of New Madrid, a northeast-striking, high-angle, reverse fault shows about $80 \mathrm{~m}$ of post-middle Eocene vertical movement. An inferred igneous intrusive body lies northwest of the fault. The intrusive activity apparently preceded the faulting, but probably was also Cenozoic in age. In the vicinity of New Madrid, the upper Paleozoic section is intensely disrupted, possibly from late Paleozoic igneous activity. A northeast-striking seismic zone west of New Madrid appears to be associated with a fault showing mostly prePaleocene vertical movement.
\end{abstract}

\section{INTRODUCTION}

Assessment of seismic risk in the mid-continent region requires that the intense seismicity of the New Madrid zone be understood in relation to geologic structures and tectonic history. The main difficulty in establishing such a relation is that most of the seismic zone is covered by thick and poorly consolidated sediments of the Mississippi River valley. The bedrock geology is buried and any faulting of the bedrock could be greatly diminished and may not be well preserved in the soft sediments at the surface.

A variety of geophysical methods have been employed in an effort to improve knowledge of seismicity and structure in the New Madrid seismic zone. Installation of a seismograph network of moderate density has led to a marked improvement in resolution of the seismicity pattern (Stauder and others, 1976; Stauder and others, 1979). Lineations in the seismicity pattern can now be clearly seen, suggesting the location of faults, whereas earlier epicenter maps (for example, Hadley and Devine, 1974) show a much more diffuse pattern. Magnetic and gravity surveys have revealed several strong anomalies interpreted to be plutons and have suggested the presence of a northeast-striking basement graben or rift (Hildenbrand and others, 1977; Hildenbrand and others, 1979; Hildenbrand and others, this volume). These and other important tectonic features of the New Madrid region are shown on figure 1.

To further study the relationship between seismicity and structure, an extensive program of multichannel, commondepth- point, seismic-reflection profiling was undertaken. Preliminary work was done in the Tiptonville, Tenn., area in 1977 when $32 \mathrm{~km}$ of profiles were obtained (Zoback, 1979). Because the results from that study proved encouraging, a much larger survey was carried out in 1978 and 1979, when about $250 \mathrm{~km}$ of profiles were run. The most significant results of the more recent profiling were summarized by Zoback and others (1980). The data from both surveys were released in a report by Hamilton and Zoback (1979). This report constitutes a full presentation and comprehensive discussion of the profiles from the 1978-79 survey. Features of particular interest are analyzed in detail.

\section{GEOLOGIC SETTING}

Considerable attention must be paid to the geologic history of the New Madrid seismic region because of an apparently close relationship between current seismicity and geologic features of ancient origin. The reader is referred to the detailed summary of geologic history that is presented in the introductory chapter of this volume and to Hinze and others (1977).

The New Madrid seismic zone lies at the northern end of the Mississippi Embayment, in a region covered with poorly consolidated Cenozoic and Upper Cretaceous sediments. These sediments overlie Paleozoic sedimentary rocks, which in the study area are mostly limestones and dolomites of Ordovician and Cambrian age. The nearest exposure of Precambrian rocks is about $150 \mathrm{~km}$ north-northwest of the seismic zone in the St. Francois Mountains of Missouri.

The geologic structure of the embayment largely reflects the topography of the Paleozoic surface, which forms a broad, southwest-plunging trough. In the center of the embayment, in the area of this study, Late Cretaceous, Paleocene, and Eocene deposits over this surface are generally conformable. Knowledge of Paleozoic structure is based on subsurface information from wells. Centered in southeastern Missouri, Cam- 


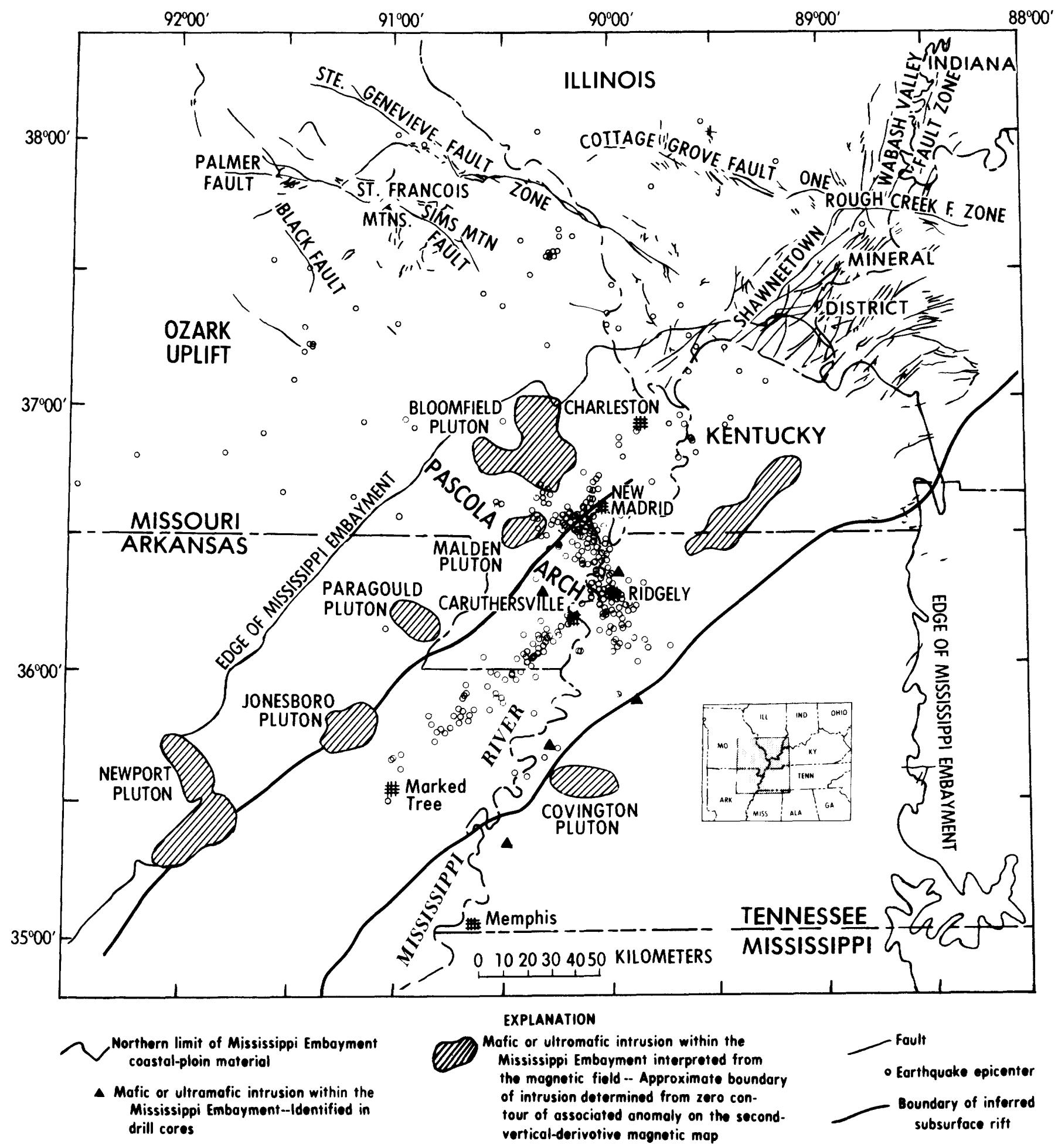

FIGURE 1.- Relationship of earthquake epicenters, plutons, rift boundaries, faults, and major geologic features in the northern Mississippi Embayment region. Epicenters, open circles (Stauder and others, 1979); plutons, lined pattern; rift boundaries, heavy solid lines (Hildenbrand and others, this volume); and faults, fine solid lines (Heyl and McKeown, 1978).

brian rocks lie at the Paleozoic surface surrounded by successive belts of Ordovician and Devonian rocks. Thus, the subcrop data reveal the presence of a structural high, which is named the Pascola arch (Grohskopf, 1955) (fig. 1).
Many of the wells in the northern Mississippi Embayment that have reached Paleozoic rocks have encountered igneous rocks of alkalic composition (Miser and Ross, 1925; Kidwell, 1947, 1950; Clegg and Bradbury, 1956), which are indicative 
of a deep magma origin (Zartman, 1977). A Permian age was determined by the $\mathbf{K}$-Ar method for cuttings from one well in the area (Zartman and others, 1967; Zartman, 1977).

Numerous faults have been mapped in the region north of the Mississippi Embayment (Heyl and McKeown, 1978) (fig. 1). Although activity in the New Madrid seismic zone extends into the region of the mapped faults, its distribution is diffuse there, and no clear correlation between faults and earthquakes has yet been established. Much of the fault movement occurred between Pennsylvanian and Cretaceous time (Krausse and Treworgy, 1979). Continuation of mapped faults under the sediments of the embayment is largely conjectural.

The deep structure of the northern embayment is indicated by geophysical data. A seismic-refraction survey along the northwestern margin of the embayment, between Cape Girardeau, Mo., and Little Rock, Ark., showed that the crust is $45 \mathrm{~km}$ thick and that a layer of material intermediate between normal crustal and mantle rocks in velocity $(7.4 \mathrm{~km} / \mathrm{s})$ exists in the lower crust (McCamy and Meyer, 1966). Regional gravity data, when used with the seismic-refraction data, suggest that this layer thickens under the middle of the embayment, and this thickening has been interpreted as evidence for a broad, northeast-striking rift of Precambrian origin (Ervin and McGinnis, 1975). Recent, detailed magnetic and gravity data show a similarly striking graben in the upper crust that has structural relief of 1.6-2.6 km; this graben may have formed as early as late Precambrian or early Paleozoic time (Hildenbrand and others, 1977; Hildenbrand and others, this volume). These data also show the locations of numerous plutons, particularly along the graben, or rift, margin and axis (fig. 1).

\section{SEISMICITY}

The improved seismograph network in the New Madrid region greatly increased the resolution of the seismicity pattern (fig. 1). The major feature is a linear zone extending for about $100 \mathrm{~km}$ from near Marked Tree, Ark., in a northeasterly direction to beyond Caruthersville, Mo. This zone lies approximately along the axis of the northeast-striking rift (fig. 1) defined by magnetic and gravity data (Hildenbrand and others, 1977; Hildenbrand and others, this volume). A more diffuse zone lies between the Ridgely, Tenn., area and New Madrid, Mo., to the north. Another northeast-striking zone passing northwest of New Madrid toward Charleston, Mo., is evident, as are other clusters of activity. Fault-plane solutions (Herrmann, 1979) suggest predominantly right-lateral, strikeslip movement along the northeast-striking seismic zones and essentially east-west compression. The nature of movement between the two northeast- striking zones, that is, in the zone between Ridgely and New Madrid, is evidently more complex because the fault-plane solutions are varied (Herrmann and Canas, 1978; Herrmann, 1979). Composite-fault-plane solu- tions from a microearthquake study in this zone, however, also indicate east-west compression ( $\mathbf{O}^{\prime}$ Connell and others, this volume). Focal depths for New Madrid earthquakes are mostly less than $15 \mathrm{~km}$ (Stauder and others, 1979).

Although the epicenters for the three main earthquakes in 1811-12 are not reliably known, a case can be made for their approximate location based on intensity data (Nuttli, 1973). The first shock, on December 16, 1811, probably occurred in northeastern Arkansas toward the southwestern end of the seismic zone. The second shock, on January 23, 1812, was closer to New Madrid than the first one. The third shock, on February 7, 1812, was nearest to New Madrid. Thus, the first large earthquake, and perhaps the second one, may have occurred along the main Marked Tree-Caruthersville seismic zone. The third earthquake could be associated with the zone of current seismicity near New Madrid. Of course, it is also possible that the faults responsible for the 1811-12 earthquakes are not revealed by current seismicity.

\section{DATA ACQUISITION AND PROCESSING}

The seismic-reflection profiling made use of the Vibroseis ${ }^{1}$ method. Data acquisition and processing were carried out by Geophysical Services Inc. (GSI) under contract to the USGS. Most of the profiles were located so as to cross linear zones in the seismicity pattern (fig. 2). To facilitate correlation, most of the profiles were tied to one another. As the land is agricultural and the water table seasonably high, the logistics of truck operations necessitated that the profiles lie along roads. Vibration points were located more than $120 \mathrm{~m}$ from buildings or water wells to prevent the possibility of damage. For the same reason, highly populated roads had to be avoided.

Three or four vibrator trucks were used with a 48-channel recording system. All profiles were run with a 122 -m offset to the nearest recording group. Thirteen of the profiles were run with 30.5-m-group intervals in split spreads. These profiles were designated by the letter " $S$ " because the parameters of the spread configuration and sweep were chosen to enhance shallow reflections. Three profiles run with 61 -m-group intervals to enhance deep reflections were designated by the letter "D. Profiles D-1 and D-3 were run as split spreads, and D-2 was run as an off-end spread. Multiplicity was $12-$ and $24-$ fold on the $\mathbf{S}$ and $\mathbf{D}$ profiles, respectively. Generally, 15 sweeps of 7-s duration were made at each vibration point with $10 \mathrm{~s}$ of recording time. The sweep frequency was usually $10-80 \mathrm{~Hz}$ for the $S$ profiles and $10-50 \mathrm{~Hz}$ for the D profiles. Additional parameters are given by Hamilton and Zoback (1979).

The fieldwork was done in two stages. Profiles S-1 through $12, \mathrm{D}-2$, and the west third of D-1 were completed before the end of 1978, when work was interrupted, first by icy road con-

\footnotetext{
${ }^{1}$ Trademark of Continental Oil Co. Any use of trade names is for descriptive purposes only and doe not imply endorsement by the U.S. Geological Survey.
} 


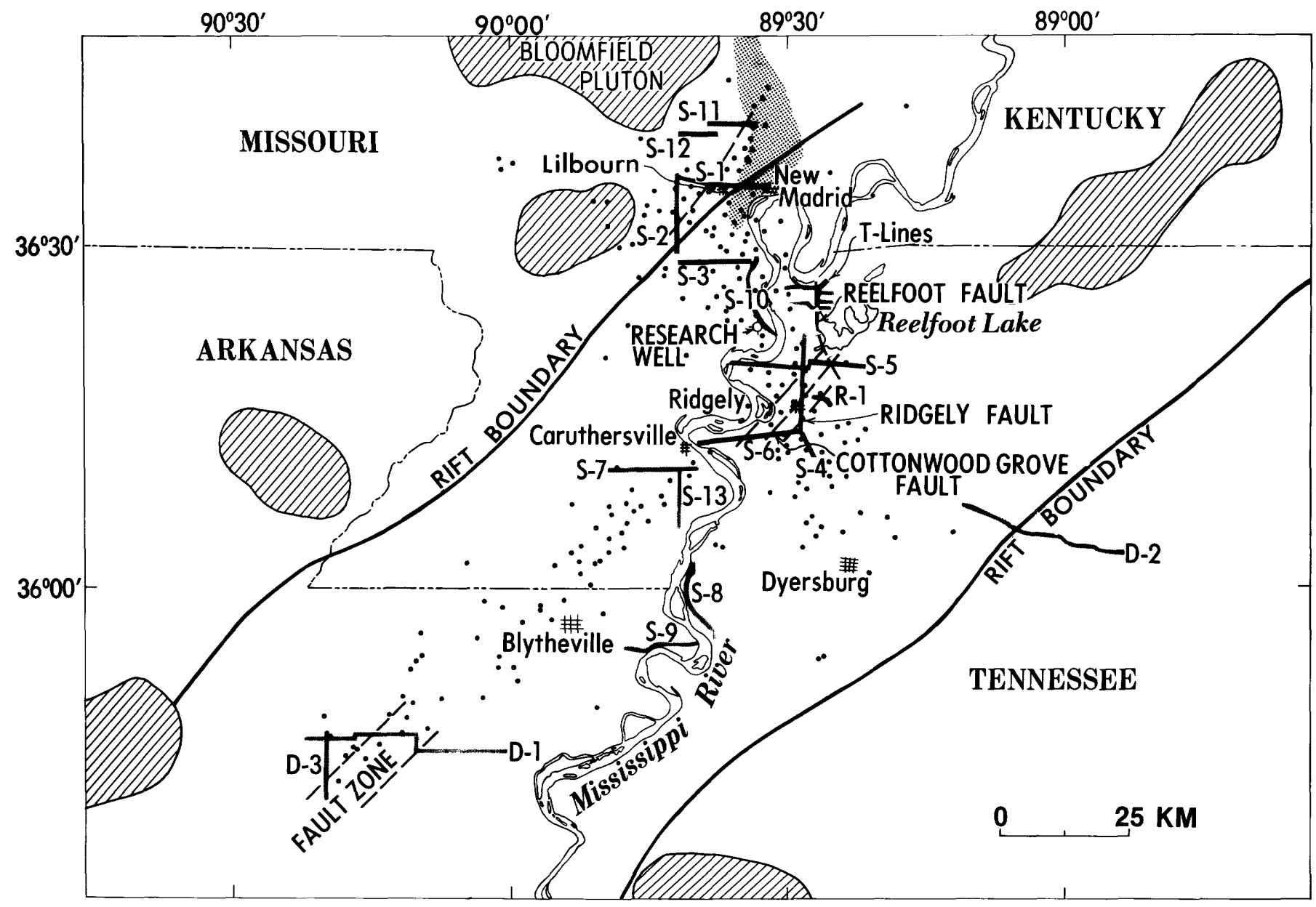

Figure 2. - Locations of the seismic reflection profiles (heavy lines), principal faults inferred from the data (dashed lines), rift boundaries, buried pluton (hachured pattern), and the research well. The T lines and line R-1 refer to profiles reported on by Zoback (1979).

ditions and then by floodwaters. The interruption proved to be beneficial because it allowed time for preliminary data processing on the completed profiles. Consequently, profiles D-3 and S-13 were added to the field program - the former line to determine true dip and strike of Paleozoic strata seen on line D-1, and the latter line to attempt to trace the southwesterly continuation of a fault seen on lines S-6 and S-4.

Data processing was done by standard procedures (see, for example, Dobrin, 1976; Sheriff, 1978; and Waters, 1978). The data were not migrated, except for a part of line S-6. In addition to the final-stack record sections, which are shown here in figures 5-14 and 16-22, the data available for analysis include correlated field records, brute-stack record sections (before residual static and residual normal-moveout corrections were made), single-fold-coverage sections (unstacked records from the individual vibrating points), velocity analyses, and computer listings of the residual static corrections.

Several features on the profiles that appear as deformation of reflections are thought instead to be artifacts of the data processing. In places where a number of sequential vibration points were skipped, a wedge-shaped gap appears at the top of a section and the reflections generally drape toward the gap. Artificial reflection offsets apparently can result both from a bend in a profile and from residual-static processing; the residual static problems appear to occur only near the ends of a profile. Examples are cited later in the section "Description and Interpretation of the Profiles." In general, static effects appear to have been treated adequately in the data processing. Most zones in which significant corrections have been made are correlated with low-lying areas; the shot and receiver corrections are mostly less than $10 \mathrm{~ms}$.

Seismic-wave velocities increase sharply at the Upper Cretaceous-Paleozoic contact. Stacking velocities for the reflections above this contact mostly fall in the range from 2.0 to $2.1 \mathrm{~km} / \mathrm{s}$. Thus, two-way travel time in milliseconds for reflections in the Tertiary and Upper Cretaceous sections is approximately equal to distance in meters. Correlation be- 
tween known depths to Paleozoic rocks in wells and the reflection times from nearby profiles yield estimates of the average velocity that are similar to each other in value. (See discussion in Crone and Brockman, this volume.) Velocity analysis of the profile data reported here did not generally yield estimates of stacking velocity below the Paleozoic surface because, except for profiles D-1 and D-3, good reflections are not seen there. Data processing was done assuming a linear increase in stacking velocity from about $2 \mathrm{~km} / \mathrm{s}$ at the Paleozoic surface to about $5.5 \mathrm{~km} / \mathrm{s}$ at $3.0 \mathrm{~s}$. The corresponding interval velocity below the Paleozoic surface is about $6.2 \mathrm{~km} / \mathrm{s}$, in agreement with seismic- refraction evidence (McCamy and Meyer, 1966).

An example of a velocity analysis from profile $D-1$ is shown in figure 3. Reflections are clearly seen from the Paleozoic surface at $0.87 \mathrm{~s}$, the Upper Cretaceous surface at $0.71 \mathrm{~s}$, and shallower horizons. Weak reflections seen for the stackingvelocity functions $\mathrm{V} 1$ and $\mathrm{V} 2$ between 1.57 and $1.70 \mathrm{~s}$ are probably multiples of the Paleozoic reflection. Most of the apparent multiple reflections arrive at about double the time for the primary reflections. A series of reflections below $1.7 \mathrm{~s}$ is

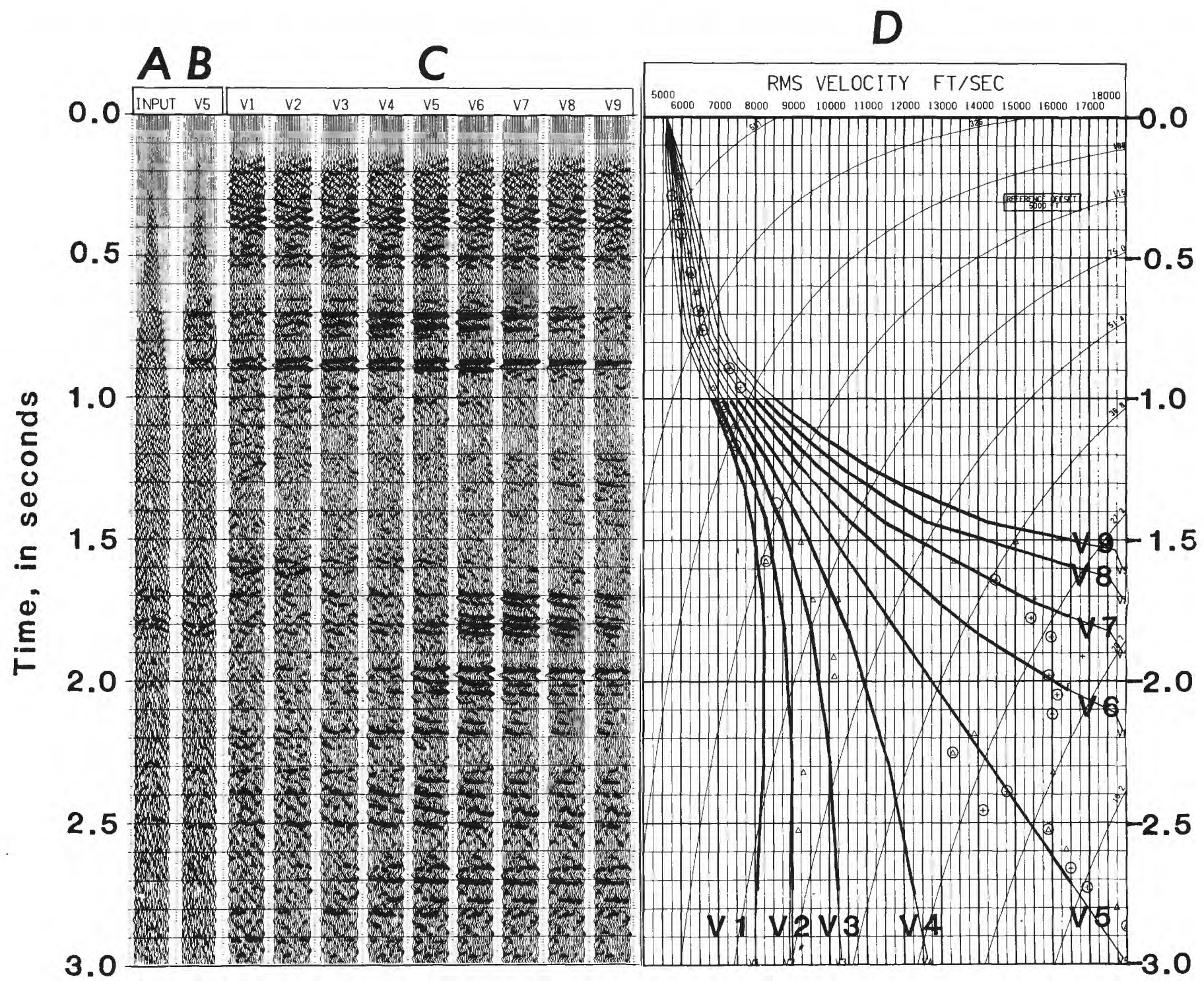

Figure 3. - Velocity analysis for VP 450, line D-1, which is shown in figure 20. From left to right, the data shown are A, a collection of the traces that reflected below VP 450, uncorrected for moveout; B, the same traces corrected for moveout using stacking-velocity function V5; C, stacked sections for 23 traces centered on VP 450 using stacking-velocity functions V1 through V9; and, D, a plot of the stacking-velocity functions against two-way travel time with the velocity picks derived from the reflections. The symbols under $\mathrm{D}$ are defined as follows: circle, highest amplitude in a 100 -ms interval; cross, events from 0 to $-6 \mathrm{db}$; and triangle, events from -6 to $-12 \mathrm{db}$. 
seen to stack well at the higher velocities, which is part of the basis for their interpretation as primary reflections rather than multiples.

\section{CORRELATION OF REFLECTIONS WITH STRATIGRAPHY}

As part of the New Madrid studies, a research well was drilled in 1978 to a depth of $700 \mathrm{~m}$ in extreme southeastern Missouri (Crone and Russ, 1979) (fig. 2). Paleozoic rocks of possible Cambrian age were reached (John Repetski, written commun., 1979). Much of the hole was cored and numerous samples of cuttings were collected. A complete suite of logs was obtained in the well, including density and sonic logs from which a synthetic seismogram was derived. Profile $S-10$ was run within $10 \mathrm{~m}$ of the well. The actual record section, synthetic section, logs, and stratigraphic column from Crone and Russ (1979) are compared in figure 4 . This information permits detailed correlation of the reflections on profile $S-10$ with stratigraphy above the Paleozoic surface. Because most of the profiles cross, or come close to doing so, reflections could usually be correlated between profiles. Two strong reflectors, the Paleocene-Upper Cretaceous contact and the Upper Cretaceous- Paleozoic contact, could be correlated over most of the study area. The Eocene-Paleocene contact is also a good reflector that could be correlated over much of the study area, but not too well in the northern part. Reflections from within the Eocene section could be correlated only locally.

\section{DESCRIPTION AND INTERPRETATION OF THE PROFILES}

In order to provide coherent organization to the presentation of the large number of record sections, the profiles are discussed systematically from north to south (fig. 2). The profiles are treated in four groups: (1) a northern group from the area generally west of New Madrid-S-1, 2, 3, 10, 11, and 12; (2) a group from the Ridgely area--S-4,5, and 6; (3) a group from the area south of Caruthersville-S-7, 8, 9, and 13; (4) and the three deep-resolution profiles (two lines being located southwest of Blytheville, Ark. - D-1 and D-3-and one line running east-northeast of Dyersburg, Tenn.--D-2). The most significant tectonic features are seen on profiles $S-4,5$, and 6 of group 2, and on profiles D-1 and 3 of group 4 .

For brevity, the reflectors are referred to by the geologic age symbol of the underlying unit: the contact between Eocene and Paleocene rocks is referred to as the $\mathrm{Pa}$ reflector, $\mathrm{K}$ is used for the Paleocene-Upper Cretaceous contact, and $\mathrm{Pz}$ for the Late Cretaceous-Paleozoic contact. The $\mathrm{K}$ and $\mathrm{Pz}$ reflections are marked on all profiles; the $\mathrm{Pa}$ reflection is marked only on

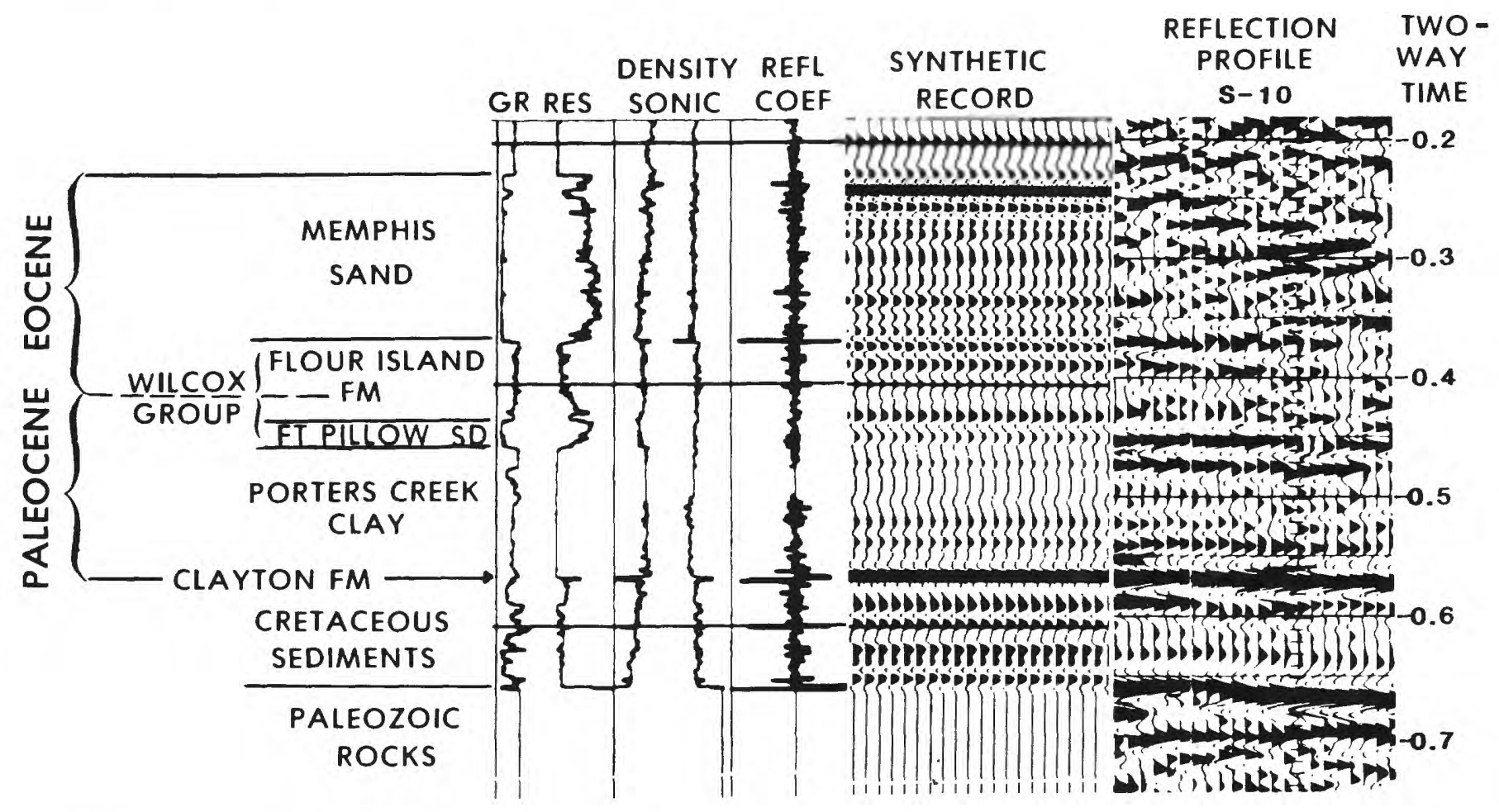

FIGURE 4. - Correlation of stratigraphic units with a synthetic seismogram based on logs from the research well and part of nearby reflection profile $S$ - 10 . GR, gamma-ray log; RES, resistivity log; and REFL COEF, reflection coefficient. Two-way travel time is in seconds (from Crone and Russ, 1979). The Porters Creek Clay is of Paleocene age; shallower beds are of Eocene age. 
the profiles where it is discussed. In the following discussion, interpretive comments closely follow descriptive comments in order to avoid redescribing features.

\section{NORTHERN PROFILES}

\section{PROFILES S-12 AND S-11}

Profiles S-12 (fig. 5) and S-11 (fig. 6), which are nearly colinear, are located north of New Madrid at the northern margin of the study area (fig. 2). They extend from near the flank of the Bloomfield pluton at the west end of line S-12 onto Sikeston Ridge at the east end of line S-11, where a northeast-striking zone of seismicity is crossed. (See also fig. 1.)

The $\mathrm{K}, \mathrm{Pz}$, and other reflections show a slight easterly, regional apparent dip. The $\mathrm{Pz}$ reflection is disrupted and discontinuous in places, progressively more so toward the east end of profile $\mathrm{S}-11$. Below the $\mathrm{Pz}$ reflection, the level of incoherent energy is high, with many diffractions in evidence.

A possible explanation for the disruption of the upper Paleozoic section could be fracturing, rock alteration, and mineralization associated with intrusive igneous activity. The proximity of the lines to the Bloomfield pluton (fig. 2) and the finding of cuttings of igneous rocks in nearby wells support this interpretation. The lack of corresponding disruption of the Upper Cretaceous section indicates that the inferred intrusive activity occurred before Late Cretaceous deposition. The Paleozoic rocks in the area of lines S-11 and S-12 are probably Ordovician in age (Grohskopf, 1955), which fixes the earliest date of the igneous activity. A Permian age was determined for intrusive rocks from a well near Tiptonville, Tenn. (Zartman and others, 1967). Magnetic data suggest a post-early Mesozoic age for the Bloomfield pluton (Hildenbrand and others, this volume). Both of these ages fall within the range suggested by the seismic data.

The main feature of interest on profiles $\mathrm{S}-11$ and S-12 is a low arch in the $\mathrm{Pz}, \mathrm{K}$, and shallower reflections centered under vibration point (VP) 172 on S-11, reversal in the regional dip occurs under VP 188 at the west margin of the arch, and an increased gradient at VP 160 marks the east margin, although some reflections at about $0.25 \mathrm{~s}$ show unusual easterly dips to VP 148. The significance of the arch is not clear. Because all reflections have a similar arch, at first glance the feature seems to have the characteristics of a static effect; however, the position of the steepest gradient, near VP 160, is actually located progressively more easterly on the shallower reflections in the section. Thus the arch is not thought to be a static effect, but it is thought to represent a structural feature. At VP 162, in the zone where the steeper gradient occurs, the line crosses the western flank of Sikeston Ridge, a 6-m-high, north-trending topographic feature. The sense of displacement of the reflections at VP 162 is opposite to that of the topography, which argues against interpretation of the ridge flank as a fault scarp, unless the sense of fault movement associated with the scarp has reversed. In any case, geologic evidence indicates that Sikeston Ridge is an erosional rather than structural feature (Russ, this volume). It may nevertheless be significant that the gradient near VP 162 is at about the place where profile $\mathrm{S}-11$ crosses the seismic zone.

\section{PROFILE S-1}

Profile S-1 (fig. 7) extends west from New Madrid across the same northeast-striking seismic zone that cuts the east end of profile S-11 (fig. 2).

The $\mathrm{K}$ reflection is fairly smooth and continuous along the whole profile. The $\mathrm{Pz}$ reflection is similar in character to the $\mathrm{K}$ reflection except in the eastern quarter of the line, east of about VP 437, where it is much more discontinuous. As in the case of profiles S-11 and S-12, diffractions and a high level of incoherent energy are seen below the $\mathrm{Pz}$ reflection on profile S-1. All reflections show regional apparent dip to the east. Superimposed on this trend are several features worth noting. Between VP 171 and 175 the trend is reversed, and between VP 278 and 290 the trend is steepened. These two places also mark changes in the general dip of the reflections. Reflections west of VP 171 dip more steeply to the east than they do east of VP 175, where they are nearly horizontal. East of VP 290 the reflections actually rise in a low arch, reaching their crest between VP 355 and 359. From there the regional dip to the east continues with only minor undulations in the reflections.

The reversal in trend between VP 171 and 175 is interpreted to be a fault that offsets the $\mathrm{K}$ and $\mathrm{Pz}$ reflections by about 20 $\mathrm{ms}$, west side down. Apparent diffractions immediately below the $\mathrm{Pz}$ reflection support this interpretation. Evidence for the minimum age of faulting is not entirely clear, as the reflections in the Tertiary section are not continuous; however, the reflections in the lower part of the Tertiary section appear to be offset at least $10 \mathrm{~ms}$. This then may be a case of fault reactivation with initial movement between deposition of sediments during the Late Cretaceous and Paleocene and further movement after Paleocene deposition.

The change in dip between VP 278 and 290 could be a fault or a flexure. The Pa reflection (at about $0.3 \mathrm{~s}$ ) is conformable with the $\mathrm{K}$ and $\mathrm{Pz}$ reflections, but shallower reflections (at about $0.2 \mathrm{~s}$ ) apparently are not. Thus, the deformation occurred before the Eocene.

The disruption of the $\mathrm{Pz}$ reflection in the eastern quarter of line S-1 does not occur in shallower reflections. Following the reasoning used in interpreting profiles $S-11$ and $S-12$, this disruption may indicate intrusive activity between Ordovician and Late Cretaceous time.

\section{PROFILE S-2}

Profile S-2 (fig. 8) runs south from the west end of profile S-1 to near the west end of profile S-3 (fig. 2). The profile 


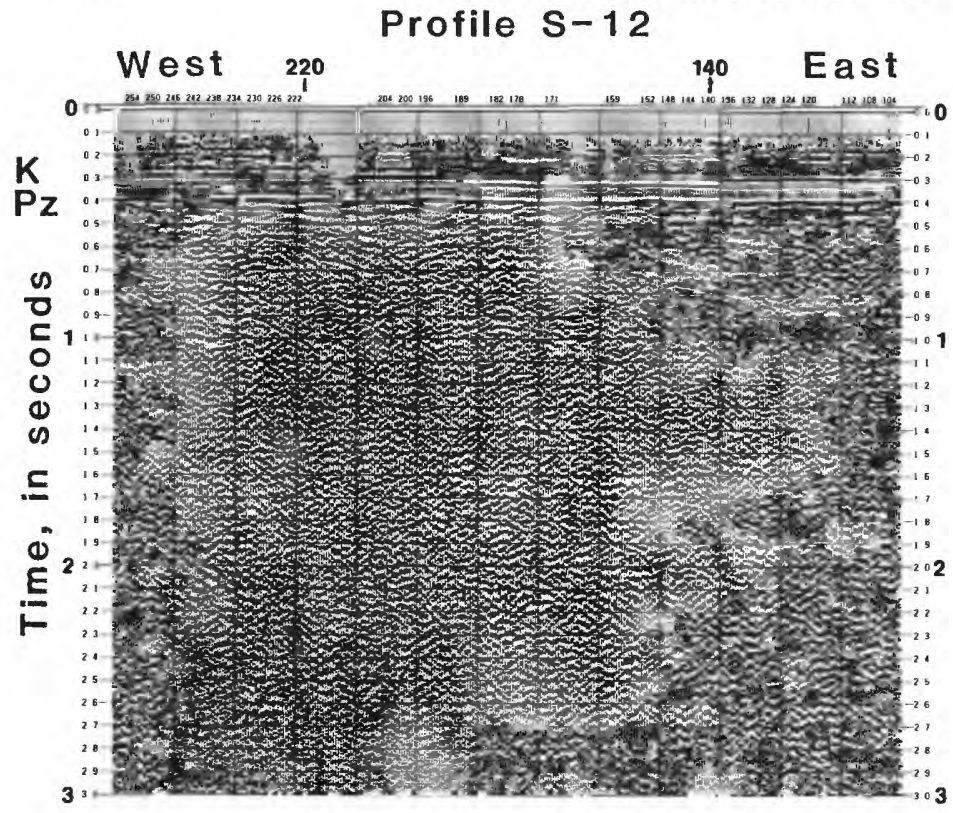

Figure 5.--Profile S-12. K, Tertiary-Upper Cretaceous contact; Pz, Upper Cretaceous-Paleozoic contact. Vibration point (VP) number is shown on the horizontal scale; the vibration point interval is $305 \mathrm{~m}$. To estimate interval thickness in kilometers, multiply interval time in seconds by 1 above $\mathrm{Pz}$ reflector and by 3 below it.

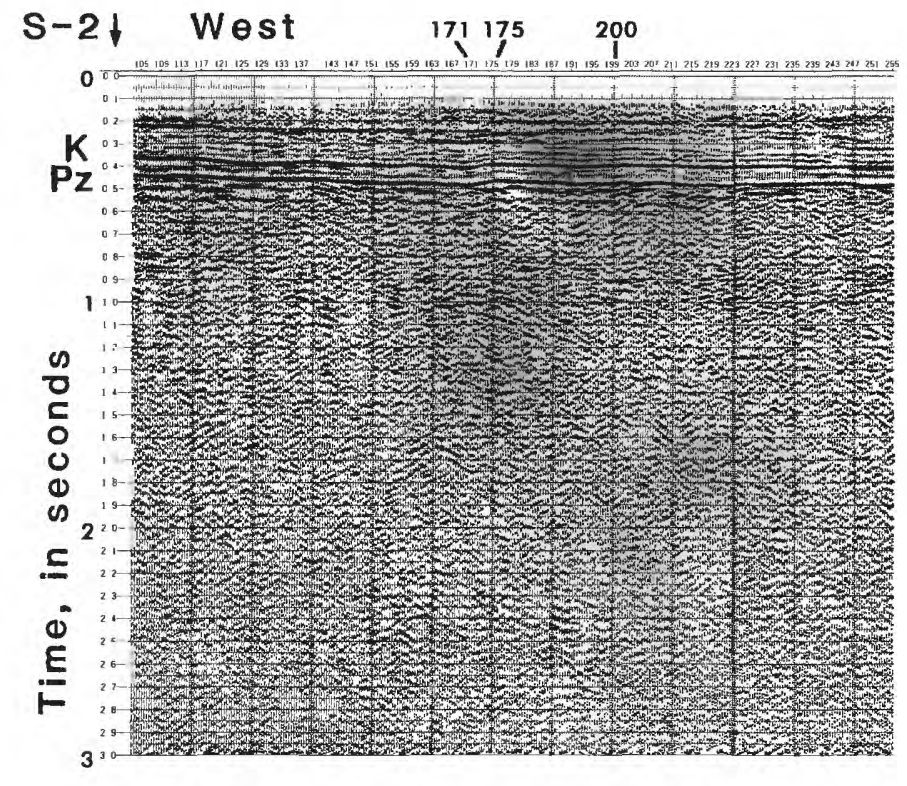

Figure 7. -- Profile S-1. K, Tertiary-Upper Cretaceous contact; Pz, Upper Cretaceous-Paleozoic contact. Vibration point (VP) number is shown on the horizontal scale; the vibration point interval is $30.5 \mathrm{~m}$. Arrow indicates where profile $\mathrm{S}-2$ crosses.

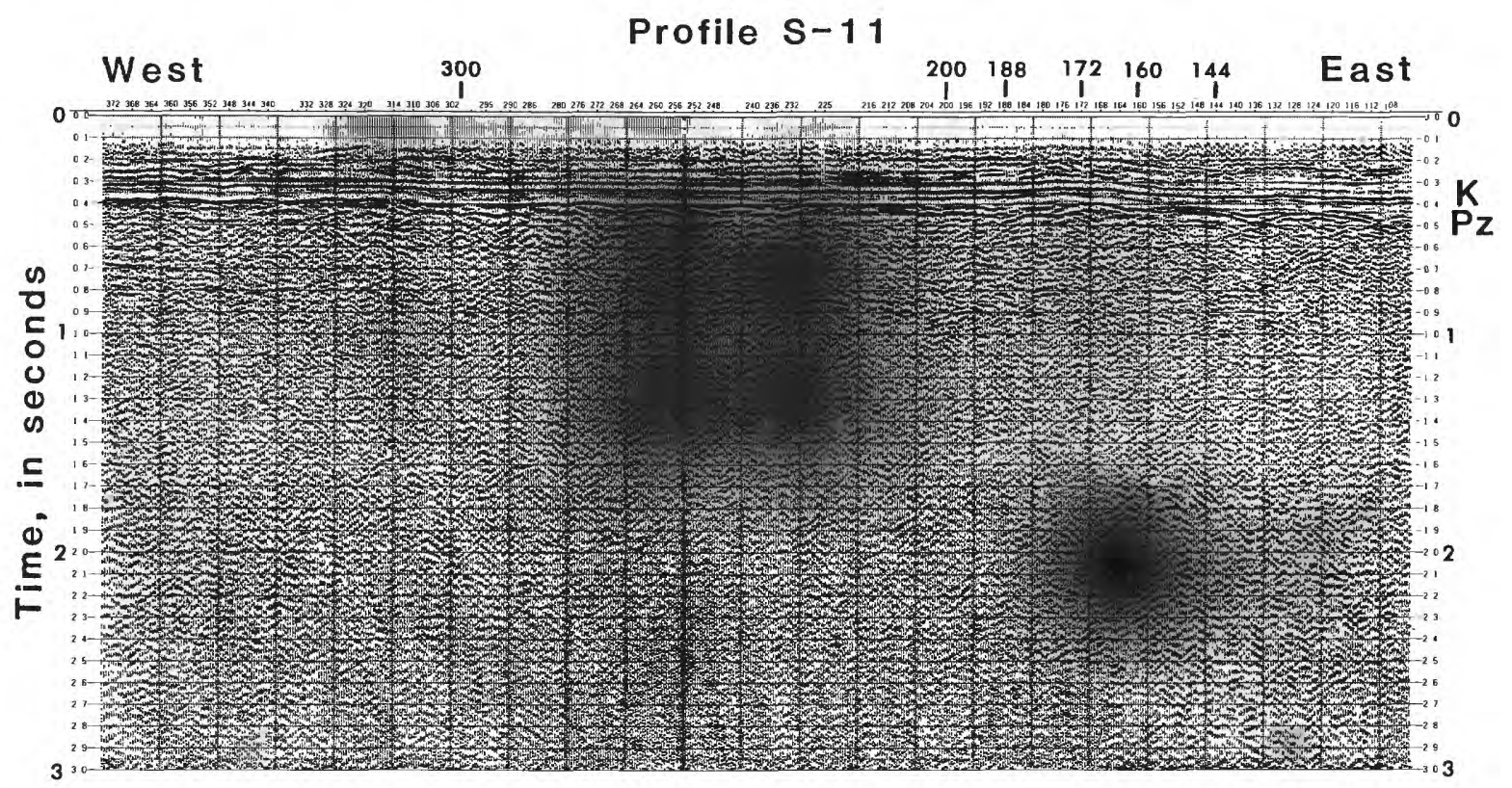

Figure 6. -- Profile S-11. K, Tertiary-Upper Cretaceous contact; Pz, Upper Cretaceous-Paleozoic contact. Vibration point (VP) number is shown on the horizontal scale; the vibration point interval is $30.5 \mathrm{~m}$.

passes between a cluster of epicenters located to the west and the north-northwest-striking seismic zone to the east.

Again, the $\mathrm{K}$ reflection is generally smooth and continuous, whereas the $\mathrm{Pz}$ reflection is somewhat disrupted. All reflec- tions show a southerly regional dip. The most important feature on the profile is an offset or flexure of about $25 \mathrm{~ms}$ in the $\mathrm{K}$ and $\mathrm{Pz}$ reflections between VP 370 and 374 . A diffraction appears below the $\mathrm{Pz}$ reflection. Reflections above the $\mathrm{K}$ 


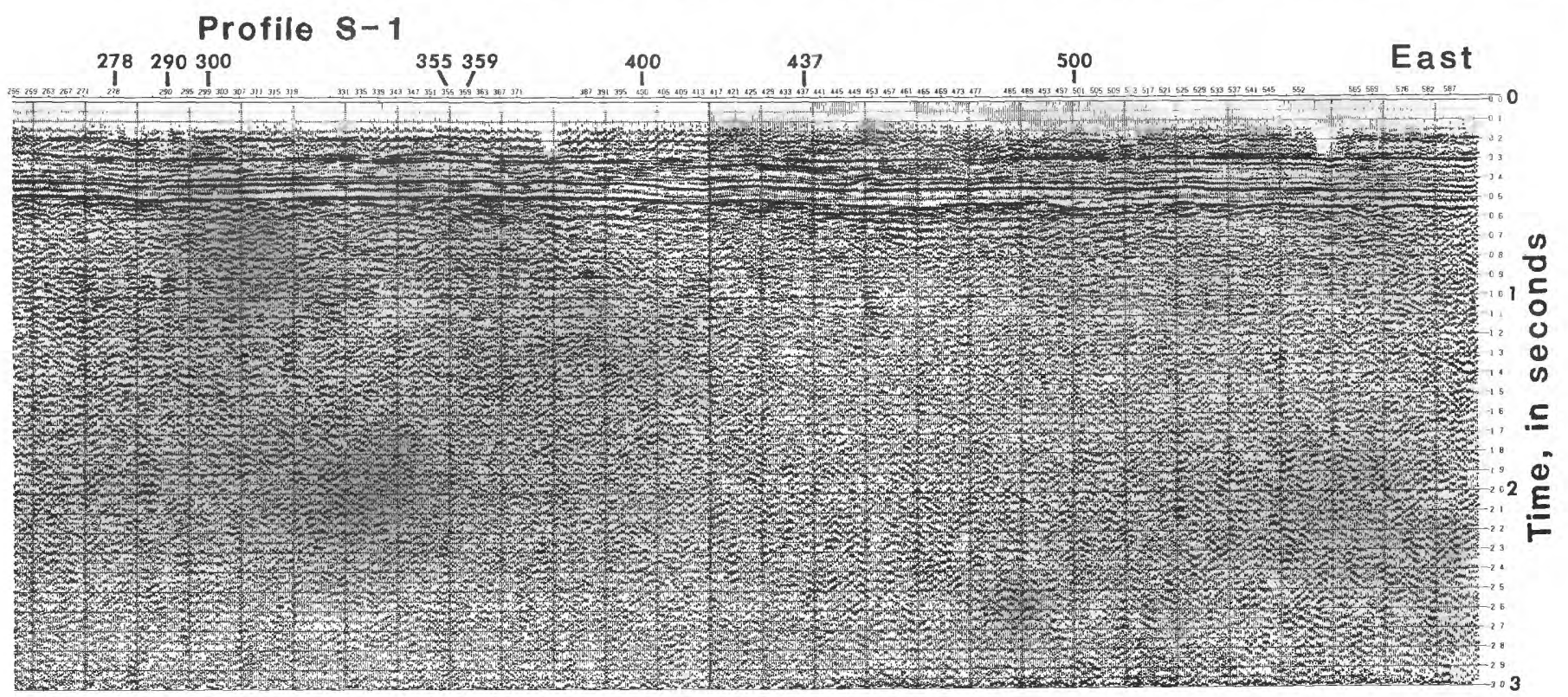

Figure 7. - Continued

reflection do not show the offset. The brute-stack and singlefold-coverage record sections show the feature more clearly as an offset than does the final-stack section in figure 8. Apparently, processing the data for residual statics had the effect of smoothing out the offset somewhat in the final-stack section.

The offset is interpreted as a normal fault, of about $25 \mathrm{~m}$ offset, south side down. Movement occurred after Late Cretaceous deposition but before deposition of the Cenozoic sediments. There is no evidence in the record section of fault reactivation. The fault, however, lies at the point where the northeast-striking seismicity zone crosses the profile.

\section{PROFILE S-3}

From near the south end of profile S-2, profile S-3 (fig. 9) runs easterly across the seismic zone to near the Mississippi River (fig. 2).

The $\mathrm{K}$ and $\mathrm{Pz}$ reflections are both fairly continuous and show easterly regional apparent dip, with a drop of about 100 ms over the line length. Much of this drop occurs from VP 234 to 329 and from VP 432 to the east end of the line. Several arches appear in the reflections, for example, between VP 329 and 386 , but their significance is unclear.

The only feature on profile $S-3$ that can be confidently interpreted as a fault is the offset near VP 488. The brute- stack section shows the fault more clearly than does the final- stack section. A normal offset of about $20 \mathrm{~ms}$ in the $\mathrm{K}$ and $\mathrm{Pz}$ reflections appears to carry into the Eocene section with similar amplitude. Thus, the age of movement would be post-middle Eocene.

\section{PROFILE S-10}

Tying with the east end of profile $S-3$, profile S-10 (fig. 10) runs in a south-southeasterly direction along the seismic zone (fig. 2). At VP 411, the line passes near the well used for stratigraphic correlation (Crone and Russ, 1979).

The $\mathrm{K}$ and $\mathrm{Pz}$ reflections are smooth and show regional apparent dip to the south with a total drop of about $90 \mathrm{~ms}$. This drop occurs in an irregular manner. Between VP 340 and 452 it is negligible. Near VP 452 the drop is about $40 \mathrm{~ms}$. The features near VP 245 and near VP 228 that have offsets of 15 $\mathrm{ms}$ in all reflections are interpreted to be processing effects associated with a line bend. The discontinuities and diffractions near the south end of profile S-10 may be the result of pre-Late Cretaceous igneous intrusive activity.

\section{SUMMARY}

The profiles in the northern part of the study area (S-1, 2, $3,10,11$, and 12) reveal only a few features that are clearly of structural significance.

The best example of faulting in the area is seen on profile S-2 at the point where the northeast-striking seismic zone crosses the profile (fig. 8, VP 370-378). To the northeast, where the seismic zone crosses profile $\mathrm{S}-1$, there is a flexure that could be a fault (fig. 7, VP 278-290) with the same sense of offset as that observed on profile S-2. Farther northeast along the zone, there is a similar feature with the same sense of offset on profile S-11 (fig. 6, VP 164-160). Thus, using the seismic zone as a guide, one can identify similar features that suggest the presence of a through-going fault. A fault-plane 
solution suggests current right-lateral strike-slip movement on the fault (Herrmann, 1979). The largest earthquake in the New Madrid area since 1812 occurred in 1895 near Charleston, Mo. (Heinrich, 1941), which lies near the northeastward projection of this fault (fig. 1). A problem with the suggested correlation is that on profile $\mathrm{S}-2$ only the $\mathrm{K}$ and $\mathrm{Pz}$ reflections appear to be offset, whereas on profiles $\mathrm{S}-1$ and S-11 shallower reflections are deformed as well. Correlation of the features, therefore, remains questionable. An alternative interpretation is to associate the fault on profile S-2 with a hypothetical east-west striking fault defined by microearthquakes (O'Connell and others, this volume). The latter fault, when projected westerly, crosses profile S-2 near the offset, and the sence of displacement, as inferred from a composite fault-plane solution, is consistent with the observed offset on profile S-2.

The fault on the east end of profile S-3 (fig. 9, VP 488) provides probably the best evidence in the area for post-middle Eocene movement. A similar offset is not seen on profile S-10. so the fault probably strikes in a northerly to northeasterly direction.

The many other undulations and flexures seen on the profiles may be of tectonic significance; however, they are not sufficiently distinctive in nature to permit correlation between lines. The distinct changes in slope and arching of the reflections may represent faulting of Paleozoic rocks. Such deformation carries into the Tertiary section in only a few places.

Disruption of the $\mathrm{Pz}$ reflection and the upper Paleozoic section is seen over most of the area, but seerrs to be greatest at the east ends of profiles S-11, S-1, and S-3, along much of S-2, and at the southern end of S-10. This may indicate that igneous rocks were emplaced higher in the stratigraphic section or that intrusive activity was generally more abundant there. As the seismicity is generally more intense in the area of this disruption, a correlation between modern seismicity and the zone of shallow or more intense Paleozoic intrusive activity is suggested.

\section{RIDGELY AREA PROFILES}

\section{PROFILE S-5}

Profile S 5 (fig. 11) extends from the east shore of the Mississippi River across the seismic zone and south of Reelfoot Lake onto the bluffs at the eastern margin of the flood plain (fig. 2). In 1811 and 1812, parts of Reelfoot Lake subsided and sections of the bluffs collapsed.

As in the case of the profiles to the north, the $\mathrm{K}$ reflection on profile $S_{-} \mathbf{5}$ is the most prominent one and is fairly continuous. The Pa reflection is fairly continuous, but cannot be traced along the whole profile. Several shallower reflections are locally continuous.

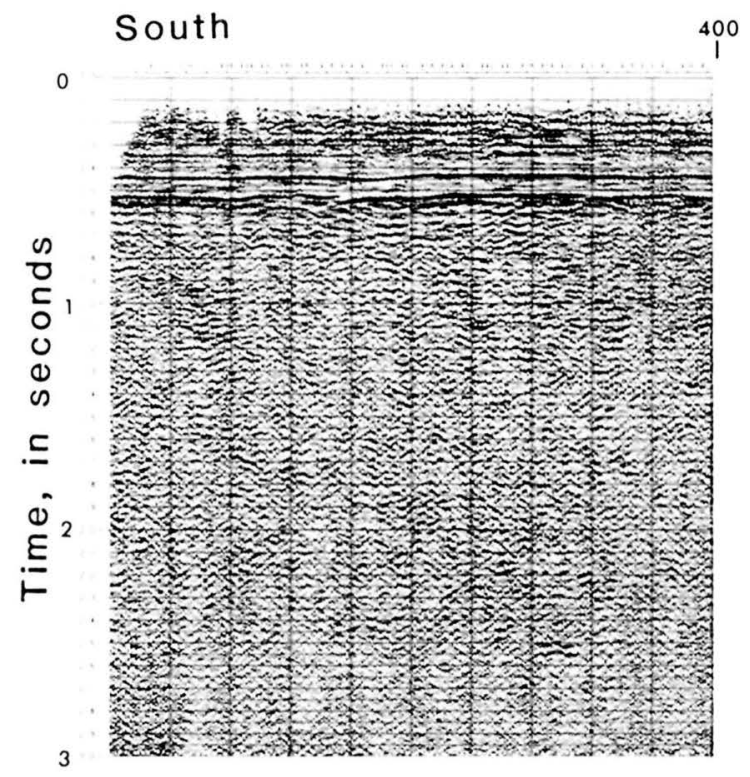

Figure 8. Profile S 2. K. Tertiary-Upper Cretaceous contact; Pz, Upper Cretaceous-Paleozoic contact. Vibration point (VP) number is shown on the horizontal scale; the vibration point interval is $30.5 \mathrm{~m}$. Arrow in. dicates where profile S 1. crosses.

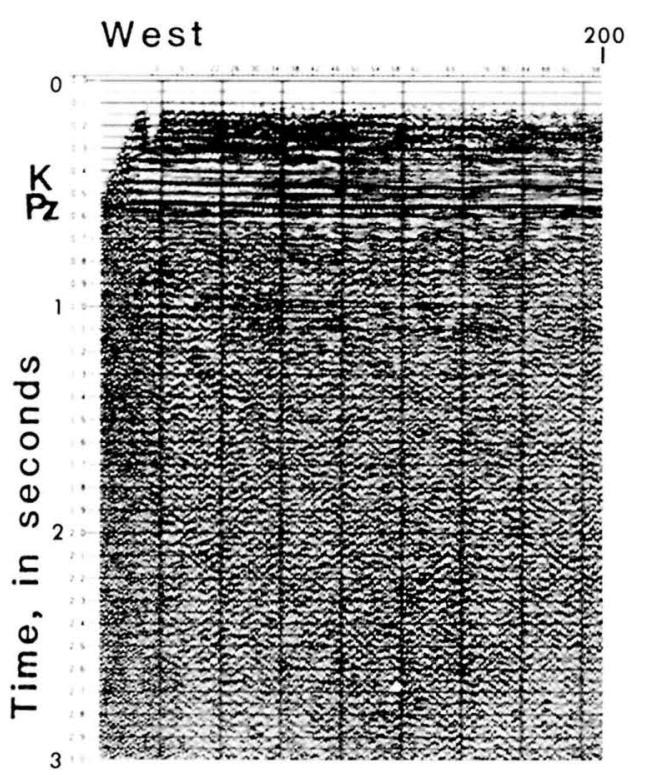

Figure 9. Profile S 3. K. Tertiary-Upper Cretaceous contact; Pz, Upper Cretaceous-Paleozoic contact. Vibration point (VP) number is shown on the horizontal scale; the vibration point interval is $30.5 \mathrm{~m}$. Arrow in. dicates where profile $\mathrm{S}-10$ crosses.

The $\mathrm{Pz}$ reflection is quite variable in character. In the western third of the line, it is seen clearly in only a few places; for example, beneath VP 675 and VP 571 . Beneath these two places, the Paleozoic section shows a relatively low level of in- 


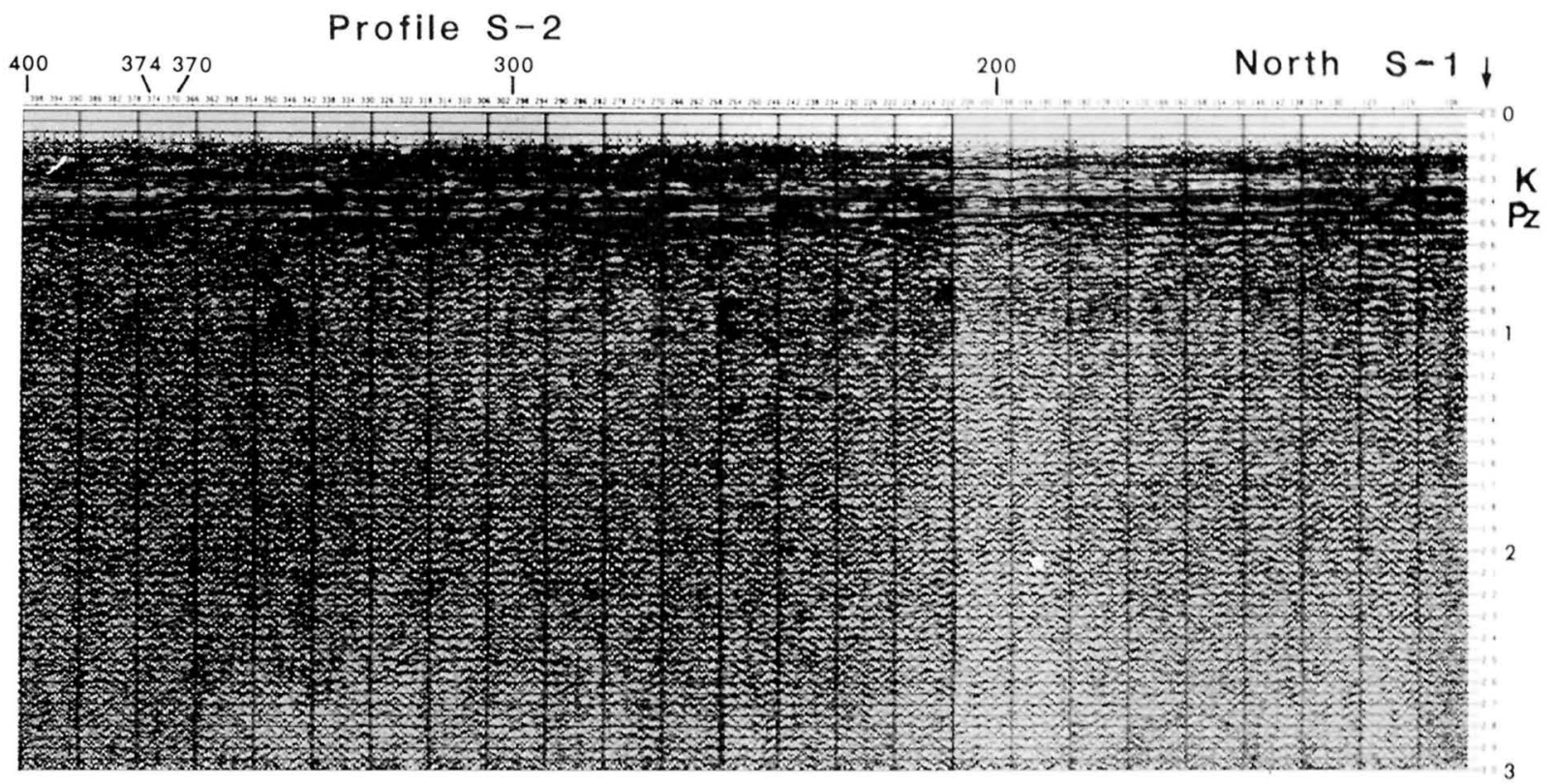

Figure 8.- Continued

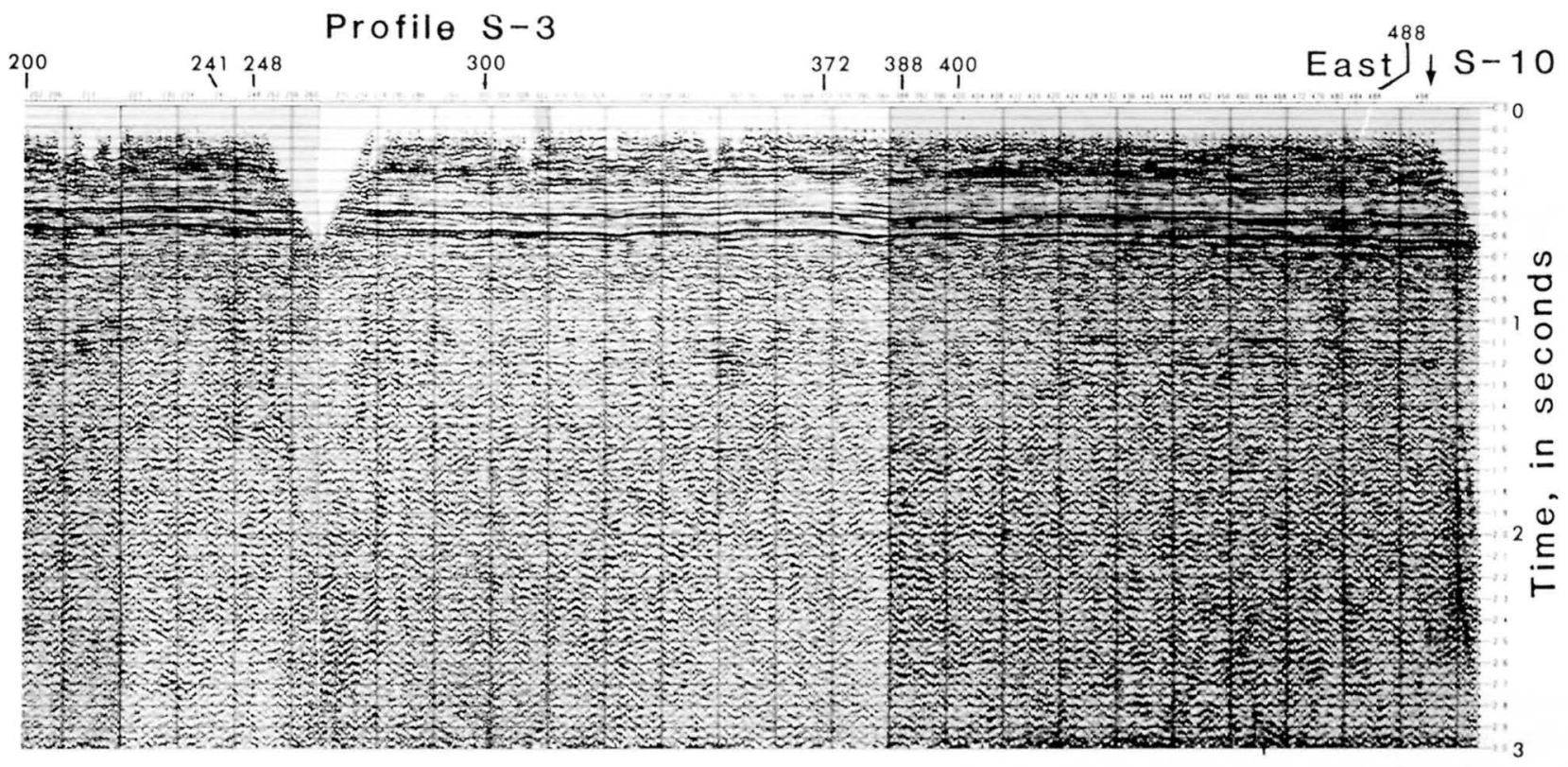

Figure 9. Continued

coherent energy. This effect is possibly caused by the combination of a particularly strong $\mathrm{Pz}$ reflection and the data processing. East of VP 481 the $\mathrm{Pz}$ reflection is somewhat discontinuous, but it can be traced to the east end of the line. Many diffractions are seen below the $\mathrm{Pz}$ reflection. At VP 389, the $\mathrm{Pz}$ reflection is disrupted by many discontinuous reflections that appear below where the $\mathrm{Pz}$ reflection would be. East of VP 357, which marks a shallow trough in the reflections, this energy drops in amplitude and a highly discontinuous $\mathrm{Pz}$ reflection is seen together with diffractions. 
Because line $\mathrm{S}-5$ crosses the middle of the embayment, the reflections show little regional dip across the profile. The reflections show a broad arch, which may be quite significant, as will be discussed later in this section. The arch can best be seen in the $\mathrm{K}$ reflection, which rises from $0.68 \mathrm{~s}$ beneath VP 755 to less than $0.60 \mathrm{~s}$ at VP 265, only to fall again to $0.67 \mathrm{~s}$ beneath VP 5.

Several features on profile S- 5 that at first glance appear to be faults may in fact be data-processing effects. The offset in the K reflection between VP 755 and 763 at the west end and the offsets at four places east of VP 79 near the east end are associated with relatively large residual static corrections, which have a large reversal in sign between two depth points. It is thought, therefore, that the features resulted from the residual-statics processing routine "skipping a leg" in the correlation process.

At VP 219 a trough appears in the $\mathrm{K}$ and shallower reflections. The $\mathrm{Pz}$ reflection shows similar structure, but owing to its discontinuous nature, this is not entirely clear. Note the character of the Pz reflection between the trough and VP 187, because this feature may correlate with features on profiles $S-4$ and S-6. An arch in the reflections between VP 133 and 105 also may correlate with features on the other lines.

Below the $\mathrm{Pz}$ reflection near the eastern end of profile $\mathrm{S}-5$ (east of VP 105), there are numerous short, strong reflections and many lower amplitude reflections. A gentle westerly dip of strata is indicated by the reflections east of about VP 87, but flattening and a possible reversal appears farther west. This evidence for the orientation of Paleozoic strata is seen more clearly on profiles D-1 and D-3.

Interpretation of the features on profile $\mathrm{S}-5$ will follow the descriptive sections on profiles $S-4$ and S-6.

\section{PROFILE S-4}

Running in a southerly direction from west of Reelfoot Lake, profile S-4 (fig. 12) crosses the middle of profile S-5, passes through Ridgely, and ties with the east end of profile S-6 (fig. 2). It passes through and along the eastern margin of the seismic zone.

Overall, the reflections show regional dip to the south amounting to about $90 \mathrm{~ms}$ between the ends of the profile. $\mathrm{The} \mathrm{Pa}$. K, and $\mathrm{Pz}$ reflections are clear and fairly continuous at the north end of the line. South of about VP 217, the Pz reflection becomes discontinuous and the Paleozoic section shows many diffractions. South of VP 237, the Pa, K, and possibly the Pz reflections dip into a trough at about VP 243. From VP 243 to 393, all reflections form an arch that crests at about VP 329. What appears to be the Pz reflection is relatively tightly arched and the Upper Cretaceous section is substantially thinned. The Paleocene section is only slightly thinned.

Centered at VP 395, an arched reflection, or diffraction, is seen slightly below and tangent to the $\mathrm{K}$ reflection. Between VP 393 and 413 the reflections rise about $80 \mathrm{~ms}$. The data gap

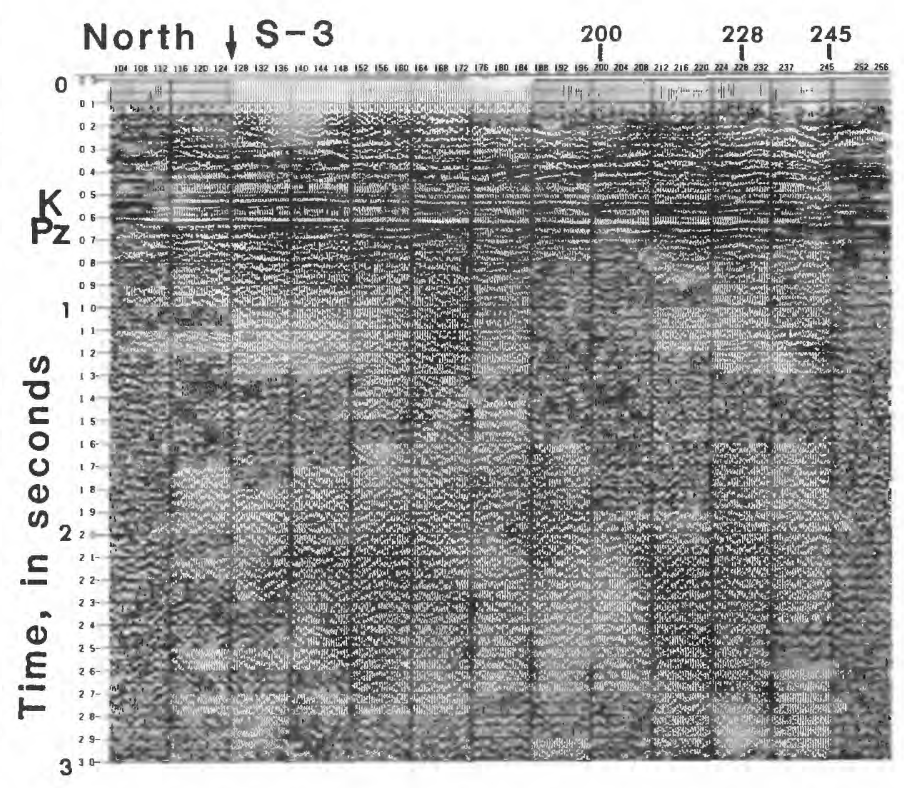

Figure 10.--Profile S-10. K, Tertiary-Upper Cretaceous contact; Pz, Upper Cretaceous-Paleozoic contact. Vibration point (VP) number is shown on the horizontal scale; the vibration point interval is $30.5 \mathrm{~m}$. Arrows indicate where profile $S-3$ crosses and where profile $S-10$ passes the research well.

near this feature is at the town of Ridgely. Between VP 545 and 609 , the Pz reflection is again strong, but between VP 609 and 680 the reflection is disrupted.

Interpretation of profile S-4 will follow the description of profile S-6.

\section{PROFILE S-6}

Profile S-6 (fig. 13) bridges the interval between the Marked Tree-Caruthersville seismic zone and the zone centered on Ridgely. It extends from the Mississippi River near Caruthersville in an easterly direction to tie with profile S-4 (fig. 2).

The $\mathrm{K}$ reflection is clear across the whole line with one major disruption. The Pz reflection is weak and disrupted from the west end of the line to about VP 536. Diffractions are clearly seen below the $\mathrm{Pz}$ surface. The $\mathrm{K}$ and $\mathrm{Pz}$ reflections gently rise from the west end of the line to VP 416, where they reverse their dip and form a trough at VP 400. From there to VP 249 they form an arch that crests in the vicinity of VP 324. Over the arch the Upper Cretaceous section is substantially thinned. The $\mathrm{Pa}$ reflection is slightly arched and the Paleocene section is somewhat thinned. A reflection is seen about 50 ms below the Pz reflection between VP 364 and 300 under the crest of the arch.

Bewteen VP 249 and 236 the Pz reflection and all reflections above it are offset; an enlarged view of this portion of profile S-6 is shown on figure 14. This is the most significant zone of post-Paleozoic offset seen on any of the profiles. Numerous apparent diffractions are seen in the zone. Also shown in figure 


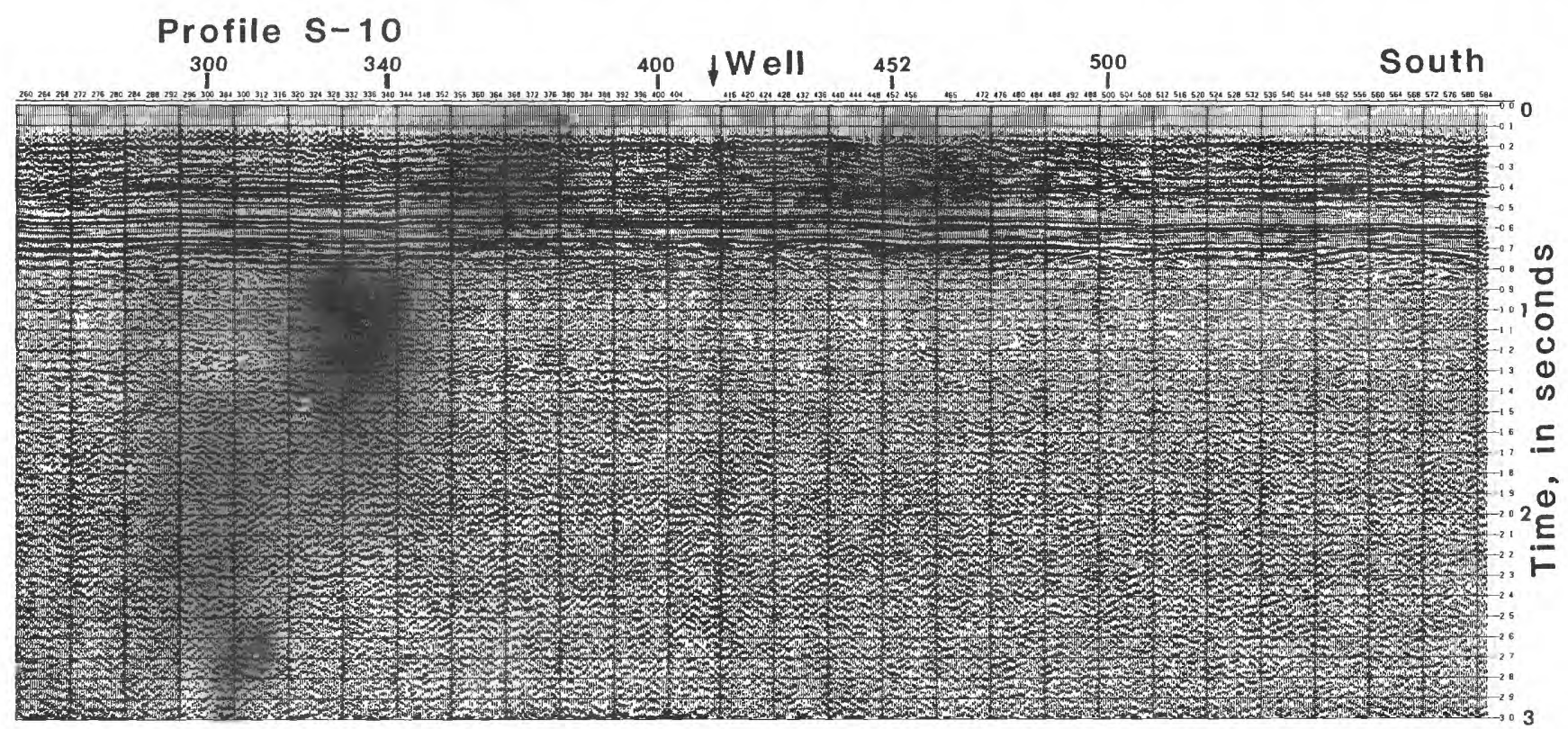

FIGURE 10.--Continued

14 is an interpretation of the zone of offset. The primary feature is a high-angle reverse fault with about $80 \mathrm{~ms}$ of displacement, east side up. The nature of the faulting in the zone is not entirely clear and there is some uncertainty in this interpretation. Migration of the part of profile S-6 centered on the Cottonwood Grove fault was carried out without significant improvement in record clarity (J. J. Miller, written commun., 1979).

The thinning of the Paleocene and Upper Cretaceous sections seen across the arch west of the fault zone continues east of the zone. At about VP 221 (fig. 13) the Pz reflection curves downward in a possible diffraction, and overlying reflections indicate subtle offsets. Between VP 216 and 160 the $\mathrm{Pz}$ reflection is highly disrupted, with one slight disruption of the $K$ reflection. Another zone of arched $\mathrm{Pz}$ and $\mathrm{K}$ reflections with associated thinning of the Upper Cretaceous section is centered at VP 156.

\section{INTERPRETATION}

Several features seen on profiles $S-4$ and $S-6$ are quite similar and are probably associated with the same structures (fig. 15). These correlations are also discussed by Zoback and others (1980).

The offset of $80 \mathrm{~ms}$ on profile S-4 (fig. 12) at VP 405 and the one of 80 ms on profile S-6 (figs. 13, 14) at VP 249 are unique in that no other offsets of similar size and character are seen on any of the sections. The feature delineated by connecting them is interpreted to be a reverse fault with about $80 \mathrm{~m}$ of offset, northwest side down, which strikes N. $40^{\circ} \mathrm{E}$. The nature of the offsets shows that most of the movement occurred dur- ing post-middle Eocene time. The name Cottonwood Grove fault has been given to the structure because it passes under the community of that name on profile $S-6$, where the offset is best seen.

The Cottonwood Grove fault appears to cross profile $S-5$ at about VP 215, where a trough is seen in the reflections. The 80 ms of offset seen on profiles S-4 and S-6 is certainly not in evidence on profile $S-5$, but similarities in reflection character occur between VP 215 and 183 on profile $S-5$ (fig. 11) and between VP 249 and 216 on profile S-6 (fig. 13), including similar westward thinning of the Upper Cretaceous section.

The arch centered at VP 324 west of the fault on profile S-6 and the arch centered at VP 329 north of the fault on profile S-4 are also unique features that appear to be correlative. They too define a northeast-striking structure. The trend when projected to profile S-5 intersects the section near the arch centered at VP 265. This arch is not as distinctive as the ones on profiles $S-4$ and $S-6$, but it does show slight thinning of the Upper Cretaceous section. Correlation with the other arches, therefore, seems reasonable.

The arch on profile S- 6 between VP 168 and 148 appears to have a counterpart on profile $S-5$ between VP 133 and 105 . It could represent a horst block. Further correlation suggests that the troughs at VP 400 on profile S-6, VP 243 on profile S-4, and VP 357 on profile S- 5 may be associated.

To recapitulate, correlation among profiles $S-4,5$, and 6 has delineated the northeast-striking Cottonwood Grove fault, which is associated with a similarly striking arch located northwest of it (fig. 15). Movement on this fault clearly occurred after middle Eocene time. That most of it occurred after the 


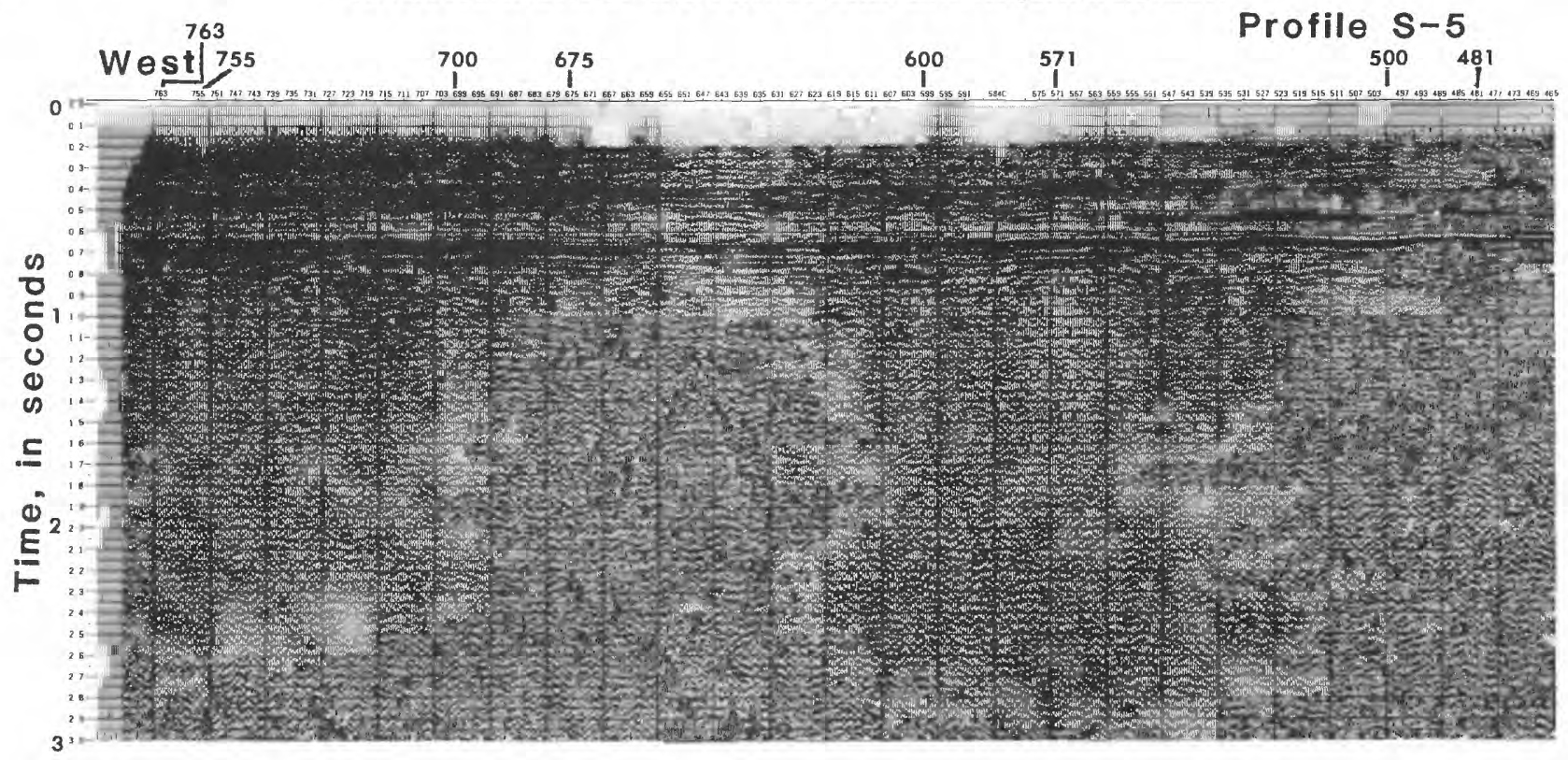

Figure 11.--Profile S-5. Pa, Paleocene; K, Tertiary-Upper Cretaceous contact; Pz, Upper Cretaceous-Paleozoic contact. Vibration point (VP) number is shown on the horizontal scale; the vibration point interval is $30.5 \mathrm{~m}$. Arrow indicates where profile S-4 crosses.

arch was formed is indicated by northwestward thinning of the Upper Cretaceous section on the southeast side of the fault. It appears that the arch originally spanned the zone of the fault. The broad arch seen on profile S- 5 apparently is one that did not collapse to the same extent as those seen on profiles $\mathrm{S}-4$ and $\mathrm{S}-6$.

Determination of the time of arching is linked with assumptions about its origin. One possibility is that the arch was caused by topographic relief on the Paleozoic surface during postPaleozoic deposition. The argument would be that when Late Cretaceous sedimentation began, a ridge existed on the Paleozoic surface. The resulting thinner section of sediments over the arch would have been less compacted than the thicker section on the flanks, which resulted in the arching of the Tertiary strata. This idea is not favored because the $\mathrm{Pz}$ arch seen on S-4 and S-6 is unique on the profiles; many topographic features should be seen in the $250 \mathrm{~km}$ of profiles if significant relief on the Paleozoic surface existed at the time of renewed deposition.

The preferred explanation for the arching is that an igneous body intruded the Paleozoic section after middle Eocene deposition. Previous evidence of post-Late Cretaceous intrusive activity in the northern Mississippi Embayment has been found at the Newport pluton in central Arkansas along the western edge of the embayment (Glick, this volume). A sill of possible Tertiary age has also been reported in a well located $7 \mathrm{~km}$ northwest of New Madrid (E. B. Kisvarsanyi, Missouri Geological Survey, written commun., 1979). The presence of Tertiary intrusive masses in nearby areas of the northern embayment lends support to the hypothesis that the arch is the product of warping caused by igneous intrusions of Tertiary age. Gravity data provide additional backing for the existence of the intrusions because the location of the inferred intrusive body coincides with a local gravity high (fig. 15). Also note in figure 15 that the upthrown block southeast of the Cottonwood Grove fault approximately coincides with Ridgely Ridge. The Ridgely fault (Zoback, 1979) bounds the southeast margin of the ridge.

The greatest disruption of the $\mathrm{Pz}$ reflection and the upper Paleozoic section occurs on the western part of profiles $\mathrm{S}-5$ and S-6. Recall that the greatest disruption in the northern area is on the eastern part of profiles S-11 and S-1 and on the southeastern part of profile S-10. In both sets of profiles the more intense disruption is nearer the river and in the vicinity of the seismic zone. As mentioned before, the disruption is interpreted to be evidence of igneous intrusive activity.

\section{CARUTHERSVILLE AREA PROFILES}

\section{PROFILE S-7}

Profile S-7 (fig. 16) extends west from near Caruthersville across the northern end of the Marked Tree-Caruthersville seismic zone (fig. 2).

The profile shows remarkably smooth and continuous reflections. In the western half of the profile, the reflections dip uniformly to the east. At VP 346 there is a V-like feature and possible diffractions. Farther east the reflections are virtually flat lying to about VP 148, where they dip east to the end of the line. The brute-stack sections show a sharp offset of $20 \mathrm{~ms}$ between VP 137 and 133.

The V-like feature at VP 346 is interpreted to be a fault at the hinge line between two tilted blocks of rock. The hinge line 


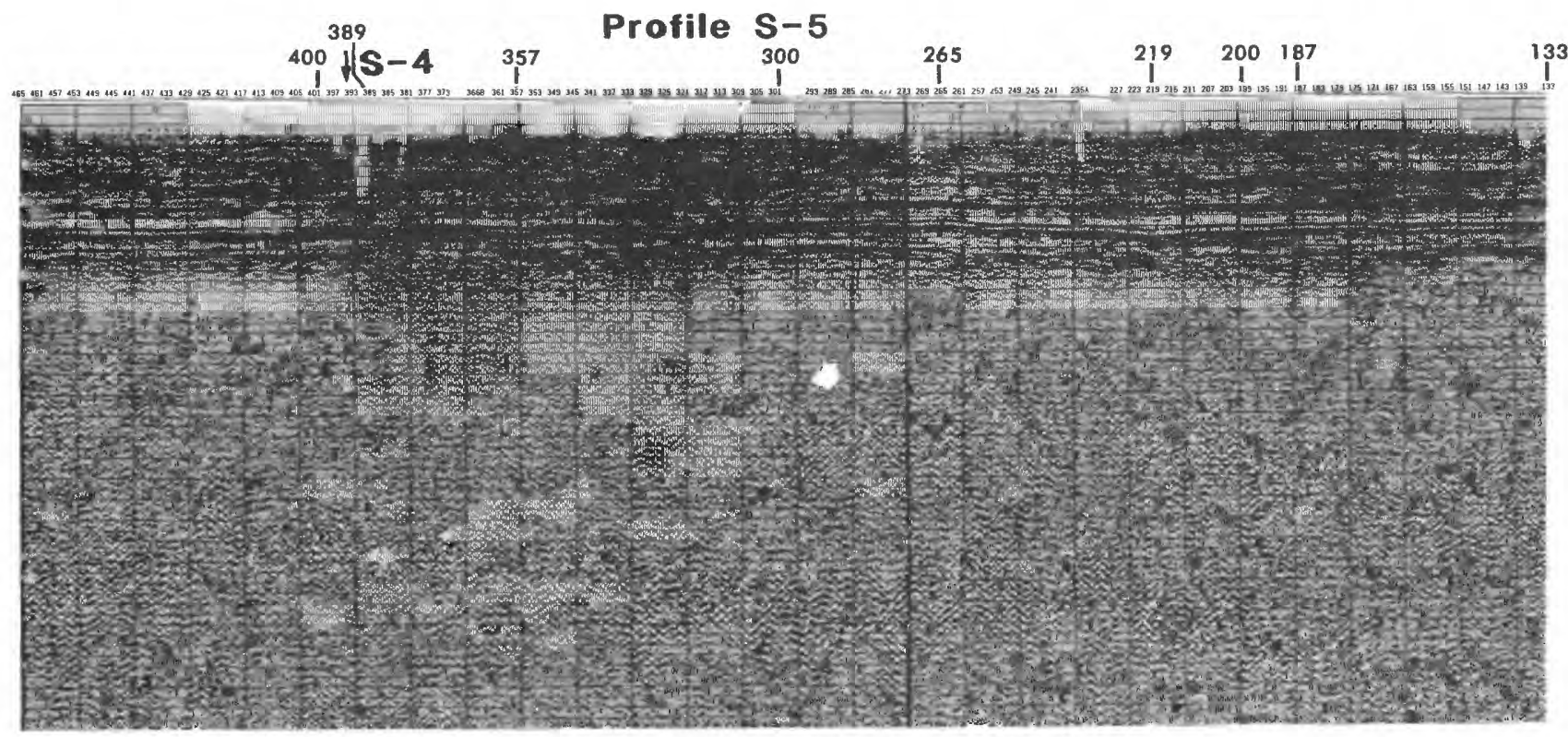

Figure 11.--Continued

coincides with the northeastern margin of the Marked TreeCaruthersville seismic zone. The feature at the east end of profile $\mathrm{S}-\mathbf{7}$ can be interpreted as a fault, but it may instead be a processing effect.

\section{PROFILE S-13}

Extending south from profile S-7 near Caruthersville, profile $\mathrm{S}-13$ (fig. 17) lies at the northern end of the Marked TreeCaruthersville seismic zone (fig. 2). It was added to the original profiling program in an effort to locate the southwestward extension of the Cottonwood Grove fault.

The character of profile $\mathrm{S}-13$ is different from that of the other $\mathrm{S}$ lines because the vibrator sweep ranged only up to 50 $\mathrm{Hz}$ instead of to $80 \mathrm{~Hz}$. The profile shows many gaps in the shallow data because many vibration points were skipped owing to the large number of buildings along the road. Nevertheless, the $\mathrm{K}$ and $\mathrm{Pz}$ reflections are strong. The $\mathrm{K}$ reflection is almost flat across the profile; the $\mathrm{Pz}$ reflection dips to the south with a 50 ms net drop.

Structurally, profile $S-13$ is virtually featureless and certainly shows no evidence for the continuation of the Cottonwood Grove fault. It must be concluded that the fault either dies out northeast of the line or misses it (fig. 2).

\section{PROFILE S-8}

Profile S-8 (fig. 18) runs near the east shore of the Mississippi River from $4 \mathrm{~km}$ south of profile S-13 in a southerly direction to near the east end of profile S-9 (fig. 2). Profile S-8 crosses the inferred location of an east-southeast-trending fault (Heyl and McKeown, 1978; Buschbach, 1978, fig. A-1).

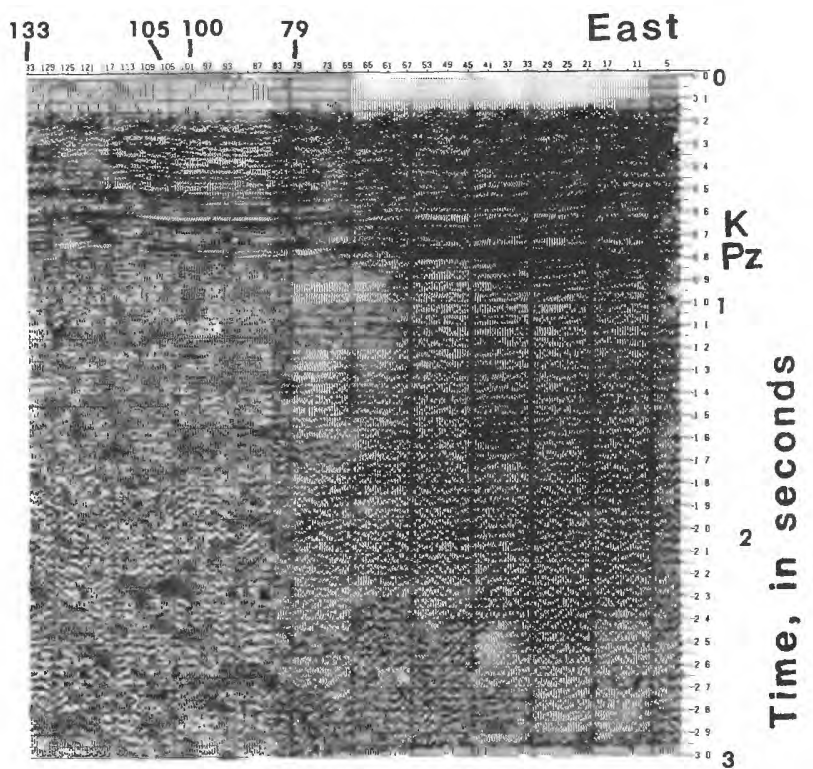

FIGURE 11. - Continued

Both the $\mathrm{K}$ and $\mathrm{Pz}$ reflections are strong and show a broad, shallow basin across the profile that reaches its low point at about VP 287. A few discontinuities and short undulations are seen in the Pz reflection. At VP 89 a tight undulation is seen with some possible diffracted energy below the $\mathrm{Pz}$ reflection. Above this point, between VP 81 and 85 , the reflections in the Eocene section are disrupted. The sharpest discontinuity in profile S-8 lies at VP 137, where a 20 -ms offset in the Pz reflection occurs. The overlying $\mathrm{K}$ reflection shows an undula- 
tion. Farther south at VP 177, the Pz reflection is offset about $10 \mathrm{~ms}$; this offset appears to extend toward the surface as a change in shape of the K reflection. Disruption of shallower reflections is seen between VP 177 and 173. The thickness of the Upper Cretaceous section thins about $10 \mathrm{~ms}$ from VP 177 to 137. Such thinning is similar to that seen southeast of the Cottonwood Grove fault. Association of this feature with that fault would require that the fault become more southerly in strike south of profile S-6.

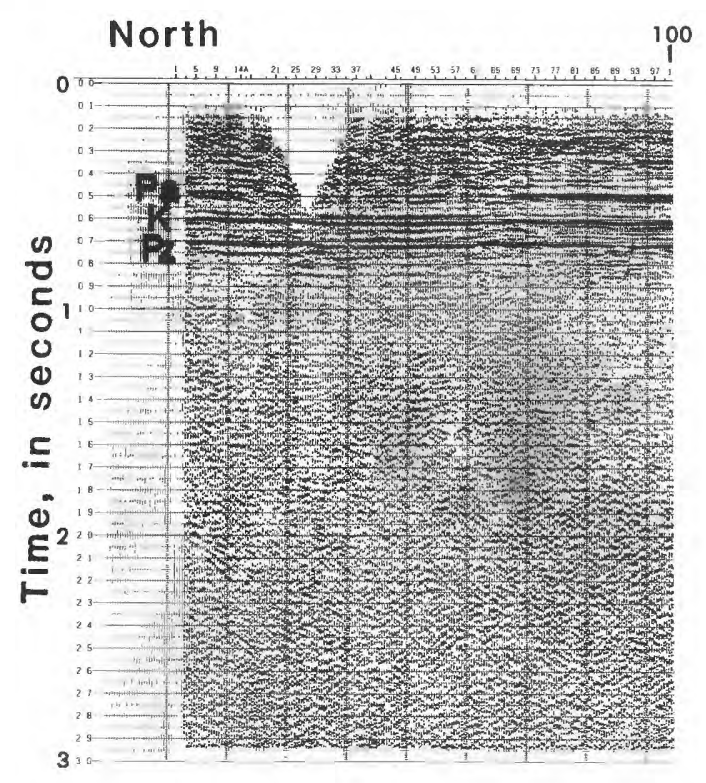

Between about VP 367 and 443 on profile S-8, a set of reflections immediately below the $\mathrm{Pz}$ reflection reveals a basin structure. Other short reflections are seen in the lower part of the profile over much of its length. Near the south end, VP 523 to 543 , a set of reflections is seen below 1.5 sec that indicates a northerly apparent dip of strata. There do not, however, appear to be any discontinuities of sufficient clarity to indicate faults within the Paleozoic section.

If the feature at VP 137 on profile S-8 is not the Cottonwood Grove fault, then it is possible that the Cottonwood Grove fault and the associated features pass between profiles $\mathrm{S}-13$ and $\mathrm{S}-8$; however, this seems unlikely. The $\mathrm{K}$ reflection at the southern end of profile S-13 is at $0.70 \mathrm{~s}$; at the northern end of profile S- 8 it is at $0.73 \mathrm{~s}$. Thus it would be difficult to accommodate the $80 \mathrm{~ms}$ of slip seen on profiles S-6 and S-4, and there is hardly room in the interval between profiles $\mathrm{S}-13$ and S-8 for the fault and associated arch structure.

\section{PROFILE S-9}

Profile S-9 (fig. 19) runs westerly from a point across the Mississippi River from the southern end of profile S-8 (fig. 2).

The $\mathrm{K}$ and $\mathrm{Pz}$ reflections are strong and continuous. They show a regional dip to the east. Gentle undulations are seen, the most pronounced of which is centered between VP 207 and 230. No discontinuities are seen.

Profiles S-9 and S- 8 were sited to look for the possible northeastward continuation of an interpreted fault on a proprietary seismic line located southwest of profile S-9. The proprietary data suggested that the fault might continue to the

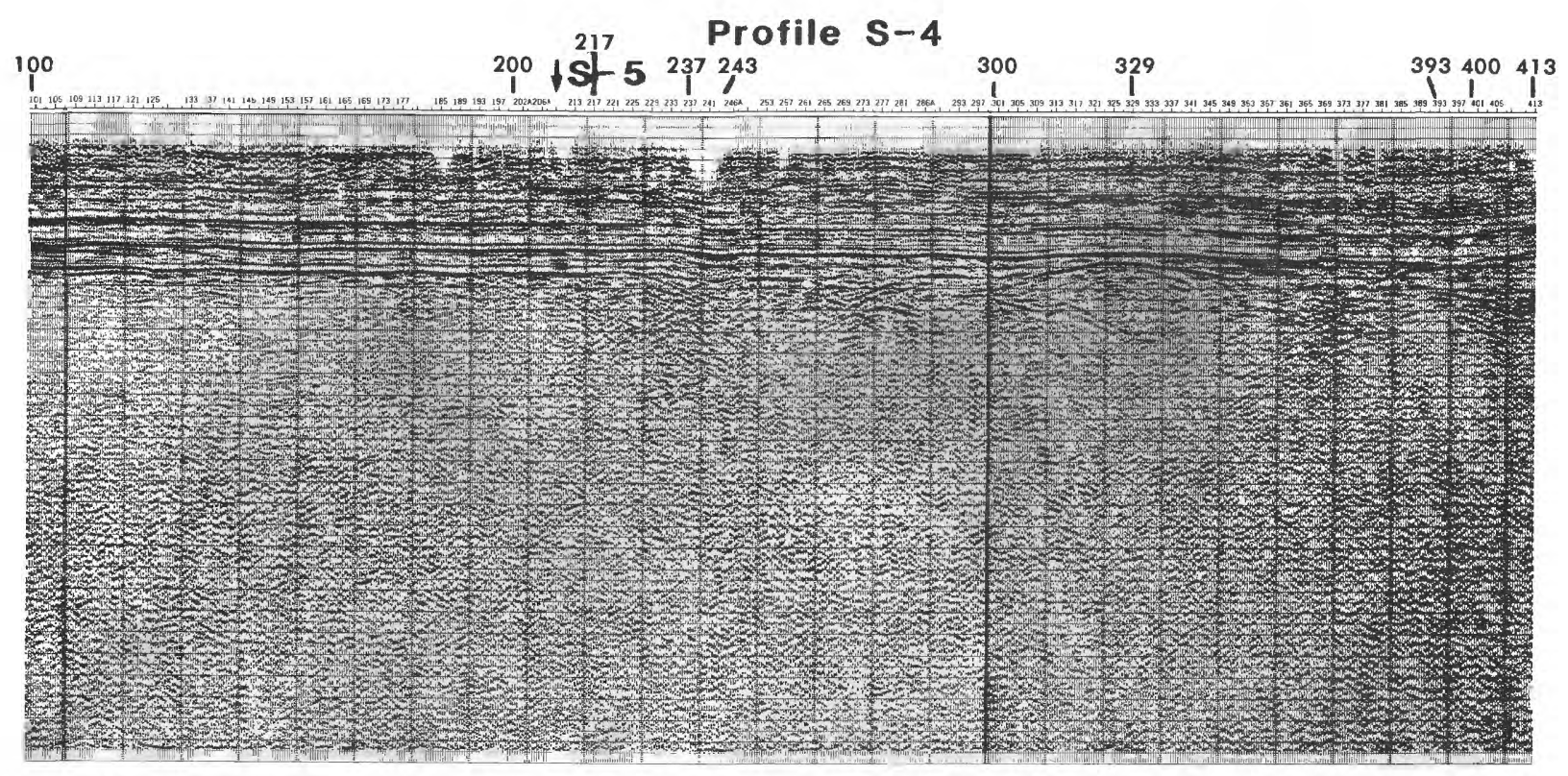

Figure 12.--Profile S-4. Pa, Paleocene; K, Tertiary-Upper Cretaceous contact; Pz, Upper Cretaceous-Paleozoic contact. Vibration point (VP) number is shown on the horizontal scale; the vibration point interval is $30.5 \mathrm{~m}$. Arrows indicate where profiles $\mathrm{S}-5$ and $\mathrm{S}-6$ cross. 
northeast but there is no evidence of the fault on either profiles S-8 or S-9.

\section{DEEP-RESOLUTION PROFILES}

PROFILES D-1 AND D-3

Profile D-1 (fig. 20) crosses the Marked Tree-Caruthersville seismic zone in an east-west direction southwest of Blytheville, Ark. (fig. 2). Profile D-3 (fig. 21) runs south from near the west end of profile D-1 into and possibly across the seismic zone.

In contrast with the other profiles, profiles $\mathrm{D}-1$ and $\mathrm{D}-3$ show good reflections below the $\mathrm{Pz}$ reflection. The $\mathrm{K}$ and $\mathrm{Pz}$ reflections are strong and fairly continuous.

Structure in the reflections below the Paleozoic surface is clearly seen in profile $\mathrm{D}-1$. A strong reflection is observed to dip from about $1.7 \mathrm{~s}$ at VP 118 to about $2.0 \mathrm{~s}$ at VP 8 . A similar dip is shown by other reflections above and below it, particularly those between 1.2 and $2.7 \mathrm{~s}$. East of VP 118, the dipping reflections are not clearly seen, although some reflections are seen shallower in the section between VP 199 and 250. Weak subhorizontal reflections are present between VP 136 and 250 . In the eastern part of profile D-1, a set of nearly horizontal reflections is seen that dips slightly to the west. In the vicinity of VP 400, a shallow basin appears in the $\mathrm{K}$ and $\mathrm{Pz}$ reflections, and the deeper reflections flatten out. West of VP 400 they reverse dip, and between about VP 400 and 363 a set of easterly dipping reflections is seen. The D-1 profile thus shows a complex broad arch in Paleozoic rocks that appears to be disrupted and faulted.
The zone in the middle of profile D-1, between VP 310 and 363 , shows a high level of incoherent energy and little continuity in reflections. Some of this disruption could be due to problems in the static corrections because the right side of the disrupted zone occurs where a river is crossed; however, this explanation could account for only a small part of the disruption. The shallower reflections show several offsets and disruptions across this zone; the $\mathrm{K}$ and $\mathrm{Pz}$ reflections drop about 80 ms between VP 281 on the west and VP 392 the east.

The amount of structural relief on reflections across the disrupted zone is uncertain because reflections cannot be correlated across it reliably. The best correlation appears to be between the strongest reflections on each side; that is, the ones at $1.75 \mathrm{~s}$ at VP 105 and $2.0 \mathrm{~s}$ at VP 375 . Such a correlation implies about $1 \mathrm{~km}$ of vertical structural relief.

The west-dipping reflections near the west end of profile D- 1 correlate very well with a set of reflections on profile D-3 (fig. 21) that show northerly dip. The true dip of these strata is about $12^{\circ} \mathrm{NW}$., with a strike of $\mathrm{N} .45^{\circ} \mathrm{E}$. The termination points of the reflections, though not sharply defined, also define a strike of about N. $45^{\circ} \mathrm{E}$. True dip cannot be determined for strata on the southeast side of the disrupted zone.

The structure in the disrupted zone is interpreted as faulting of arched Paleozoic rocks. The fault zone strikes about N. $45^{\circ}$ E. (fig. 2), with about $1 \mathrm{~km}$ of vertical structural relief. Cenozoic and Tertiary strata across the zone show about $80 \mathrm{~m}$ of cumulative vertical displacement, southeast side down. The fault zone coincides with the Marked Tree-Caruthersville seismic zone and has a similar strike (fig. 2). Fault-plane solutions (Herrmann, 1979) indicate that movement on this fault

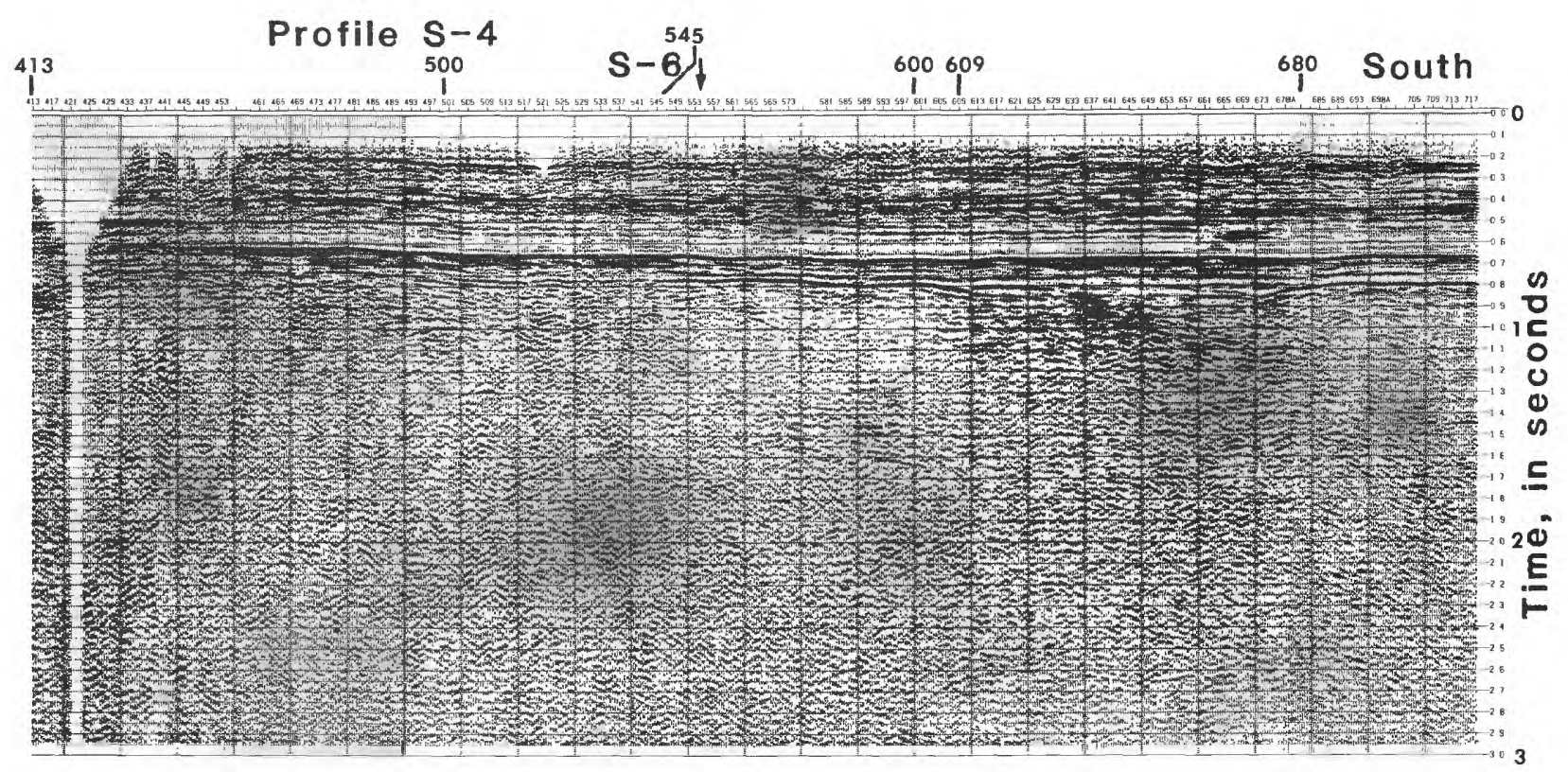

Figure 12.-- Continued 


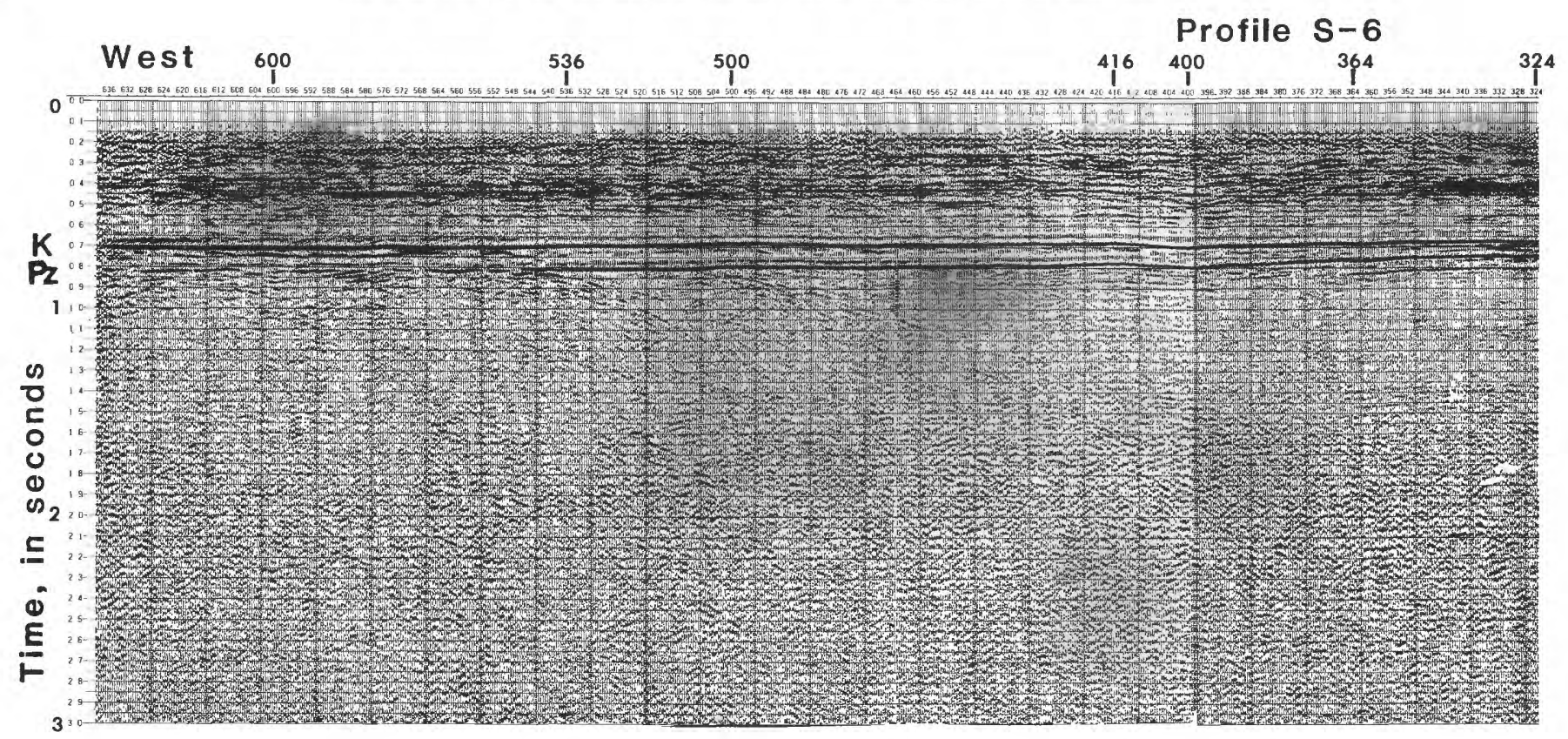

Figure 13.--Profile S-6. Pa, Paleocene; K, Tertiary-Upper Cretaceous contact; Pz, Upper Cretaceous-Paleozoic contact. Vibration point (VP) number is shown on the horizontal scale; the vibration point interval is $30.5 \mathrm{~m}$. Arrow inidcates where profile $S-4$ crosses.

is predominantly right-lateral, strike-slip, with a component of vertical displacement indicating northwest side up.

Correlation of the reflections below the Paleozoic surface with lithologic units is uncertain because there are no wells near the lines. On the basis of regional well data, Ordovician rocks are thought to lie at the Paleozoic subcrop (Caplan, 1954; Grohskopf, 1955). As the thickness of the CambrianOrdovician rocks is believed to be approximately $4 \mathrm{~km}$ (Buschbach, 1978; Caplan, 1954), reflections in the lower part of the section could be from Precambrian strata. This depth is in approximate agreement with the depth to magnetic basement (Hildenbrand and others, this volume). However, Precambrian rifting could have resulted in the deposition of an anomalously thick section of Cambrian sediments. The northwest dip calculated for the strata northwest of the zone of disruption contrasts with the south to southwesterly dip that would be expected from the general structure of the Pascola arch situated to the north. Profile D-1 crosses the north flank and profile D-3 crosses the west flank of a circular magnetic anomaly interpreted to be caused by intrusive igneous rocks (Hildenbrand and others, this volume); the northwest-dipping reflections in the profiles may indicate deformation caused by intrusion of the rocks.

The offset in the $\mathrm{Pz}, \mathrm{K}$, and other shallow reflections near the east end of line D-1 at VP 580 may possibly indicate the extension of the Cottonwood Grove fault, although the nature of the zone of deformation is somewhat different than that seen on lines S-6 and S-4.

\section{PROFILE D-2}

Profile D-2 (fig. 22) strikes east-southeast in the area west of Dyersburg, Tenn. It passes near a well that reached rocks thought to be of Precambrian age at a depth of $2100 \mathrm{~m}$ (Buschbach, 1978; A. J. Crone, oral commun., 1979), and it crosses the southeast boundary of the rift defined by magnetic data (fig. 2).

On profile $\mathrm{D}-2$, the Pz reflection is strong, but it is discontinuous. The $\mathrm{K}$ reflection on profile $\mathrm{D}-2$ is weak compared with that on the other profiles; it cannot be traced continuously across the profile.

The data on profile D-2 are disappointing, perhaps due to static problems. There are no particularly interesting features in the shallow section and no good reflections below the $\mathrm{Pz}$ reflection.

\section{NATURE OF GEOLOGIC STRUCTURE AND FAULTING IN THE REGION OF THE EMBAYMENT}

The main findings from the seismic-reflection profiling are (1) a fault zone coincident with the main zone of seismicity and the nature of deformation of Paleozoic strata, (2) the Cottonwood Grove fault and evidence for post-middle Eocene movement that appears to be reverse faulting, (3) deformation inferred to be the result of igneous intrusive activity that occur- 


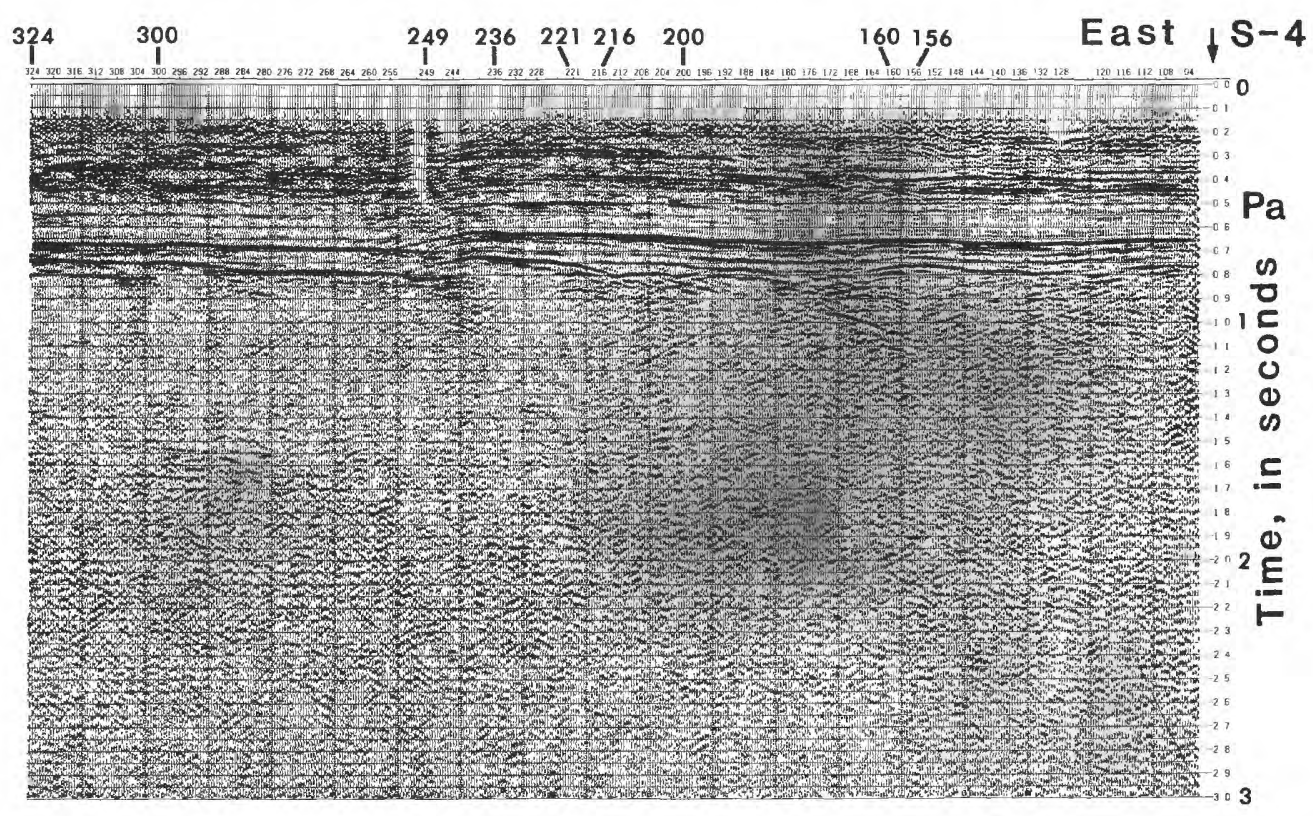

FIGURE 13.--Continued

red after middle Eocene time but before movement on the Cottonwood Grove fault, (4) disrupted areas of Paleozoic rocks that indicate igneous intrusive activity, and (5) a possible fault associated with the northeast-striking seismic zone northwest of New Madrid.

The seismic-reflection profiles provide new evidence of the nature of faulting in the northern Mississippi Embayment. A major question is the relationship between faults in the embayment and those in nearby regions. This relationship is of particular importance with regard to seismic-risk assessment, wherein the continuity and length of fault systems are critical elements. It has been suggested that the fault systems in the northern Mississippi Embayment, the Illinois-Kentucky mineral district, and the Wabash valley are continuous (fig. 1; Woollard, 1958; Heyl and Brock, 1961; Heyl and others, 1965). Therefore, a brief discussion of those fault systems and others in the region is relevant here as a basis for comparison with the faults of the embayment.

\section{ILLINOIS-KENTUCKY MINERAL DISTRICT}

The larger structure of the mineral district is an arch that is about $45 \mathrm{~km}$ wide and has about $600 \mathrm{~m}$ of structural relief. Superimposed on it is Hicks Dome, a cryptovolcanic structure about $15 \mathrm{~km}$ in diameter that has $1200 \mathrm{~m}$ of structural relief (Hook, 1974).

The main fault system of the mineral district can be traced northeasterly from the edge of the Mississippi Embayment to the southern margin of the Shawneetown-Rough Creek fault zone (fig. 1), but not across it. The mineral district faults are predominantly high-angle normal faults that form a complex horst-and-graben system. Vertical offsets are commonly $160-460 \mathrm{~m}$, with a maximum of $900 \mathrm{~m}$. Evidence exsists for horizontal movement as well, but it is considered to be less than vertical movement (Hook, 1974; Trace, 1974). Overall, the mineral district is a regime of extensional tectonics.

The northeast-trending faults crosscut and postdate a system of northwest-trending faults that are filled in places by mafic dikes, which are Early Permian in age (Zartman and others, 1967). Thus the northeast-trending faulting is postEarly Permian. The lower limit on the age of the faulting can be placed as pre-Late Cretaceous, although some movement continued through the Cretaceous and Tertiary (Trace, 1974).

\section{COTTAGE GROVE-SHAWNEETOWN-ROUGH CREEK FAULT ZONE}

The east-west-striking fault complex that lies north of the mineral district exhibits a variety of faulting styles including high-angle reverse, block, and scissors faulting. These styles of faulting and the presence of many sliver-shaped grabens are the basis for considering strike-slip or wrench faulting to be the predominant mechanism of displacement (Clark and Royds, 1948). Fault movements occurred in Middle Cambrian and Devonian time with net vertical displacement down to the south, but the predominant vertical displacement occurred, in a reverse sense, after Pennsylvanian and probably after Early 


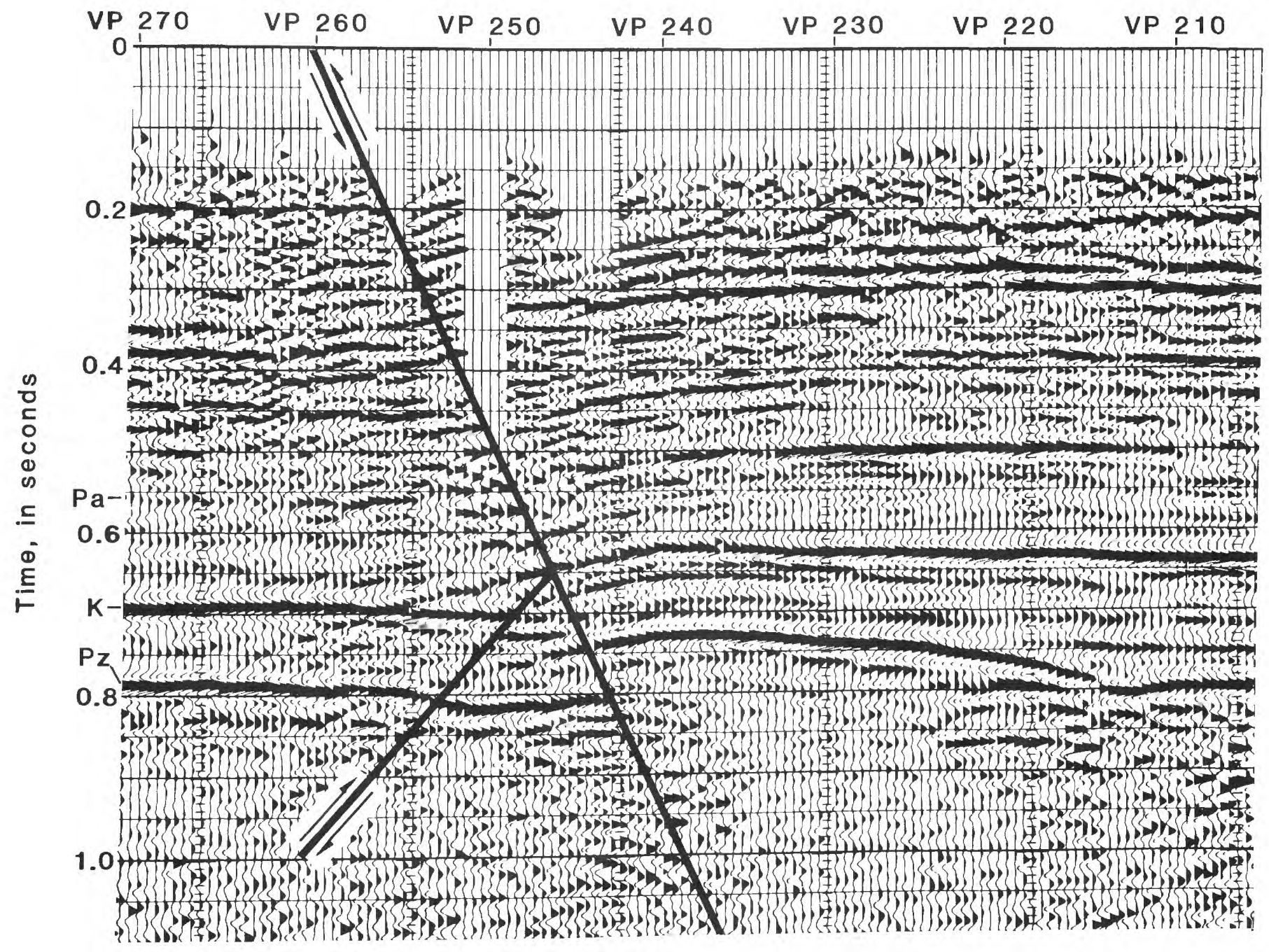

Figure 14.-- Enlargement of part of profile S-6 showing the Cottonwood Grove fault. Lines show interpreted reverse faults; arrows indicate direction of movement. The seismic-reflection line crosses the fault zone at about a $45^{\circ}$ angle; thus reflections may be coming from both the upthrown and downthrown strata where the line crosses the fault zone.

Permian time (Krausse and Treworgy, 1979). The Cottage Grove-Shawneetown- Rough Creek fault zone may be part of an even larger feature called the 38th Parallel Lineament, which is thought to have a late Precambrian origin (Heyl, 1972). On the basis of the pattern of subsidiary faults and folds, movement is right-lateral on the Cottage Grove fault and left-lateral on the Rough Creek fault; the Shawneetown fault shows a strong component of reverse or thrust movement (Heyl and others, 1965; Heyl, 1972).

\section{WABASH VALLEY FAULT ZONE}

The Cottage Grove-Shawneetown-Rough Creek fault zone apparently marks a discontinuity between the fault systems of the mineral district and the Wabash valley because faults can- not be traced across the zone and their strike changes significantly (Heyl and McKeown, 1978). The fault system of the Wabash valley is characterized by generally north-northeaststriking, high- angle normal faults that bound horsts and grabens. Individual fault displacements reach $146 \mathrm{~m}$. Arcuate and overlapping fault segments are common. Pleistocene glacial deposits that rest on Pennsylvanian rocks in the region are not faulted. Faulting is believed to extend downward at least to basement at about $4 \mathrm{~km}$ in depth (Bristol and Treworgy, 1979).

Thus, although the style and age of faulting in the Wabash valley fault zone is similar to that of the faulting in the mineral district, the break in strike and continuity of faulting across the Shawneetown-Rough Creek fault zone suggest a zone of detachment between the systems. 


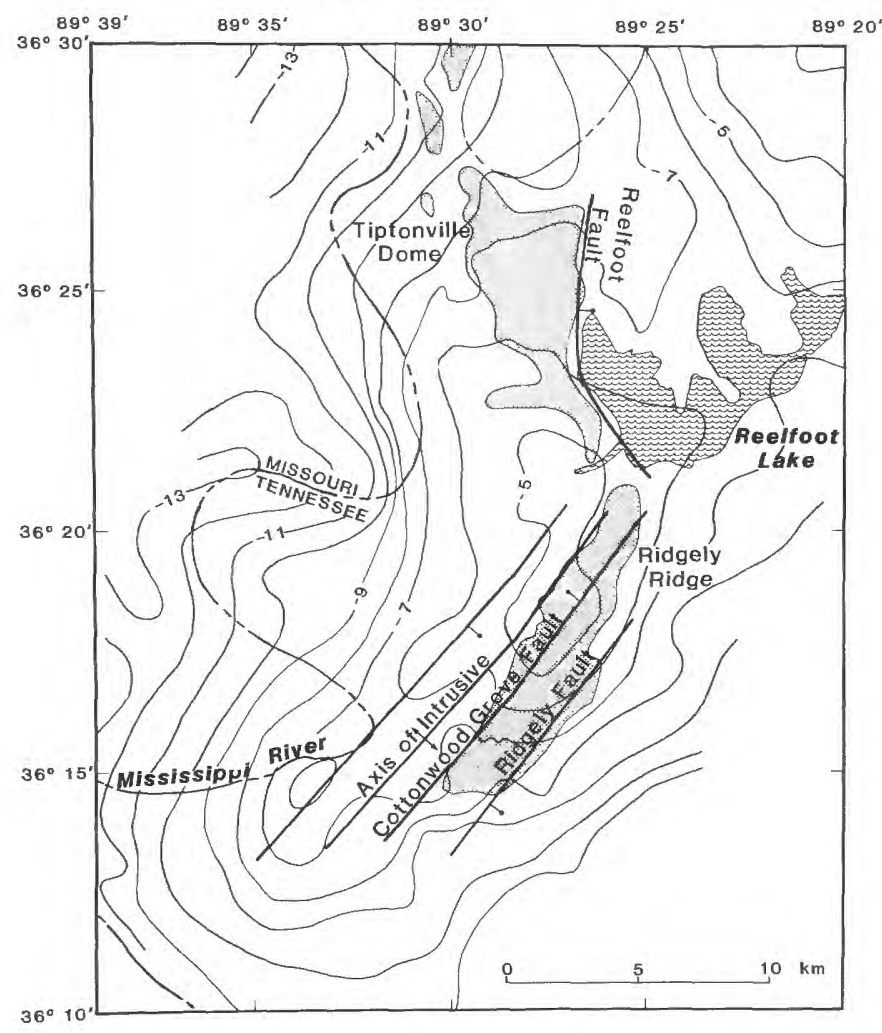

FIGURE 15. - Spatial relationship of faults and of an igneous intrusive mass (as inferred from seismic-reflection profiles) to topographic ridges (stippled areas), and Bouguer gravity anomalies (contour lines, contour interval 1 milligal, modified from Stearns, 1979) in the Reelfoot Lake, Tenn., area.

\section{STE. GENEVIEVE FAULT ZONE}

The Ste. Genevieve fault zone is a northwest-striking system of high-angle normal and reverse faults with the southwestern block upthrown. Maximum displacement is $900 \mathrm{~m}$. Movement occurred in post-Devonian and in post-Mississippian or postPennsylvanian time (McCracken, 1971). Strong gravity and magnetic anomalies apparently associated with the Ste. Genevieve fault zone extend southeasterly into Kentucky (Lidiak and Zietz, 1976; Hildenbrand, this volume).

\section{SUMMARY}

An important episode of faulting occurred in the region north of the Mississippi Embayment after the Pennsylvanian. Estimates of the minimum age of this faulting are uncertain, but in some places a pre-Cretaceous age can be established. Some of the fault systems were active in the early and middle Paleozoic as well. In some areas, doming and intrusive activity are associated with the faulting. A Permian age has been assigned to some intrusive rocks in the mineral district (Zartman and others, 1976). Formation of the Pascola arch probably occurred in Late Pennsylvanian or Permian time
(Buschbach and Atherton, 1979; Sloss, 1979). These various happenings suggest that a major episode of tectonic activity occurred near the end of the Paleozoic, possibly in the Permian. This tectonic activity may have been associated with the Allegheny and Ouachita orogenies. Extensional deformation occurred on many of the fault systems, except along the Cottage Grove-Shawneetown-rough Creek fault system, where wrench and thrust faulting occurred.

\section{TECTONIC IMPLICATIONS}

Formation of the arched and faulted structure seen on profiles D-1 and D-3 can be dated from the seismic-reflection data as post-Ordovician and pre-Late Cretaceous, although some minor movement occurred later. Considering the geologic history of the region, a likely time for formation of the structure is late Paleozoic, possibly Permian, perhaps associated with development of the Pascola Arch. Because the fault zone lies along the rift axis, which is thought to have formed in Early Cambrian or late Precambrian time (Hildenbrand, this volume), its origin is probably the result of reactivation of rifting. Modern movement on the fault, however, is predominantly right-lateral, strike-slip, with a vertical component of southeast side down, as indicated by fault-plane solutions (Herrmann, 1979). This indicates an east-west compressional stress regime. The fault zone may have been the source for two of the 1811 and 1812 earthquakes, as the estimated epicenters for two of the three largest shocks are near the fault (Nuttli, 1973).

The northwest dip determined for Paleozoic and possibly Precambrian strata northwest of the fault zone adds new information on regional structure. As the area lies on the south flank of the Pascola arch, a south or southwest dip would be expected. The structure seen on profiles $\mathrm{D}-1$ and $\mathrm{D}-3$ may be the result of post-Ordovician igneous intrusive activity, as sug. gested by its coincidence with a magnetic anomaly.

The style of faulting associated with the Cottonwood Grove fault is particularly significant if the interpretation of reverse movement is correct. Such movement is characteristic of compressional tectonics. The age of the movement is post-middle Eocene. Composite-fault-plane solutions indicate that the area is currently under east-west compression (O'Connell and others, this volume), as is the entire region (Zoback and Zoback, 1980). Thus, movement on the Cottonwood Grove fault is consistent with the modern east-west compressional stress field causing the current seismicity rather than with the extensional stress regime that prevailed in the Paleozoic. The normal fault on profile $\mathrm{S}-2$ indicates an extensional stress regime in the Late Cretaceous as well.

The evidence for disruption of Paleozoic rocks seen on the seismic profiles, which is interpreted as the result of igneous intrusive activity, occurs mostly in the vicinity of the northnorthwest-striking seismic zone in the Ridgely-New Madrid area. This area also is the location of the inferred intrusive 


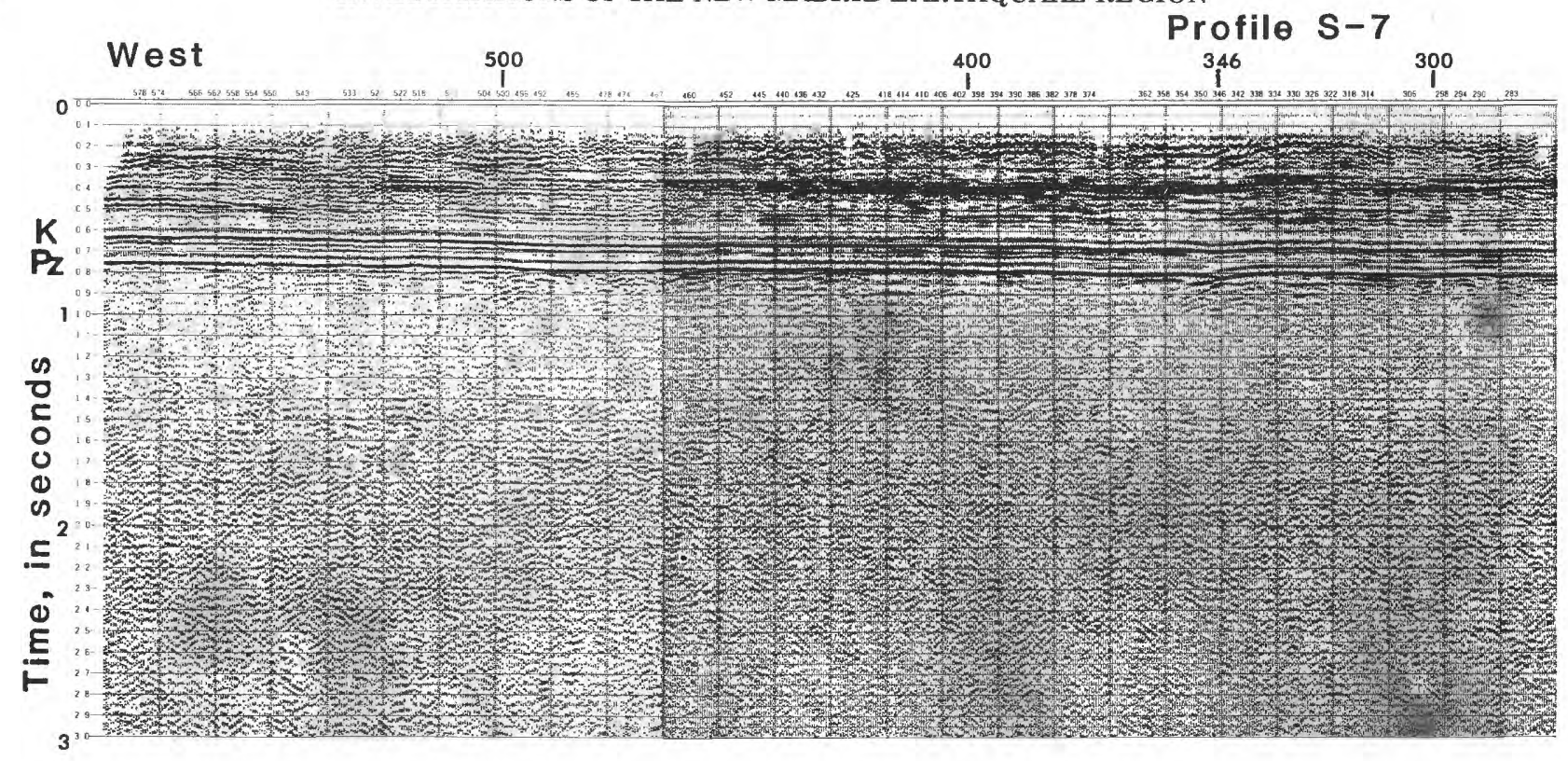

FiguRE 16. - Profile S-7. K, Tertiary-Upper Cretaceous contact; Pz, Upper Cretaceous-Paleozoic contact. Vibration point (VP) number is shown on the horizontal scale; the vibration point interval is $30.5 \mathrm{~m}$. Arrow indicates where profile $\mathrm{S}-13$ crosses.

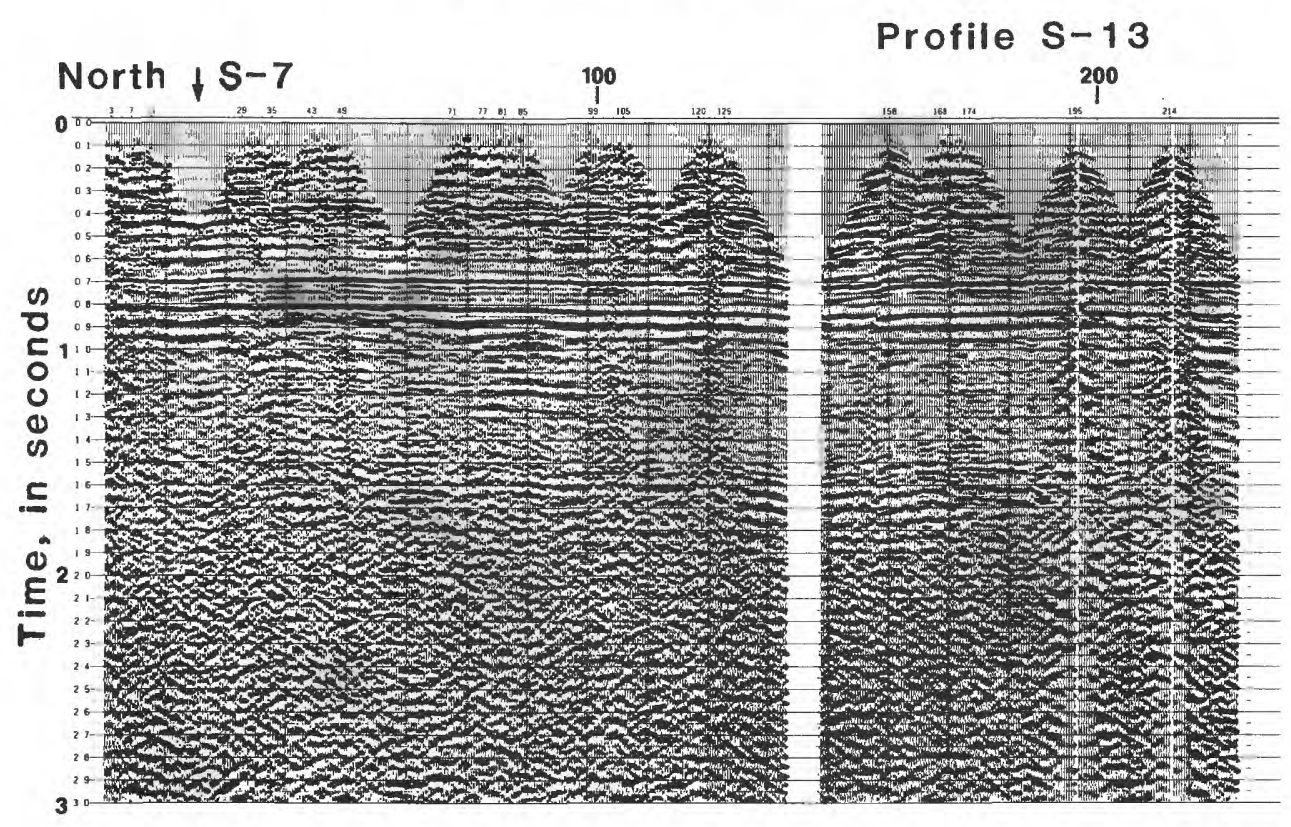

Figure 17. - Profile S-13. K, Tertiary-Upper Cretaceous contact; $\mathrm{Pz}$, Upper Cretaceous-Paleozoic contact. Vibration point (VP) number is shown on the horizontal scale; the vibration point interval is $30.5 \mathrm{~m}$. Arrow indicates where profile $S-7$ crosses.

body which was delineated on the basis of overlying arched strata near the Cottonwood Grove fault. In addition, topographic domes and ridges in the Ridgely-New Madrid area, which apparently experienced uplift, in part, during the 1811-12 earthquakes, correlate with structure on the Paleozoic surface (Crone and Brockman, this volume).
On the basis of a fault-plane solution (Herrmann, 1979), the faulting that correlates with the northeast-striking seismic zone northwest of New Madrid is right-lateral, strike-slip.

The strikes of fault zones in the northern Mississippi Embayment region are similar to those of the fault system in the Illinois-Kentucky mineral district. Evidence of post-Late Cre- 


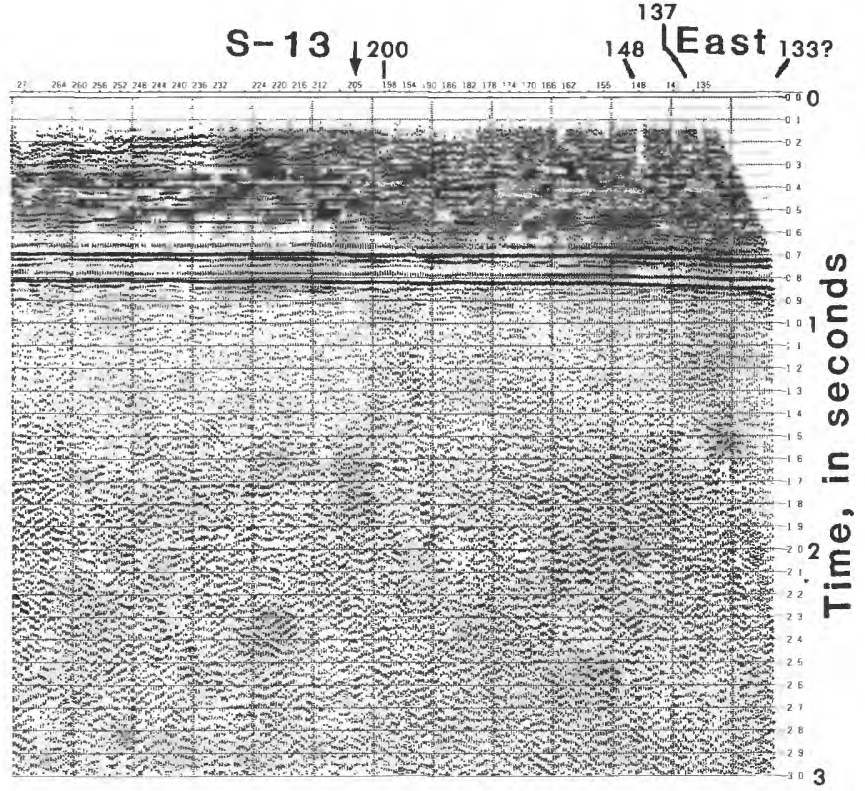

Figure 16.--Continued

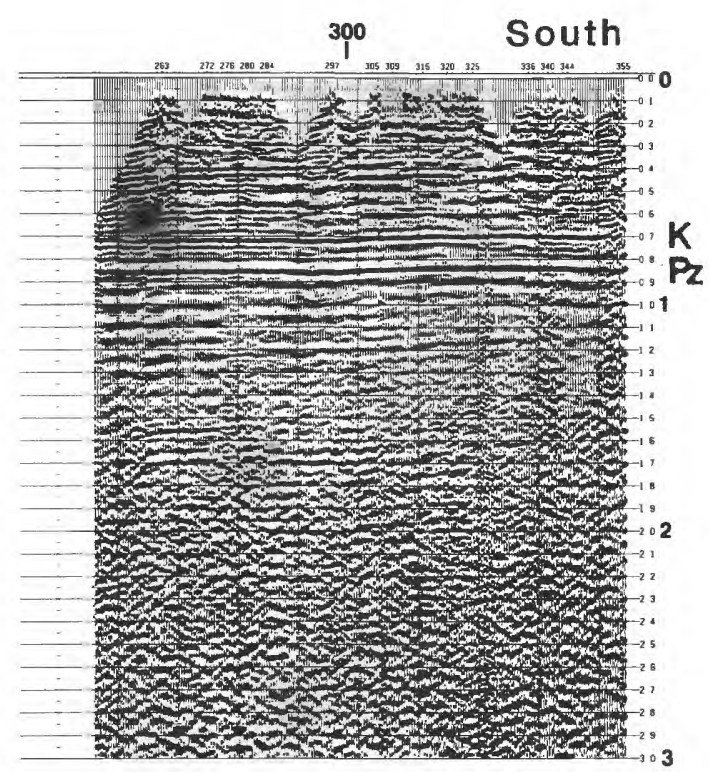

Figure 17.--Continued

taceous faulting in western Kentucky exists, but its nature is unknown (Rhoades and Mistler, 1941). The idea of continuity between the fault systems of the two regions cannot be ruled out, although magnetic data suggest that the rift zone terminates in western Kentucky and southern Illinois (Hildenbrand and others, this volume). The fault systems of the Wabash valley and the Ste. Genevieve fault zone are similar to those of the embayment in some respects, but differences in strike and lack of fault continuity argue against structural continuity with those fault systems.

These various results provide a partial picture of the sequence of tectonic events that are the underlying cause of New Madrid seismicity. In the late Precambrian or Early Cambrian, a large-scale rift formed along the axis of what later became the Mississippi Embayment. Through the Paleozoic some of the fault systems in the region were active, but the main episode of deformation and fault activity came in the late Paleozoic. This was an episode of mostly extensional faulting on fault systems north of the embayment. During the Late Cretaceous and early Tertiary, little deformation occurred. Faulting after the middle Tertiary and the nature of modern seismicity reflect a different stress regime than that of the Paleozoic. Thus, modern seismicity is seen as the result of east-west compression of fault zones and zones weakened by intrusive activity that originally formed as a result of rifting.

\section{ACKNOWLEDGMENTS}

We greatly benefited from discussions with USGS colleagues A. J. Crone, E. E. Glick, T. G. Hildenbrand, F. A. McKeown, and D. P. Russ. Migration of profile S- 6 was carried out by J. J. Miller and A. H. Balch of the USGS. Partial support for the test well was provided by the U.S. Nuclear Regulatory Commission.

\section{REFERENGES GITED}

Bristol, H. M., and Treworgy, J. D., 1979, The Wabash Valley fault system in southeastern Illinois: Illinois State Geological Survey Circular 509, $19 \mathrm{p}$.

Buschbach, T. C., 1978, New Madrid seismotectonic study-- Activities during fiscal year 1978: U.S. Nuclear Regulatory Commission NUREG/CR-0450, $129 \mathrm{p}$.

Buschbach, T. C., and Atherton, E., 1979, History of the structural uplift of the southern margin of the Illinois Basin, in Palmer, J. E., and Dutcher, R. R., eds., Depositional and structural history of the Pennsylvanian system of the Illinois Basin, Part 2: International Congress of Carboniferous Stratigraphy and Geology, 9th, Guidebook for Field Trip No. 9, pt. 2, p. 112-115.

Caplan, W. M., 1954, Subsurface geology and related oil and gas possibilities of northeastern Arkansas: Arkansas Division of Geology Bulletin 20, $124 \mathrm{p}$.

Clark, S. K., and Royds, J. S., 1948, Structural trends and fault systems in Eastern Interior Basin: of the American Association of Petroleum Geologists Bulletin, v. 32, p. 1728-1749.

Clegg, K. E., and Bradbury, J. C. 1956, Igneous intrusive rocks in Illinois and their economic significance: Illinois Geological Survey Report of Investigations 197 , p. 5-19.

Crone, A. J., and Russ, D. P., 1979, Preliminary report on an exploratory drill hole--New Madrid test well-1-X in southeast Missouri: U.S. Geological Survey Open-File Report 79-1216, 12 p.

Dobrin, M. B., 1976, Introduction to geophysical prospecting: New York, McGraw-Hill, $630 \mathrm{p}$.

Ervin, C. P., and McGinnis, L. D., 1975, Reelfoot rift-- Reactivated precursor to the Mississippi embayment: Geological Society of America Bulletin, v. 86, p. 1287-1295. 


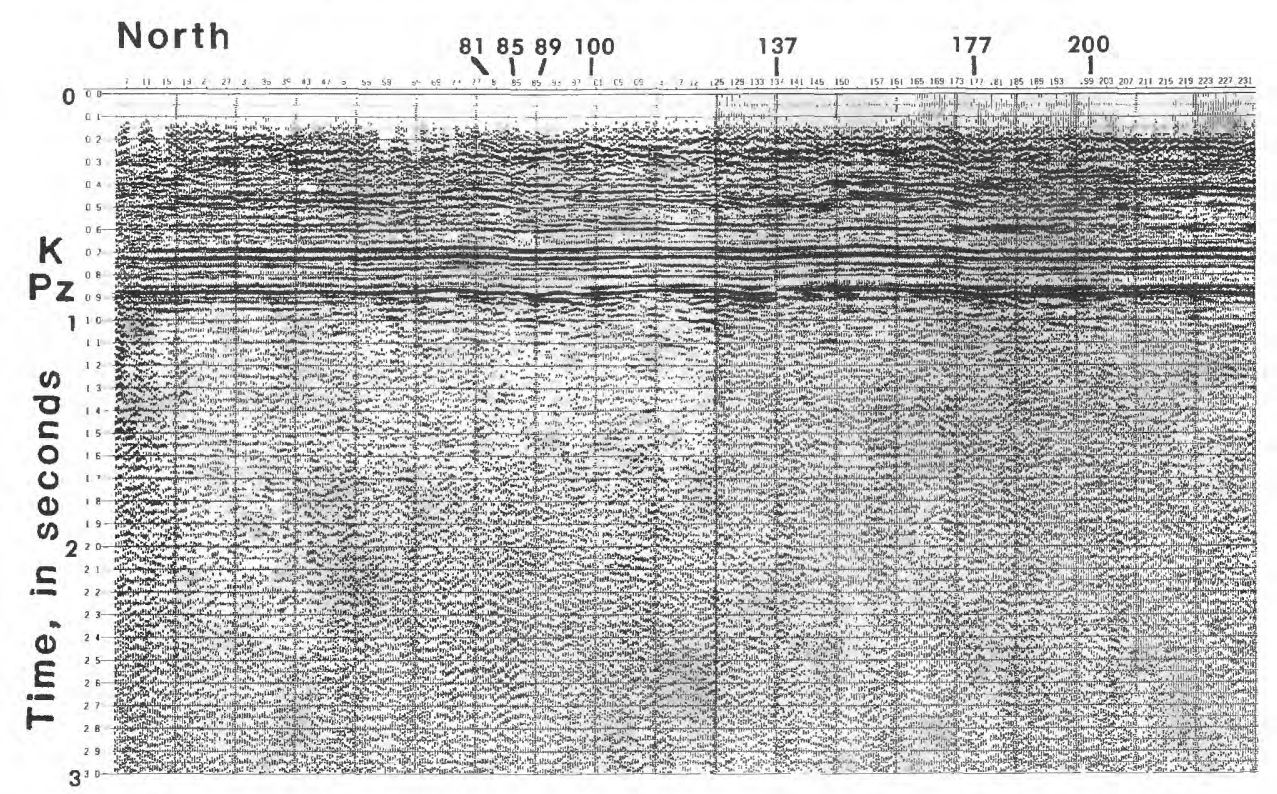

Fugure 18. - Profile S-8. K, Tertiary-Upper Cretaceous contact; Pz, Upper Cretaceous-Paleozoic contact. Vibration point (VP) number is shown on the horizontal scale; the vibration point interval is $30.5 \mathrm{~m}$.

Grohskopf, J. G., 1955, Subsurface geology of the Mississippi embayment of southeast Missouri: Missouri Division of Geological Survey and Water Resources Report, ser. 2, v. 37, 133 p.

Hadley, J. B., and Devine, J. F., 1974, Seismotectonic map of the eastern United States: U.S. Geological Survey Miscellaneous Field Studies Map MF-620.

Hamilton, R. M., and Zoback, M. D., 1979, Seismic reflection profiles in the northern Mississippi embayment: U.S. Geological Survey Open-File Report 79-1688.

Heinrich, R. R., 1941, A contribution to the seismic history of Missouri: Seismological Society of America Bulletin, v. 31, p. 187-224.

Herrmann, R. B., 1979, Surface wave focal mechanisms for eastern North American earthquakes with tectonic implications: Journal of Geophysical Research, v. 84 , p. $3543-3552$.

Herrmann, R. B., and Canas, J. A., 1978, Focal mechanism studies in the New Madrid seismic zone: Seismological Society of America Bulletin, v. 68, p. 1095-1102.

Heyl, A. V., 1972, The 38th Parallel Lineament and its relationship to ore deposits: Economic Geology, v. 67, p. 879-894.

Heyl, A. V., and Brock, M. R., 1961, Structural framework of the IllinoisKentucky mining district and its relation to mining deposits, in Short papers in the geologic and hydrologic sciences: U.S. Geological Survey Professional Paper 424-D, p. D3-D6.

Heyl, A. V., Brock, M. R., Jolly, J. L., and Wells, C. E., 1965, Regional structure of the southeast Missouri and Illinois-Kentucky mineral districts: U.S. Geological Survey Bulletin 1202-B, 20 p.

Heyl, A. V., and McKeown, F. A., 1978, Preliminary seismotectonic map of central Mississippi Valley and environs: U.S. Geological Survey Miscellaneous Field Studies Map MF-1011.

Hildenbrand, T. G., Kane, M. F., and Stauder, William, 1977, Magnetic and gravity anomalies in the northern Mississippi embayment and their spatial relation to seismicity: U.S. Geological Survey Miscellaneous Field Studies Map MF-914.

Hildenbrand, T. G., Kucks, R. P., Kane, M. F., and Hendricks, J. D., 1979, Aeromagnetic map and associated depth map of the upper Mississippi embayment region: U.S. Geological Survey Miscellaneous Field Studies Map MF-1158.

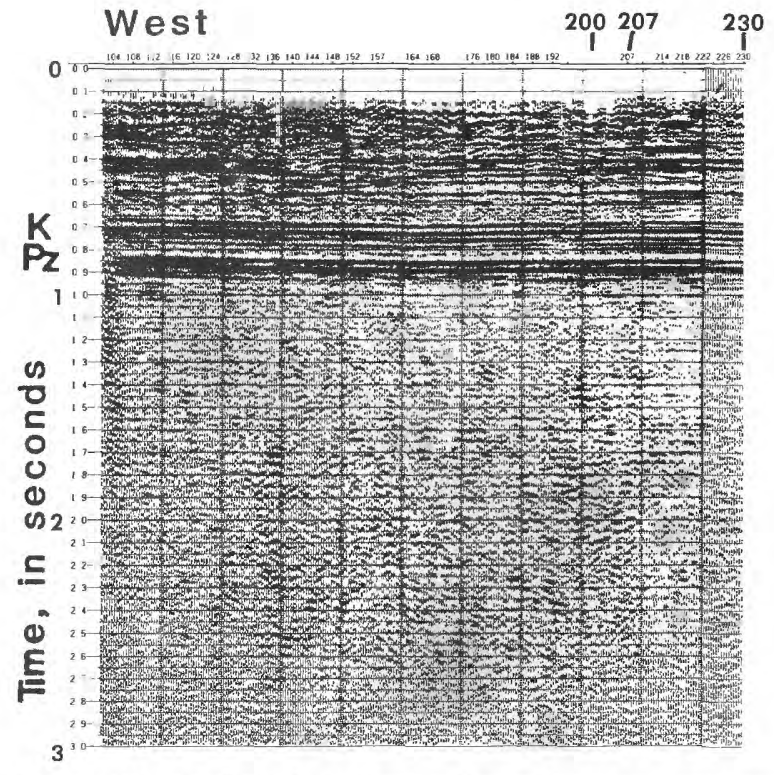

Figure 19.--Profile S-9. K, Tertiary-Upper Cretaceous contact; $\mathrm{Pz}$, Upper Cretaceous-Paleozoic contact Vibration point (VP) number is shown on the horizontal scale; the vibration point interval is $30.5 \mathrm{~m}$.

Hinze, W. J., Braile, L. W., Keller, G. R., and Lidiak, E. G., 1977, A tectonic overview of the central Midcontinent: U.S. Nuclear Regulatory Commission NUREG-0382, 106 p.

Hook, J. W., 1974, Structure of the fault systems in the Illinois-Kentucky fluorspar district, in Hutchinson, D. W., ed., A symposium on the geology of fluorspar: Proceedings of the Ninth Forum on Geology of Industrial Minerals, Kentucky Geological Survey, Series X, Special Publication 22, p. $77-86$. 


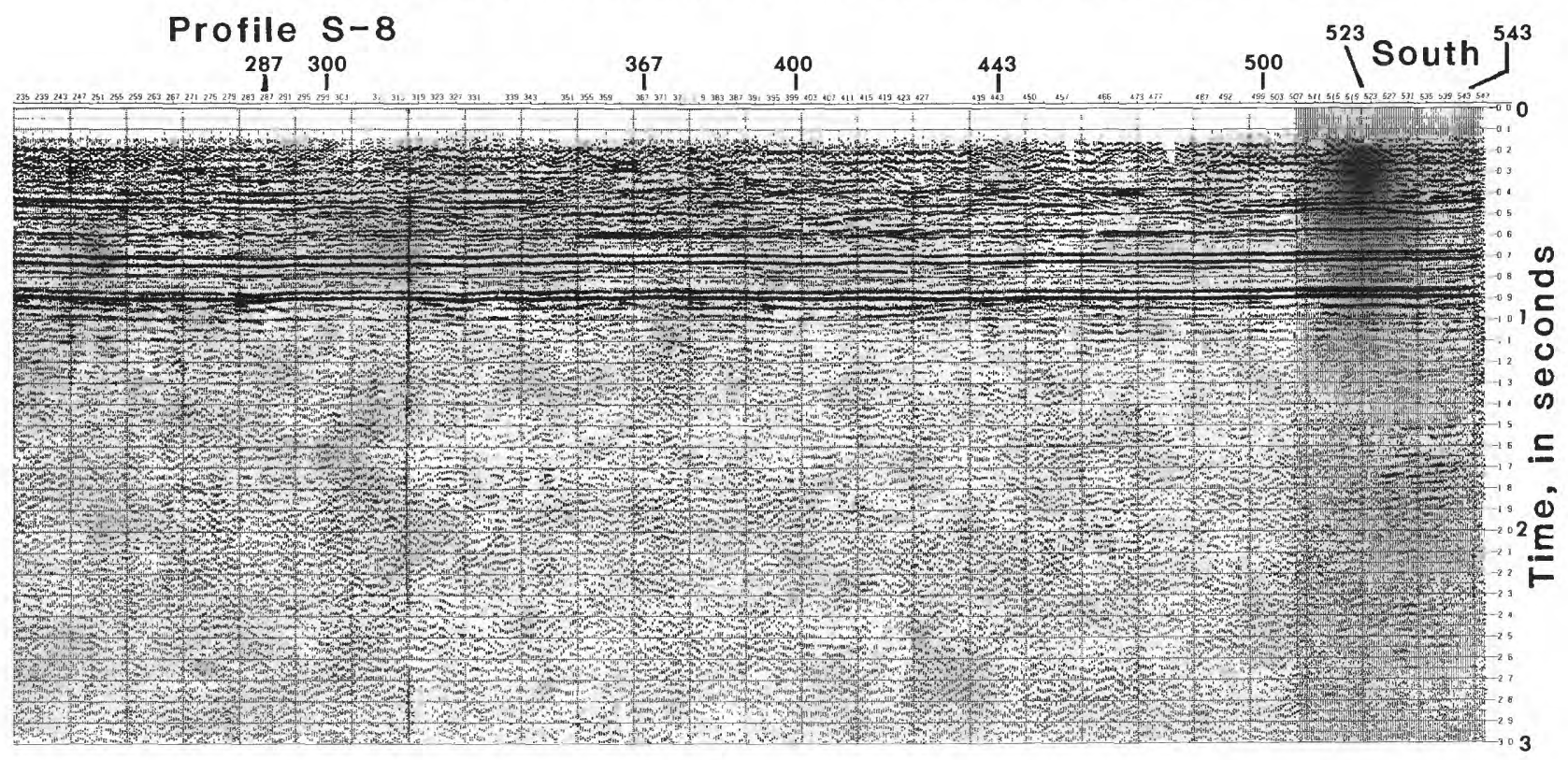

FIGURE 18.-- Continued

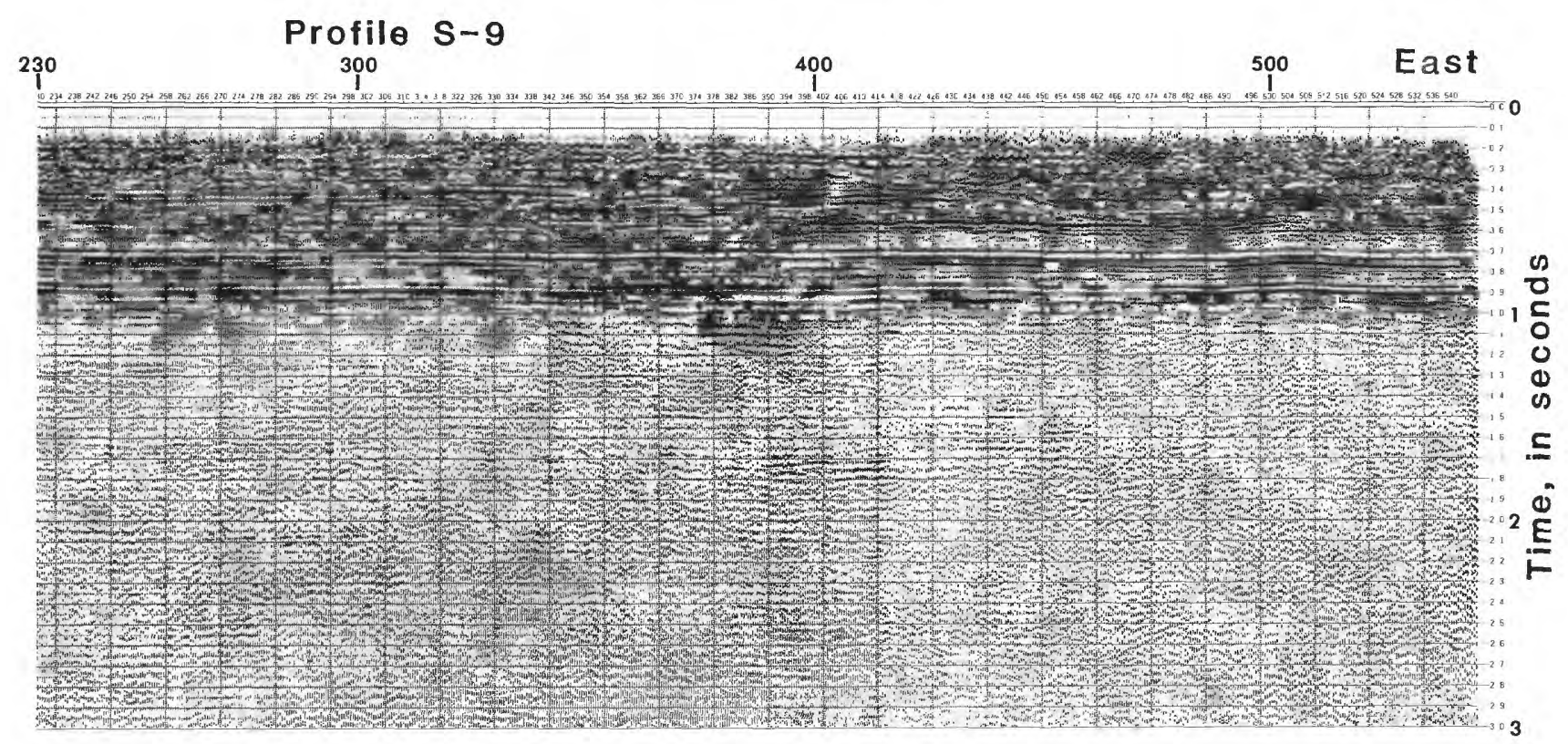

FIGURE 19.-- Continued

Kidwell, A. L., 1947, Post-Devonian igneous activity in southeastern Missouri: Missouri Division of Geological Survey and Water Resources Report of Investigations, v. 4, 83 p.

1950, Mesozoic igneous activity in the northern Gulf Coastal plain: Gulf Coast Association of Geological Societies Transactions, 1st Annual Meeting, p. 182-199.

Krausse, H. F., and Treworgy, C. G., 1979, Major structures of the southern part of the Illinois Basin, in Palmer, J. E., and Dutcher, R. R., eds., Depositional and structural history of the Pennsylvanian system of the
Illinois Basin, Part 2: International Congress of Carboniferous Stratigraphy and Geology, 9th, Guidebook for Field Trip No. 9, pt. 2, p. 115-120.

Lidiak, E. G., and Zietz, Isidore, 1976, Interpretation of aeromagnetic anomalies between latitudes $37^{\circ} \mathrm{N}$ and $38^{\circ} \mathrm{N}$ in the eastern and central United States: Geological Society of America Special Paper 167, $37 \mathrm{p}$. McCamy, K., and Meyer, R. P., 1966, Crustal results of fixed multiple shots in the Mississippi embayment, in Steinhart, J. S., and Smith, T. J., eds., The eny beneath the continents: American Geophysical Union Geophysics Monograph 10, p. 370-381. 


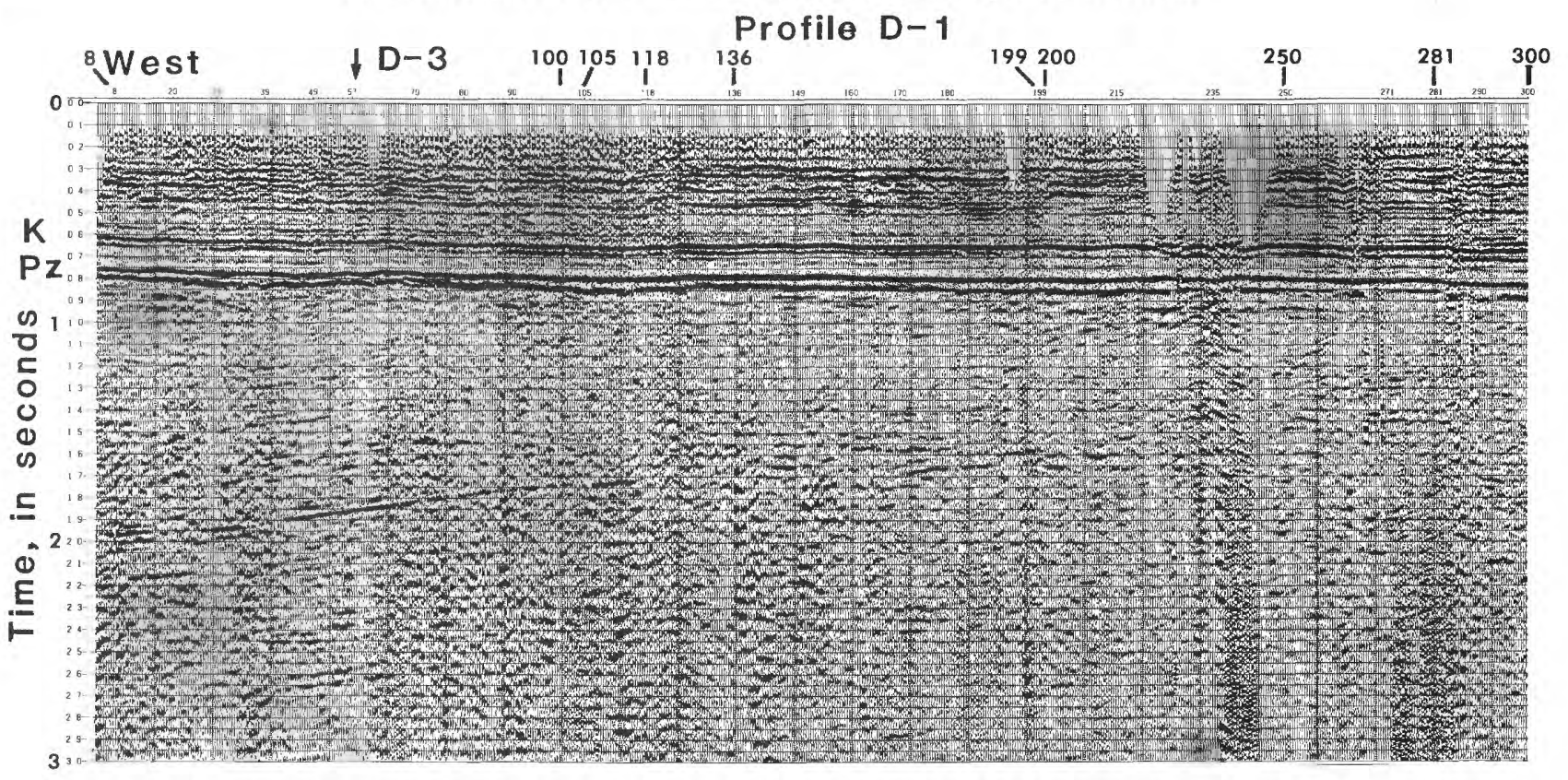

Figure 20. - Profile D-1. K, Tertiary-Upper Cretaceous contact; Pz, Upper Cretaceous-Paleozoic contact. Vibration point (VP) number is shown on the horizontal scale; the vibration point interval is $61 \mathrm{~m}$. Arrow indicates where profile D-3 crosses.

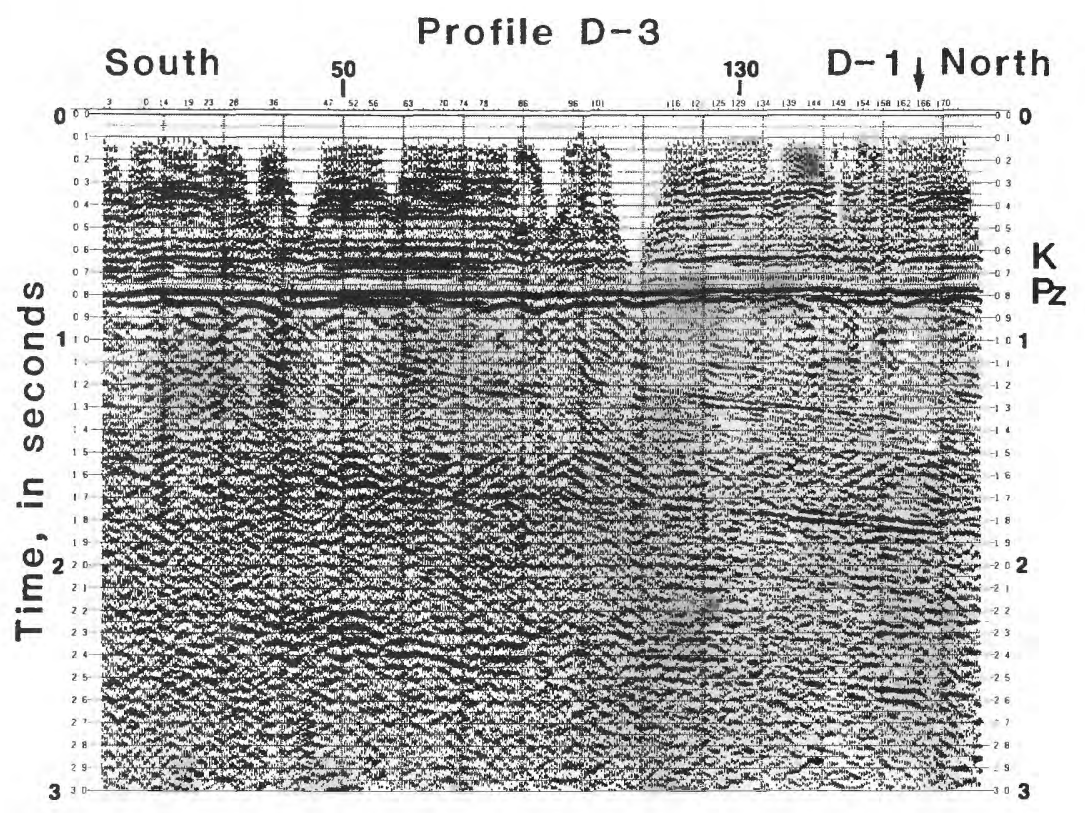

Figure 21.--Profile D-3. K, Tertiary-Upper Cretaceous contact; Pz, Upper CretaceousPaleozoic contact. Vibration point (VP) number is shown on the horizontal scale; the vibration point interval is $61 \mathrm{~m}$. Arrow indicates where profile D-1 crosses. 


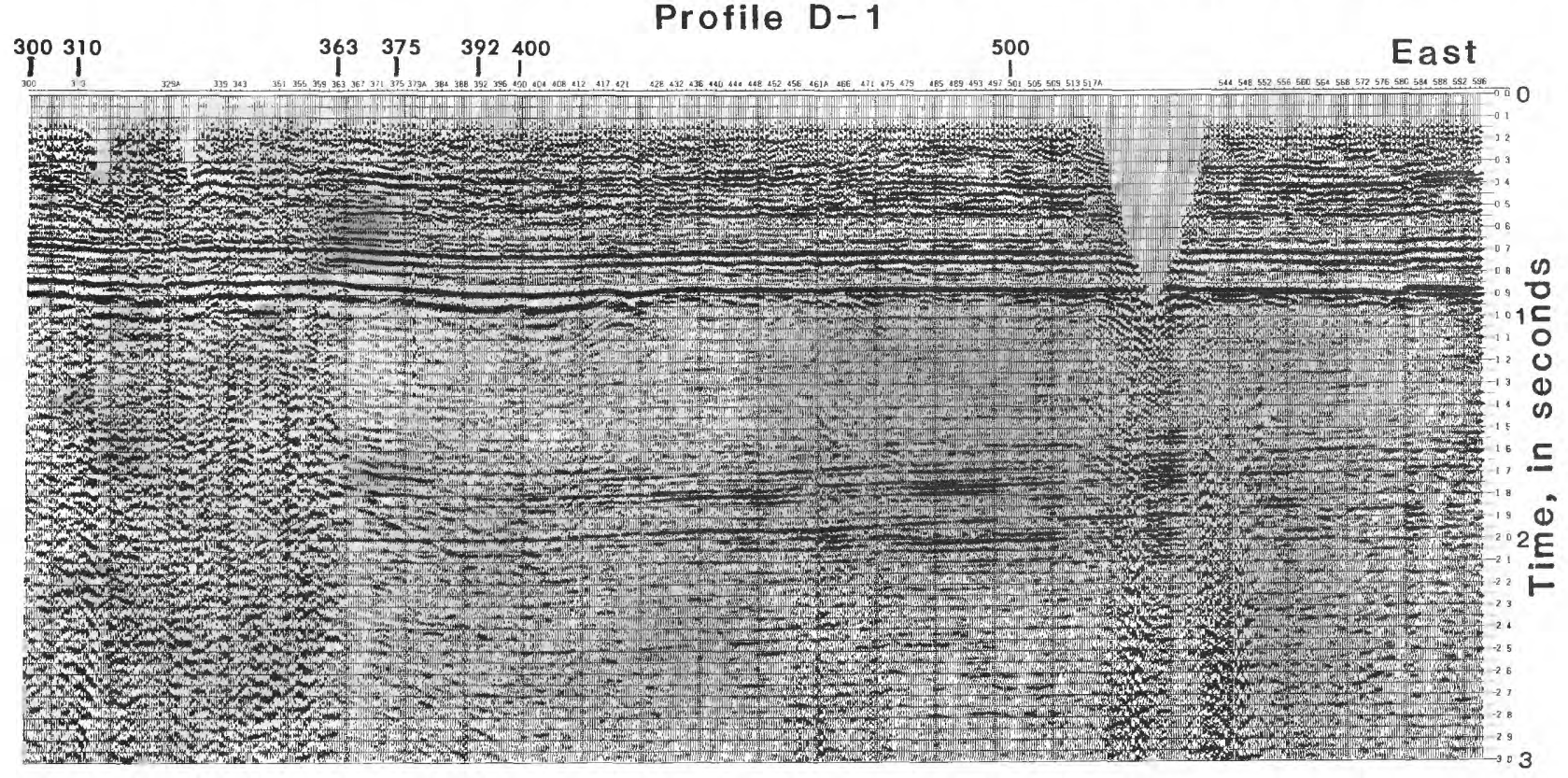

FIGURE 20.--Continued

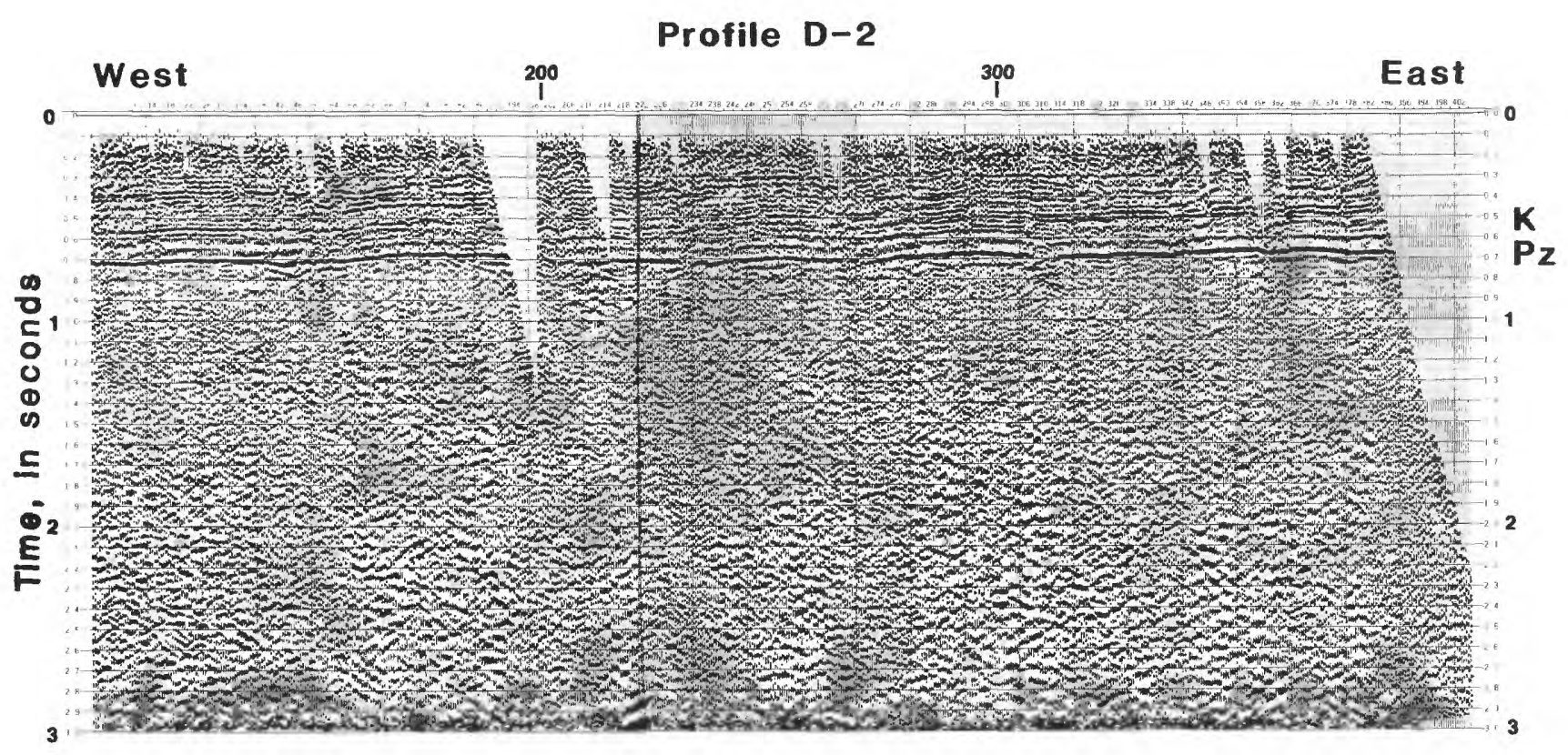

Figure 22. - Profile S-2. K, Tertiary-Upper Cretaceous contact; Pz, Upper Cretaceous-Paleozoic contact. Vibration point (VP) number is shown on the horizontal scale; the vibration point interval is $61 \mathrm{~m}$. 
McCracken, M. H., 1971, Structural features of Missouri: Missouri Division of Geological Survey and Water Resources Report of Investigations 49, $99 \mathrm{p}$.

Miser, H. D., and Ross, C. S., 1925, Volcanic rocks in the Upper Cretaceous of southwestern Arkansas and southeastern Oklahoma: American Journal of Science, 5 th ser. 5, v. 9, p. 113-126.

Nuttli, O. W., 1973, The Mississippi Valley earthquakes of 1811 and 1812 -. Intensities, ground motion and magnitudes: Seismological Society of America Bulletin, v. 63 , p. 227-248.

Rhoades, R., and Mistler, A. J., 1941, Post-Appalachian faulting in western Kentucky: American Association of Petroleum Geologists Bulletin, v. 25, p. 2046-2056.

Sheriff, R. E., 1978, A first course in geophysical exploration and interpretation: Boston, MA 02116, International Human Resources Development Corporation, 313 p.

Sloss, L. L., 1979, Plate-tectonic implications of the Pennsylvanian system in the Illinois Basin, in Palmer, J. E., and Dutcher, R. R., eds., Depositional and structural history of the Pennsylvanian system of the Illinois Basin, Part 2: International Congress of Carboniferous Stratigraphy and Geology, 9th, Guidebook for Field Trip No. 9, p. 107-112.

Stauder, William, Herrmann, R., Singh, S., Perry, R., Haug, E., and Morrissey, S. T., 1979, Central Mississippi Valley earthquake bulletin: Saint Louis University Quarterly Report no. 21, 28 p.

Stauder, William, Kramer, M., Fischer, G., Schaefer, S., and Morrissey, S. T., 1976, Seismic characteristics of southeast Missouri as indicated by a regional telemetered microearthquake array: Seismological Society of America Bulletin, v. 66, p. 1953-1964.
Stearns, R. G., 1979, Recent vertical movement of the land surface in the Lake County uplift and Reelfoot Lake basin areas, Tennessee, Missouri and Kentucky: U.S. Nuclear Regulatory Commission NUREG/CR$0874,37 \mathrm{p}$.

Trace, R. D., 1974, Illinois-Kentucky fluorspar district, in Hutchinson, D. W., ed., A symposium on the geology of fluorspar: Proceedings of the Ninth Forum on Geology of Industrial Minerals, Kentucky Geological Survey, Series X, Special Publication 22, p. 58-76.

Waters, K. H., 1978, Reflection seismology: New York, John Wiley, 377 p. Woollard, G. P., 1958, Areas of tectonic activity in the United States as indicated by earthquake epicenters: EOS (American Geophysical Union Transactions), v. 39, p. 1135-1150.

Zartman, R. E., 1977, Geochronology of some alkalic rock provinces in eastern and central United States: Annual Review of Earth and Planetary Sciences, v. 5, p. 257-286.

Zartman, R. E., Brock, M. R., Heyl, A. V., and Thomas, H. H., 1967, K-Ar and $\mathrm{Rb}-\mathrm{Sr}$ ages of some alkalic intrusive rocks from central and eastern United States: American Journal of Science, v. 265, p. 848-870.

Zoback, M. D., 1979, Recurrent faulting in the vicinity of Reelfoot Lake, northwest Tennessee: Geological Society of America Bulletin, pt. 1, v. 90, p. $1019-1024$.

Zoback, M. D., Hamilton, R. M., Crone, A. J., Russ, D. P., Mckeown, F. A., and Brockman, S. R., 1980, Recurrent intraplate tectonism in the New Madrid seismic zone: Science, v. 209, p. 971-976.

Zoback, M. L., and Zoback, M. D., 1980, State of stress in the conterminous United States: Journal of Geophysical Research, v. 85, p. 6113-6156. 


\section{A Crustal Structure Study of the Northern Mississippi Embayment}

By C. B. AUSTIN and G. R. KELLER

INVESTIGATIONS OF THE NEW MADRID, MISSOURI, EARTHQUAKE REGION GEOLOGICAL SURVEY PROFESSIONAL PAPER 1236 -G 


\section{CONTENTS}

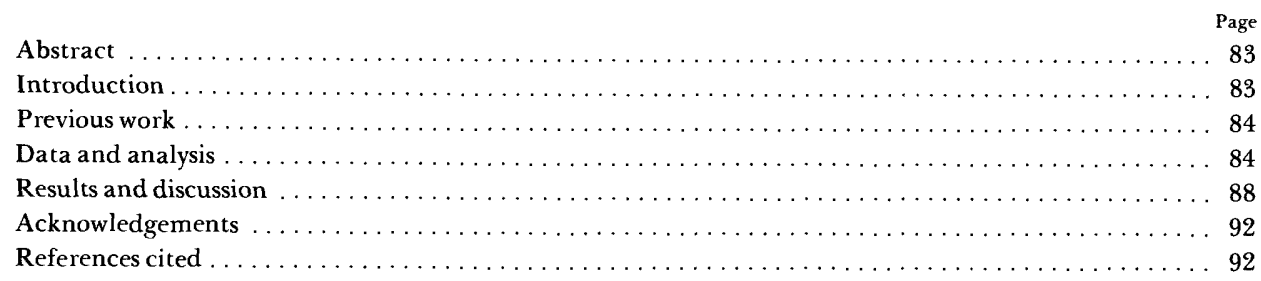

\section{ILLUSTRATIONS}

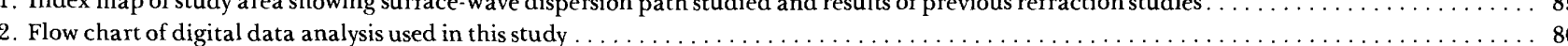

3. Samples of moving-window analysis applied to sample of cross- correlograms of legs of tripartite between Oxford, Miss., St. Louis Mo., and Ann Arbor, Mich.

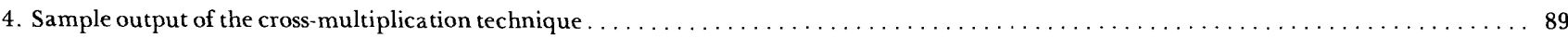

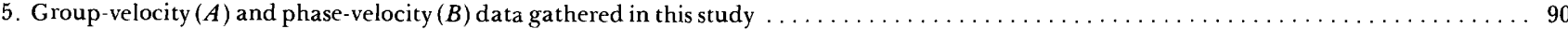

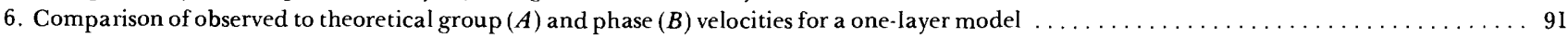

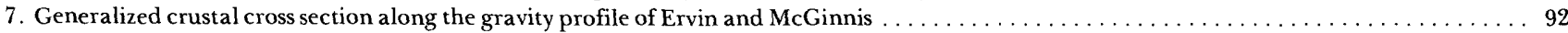

\section{TABLES}

Page

TABLE 1. Epicentral data for earthquakes used as surface-wave sources $\ldots \ldots \ldots \ldots \ldots \ldots$

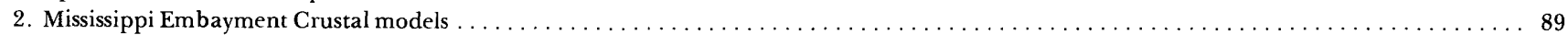




\title{
A CRUSTAL STRUCTURE STUDY OF THE NORTHERN MISSISSIPPI EMBAYMENT
}

\author{
By C. B. Austin ${ }^{1}$ and G. R. KelleR ${ }^{1}$
}

\begin{abstract}
Short- to intermediate-period (5-80 s) Rayleigh waves recorded at Worldwide Seismograph Station Network stations FLO (near St. Louis, Mo.) and OXF (Oxford, Miss.) were analyzed digitally to obtain group- and phase- velocity dispersion curves. These data were used to determine the crustal and upper mantle shear-velocity structure of the northern Mississippi Embayment. The models derived suggest that the crustal thickness near the axis of the northern Mississippi Embayment is probably in the range from 50 to $55 \mathrm{~km}$. An anomalously high velocity layer $(\mathrm{VP} \sim 7.0 \mathrm{~km} / \mathrm{s}, \mathrm{Vs} \sim 4.0$ $\mathrm{km} / \mathrm{s}$ ) is found in the lowermost crust throughout the region. The crustal model derived is in good agreement with previous refraction studies.

The results of this study were integrated with previous work to produce a hypothetical crustal cross section for the northern Mississippi Embayment. This Earth model is similar to that which would be expected to be associated with an ancient rift zone (aulacogen?).
\end{abstract}

\section{INTRODUGTION}

The Mississippi Embayment is a broad structural trough or reentrant of the gulf coastal plain which extends into the North American craton from the south. This feature, whose axis generally parallels the course of the Mississippi River, plunges toward the Gulf of Mexico where Cretaceous and Tertiary sediments reach a maximum thickness of $5.5 \mathrm{~km}$ (Cushing and others, 1964). A popular theory for the origin of the embayment is that it represents a reactivated late Precambrian aulacogen (Ervin and McGinnis, 1975).

${ }^{2}$ Kidd Seismological Observatory, Department of Geological Sciences; University of Texas at El Paso, El Paso, TX 79968.
The presence of the New Madrid seismic zone (Stauder and others, 1976) indicates that the northern Mississippi Embayment is tectonically active. However, the forces responsible for this activity are poorly understood. Because crustal discontinuities may be related to contemporary tectonism (Hinze and others, 1977), a knowledge of crustal structure is important. Crustal structure has been of particular recent interest because of studies which suggest that the northern embayment may be underlain by anomalous crust (McCamy and Meyer, 1966; Kurita, 1973; Ervin and McGinnis, 1975; Mitchell and Hashim, 1977; and Mitchell and others, 1977).

This study was designed to determine the general crustal and upper mantle shear-velocity structure of the northern Mississippi Embayment by measuring Rayleigh-wave dispersion between WWSSN (Worldwide Seismograph Station Network) seismograph stations in the area and to integrate these results with those of previous studies in the area. Tectonic implications of variations in crustal structure are considered, as well as rift models which have been proposed for the development of the embayment (Burke and Dewey, 1973; Ervin and McGinnis, 1975; Hildenbrand and others, 1978).

Burke and Dewey (1973) originally suggested that the present-day Mississipppi Embayment was a Mesozoic aulacogen (failed rift) originating from a triple junction near Jackson, Miss. Ervin and McGinnis (1975), using gravity data tied to the refraction line of McCamy and Meyer (1966), examined this model and concluded that the current embayment is the result of readjustment of the Earth's crust along zones of weakness created by a Precambrian aulacogen (Reelfoot Rift). They suggested that the Reelfoot Rift is of the same age and origin as the southern Oklahoma aulacogen 
(Burke and Dewey, 1973; Hoffman and others, 1974) and that both of these features formed as a Precambrian land mass broke up prior to the formation of the Appalachian- Ouachita mountain belt.

By the Late Cretaceous, the present Atlantic Ocean basin was forming and subsidence of the gulf coastal plain created tensional forces that initiated reactivation along the ancient rift zone (Ervin and McGinnis, 1975). Intrusion of syenite and lamprophyre along the axis of the Mississippi Embayment (Bond and others, 1971) marked the initial stage of reactivation and may have initiated isostatic adjustments that produced the present-day embayment (McGinnis, 1970). Although geologic evidence points to a stable embayment since Neogene time (Stearns and Wilson, 1972), both the extent of historical seismicity (Nuttli, 1974) and level of recent seismic activity (Stauder and others, 1976) indicate contemporary tectonism.

\section{PREVIOUS WORK}

The crustal structure of the Central United States seems to be relatively uncomplicated (McEvilly, 1964; Stewart, 1968; Warren, 1968; Long and Mather, 1972; and others). In general, the crust of the midcontinent region can be modeled as being composed of two layers overlain by a veneer of Paleozoic sediments. The sedimentary layer varies in thickness from $\sim 5 \mathrm{~km}$ in various basins to $0 \mathrm{~km}$ on the Ozark uplift and has an average compressional velocity of $\sim 5.0 \mathrm{~km} / \mathrm{s}$. The upper crustal layer (granitic) averages $\sim 20 \mathrm{~km}$ in thickness and has a compressional velocity of $6.0-6.4 \mathrm{~km} / \mathrm{s}$. The lower crustal layer (gabbroic) is $10-20 \mathrm{~km}$ thick and has a compressional velocity of $6.5-6.9 \mathrm{~km} / \mathrm{s}$. Thus, the crustal thickness is $\sim 40 \mathrm{~km}$. Upper mantle velocities $(\mathrm{Pn})$ range from 8.0 to 8.2 $\mathrm{km} / \mathrm{s}$.

However, seismic studies in the vicinity of the embayment (fig. 1) suggest the presence of a thick crust that has a basal high-velocity ( $>7.0 \mathrm{~km} / \mathrm{s}$ ) layer overlying the Moho. Interpretation of a refraction line from Hercules to Gladden (fig. 1) in southern Missouri (Stewart, 1968) indicated a 42-km-thick crust containing an $11-\mathrm{km}$-thick lower layer that has a compressional velocity of $7.3 \mathrm{~km} / \mathrm{s}$. However, Stewart (1968) noted that it may be inappropriate to regard the crust of southeastern Missouri as being simply layered due to pronounced lateral changes in the velocity structure. The refraction line of McCamy and Meyer (1966) from Cape Giradeau, Mo., to Little Rock, Ark., approached much nearer the axis of the embayment and the New Madrid seismic zone (fig. 1). This study reversed the earlier line of Steinhart and Meyer (1961) and, thus, is the best control for deep crustal structure in this area. McCamy and Meyer (1966) found a 45-km-thick crust containing a basal layer $15 \mathrm{~km}$ thick that has a compressional velocity of $7.4 \mathrm{~km} / \mathrm{s}$. The upper mantle velocity they determined was $8.1 \mathrm{~km} / \mathrm{s}$.

Kurita (1973), modeling long-period P-wave spectra beneath the seismograph station FLO near St. Louis, Mo., found the crust to be about $57 \mathrm{~km}$ thick and to have a mafic basal crustal layer of compressional velocity $7.4 \mathrm{~km} / \mathrm{s}$. He also found an upper mantle velocity of approximately $8.1 \mathrm{~km} / \mathrm{s}$. Kurita (1973) suggested that a complex crustal tructure existed beneath station FLO.

More recent studies utilizing data from the Saint Louis University microearthquake array (Stauder and others, 1976) have also suggested the presence of a basal crustal layer having velocities greater than $7.0 \mathrm{~km} / \mathrm{s}$ in the area of the New Madrid seismic zone. Mitchell and Hashim (1977) derived an Earth model from travel times for local earthquakes. Their model consisted of a 5.6-km-thick layer that had a compressional velocity of $6.19 \mathrm{~km} / \mathrm{s}$ overlying an $18.1-\mathrm{km}$-thick layer that had a compressional velocity of $6.38 \mathrm{~km} / \mathrm{s}$. These layers were underlain by a basal crustal layer that had a compressional velocity of $7.17 \mathrm{~km} / \mathrm{s}$.

Mitchell and others (1977), using travel-time residuals of teleseismic P- waves, produced a three-dimensional crustupper mantle model of the New Madrid seismic zone. They proposed the existence of a region of low velocities extending to a depth of at least $150 \mathrm{~km}$ and dipping westward beneath the most active region of the seismic zone. They suggested that the New Madrid seismic zone may be underlain by a mantle hot spot such as that proposed for Yellowstone, Wyo.

Ervin and McGinnis (1975) analyzed and modeled the positive gravity anomaly associated with the embayment as being due to a thick lower crustal layer of high density. In a similar study, Cordell (1977) corrected for the low-density sediments of the embayment and found a continuous, longwavelength, positive anomaly with amplitude (15-45 mgals) increasing southward along the embayment's axis.

Hildenbrand and others (1978) interpreted the extensive recent aeromagnetic and gravity surveys in the northern Mississippi Embayment and delineated several prominent anomalies that appear to reflect the presence of major geological or tectonic features. A narrow, linear, northeast-trending zone of subdued magnetic anomalies was found which indicates a downfaulted block (graben?) in the basement.

\section{DATA AND ANALYSIS}

Analysis of Rayleigh-wave dispersion is a powerful tool for determining Earth structure through modeling in which theoretically derived values are compared with those observed. The recent articles by Dziewonski and Hales (1972) and Kovach (1978) provide good reviews of the use of Rayleigh waves in crustal studies. Rayleigh-wave dispersion is most sensitive to variations in shear-wave velocity (Der and others, 1970). Because shear velocities are difficult to obtain from refraction profiling, Rayleigh-wave data provide complementary information to the compressional velocities derived from other studies and provide data needed for determination of Poisson's ratios. These ratios have considerable tectonic significance, especially considering recent studies of dilatancy and 


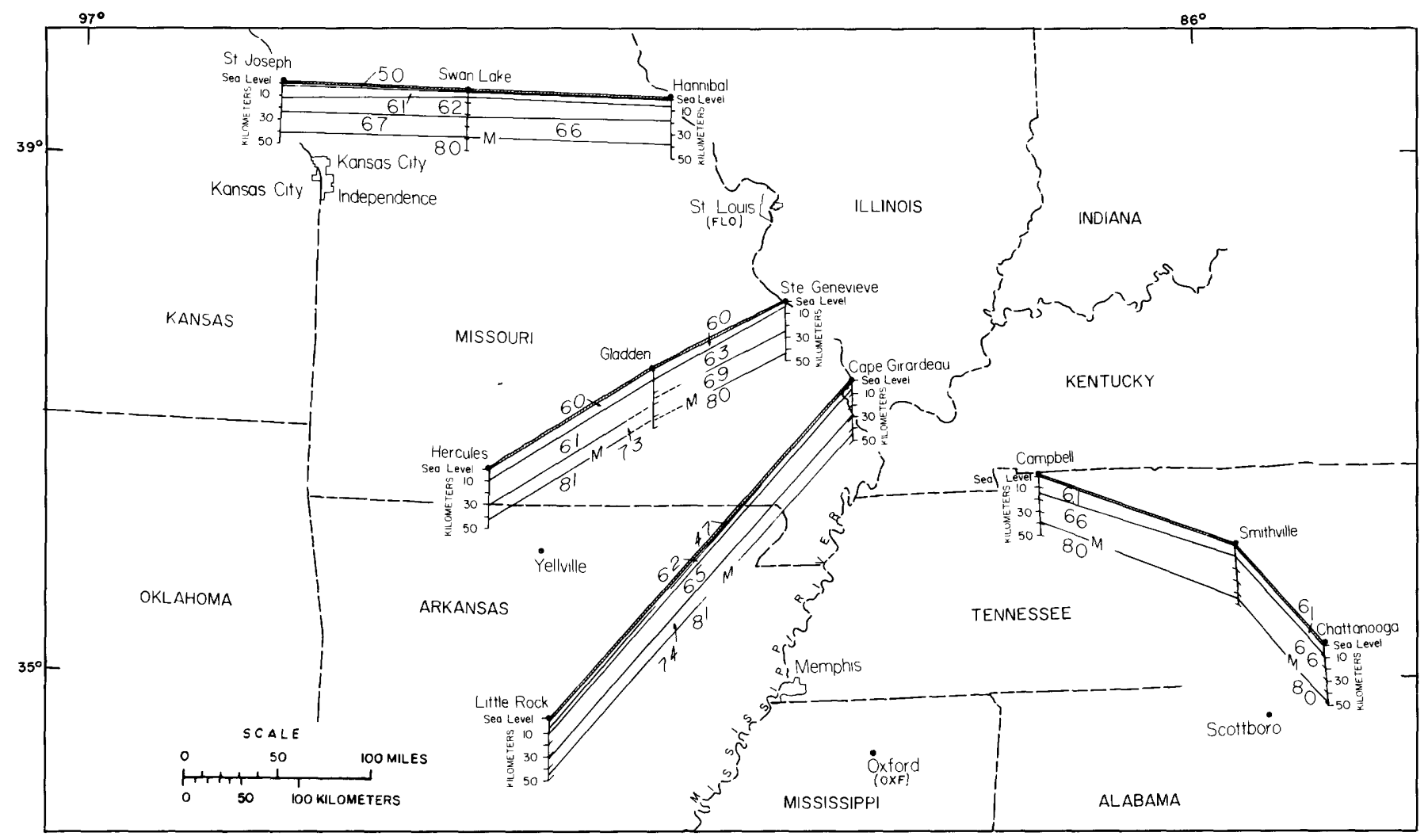

FiguRe 1.--Index map of study area showing surface-wave dispersion path studied (screened pattern) and results of previous refraction studies (fence diagrams). The fence diagrams show crustal thickness, P-wave velocities, and the M-discontinuity. St. Joseph to Hannibal and Hercules to Ste. Genevieve from Stewart (1968). Little Rock to Cape Girardeau from McCamy and Meyer (1966). Campbell to Chattanooga from Warren (1968). Results of Warren and others (1968) indicate a complex crustal structure in central and southern Mississippi (near and south of the Ouachita Front) and that is not shown.

earthquake prediction. Furthermore, a low-velocity zone such as that proposed for the New Madrid seismic zone area (Mitchell and others, 1977) may be more pronounced for shear waves than for compressional waves.

However, it is important to remember that Rayleigh-wavedispersion studies produce Earth models that represent the gross Earth structure averaged over the path of propagation. Therefore, to obtain geologically meaningful results, propagation paths confined to a single geological province must be studied. Modern digital techniques allow this to be done with relative ease, and the resolution obtainable with this method, combined with the low cost of such studies, makes it an ideal technique for determining shear-velocity crustal structure.

In this study, modern digital techniques were used to determine crustal and upper mantle structure along one leg of a tripartite array of stations (Press, 1956; Knopoff and others, 1966). The method of analysis is illustrated in graphical form by the flow chart shown in figure 2 .

The propagation path studied (fig. 1) traversed the area between the stations OXF (Oxford, Miss.) and FLO (near St. Louis, Mo.). This path was of interest because it crosses the
New Madrid seismic zone and the Mississippi Embayment. A third station (AAM, Ann Arbor, Mich.) was used to perform a tripartite solution to check for horizontal refractions which could be produced by major discontinuities in crustal structure.

The data for this study consist of long-period verticalcomponent seismograms from five earthquakes (table 1) selected on the basis of their epicenters lying very near the great-circle path joining the staions OXF and FLO. The earthquakes were selected from the earthquake data file of the Environmental Data Service, National Oceanic and Atmospheric Administration, at Boulder, Colo.; and records for each event were handpicked to insure quality data for each station. The paper seismograms were digitized to provide data at a rate of two samples per second.

In order to determine the interstation group velocities, a cross- correlation was performed for the paths OXF-FLO and OXF-AAM (Dziewonski and Hales, 1972). A time-variable, bandpass filter (Pilant and Knopoff, 1964; Dziewonski and Hales, 1972) was applied to the cross-correlograms to separate modes and smooth the data.

The moving-window technique of Landisman and others 


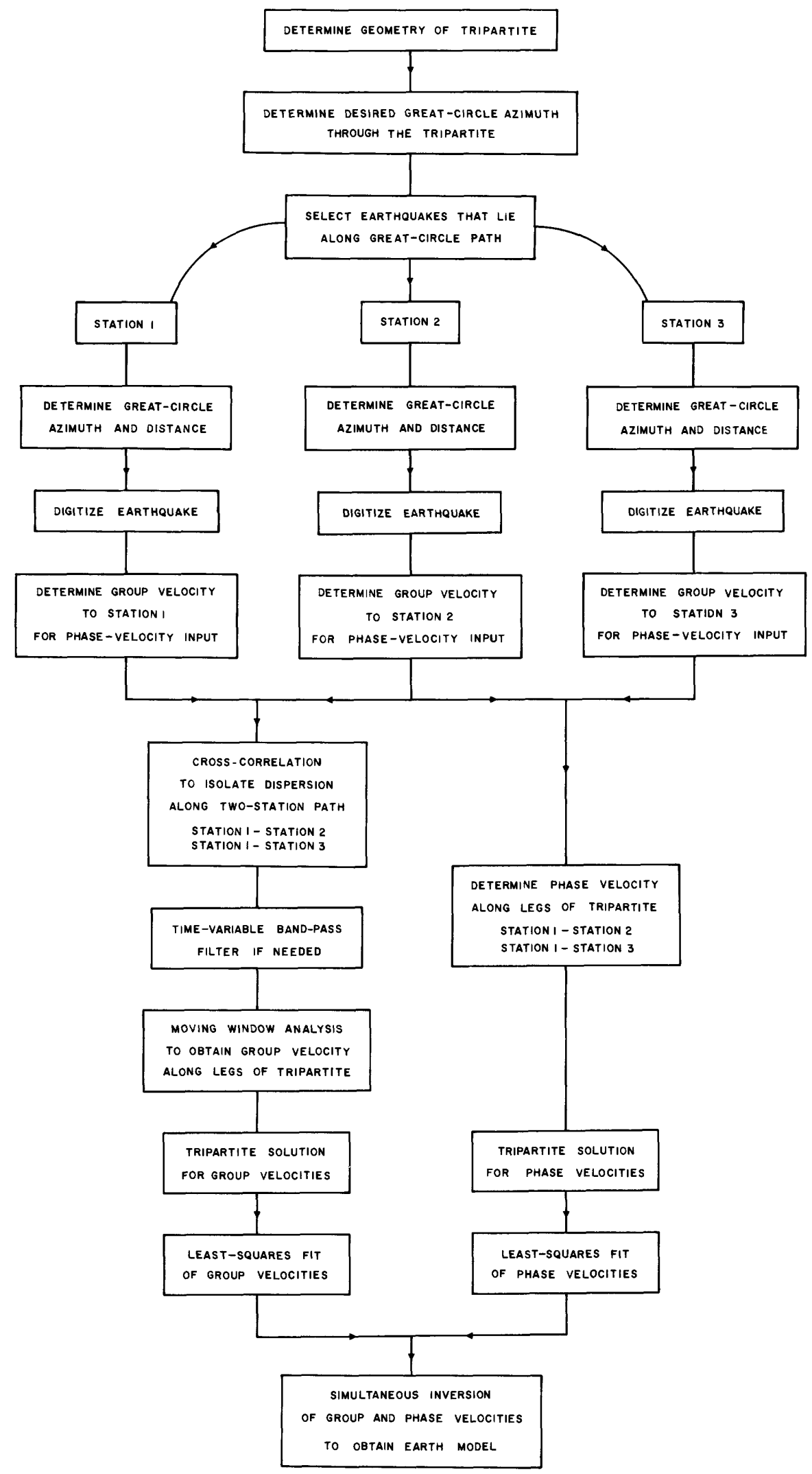

Figure 2.--Flow chart of digital data analysis used in this study. 
TABLE 1.-Epicentral data for earthquakes used as surface-wave sources

\begin{tabular}{|c|c|c|c|c|c|c|c|c|}
\hline Number & Date & $\begin{array}{c}\text { Origin } \\
\text { Time (GMT) } \\
h \text { min } s\end{array}$ & $\begin{array}{l}\text { Latitude } \\
\left({ }^{\circ} \mathrm{N} .\right)\end{array}$ & $\begin{array}{l}\text { Longitude } \\
\left({ }^{\circ} \mathrm{W} .\right)\end{array}$ & $\begin{array}{l}\text { Magnitude } \\
\left(\mathrm{m}_{\mathrm{b}}\right)\end{array}$ & $\begin{array}{l}\text { Station } \\
\text { code }\end{array}$ & $\begin{aligned} \text { Distance to } \\
\text { epicenter }(\mathrm{km})\end{aligned}$ & $\begin{array}{l}\text { Azimuth from } \\
\text { epicenter (deg) }\end{array}$ \\
\hline 2 & $04 / 21 / 1969$ & $\begin{array}{lll}02 & 19 & 07.1\end{array}$ & 1406.0 & 9100.0 & 5.5 & OXF & $\begin{array}{c}2273.36 \\
\text { FLO } \\
\text { AAM }\end{array}$ & $\begin{array}{r}4.4147 \\
2745.05 \quad 1.4556 \\
3211.3514 .8612\end{array}$ \\
\hline 3 & $05 / 01 / 1970$ & $\begin{array}{lll}08 & 35 & 24.2\end{array}$ & 1436.0 & 9312.0 & 5.4 & OXF & $\begin{array}{c}2244.58 \\
\text { FLO } \\
\text { AAM }\end{array}$ & $\begin{array}{ll}10.6754 & \\
2703.05 & 6.6589 \\
3221.5820 .1643\end{array}$ \\
\hline 4 & $05 / 01 / 1970$ & $\begin{array}{lll}20 & 03 & 27.9\end{array}$ & 1436.0 & 9336.0 & 5.0 & OXF & $\begin{array}{c}2251.71 \\
\text { FLO } \\
\text { AAM }\end{array}$ & $\begin{array}{l}11.7793 \\
2707.35 \quad 7.5930 \\
3221.5820 .1643\end{array}$ \\
\hline 5 & $05 / 02 / 1970$ & $\begin{array}{lll}02 & 06 & 56.3\end{array}$ & 1442.0 & 93.42 & 5.4 & OXF & $\begin{array}{c}2242.67 \\
\text { FLO } \\
\text { AAM }\end{array}$ & $\begin{array}{l}12.1050 \\
2697.47 \quad 7.8525 \\
3213.7220 .4116\end{array}$ \\
\hline 6 & $05 / 15 / 1970$ & $09 \quad 44 \quad 45.2$ & 1430.0 & 9248.0 & 5.4 & OXF & $\begin{array}{c}2249.15 \\
\text { FLO } \\
\text { AAM }\end{array}$ & $\begin{array}{r}9.5246 \\
2710.395 .7014 \\
3210.5318 .5643\end{array}$ \\
\hline
\end{tabular}

(1969) was applied to the filtered cross-correlograms to determine group velocities along the legs of the tripartite. This technique involves a $\cos ^{2}$ window function that moves down the digitized time trace centering on each velocity of interest. The width of the window is a function of the period being examined, and for this study, a window factor of 3.0 was used. At each time, corresponding to a step in group velocity, the windowed data are Fourier-analyzed at the period of interest. This process is repeated for each period of interest. The individual Fourier-amplitude values obtained are displayed in matrix form as a function of group velocity and period. The plotted amplitudes are normalized so that the largest value is set to $100 \mathrm{db}$. The mapped values are then contoured and the resulting group-velocity dispersion curve is drawn through the contoured data. Figure 3 shows the results of a movingwindow analysis.

Corresponding phase velocities for each leg of the tripartite were determined using the cross-multiplication method of Bloch and Hales (1968). In this technique seismograms recorded at the two stations of interest are windowed by a $\cos ^{2}$ window function, centered at the time of interest determined by the group-velocity arrival time. The seismograms are then filtered and a windowed section of one seismogram, whose length is two thirds the period of interest, is point-by-point multiplied by the other trace. The results are summed and normalized to obtain an amplitude value for the corresponding period and velocity. When the two traces are in phase, the amplitude is a maximum of $99 \mathrm{db}$. At 180 degrees out of phase, a minimum of $-99 \mathrm{db}$ is plotted. Results àre displayed in the same format as group-velocity (fig. 4) determinations.
Using the group and phase velocities calculated between station pairs OXF-FLO and OXF-AAM as input, a tripartite solution was computed for each period of interest. The angle of approach of the wave front and its velocity across the array of stations were determined using standard equations (Press, 1956).

The geometry of the tripartite used in this study was designed so that the tripartite velocities derived represent velocities along the leg OXF-FLO. The accuracy of the angles of approach used to calculate these velocities depends on the validity of the assumption that no significant lateral refractions take place within the array. Our present knowledge of crustal variations found in the midcontinent outside the embayment suggests that these variations are too small to significantly affect this assumption. The tripartite velocity obtained for each period was plotted and a least- squares fit of the data provided the dispersion curve for inversion.

The scatter in these data (fig. 5) is somewhat greater than that usually found in the results of simple two-station analyses. However, the lateral refractions observed in this study (usually 10-15) suggest that the tripartite calculation was worthwhile.

The generalized inversion program of Braile and Keller (1975) was employed to invert both group- and phase-velocity data simultaneously to obtain an Earth model. This inversion technique uses an iterative procedure based on the BackusGilbert inversion formulation (for example, Backus and Gilbert, 1970). In the inversion, theoretical data are calculated using the Haskell-Thompson matrix approach (Thompson, 1950; Haskell, 1953) as modified by Dunkin (1965). For a given layer, variations in compressional velocity and density do 

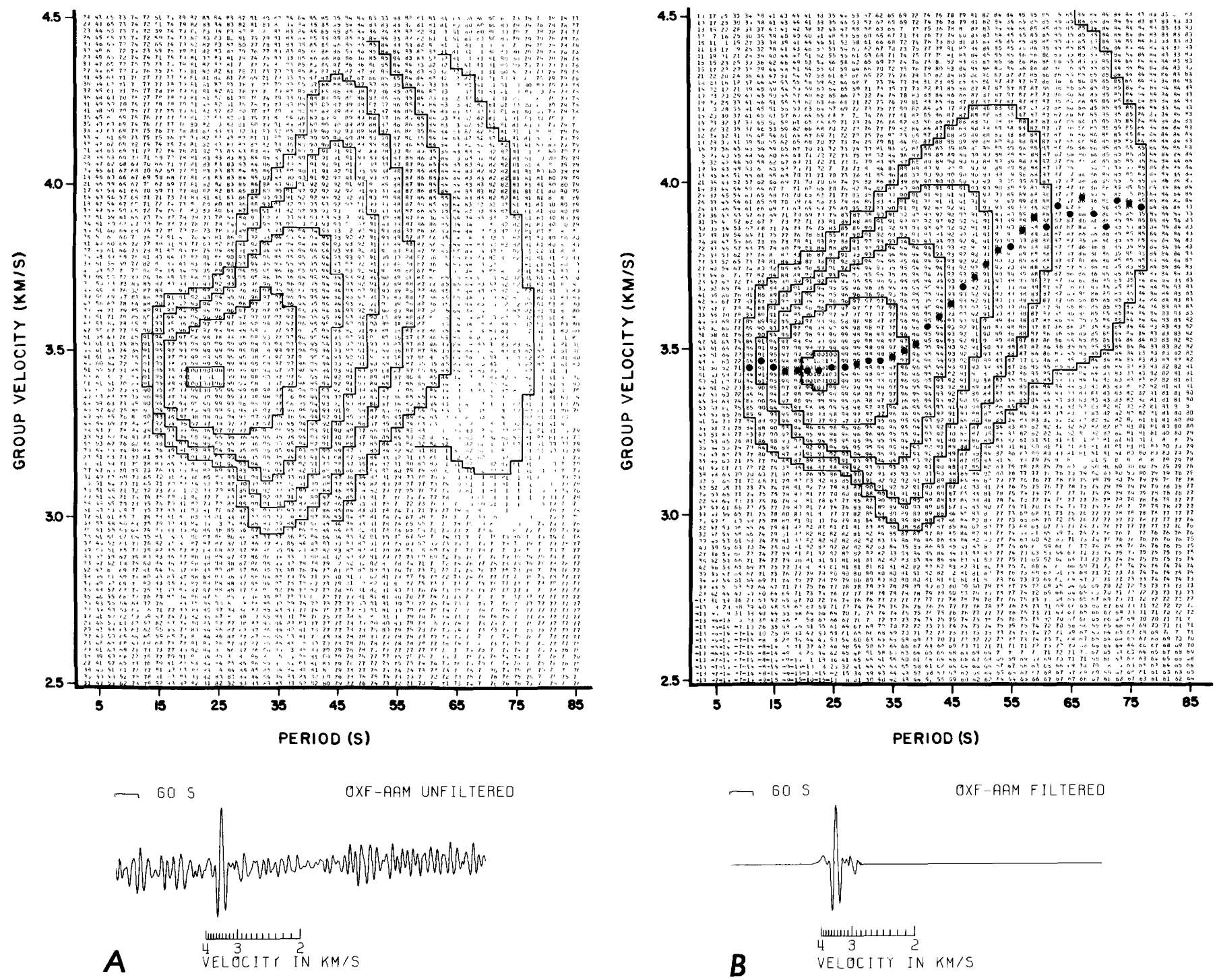

Figure 3. - Samples of moving-window analysis applied to sample of cross- correlograms of legs of tripartite between Oxford, Miss., St. Louis, Mo., and Ann Arbor, Mich. A, results for unfiltered correlogram; B, results for filtered correlogram.

not strongly influence theoretical dispersion curves (Der and others, 1970). Thus, the shear-wave velocity is the only independent variable considered in the inversion process. Compressional velocities are calculated from derived shear velocities using assumed Poisson's ratios, and densities are derived from empirical compressional velocity and density relations (summarized by Cook, 1962).

\section{RESULTS AND DISCUSSION}

The group- and phase-velocity data obtained in this study are shown in figure 5 , along with the curves which represent the best "least-squares fit" to these data. Assuming no major lateral refractions occur within the tripartite of stations OXF-
FLO-AAM, these dispersion curves reflect the general crustal structure along the path OXF-FLO.

Two approaches were employed to derive estimates of the uniqueness of the Earth models derived in this study. First of all, the inversion program provides standard-deviation estimates for the parameters treated as unknowns. Secondly, a wide variety of inversion runs were made with differing numbers of layers and radically different starting models. With the resolution of the technique in mind, the models discussed are those which satisfy the observed data and have the fewest number of layers. Also, the main aspects of embayment crustal structure were common to all of the Earth models derived and had standard-deviation estimates suggesting that their geological implications are valid.

Two relatively thin layers representing the Cenozoic and 
Paleozoic- Mesozoic sedimentary rocks in the embayment were required in all models on the basis of geological evidence. The thicknesses and velocities derived for these layers $(0.5 \mathrm{~km}, 4.3$ $\mathrm{km} / \mathrm{s} ; 2.3 \mathrm{~km}, 5.4 \mathrm{~km} / \mathrm{s}$ ) represent reasonable averages for the propagation path, but have little geologic significance because they represent averages over such a large area.

A simple one layer (exclusive of sedimentary cover) crustal model (table 2) approaches an acceptable fit to the observed data but fails to fall within the error bounds ( 95 percent confidence interval) for the observed data (fig. 6) and does not honor the trend of the data. However, this model and the results of previous studies suggest some general conclusions: (1) $47 \mathrm{~km}$ represents a good minimum value for the crustal thickness of the northern Mississippi Embayment, and (2) the average velocities of the crust are anomalously high $(\mathrm{Vp} \sim 6.8$ $\mathrm{km} / \mathrm{s} ; \mathrm{Vs} \sim 3.9 \mathrm{~km} / \mathrm{s}$ ).

The model providing the best fit to the observed data is a more complex three-layer (exclusive of sedimentary cover) crustal model (table 2). This model is interpreted as the best representation of the average crustal structure along the propagation path (OXF-FLO) which could be derived from these data, because the addition of more layers did not improve the fit to the observed data. This model shows the average crustal thickness near the axis of the northern Mississippi Embayment to be $50-55 \mathrm{~km}$. However, the inversion results showed that the

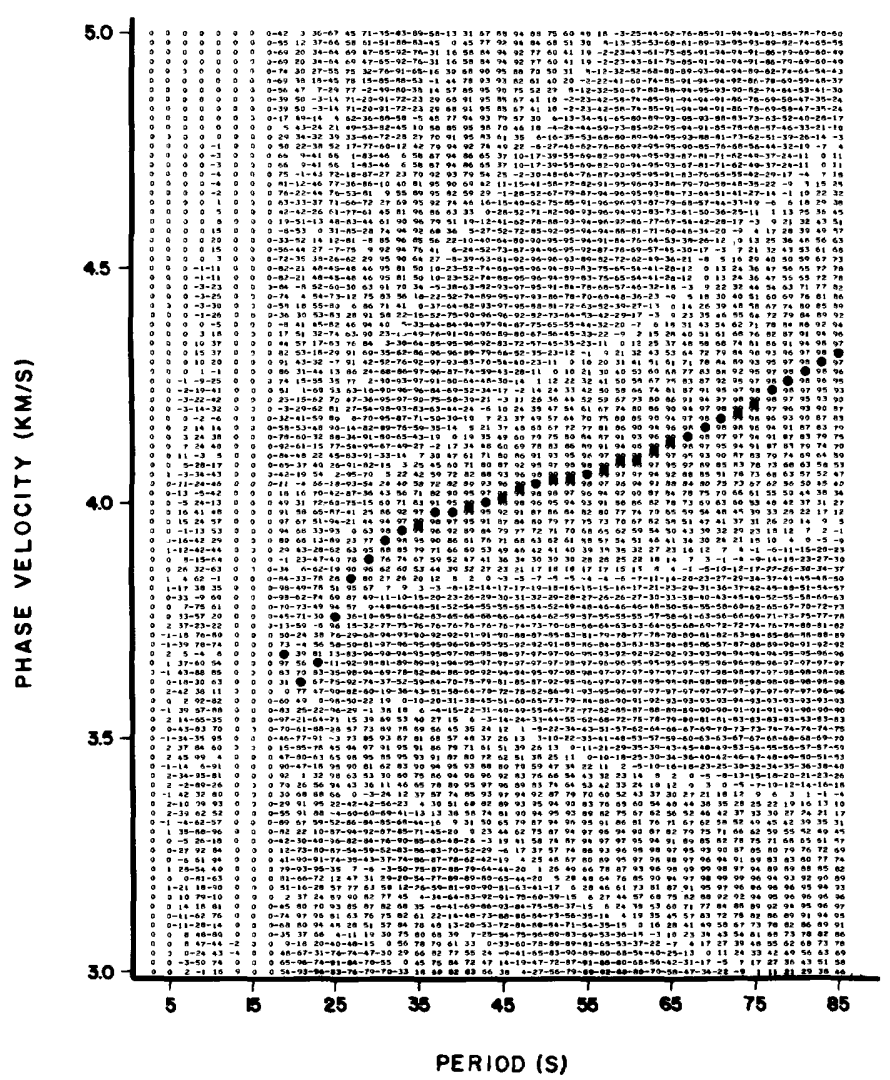

FIgURE 4. --Sample output of the cross-multiplication technique. This example is for the path from Oxford, Miss., to Ann Arbor, Mich.
TABLE 2. - Mississippi Embayment Crustal models [Numbers in parentheses are total crustal thickness]

\begin{tabular}{|c|c|c|}
\hline Reference & $\begin{array}{l}\text { Thickness } \\
(\mathrm{km})\end{array}$ & $\begin{array}{c}\text { P-velocity } \\
(\mathrm{km} / \mathrm{s})\end{array}$ \\
\hline MeCdmy and Meyer (1966) & $\begin{array}{c}3.0 \\
5.0 \\
22.0 \\
15.0 \\
(45.0)\end{array}$ & $\begin{array}{l}4.7 \\
6.2 \\
6.5 \\
7.4 \\
8.1\end{array}$ \\
\hline $\begin{array}{l}\text { Stewart (1963): } \\
\quad \text { Hercules to Gladden-- }\end{array}$ & $\begin{array}{c}1.0 \\
8.0 \\
22.0 \\
11.0 \\
(42.0)\end{array}$ & $\begin{array}{l}5.0 \\
6.0 \\
6.1 \\
7.3 \\
8.0\end{array}$ \\
\hline Gladden to Ste. Genevieve-..-- & $\begin{array}{c}.5 \\
3.5 \\
21.0 \\
17.0 \\
(42.0)\end{array}$ & $\begin{array}{l}5.0 \\
6.0 \\
5.3 \\
6.9 \\
7.8\end{array}$ \\
\hline Warren (1968) & $\begin{array}{c}15.0 \\
25.0 \\
(40.0)\end{array}$ & $\begin{array}{l}5.1 \\
6.6 \\
3.0\end{array}$ \\
\hline Kurita (1973) & $\begin{array}{c}1.0 \\
9.0 \\
38.0 \\
9.0 \\
(57.0)\end{array}$ & $\begin{array}{l}5.0 \\
6.2 \\
6.5 \\
7.4 \\
8.2\end{array}$ \\
\hline Mitche11 and Hashim (1977) - . & $\begin{array}{c}1.0 \\
1.0 \\
5.6 \\
18.1 \\
?\end{array}$ & $\begin{array}{l}2.4 \\
4.0 \\
6.2 \\
6.4 \\
7.2\end{array}$ \\
\hline $\begin{array}{l}\text { This study (one-layer crust; ex- } \\
\text { clusive of surficial layers) } \\
(\sigma=0.25)\end{array}$ & $\begin{array}{r}.6 \\
3.0 \\
43.3 \\
(46.9)\end{array}$ & $\begin{array}{l}4.0 \\
4.7 \\
6.8 \\
7.9\end{array}$ \\
\hline $\begin{array}{l}\text { This study (three-layer crust; } \\
\text { exclusive of surficial lay- } \\
\text { layers) }(\sigma=0.25)-\end{array}$ & $\begin{array}{c}.5 \\
2.3 \\
12.6 \\
12.1 \\
25.8 \\
(53.3)\end{array}$ & $\begin{array}{l}4.3 \\
5.4 \\
6.3 \\
6.8 \\
7.1 \\
7.9\end{array}$ \\
\hline
\end{tabular}

resolution of the depth to the Moho provided by these data is relatively poor for two reasons: First of all the various inversion runs all converged to models with thick ( $\sim 26 \mathrm{~km}$ ), highvelocity $(\mathrm{Vp} \sim 7.1 \mathrm{~km} / \mathrm{s} ; \mathrm{Vs} \sim 4.0 \mathrm{~km} / \mathrm{s})$ layers in the lower crust. Thus, the velocity contrast between the lower crust and upper mantle is considerably less than normal, and the Moho is more difficult to resolve. Secondly, the Moho may be a transitional boundary in this region.

The general aspects of crustal structure indicated by the results of this study compare favorably with previous work in the area (table 2). Inversions with complicated velocity structures in the mantle were run, but it should be noted that an upper mantle, low-velocity layer at a depth of $\sim 100 \mathrm{~km}$ (Mitchell and others, 1977) is consistent with but not required by the data. The thick, high-velocity, lower crustal layer is of particular tectonic significance. Discrepancies in the thickness of this layer (compare this study to McCamy and Meyer, 1966) 


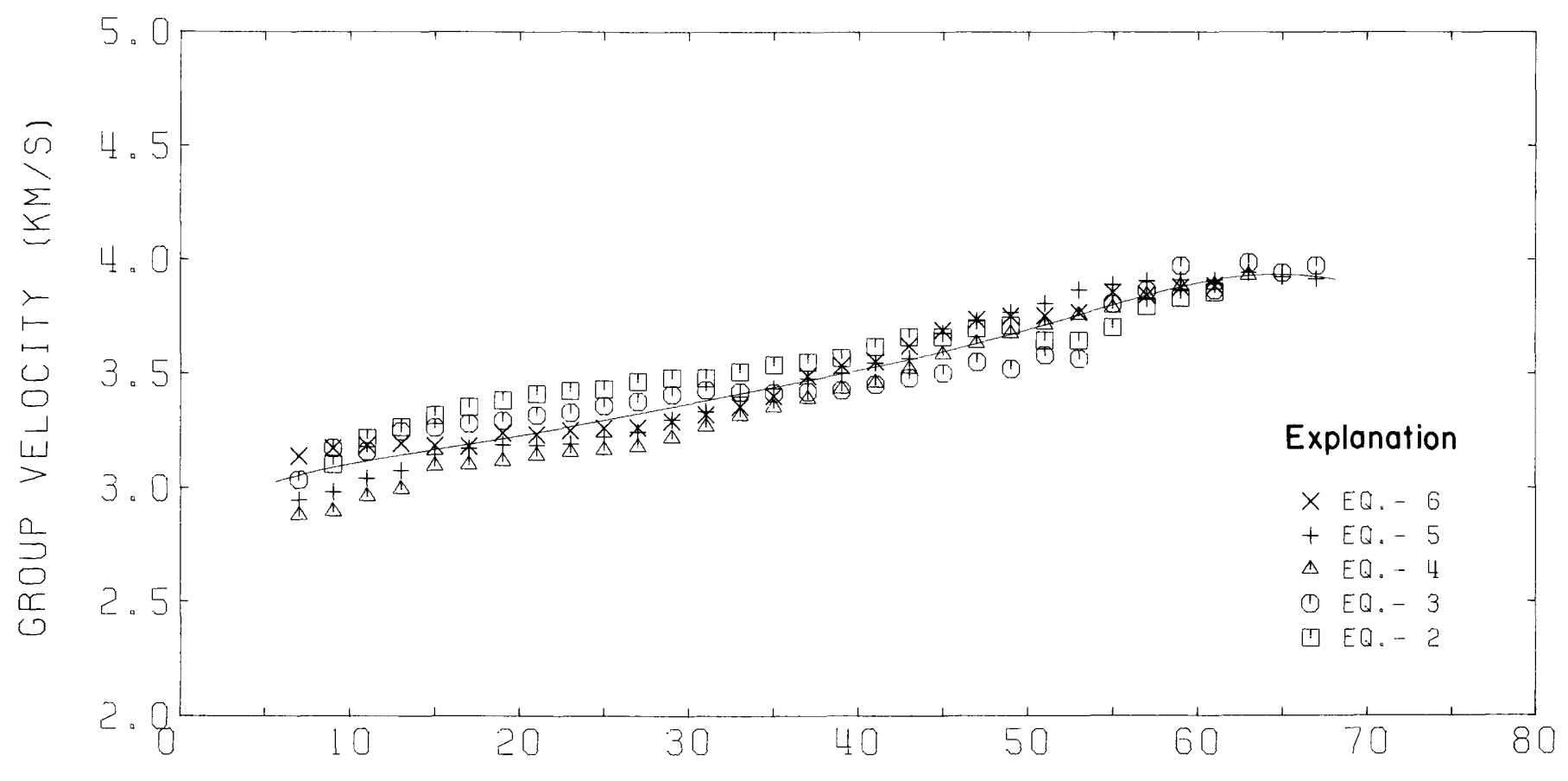

A

PERIOD (S)

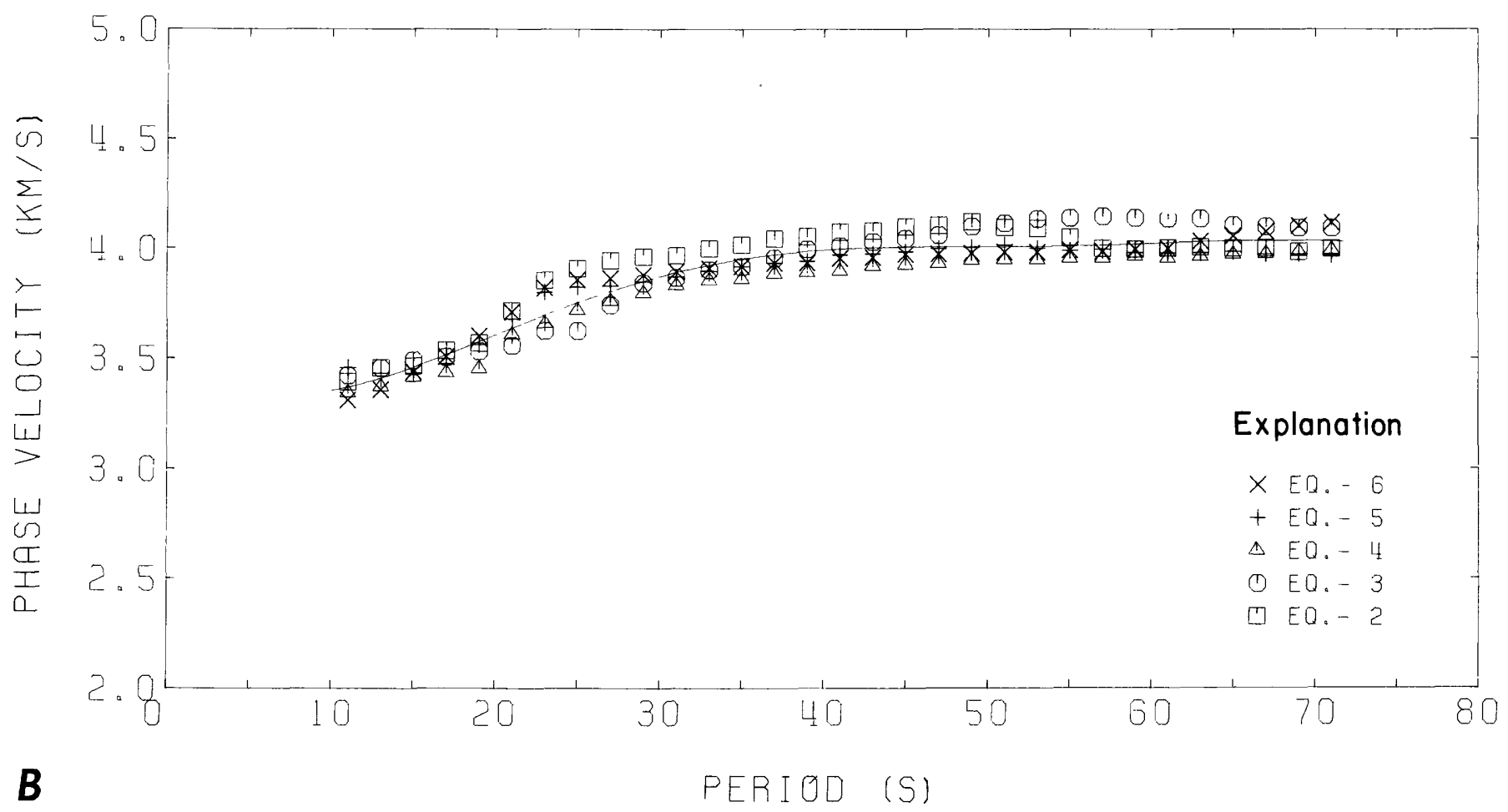

FIGURE 5.--Group-velocity $(A)$ and phase-velocity $(B)$ data gathered in this study. Least-squares fits to observed data are solid lines. 

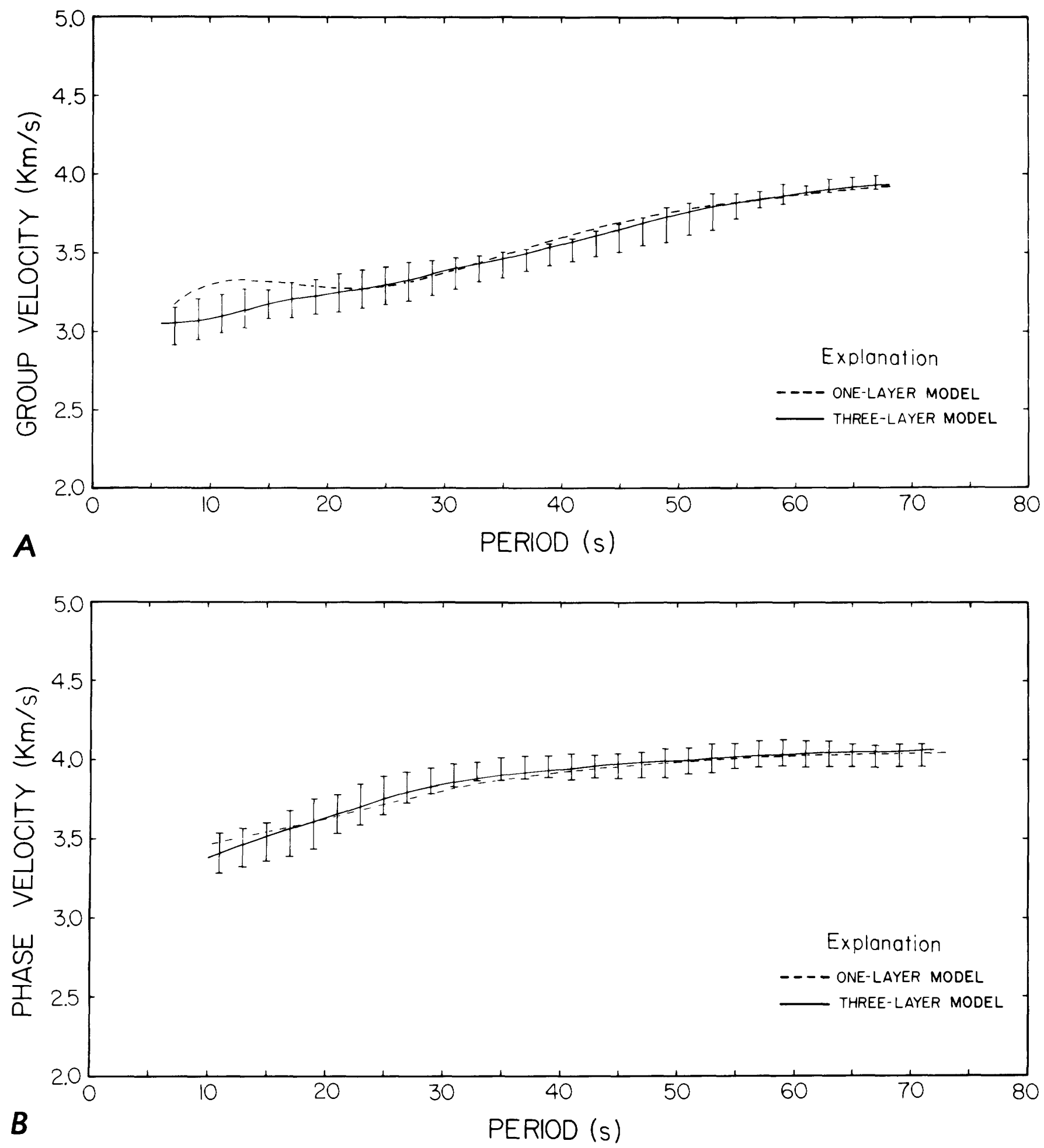

FIGURE 6. - Comparison of observed to theoretical $(A)$ and phase $(B)$ velocities for a one-layer model (dashed lines) and a three-layer model (solid lines) calculated from the one-and three-layer crusted models shown in table. The observed data are plotted as error bars at the 95 percent confidence interval. 
may be accounted for by consideration of geographical locations of the paths transversed with respect to the large positive gravity anomaly associated with the embayment (Ervin and McGinnis, 1975; Cordell, 1977). The path considered in this study passes near the axis of the embayment where gravity modeling (Ervin and McGinnis, 1975) suggests that this layer thickens.

The good agreement between this study, refraction data (McCamy and Meyer, 1966; Stewart, 1968; Warren, 1968), and gravity data (Ervin and McGinnis, 1975; Cordell, 1977) prompted inversion runs in which Poisson's ratios were varied so as to bring the compressional velocities of this study in line with those determined by McCamy and Meyer (1966). The integration of these data to produce a hypothetical cross section of the northern Mississippi Embayment is shown in figure 7. This generalized cross section lies along the gravity profile modeled by Ervin and McGinnis (1975) and includes compressional velocities, shear velocities, densities, and Poisson's ratios for the various layers.

The tectonic implications of these results are important but can be briefly stated. The cross section is highly suggestive of a failed rift zone (aulacogen?). When the rift was active, the Moho could have been the boundary between the highvelocity lower crust and the upper crust. The high-velocity lower crust could have been a rift cushion, possibly represen- ting a mixture of crust and upper mantle material (Cook, 1962). Thus, an upwarp of the mantle could have existed beneath the embayment. However, by the Mesozoic, this rift cushion would have cooled to form a block of high-density material which could have played a role in the isostatic subsidence of the embayment (McGinnis, 1970).

\section{ACKNOWLEDGMENTS}

The authors would like to thank L. W. Braile for his helpful comments and suggestions. Computing facilities were provided by the computation center, University of Texas at El Paso.

Support for this study has been provided by National Aeronautics and Space Administration, contract number NA55-25030, and the Kidd Memorial Seismic Observatory.

\section{REFERENCES CITED}

Backus, G., and Gilbert, F., 1970, Uniqueness in the inversion of inaccurate gross earth data: Philosophical Transactions of the Royal Society (London), ser. A, v. 266, p. 123-192.

Bloch, S., and Hales, A. L., 1968, New techniques for the determination of surface wave phase velocities: Seismological Society of America Bulletin, v. 58, p. 1021-1034.

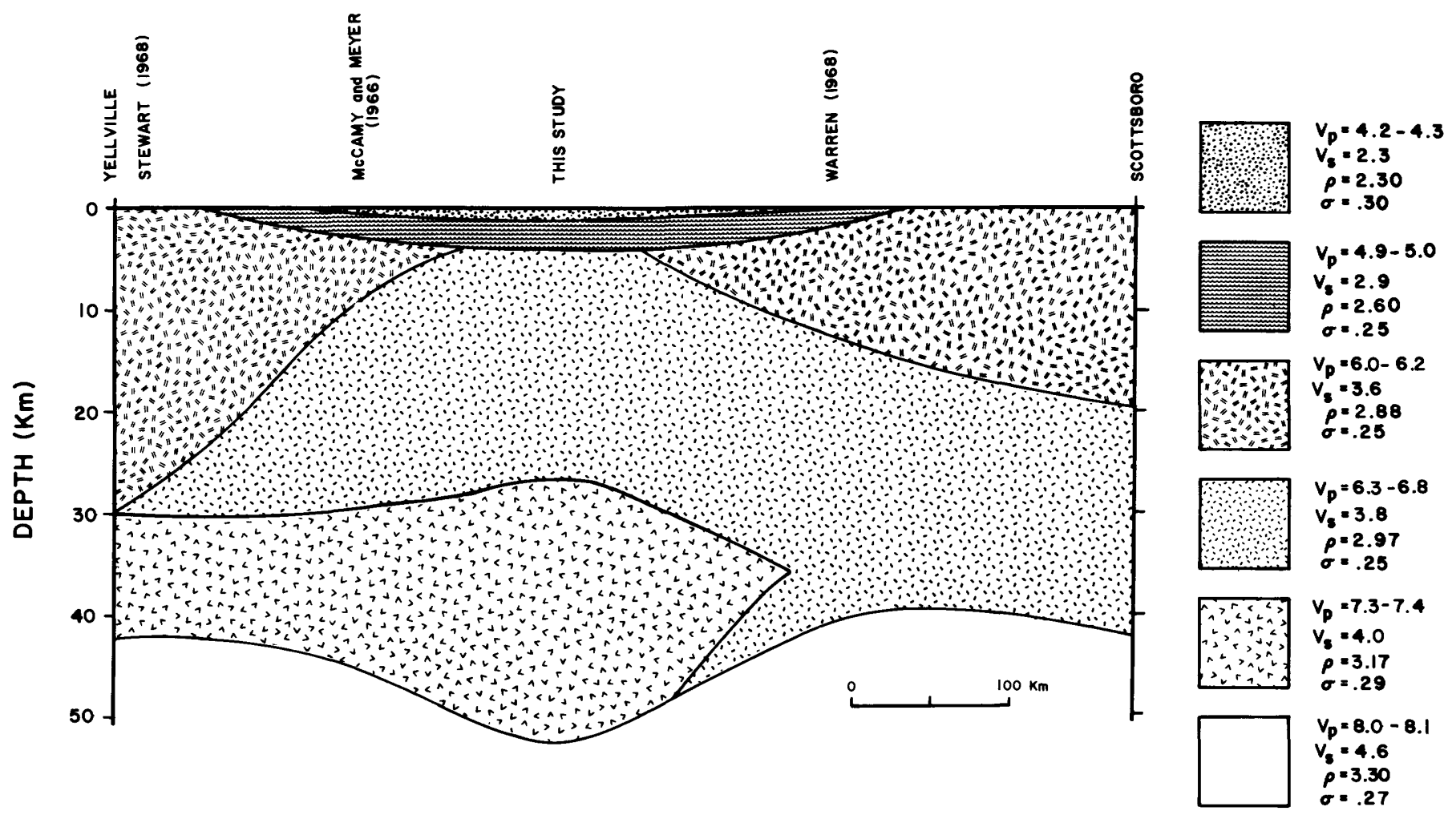

Figure 7.--Generalized crustal cross section along the gravity profile of Ervin and McGinnis (Yellville to Scottsboro, fig. 1). Seismic data used for control are labeled. 
Bond, D.C., and others, 1971, Possible future petroleum potential of region 9, in Cram, I. H., ed., Future petroleum provinces of the United States -- Their geology and potential: American Association of Petroleum Geologists Memoir 15, v. 2, p. 1165-1218.

Braile, L. W., and Keller, G. R., 1975, Fine structure of the crust inferred from linear inversion of Rayleigh-wave dispersion: Seismological Society of America Bulletin, v. 65, p. 71-83

Burke, K., and Dewey, J. F., 1973, Plume-generated triple junctions--Key indicators in applying plate tectonics to old rocks: Journal of Geology, v. 81, p. $406-433$.

Cook, K. L., 1962, The problem of the mantle-crust mix--Lateral inhomogeneity in the uppermost part of the earth's mantle: Advances in Geophysics, v. 9, p. 295-360.

Cordell, Lindrith, 1977, Regional positive gravity anomaly over the Mississippi Embayment: Geophysical Research Letters, v. 4, p. 285-287.

Cushing, E. M., Boswell, E. H., and Hosman, R. L., 1964, General geology of the Mississippi Embayment: U.S. Geological Survey Professional Paper 448-B, 28 p.

Der, Z., Masse, R., and Landisman, M., 1970, Effects of observational errors on the resolution of surface waves at intermediate distances: Journal of Geophysical Research, v. 75, p. 3399-3409.

Dunkin, J. W., 1965, Computation of model solutions in layered, elastic media at high frequencies: Seismological Society of America Bulletin, v. 55 , p. 335-358.

Dziewonski, A. M., and Hales, A. L., 1972, Numerical analysis of dispersed seismic waves: Methods in Computational Physics, v. 11, p. 39-85

Ervin, C. P., and McGinnis, L. D., 1975, Reelfoot rift--Reactivated precursor to the Mississippi Embayment: Geological Society of America Bulletin, v. 86, p. 1287-1295.

Haskell, N. S., 1953, The dispersion of surface waves on multilayered media: Seismological Society of America Bulletin, v. 43, p. 17-34.

Hildenbrand, T. G., Kane, M. F., and Stauder, William, 1978, Magnetic and gravity anomalies in the northern Mississippi Embayment and their spatial relation to seismicity: U.S. Geological Survey Miscellaneous Field Studies Map MF-914.

Hinze, W. J., Braile, L. W., Keller, G. R., and Lidiak, E. G., 1977, A tectonic overview of the central midcontinent: U.S. Nuclear Regulatory Commission NUREG-0382, 106 p.

Hoffman, P., Dewey, J. F., and Burke, K. A. C., 1974, Aulacogens and their genetic relation to geosynclines, with a Proterozoic example from Great Slave Lake, Canada, in Dott, R. H., Jr., and Shaver, R. H., Modern and ancient geosynclinal sedimentation: Society of Economic Paleontologists and Mineralogists Special Publication 19, p. 38-55.

Knopoff, L., Mueller, S., and Pilant, W. L., 1966, Structure of the crust and upper mantle in the Alps from phase velocity of Rayleigh waves: Seismological Society of America Bulletin, v. 56, p. 1009-1044.

Kovach, R. L., 1978, Seismic surface waves and crustal and upper mantle structure: Geophysical and Space Physics Reviews, v. 16, p. 1-13.

Kurita, Tuneto, 1973, Regional variations in the structure of the crust in the United States from P-wave spectra: Seismological Society of America Bulletin, v. 63, p. 1663-1687.
Landisman, M., Dziewonski, A. M., Sato, Y. 1969, Recent improvements in the analysis of surface wave observations: Geophysical Journal of the Royal Astronomical Society, v. 17, p. 369-403.

Long, L. T., and Mather, U. P., 1972, Southern Appalachian crustal structure from the dispersion of Rayleigh waves and refraction data: Earthquake Notes, v. 43 , p. 31-40.

McCamy, K., and Meyer, R. P., 1966, Crustal results of fixed multiple shots in the Mississippi Embayment: in, Steinhart, J. S., and Smith T. J., eds., The earth beneath the continents: American Geophysical Union, Geophysics Monograph 10, p. 370-381.

McEvilly, T. V., 1964, Central United States crust- upper mantle structure from Love and Rayleigh wave phase velocity inversion: Seismological Society of America Bulletin, v. 54, p. 1997-2015.

McGinnis, L. D., 1970, Tectonics and the gravity field in the continental interior: Journal of Geophysical Research, v. 75, p. 317-331.

Mitchell, B. J., Cheng, C. C., and Stauder, William, 1977, A three-dimensional velocity model of the lithosphere beneath the New Madrid seismic zone: Seismological Society of America Bulletin, v. 67, p. 1061-1074.

Mitchell, B. J., and Hashim, B. M., 1977, Seismic velocity determination in the New Madrid seismic zone-A new method using local earthquakes: Seismological Society of America Bulletin, v. 67, p. 413-424.

Nuttli, O. W., 1974, Magnitude-recurrence relation for central Mississippi Valley earthquakes: Seismological Society of America Bulletin, v. 64, p. 1189-1207.

Pilant, W. L., and Knopoff, L., 1964, Observations of multiple seismic events: Seismological Society of America Bulletin, v. 54, p. 19-39.

Press, F., 1956, Determination of crustal structure from phase velocity of Rayleigh waves, pt. 1, Southern California: Geological Society of America Bulletin, v. 67, p. 1647-1658.

Stauder, William, Kramer, M., Fischer, G., Schaefer, S., and Morrissey, S., 1976, Seismic characteristics of southeast Missouri as indicated by a regional telemetered micro-earthquake array: Seismological Society of America Bulletin, v. 66, p. 1953-1964.

Stearns, R. G., and Wilson, C. W., Jr., 1972, Relationship of earthquakes and geology in west Tennessee and adjacent areas: Nashville, Tenn., Vanderbilt University, Report for Tennessee Valley Authority, 344 p.

Steinhart, J. S., and Meyer, R. P., 1961, Explosion studies of continental structure--Arkansas-Missouri: Carnegie Institution of Washington Publication 622, $409 \mathrm{p}$.

Stewart, S. W., 1968, Crustal structure in Missouri by seismic refraction methods: Seismological Society of America Bulletin, v. 58, p. 291-323.

Thompson, W. T., 1950, Transmission of elastic waves through a stratified solid medium: Journal of Applied Physics, v. 21, p. 89-93.

Warren, D. H., 1968, Transcontinental geophysical survey (35-39 N.), seismic refraction profiles of the crust and upper mantle from 87 to 100 W. longi tude: U.S. Geological Survey Miscellaneous Geologic Investigations Map I-534-D, scale 1:1,000,000.

Warren, D. H., Healy, J. H., and Jackson, W. J., 1966, Crustal seismic measurements in southern Mississippi: Journal of Geophysical Research, v. 71, p. 3437-3458. 



\section{Style and Significance of Surface Deformation in the Vicinity of New Madrid, Missouri}

By D. P. RUSS

INVESTIGATIONS OF THE NEW MADRID, MISSOURI, EARTHQUAKE REGION GE OLOGICA L SUR VEY PROFESSIONAL PA PER $1236-\mathrm{H}$ 


\section{CONTENTS}

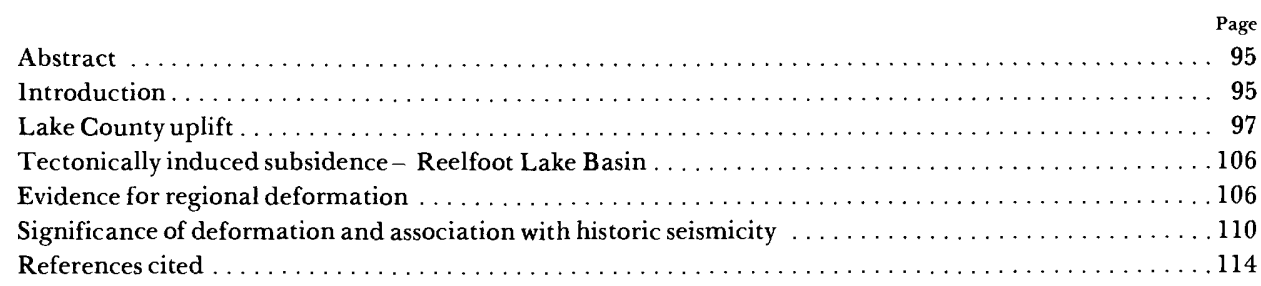

\section{ILLUSTRATIONS}

FIGURE 1. Map of New Madrid region showing location of geomophosic features, towns, and limits of

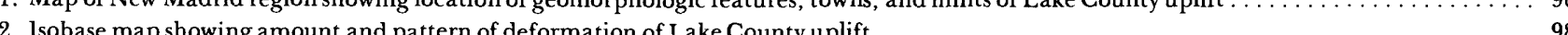

3. Map showing area of Lake County uplift modified by Mississippi River meander belt that has been reworked by river migration from 1820 to

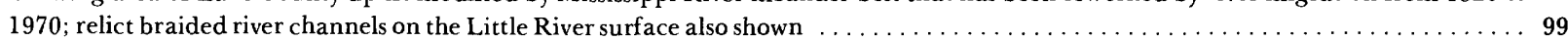

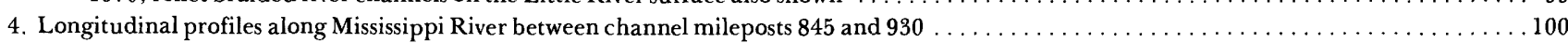

5. Index map showing locations of Cronanville, Lake lsom, and Tiptonville meanders shown in profile on figure $6 \ldots \ldots \ldots \ldots \ldots \ldots$

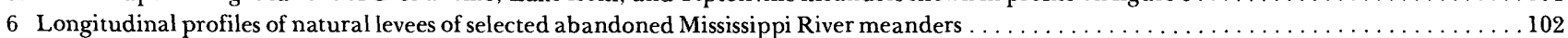

7. Regional map of upper Mississippi Embayment showing location of braided-stream surfaces, Mississippi River meander belt,

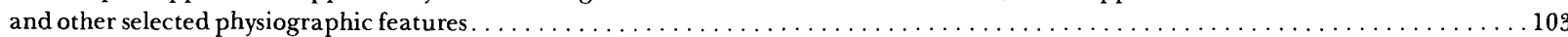

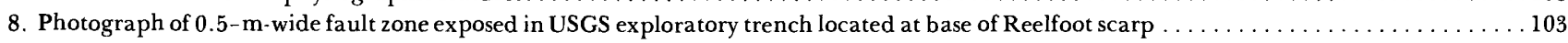

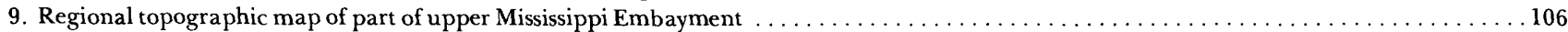

10. Cross section $\mathrm{X} \cdot \mathrm{X}$ ' showing topographic and sedimentologic relationships of Mississippi River meander belt, Little River braided-stream

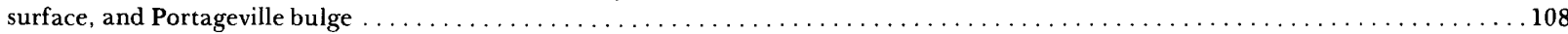

11. Aerial photograph of Portageville, Mo., area showing part of Little River braided-stream surface, Mississippi River meander belt,

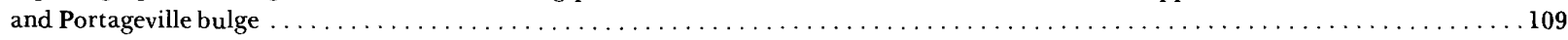

12. Map showing spatial relationship between modern microearthquakes and area of Lake County uplift $\ldots \ldots \ldots \ldots \ldots \ldots \ldots \ldots \ldots \ldots \ldots$

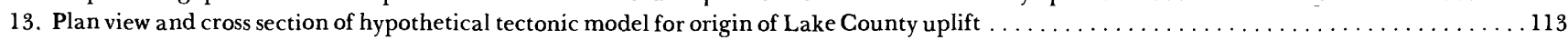

\section{TABLES}

TABLE 1. Comparison of geological and geophysical characteristics of topographic components of the Lake County uplift . 


\title{
STYLE AND SIGNIFICANCE OF SURFACE DEFORMATION IN THE VICINITY OF NEW MADRID, MISSOURI
}

\author{
By David P. Russ
}

\begin{abstract}
A geomorphic analysis of tectonic surface deformation in the vicinity of New Madrid, Mo., shows that the Lake County uplift is an elongate, composite Quaternary structure that is associated with active faults and modern seismicity. The uplift is about $50 \mathrm{~km}$ long and $23 \mathrm{~km}$ wide; it upwarps the Mississippi River valley as much as $10 \mathrm{~m}$ in parts of northwestern Tennessee, southeastern Missouri, and southwestern Kentucky. The composite nature of the uplift is apparently the result of vertical movement along several ancient subsurface structures that are oriented with the modern stress field so as to optimize tectonic movement. The majority of the vertical movement has occurred during earthquakes. The Lake County uplift can be subdivided into several topographic bulges, the most prominent of which are Tiptonville dome, Ridgely Ridge, and the south end of Sikeston Ridge.

Tiptonville dome is an asymmetrical, monoclinal ridge that exhibits the greatest upwarping and the highest topographic relief on the uplift. Its relatively steep eastern flank is bounded by Reelfoot scarp, a complex monoclinal fold that has a zone of normal faults (displacement about $3 \mathrm{~m}$ ) at its base. The zone of faults overlies, and is probably continuous with, Reelfoot fault, a high-angle dip-slip fault that offsets subsurface Paleozoic, Mesozoic, and Tertiary rocks. Seismic-reflection profiles reveal that the rocks beneath Tiptonville dome are upwarped in a manner that is spatially similar to the surface warping. The surface uplift accounts for about onefifth of the total deformation. Most of Tiptonville dome formed between 200 and 2000 years ago. Additional uplifting deformed the northwest and southeast parts of the dome during the 1811-12 New Madrid earthquakes. Ridgely Ridge is a northeast-trending symmetrical bulge underlain by a similarly trending zone of faults. Although investigations are currently incomplete, none of the faults has been found to displace surface sediments. As with the Tiptonville dome, the surface expression of Ridgely Ridge mimics the structural pattern of the subsurface rocks. Much of Ridgely Ridge appears to be older than the Tiptonville dome, but geomorphic evidence suggests that it is younger than 6000 years B.P. The southern end of Sikeston Ridge and adjacent areas of the Mississippi River valley have undergone broad shallow upwarping. The deformation in this area probably occurred during late Wisconsin or early Holocene time.

The Portageville bulge, located $25 \mathrm{~km}$ southwest of New Madrid, is not a product of tectonism, as has been suggested, but was formed by geomorphic and sedimentologic processes. The bulge owes its topographic expression to the buildup of overbank deposits that have spilled from the adjacent ag-
\end{abstract}

grading Mississippi River meander belt onto an old braided-stream surface The anomalously high topography in the uplands along the Mississippi River valley bluffs between Hickman, Ky., and Memphis, Tenn., is the result of an inversion of relief that was caused by differential erosion and is not the product of tectonism.

A strong correlation exists between modern seismicity and the Lake County uplift. Approximately 75 percent of the microearthquakes recorded from July 1974 through June 1978 in the general region between Ridgely, Tenn., and New Madrid, Mo., have occurred in the upwarped area. The patterns of epicenter locations reveal intense activity along the northwestern part of the Tiptonville dome and in the vicinity of Ridgely Ridge. The seismotectonics of the Ridgely area, however, are quite complex. Whereas Ridgely Ridge and underlying near-surface structures have a northeast trend, seismicity seems to have a northwest trend. Geomorphic investigations of surface sediments and structures, as well as historic reports, provide evidence that the New Madrid region has been shaken by at least three earthquakes of $m_{b} \geq 6.2$ in the last 2000 years. A recurrence interval of about 600 years for these large earthquakes is therefore hypothesized.

Fault-plane solutions and structural relationships are used to develop a tectonic model for the formation of the Lake County uplift. The focal mechanisms reveal that the major compressive stress of the modern stress field in the New Madrid region is horizontal and trends approximately eastwest. The mechanisms also show that two of the major linear zones of seismicity in the area are best represented as northeast-trending, en echelon, right-lateral strike-slip faults. Movement on the two faults generates compression in the region between the faults. The compression is translated into vertical strain, resulting in uplift above the area of opposed fault movement This area corresponds precisely with the location of abundant epicenters and with the area of the Lake County uplift.

\section{INTRODUCTION}

The identification and characterization of tectonic surface deformation are often important elements in the establishment of relationships between structural framework and seismicity. This paper describes the occurrence and style of Holocene surface deformation in the general region surrounding New 
Madrid, Mo., and examines the significance of the deformation in terms of the modern stress field, of a tectonic model, and of patterns of historic earthquakes.

New Madrid, Mo., is located on the Mississippi River along the eastern margin of the Mississippi River valley (fig. 1). The valley occupies the western one-half of the upper Mississippi Embayment which, physiographically, is the northern extension of the gulf coastal plain. Popular accounts, largely in private correspondence, citing evidence of surficial deformation in this area were reported as long ago as 1811 and 1812 , during and shortly following the devastating New Madrid earthquake sequence. The first scientific article on the subject (Usher, 1837) investigated uplift along the banks of the Mississippi River in northwestern Tennessee. Of the several studies addressing the problem, almost all have considered Holocene tectonic deformation to be in genetic association

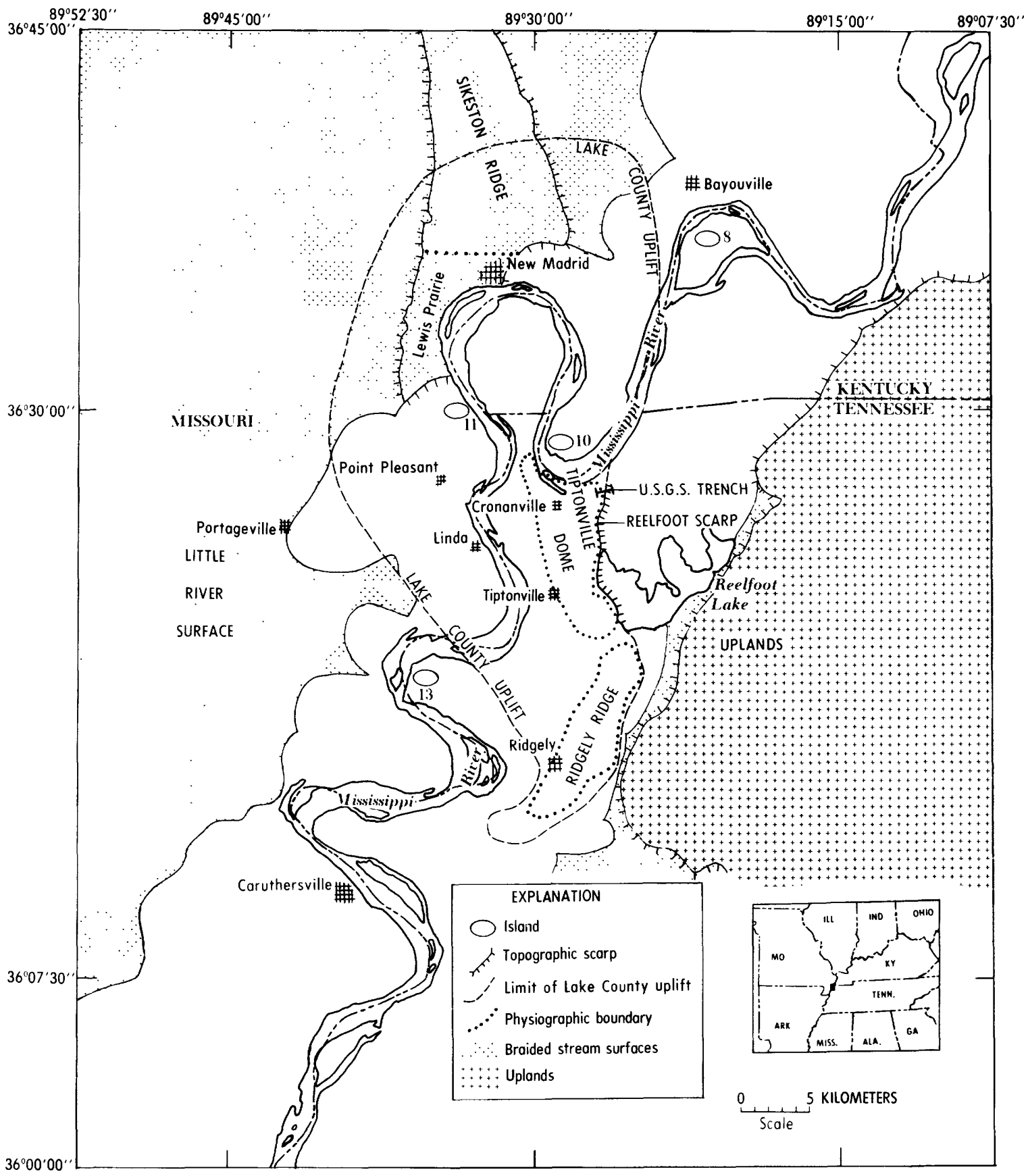

FigUre 1.- Map of New Madrid region showing location of geomorphologic features, towns, and limit of the Lake County uplift. 
with earthquakes; little is known about large-scale aseismic deformation.

The surficial tectonic structures identified in the present investigation and, in part, described in previous reports are low uplifts that have only subtle expression in the landscape and folds and faults exposed in a shallow exploratory trench. Consequently, sensitive geomorphological methods capable of detecting and resolving very minor anomalies and small-scale structural features, as well as standard geologic techniques, have been used in the investigation. With the exception of the Reelfoot Lake area, basins or "sunk lands" are not included in this report. Although many of these features may have been directly or indirectly generated by tectonic processes, they are not tectonic structures by strict definition. The structures that are identified near New Madrid have resulted in interpretations that afford a clearer picture of the temporal and spatial interrelations among surface and subsurface tectonic deformation, the geomorphic evolution of the Mississippi River valley, and seismicity.

\section{LAKE COUNTY UPLIFT}

Lake County uplift is a gently sloping, irregularly shaped topographic bulge whose surface has been upwarped as much as $10 \mathrm{~m}$ above the general level of the Mississippi River valley in parts of northwestern Tennessee, southwestern Kentucky, and southeastern Missouri (figs. 1 and 2). The deformed area has a maximum length (roughly north-south) of about $50 \mathrm{~km}$ and a maximum width of about $23 \mathrm{~km}$. Relief across the surface of the uplift is uneven and asymmetric. The surface is largely dominated by two elongated bulges: one trending north-south and located northeast of Tiptonville, Tenn. (Tiptonville dome), and the other trending northeast in the vicinity of Ridgely, Tenn. (Ridgely Ridge). The former feature is strongly asymmetric, being bordered along its eastern flank by Reelfoot scarp. The Lake County uplift encompasses parts of four different geomorphic surfaces: the modern Mississippi River meander belt (the Mississippi River flows obliquely across the uplift from northeast to southwest) and three separate Mississippi River braided-stream terraces (Little River surface, Sikeston Ridge, and an unnamed surface east of Sikeston Ridge) (fig. 2). Because these surfaces have had different origins, are of different ages, and have experienced varying forms of geomorphic modification subsequent to their formation, determination of the magnitude, character, and timing of the uplift is complex and must be evaluated carefully. For example, lateral planation of the Mississippi River during and following the most active periods of deformation has eroded a considerable amount of the uplift's surface. Figure 3 delineates that part of the uplift which the river modified between 1820 and about 1970 .

Although the presence of an uplift in Lake County, Tenn., has been suggested for more than 150 years, few detailed studies that characterize the deformation have been made.
Usher's (1837) early work inferred an area of uplift east of the Mississippi River from just south of New Madrid to the mouth of the Obion River. He attributed the uplift to deformation produced during the New Madrid earthquakes of 1811-12. McGee (1892) recognized that the deformation extended from Tennessee into southeastern Missouri, and he named it the Lake County uplift. In his classic bulletin on the New Madrid earthquake, Fuller (1912) called the uplift the Tiptonville dome. More recently, in a lengthy study, Stearns (1979) revived the name "Lake County uplift" and subdivided the structure into physiographic bulges or "flood islands," of which the two most prominent are Tiptonville dome and Ridgely Ridge. This report will continue the use of the name "Lake County uplift" because of the precedents in the literature, and because such a broad term permits the individual parts of the uplift to be described with greater flexibility, clarity, and precision.

The investigations listed above, as well as those by Glenn (1933), Fisk (1944), and Krinitzsky (1950), concur with Usher's conclusion that the topographically high area in Lake County, Tenn., is of tectonic origin. Proof, however, of the tectonic origin of the structure and of its time of formation has generally been inconclusive, largely because subsurface drilling, geophysical information, and absolute age data have not been available, and because appropriate studies were simply not undertaken. Evidence gathered during the current investigation, combined with previously published data confirms the tectonic origin of the topographic bulge. This evidence is as follows:

1. Comparison of longitudinal topographic profiles made along the modern natural levee of the Mississippi River (generally the highest elevations on the flood plain) with profiles made on adjacent parts of the Lake County uplift reveals that the surface of the uplift is significantly higher than any naturally occurring landform in the modern meander belt (fig. $4 A$ ). This observation agrees with previously stated qualitative assessments of an anomalously high surface in the area in question (Usher, 1837; McGee, 1892; Fisk, 1944).

2. Interpretation of longitudinal topographic profiles made of abandoned river channels and natural levees situated on the old meander-belt surface of the uplift shows, conclusively, that the original channel and levee gradients have been significantly warped, some to the extent that slopes, representing the original river-flow direction, have been reversed (figs. 5, 6A, 6B, 6C).

3. Transverse topographic profiles drawn across Reelfoot scarp, which forms the boundary of Tiptonville dome on the east side, reveal a predominantly convex slope, consistent with an uplift origin (Russ and others, 1978). If the scarp had formed solely by erosion, a straight or convexconcave slope would have most likely developed. Reelfoot scarp vertically offsets abandoned Mississippi River channels, which once crossed the area. 


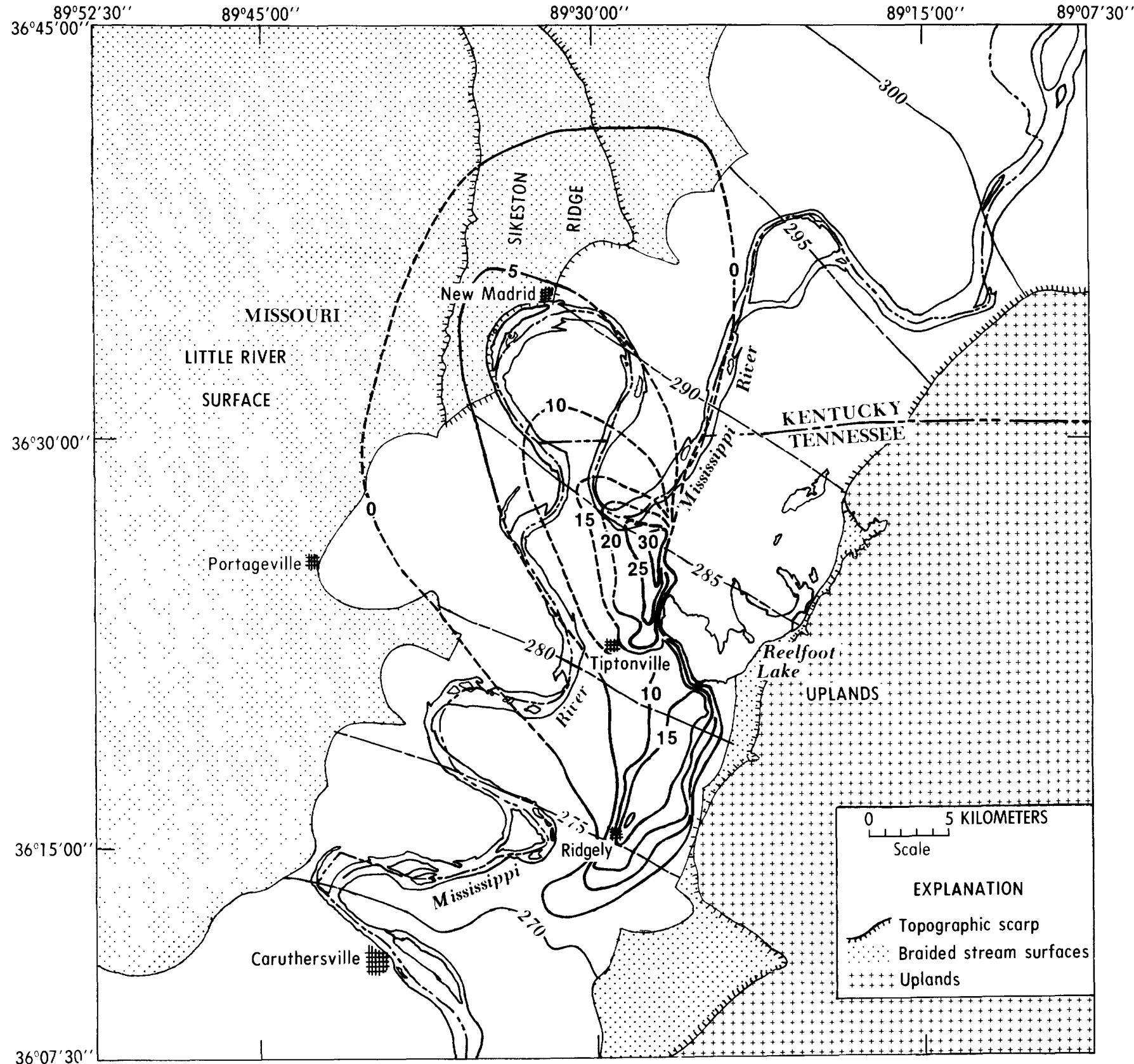

Figure 2. - Isobase map showing amount and pattern of deformation of Lake County uplift. Bold lines indicate contours of equal uplift; solid where deter mined by direct measurement; dashed where calculated by reconstruction process (see text). Thin lines indicate idealized preuplift meander-belt contours; solid where determined by direct measurement; long and short dashed where determined by reconstruction process (see text). Values are in feet; to convert to meters divide values by 3.281 .

4. Structures identified in an exploratory trench excavated across Reelfoot scarp indicate that the majority of the scarp is a monoclinal flexure formed as the adjacent Tiptonville dome was uplifted (Russ and others, 1978; Russ, 1979).

5. Standard Vibroseis reflection profiles, part of an extensive series of lines run in the upper Mississippi Embayment dur- ing the past 4 years (Zoback, 1979; Hamilton and Zoback, 1979; Crone and Brockman, this volume), show that the well-resolved Late Cretaceous-Paleozoic, Paleocene-Late Cretaceous, and Eocene-Paleocene reflectors are arched upwards over an area generally coincident with the Lake County uplift. The subsurface arching reaches a max imum precisely where the surface uplift is greatest: beneath Tiptonville dome and Ridgely Ridge. Beneath the 
uplift, the post-Paleozoic section is generally characterized by intense deformation including local doming, fracturing, and faulting. Apparent igneous intrusive masses have also been identified.

The deformation that generated the Lake County uplift is reflected in the surface topography. Constructional and erosional fluvial processes operating before, during, and after the most intense periods of upwarping, together with the original relief, have resulted in a surface that is uneven and irregular. The uplifted surface is relatively broad and flat north of the
Tennessee State line (lat $36^{\circ} 30^{\prime}$ N.). Most of the relief in this area is erosional in origin. It was produced during the cutting of the Sikeston Ridge scarps by braided streams, during lateral migration of the Mississippi River as it eroded parts of Sikeston Ridge and older uplifted areas within the meander belt, and by incision along local streams in response to man's activities. Positive relief of a nontectonic origin is especially evident within the large meander loop immediately south of New Madrid and on the Little River surface west of the meander belt. The former location has been aggraded by deposition of

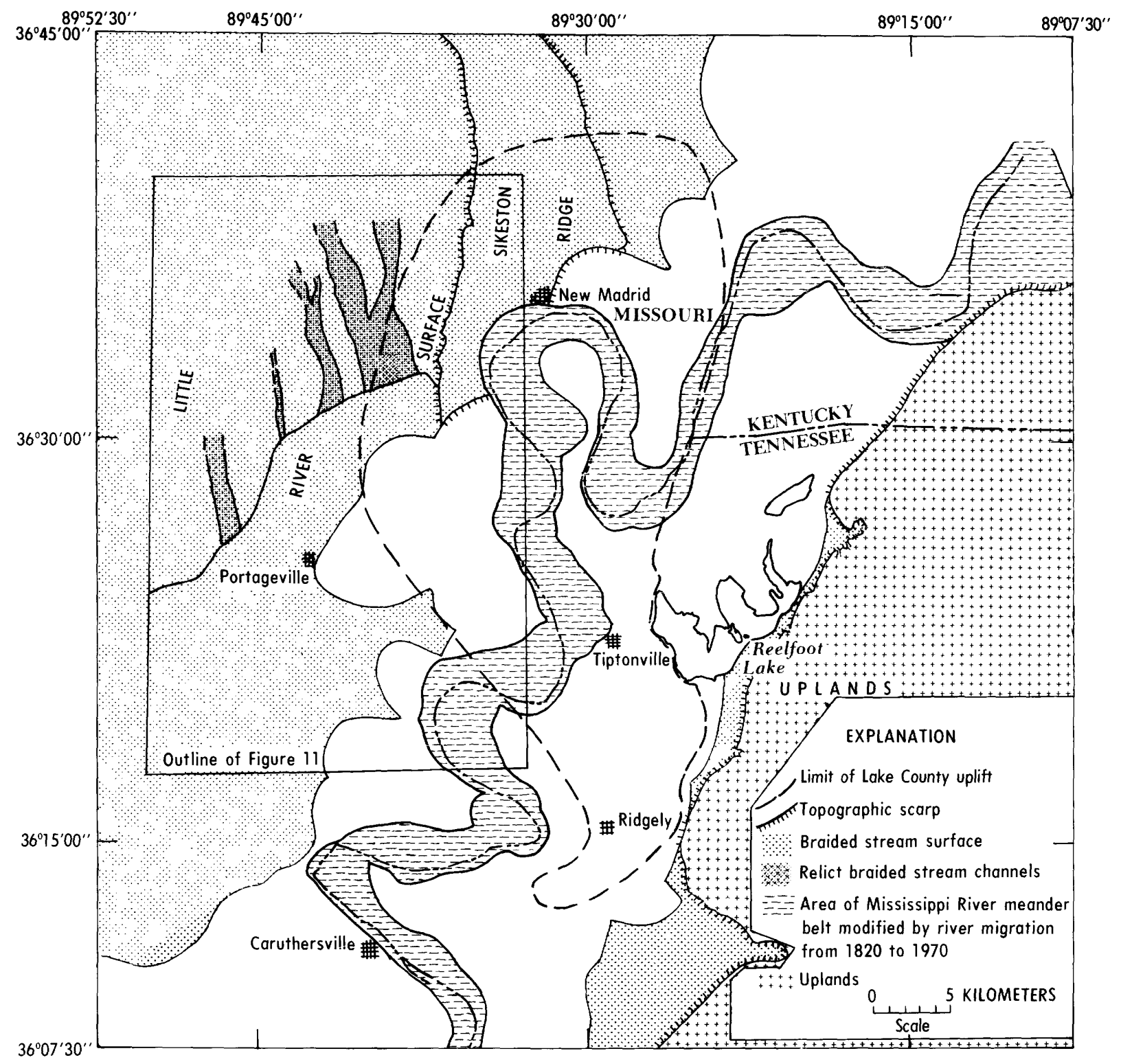

FIGURE 3. - Map showing area of Lake County uplift modified by Mississippi River meander belt that has been reworked by river migration from 1820 to 1970; relict braided river channels on the Little River surface also shown. Data from Fisk, 1944. 
SOUTH
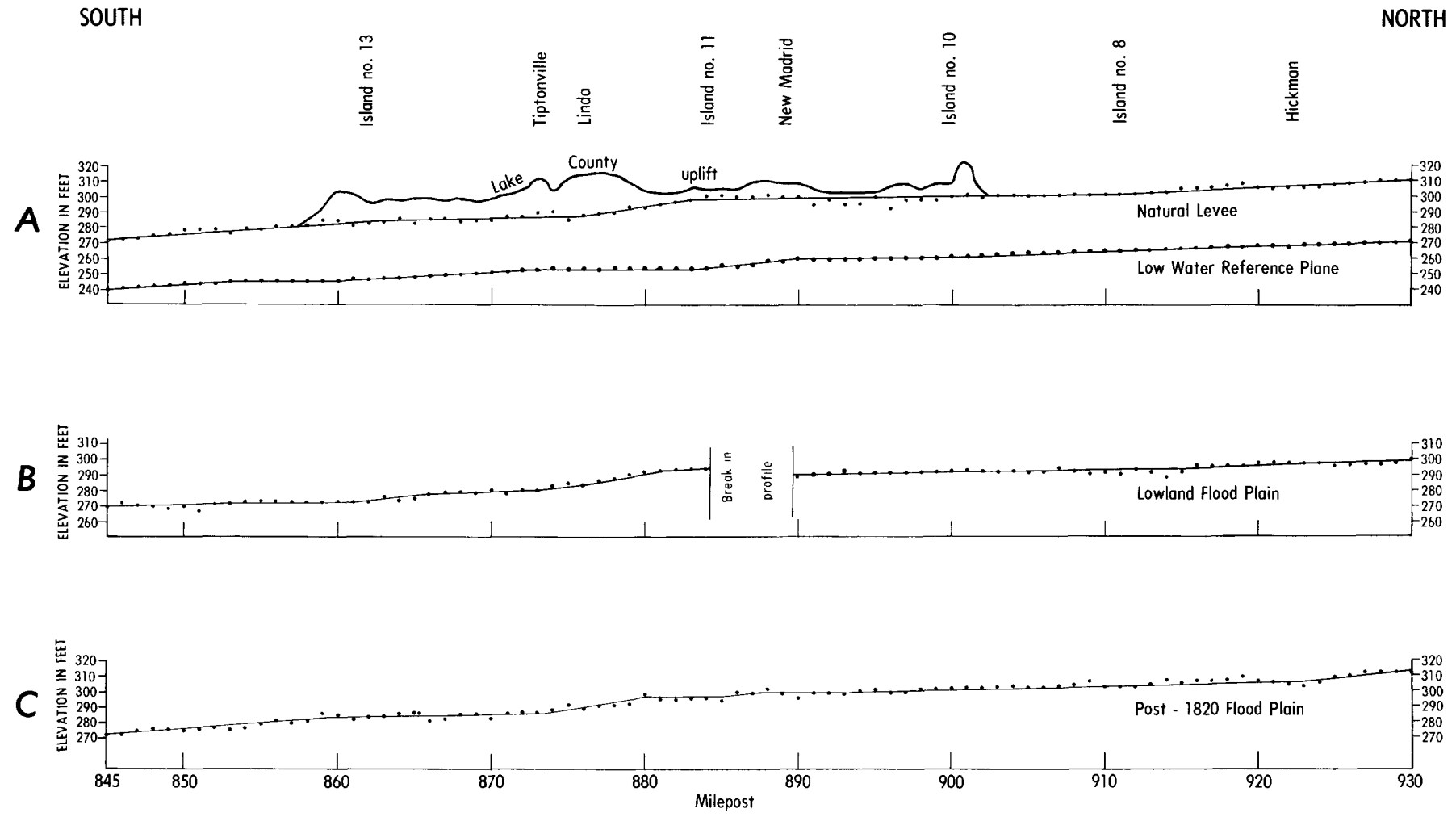

FIGURE 4. - Longitudinal profiles along Mississippi River between channel mileposts 845 and 930 . Mileposts and elevation data from U.S. Geological Survey 7-minute topographic quadrangles; locations plotted on figure 7. Locations of islands shown on figure 1. $A$, natural-levee profile and projected elevations of adjacent Lake County uplift; low water reference plane from data collected in 1962 and adjusted using 20-yr average minimum discharge data from 1954 to 1975 (U.S. Army Corps of Engineers, 1976). B. lowland flood-plain profile. $C$, profile of Mississippi River meander belt that was reworked from 1820 to 1970 .

natural-levee deposits and by the accumulation of more than 3 $\mathrm{m}$ of dune sands. The latter surface has received a sizable amount of natural-levee deposits.

Between the Kentucky-Tennessee State line and the city of Tiptonville, the topography is dominated by Tiptonville dome. This north-south-trending elliptical bulge has the greatest uplift and consequently the highest elevation of any point within the Lake County uplift. Relief between the dome and the adjoining area east of the uplifted area reaches a maximum value of slightly more than $10 \mathrm{~m}$. The east side of Tiptonville dome is bounded by Reelfoot scarp, a folded and faulted structure whose convex slope has a maximum dip of about $3^{\circ}$ (which in an area of very low relief like the Mississippi valley is a prominent slope!). The northwestern physiographic edge of Tiptonville dome (about $0.5 \mathrm{~km}$ west of Cronanville, Tenn.) is marked by a low but conspicuous $1.5-\mathrm{m}$ scarp. The scarp, and the area immediately west of it, was formed by lateral migration of an ancient Mississippi River course and is not directly the product of tectonic deformation. The meandering channel incised the older meander-belt deposits and left behind a well-developed set of point-bar ridges and swales. It is difficult to establish whether the incision occurred prior to, during, or between pulses of uplift on the Tiptonville dome. The incised surface is itself warped upwards about 4.5 $\mathrm{m}$. The southwestern edge of Tiptonville dome is sharply truncated by an abandoned Mississippi River channel, which cut into the edge of the dome as recently as the 1890's.

Between Reelfoot Lake and Ridgely, Tenn., the Lake County uplift narrows. The surface in this area is dominated by northeast-trending Ridgely Ridge. The flanks of the ridge have dips of $1^{\circ}$ or less. Maximum relief on the ridge is about $6.0 \mathrm{~m}$.

In general, the physiographic boundary of the Lake County uplift is only approximately known. This is because as the uplift diminishes outward toward areas of no deformation, the erosional and depositional relief on the various fluviatile surfaces begin to exceed the amount of uplift and thus obscure the zero-uplift boundary. Along most of this boundary the slope is less than $1^{\circ}$. Only along Reelfoot scarp between the Mississippi River and the southern edge of Reelfoot Lake and in an area southwest of Ridgely, Tenn., is the border of the uplift sharp and easily distinguishable.

Determination of the pattern and amounts of absolute uplift for the Lake County uplift is a complex process involving an interrelated study of soils, subsurface boring data, landform morphologies, and the topographic framework of the 
three abandoned braided-stream surfaces and of the modern Mississippi River meander belt. Figure 2 is an isobase map showing the cumulative gross upwarping of Lake County uplift. Because of substantial differences in original elevation and slope, mode and time of formation, and type and amount of post-formation geomorphic modification, each of the four surfaces must be analyzed individually before being combined into a single map displaying total uplift such as is shown in figure 2 . The thin contours shown on figure $2(275,280,285$, 290,295 ,) represent an idealized configuration of the downstream slope of the modern Mississippi River meander belt as it may have existed prior to modification. (The possibility of uplift in the vicinity of the meander belt prior to the meander belt's formation will be discussed shortly.) The position of these contours was ascertained by dividing the area between the nearest undisturbed upstream and downstream contours (270 and $300 \mathrm{ft}$, on fig. 2) into generally equally spaced segments. The idealized flood plain has, therefore, a relatively smooth slope, characteristic of the meander belt as a whole. On the other hand, examination of a detailed topographic map of the area reveals that the present slope of the meander belt is highly uneven and has been significantly disturbed. The bold isobase contours drawn on figure 2 consist of solid lines representing lines of equal uplift determined by direct comparison of the modern deformed topographic surface with the

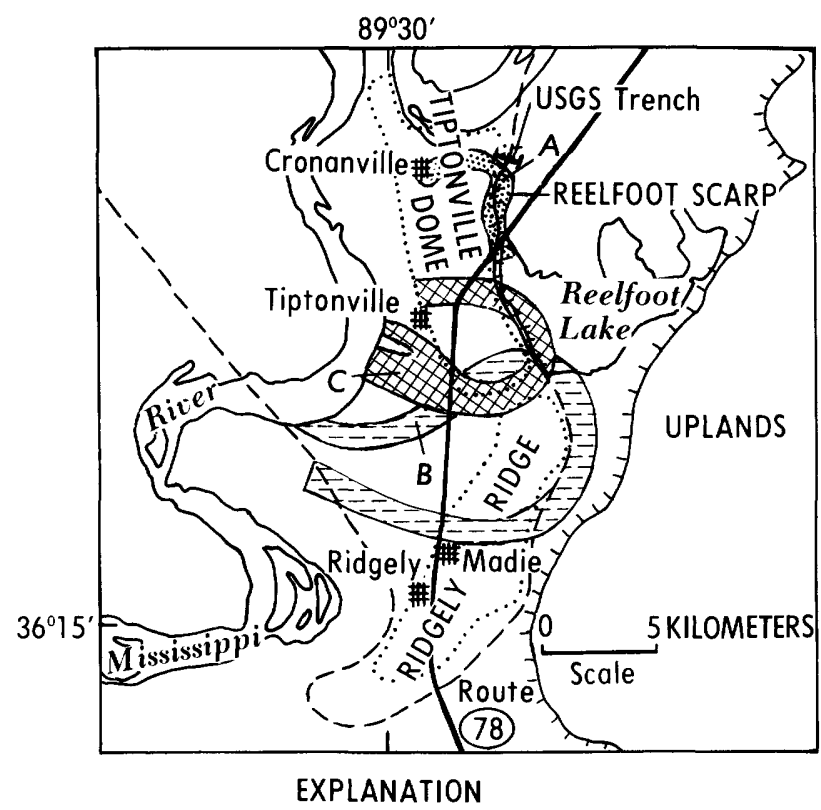
A $)$ Cronanville meander
E Topographic scarp
$B=$ Lake Isom meander
' Limit of Lake County uplift
C Tiptonville meander
$\therefore$ Physiographic boundary

FIGURE 5.- Index map showing locations of Cronanville, Lake lsom, and Tiptonville meanders shown in profile on figure 6 . reconstructed "preuplift" meander-belt surface and of short dashed lines representing lines of equal uplift, determined by comparing the reconstructed "preuplift" meander-belt surface with a deformed surface substantially modified by geomorphic processes. Thus, the positions of the bold dashed contours take into account degradation of the uplifted area by river erosion and aggradation produced by natural levee, backswamp, crevasse, and eolian deposition. Geomorphic modification occurred both concurrently and subsequent to the uplift. When comparing the uplift measured on the modern Mississippi meander belt with that on the braided terraces, it is important to consider that the meander belt is younger than, slopes at a different angle and direction than, and was formed by modification quite different from that on the braided terraces. Careful comparison of the reconstructed meander-belt contours of figure 2 with reconstructed contours on the adjacent braided surfaces (not shown) reveals that throughout most of the region the meander belt has aggraded itself above the level of the older Little River surface and the unnamed braided surface east of Sikeston Ridge by amounts ranging from 0 to 4.5 $\mathrm{m}$ and averaging $3.7 \mathrm{~m}$. In places, the aggradation has dammed off the mouths of small stream valleys tributary to the Mississippi River from the the east. Hatchie River valley, for example, lies 1.2-2.7 $\mathrm{m}$ below the level of the Mississippi meander belt (fig. 7). In the far northeastern part of the area, the meander belt has entrenched the braided terrace by about $1.5 \mathrm{~m}$. Failure to recognize basic sedimentologically produced differences in the elevations of the surfaces under study would result in substantial errors in the amount of calculated uplift.

In the deformed area where the braided-stream terraces flank the northwestern edge of the Mississippi River meander belt, the upwarping has been less than $2 \mathrm{~m}$. Consequently, precise quantitative delineation of the deformation here is difficult to determine. This is especially true on lower terraces that have received natural-levee and backswamp sediments from the Mississippi River since it has occupied its meander belt. Examination of topographic profiles on Sikeston Ridge and the surface immediately east of the ridge constructed parallel to the slope of these braided surfaces shows that the gradients in their southernmost parts flatten significantly. The flattening exceeds that which might reasonably be expected to have been produced by the combination of the normal downstream decrease in flood-plain gradient and the deposition of the natural-levee sediments. On the Lewis Prairie segment of Sikeston Ridge (fig. 1), soil data supplement the topographic evidence that the surface there has received only a minor amount of natural-levee deposits.

Structural deformation of the near-surface sediments of the Lake County uplift (other than the general upwarping shown in fig. 2) has been mapped and studied in a 260-m-long exploratory trench excavated across the northern part of Reelfoot scarp (location shown on fig. 1; discussion in Russ and others, 1978). Sediments in the trench are faulted and folded into a broad, shallow monoclinal arch which mimics 


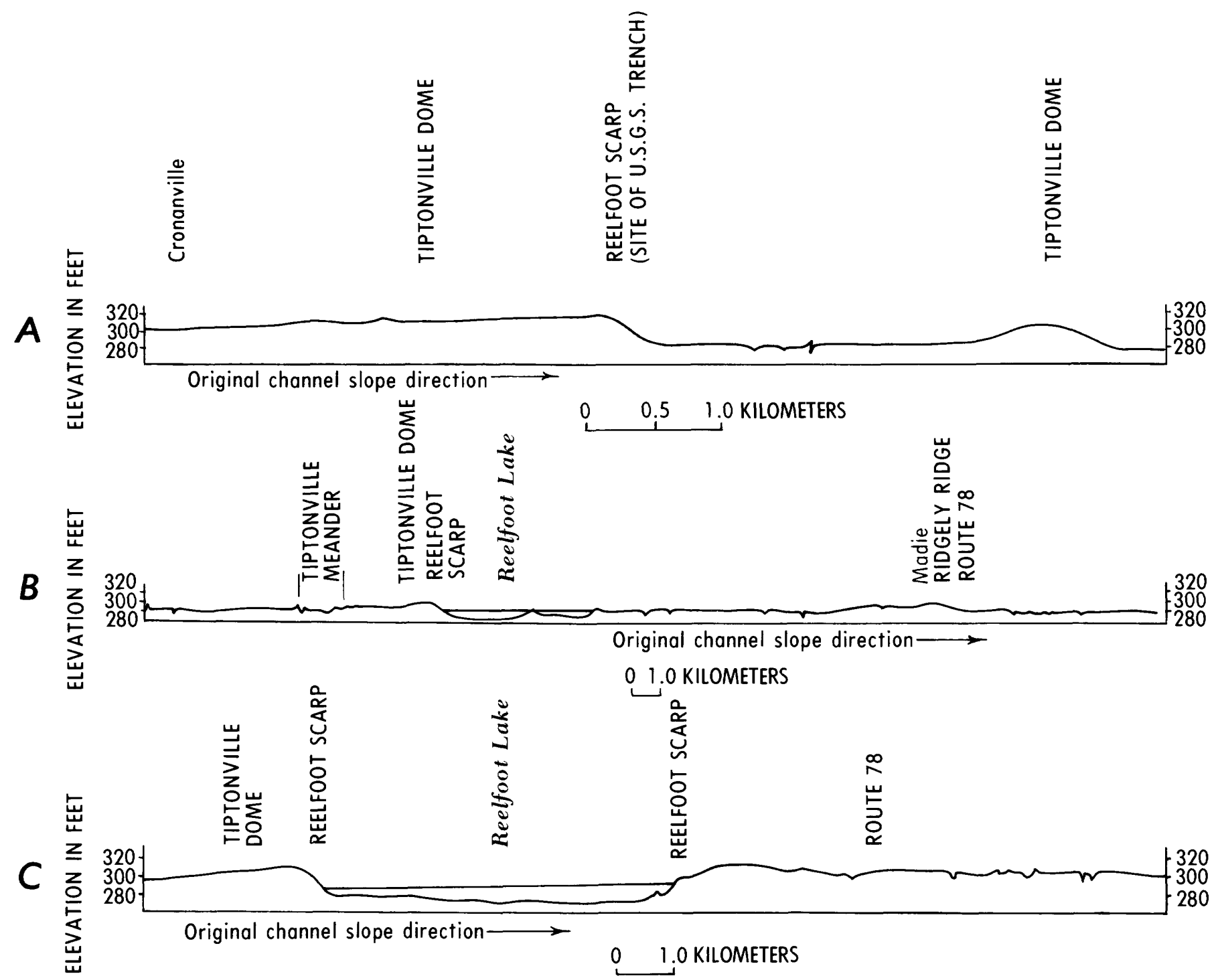

Figure 6.-- Longitudinal profiles of natural levees of selected abandoned Mississippi River meanders. Location of channel meanders shown on figure 5. Elevation data from U.S. Geological Survey 7 -minute topographic quadrangles. $A$, profile of the Cronanville meander. Uplift has deformed channel profile, reversing the slope direction between Cronanville and the site of the USGS trench and offsetting the channel levee at Reelfoot scarp. $B$, profile of the Lake Isom meander. Channel profile has been obviously deformed by uplift of Tiptonville dome and Ridgely Ridge. $C$, profile has been significantly warped by formation of Tiptonville dome, Reelfoot scarp, and Reelfoot Lake. The lake bottom has been downdropped relative to the dome.

the geometry of the subaerial scarp. Small-scale monoclines, anticlines, and synclines were mapped in the trench. The monoclines are located along the upper one-third of the scarp and occur in inward-dipping pairs that form incipient grabens. The monoclines and numerous small faults identified in the upper part of the trench were apparently formed as a result of tensional strain when the sediments of Tiptonville dome were arched upwards. A 0.5-m-wide zone of eastdipping normal faults with an aggregate vertical displacement greater than $3 \mathrm{~m}$ was mapped near the scarp base (fig. 8). The faults overlie, in a parallel fashion, a subsurface fault (named Reelfoot fault) detected by Vibroseis-reflection profiling
(Zoback, 1979), thus suggesting that the surficial faults are tectonic, deep-seated, and related to the uplift that created Tiptonville dome. These faults are the only known examples of surficial Holocene tectonic faulting in the upper Mississippi Embayment. Examination of the reflection profiles also reveals that the Tertiary-Cretaceous and Cretaceous-Paleozoic reflectors located about 450-600 m beneath Reelfoot scarp are upwarped into a broad, east-dipping monocline (Crone and Brockman, this volume). Cumulative structural relief on the monocline and Reelfoot fault amounts to $36-46 \mathrm{~m}$ as compared to about $9 \mathrm{~m}$ on Reelfoot scarp. The spatial coincidence and similar geometries of the surface and subsurface faults 
and folds suggest that they are genetically related. If this is so, then the Holocene deformation on Tiptonville dome may account for about 20 percent of the total vertical deformation to occur in this area since the Late Cretaceous. If, however, because of compaction or other mechanical processes, the deformation associated with any single event is unevenly propagated to the surface, then few conclusions can be made concerning the rate of subsurface deformation in comparison with surface deformation. Geologic investigation of sand-blow dikes and of all the faults exposed in the exploratory trench suggests that the dikes and faults formed simultaneously during strong earthquakes. Evidence indicates, however, that little, if any, movement occurred on the faults during the 1811-12 New Madrid earthquake (Russ, 1979). Nevertheless, popular historic accounts indicate that, during these earthquakes, uplift occurred along the south end of Reelfoot scarp at the southern end of Reelfoot Lake. The uplift caused the damming of Reelfoot River (not shown) and the enlargement of the lake.

Although no evidence is currently available that documents possible faulting of near-surface sediments along Ridgely

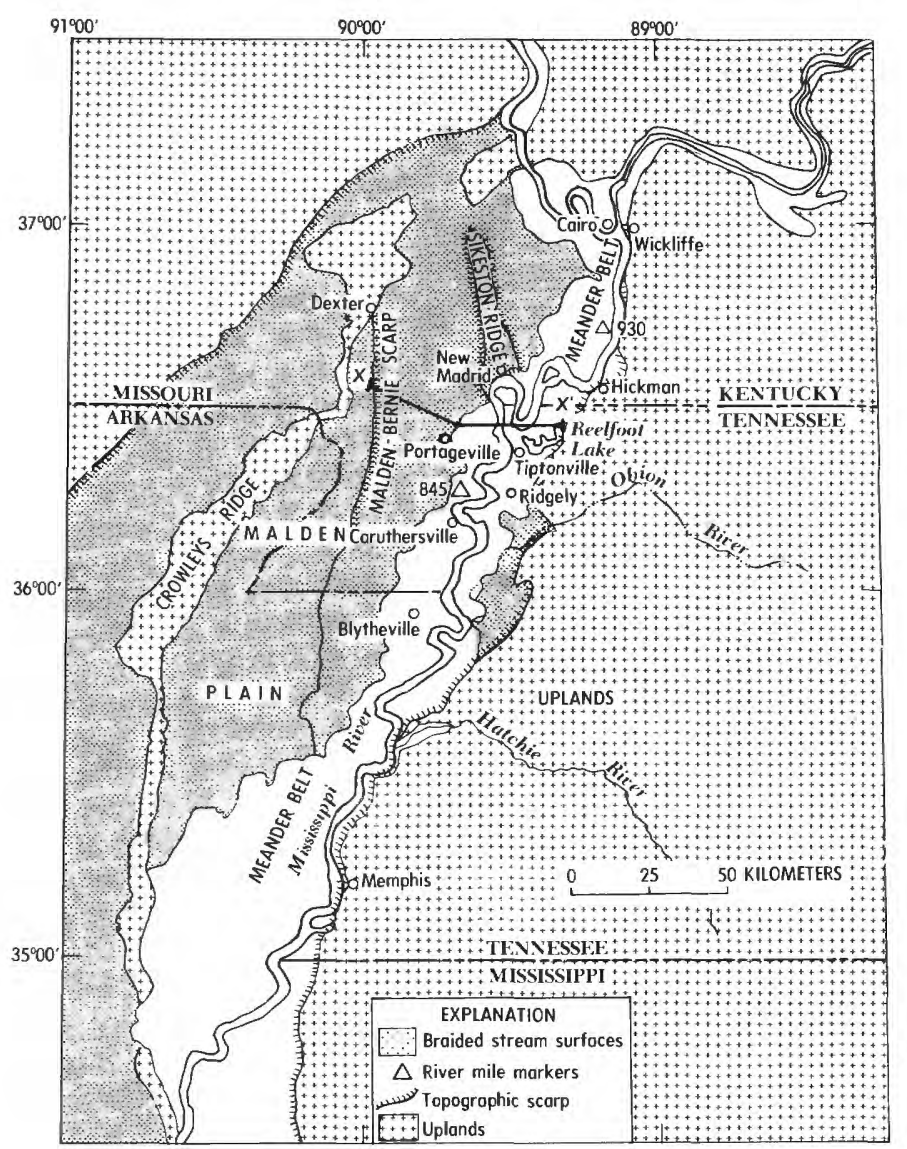

Figure 7.--Regional map of upper Mississippi Embayment showing location of braided-stream surfaces, Mississippi River meander belt, and other selected physiographic features. River mile markers (fig. 4) and cross section $X-X^{\prime}$ (fig. 10) are shown.

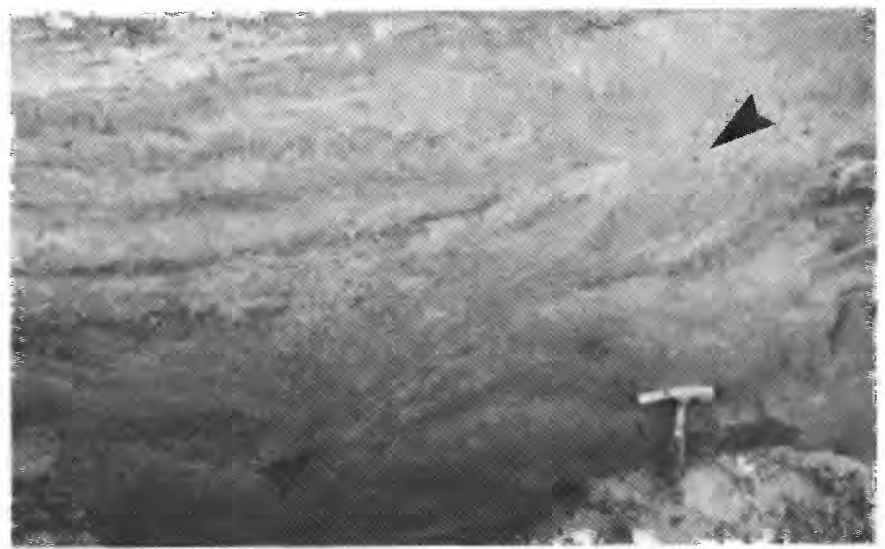

Figure 8.-- Photograph of 0.5-m-wide fault zone (between arrows) exposed in USGS exploratory trench located at base of Reelfoot scarp. Faults displace alluvium in a normal sense and may be continuous with the subsurface Reelfoot fault. Location of trench shown on figure 1.

Ridge, Vibroseis-reflection profiling recently completed in the area (Hamilton and Zoback, 1979) shows subsurface warping related to the surface uplift. The subsurface warping is observed on Eocene, Late Cretaceous, and Paleozoic reflectors, the shallowest of which comes to within about $150 \mathrm{~m}$ of the surface. The reflections show a linear zone of faults that trends northeast, from southeast of Ridgely to the vicinity of Reelfoot Lake (Zoback and others, 1978; Zoback and others, 1980). Close examination of the seismic profiles suggests that all of the major reflectors are upwarped into a broad, shallow, northeast-trending arch. The faults and arch are largely parallel to, and coincident with, the overlying Ridgely Ridge. A part of the arched area extends beyond the limits of the overlying surface uplift into the area southwest of Ridgely, Tenn. It is possible that uplifting has not occurred in this area during the lifetime of the Mississippi River meander belt. The maximum upwarping measured on any structure beneath Ridgely Ridge amounts to about $80 \mathrm{~m}$. This structural relief occurs on the Cottonwood Grove fault, the largest dip-slip fault observed on the seismic profiles in this area (Zoback and others, 1978; Zoback and others, 1980). The maximum surface uplift on Ridgely Ridge is about $6 \mathrm{~m}$.

Although the earliest workers (Usher, 1837; McGee, 1892) believed that the Lake County uplift was formed during the 1811-12 New Madrid earthquakes, a significant amount of evidence suggests that the deformation has occurred in spatially irregular pulses over a period of at least several thousand years. The oldest landform to be affected by the uplift is Sikeston Ridge, an early- Wisconsin braided-stream surface that probably formed more than 30,000 years ago (Saucier, 1974). The Little River surface and the unnamed braided surface to the east of Sikeston Ridge formed during the late Wisconsin and earliest Holocene and may have elements as young as 6000 years old (Saucier, 1974). The key to possible early deformation of these landforms is the elevation of the surface of the abandoned meander, which carved the reentrant into Sikeston Ridge just northeast of New Madrid 
(figs. 1 and 2). Careful examination of the meander's surface reveals that it has not undergone uplift or recently been reworked. Saucier's (1974) studies suggest that the maximum age of the Mississippi River meander-belt deposits is about 6000 years. Geomorphic analysis, using crosscutting relationships, continuity of form, and degree of preservation, indicates that the meander northeast of New Madrid is one of the oldest in the meander belt and that it is quite a bit older than the ancient meanders deformed by Tiptonville dome. The absence of uplift on the old meander surface suggests that Sikeston Ridge, the area now occupied by the old meander, and probably the other braided surfaces were upwarped before the old meander was created. The surfaces, therefore, must have been deformed more than 4000 years ago and possibly several tens of thousands of years ago. Because the New Madrid area has experienced only a minor amount of total uplift, no obvious discordancy exists among the gradients of the three braided-stream surfaces, and thus it is very difficult to determine exactly when the uplift took place. Nevertheless, it is known that the meander northeast of New Madrid was carved considerably before those on the Tiptonville dome, and thus much of the uplift on the braided-stream surfaces antedates that to the south.

It is apparent that because most of the Lake County uplift is situated within the Mississippi River meander belt, the majority of the uplift as expressed at the surface can be no older than the oldest meander-belt sediments - or about 6000 years B.P. If Holocene uplift in this area occurred prior to the formation of the meander belt, when the surface still had a braided pattern, then it is possible that as much as $3 \mathrm{~m}$ of the total uplift now measured across the area may represent deformation inherited from the braided-stream surface. It is probable, however, that when the Mississippi River meander belt formed, the eroding activity of the migrating belt would have altered the gradients of surfaces that had been upwarped more than $3 \mathrm{~m}$. Radiometric C-14 ages obtained on freshwater gastropod and pelecypod shells collected from the alluvium in the USGS exploratory trench on Reelfoot scarp indicate that the Tiptonville dome segment of the meander belt has a maximum age of about 2000 years (Russ, 1979). Thus, most of the deformation on the dome has occurred within the last 2,000 years. Structural evidence observed in the trench indicates that most of the uplift that produced Reelfoot scarp and the adjacent Tiptonville dome occurred during two pre-1800, high-intensity earthquakes (Russ, 1979; Russ and others, 1978). Uplift also took place on parts of the dome during the 1811-12 New Madrid earthquakes (evidence for post-1800-modern - uplift will be discussed in more detail later in this section). It is therefore concluded that Tiptonville dome is the product of at least three distinct pulses of uplift associated with seismicity, as well as an unknown component of aseismic deformation.

The timing of the deformation on Ridgely Ridge is less clear than is that for Tiptonville dome. It appears, however, that the majority of the uplift is out of phase with, and occurred earlier than, the uplift of the dome. Evidence for this conclusion is as follows:

1. Ridgely Ridge has a subdued physiography with no sharp topographic breaks. Reelfoot scarp on the eastern edge of Tiptonville dome, on the other hand, is relatively high and steep. It is possible that subaerial erosion has diminished the relief on a hypothetically higher Ridgely Ridge, whereas the youthful dome topography is quite apparent.

2. As seen on topographic maps and bathymetric charts of Reelfoot Lake, Reelfoot scarp swings to the southeast around the southern shore of Reelfoot Lake and cuts across the projection of the buried faults associated with Ridgely Ridge. Reelfoot scarp, it is to be remembered, overlies Reelfoot fault. Thus one of the major structures of the Tiptonville dome truncates structures related to Ridgely Ridge. No youthful-appearing surficial features have yet been identified that overlie the subsurface structures of Ridgely Ridge as Reelfoot scarp does the Reelfoot fault.

3. Somewhat contradictory soils data support the hypothesis that Ridgely Ridge is older than the Tiptonville dome. As pointed out by Stearns (1979), soils with "B" horizons (particularly " $B$ " horizons with illuviated clay) are much more common on Ridgely Ridge than on Tiptonville dome. The presence of a textural " $B$ " horizon is supposedly indicative of greater age: if the surface upon which the soil has developed has been uplifted high enough, then the soil will not have been affected by recurrent overbank deposits. Soils thus positioned will undergo a more rapid pedogenic development than soils that are frequently inundated and consequently will appear older than flooded soils. Unfortunately, Lake County, Tenn., also has a large area of soils with " $B$ " horizons that are situated on the lowest floodplain levels outside of the area of uplift. Thus, the relationship of soil-horizon development to relative flood-plain evaluation is not altogether clear.

Post-1800 deformation on the Lake County uplift near Portageville and Linda, Mo., is supported by several lines of evidence (fig. 1). Professor J. W. Foster recounts that keelboats used to regularly make passage from the Mississippi River through Portage Bayou (not shown), past the present town of Portageville (fig. 2), and on to St. Francis River (not shown)(Broadhead,1902). Following the 1811-12 earthquakes, however, such passage was no longer possible because the land had apparently been uplifted, thus causing Portage Bayou to shallow. The upwarping most probably occurred in the area southeast of Point Pleasant, Mo., along the northwestern edge of the Tiptonville dome (fig. 1). The uplift may have been related to deformation associated with a waterfall which reportedly formed across the Mississippi River during the earthquake of February 7, 1812 (Penick, 1976). In order to in- 
vestigate the possibility of post-1800 deformation, I have constructed longitudinal profiles along the modern channel of the river using elevations taken from the most recent USGS 7 1/2-minute topographic maps. (Bayouville, Mo.-Ky., Bondurant, Ky.-Mo.-Tenn., Caruthersville, Mo.-Tenn., Hickman, Ky.-Mo.-Tenn., Hubbard Lake, Mo.-Ky.-Tenn., Mooring, Mo.-Tenn., New Madrid, Mo.-Ky., Point Pleasant, Mo.-Tenn.-Ky., Ridgely, Tenn., Stanley, Mo.-Tenn., Tennemo, Tenn.-Mo., Tiptonville, Tenn.-Mo.-Ky., and Wolf Island, Mo.-Ky., figs. $4 A, B, C$ ). They cover the area between Hickman, Ky., and Caruthersville, Mo. (fig. 7). Three separate sections were constructed in order to clarify whether plotted anomalies are the result of geomorphic or tectonic processes and to distinguish deformation that may have occurred during the 1811-12 earthquakes from that which may be even younger. A cursory examination of figure 4 reveals that all of the sections have similar profiles, suggesting that they may be the result of identical processes. Over their total length the profiles are convex upward, a configuration that is commonly associated with areas that have been uplifted. Fisk (1944, pl. 19) noted that this same stretch of valley had a convex-upward profile in 1874. A more comprehensive interpretation of figure 4 follows. The positions of the islands plotted on the cross sections are shown on figure 1. Figure 7 shows Mississippi River mileage markers.

As delineated on figure $4 A$, the levee gradient north of island No. 8 is $0.33 \mathrm{~m} / \mathrm{km}$, a value about average for most of the levee in the upper Mississippi Embayment. South of island No. 8 the levee gradient flattens significantly, to a value of $0.19 \mathrm{~m} / \mathrm{km}$. This degree of flattening is greater than that normally produced as a result of excessive meandering by the Mississippi River in a direction oblique to the regional valley slope. In fact the change in gradient commences on a long reach that parallels the valley slope, a stretch in which flattening would not normally be expected. The flattening is most probably the result of upwarping along the northern edge of Tiptonville dome. In the vicinity of island No. 11, the levee gradient steepens sharply over a distance of $11 \mathrm{~km}$. This stretch is in the approximate location where one of the two waterfalls was reported to have formed during the February 7 , 1812 , earthquake. The faulting(?) that produced the waterfall probably also caused uplift and tilting of the adjacent flood plain. The direction of slope change and the restricted length of the anomaly are consistent with this interpretation. A possible determination of the amount of uplift that occurred in the area can be obtained by drawing a line between "normal" or undeformed segments of the profile in such a way as to approximate a preuplift gradient. Measuring vertically from this line to the high point on the profile near island No. 11 suggests that a maximum of $2 \mathrm{~m}$ of uplift is represented. Between Lin$\mathrm{da}$ and island No. 13, the natural-levee gradient flattens once again. Here the flattening occurs in a zone where the river flows directly down the regional slope. Such a gradient change would not normally be expected to occur as a result of fluvial processes. Minor uplift may have deformed this section of the river course also. Near island No. 13, the river leaves the vicinity of the Lake County uplift, and the natural levee has a slope typical of that of most of the meander belt in the upper embayment.

The lowland flood-plain profile of figure $4 B$ is quite similar to the natural-levee profile. As in figure $4 A$ a steepening of the profile gradient occurs between island No. 11 and Linda. Because the change in slope does not appear to be the product of any recognizable geomorphic or hydrologic process, the lowland flood plain and natural levee are inferred to have been simultaneously upwarped. Response by the two landforms to the deformation has been similar.

It is intriguing that the part of the Mississippi River flood plain which has formed since 1820 (fig. 4C) has a profile that closely matches those of the lowland flood plain and natural levee. It may be that the profiles are similar because the modern Mississippi River has not yet been able to erode away the effects of previous deformation to arrive at a profile of equilibrium. Alternatively, the post- 1820 profile may be convex upward, with a relatively steeply sloping stretch between Tiptonville, Tenn., and island No. 11, because recent, and perhaps even current, deformation has warped the flood-plain surface. Supporting evidence for the latter interpretation is found on the LWRP (low water reference plane) shown in figure $4 A$. The LWRP has an anomalous convex-upward profile. In terms of possible recent movement, this profile is even more significant than the others, because the river's water surface would be expected to adjust itself relatively quickly to any imposed perturbation in its gradient, either by eroding its bed (and thus changing the gradient), its banks (and thus modifying the width-depth ratio), or both in an effort to achieve an equilibrium state. Such hydraulic equilibriums are generally believed to be attained relatively rapidly and certainly before significant modification of flood-plain landforms can be achieved.

Several aspects of the meander pattern of the Mississippi River suggest control by tectonic processes. Between Cairo, Ill., and Hickman, Ky., the river is relatively straight; from Hickman southward to Blytheville, Ark., however, it is highly sinuous (fig. 7). It is quite possible that the river has straightened its course in order to increase the slope in an area (Lake County uplift) where tectonism is reducing it. Since the uplift of the Tiptonville dome, the migration of the large New Madrid meander loop has undoubtedly been inhibited. The river has, in a sense, been wedged between the topographically high Sikeston Ridge to the north and the dome to the south. The position of the Mississippi River course within its meander belt also suggests the possibility of tectonic influence. Between Cairo, Ill., and Hickman, Ky., and, in general, between Blytheville, Ark., and Memphis, Tenn., the river flows along the eastern edge of its meander belt (fig. 7). However, between 
Hickman and Blytheville the river "deflects" out into the western half of its meander belt. The excursion approximately covers the area of the Lake County uplift and is most pronounced at New Madrid. It is conceivable that the river has been deflected to the west as a result of tectonic uplift. Old channel maps indicate that the position of the river in $\mathbf{1 7 6 5}$ was similar to the river's modern location. Thus, any significant tectonic deflection must have occurred before 1765 .

\section{TECTONICALLY INDUCED SUBSIDENCE- REELFOOT LAKE BASIN}

Historic accounts by Lyell (1849), Usher (1837), McGee (1892), and Fuller (1912) reported that Reelfoot Lake, Tenn., formed as a result of subsidence during the 1811-12 New Madrid earthquakes. Located just east of Tiptonville dome, the lake is actually a series of irregularly shaped, interconnected water bodies, most of which occupy parts of abandoned Mississippi River channels (fig. 1). An analysis of bathymetric maps of the lake bottom discloses that much of the lake is less than $2 \mathrm{~m}$ deep, though some spots are as deep as $5 \mathrm{~m}$. The lake bottom (contoured at a $1-\mathrm{ft}$ interval) contains no discontinuities or scarps that cannot be attributed to relict fluviatile morphologies. It is therefore inferred that the lake bottom has not been broken by dip-slip faulting. The bathymetric survey also shows that relict bayous flanked by small levees (which are now beneath the lake's surface) once flowed between deeper pockets of water but were not present within them. The association of the lake with old river channels, the occurrence of water depths in excess of $3 \mathrm{~m}$, particularly in the southern part of the lake, and the presence of discontinuous bayou levees suggest that remnants of old oxbow lakes were present in the area before the time of the New Madrid earthquakes. Drowned cypress trees lying just beneath the modern water surface, partially eroded Indian mounds located on the lake's northwest shore, and submerged sycamore, hackberry, and box elder trees that formerly marked the boundaries of several of the old George Doherty land grants (McGill and Craig, 1933; Tennessee State Library and Archives, 1979) are evidence that the lake was enlarged during the earthquakes. The available evidence is insufficient to prove whether the enlargement was caused by compaction of Holocene channel clays as suggested by Glenn (1933), by tectonic subsidence, or by faulting (?) and uplift which would have dammed off the lake's natural drainage across the abandoned Tiptonville meander (figs. 1 and $6 C$ ). Figure $6 C$ clearly shows the tectonic warping of the Tiptonville meander along Reelfoot scarp at the lake's southern edge. It may be that compaction, subsidence, and upwarping occurred simultaneously during the New Madrid earthquakes to effect the enlargement of the lake. Thus the genesis of Reelfoot Lake basin seems to have been associated with Reelfoot scarp and Tiptonville dome and not with the zone of faults that underlies Ridgely Ridge and that appears to continue into the subsurface beneath the lake.

\section{EVIDENCE FOR REGIONAL DEFORMATION}

Several areas of considerable areal extent adjacent to the Lake County uplift have been suggested as having been upwarped (Glenn, 1906; Fuller, 1912; Wells, 1933; Stearns, 1979). Two such areas on the Little River surface and one within the uplands immediately east of Reelfoot Lake, Tenn., have been investigated. Using the technique of contour averaging, a procedure similar to the topographic-envelope method employed by Stearns (1979), I have generated a contour map (5- $\mathrm{ft}$ interval for the Mississippi River valley and 100-ft for most of the Mississippi Embayment uplands north of Memphis, Tenn.) (fig. 9). Examination of the map reveals that the Little River surface west of the area between New Madrid, Mo., and Caruthersville contains anomalous deflections of topographic contours. Normally, the contours on this surface would be expected to trend in an approximate eastwest direction, perpendicular to the original river gradient. However, the map shows that the contours are deflected strongly to the southeast. Stearns (1979) has suggested that the contour excursions may have been caused by possible gentle warping of the flood plain, and he referred to the anomalous area as the Portageville bulge. More recently, Steven Obermeier (written commun., 1979) has collected more than 600 logs of drill holes on the Little River surface. Analysis of the types, distributions, and thicknesses of sediments recorded in the logs conclusively shows that the anomalous bulging is solely the product of recent overbank sedimentation produced by floodwaters that spilled onto the old braided surface from the modern meander belt. Figure 10 shows, pictorially, the relationships of the Little River surface, the Mississippi River meander belt, and Portageville bulge. As the meander belt aggraded its surface above the level of the adjacent Little River plain, backswamp, natural-levee, and crevasse deposits spread over the surface and began to bury it. In particular, Right Hand Chute of Little River, a major crevasse of the Mississippi River, aggraded its channel and formed prominent natural levees of its own near Portageville (fig. 7). The bulging effect was enhanced at the critical location where aggrading crevasse deposits and levee deposits of an abandoned Mississippi River channel coalesce. The burial of the old braided channels of the Little River surface by the younger overbank sediments is clearly seen in the photograph of figure 11. The location of the photograph and a diagrammatic representation of the morphologies present are shown as an inset in figure 3. Significantly, the places on the photo where the braided pattern is truncated are also the exact locations where the topographic contours begin their deflection. The sum of the evidence, therefore, supports a nontectonic origin for the Portageville bulge.

Fuller (1912) described a topographic bulge on the Little River surface in northeastern Arkansas, which he named the Blytheville dome. He believed that the Blytheville dome was, along with the Tiptonville dome, one of the major tectonic features formed during the New Madrid earthquakes. 


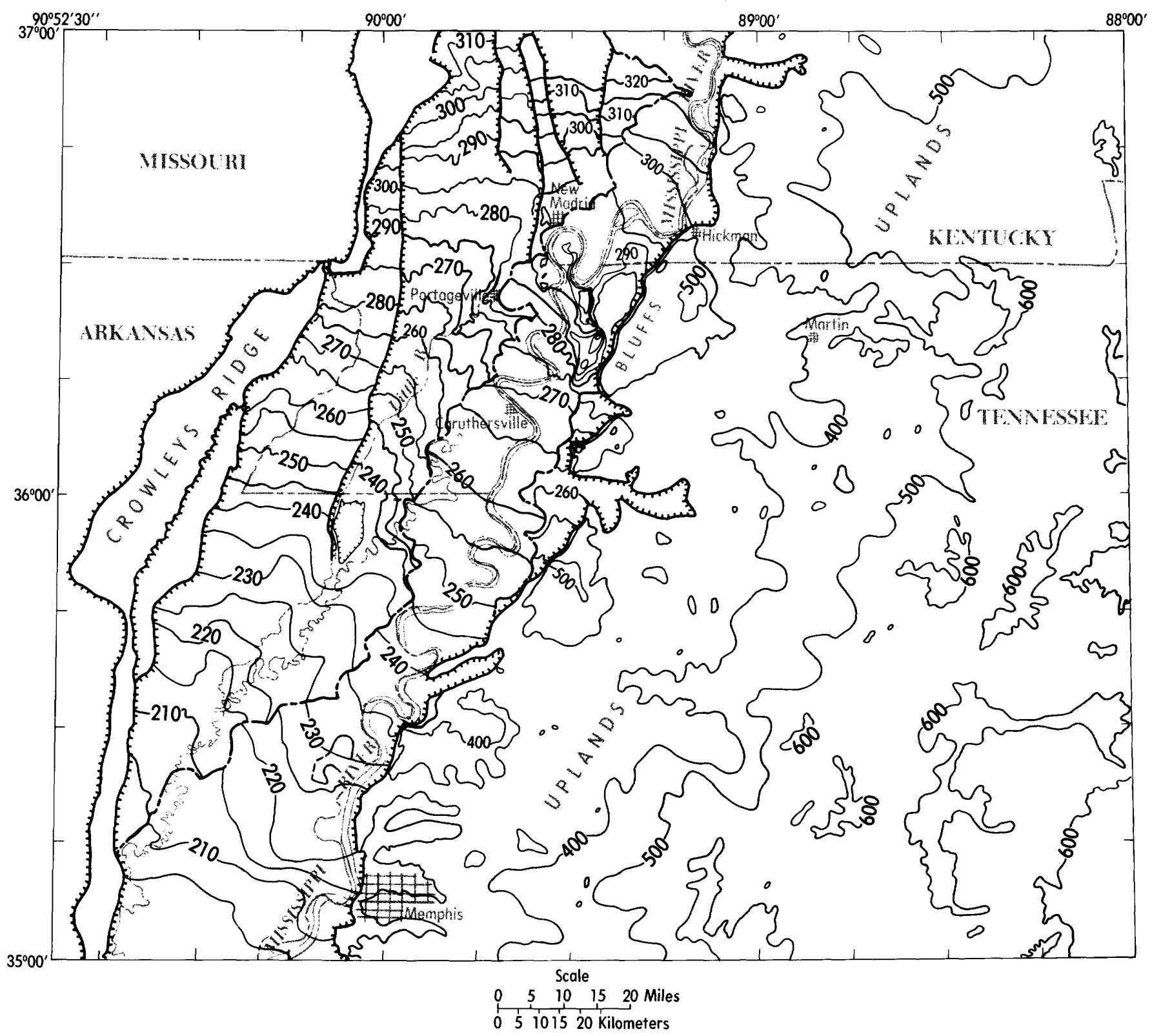

FIGURE 9. - Regional topographic map of part of the upper Mississippi Embayment. The Mississippi River meander belt, uplands, and individual braidedstream surfaces are contoured separately using contour intervals of $5 \mathrm{ft}$ in the Mississippi River valley and $100 \mathrm{ft}$ in the uplands north of Memphis, Tenn. Contours were determined by averaging method. Hachured symbols denote topographic scarps. Bold dashed lines define boundaries of meander belt.

However, detailed analysis of topographic maps and profiles and of subsurface data indicates that, like the Portageville bulge, the Blytheville dome is the product of depositional processes. Blytheville is situated at the junction of the Mississippi River meander belt and Left Hand Chute of Little River, a major Mississippi River crevasse. Natural-levee deposits from both the aggraded crevasse channel and adjacent meander belt combine to form a topographic bulge that has no association with tectonic upwarping.

In studies of ground water and stratigraphic sequences in the uplands east of the Mississippi River valley, Glenn (1906) and Wells (1933) recognized an inconsistency in the regional slope of the land surface. The slope, which has a northwesterly dip, reverses its direction and rises anomalously in the vicinity of the Mississippi River valley bluffs. Projection of the regional slope across the uplands reveals that, near the bluffs, upland elevations should be about $350 \mathrm{ft}$ above mean sea level. In actuality, however, elevations within a zone extending from the line of bluffs southeastwardly about $10-25 \mathrm{~km}$ range from 400 $\mathrm{ft}$ to more than $500 \mathrm{ft}$ above mean sea level (fig. 9). Glenn and Wells attributed the anomalous topographic rise to uplift associated with Mississippi River valley earthquakes. Because an uplift of about $150 \mathrm{ft}$ far exceeded the inferred upwarping that they believed to have been produced during the New 


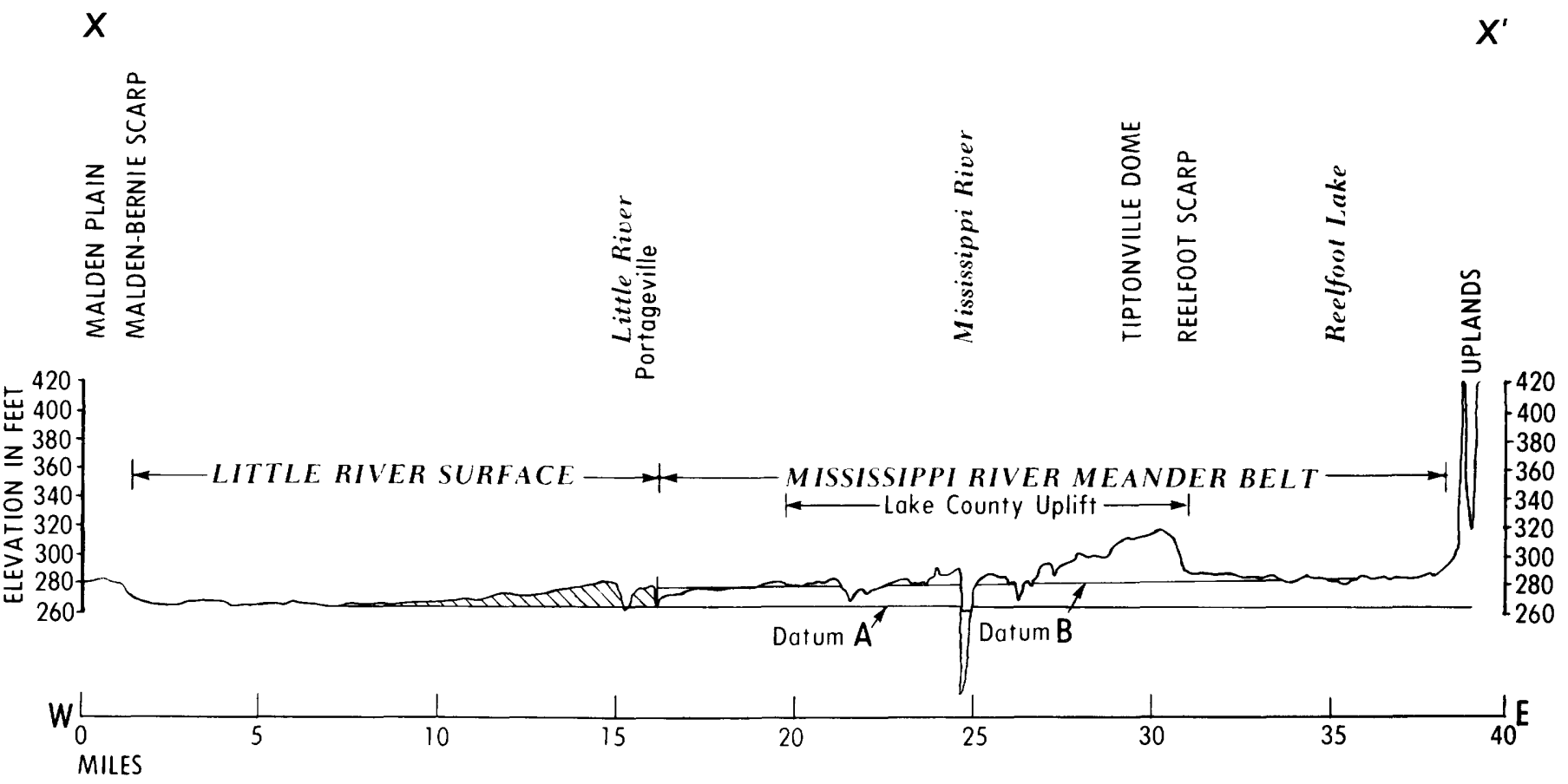

Figure 10. - Cross section $X-X^{\prime}$ showing topographic and sedimentologic relationships of the Mississippi River meander belt, the Little River braidedstream surface, and the Portageville bulge. Location of section shown on figure 7. Datum A represents the original level of the once-continuous composite Little River surface. Datum B represents the level of the aggraded Mississippi River meander belt prior to deformation by the Lake County uplift. Patterned area represents extent and thickness of the Portageville bulge, composed of overbank sediments deposited during and following aggradation of the adjacent meander belt. Vertical exaggeration, 211 times.

Madrid earthquakes in the Mississippi River valley, Glenn and Wells postulated that the rise was the cumulative result of uplift associated with numerous previous earthquakes. Although Glenn's and Well's explanation for the topographic rise sounded plausible, no substantial evidence was advanced to support it. They relied solely on spatial coincidence.

Geomorphic and tectonic investigations of the uplands and nearby Mississippi River strongly indicate that the anomalously high topography in the uplands east of the Mississippi River valley bluffs is the product of differential erosion and eolian deposition unrelated to tectonism. As seen in figure 9, topographically high areas occur all along the bluffs from Memphis, Tenn., northward to Hickman, Ky. The pattern produced by the distribution of these "highs" is neither closely related to any known tectonic feature or mechanism, nor is it spatially coincident with the pattern of historic or modern earthquake epicenters (Nuttli, 1973; Stauder and others, 1979). Field studies and geologic maps (for example, Schreurs and Marcher, 1959) indicate that the topographically high areas are, however, coincident with a belt of Pliocene (?) gravel (Lafayette Gravel of former usage), a widespread fluviatile deposit of variable thickness, and thick sections of Pleistocene loess that overlie the gravel. The gravel deposits also occur along a high stream divide adjacent to the Tennessee River but are not present between this divide and the general area of the
Mississippi River valley bluffs (Hardeman and Miller, 1959). Outcrops in this intervening zone are dominated by unconsolidated Pleistocene, Eocene, and Cretaceous sands (Miller and others, 1966). Reconstruction of the geomorphic history of western Tennessee indicates that immediately prior to deposition of the Pliocene (?) gravel, the relatively low area occupied by the Cenozoic and Mesozoic sands was a broad, regional topographic high. The center of the high ran in a northeasterly direction through Martin, Tenn., and formed the divide between the Mississippi River and Tennessee River drainages. (See, for example, Olive, 1981.) Primary deposition of the gravel probably occurred during Pliocene time (Olive, 1981) and filled the ancestral Mississippi and Tennessee River valleys, which were somewhat wider than their modern counterparts. No significant gravel deposition, however, took place on the northeast-trending divide region.

Figure 11. - Aerial photograph of the Portageville, Mo., area showing part of Little River braided-stream surface, Mississippi River meander belt, and Portageville bulge. Note extremely sharp contact between darktoned braided-stream pattern and light-toned Portageville bulge. Contact occurs where topographic contours are deflected from an east-west to a northwest-southeast trend and represents boundary of significant overbank deposition. Outline of area of photograph shown on figure 3 . 


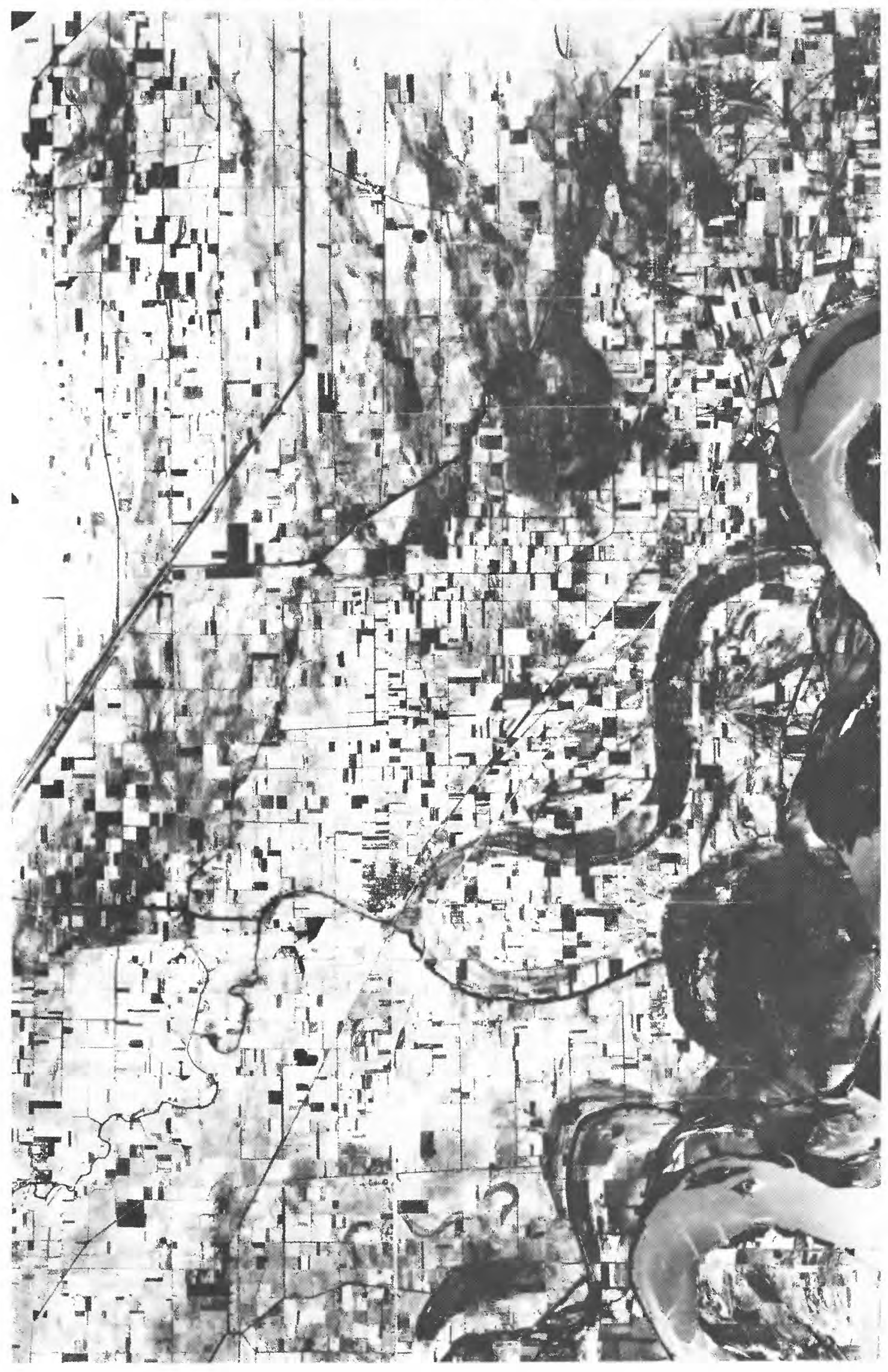


Since the Pliocene, differential erosion has removed the soft unconsolidated sands of the ancient divide area much more easily and rapidly than the gravel deposits. The gravel has acted as an armoring veneer and has undergone insignificant denudation relative to the sandy area. Thus, since the Pliocene, much of western Tennessee has suffered a striking inversion of topographic relief. Formation of the modern Mississippi and Tennessee River valleys has accentuated the inversion. Beds of Pliocene (?) gravel originally deposited in and along topographically low valleys today survive as remnant, narrow bands along high topographic divides. The once broad and high sandy divide has been reduced to a relatively low and rolling plain. Deposition of eolian loess during the Illinoian and Wisconsin Glaciations has resulted in deposits 6-18 $\mathrm{m}$ thick on and immediately east of the Mississippi River valley bluffs (Leighton and Willman, 1950). Though these sediments continue to the east for a considerable distance, their thickness rapidly diminishes away from the bluffs.

All of the available evidence indicates that the topographically high area adjacent to the Mississippi River valley bluffs formed as a compound result of a profound inversion of topographic relief due to differential erosion, followed by the deposition of significant sections of loess. There is no need to invoke a tectonic explanation for the high area, nor is there sufficient evidence to support such an explanation.

\section{SIGNIFICANCE OF DEFORMATION AND ASSOCIATION WITH HISTORIC SEISMICITY}

The evidence gathered in this investigation indicates that the surface- geologic structures in the New Madrid region are complex, composite features that formed during a series of tectonic events. Most of the deformation occurred in association with large-magnitude earthquakes. Correlations show that the geometry and location of the surficial structures are to a large measure controlled by underlying, ancient and deepseated geologic structures. Most of these structures lie along the axial zone of an inferred Precambrian crustal rift interpreted from aeromagnetic and gravity data (Hildenbrand and others, 1977; Hildenbrand and others, this volume).

The complexity of the Lake County uplift is revealed by the presence of several distinct topographic bulges within the greater zone of upwarping. The bulges exhibit differences in relief, geometry, orientation, time of formation and relation to subsurface structures, gravity, and locations of modern seismicity. Yet, as will be discussed later in this section, the component elements of the uplift are probably genetically interrelated by the common modern stress field responsible for their formation. The composite nature of the uplift is clearly seen by comparing the characteristics of Tiptonville dome, Ridgely Ridge, and the warped area located at the southern end of Sikeston Ridge (table 1).
The uplifted area at the southern end of Sikeston Ridge is a broad, gentle flexure, which apparently formed more than 4000 years ago. Recordings by the Saint Louis University seismic network reveal, however, that this region and an adjacent part of the Little River surface are the sites of numerous recent microearthquakes (fig. 12). Thus the stresses that produced the uplift are probably still active today. Farther to the south, Tiptonville dome deforms sediments that were deposited about 2000 years ago (Russ, 1979). The shape and origin of Tiptonville dome are closely associated with Reelfoot fault and the monoclinal fold that underlies Reelfoot scarp. The exploratory trench that was excavated across Reelfoot scarp in the summer of 1977 revealed a close genetic relationship between structures exposed in the trench walls and the morphology of the scarp and adjacent dome (Russ, 1979; Russ and others, 1978). In addition, evidence in the trench indicates that much of Tiptonville dome was formed during at least two earthquakes of intensities $M M \geq$ VIII that occurred before 1800. Other evidence not associated with the trench suggests that some uplift took place along the western edge of the dome during and possibly subsequent to the 1811-12 earthquakes. The New Madrid region therefore has experienced at least three large earthquakes $\left(m_{b} \geq 6.2\right)$ in about the last 2000 years. The seismogenic significance of Reelfoot fault is somewhat problematic. It is possible that the fault may shallow out and die above depths of about 5-15 km, which are the depths generally calculated for earthquake hypocenters in the New Madrid region (Stauder and others, 1979). Plots of recent microearthquake epicenters determined by the Saint Louis University network show that most of Tiptonville dome, including the Reelfoot fault area, has been relatively quiet seismically at least for the past 5 years (Stauder and others, 1979). Only along the westernmost part of the dome, near the Mississippi River, are modern earthquakes abundant. And as was previously pointed out, the Mississippi River profile at this position is convex, possibly as a result of minor active upwarping.

In contrast to the general seismic quiescence of much of Tiptonville dome, Ridgely Ridge is currently the locus of the most abundant seismic activity in the entire New Madrid region. The great amount of seismicity is somewhat perplexing because most of the deformation of the ridge appears to predate the creation of Tiptonville dome. And whereas parts of Tiptonville dome were uplifted during the 1811-12 earthquakes, there is no evidence to suggest that deformation occurred along Ridgely Ridge at that time. The seismotectonic framework of the Ridgely Ridge area has not yet been resolved satisfactorily. The ridge coincides spatially with an underlying zone of faults and a well-defined gravity anomaly. All of these features trend northeast-southwest and may possibly be genetically related to the geologic structures associated with a well-defined zone of earthquake epicenters trending southwest from Caruthersville for about $100 \mathrm{~km}$. Conversely, some recent epicentral plots in the Ridgely area (Stauder and others, 
TABLE 1.-- Comparison of geological and geophysical characteristics of topographic components of the Lake County uplift

\begin{tabular}{|c|c|c|c|c|c|c|c|}
\hline $\begin{array}{l}\text { Topographic } \\
\text { component }\end{array}$ & $\begin{array}{l}\text { Relative } \\
\text { topographic } \\
\text { relief }\end{array}$ & $\begin{array}{l}\text { Cross- } \\
\text { sectional } \\
\text { geometry }\end{array}$ & $\begin{array}{l}\text { Drientation } \\
\text { of axis }\end{array}$ & $\begin{array}{l}\text { Time of } \\
\text { formation }\end{array}$ & Surface faults & $\begin{array}{l}\text { Subsurface } \\
\text { faults }\end{array}$ & $\begin{array}{l}\text { Correlations of } \\
\text { gravity with topo- } \\
\text { graphic component } \\
\text { (from Hildenbrand } \\
\text { and others, 1979; } \\
\text { and Stearns, 1979) }\end{array}$ \\
\hline $\begin{array}{l}\text { Southern end } \\
\text { of Sikeston } \\
\text { Ridge. }\end{array}$ & Low---- & $\begin{array}{l}\text { Shallow, broad } \\
\text { arch. }\end{array}$ & $\begin{array}{l}\text { Generally } \\
\text { north- } \\
\text { northwest. }\end{array}$ & $\begin{array}{l}\text { Late Pleistocene } \\
\text { to about } 6000 \\
\text { yr B.P. }\end{array}$ & None known---- & $\begin{array}{l}\text { Single identified } \\
\text { dip-slip } \\
\text { fault. }\end{array}$ & No correlation. \\
\hline Tiptonville dome & High--- & $\begin{array}{l}\text { Strongly asymetric } \\
\text { arch; relatively } \\
\text { steeply dipping } \\
\text { limb on the east: } \\
\text { moderate width. }\end{array}$ & North------ & $\begin{array}{l}\text { Generally less than } \\
2000 \text { yr B.P. }\end{array}$ & $\begin{array}{l}3+\mathrm{m} \\
\text { of normal } \\
\text { offset along } \\
\text { eastern edge } \\
\text { of dome; } \\
\text { believed con- } \\
\text { tinuous with } \\
\text { subsurface of }- \\
\text { set of Reelfoot } \\
\text { fault. }\end{array}$ & $\begin{array}{l}\text { Several } \\
\text { high-angle faults } \\
\text { that have general } \\
\text { strike parallel to } \\
\text { orientation of } \\
\text { axis. }\end{array}$ & $\begin{array}{l}\text { Moderate corre- } \\
\text { lation with } \\
\text { gravity high. }\end{array}$ \\
\hline Ridgely Ridge & Moderate & $\begin{array}{l}\text { Generally symmetric } \\
\text { arch; relatively } \\
\text { narrow width. }\end{array}$ & Northeast-- & $\begin{array}{l}\text { Generally less than } \\
6000 \text { yr B.P. }\end{array}$ & None known---- & $\begin{array}{l}\text { Parallel and coinci- } \\
\text { dent with a } \\
\text { northeast-trending } \\
\text { zone of faults. }\end{array}$ & $\begin{array}{l}\text { Strong correlation } \\
\text { with northeast- } \\
\text { trending linear } \\
\text { gravity high. }\end{array}$ \\
\hline
\end{tabular}

1979; Nicholson and Singh, 1979; O'Connell and others, this volume; R. M. Hamilton, written commun., 1979) reveal the presence of a northwest-trending zone of seismic events. The relationship of this zone to the northeast-trending faults and to the overall occurrence of seismicity in the Ridgely area is currently unknown.

In summary, it is worthwhile emphasizing two points:

1. A very close spatial relationship exists between modern seismicity and the geographic extent of tectonic surface deformation (fig. 12). Approximately 75 percent of the microearthquakes recorded in the New Madrid region between 1974 and 1978 have occurred within the area of the Lake County uplift. The northwestern part of Tiptonville dome that was uplifted during the 1811-12 earthquakes is still active today, whereas the eastern part of the dome along Reelfoot fault (including the southern part that is believed to have been uplifted in 1811-12) is not an area of abundant modern seismicity. Though there is no evidence of deformation on Ridgely Ridge in 1811-12, that area is currently seismically active.

2. At least three earthquakes of intensity strong enough to cause tectonic faulting, folding, and liquefaction of surface sediments have occurred in the New Madrid region in the last 2000 years. A recurrence rate of about 600 years for earthquakes of $\mathrm{mb}_{\mathrm{b}} \geq 6.2$ (the approximate threshold of liquefaction in the New Madrid region) is therefore indicated. Inasmuch as this rate is similar to the recurrence interval for earthquakes of $\mathrm{m}_{\mathrm{b}} \geq 7$ as determined from earthquake intensity data (Nuttli, 1974), it is suggested that the faulting, folding, and liquefaction are related to earthquakes of $\mathrm{mb}_{\mathrm{b}} \geq 7$ that recur about every 600 years.

Until recently, few data have been available to help explain the cause of the Lake County uplift. Even with the recently ob- tained geomorphic and seismic evidence, the origin of the uplift remains somewhat problematic. After considering several causes, Fuller (1912) concluded that the most probable explanation for the upwarping involved subsidence of the deep center of the Mississippi Embayment. He thought that such subsidence might produce a depression that would cause the overlying unconsolidated sediments to slide or slump toward the embayment center and that would produce, in the process, a corrugated surface. The high parts of the surface would have the configuration of domes. Recent subsurface drilling and seismic evidence, however, do not support this hypothesis. Offsets of the base of the Mesozoic section of sufficient magnitude to produce the required depression have not been identified. In addition, the deep center of the embayment is located beneath the Lake County uplift and not farther to the west, in southeastern Missouri, as Fuller suspected.

Detailed examination of the seismicity and the structures beneath the uplift strongly suggests that the uplift is related to tectonic processes localized on the ancient subsurface structures. Such processes appear to be strongly dependent upon the orientation and magnitude of the modern stress field. Herrmann and Canas (1978) and Herrmann (1979) have determined composite and single-event fault-plane solutions, respectively, for earthquakes in the New Madrid region. Their results indicate that the maximum regional compressive stress is horizontal and trends in an approximate east- west direction. The mechanisms they calculated also show that major zones of seismicity extending in a linear trend southwest from Caruthersville and northeast from Lilbourn, Mo., are best modeled as continuous faults having right-lateral strike-slip displacement. Focal-plane mechanisms for the numerous earthquakes that have occurred between Ridgely, Tenn., and Lilbourn, Mo. (fig. 12), have been determined by Herrmann and Canas (1978), Herrmann (1979), O'Connell and others 
This paper describes the significant characteristics and areal extent of the uplift as they are expressed on the Paleozoic bedrock. In the study area (fig. 1), two-way travel times to the reflection that represents the top of the Paleozoic rocks were read from the profiles and gridded to produce an evenly spaced network of data points. Hand- and computer-contoured plots of the gridded data illustrate the complex nature of the Paleozoic bedrock surface. Trend-surface analyses of the gridded data define the regional extent of the warping and emphasize anomalously high and low areas. The amount of relief on the uplift has been estimated from reconstructed contours.

The purpose of this study was to identify the regional structural trends in the area and to evaluate them in terms of the overall pattern of seismicity. Detailed analyses of the reflection profiles show a variety of complex faulted features and bodies of intrusive igneous rock (Zoback and others, 1978; Zoback and others, 1980). Because of the regional scope of this study, the effects of individual faults and other local features were not incorporated into this analysis.

\section{GENERAL GEOLOGIC SETTING}

The upper Mississippi Embayment is a broad, slightly asymmetrical, southwest-plunging syncline of unconsolidated Cretaceous and Tertiary sediments (Murray, 1961; Stearns and Marcher, 1962; Cushing and others, 1964) which rest on deformed bedrock of Cambrian to Pennsylvanian age (Freeman, 1953; Caplan, 1954; Grohskopf, 1955). A major unconformity, representing erosion which may have begun as early as the Pennsylvanian and continued into the Late Cretaceous (Marcher and Stearns, 1962), developed on the Paleozoic rocks. Downwarping of the Paleozoic rocks began in the Late Cretaceous, and by the end of Cretaceous time, the first major marine invasion deposited sands, silts, and clays throughout the area (Stearns, 1957). The embayment continued to subside as repeated transgressive-regressive cycles persisted into the middle Eocene and deposited thick sequences of marine and nonmarine sediments. By the end of the Eocene, subsidence generally ceased and the upper embayment filled with sediments (Cushing and others, 1964; Russell and Parks, 1975). In the Pliocene or early Pleistocene, a veneer of coarse alluvial and fluvial gravels blanketed the area (Potter, 1955; Russell and Parks, 1975). In response to the Pleistocene glaciations, the ancestral Mississippi and Ohio River systems filled lowland areas with braided-stream deposits while prevailing winds mantled the adjacent uplands with loess (Saucier, 1974). Starting about 6000 years ago, the braided river systems evolved into a meandering regime and began reworking the older unconsolidated deposits.

Because of the thick veneer of Cretaceous and Tertiary sediments and sparse exploratory drilling, the configuration of the Paleozoic bedrock surface in the upper embayment is only generally known. Only a handful of widely separated wells have penetrated Paleozoic rocks in the New Madrid region. Most of these wells are old and have poor records, which usually consist of crude drillers' logs. A few of the wells have geophysical logs, which are necessary for accurate correlations, but those wells are so scattered that detailed structural interpretations are impossible or meaningless. From the limited subsurface information, numerous regional studies have confirmed the basic synclinal character of the Paleozoic bedrock surface (fig. 2) (Roberts and Gildersleeve, 1950; Caplan, 1954; Grohskopf, 1955; Cushing and others, 1964; Schwalb, 1969; Stearns and Wilson, 1972). However, subtle structures remain undetectable because of insufficient and scattered subsurface data. On the basis of limited well control and topographic lineations, Stearns and Zurawski (1976) constructed a series of interpretative structural contour maps which attempted to portray the configuration of the Paleozoic bedrock surface more accurately. Nevertheless, to date, the reflection profiles are the most complete and most reliable source of subsurface structural information available in the upper Mississippi Embayment.

The assumption that the bedrock surface in the study area was of low relief prior to Upper Cretaceous sedimentation is critical to all of the structural interpretations presented here. The top of the Paleozoic bedrock gently slopes toward the axis of the embayment at about $35 \mathrm{ft} / \mathrm{mi}(6.6 \mathrm{~m} / \mathrm{km}$ ) (Boswell and others, 1965) with only minor interruptions (Grohskopf, 1955). Any significant deformation recognized on the bedrock surface other than the broad downwarping of the embayment is attributed to and interpreted in terms of tectonic processes.

General knowledge of the geologic history of the northern Mississippi Embayment suggests that there was very little topographic relief on the bedrock by Upper Cretaceous time. The Paleozoic bedrock in the study area is predominantly Cambrian and Ordovician carbonates that were uplifted as part of the Pascola arch (Grohskopf, 1955). For perhaps as long as 180 m.y. (Davis and others, 1973) during the Paleozoic and Mesozoic, the arch was extensively eroded and several kilometers of sediments were removed (Marcher and Stearns, 1962). By Late Cretaceous time, the Paleozoic bedrock was beveled to a mature, low-relief surface with a well-developed drainage system (Pryor, 1960).

The character of the Paleozoic reflector on profile line S-10 and data from the USGS New Madrid test well adjacent to the profile line (drill hole $C$, fig. 1) further support the belief that only minor relief remained on the bedrock surface. The USGS well shows that the bedrock beneath line S-10 is altered, highly fractured dolomite (Crone and Russ, 1979). Because the test well is located near the crest of the Pascola arch, which is an uplift that may have been structurally elevated more than $8000 \mathrm{ft}(2625 \mathrm{~m})$ (Marcher and Stearns, 1962) beginning in the late Paleozoic (Bond and others, 1971), it is reasonable to expect that the brittle dolomites beneath line S-10 would have been fractured prior to the erosion that produced the Paleozoic-Late Cretaceous unconformity. When exposed, soluble, 
TABLE 1.-- Comparison of geological and geophysical characteristics of topographic components of the Lake County uplift

\begin{tabular}{|c|c|c|c|c|c|c|c|}
\hline $\begin{array}{l}\text { Topographic } \\
\text { component }\end{array}$ & $\begin{array}{l}\text { Relative } \\
\text { topographic } \\
\text { relief }\end{array}$ & $\begin{array}{l}\text { Cross- } \\
\text { sectional } \\
\text { geometry }\end{array}$ & $\begin{array}{l}\text { Orientation } \\
\text { of axis }\end{array}$ & $\begin{array}{l}\text { Time of } \\
\text { formation }\end{array}$ & Surface faults & $\begin{array}{l}\text { Subsurface } \\
\text { faults }\end{array}$ & $\begin{array}{l}\text { Correlations of } \\
\text { gravity with topo- } \\
\text { graphic component } \\
\text { (from Hildenbrand } \\
\text { and others, 1979; } \\
\text { and Stearns, 1979) }\end{array}$ \\
\hline $\begin{array}{l}\text { Southern end } \\
\text { of Sikeston } \\
\text { Ridge. }\end{array}$ & Low---- & $\begin{array}{l}\text { Sha1low, broad } \\
\text { arch. }\end{array}$ & $\begin{array}{l}\text { Genera11y } \\
\text { north- } \\
\text { northwest. }\end{array}$ & $\begin{array}{l}\text { Late Pleistocene } \\
\text { to about } 6000 \\
\text { yr B.P. }\end{array}$ & None known---- & $\begin{array}{l}\text { Single identified } \\
\text { dip-slip } \\
\text { fault. }\end{array}$ & No correlation. \\
\hline Tiptonville dome & High--- & $\begin{array}{l}\text { Strongly asymmetric } \\
\text { arch; relatively } \\
\text { steeply dipping } \\
\text { limb on the east; } \\
\text { moderate width. }\end{array}$ & North------- & $\begin{array}{l}\text { Generally less than } \\
2000 \mathrm{yr} \text { B.P. }\end{array}$ & $\begin{array}{l}3+\mathrm{m} \\
\text { of normal } \\
\text { of fset along } \\
\text { eastern edge } \\
\text { of dome; } \\
\text { believed con- } \\
\text { tinuous with } \\
\text { subsurface off- } \\
\text { set of Reelfoot } \\
\text { fault. }\end{array}$ & $\begin{array}{l}\text { Several } \\
\text { high-angle faults } \\
\text { that have general } \\
\text { strike parallel to } \\
\text { orientation of } \\
\text { axis. }\end{array}$ & $\begin{array}{l}\text { Moderate corre- } \\
\text { lation with } \\
\text { gravity high. }\end{array}$ \\
\hline Ridgely Ridge & Moderate & $\begin{array}{l}\text { Generally symmetric } \\
\text { arch; relatively } \\
\text { narrow width. }\end{array}$ & Northeast-- & $\begin{array}{l}\text { Generally less than } \\
6000 \text { yr B.P. }\end{array}$ & None known---- & $\begin{array}{l}\text { Parallel and coinci- } \\
\text { dent with a } \\
\text { northeast-trending } \\
\text { zone of faults. }\end{array}$ & $\begin{array}{l}\text { Strong correlation } \\
\text { with northeast- } \\
\text { trending linear } \\
\text { gravity high. }\end{array}$ \\
\hline
\end{tabular}

1979; Nicholson and Singh, 1979; O'Connell and others, this volume; R. M. Hamilton, written commun., 1979) reveal the presence of a northwest-trending zone of seismic events. The relationship of this zone to the northeast-trending faults and to the overall occurrence of seismicity in the Ridgely area is currently unknown.

In summary, it is worthwhile emphasizing two points:

1. A very close spatial relationship exists between modern seismicity and the geographic extent of tectonic surface deformation (fig. 12). Approximately 75 percent of the microearthquakes recorded in the New Madrid region between 1974 and 1978 have occurred within the area of the Lake County uplift. The northwestern part of Tiptonville dome that was uplifted during the $1811-12$ earthquakes is still active today, whereas the eastern part of the dome along Reelfoot fault (including the southern part that is believed to have been uplifted in 1811-12) is not an area of abundant modern seismicity. Though there is no evidence of deformation on Ridgely Ridge in 1811-12, that area is currently seismically active.

2. At least three earthquakes of intensity strong enough to cause tectonic faulting, folding, and liquefaction of surface sediments have occurred in the New Madrid region in the last 2000 years. A recurrence rate of about 600 years for earthquakes of $\mathrm{mb}_{\mathrm{b}} \geq 6.2$ (the approximate threshold of liquefaction in the New Madrid region) is therefore indicated. Inasmuch as this rate is similar to the recurrence interval for earthquakes of $\mathrm{m}_{\mathrm{b}} \geq 7$ as determined from earthquake intensity data (Nuttli, 1974), it is suggested that the faulting, folding, and liquefaction are related to earthquakes of $\mathrm{mb}_{\mathrm{b}} \geq 7$ that recur about every 600 years.

Until recently, few data have been available to help explain the cause of the Lake County uplift. Even with the recently ob- tained geomorphic and seismic evidence, the origin of the uplift remains somewhat problematic. After considering several causes, Fuller (1912) concluded that the most probable explanation for the upwarping involved subsidence of the deep center of the Mississippi Embayment. He thought that such subsidence might produce a depression that would cause the overlying unconsolidated sediments to slide or slump toward the embayment center and that would produce, in the process, a corrugated surface. The high parts of the surface would have the configuration of domes. Recent subsurface drilling and seismic evidence, however, do not support this hypothesis. Offsets of the base of the Mesozoic section of sufficient magnitude to produce the required depression have not been identified. In addition, the deep center of the embayment is located beneath the Lake County uplift and not farther to the west, in southeastern Missouri, as Fuller suspected.

Detailed examination of the seismicity and the structures beneath the uplift strongly suggests that the uplift is related to tectonic processes localized on the ancient subsurface structures. Such processes appear to be strongly dependent upon the orientation and magnitude of the modern stress field. Herrmann and Canas (1978) and Herrmann (1979) have determined composite and single-event fault-plane solutions, respectively, for earthquakes in the New Madrid region. Their results indicate that the maximum regional compressive stress is horizontal and trends in an approximate east- west direction. The mechanisms they calculated also show that major zones of seismicity extending in a linear trend southwest from Caruthersville and northeast from Lilbourn, Mo., are best modeled as continuous faults having right-lateral strike-slip displacement. Focal-plane mechanisms for the numerous earthquakes that have occurred between Ridgely, Tenn., and Lilbourn, Mo. (fig. 12), have been determined by Herrmann and Canas (1978), Herrmann (1979), O'Connell and others 


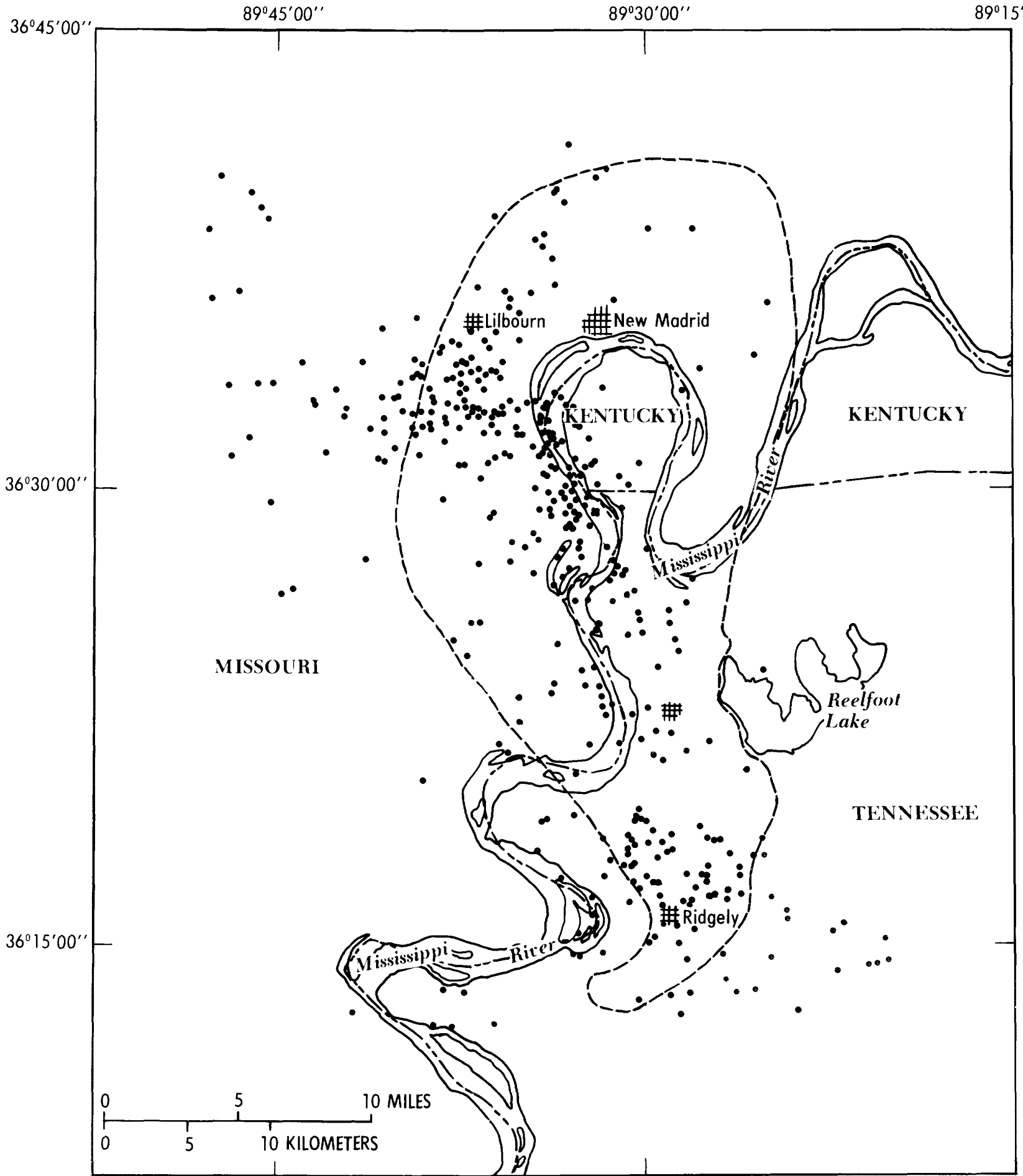

FiguRE 12.-- Map showing spatial relationship between modern microearthquakes (small dots) and the area of the Lake County uplift (dashed line). Microearthquakes shown here were recorded during the time interval from 1 July 1974 to 30 June 1978 by the Saint Louis University network. Modified from Stauder, this volume.

(this volume), and Nicholson and Singh (1978). Results of the analyses show a variety of solutions, indicating a complex tectonic regime. The majority of the analyses, however, have produced reverse-fault solutions. Based upon the fault-plane solu- tions and the calculated direction of the maximum compressive stress, a theoretical model can be constructed that offers a plausible explanation for the origin of the Lake County uplift. As displayed in figure 13, the maximum compressive stress of 
the regional modern stress field is oriented in a horizontal eastwest direction. This direction is consistent with right-lateral displacement on the faults of the two major northeasttrending seismic zones. Movement on the two faults generates compression in the region between the faults. The compression would be highest in the area where the opposite-moving blocks abut one another. The area coincides precisely with the locations of abundant epicenters, some with reverse-fault focal mechanisms, and with the area of the Lake County uplift. As displayed in the cross-sectional diagram of figure $13\left(X-X^{\prime}\right)$, the compression is translated into vertical strain (Poisson bulge), resulting in uplift above the area of opposed block movement. The theoretical model just presented is quite similar to the concept of en echelon surface folds that are produced by wrench tectonics (Wilcox and others, 1973). In the New Madrid region the transverse offset in the strike-slip system between Caruthersville and New Madrid, Mo., would serve to increase the horizontal compression and localize the folding in the area of offset.

It is doubtful that any of the surface uplift could be the product of warping associated with the emplacement of intrusive rocks. Evidence interpreted from seismic-reflection profiles suggests that intrusions occurred beneath Ridgely Ridge some time following the middle Eocene (Zoback and others, 1980). The absence of significant subsurface heat-flow anomalies in this area (Swanberg and others, this volume), however, suggests that intrusions have not occurred during the last few thousand years. Consequently the surface sediments, which are about 2000-6000 years old, were not deformed by stresses caused by intrusive activity.

The Lake County uplift can be compared to similar surface warping associated with large earthquakes in other parts of the country. The Ocotillo Badlands in southern California is an anticlinal dome that lies astride left- stepping en echelon segments of Coyote Creek fault (Clark, 1972; Sharp and Clark, 1972; Segall and Pollard, 1980). Through geologic time the predominant movement on segments of the fault has been right-lateral strike slip. During the 1968 Borrego Mountain earthquake, three segments of Coyote Creek fault broke, causing compression in the Ocotillo Badlands (Clark, 1972; Sharp and Clark, 1972). Recurring offset on these faults during the Quaternary has caused sedimentary strata to be uplifted, producing a complexly-folded dome with a topographic relief of and a width of $2 \mathrm{~km}$. Fold axes in the $\sim 200 \mathrm{~m}$ Ocotillo Badlands are oriented to strikes of segments of the Coyote Creek fault in a manner similar to the orientation of fold axes to faults in the Lake County uplift area of northwest Tennessee. In studies of the great Alaska earthquake of 1964 (Plafker, 1972), it was determined that a large part of Montague Island adjacent to Prince William Sound had been upwarped $10 \mathrm{~m}$. The deformed area of the Island has an elongated elliptical shape and is of a considerably larger magnitude than the Lake County uplift. As with the Lake County uplift, upwarping on Montague Island appears to

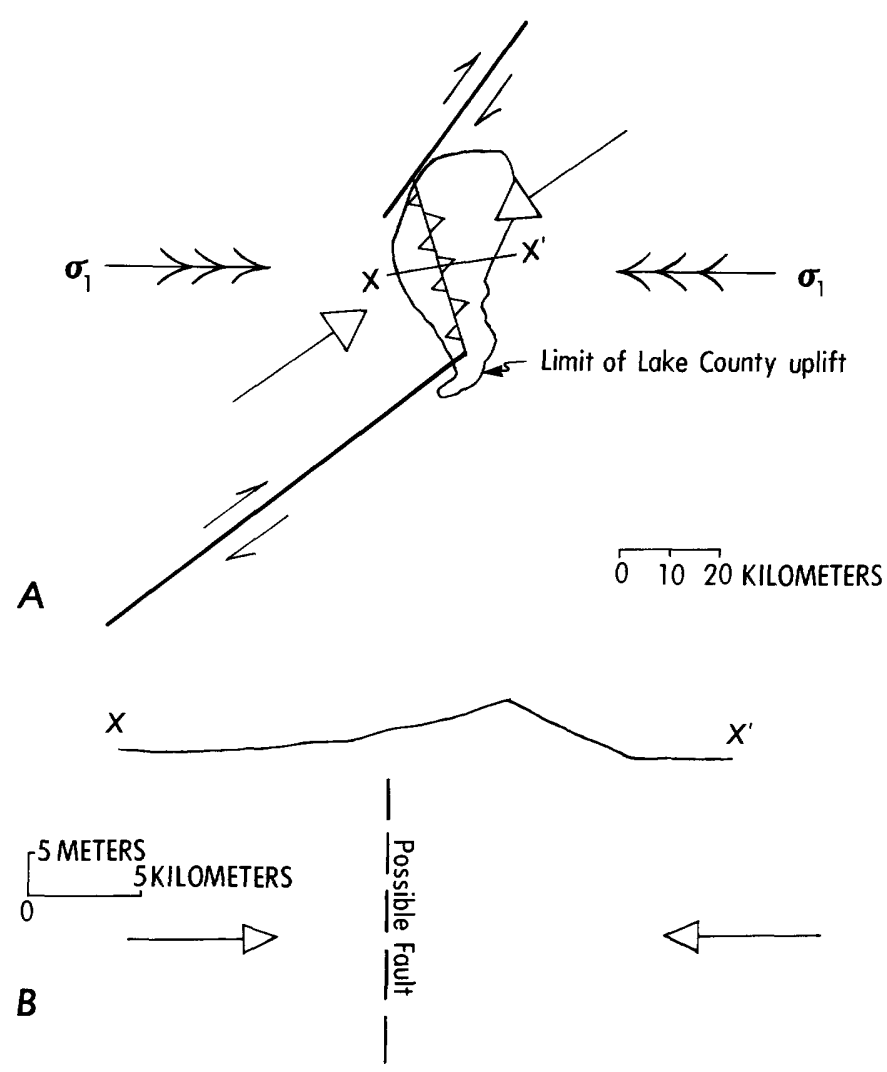

Figure 13.-- Plan view $(A)$ and cross section $(B)$ of hypothetical tectonic model for the origin of the Lake County uplift. Model interrelates the modern stress field with fault movement and the location of uplift. Barbed arrows indicate $\sigma_{1}$, the direction of maximum compressive stress; single arrows indicate right-lateral displacement on faults of ma jor northeast-trending seismic zones; large open-headed arrows in dicate compression generated by movement along faults; and saw teeth indicate area of highest compression. See text for explanation.

have been produced by strong horizontal compression. The Alaskan surface deformation, however, was caused by elastic rebound along the upward-moving plate of a megathrust and was locally intensified by subsidiary reverse faults that broke through the upper plate to the surface (Plafker, 1972). In contrast, surface deformation in the Lake County area is probably the result of compression along a deflection or offset in a major strike-slip fault system. Seismic data and focal mechanisms reveal the presence of reverse faults and antithetic normal faults in the region of offset between Caruthersville and New Madrid. There appears to be little similarity in origin between the Lake County uplift and the recently discovered Palmdale bulge in southern California. In contrast to the seismically generated Lake County uplift, the Palmdale bulge appears to be the product of aseismic warping caused by the accumulation of elastic strain (Castle and others, 1976). But like the Palmdale bulge, the significance of the Lake County uplift as it pertains to potential future earthquakes is unknown. 


\section{REFERENCES CITED}

Broadhead, G. C., 1902, The New Madrid earthquake: The American Geologist, v. 30, p. 76-87.

Castle, R. O., Church, J. P., and Elliott, M. R., 1976, Aseismic uplift in southern California: Science, v. 192, p. 251-253.

Clark, M. M., 1972, Surface rupture along the Coyote Creek fault, in The Borrego Mountain earthquake of April 9, 1968: U.S. Geological Survey Professional Paper 787, p. 55-86.

Fisk, H. N., 1944, Geological investigation of the alluvial valley of the lower Mississippi River: Vicksburg, U.S. Corps of Engineers Mississippi River Commission, $78 \mathrm{p}$.

Fuller, M. L., 1912, The New Madrid earthquake: U.S. Geological Survey Bulletin 494, $118 \mathrm{p}$

Glenn, L. C., 1906, Underground waters of Tennessee and Kentucky west of Tennessee River: U.S. Geological Survey Water Supply and Irrigation Paper 164, 173 p.

1933, The geography and geology of Reelfoot Lake: Tennessee Academy of Science Journal, v. 8, no. 1, p. 2-12.

Hamilton, R. M., and Zoback, M. D., 1979, Seismic reflection profiles in the northern Mississippi embayment: U.S. Geological Survey Open-File Report 79- 1688.

Hardeman W. D., and Miller,R. A., 1959, Map of mineral resources and mineral industries of Tennessee: Tennessee Department of Conservation and Commerce, Division of Geology, scale 1:500,000.

Herrmann, R. B., 1979, Surface wave focal mechanisms for eastern North American earthquakes with tectonic implications: Journal of Geophysi. cal Research, v. 84, p. 3543-3552.

Herrmann, R. B., and Canas, J. A., 1978, Focal mechanism studies in the New Madrid seismic zone: Seismological Society of America Bulletin, v. 68 , no. 4, p. 1095-1102.

Hildenbrand, T. G., Kane, M. F., and Stauder, William, 1977, Magnetic and gravity anomalies in the northern Mississippi embayment and their spacial relation to seismicity: U.S. Geological Survey Miscellaneous Field Studies Map MF-914, scale 1:1,000,000.

Hildenbrand, T. G., Kucks, R. P., and Kane, M. F., 1979, Simple Bouguer gravity map of the Dyersburg $1^{\circ}$ by $2^{\circ}$ quadrangle, Kentucky, Missouri, and Tennessee: U.S. Geological Survey Open-File Report 79-1183, scale $1: 1,000,000$.

Krinitzsky, E. L., 1950, Geological investigation of faulting in the lower Mississippi Valley: U.S. Army Corps of Engineers Waterways Experiment Station Technical Memorandum 3-311, 50 p.

Leighton, M. M., and Willman, H. B., 1950, Loess formations of the Mississippi Valley: Journal of Geology, v. 58, no. 6, p. 599-623.

Lyell, Charles, 1849, A second visit to the United States, v. 2: New York, Harper and Brothers, $287 \mathrm{p}$.

McGee, W. J., 1892, A fossil earthquake [abs.]: Geological Society of America Bulletin, v. 4, p. 411-415.

McGill, J. T., and Craig, W. W., 1933, The ownership of Reelfoot Lake: Tennessee Academy of Science Journal, v. 8, no. 1, p. 13-21.

Miller, R. A., Hardeman, W. D., and Fullerton, D. S., 1966, Geologic map of Tennessee: Tennessee Department of Conservation and Commerce, Division of Geology, scale 1:250,000.

Nicholson, C., and Singh, S., 1978, A detailed microearthquake study of the New Madrid fault system's western Tennessee segment [abs.]: Seismological Society of America Earthquake Notes, Eastern Section, v. 49, no. 4, p. 19.

Nuttli, O. W., 1973, The Mississippi Valley earthquakes of 1811 and 1812 intensities, ground motion and magnitudes: Seismological Society of America Bulletin, v. 63, no. 1, p. 227-248.
Nuttli, O. W., 1974, Magnitude-recurrence relation for central Mississippi Valley earthquakes: Seismological Society of America Bulletin, v. 64 , no. 4, p. 1189-1207.

Olive, W. W., 1981, Geologic map of the Jackson Purchase region, Kentucky: U.S. Geological Survey Miscellaneous Investigations Map I-1217.

Penick, James, Jr., 1976, The New Madrid earthquakes of 1811-1812: Columbia, Mo., The University of Missouri Press, $181 \mathrm{p}$.

Plafker, George, 1972, Tectonics, in The great Alaska earthquake of 1964 , seismology and geodesy: Washington, National Academy of Sciences, p. 112-188.

Russ, D. P., 1979, Late Holocene faulting and earthquake recurrence in the Reelfoot Lake area, northwestern Tennessee: Geological Society of America Bulletin, pt. 1, v. 90, p. 1013-1018.

Russ, D. P., Stearns, R. G., and Herd, D. G., 1978, Map of exploratory trench across Reelfoot scarp, northwestern Tennessee: U.S. Geological Survey Miscellaneous Field Studies Map MF-985, scale 1:39.4.

Saucier, R. T., 1974, Quaternary geology of the lower Mississippi Valley: Arkansas Archaeological Survey Research Series 6, 26 p.

Schreurs, R. L., and Marcher, M. V., 1959, Geology and groundwater resources of the Dyersburg quadrangle, Tennessee: Tennessee Department of Conservation, Division of Geology, Report of lnvestigations 7, $61 \mathrm{p}$.

Segall, P., and Pollard, D. D., 1980, Mechanics of discontinuous faults: Journal of Geophysical Research, v. 85, p. 4337-4350.

Sharp, R. V., and Clark, M. M., 1972, Geologic evidence of previous faulting near the 1968 rupture on the Coyote Creek fault, in The Borrego Mountain earthquake of April 9, 1968: U.S. Geological Survey Professional Paper 787, p. 131-140.

Stauder, William, Herrmann, R. B., Singh, Sudarshan, and others, 1979, Central Mississippi Valley earthquake bulletin: Saint Louis University, Department of Earth and Atmospheric Sciences, Quarterly Report 19, $51 \mathrm{p}$.

Stearns, R. G., 1979, Recent vertical movement of the land surface in the Lake County uplift and Reelfoot Lake basin areas, Tennessee, Missouri, and Kentucky: U.S. Nuclear Regulatory Commission NUREG/CR - 0874, $37 \mathrm{p}$.

Tennessee State Library and Archives, 1979, George Doherty land grant records: Roll no. 5, p. 62, 63, 81 .

U.S. Army Corps of Engineers, 1976, Mississippi River hydrographic survey-Cairo, Illinois, to White River, Arkansas: Memphis, Tenn., U.S. Army Engineer District, 98 p.

Usher, F. C., 1837, On the elevation of the banks of the Mississippi in 1811: Silliman's Journal (American Journal of Science, First Series), v. 31, p. 291-294.

Wells, F. G., 1933, Ground-water resources of western Tennessee: U.S. Geological Survey Water-Supply Paper 656, $319 \mathrm{p}$.

Wilcox, R. E., Harding, T. P., and Seely, D. R., 1973, Basic wrench tectonics: American Association of Petroleum Geologists Bulletin, v. 57, no. 1, p. 74-96.

Zoback, M. D., 1979, Recurrent faulting in the vicinity of Reelfoot Lake, northwestern Tennessee: Geological Society of America Bulletin, pt. 1, v. 90 , p. 1019-1024.

Zoback, M. D., Hamilton, R. M., Crone, A. J., Russ, D. P., and Brockman, S. R., 1978, Seismic reflection profiling to delineate tectonic features of the New Madrid seismic region [abs.]: Seismological Society of America Earthquake Notes, Eastern Section, v. 49, no. 4, p. 27-28.

Zoback, M. D., Hamilton, R. M., Crone, A. J., Russ, D. P., McKeown, F. A., and Brockman, S. R., 1980, Recurrent intraplate tectonism in the New Madrid seismic zone: Science, v. 209, no. 4460, p. 971-976. 


\section{Configuration and Deformation of the Paleozoic Bedrock Surface in the New Madrid Seismic Zone}

By A. J. CRONE and S. R. BROCKMAN

INVESTIGATIONS OF THE NEW MADRID, MISSOURI, EARTHQUAKE REGION

GEOLOGICAL SURVEY PROFESSIONAL PAPER 1236 -I 


\section{CONTENTS}

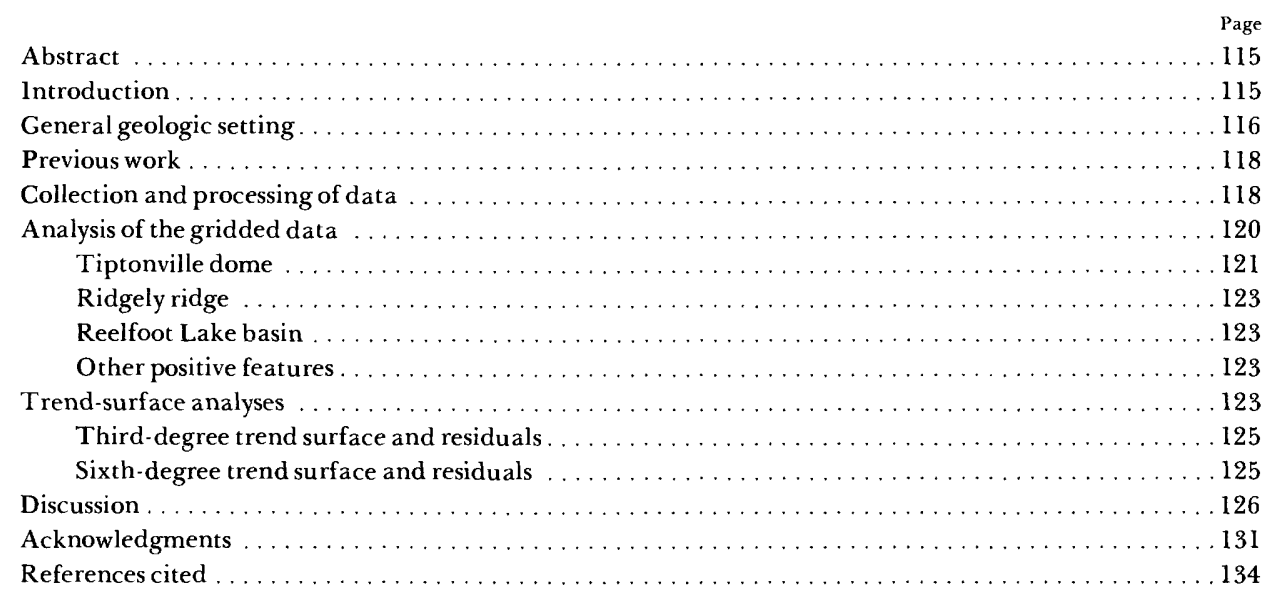

\section{ILLUSTRATIONS}

Ficure 1. Location map of seismic-reflection profiles and subsurfacecontolin the New Madrid region

2. General synclinal configuration of the Paleozicissippi Embayment

3. Configuration of the Paleozoic bedrock surface interpreted from the calculated two-way travel times $\ldots \ldots \ldots \ldots \ldots \ldots \ldots \ldots \ldots \ldots \ldots$

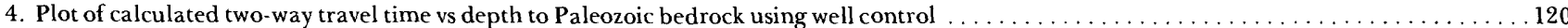

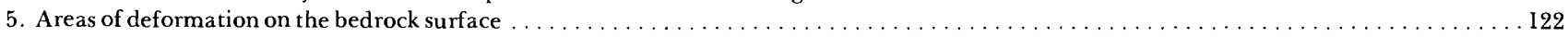

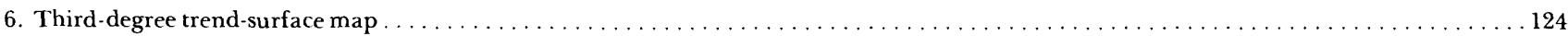

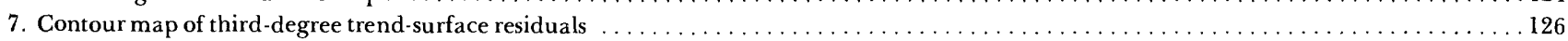

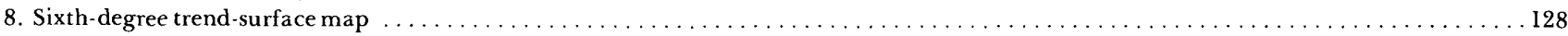

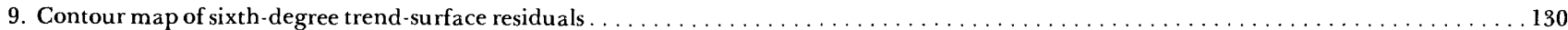

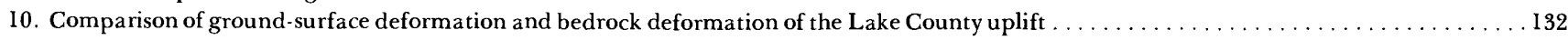

11. Comparison of seismicity with ground-surface and bedrock-surface deformation in the area of the Lake County uplift $\ldots \ldots \ldots \ldots \ldots . \ldots 133$

\section{TABLE}

TABLE 1. Well control for depth to bedrock in the New Madrid area and travel-time data 


\title{
CONFIGURATION AND DEFORMATION OF THE PALEOZOIC BEDROCK SURFACE IN THE NEW MADRID SEISMIC ZONE
}

\author{
By Anthony J. Crone and Stanley R. Brockman
}

\begin{abstract}
More than $280 \mathrm{~km}$ of multi-channel seismic-reflection profiles provide the first detailed information about the configuration of the Paleozoic bedrock surface beneath the unconsolidated sediments in the upper Mississippi Embayment. In the area of intense seismicity, roughly between Ridgely, Tenn. and New Madrid, Mo., data representing two-way travel times to the top of the Paleozoic bedrock reflector were orthogonally gridded by computer Uplifted and downwarped areas were recognized and the amount of deformation was estimated by using reconstructed contours. Trend-surface analyses of the travel times produced mathematical models of the bedrock surface and allowed regional trends to be recognized.

Analysis of the gridded data, the trend-surface maps, and the trend- surface residuals confirmed that the Lake County uplift, an area of anomalously high ground elevations in western Tennessee, is underlain by uplifted bedrock. The subsurface uplift encompasses about $367 \mathrm{~km}^{2}$ and, like the topographic feature, is divided into two main parts: Tiptonville dome and Ridgely ridge. Tiptonville dome, a roughly equidimensional uplift, is about $95 \mathrm{~km}^{2}$ in area and locally has been uplifted as much as $42 \mathrm{~m}$. Ridgely ridge is a large, complex uplift that trends northeast-southwest from the southern end of Reelfoot Lake to beyond Cottonwood Grove, Tenn. Parts of the ridge are highly faulted, and in some places, the bedrock has been upwarped more than $50 \mathrm{~m}$. Several other small areas of uplift, apparently unrelated to the much larger Lake County uplift, are present in the study area.

Reelfoot Lake basin, a topographically low area directly east of Tiptonville dome that is partially occupied by Reelfoot Lake, coincides with an area of downwarped bedrock. This suggests that the basin may be, in part, a structural depression which may have influenced the location of the lake. Abundant evidence indicates that Reelfoot Lake was enlarged during the 1811-12 earthquakes, but it remains unclear whether the enlargement was due to tectonic or nontectonic processes.

The orientation and maximum upwarping on the Lake County uplift, as expressed on the ground surface and on the bedruck surface, were determined by different techniques, but the results are remarkably similar. This strong similarity suggests that the surface and subsurface features are genetically related.

Different parts of the Lake County uplift have been tectonically active at different times. Tiptonville dome has been active most recently, the eastern portion of Ridgely ridge has been uplifted in the past 6000 years, and the western part of Ridgely ridge was deformed more than 6000 years ago. The
\end{abstract}

patterns of modern seismicity in the vicinity of the Lake County uplift do not clearly show which segments of the uplift are most active today.

The close spatial relationship between the modern seismicity and the areal extent of the uplift suggests that the forces responsible for the earthquakes are also producing the uplift, and that those forces are active today. The formation of the Lake County uplift is best explained by a tectonic model proposed by Russ (this volume) that is consistent with local and regional geologic and geophysical data, and with fault-plane solutions.

\section{INTRODUGTION}

As part of a series of continuing investigations to characterize the tectonic processes and to evaluate the seismic hazards in the upper Mississippi Embayment, the USGS (U.S. Geological Survey) has obtained about $280 \mathrm{~km}$ of multi-channel seismicreflection profiles in the area of intense seismic activity from northeastern Arkansas to New Madrid, Mo. The reflection profiles provide the first detailed information about the configuration of the bedrock surface beneath the unconsolidated embayment sediments and confirm the existence of a positive structural feature in Lake County, Tenn., which has deformed competent Paleozoic rocks.

An area of anomalously high ground has long been recognized in Lake County, Tenn. (Usher, 1837). The elevated ground has been presumed to be of tectonic origin (McGee, 1892; Fuller, 1912), but the relationship between this surface feature in unconsolidated alluvium and any subsurface structure in lithified bedrock has not been firmly established. The reflection profiles show for the first time that the surface deformation is a direct expression of deeper warping on the Paleozoic bedrock. Thus, the surface doming is a tectonic feature. Furthermore, the areas of surface and subsurface warping coincide with some of the most intense seismicity, suggesting that the tectonic stresses responsible for the formation of the uplift are still active today. 
This paper describes the significant characteristics and areal extent of the uplift as they are expressed on the Paleozoic bedrock. In the study area (fig. 1), two-way travel times to the reflection that represents the top of the Paleozoic rocks were read from the profiles and gridded to produce an evenly spaced network of data points. Hand- and computer-contoured plots of the gridded data illustrate the complex nature of the Paleozoic bedrock surface. Trend-surface analyses of the gridded data define the regional extent of the warping and emphasize anomalously high and low areas. The amount of relief on the uplift has been estimated from reconstructed contours.

The purpose of this study was to identify the regional structural trends in the area and to evaluate them in terms of the overall pattern of seismicity. Detailed analyses of the reflection profiles show a variety of complex faulted features and bodies of intrusive igneous rock (Zoback and others, 1978; Zoback and others, 1980). Because of the regional scope of this study, the effects of individual faults and other local features were not incorporated into this analysis.

\section{GENERAL GEOLOGIC SETTING}

The upper Mississippi Embayment is a broad, slightly asymmetrical, southwest-plunging syncline of unconsolidated Cretaceous and Tertiary sediments (Murray, 1961; Stearns and Marcher, 1962; Cushing and others, 1964) which rest on deformed bedrock of Cambrian to Pennsylvanian age (Freeman, 1953; Caplan, 1954; Grohskopf, 1955). A major unconformity, representing erosion which may have begun as early as the Pennsylvanian and continued into the Late Cretaceous (Marcher and Stearns, 1962), developed on the Paleozoic rocks. Downwarping of the Paleozoic rocks began in the Late Cretaceous, and by the end of Cretaceous time, the first major marine invasion deposited sands, silts, and clays throughout the area (Stearns, 1957). The embayment continued to subside as repeated transgressive-regressive cycles persisted into the middle Eocene and deposited thick sequences of marine and nonmarine sediments. By the end of the Eocene, subsidence generally ceased and the upper embayment filled with sediments (Cushing and others, 1964; Russell and Parks, 1975). In the Pliocene or early Pleistocene, a veneer of coarse alluvial and fluvial gravels blanketed the area (Potter, 1955; Russell and Parks, 1975). In response to the Pleistocene glaciations, the ancestral Mississippi and Ohio River systems filled lowland areas with braided-stream deposits while prevailing winds mantled the adjacent uplands with loess (Saucier, 1974). Starting about 6000 years ago, the braided river systems evolved into a meandering regime and began reworking the older unconsolidated deposits.

Because of the thick veneer of Cretaceous and Tertiary sediments and sparse exploratory drilling, the configuration of the Paleozoic bedrock surface in the upper embayment is only generally known. Only a handful of widely separated wells have penetrated Paleozoic rocks in the New Madrid region. Most of these wells are old and have poor records, which usually consist of crude drillers' logs. A few of the wells have geophysical logs, which are necessary for accurate correlations, but those wells are so scattered that detailed structural interpretations are impossible or meaningless. From the limited subsurface information, numerous regional studies have confirmed the basic synclinal character of the Paleozoic bedrock surface (fig. 2) (Roberts and Gildersleeve, 1950; Caplan, 1954; Grohskopf, 1955; Cushing and others, 1964; Schwalb, 1969; Stearns and Wilson, 1972). However, subtle structures remain undetectable because of insufficient and scattered subsurface data. On the basis of limited well control and topographic lineations, Stearns and Zurawski (1976) constructed a series of interpretative structural contour maps which attempted to portray the configuration of the Paleozoic bedrock surface more accurately. Nevertheless, to date, the reflection profiles are the most complete and most reliable source of subsurface structural information available in the upper Mississippi Embayment.

The assumption that the bedrock surface in the study area was of low relief prior to Upper Cretaceous sedimentation is critical to all of the structural interpretations presented here. The top of the Paleozoic bedrock gently slopes toward the axis of the embayment at about $35 \mathrm{ft} / \mathrm{mi}(6.6 \mathrm{~m} / \mathrm{km})$ (Boswell and others, 1965) with only minor interruptions (Grohskopf, 1955). Any significant deformation recognized on the bedrock surface other than the broad downwarping of the embayment is attributed to and interpreted in terms of tectonic processes.

General knowledge of the geologic history of the northern Mississippi Embayment suggests that there was very little topographic relief on the bedrock by Upper Cretaceous time. The Paleozoic bedrock in the study area is predominantly Cambrian and Ordovician carbonates that were uplifted as part of the Pascola arch (Grohskopf, 1955). For perhaps as long as 180 m.y. (Davis and others, 1973) during the Paleozoic and Mesozoic, the arch was extensively eroded and several kilometers of sediments were removed (Marcher and Stearns, 1962). By Late Cretaceous time, the Paleozoic bedrock was beveled to a mature, low-relief surface with a well-developed drainage system (Pryor, 1960).

The character of the Paleozoic reflector on profile line S-10 and data from the USGS New Madrid test well adjacent to the profile line (drill hole $C$, fig. 1) further support the belief that only minor relief remained on the bedrock surface. The USGS well shows that the bedrock beneath line S-10 is altered, highly fractured dolomite (Crone and Russ, 1979). Because the test well is located near the crest of the Pascola arch, which is an uplift that may have been structurally elevated more than $8000 \mathrm{ft}(2625 \mathrm{~m})$ (Marcher and Stearns, 1962) beginning in the late Paleozoic (Bond and others, 1971), it is reasonable to expect that the brittle dolomites beneath line $\mathrm{S}-10$ would have been fractured prior to the erosion that produced the Paleozoic-Late Cretaceous unconformity. When exposed, soluble, 


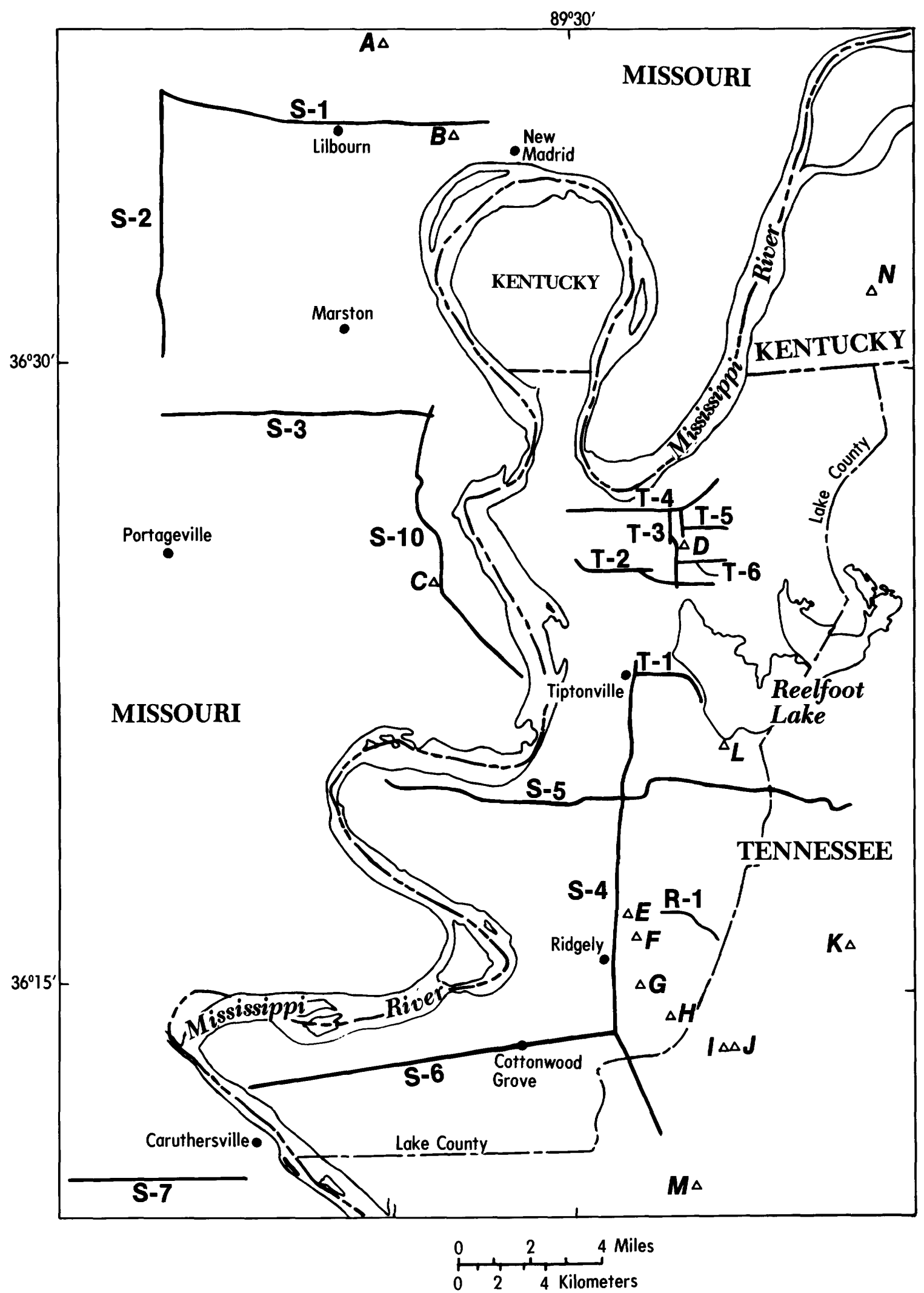

Figure 1.-- Location map of seismic-reflection profiles and subsurface control in the New Madrid region. Reflection profile lines shown by heavy solid lines; wells listed in table 1 shown by triangles and letters. Drill hole $C$ is the New Madrid test well. R-, S-, and T-lines are seismic-reflection profile lines. 

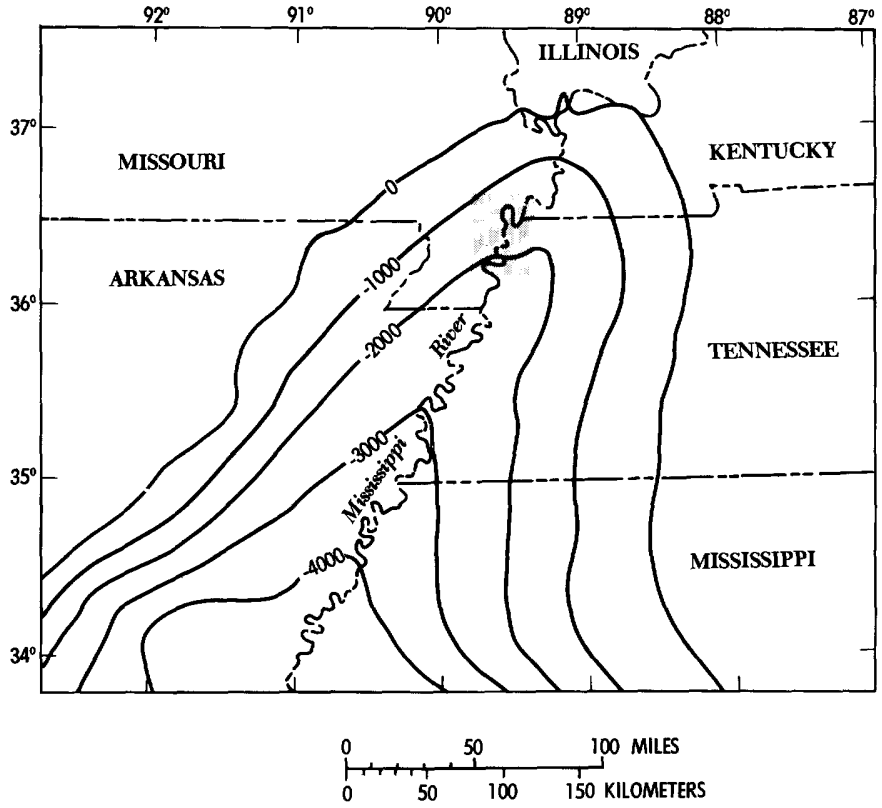

Figure 2.-- General synclinal configuration of the Paleozoic bedrock surface in the Mississippi embayment (modified from Cushing and others, 1964). Contour interval, $1000 \mathrm{ft}$; datum is mean sea level. Study area is shaded.

fractured dolomites would rapidly weather into a high-relief karst landscape. Thus, if any significant relief remained on the bedrock surface prior to Upper Cretaceous sedimentation, it should be preserved beneath profile line S-10. However, the Paleozoic reflector on line S-10 near the well is smooth, is continuous, and shows no evidence of substantial topographic relief.

\section{PREVIOUS WORK}

Numerous accounts describing the effects of the 1811-12 earthquakes in the upper Mississippi Embayment reported startling changes in the land surface. Usher (1837) first described an area of elevated land east of the Mississippi River, between New Madrid, Mo., and the mouth of the Obion River in western Tennessee, and attributed it to movements during the 1811-12 earthquakes. Likewise, McGee (1892), Purdue (1916), and Glenn (1933) all attributed the topographically high area in Lake County, Tenn., and the adjacent low areas to deformation caused by the 1811-12 or earlier earthquakes. In his classic study, Fuller (1912) described the size, shape, and amount of relief of this topographic feature and formally named it the Tiptonville dome.

Born (1935) presented the first evidence that the area of elevated ground in western Tennessee could be related to subsurface structure. In a north- south stratigraphic cross section, he showed a structurally high well at Proctor City, on top of the uplift. More recently, from drill data, Fisk (1944) and Krinitzsky (1950) interpreted faulting along the east edge of the Tiptonville dome and regarded the dome as a tectonic feature. Stearns (1979) and Russ (this volume) mapped the size and shape of the dome, divided it into component parts, and likewise concluded that it has a tectonic origin.

\section{COLLECTION AND PROCESSING OF DATA}

The USGS program of seismic-reflection profiling in the upper embayment was conducted in two stages: first, $32 \mathrm{~km}$ of profiles ( $T$-lines and line $R-1$ ) were collected in the vicinity of Reelfoot Lake (Zoback, 1979), and later about $250 \mathrm{~km}$ of profiles (S-lines) were run throughout the seismically active area (Hamilton and Zoback, 1979). Figure 1 shows the locations of the profiles. A synthetic seismogram from the sonic-velocity and density logs of the New Madrid test well (drill hole $C$, fig. 1 ), drilled into Paleozoic rocks near line $S-10$, was used to correlate the reflectors on the profiles with geologic units. The synthetic data agree well with the real data (Crone and Russ, 1979). Additional details of the reflection-profiling program are provided by Hamilton and Zoback (1979).

Two-way travel times to the Paleozoic reflector measured at $4000-\mathrm{ft}(1312 \mathrm{~m})$ intervals (20 vibration points) along the profiles, are accurate to within $5 \mathrm{~ms}$. The original 240 data points were processed using a minimum curvature program (M. W. Webring, unpub. computer program, 1978) designed to produce a smooth contour map that confidently represents the data (Briggs, 1974). The program generated a north-south east-west orthogonal grid of calculated two-way travel times spaced about $1.6 \mathrm{~km}$ apart. Hand- and computer-contoured maps of the calculated travel times approximate the configuration of the Paleozoic bedrock surface. Both versions of the contour maps are essentially identical, suggesting that the hand-contoured version was not noticeably biased. This study uses the hand-contoured maps because the map lines are generally smoother.

Two sources of potential error exist in the gridded data. First, a comparison of the calculated two-way travel times with the original data shows that the gridding process tends to reduce sharp, local variations; however, significant regional trends remain basically unaffected. Secondly, there are places near the edge of the study area, such as the region directly east of New Madrid and the region south of Portageville, where the gridded data were extrapolated beyond the data from the reflection profiles (fig. 3). East of New Madrid, limited well data act as a check on these gridded data and suggest that contours of the gridded data in the area are reasonably accurate. The gridding program calculated a two-way travel time of 636 $\mathrm{ms}$ for the Mt. Carmel Drilling-Florence Smith well $(N$, table 1). Using the depth-travel time relationship of $0.94 \mathrm{~m} / \mathrm{ms}$ developed later in this paper, the calculated depth to Paleozoic bedrock is $598 \mathrm{~m}$ compared to the actual depth of $600 \mathrm{~m}$ (Finch, 1971) (both depths referenced to $91 \mathrm{~m}$ ). Thus, in areas remote from the profile lines, the gridded data seem reliable.

No well control is available to check the gridded data in the area south of Portageville and thus to confirm the accuracy of the contour lines. However, the position of the contours is con- 


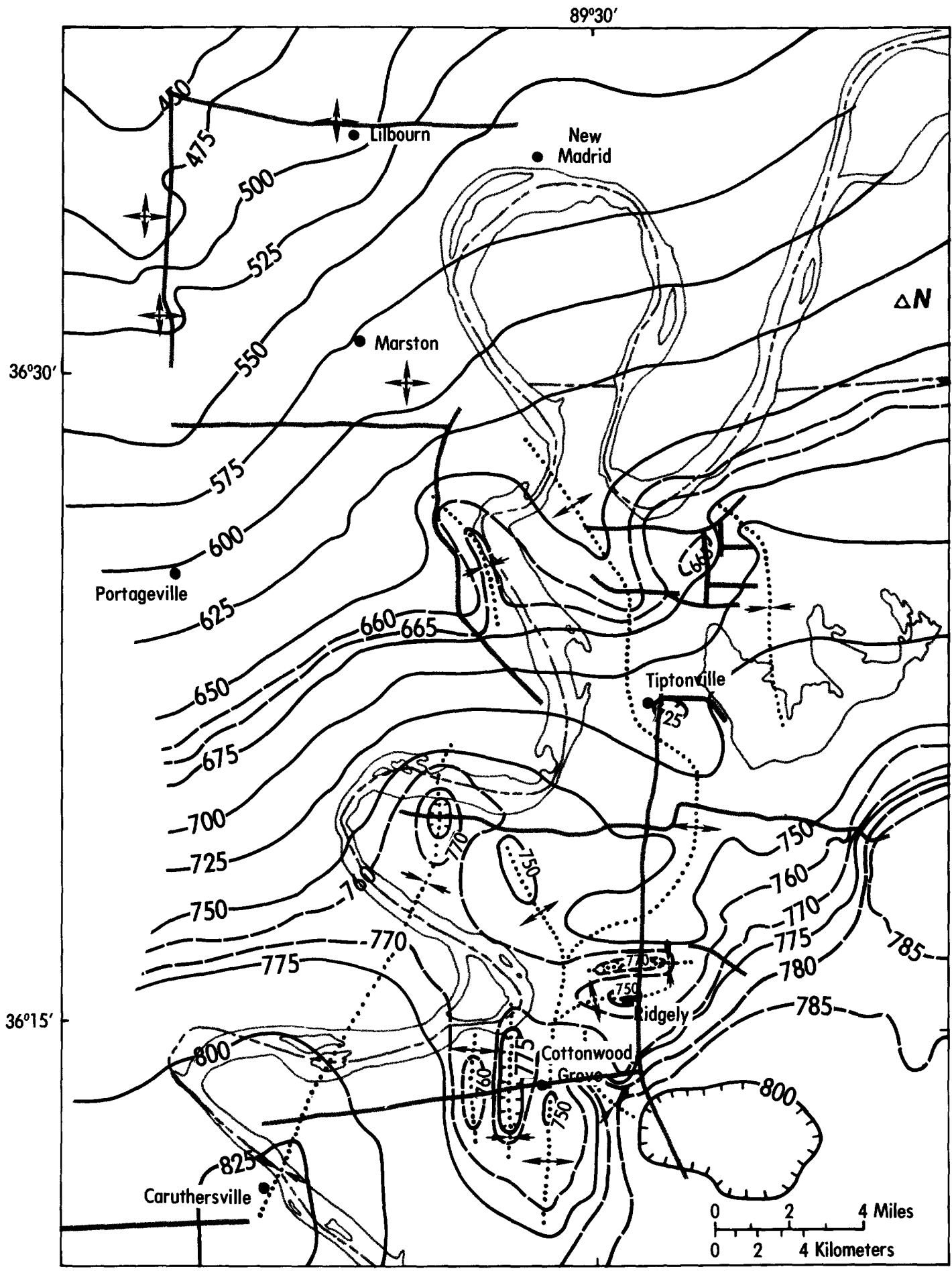

EXPLANATION
...... Structural low calculated from seismic data with interpreted orientation

...... Structural high calculated from seismic data with interpreted orientation

Structural high calculated from seismic data with no interpreted orientation

Figure 3. - Configuration of the Paleozoic bedrock surface interpreted from the calculated two-way travel times. Contour interval, $25 \mathrm{~ms}$; dashed contours are intermediate contours selected to show detail. Hachured contours show closed depressions. Longer two-way travel times indicate deeper bedrock. Reflection profiles shown by heavy screened lines and identified on figure 1. Areas of poor data control have not been contoured. Triangle is drill hole $N$ (table 1). The outline of Lake County uplift, Tiptonville dome, Ridgely ridge, and Reelfoot Lake basin are shown on figure 5. 
trolled by data from reflection profiles that lie to the north, east, and south. Also, the regular, even spacing of the contours suggests that the gridding program has generated reasonable travel-time values as it did in the region east of New Madrid (fig. 3).

In areas of absent or sparse data, the gridding program calculates values that tend toward a planar surface (Briggs, 1974) rather than create artificial structures. Despite the evidence that the gridding program works well in areas of poor data, we regard the contours in these areas skeptically because of the distance from the profile lines.

\section{ANALYSIS OF THE GRIDDED DATA}

On the basis of regional data, the Paleozoic bedrock in the study area dips gently and regularly to the south and southeast (fig. 2) (Cushing and others, 1964; Stearns and Wilson, 1972). In this study, significant deflections and clustering of contours contrary to the anticipated regular gradient of the embayment are interpreted as structures such as folds, faults, and flexures.

A contour map of the gridded two-way travel times (fig. 3) reveals a broad positive feature on the bedrock surface in western Tennessee which corresponds in size, location, and general shape to the Lake County uplift identified on the ground surface and described by Stearns (1979) and Russ (this volume). Furthermore, a distinct change in the trends of the contours suggests that the positive area may be subdivided into two component parts. North of Tiptonville, the Lake County uplift has an axis that trends northwest-southeast; in contrast, the southern part trends more northeast- southwest. In accordance with previously established terminology (McGee, 1892; Fisk, 1944; Stearns, 1979; Russ, this volume), this report refers to the entire broad, positive feature as the Lake County uplift; the northern portion of the uplift is identified as Tiptonville dome and the southern part is named Ridgely ridge.

Several lines of evidence suggest that the contoured two-way travel times (fig. 3) can be converted to depth estimates by using the approximate relationship that $1 \mathrm{~ms}$ equals $1 \mathrm{~m}$ of depth. The depths to Paleozoic bedrock from 13 drill holes in the area (fig. 1, table 1) are plotted against the two- way travel times predicted by the gridded data at the wells (fig. 4). Drill hole $E$ is not included in figure 4 because of uncertainty in the depth to Paleozoic bedrock. The bedrock depths are referenced to the 91-m datum used to process the reflection profiles for statics corrections. For some of the wells, the gridded travel times were adjusted to compensate for predictable variations in local structure and for some smoothing effects of the gridding routine (table 1). The local variations in structure were predicted on the basis of detailed analysis of the reflection profiles (Zoback and others, 1980). A linear-regression line fitted to the adjusted data and designed to intercept the origin yields a slope of $0.95 \mathrm{~m} / \mathrm{ms}$. Over large depth intervals, the two-way

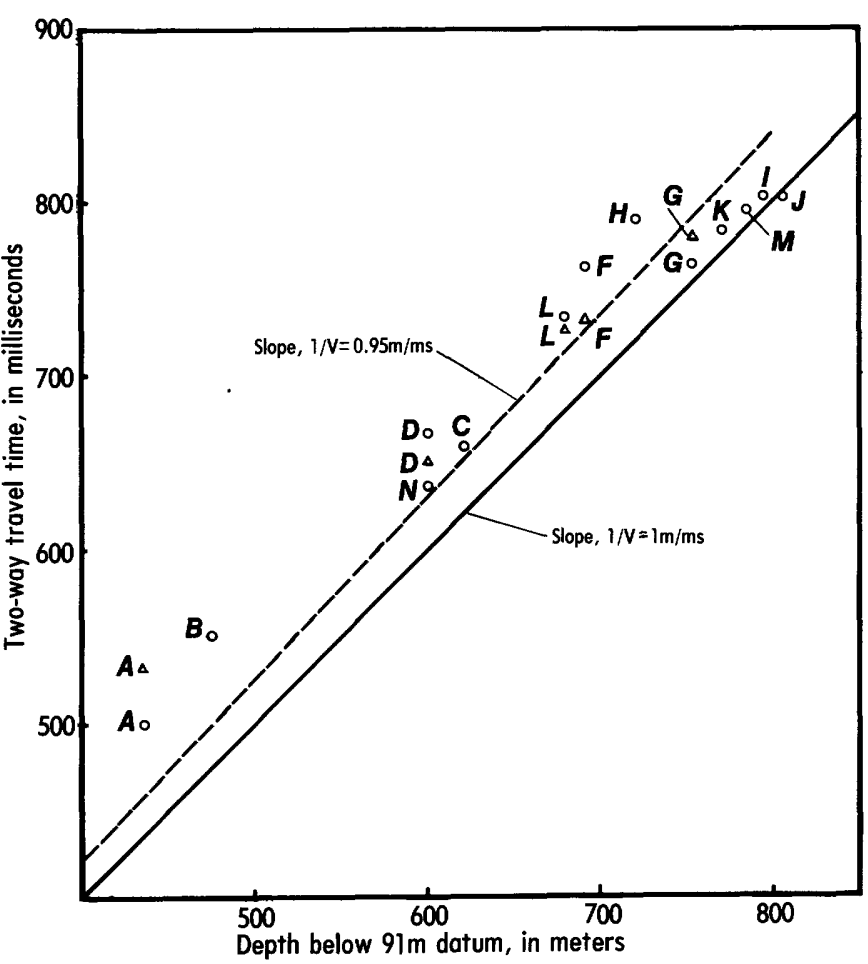

Figure 4.-- Plot of calculated two-way travel time vs depth to Paleozoic bedrock using well control. Letters identify wells listed in table 1; open circles are depth vs two-way travel time and triangles are depth vs adjusted two-way travel time. Depth values are referenced to the $91-\mathrm{m}$ datum used to process the reflection profiles. Slope of $0.95 \mathrm{~m} / \mathrm{ms}$ is linear regression line of the adjusted data required to intercept the origin (dashed line); slope of $1 \mathrm{~m} / \mathrm{ms}$ is shown for comparison (solid line). Drill hole $E$ is not included because of uncertainty in depth to Paleozoic bedrock.

travel time versus depth relationship is characteristically nonlinear; however, for the small depth interval considered here, a linear function is a reasonable assumption.

The mean value of the ratios of travel time versus depth for all wells listed in table 1 is $0.94 \mathrm{~m} / \mathrm{ms}$. Likewise, the ratio for the New Madrid test well (drill hole $C$, table 1) is $0.94 \mathrm{~m} / \mathrm{ms}$. Because the test well has excellent subsurface control and because profile line $S-10$ runs within a few meters of the well, no corrections are necessary and, thus, this ratio is very reliable. Finally, the best fit of the stacking velocities used to process the reflection profiles yields a relationship of $1 \mathrm{~m} / \mathrm{ms}$ (Zoback and others, 1980). All of these various lines of evidence indicate that $1 \mathrm{~m}$ of depth per $1 \mathrm{~ms}$ in two-way travel time is a useful approximation.

The amount of error introduced by using this rule of thumb to convert travel time to depth is variable because of local variations in the average velocity of the Upper Cretaceous to Tertiary sediments. The local variability and other contributing errors in the conversion mean that travel times converted to meters are only approximate.

Unrecognized lateral velocity changes in the Upper Cretace- 
TABLE 1. - Well control for depth to bedrock in the New Madrid area and travel-time data

[Leader (--) indicate data not calculated. Well depths were converted from feet to meters using a conversion factor of $0.3048 \mathrm{~m} / \mathrm{ft}$ ]

\begin{tabular}{|c|c|c|c|c|c|c|}
\hline Well & Well & $\begin{array}{l}\text { Depth (m) to top } \\
\text { of Paleozoic rocks } \\
\text { below } 91-\mathrm{m} \text { datum }\end{array}$ & $\begin{array}{l}\text { Two-way } \\
\text { travel time from } \\
\text { gridded data }\end{array}$ & $\begin{array}{l}\text { Adjusted } \\
\text { two-way travel } \\
\text { time }\end{array}$ & $\begin{array}{l}\text { Ratio of depth } \\
\text { to ad justed } \\
\text { travel time } \\
(\mathrm{m} / \mathrm{ms})\end{array}$ & Comments \\
\hline A & Lillbourn oil - \#1 Hnter & 436 & 500 & 532 & 0.82 & Ad justed $+32 \mathrm{~ms}$ because of local structure. \\
\hline$\underline{\bar{B}}$ & $\begin{array}{l}\text { Unton-Cordova Oil- } \\
\text { \#1 Phillips. }\end{array}$ & 475 & 551 & 551 & .86 & No major correction \\
\hline$\underline{\mathrm{C}}$ & U.S.G.S. -NMTW-1-X & 621 & 659 & 659 & .94 & Do. \\
\hline $\bar{D}$ & $\begin{array}{l}\text { Reelfoot Dame oil- } \\
\text { \#1 Kate Wright. }\end{array}$ & 600 & 667 & 650 & .92 & Adjusted $-17 \mathrm{~ms}$ because of local structure. \\
\hline$\underline{\mathrm{E}}$ & $\begin{array}{l}\text { Henderson Oil- } \\
\quad \# 1 \text { Linda Morris }(A, C \& D)\end{array}$ & $773,752,734$ & 762 & --- & --- & $\begin{array}{l}\text { Disregarded due to uncertainty in depth } \\
\text { to Paleozoic bedrock. }\end{array}$ \\
\hline$\underline{\mathbf{F}}$ & $\begin{array}{l}\text { Frazier \& Benz- } \\
\quad \text { झ1-B Sam Hays. }\end{array}$ & 692 & 763 & 733 & .94 & $\begin{array}{l}\text { Adjusted }-30 \text { ms to compensate for } \\
\text { smoothing by gridding program. }\end{array}$ \\
\hline$\underline{G}$ & $\begin{array}{l}\text { Corley, Geiselman \& Berz- } \\
\text { \#1 J. E. Vaughn. }\end{array}$ & 754 & 765 & 780 & .97 & $\begin{array}{l}\text { Ad justed }+15 \text { ms to campensate for } \\
\text { smoothing by gridding program. }\end{array}$ \\
\hline$\underline{\mathrm{H}}$ & $\begin{array}{l}\text { Benz Oil - } \\
\# 1 \text { Merritt Estate. }\end{array}$ & $722 ?$ & 790 & $790 ?$ & .91 & $\begin{array}{l}\text { Ad justment carmot be estimated because } \\
\text { of inaccurate top of Paleozolic } \\
\text { bedrock and structural complications. }\end{array}$ \\
\hline$\underline{I}$ & $\begin{array}{l}\text { Johnson 0i1 - } \\
\quad \text { \#1 } \\
\text { S. J. Bradshaw. }\end{array}$ & 795 & 804 & 804 & .99 & No major corrections recognized. \\
\hline$\underline{J}$ & $\begin{array}{l}\text { Henderson 011- } \\
\text { \#1 } \quad \text { S. J. Bradshaw. }\end{array}$ & 807 & $804 ?$ & 804 & 1.00 & Do. \\
\hline$\underline{\mathrm{K}}$ & $\begin{array}{l}\text { Henderson ofl - } \\
\# 1 \text { F. B. Carroll. }\end{array}$ & 772 & $784 ?$ & 784 & .98 & Do. \\
\hline$\underline{L}$ & $\begin{array}{l}\text { Henderson Oil - } \\
\text { \#1 A. E. Markham. }\end{array}$ & 680 & 734 & 727 & .94 & Adjusted $-7 \mathrm{~ms}$ because of local structure. \\
\hline$\underline{\mathrm{M}}$ & $\begin{array}{l}\text { Henderson Oil - } \\
\# 1 \text { J. E. Rice. }\end{array}$ & 785 & 796 & 796 & .99 & No major corrections recognized. \\
\hline$\underline{N}$ & Mt. Canmel Drlg.- & 600 & 636 & 636 & .94 & \\
\hline \multicolumn{6}{|c|}{ Florence Smith. } & Do. \\
\hline
\end{tabular}

1 Locations shown on figure 1 , and data plotted on figure 4.

ous to Tertiary sediments may cause spurious structures. In areas of abnormally high velocities, two-way travel times are shorter, resulting in apparent bedrock highs. Likewise, in abnormally low velocity areas, apparent bedrock lows result. The average velocities from the well control data in table 1 (ratios of depth to adjusted travel time) provide evidence that the structures described in this report are not an artifact of velocity changes. The wells with the highest average velocities $(I, J, K$, and $M$ in table 1) are situated in structurally low areas (figs. 1, 3,7 , and 9). This indicates that lateral velocity variations alone cannot account for the structures developed on the bedrock surface.

\section{TIPTONVILLE DOME}

Tiptonville dome is a large positive feature that extends from the west edge of Reelfoot Lake north and northwest to the neck of the New Madrid meander (fig. 3). The axial trace of the dome trends north-northwest from the town of Tiptonville. The dome is bounded on the east by a large structural low that lies directly below Reelfoot Lake, and merges with Ridgely ridge on the south. To the west, the dome grades into a shallow structural low. Northward, the deformation diminishes, and the uplift apparently merges with the normal slope of the embayment.

Reconstructed contours, which project across the warped areas, were drawn in an attempt to model the regional structure prior to any deformation (fig. 5). When compared with the gridded travel times, the reconstructed contours allow the amount of deformation to be estimated and permit uplifted and downwarped areas to be mapped (fig. 5). Gridded data points that clearly lie above or below the surface defined by the reconstructed contours are considered as evidence of tectonic deformation. The two segments of the Lake County uplift, Tiptonville dome and Ridgely ridge, are clearly shown on figure 5 .

As expressed on the Paleozoic bedrock (fig. 5), Tiptonville dome has a maximum east-west dimension of $14 \mathrm{~km}$, has a maximum north-south dimension of slightly more than $11 \mathrm{~km}$, and covers an area of about $95 \mathrm{~km}^{2}$. At the north end of the dome, the $650-\mathrm{ms}$ contour (fig. 3) is deflected to the southeast to a point where the reconstructed contours (fig. 5) suggest that the bedrock should be at about $685 \mathrm{~ms}$. This indicates about $35 \mathrm{~m}$ of uplift. Along profile line $\mathrm{T}-2$, at least $42 \mathrm{~m}$ of uplift can be measured where a $658-\mathrm{ms}$ data point on the grid- 

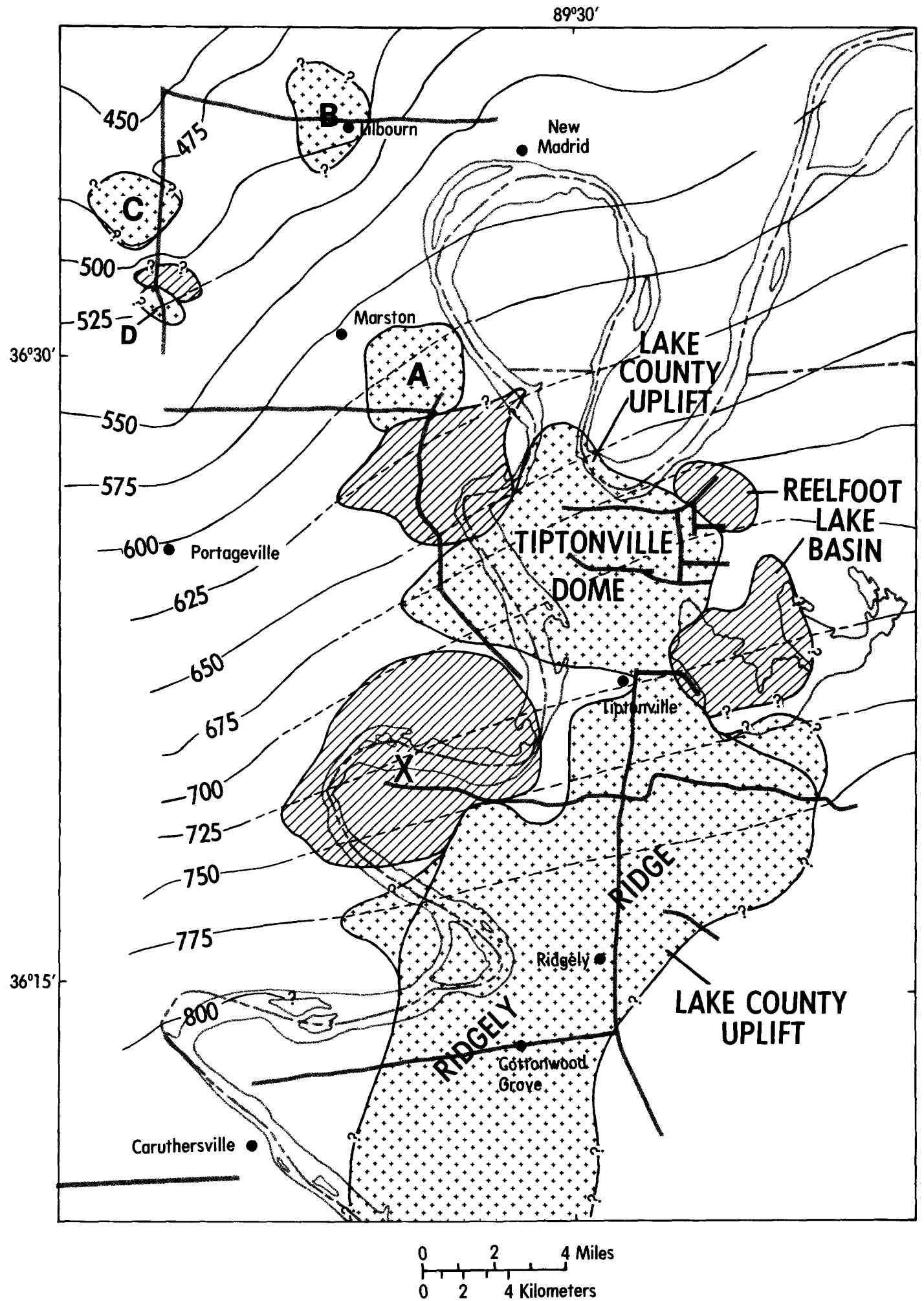

Figure 5.-Areas of deformation on the bedrock surface defined by reconstructed contours. Contour interval, 25 ms; solid where gridded data; dashed where reconstructed contours were projected across deformed areas. Downwarped areas (line pattern) and uplifted areas (stipple pattern) shown; queried where indefinite boundaries. Letters refer to unnamed deformed areas discussed in the text. Reflection profiles shown by heavy screened lines and identified on figure 1. 
ded surface (fig. 3) lies on the 700-ms reconstructed contour. This is the maximum amount of uplift detected on Tiptonville dome.

\section{RIDGELY RIDGE}

Ridgely ridge is a large northeast-southwest-trending uplift that extends from the southern shore of Reelfoot Lake to beyond Cottonwood Grove, Tenn. The ridge is a complex, faulted feature with numerous small intrusives (Zoback and others, 1980). Faulting of Ridgely ridge has produced local areas of high relief on the bedrock surface that are generally oriented northeast-southwest (Zoback and others, 1980). However, several of these areas, indicated by the closed contours in the vicinity of Ridgely and Cottonwood Grove in figure 3, are strongly oriented north-south and east-west. This is probably an inaccurate representation and is most likely due to the strong influence of the north-south gridding pattern upon small structures. Larger features whose orientations are determined by numerous data points are not unduly influenced by the orthogonal patterning of the gridded data.

Ridgely ridge covers more than $260 \mathrm{~km}^{2}$, exceeds $20 \mathrm{~km}$ in length, and is about $11 \mathrm{~km}$ wide. The ridge is bounded on the northeast by Reelfoot Lake basin, on the northwest by a structural low (fig. 5 , feature $\mathrm{X}$ ), and on the north by the Tiptonville dome. On the basis of present data, the southern limit of the uplift is undefined because the ridge extends beyond the data.

Without the reconstructed contours, it is difficult to estimate the amount of uplift that has occurred on Ridgely ridge. However, in some areas, the uplift has been substantial. For example, just southeast of Cottonwood Grove, a closed 750 -ms contour (fig. 3) lies in an area where even a crude projection of the reconstructed contours (fig. 5) would indicate that the bedrock should be at least $800 \mathrm{~ms}$. This means that parts of Ridgely ridge have been elevated at least $50 \mathrm{~m}$.

\section{REELFOOT LAKE BASIN}

Reelfoot Lake basin ${ }^{1}$ (Fisk, 1944; Stearns, 1979) is a topographically low area that is partially occupied by Reelfoot Lake. The origin of the basin is unclear. Various workers believe that it is a tectonic depression produced by faulting (Fuller, 1912; Fisk, 1944; Krinitzsky, 1950), whereas others attribute at least part of the surface depression to compaction and settling of clays (Purdue, 1916; Glenn, 1933; Russ, 1979). The two areas of low bedrock along the east side of Tiptonville dome (fig. 5) appear to be the subsurface equivalents of the surficial Reelfoot Lake basin. The larger depression, covering

${ }^{1}$ Reelfoot Lake basin as discussed here is not the same feature as the Reelfoot basin defined by Schwalb (1969). about $28 \mathrm{~km}^{2}$, lies directly below Reelfoot Lake. This relationship suggests that the location of the lake may be, in part, structurally controlled.

\section{OTHER POSITIVE FEATURES}

Four small areas of elevated bedrock in the northwest portion of the study area are indicated by perturbations in the contour lines. The four areas (fig. 5, features A, B, C, and D) are local features apparently unrelated to the Lake County uplift.

Feature A, directly southeast of Marston, covers about 17 $\mathrm{km}^{2}$ and has been elevated about 7-9 $\mathrm{m}$ above the projected undeformed surface. It is bounded on the south by an area of low bedrock that separates it from the much larger Lake County uplift.

Features B, C, and D are small warped areas probably produced by local faulting and flexing. The limits of these small deformed areas are difficult to accurately define because the areas are based on only a few data points. The amount of warping on these features generally appears to be small, but the exact amount is difficult to estimate because reconstructed contours cannot be confidently projected across the features.

\section{TREND-SURFACE ANALYSES}

Trend-surface analyses are valuable mathematical techniques that identify trends in data sets and isolate the trends from local fluctuations (Merriam and Harbaugh, 1964; Doornkamp, 1972; Davis, 1973). In trend-surface analyses, linear regression of the data produces a series of polynomial equations which describe surfaces that model trends in the data. The higher the order of the polynomial equation, the more complex the surface, and the more accurately the trend surface fits the input data. The trend-surface program used in this study has the maximum capability of fitting a sixth-degree polynomial surface. Residuals, the difference between the input values and the values calculated for the trend surface, can be used for structural interpretations (Merriam and Harbaugh, 1964); they emphasize areas of particularly intense deformation superimposed on the regional trends.

Using the gridded data as input, trend-surface analyses in this study show the regional extent and characteristics of the Lake County uplift, whereas the residuals reveal the local complexities of the Paleozoic bedrock surface. The trend surfaces and residuals are plotted as contour maps (figs. 6-9).

The percentage reduction in the total sum of the squares is a common way of describing how much of the variation of the data can be explained by the regression surface (Merriam and Harbaugh, 1964; Doornkamp, 1972; Davis, 1973). It is similar to the coefficient of determination. Higher percentages indicate better fits; thus, if a trend surface perfectly matches all of the data, the reduction in the total sum of the squares is $\mathbf{1 0 0}$ 


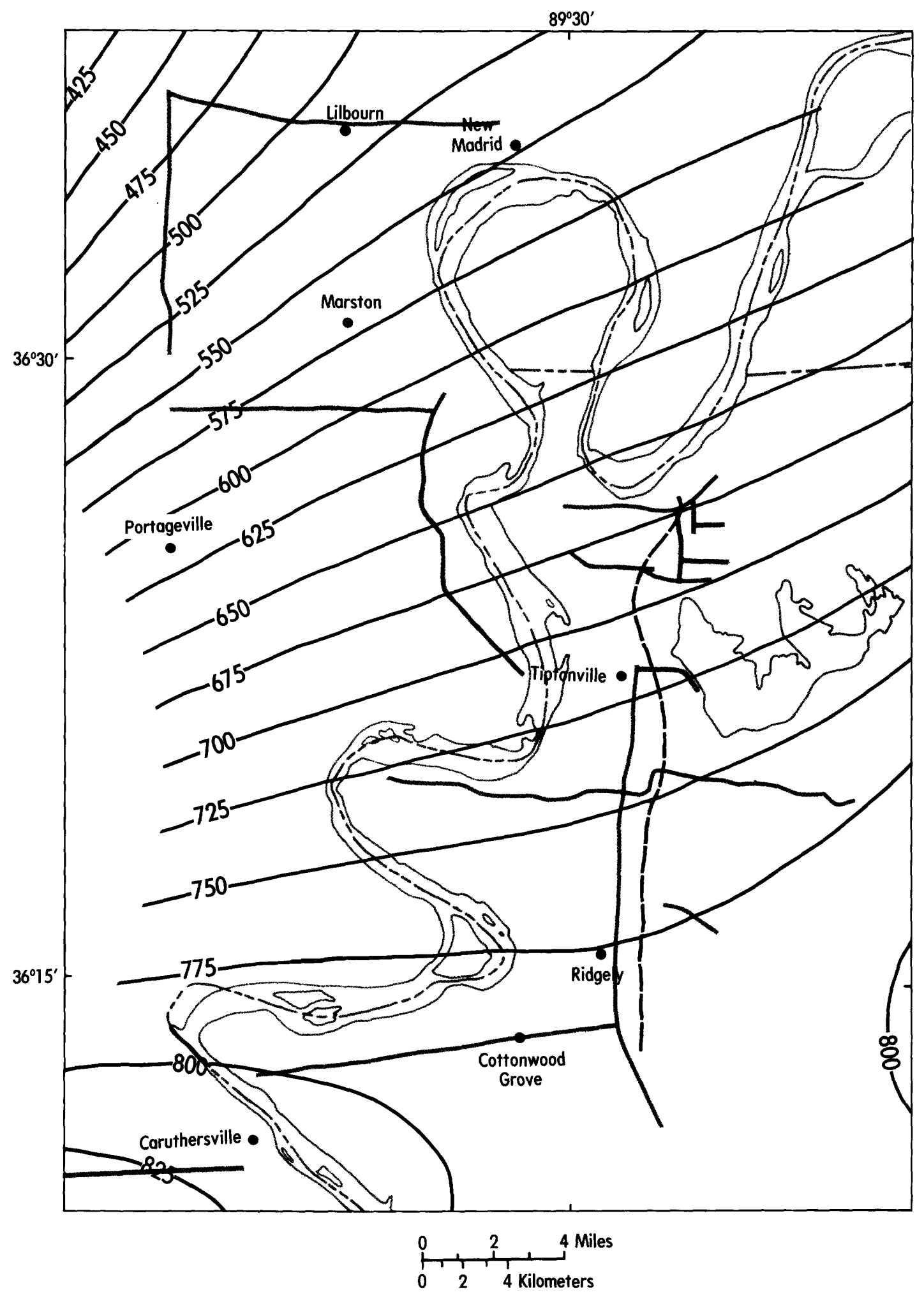

Figure 6.-- Third-degree trend-surface map. Contour interval, $25 \mathrm{~ms}$. Areas of poor data control have not been contoured. Reflection profiles shown by heavy screened lines and identified on figure 1. Axial trace of uplift on third- degree surface indicated by dashed line. 
percent. The percentage reduction in the total sum of the squares for the surfaces generated in this study ranges from a low of 93 percent for the first-degree surface to more than 99 percent for the fifth- and sixth-degree surfaces. These high values show that the surfaces are faithful representations of trends in the data, although, as indicated by the residuals, locally large deviations do exist.

Several mathematical tests are available to determine the statistical significance of a trend surface. Most of the tests require that the input data be normally distributed about the mean (Doornkamp, 1972). Chi-square tests on the original data and on the gridded data indicate that neither set is normally distributed; thus, the statistical significance of the trend surfaces cannot be evaluated using conventional hypothesistesting techniques. Despite this shortcoming, the surfaces are geologically valuable and are useful for detecting patterns and recognizing structural trends.

Severe distortion often occurs at the edges of trend-surface maps because, typically, the periphery of the surface is poorly constrained by data. This distortion is commonly described as "edge effects" (Davis, 1973). The "edge effects" on the trendsurface maps presented here appear to be minimal, with the exception of part of the sixth-degree surface, which will be discussed later.

\section{THIRD-DEGREE TREND SURFACE AND RESIDUALS}

The Mississippi Embayment, when mathematically modeled as a gently plunging syncline, can be most simply described by a third-degree polynomial equation. In the ideal model, contours of the Paleozoic bedrock surface in the study area would be slightly convex to the north or northwest (fig. 2). Areas where the configuration of the bedrock surface deviate significantly from this model are assumed to have been structurally disturbed. An analysis of the third-degree trend surface can make these deviations obvious.

A prominent positive feature that corresponds to the Lake County uplift is defined by deflected contours that are convex to the south-southeast; it is apparent on the third-degree trend surface (fig. 6). On the basis of these deflected contours, the uplift can be seen to extend from south of Ridgely, where the deformation is most pronounced, to north of Tiptonville. The 675-ms contour north of Tiptonville has been deflected, indicating deformation, but the 600-ms contour and those farther north are slightly convex to the northwest, indicating little or no detectable deformation. The available data fail to define the southern limit of the uplift, although the break in the 800-ms contour suggests that it extends at least as far as the southernmost data points.

The crest of the uplift can be roughly located by connecting the point of maximum southward deflection for each contour line (fig. 6). The overall trend of the crest is generally northsouth.

A contour map of the third-degree surface residuals (fig. 7) shows that the Lake County uplift can be divided into Tiptonville dome to the north and Ridgely ridge to the south. These two features are separated by an east-west saddle that lies under the town of Tiptonville.

On the basis of the residuals, the highest point of Tiptonville dome lies about $4 \mathrm{~km}$ north of Tiptonville and rises about $31 \mathrm{~m}$ above the computed trend surface. Three arms radiate out from this high point: one arm extends to the northeast, a second arm trends north-northwest toward the neck of the New Madrid meander, and a third arm strikes directly west toward drill hole $C$.

The eastern boundary of Tiptonville dome is marked by north-south- striking contours that separate the uplifted area from a large low area, the Reelfoot Lake basin. The basin extends from near the Mississippi River to beneath the western portion of Reelfoot Lake. As previously discussed, the location of the lake within an area of low bedrock suggests possible structural control. The boundary between Tiptonville dome and Reelfoot Lake basin that is suggested by the contours closely coincides with the location, orientation, and sense of movement of the Reelfoot fault defined by Zoback (1979). Apparently some parts of the Lake County uplift are fault bounded.

Ridgely ridge, the segment of the Lake County uplift that extends southwesterly from the southern end of Reelfoot Lake, is a complex feature with a highly irregular bedrock surface (fig. 7). The ridge is actually a system of northeast-southwesttrending structures (Zoback and others, 1980) that locally have as much as $40 \mathrm{~m}$ of relief. The irregularity of the bedrock surface is obvious from the numerous small, closed contours of positive and negative residuals in figure 7, especially near the towns of Ridgely and Cottonwood Grove. As already noted, the north-south and east-west orientations of the closed contours are probably artifacts of the gridding process; they do not represent the true orientation of these structures.

\section{SIXTH-DEGREE TREND SURFACE AND RESIDUALS}

The sixth-degree trend surface represents the most accurate model of the Paleozoic bedrock surface produced by the study (fig. 8). The Lake County uplift, indicated by deflected contours, is shown as a prominent north- northeast-trending feature. North of Tiptonville it is a broad, low-amplitude structure. To the south near Ridgely, it increases in amplitude, becomes very clearly defined, and is bounded on both the east and west by areas of low bedrock. The southern end of the uplift cannot be firmly established. 


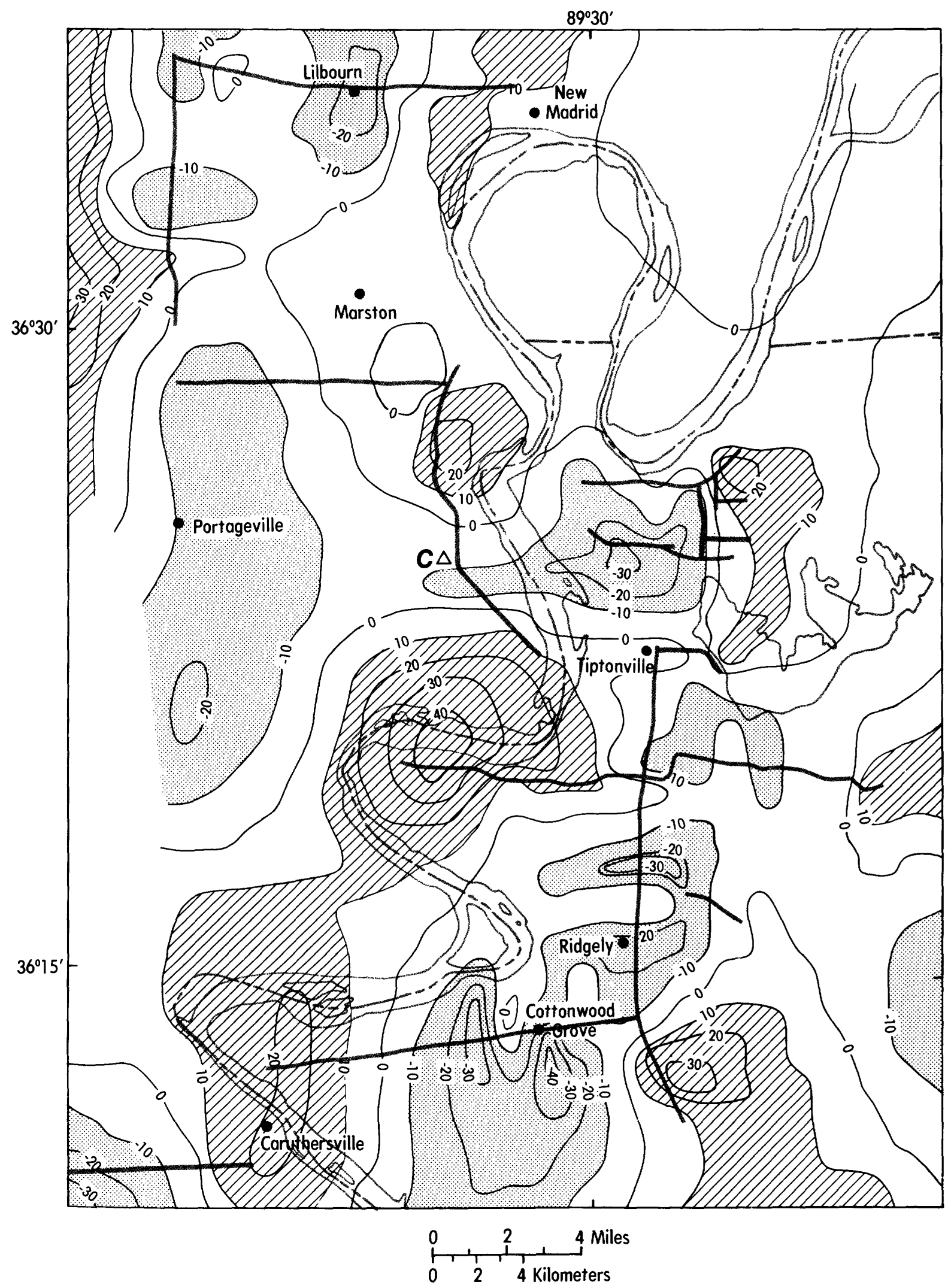

Figure 7.-Contour map of third-degree trend-surface residuals. Contour interval, $10 \mathrm{~ms}$. Negative residuals lie above and positive residuals lie below the trend surface. Areas with residuals less than $-10 \mathrm{~ms}$ shown by stipple pattern; areas with residuals greater than +10 ms shown by line pattern. Reflection profiles shown by heavy screened lines and identified on figure 1 . Triangle is New Madrid test well (drill hole $C$, table 1). The outline of Lake County uplift, Tiptonville dome, Ridgely ridge, and Reelfoot Lake basin are shown on figure 5 . 
When compared with the third-degree surface (fig. 6), the axial trace of the uplift, interpreted from the sixth-degree surface, is rotated slightly to the northeast (fig. 8). Even though deflections in the contours suggest that the axial trace could be extended (fig. 8), it has not been projected north of the river because of the lack of control from reflection profiles in the entire northeast quadrant of the study area.

The western edge and the extreme southeastern corner of the sixth-degree trend surface are distorted by "edge effects." The apparent north-south- trending high area just west of Portageville is, most likely, artificially introduced by the trend program, because the trend surface in this area is not controlled by any data points. Likewise, the gradient indicated by the 775-ms contour in the extreme southeast corner of the map is not constrained by data points and is probably inaccurate.

The contour map of the sixth-degree residuals (fig. 9) is very similar to that for the third-degree surface. Tiptonville dome is separated from Ridgely ridge by a conspicuous saddle located beneath the town of Tiptonville. The saddle breaches the uplift and connects the Reelfoot Lake basin on the east with another low area under the Mississippi River, southwest of Tiptonville.

The characteristics of Ridgely ridge shown by the sixthdegree residuals are virtually the same as those shown by the third-degree residuals. Despite the increased capability of the sixth-degree surface to model complicated surfaces, numerous negative and positive residuals (areas of high and low bedrock) still exist along the ridge. Once again, this demonstrates the complex character of this portion of the uplift. Most of these anomalies cover such small areas that they cannot be reasonably accommodated by any trend surface.

\section{DISCUSSION}

The Lake County uplift is a clearly defined positive feature covering about $367 \mathrm{~km}^{2}$ on the Paleozoic bedrock surface. Portions of the uplift have been elevated more than $50 \mathrm{~m}$ above the reconstructed, undeformed surface. In some areas the uplift is probably bounded by faults, but, as seen on the seismic profiles (see the western part of S-6 in Hamilton and Zoback, this volume, fig. 13), in many places the vertical movements have simply flexed the bedrock surface without any evidence of substantial breaks.

The general shape, orientation, and areas of maximum uplift on the bedrock surface are similar to the ground-surface uplift documented by Russ (this volume), suggesting that the two features are genetically related (fig. 10). Furthermore, both Tiptonville dome and Ridgely ridge are distinct, recognizable features on the ground surface and in the subsurface. The areas of maximum ground deformation are nearly coincident with the crest of the Lake County uplift as defined by both the third- and sixth-degree trend-surface analyses. This relationship is especially striking when the axial trace of the third-degree surface is compared with the $30-\mathrm{ft}$ contour of Russ on Tiptonville dome and with his $20-\mathrm{ft}$ contour on
Ridgely ridge immediately northeast of Ridgely. The comparison for the sixth-degree surface is not quite as strong; nevertheless, the similarity is still obvious.

In several areas the surface and subsurface characteristics of the Lake County uplift are noticeably different. One or more of the following factors contribute to these differences: (1) resolution of the surface data is considerably better than that of the seismic-reflection data, (2) all of the subsurface deformation may not propagate through the unconsolidated sediments to the ground surface, (3) the morphology of the surface feature is subject to modification by erosional and depositional processes, and (4) subsurface deformation that predates the development of the modern meander belt will not be mirrored on the ground surface. Careful analysis of the effects of these factors provides insight into the evolution of the uplift.

The surface uplift can be accurately defined using modern topographic maps (Russ, this volume); by comparison, the subsurface feature is defined by much less precise data. Reading errors of several milliseconds and gridding the twoway travel times reduce the resolution of the reflection data to perhaps $\pm 3 \mathrm{~m}$. As a result, slightly deformed areas in the subsurface may escape unnoticed while equally deformed areas on the ground surface can be recognized.

Before it warps the ground surface, deformation of the Paleozoic bedrock in the upper embayment must propagate through approximately $600 \mathrm{~m}$ of unconsolidated sediment. Soft-sediment flowage, slumping, and compaction may compensate for much of the bedrock deformation; perhaps only 20 percent of the subsurface warping is actually expressed on the ground surface (Russ, this volume). This would produce a significantly smaller surface uplift with much less relief than the corresponding subsurface feature.

The surface expression of the Lake County uplift is subject to rapid modification by various geomorphic processes, the most important of which is probably erosion and deposition by the Mississippi River. Older portions of the surface feature may have been partially eroded or otherwise obscured by the river, whereas younger portions, essentially unmodified, can be easily recognized by their prominent scarps or other geomorphic characteristics (Russ, this volume). Thus, areas of old uplift may be detectable in the subsurface but have been destroyed or concealed on the ground surface.

The warped Paleozoic bedrock examined in this study records the cumulative deformation that has occurred on the Lake County uplift since the weathered bedrock surface was buried by sediments of Late Cretaceous age more than $65 \mathrm{~m}$.y. ago. By comparison, the deformation recorded on the ground surface has occurred only within the past 6000 years, since the development of the Mississippi River meander belt (Saucier, 1974). Thus, considerably more deformation than is actually recorded on the modern ground surface, perhaps encompassing an even larger area, may have occurred on the bedrock surface.

The northern portion of the Lake County uplift defined by Russ (this volume) covers a considerably larger area than the 


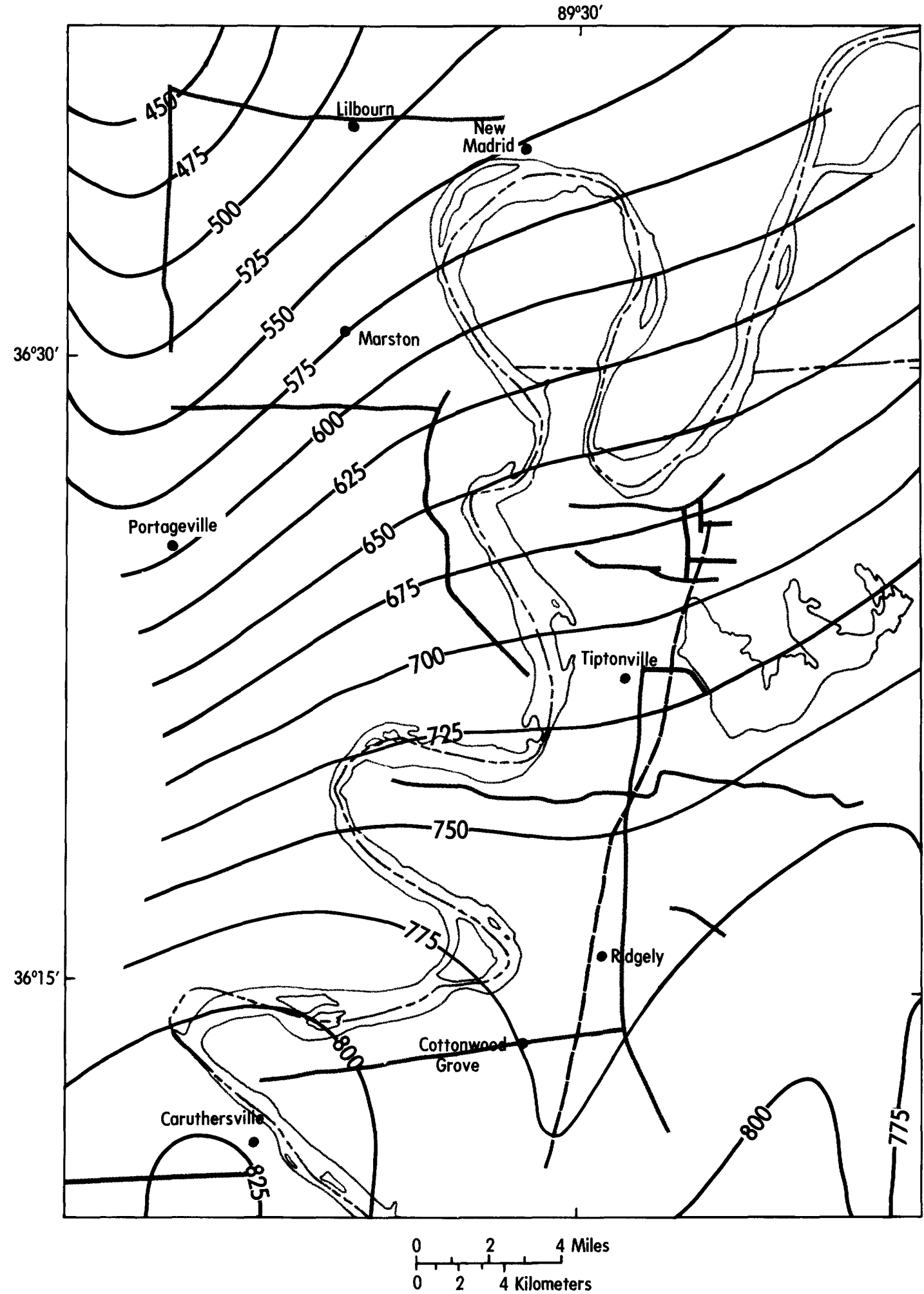

FiguRE 8. - Sixth-degree trend-surface map. Contour interval, $25 \mathrm{~ms}$. Areas of poor data control have not been contoured. Reflection profiles shown by heavy screened lines and identified on figure 1. Axial trace of uplift on sixth- degree surface indicated by dashed line. 
corresponding uplift on the bedrock surface (fig. 10). Most of the discrepancy in area occurs where the ground surface has been only slightly elevated; poor resolution of the subsurface data appears to be primarily responsible for this discrepancy. In the area directly north of Tiptonville where the ground has been elevated at least $15 \mathrm{ft}$, the surface and subsurface uplifts agree fairly well. The match between the surface and subsurface features would probably improve if the resolution of the subsurface data could be increased by reducing the inherent uncertainties and if the northern limits of the subsurface uplift could be more accurately defined by additional profile lines.

The topographic expression of Ridgely ridge is generally restricted to the area east of the town of Ridgely; a large area of warped bedrock west of the town of Ridgely has essentially no surface expression (fig. 10). The absence of surface deformation above warped bedrock may have three possible explanations: (1) soft-sediment deformation and compaction in the Cretaceous and Tertiary sediments may have effectively masked part of the subsurface uplift, (2) the surface feature may have been partially eroded by the Mississippi River, or (3) only the eastern portion of the subsurface uplift may have been tectonically active in the last 6000 years.

It is unlikely that compaction and soft-sediment deformation are entirely responsible for the limited extent of Ridgely ridge on the ground surface. If soft-sediment processes were solely responsible, then the surface feature, even though subdued, should generally mimic the subsurface feature and the topographically highest areas should correspond to the areas of maximum uplift on the bedrock. In fact, the residual maps from this study (figs. 7 and 9) show that this is not true. For example, the ground surface near Cottonwood Grove has been elevated less than $5 \mathrm{ft}$ (fig. 10), while the residuals suggest that the underlying bedrock has been elevated at least $40 \mathrm{~m}$ (fig. 7). It might be argued that the amount of soft-sediment compaction and deformation is not uniform everywhere and that perhaps nearly all of the subsurface uplift near Cottonwood Grove has been absorbed by the sediments. The nonuniformity of soft-sediment processes is certainly true on a small scale, but for a feature as large as the one considered here and for a column of sediments exceeding $600 \mathrm{~m}$ in thickness, the local variations should equalize and the amount of compaction and deformation should be nearly uniform. Because soft-sediment processes cannot completely account for the limited size of the surface feature, other factors must be involved.

Partial erosion of Ridgely ridge by modern and ancient Mississippi River courses also fails to entirely explain the limited size of the surface uplift. In his classic study of the Mississippi River meander belt, Fisk (1944) showed that the former channels which traverse Ridgely ridge belong to several of the older stages of the meander belt. There is no evidence from his work, however, that a more recent course of the river has eroded the western portion of the surface uplift and left the eastern portion as the remnant of a larger topographic feature.

The best explanation for the size difference between the surface and subsurface uplifts is that different portions of the uplift have been tectonically active at different times. Careful interpretation of the reflection profiles by Zoback and others (1980) shows that, on the bedrock surface, Ridgely ridge is a broad, complex, northeast-trending arch broken by numerous faults that run subparallel to the trend of the arch. This northeast orientation of Ridgely ridge is consistent with the orientation suggested by the trend-surface residuals (figs. 7 and 9). The surface warping (fig. 10) is essentially coincident with several of the faults discussed by Zoback and others (1980). Recurrent movement has been demonstrated on several faults in the New Madrid area (Zoback, 1979; Zoback and others, 1979) and on other faults in the Eastern United States (Ratcliffe, 1971; Mixon and Newell, 1977). Thus it is plausible that parts of the uplift may have been tectonically active for a period of time and then have become temporarily quiescent. If this is true, the eastern part of Ridgely ridge may have been uplifted and tectonically active in the past 6000 years, thus warping the modern ground surface, while deformation of the western part may have occurred much earlier. The patterns of modern seismicity around Ridgely ridge show a broad, irregular distribution of epicenters (fig. 11) that neither confirms nor refutes this hypothesis.

The exact reason why the topographic expression of Ridgely ridge is small compared to the subsurface feature is still not completely clear, but localized tectonic movements offer the simplest explanation. Geomorphic and sedimentologic processes cannot solely account for the size difference between the surface and subsurface feature, suggesting that the area of elevated ground east of Ridgely must have been produced by tectonic processes.

Reelfoot Lake and the Reelfoot Lake basin (Stearns, 1979) are two other physiographic features that may also reflect bedrock warping. Reelfoot Lake basin is a topographic depression whose origin has been explained by both tectonic and nontectonic processes. The bedrock contour map (fig. 3) and the treud-surface-residual maps (figs. 7 and 9) all show a depression on the bedrock surface that lies directly beneath the topographic depression. Reelfoot Lake basin lies on the downthrown block of the Reelfoot fault, which has experienced recurrent movement since the the Late Cretaceous (Zoback, 1979) and may have moved several times in the Holocene (Russ, 1979). After movement along the fault, Reelfoot Lake basin would be tectonically depressed, producing an area of relatively low ground where drainages could be disrupted and ponding could occur. Within this relatively low area, fine-grained sediments may have preferentially ac- 


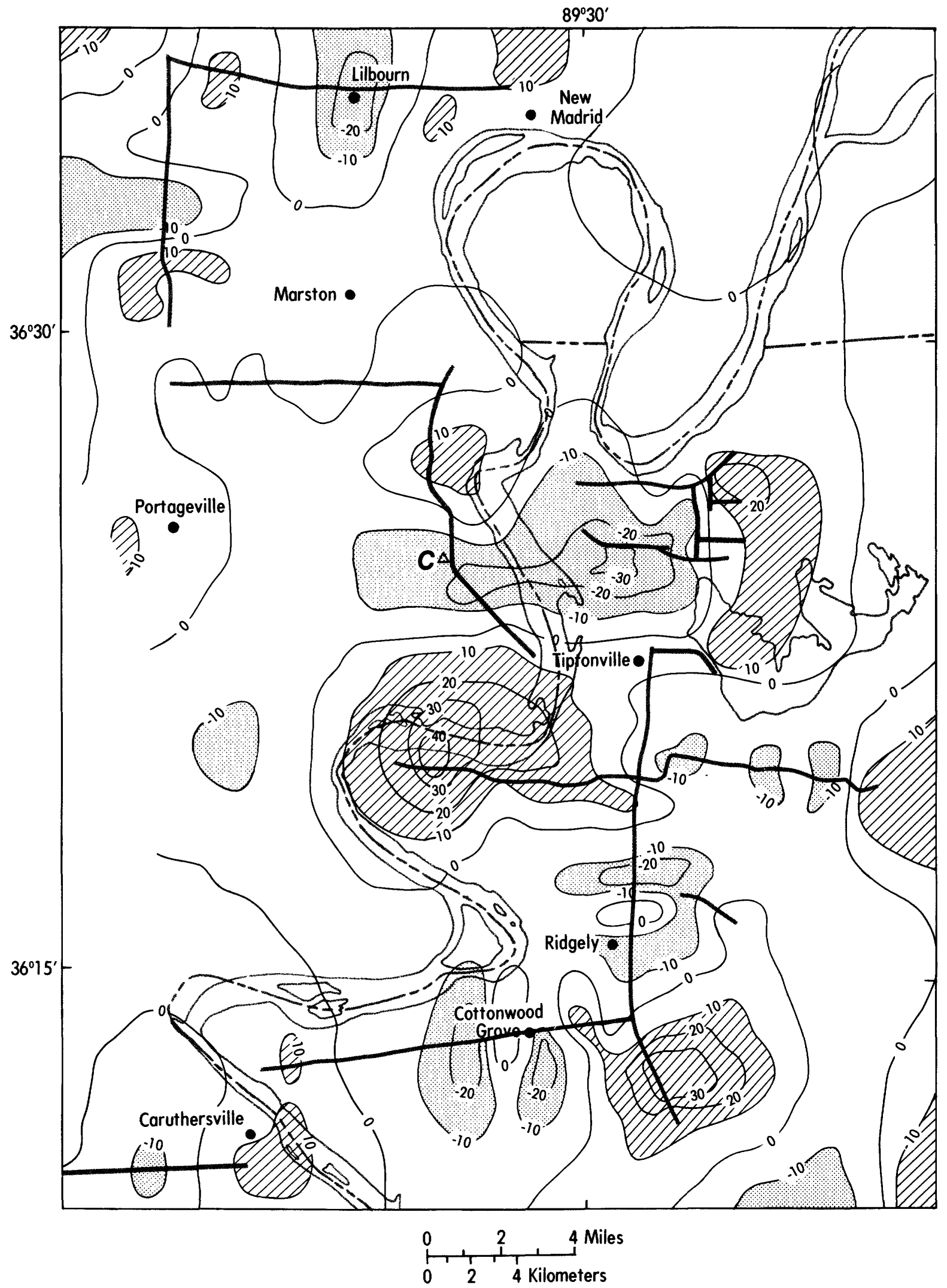

Figure 9. - Contour map of sixth-degree trend-surface residuals. Contour interval, 10 ms. Negative residuals lie above and positive residuals lie below the trend surface. Areas with residuals less than $-10 \mathrm{~ms}$ shown by stipple pattern; areas with residuals greater than $+10 \mathrm{~ms}$ shown by line pattern. Reflection profiles shown by heavy screened lines and identified on figure 1. Triangle is New Madrid test well (drill hole $C$, table 1). The outline of Lake County uplift, Tiptonville dome, Ridgely ridge, and Reelfoot Lake basin are shown on figure 5 . 
cumulated owing to one of two mechanisms. In the Holocene, when the Mississippi River adopted a meandering regime, the presence of a relatively low area could have influenced the river to occupy the Reelfoot Lake basin more frequently and deposit thick plugs of channel-filling clays (Saucier, 1964). Alternatively, the low area may have simply provided a favorable site where large quantities of overbank silts and clays could collect. Any thick accumulations of fine-grained sediment would be susceptible to settling and compaction, particularly during the periods of intense ground motion produced by major seismic events. Thus, under these circumstances, the ground surface in the basin could have subsided without any associated tectonic movements.

Historical accounts and field evidence indicate that Reelfoot Lake, the major physiographic feature in the basin, was enlarged during the 1811-12 earthquakes (Russ, this volume). However, there is conflicting evidence about movement on the Reelfoot fault having occurred at that time (Fuller, 1912, p. 58; Russ, 1979). If movement on the Reelfoot fault did occur during the 1811- 12 events, then the enlargement of Reelfoot Lake was tectonically induced. From the evidence available, it is unclear whether the lake enlargement was due entirely to compaction or to faulting; both processes most likely contributed.

In recent years increased instrumentation has firmly established the patterns of seismicity in the upper Mississippi Embayment and defined the major trends (Stauder and others, 1976; Stauder, this volume). Most of the earthquakes occur in three major zones: (1) a northeast-southwest linear trend that extends from northeastern Arkansas to Ridgely, Tenn.; (2) a broad zone of intense seismicity that trends north-northwest from near Ridgely toward Lilbourn, Mo.; and (3) a second northeast-southwest linear trend, subparallel to the first, which extends from near Lilbourn to the northeast. Focalmechanism solutions for the two linear northeast-southwest zones of seismicity indicate predominantly right-lateral strikeslip movement (Herrmann and Canas, 1978; Herrmann, 1979; O'Connell and others, this volume); solutions for the broad zone between Ridgely and Lilbourn are poorly constrained and variable, but mainly indicate reverse-fault movements.

The major tectonic element in the upper Mississippi Embayment is believed to be a northeast-trending rift, possibly of Precambrian age (Ervin and McGinnis, 1975), whose existence has been supported by Hildenbrand and others (1977, this volume) on the basis of gravity and magnetic data. Hildenbrand and others (this volume) believe that much of the modern seismicity is associated with ancient zones of crustal weakness produced by extensive faulting along the axis and margins of the rift. Some of these weak zones may have been reactivated by the contemporary east-west compressional stress field (Sbar and Sykes, 1973), producing strike-slip movement along formerly extensional features (Hildenbrand and others, this volume). Also, these weak zones may have acted as conduits for Paleozoic and Mesozoic intrusive igneous rocks (Hildenbrand and others, this volume), which have been rec- ognized throughout the embayment (Zoback and others, 1980).

The precise causes of the Lake County uplift are, at present, unknown, although geologic, geophysical, and seismic studies are continuing to clarify the seismotectonic framework of the New Madrid region. The close spatial relationship between the current seismicity and the areal extent of the Lake County uplift (fig. 11) suggests that the forces responsible for the earthquakes are also producing the uplift. Therefore, an improved knowledge of the contemporary stress field is essential to understanding the origin of the uplift.

Russ (this volume) offers a model for the origin of the Lake County uplift that is consistent with both the local and regional geologic and geophysical data and with the faultplane solutions. The model essentially proposes that the Lake County uplift has developed within an area of compression caused by a major bend in a strike-slip fault system. Within the area of compression, strain has caused vertical bulging that has produced the observed uplift on the bedrock and the ground surface.

Evidence from surface and subsurface studies shows that different portions of the Lake County uplift have been tectonically active at different times. Sharp scarps and high topographic relief indicate that Tiptonville dome has been active most recently (Russ, this volume); historical accounts suggest that parts of the dome may have been elevated during the 1811-12 New Madrid earthquakes. The eastern portion of Ridgely ridge between the town of Ridgely and the southern end of Reelfoot Lake was uplifted within the past 6000 years but, based on geomorphic evidence, is apparently older than Tiptonville dome. This study suggests that the oldest part of the Lake County uplift is the western portion of Ridgely ridge, where the Paleozoic bedrock was deformed more than 6000 years ago, prior to the development of the modern Mississippi River meander belt.

The extensive modern seismicity in the area of the uplift and the similar characteristics of the deformation on the ground surface and on the bedrock surface indicate that the stresses which produced the Lake County uplift still exist today. Furthermore, if different portions of the uplift have been tectonically active at different times in the past, then apparently the stresses responsible for the seismicity shift with time. Improved knowledge of the geologic and seismotectonic framework of the upper Mississippi Embayment will help to determine where and how the stresses accumulate and how they are released, thus providing a more accurate and realistic assessment of seismic hazards in the area.

\section{ACKNOWLEDGMENTS}

We would like to acknowledge the many beneficial discussions with D. P. Russ, R. M. Hamilton, D. M. Perkins, and other colleagues at the U.S. Geological Survey. Reviews by L. E. Cordell and R. L. Wheeler provided valuable suggestions to improve the clarity of the manuscript. 


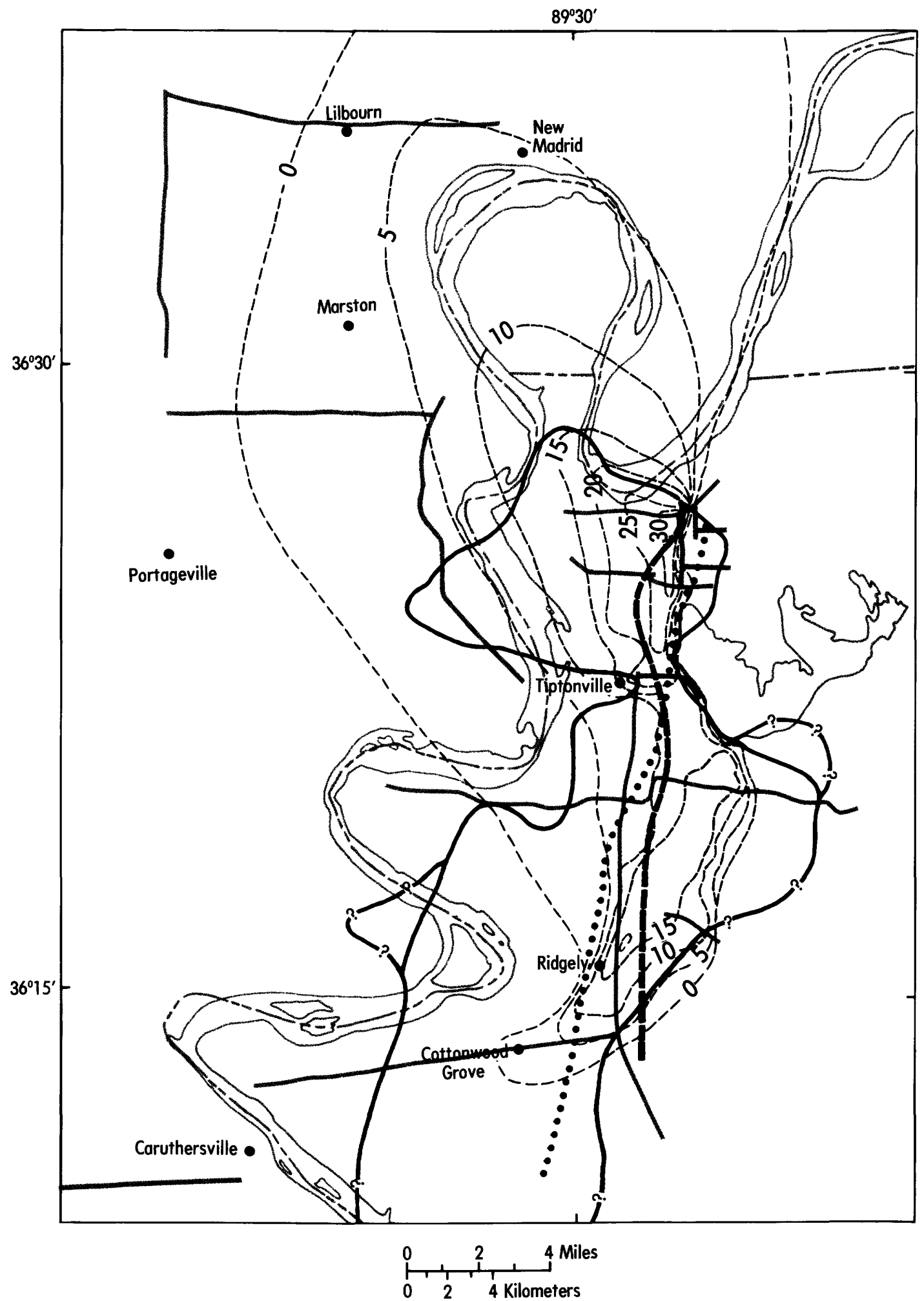

Figure 10. - Comparison of ground-surface deformation (dashed contours, in feet) and bedrock deformation of the Lake County uplift (solid line; queried where uncertain). Ground-surface deformation modified from Russ (this volume). Axial trace of uplift from third-degree trend surface (heavy dashed line) and from sixth-degree trend surface (dotted line). Reflection profiles shown by heavy screened lines and identified on figure 1 . The outline of the Lake County uplift, Tiptonville dome, Ridgely ridge, and Reelfoot Lake basin are shown on figure 5 . 


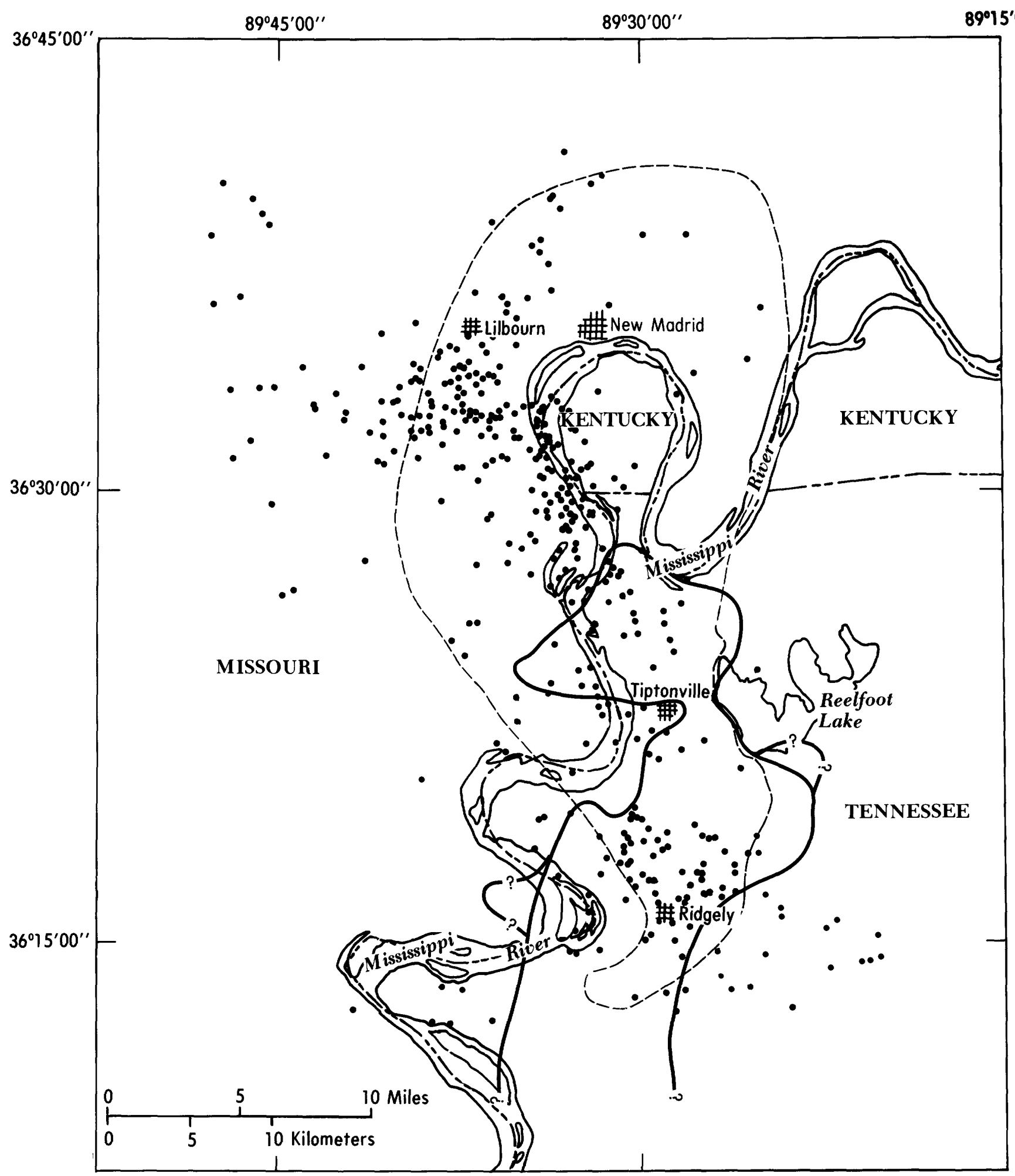

FIGURE 11.- Comparison of seismicity with ground-surface and bedrock-surface deformation in the area of the Lake County uplift. Dots show locations of microseismic events recorded by the Saint Louis University network between July 1, 1974, and June 30, 1978 (modified from Stauder, this volume). Dashed line shows the limit of ground-surface deformation (modified from Russ, this volume); heavy line shows limit of bedrock-surface deformation, queried where indefinite. 


\section{REFERENCES CITED}

Bond, D. C., Atherton, Elwood, Bristol, H. M., Buschbach, T. C., Steven son, D. L., Becker, L. E., Dawson, T. A., Fernalld, E. C., Schwalb, Howard, Wilson, E. N., Statler, A. T., Stearns, R. G., and Buehner, J. H., 1971, Possible future petroleum potential of region 9--Illinois basin, Cincinnati arch, and northern Mississippi embayment, in Crum, 1. H., ed., Future petroleum provinces of the United States- Their geology and potential: American Association of Petroleum Geologists Memoir 15, v. 2, p. 1165-1218.

Born, K. E., 1935. Notes on the Upper Cretaceous and Tertiary sub-surface stratigraphy of western Tennessee: Tennessee Academy of Science Journal, v. 10, p. 248-264.

Boswell, E. H., Moore, G. K., MacCary, L. M., and others, 1965, Cretace ous aquifers in the Mississippi embayment: U.S. Geological Survey Professional Paper 448-C, 37 p.

Briggs, 1. C., 1974, Machine contouring using minimum curvature Geophysics, v. 39, no. 1, p. 39-48.

Caplan, W. M., 1954, Subsurface geology and related oil and gas possibilities of northeastern Arkansas: Arkansas Resources and Development Commission, Division of Geology Bulletin 20, I24 p.

Crone, A. J., and Russ, D. P., 1979, Preliminary report on an exploratory drill hole - New Madrid test well-1-X in southeast Missouri: U.S. Geological Survey Open-File Report 79-1216, 12 p.

Cushing, E. M., Boswell, E. H., and Hosman, R. L., 1964, General geology of the Mississippi embayment: U.S. Geological Survey Professional Paper 448-B, 28 p.

Davis, J. C., 1973 [1974], Statistics and data analysis in geology: New York, John Wiley and Sons, lnc., $550 \mathrm{p}$.

Davis, R. W., Lambert, T. W., and Hansen, A. J., Jr., 1973, Subsurface geology and ground-water resources of the Jackson Purchase region, Kentucky: U.S. Geological Survey Water-Supply Paper 1987, 66 p.

Doornkamp, J. C., 1972, Trend-surface analysis of planation surfaces, with an East African case study, in Chorley, R. J., ed., Spatial analysis in geomorphology: New York, Harper and Row, p. 247-281.

Ervin, C. P., and McGinnis, L. D., 1975, Reelfoot rift -- Reactivated precursor to the Mississippi embayment: Geological Society of America Bulletin, v. 86, p. 1287-1295.

Finch, W. 1., 1971, Geologic map of part of the Bondurant quadrangle, Fulton County, Kentucky, and New Madrid and Mississippi Counties, Missouri: U.S. Geological Survey Geologic Quadrangle Map GQ-944, scale $1: 24,000$.

Fisk, H. N., 1944, Geological investigation of the alluvial valley of the lower Mississippi River: Vicksburg, Mississippi River Commission, 78 p.

Freeman, L. B., 1953, Regional subsurface stratigraphy of the Cambrian and Ordovician in Kentucky and vicinity: Kentucky Geological Survey Bulletin 12, ser. 9, $352 \mathrm{p}$.

Fuller, M. L., 1912, The New Madrid earthquake: U.S. Geological Survey Bulletin 494, 119 p.

Glenn, L. C., 1933, The geography and geology of Reelfoot Lake: Ten nessee Academy of Science Journal, v. 8, no. 1, p. 3-12.

Grohskopf, J. G., 1955, Subsurface geology of the Mississippi embayment of southeast Missouri: Missouri Geological Survey and Water Resources, ser. 2, v. 37,133 p.

Hamilton, R. M., and Zoback, M. D., 1979, Seismic reflection profiles in the northern Mississippi embayment: U.S. Geological Survey Open-File Report 79-1688, 8 p., 25 pls.

Herrmann, R. B., 1979, Surface wave focal mechanism for eastern North American earthquakes with tectonic implications: Journal of Geophysical Research, v. 84, B-7, p. 3542-3552.

Herrmann, R. B., and Canas, J. A., 1978, Focal mechanism studies in the New Madrid seismic zone: Bulletin of the Seismological Society of America, v. 68 , no. 4, p. 1095-1102.
Hildenbrand, T. G., Kane, M. F., and Stauder, William, 1977. Magnetic and gravity anomalies in the northern Mississippi embayment and their spatial relation to seismicity; U.S. Geological Survey Miscellaneous Field Studies Map MF-914, 2 sheets.

Krinitzsky, E. L., 1950, Geological investigation of faulting in the lower Mississippi Valley: U.S. Army Corps of Engineers Waterways Experiment Station, Technical Memorandum 3-311, 91 p.

Marcher, M. V., and Stearns, R. G., 1962, Tuscaloosa formation in Tennessee: Geological Society of America Bulletin, v. 73, p. 1365-1386.

McGee, W. J., 1892, A fossil earthquake [abs.]: Geological Society of America Bulletin, v. 4, p. 411-414.

Merriam, D. F., and Harbaugh, J. W., 1964, Trend-surface analysis of regional and residual components of geologic structure in Kansas: Kansas State Geological Survey Special Distribution Publication 11, 27 p.

Mixon, R. B., and Newell, W. L., 1977, Stafford fault system--Structures documenting Cretaceous and Tertiary deformation along the Fall Line in northeastern Virginia: Geology, v. 5, p. 437-440.

Murray, G. E., 1961 [1962], Geology of the Atlantic and Gulf coastal province of North America: New York, Harper \& Brothers, $692 \mathrm{p}$.

Potter, P. E., 1955, The petrology and origin of the Lafayette gravel, pt. 2, Geomorphic history: Journal of Geology, v. 63, no. 2, p. 115-132.

Pryor, W. A., 1960, Cretaceous sedimentation in upper Mississippi embayment: American Association of Petroleum Geologists Bulletin, v. 44, no. 9, p. 1473-1504.

Purdue, A. H., 1916, Oil and gas conditions in the Reelfoot Lake district of Tennessee: Tennessee Geological Survey, Resources of Tennessee, v. 6 , p. 17-36.

Ratcliffe, N. M., 1971, The Ramapo fault system in New York and adjacent northern New Jersey - A case of tectonic heredity: Geological Society of America Bulletin, v. 82 , p. 125-142.

Roberts, J. K., and Gildersleeve, Benjamin, 1950, Geology and mineral resources of the Jackson Purchase region, Kentucky: Kentucky Geological Survey Bulletin 4, ser. 9, 114 p.

Russ, D. P., 1979, Late Holocene faulting and earthquake recurrence in the Reelfoot Lake area, northwestern Tennessee: Geological Society of America Bulletin, v. 90, p. 1013-1018.

Russell, E. E., and Parks, W. S., 1975, Stratigraphy of the outcropping Ueper Cretaceous, Paleocene, and lower Eocene in western Tennessee (including descriptions of younger fluvial deposits): Tennessee Division of Geology Bulletin 75, $118 \mathrm{p}$.

Saucier, R. T., 1964, Geological investigation of the St. Francis basin: U.S. Army Corps of Engineers Waterways Experiment Station, Technical Report 3-659.

1974, Quaternary geology of the lower Mississippi valley: Arkansas Archeological Survey Research Series 6, $26 \mathrm{p}$.

Sbar, M. L., and Sykes, L. R., 1973, Contemporary compressive stress and seismicity in eastern North America-And an example of intra-plate tectonics: Geological Society of America Bulletin, v. 84, p. 1861-1882.

Schwalb, H. R., 1969, Paleozoic geology of the Jackson Purchase region, Kentucky, with reference to petroleum possibilities: Kentucky Geological Survey, ser. 10, Report of lnvestigations 10, $40 \mathrm{p}$.

Stauder, William, Kramer, Mark, Fischer, Gerard, Schaeffer, Stephen, and Morrissey, S. T., 1976, Seismic characteristics of southeast Missouri as indicated by a regional telemetered microearthquake array: Seismological Society of America Bulletin, v. 66, no. 6, p. 1953-1964.

Stearns, R. G., 1957, Cretaceous, Paleocene and lower Eocene geologic history of the northern Mississippi embayment: Geological Society of America Bulletin, v. 68, p. 1077-1100.

1979, Recent vertical movement of the land surface in the Lake County uplift and Reelfoot Lake basin areas, Tennessee, Missouri and Kentucky: U.S. Nuclear Regulatory Commission, NUREG/CR-0874, $37 \mathrm{p}$. 
Stearns, R. G., and Marcher, M. V., 1962, Late Cretaceous and subsequent structural development of the northern Mississippi embayment area: Geological Society of America Bulletin, v. 73, p. 1387-1394.

Stearns, R. G., and Wilson, C. W., Jr., 1972, Relationship of earthquakes and geology in west Tennessee and adjacent areas: Knoxville, Tenn., Tennessee Valley Authority, 302 p.

Stearns, R. G., and Zurawski, Ann, 1976, Post-Cretaceous faulting in the head of the Mississippi embayment: Southeastern Geology, v. 17, no. 4 , p. 207-229.

Usher, F. C., 1837, On the elevation of the banks of the Mississippi, in 1811: American Journal of Science, v. 31, p. 294-296.

Zoback, M. D., 1979, Recurrent faulting in the vicinity of Reelfoot Lake, northwestern Tennessee: Geological Society of America Bulletin, v. 90 , p. 1019-1024.

Zoback, M. D., Hamilton, R. M., Crone, A. J., Russ, D. P., and Brockman, S. R., 1978, Seismic reflection profiling to delineate tectonic features of the New Madrid seismic region [abs.]: Seismological Society of America Earthquake Notes, Eastern Section, v. 49, no. 4, p. 27-28.

1979, Preliminary interpretation of faulting in the New Madrid seismic zone [abs.]: American Geophysical Union, EOS, Transactions, v. 60 , no. 18 , p. 310 .

Zoback, M. D., Hamilton, R. M., Crone, A. J., Russ, D. P., Mckeown, F. A., and Brockman, S. R., 1980, Recurrent intraplate tectonism in the New Madrid seismic zone: Science, v. 209, no. 4460, p. 971-976. 


\section{High-Resolution Seismic-Reflection Surveying on Reelfoot Scarp, Northwestern Tennessee}

By JOHN L. SEXTON, E. P. FREY, and DAVE MALICKI

INVESTIGATIONS OF THE NEW MADRID, MISSOURI, EARTHQUAKE REGION GEOLOGICAL SURVEY PROFESIONAL PAPER $1236-\mathrm{J}$ 


\section{CONTENTS}

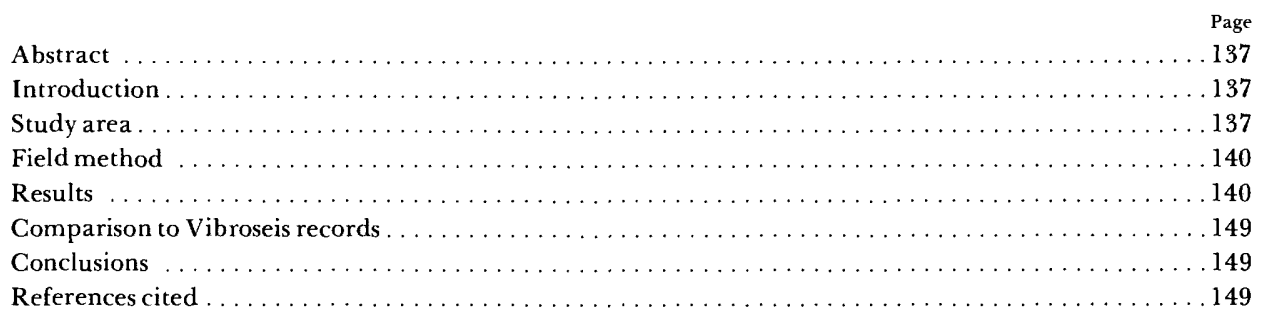

\section{ILLUSTRATIONS}

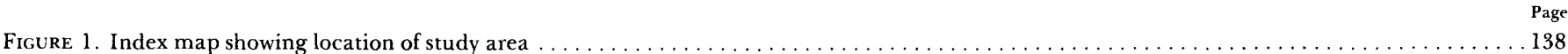

2. Stratigraphic column based on $\log$ from the Kate Wright no. 1 well located near Reelfoot scarp $1 \mathrm{mi}$ (1.6 km) north of Proctor City, Tenn. . 139

3. Map showing seismic lines JL-1, AM-1, and LDC-1 on Reelfoot scarp, Tennessee. . . . . . . . . . . . . . . . . . . . .

4. Diagram illustrating field method. $A$, source, receiver array, and schematic raypath diagram. $B$, plan view of source and receiver

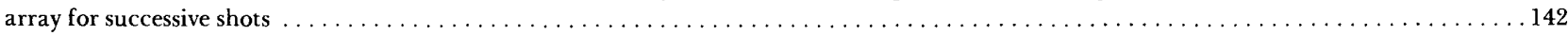

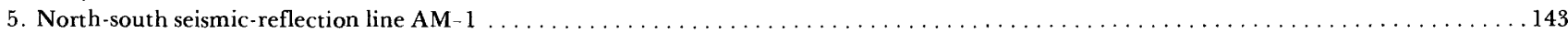

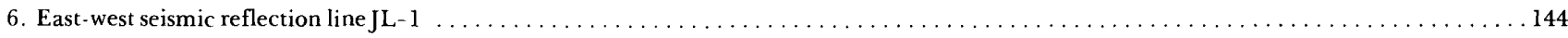

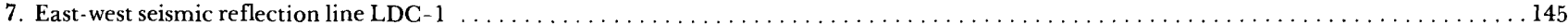

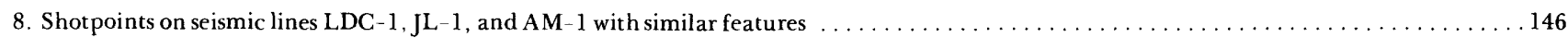

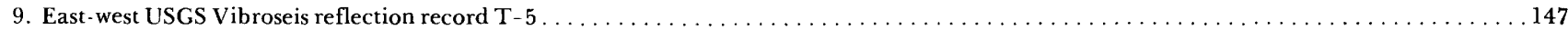

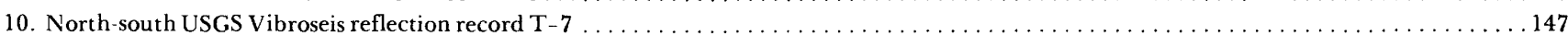

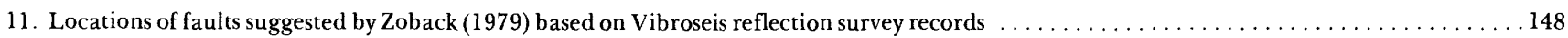




\title{
HIGH-RESOLUTION SEISMIC-REFLECTION SURVEYING ON REELFOOT SCARP, NORTHWESTERN TENNESSEE
}

\author{
By John L. Sexton ${ }^{1}$, E. P. Frey ${ }^{2}$, and Dave Malicki ${ }^{3}$
}

\section{ABSTRACT}

A high-resolution seismic-reflection survey consisting of three short lines, two that are $2,000 \mathrm{ft}(610 \mathrm{~m})$ long and one that is $1,000 \mathrm{ft}(305 \mathrm{~m})$ long, has been conducted in the region of Reelfoot scarp in northwestern Tennessee. The purpose of the survey was to examine the feasibility of using high-resolution seismic methods to delineate shallow geologic structures within a limited area of the scarp. Results show that shallow reflectors $(60-400 \mathrm{~ms})$ can be mapped well when they are reasonably continuous. Reflections from the base of the Tertiary rocks and reflections from the Paleozoic rocks are also well resolved. No faults exhibiting significant vertical offset have been found. Thus, if faulting is associated with Reelfoot scarp, it must be located farther west from this location than was previously believed. Monoclinal flexuring is one possible explanation for the scarp structure that appears to be consistent with the seismic-reflection data.

\section{INTRODUCTION}

Studies designed to define the structural setting and tectonic history of the Mississippi Embayment area have recently increased in number and intensity. Understanding the tectonism of the area is important because of the potential earthquake hazard posed by the New Madrid fault zone. Although the seismicity of the area is being monitored (Stauder, 1977), the relation between seismicity and regional tectonics is poorly understood. Understanding the relation requires knowledge of the location, extent, geometry, and activity of faults in the area. Faults of the New Madrid seismic zone are poorly defined because they are concealed by a thick cover of unconsolidated sediments. Most of the active faulting is at depth and usually does not produce detectable surface displacements.

\footnotetext{
'Department of Geosciences, Purdue University, West Lafayette, IN 47907. ${ }^{2}$ Department of Geology. Southern Illinois University, Carbondale, IL 62901.

${ }^{3}$ Amoco Production Company, Houston Division, 500 Jefferson Buildıng, Houston, TX 77001.
}

The geologic field investigations of Russ (1978) of the USGS (U.S. Geological Survey) have been of great importance in locating fault zones and interpreting the regional tectonics. To supplement these geologic studies, the USGS has initiated a seismic-reflection program to help delineate subsurface faults. As part of the USGS program, $32 \mathrm{~km}$ of 24 -fold conventional Vibroseis (registered trademark of Continental Oil Company) reflection lines were run near the western edge of Reelfoot Lake and on Reelfoot scarp, north of Tiptonville, Tenn. Results have been summarized by Zoback (1979).

The seismic-reflection program was designed to search for subsurface structure associated with Reelfoot scarp and the Ridgely lineament. The best quality reflections on the Vibroseis records are associated with (1) the Porters Creek Clay, (2) a limestone of the Clayton Formation at the base of the Tertiary, and (3) the top of the Paleozoic rocks. Above the Porters Creek reflector, no continuous reflections were observed on the Vibroseis records.

The present study examines the feasibility of using highresolution seismic-reflection techniques with explosive sources to map not only the deeper Paleozoic, Cretaceous, and Paleocene units, but also shallow reflectors that were poorly resolved in the Vibroseis survey. The study area was selected to coincide with the area where an exploratory trench was excavated by the USGS and where several Vibroseis lines were run.

\section{STUDY AREA}

Reelfoot scarp is located west and north of Reelfoot Lake in the Tiptonville $71 / 2$-minute quadrangle in Lake County, Tenn. (fig. 1). This area rests on the alluvial plain of the Mississippi River. The post-Paleozoic sediments consist of about $2,000 \mathrm{ft}(610 \mathrm{~m})$ of poorly consolidated sand, silt, and clay. A stratigraphic column (fig. 2) based on a driller's log 


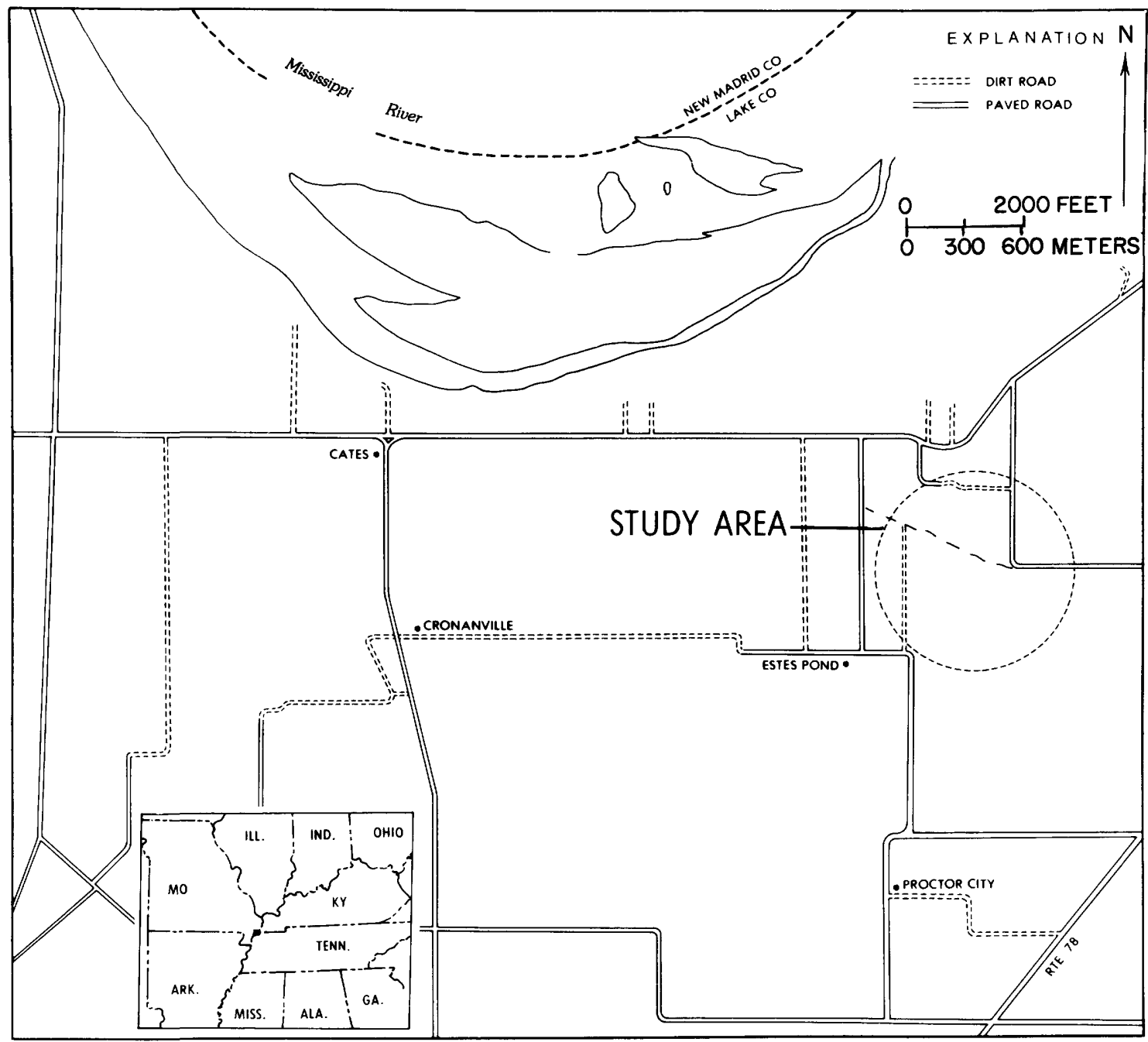

FIGURE 1. -- Index map showing location of study area (circled).

(Wells and Foster, 1933) from the Kate Wright No. 1 well, located on the scarp near Proctor City, indicates that the alluvium is approximately $145 \mathrm{ft}(44 \mathrm{~m})$ thick. Gravels of Pleistocene age are included in the alluvium. The remaining sediments are poorly consolidated down to the irregular Paleozoic surface, although several exceptions, such as the hard sandstone at the base of the Cretaceous, are noted. It should be stressed that because the stratigraphic column (fig. 2 ) is based on a driller's log, it may contain errors.

The Jackson Formation underlies the alluvium; it is reported to be $45 \mathrm{ft}(14 \mathrm{~m})$ thick and to consist of silt, clay, and thin beds of sand. The formations of the Claiborne Group, unconformably underlying the Jackson Formation, cannot be differentiated in well logs because they all consist of sand intercalated with beds and lenses of clay. The Claiborne Group is underlain by the Wilcox Group. Layers of coarse sand are found in the Wilcox Group, and the well $\log$ (Wells and Foster, 1933) includes a hard "sandrock" at a depth of $900 \mathrm{ft}$ $(274 \mathrm{~m})$, still within the Wilcox Group. However, there is some question concerning the exact location of the boundary between the Claiborne and Wilcox Groups. The total combined thickness of the Claiborne and Wilcox Groups is $1,075 \mathrm{ft}$ (328 $\mathrm{m})$.

The Wilcox Group is underlain by the Paleocene Midway Group, represented in northwestern Tennessee by the Porters Creek Clay. The Porters Creek Clay is between 150 and $250 \mathrm{ft}$ (46-76 m) thick in this area; it consists of a carbonaceous dark clay with glauconitic silt and sand. The Paleocene Clayton Formation is a thin limestone layer at the base of the Paleocene that unconformably overlies the Upper Cretaceous Ripley Formation. The Ripley consists of sand and clay, is about $250 \mathrm{ft}(76 \mathrm{~m})$ thick, and contains clay lenses. These Up- 
HIGH-RESOLUTION SEISMIC-REFLECTION SURVEYING ON REELFOOT SCARP, TENNESSEE
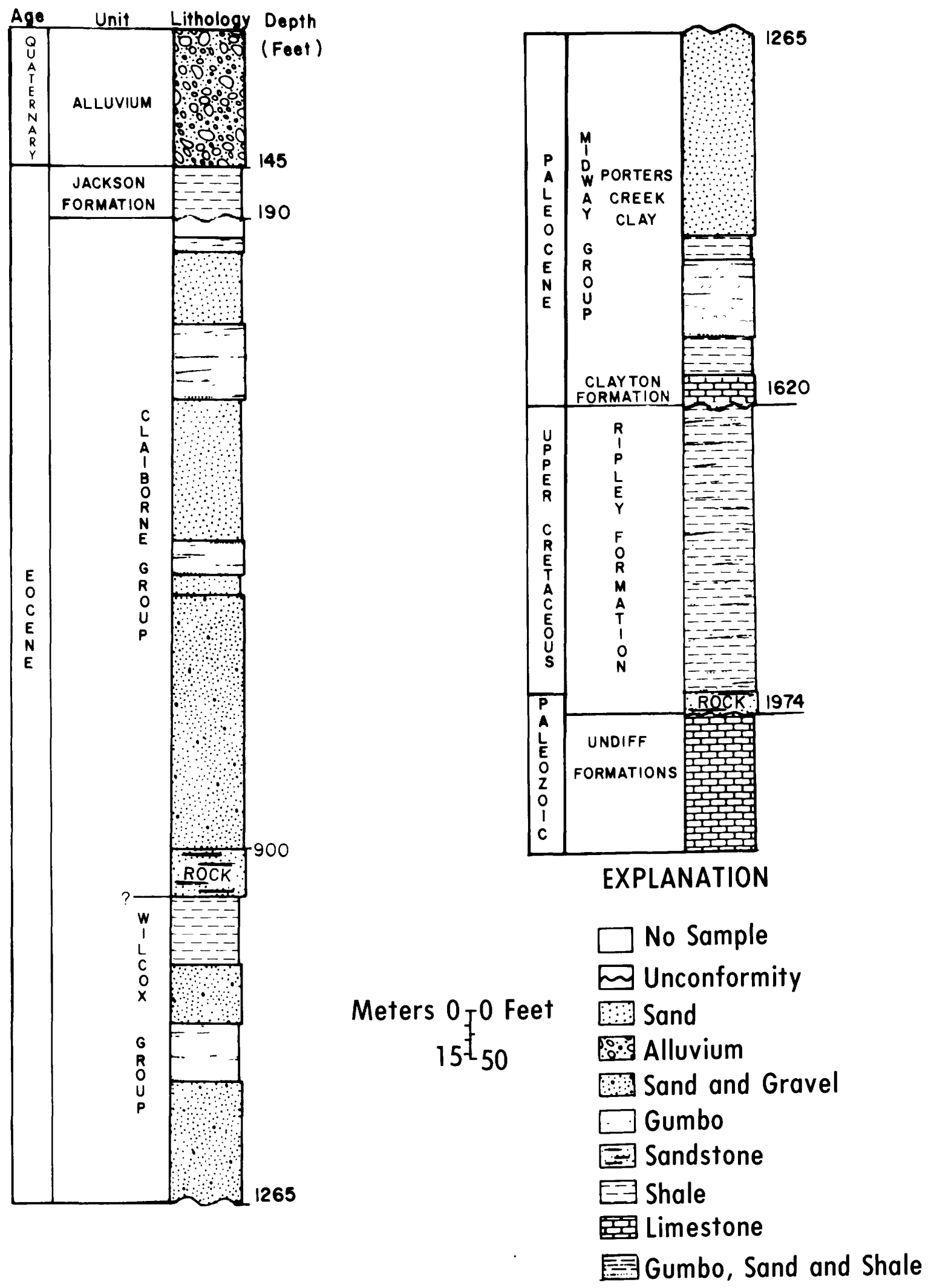

FiguRE 2. --Stratigraphic column based on $\log$ from the Kate Wright no. 1 well located near Reelfoot scarp $1 \mathrm{mi}(1.6 \mathrm{~km})$ north of Proctor City, Tenn. 
per Cretaceous sediments lie unconformably on the eroded surface of the Paleozoic rocks. The formations of the Paleozoic are consolidated and consist of limestone, shale, and chert.

An exploratory trench across Reelfoot scarp has revealed numerous faults, folds, and sandblow dikes on Holocene sediments (Russ, 1978). A 1.5-ft $(0.5-\mathrm{m})$-wide zone of eastdipping normal faults having a vertical displacement greater than about $10 \mathrm{ft}(3 \mathrm{~m})$ was mapped at the base of the scarp and is believed to be of deep-seated origin. According to Russ, faults within this zone are the only ones of probable tectonic origin known to cut Holocene sediments in the upper Mississippi Embayment. Russ also found that little or no nearsurface movement occurred across the zone, and he inferred that the structures exposed in the trench were not related to the 1811-12 New Madrid earthquakes. Further, Russ's analysis of the observations in the trench and of historical earthquake data indicate that three earthquakes strong enough to liquefy sediments and generate surface faulting have occurred in the vicinity of the trench sites, two of which predate 1800 .

Seismic-refraction profiles across Reelfoot scarp (Zoback and others, 1978) have been interpreted as showing vertical offsets of $180 \pm 33 \mathrm{ft}(55 \pm 10 \mathrm{~m})$ (down to the east) on the top of the Paleozoic bedrock. This interpretation is in agreement with interpretations made from the USGS seismic-reflection program (Zoback, 1979).

Results of the USGS seismic-reflection program indicate numerous faults, the most significant of which are two eastdipping, high-angle normal faults that have about $165-200 \mathrm{ft}$ $(50-60 \mathrm{~m})$ of vertical offset at the contact of the Upper Cretaceous sediments and Paleozoic bedrock (Zoback, 1979). One of the faults is associated with a major northeast-trending lineament (Ridgely lineament) located near the southeastern edge of Reelfoot Lake. This lineament extends from $15 \mathrm{~km}$ southwest of Ridgely, Tenn., for about $60 \mathrm{~km}$ to near Hickman, Ky. (Heyl and McKeown, 1978). The second reported fault is essentially coincident with Reelfoot scarp. The nature of the offsets on these faults is interpreted by Zoback as indicating reactivation of motion on faults of Late Cretaceous or older age.

\section{FIELD METHOD}

In May 1978, a seismic-reflection survey on Reelfoot scarp using high- resolution digital recording equipment and explosive sources was initiated. A digital sample rate of $1 / 4 \mathrm{~ms}$ was used to obtain adequate frequency resolution. Shot and geophone separations were kept small (20 ft or $6.1 \mathrm{~m}$ ) to gain spatial resolution. A 4-ms sample rate, vibrator-point spacings of $200 \mathrm{ft}(61 \mathrm{~m})$, and group intervals of $200 \mathrm{ft}(61 \mathrm{~m})$ were used in the Vibroseis survey. The seismic system used for the himh-resolution survey consisted of an 8-channel digital seismic-recording system with a digital magnetic tape recorder; one detector per channel was used. Initially, hydrophones placed in shallow holes were used in the survey; however, use of these was abandoned because the holes caved in and because of sporadic failure of the hydrophones. The hydrophones could have provided higher frequency records than geophones had field conditions allowed their use. This apparently would not have been significantly advantageous, however, as several good records obtained with the hydrophones were judged only slightly, if at all, better than geophone records. The increased time required to use hydrophones is considerable in this area owing to inflow of water and sidewall material into the drill holes.

Three seismic lines were placed such that one 2,000-ft (610-m)-long, east-west line (JL-1) crossed Reelfoot scarp at the location (fig. 3) of the exploratory trench and also overlapped Vibroseis line $T-5$. The second seismic line (AM-1), also $2,000 \mathrm{ft}(610 \mathrm{~m})$ long and oriented in a north-south direction, was located so that it intersected line JL-1 and was positioned in the same location as Vibroseis line T-7 (fig. 3). The third line ( $\mathrm{LDC}-1)$ was $1,000 \mathrm{ft}(305 \mathrm{~m})$ long and was oriented eastwest so that it crossed the scarp at a location about $2,000 \mathrm{ft}$ $(610 \mathrm{~m})$ south of line JL-1 (fig. 3). Along each 2,000- $\mathrm{ft}$ $(610-\mathrm{m})$ line 101 shots were fired, and along the $1,000-\mathrm{ft}$ $(305-\mathrm{m})$ line 51 shots were fired. The three lines were shot in a manner that produced four-fold common-depth-point coverage (fig. 4). The shot-point spacing, detector spacing, and offset to the first detector were all $20 \mathrm{ft}(6.1 \mathrm{~m})$. Each successive shot was moved $20 \mathrm{ft}$ forward, replacing the nearest geophone, which, in turn, was moved forward to become the last or number 8 geophone. The source used for each shot was one charge of Atlas kinestik ${ }^{1}(\mathrm{~K}-1 / 3)$. All shot depths and geophone elevations were surveyed to an accuracy of $0.1 \mathrm{ft}$ $(0.03 \mathrm{~m})$. Shot holes were drilled below the water table when possible and, due to hole cave-in, ranged from 8 to $22 \mathrm{ft}$ ( 2.4 to $6.7 \mathrm{~m}$ ) deep. The maximum shot-hole depth of $22 \mathrm{ft}$ was limited by drilling costs and equipment capabilities. Forward and reverse refraction profiles that were $840 \mathrm{ft}(256 \mathrm{~m})$ long and had a detector spacing of $105 \mathrm{ft}(32 \mathrm{~m})$ were shot for each line. The information was used as an aid in determining static corrections for the reflection survey.

\section{RESULTS}

Results of the high-resolution seismic-reflection feasibility study (figs. 5-7) show that very good reflections from shallow

\footnotetext{
${ }^{1}$ Any use of a brand name is for descriptive purposes only and does not imply endorsement by the USGS.
} 


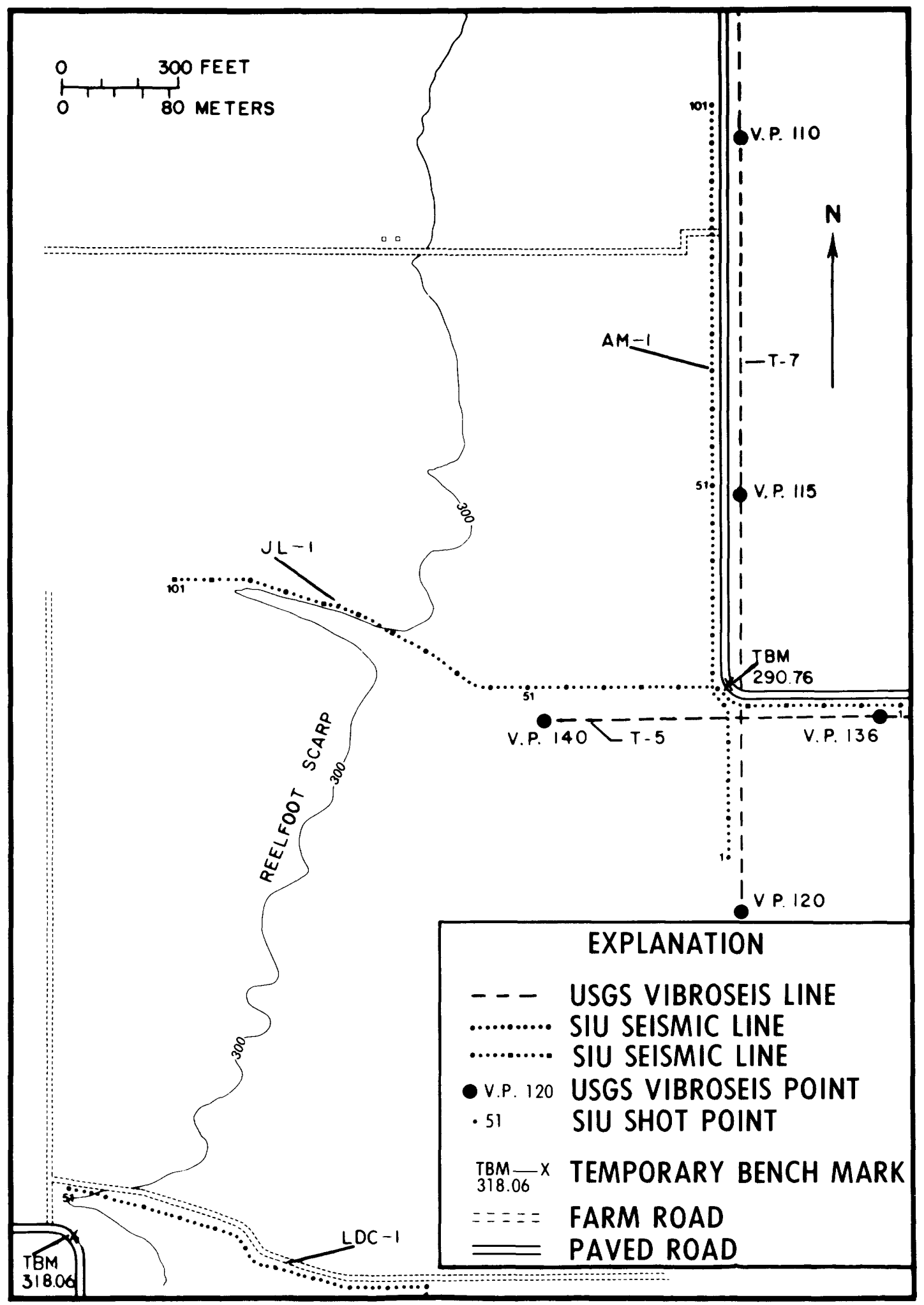

FigURE 3.--Map showing seismic lines JL-1, AM-1, and LDC-1 on Reelfoot scarp, Tennessee. Shotpoints are $20 \mathrm{ft}(6 \mathrm{~m})$ apart. 

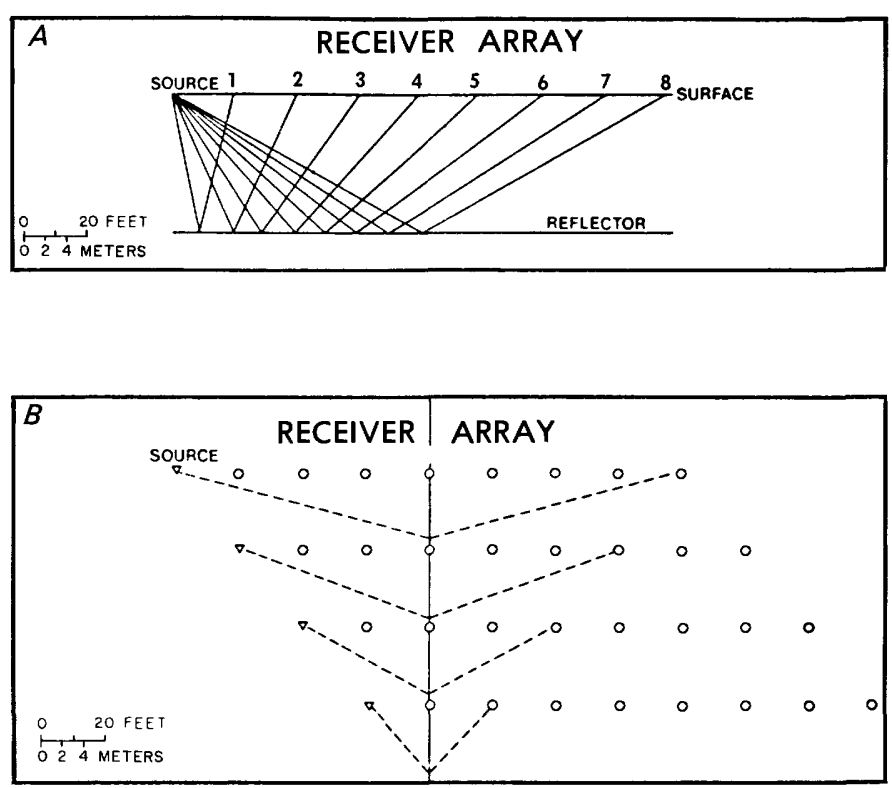

Figure 4. - Diagram illustrating field method. $A$. source, receiver array, and schematic raypath diagram. $B$. plan view of source and receiver array for successive shots. All shot and receivers are colinear but shown in separate rows for clarity. Dashed lines are schematic raypaths to illustrate how four-fold common-depth-point average is achieved. Vertical line represents common depth point for each successive shot.

Tertiary horizons, in addition to reflections from Cretaceous and Paleozoic rocks, can be obtained. Reflections were obtained at two-way travel times of about 60, 80, 130, 180, 350, 420, 580 , and $660 \mathrm{~ms}$. The reflections at 60 and 80 milliseconds were strong but generally discontinuous and cannot be correlated across the entire records. Reflections at 130, 180, 350, 580 , and 660 milliseconds were strong and can be correlated across most parts of the records. Several zones on the reflection records show disruptions of the reflectors, but in most cases these are due to bad data caused by either near-surface or shot conditions. Preliminary depth estimates based on two different (but similar) velocity functions, one derived from this survey and the other from the USGS Vibroseis survey, indicate that reflections are obtained from the top of the Jackson Formation (60 ms), the top of the Claiborne $(80 \mathrm{~ms})$, several units within the Claiborne and Wilcox Groups (130, 180, and 350 $\mathrm{ms}$ ), the top of the Midway Group (Porters Creek Clay) (420 $\mathrm{ms}$ ), and the Paleocene Clayton Formation of the Midway Group which overlies the Cretaceous rocks $(580 \mathrm{~ms})$ and the Cretaceous-Paleozoic unconformity $(660 \mathrm{~ms})$. The stratigraphic column (fig. 2), based on the de Armand driller's log (Wells and Foster, 1933), has been used as a guide for interpreting reflections.

Exact depths cannot be calculated because of the uncertainties in the calculated interval-velocity function. Use of a stacking-velocity function derived from the reflection data gives an estimate of the depths. Each of the lines shows good reflections from the various reflectors noted above. Lines AM- 1 and JL- 1 intersect at shotpoint 24 on line AM-1 and shotpoint 26 on line JL-1. Overlaying the seismograms at this tie point reveals that all reflectors on both lines match almost perfectly, as they should. Line LDC-1 does not intersect the other two lines; however, it is roughly parallel to JL-1 and is nearly perpendicular to the strike of Reelfoot scarp, as is JL-1. Therefore, if no dip parallel to the strike of the scarp exists, it can be assumed that subsurface reflections should correlate well on both lines at shotpoints connected by straight lines roughly parallel to the scarp. Accordingly, all reflections at shotpoint 1 on line LDC- 1 correlate very well with reflections at shotpoint 46 on line JL-1. Reflections at subsequent shotpoints on LDC- 1 and JL-1 also correlate well, except beyond about shotpoint 25 on line LDC- 1 where very few good reflections are recorded.

On line AM-1, shotpoints 1-20 were recorded using hydrophones; the general character of the record (fig. 5) for those shotpoints is of slightly higher frequency content than for those shotpoints for which geophones were used. Disruptions in the continuity of reflections on line AM-1 occur for all reflectors between shotpoints 12 and 20 and between 90 and 98 . The poor reflection quality between 12 and 20 is associated with the previously mentioned hydrophone problem. Between shotpoints 90 and 98 , reflections are not traceable for the Clayton unit; however, the only vertical offset is due to dip, and no faulting of the Cretaceous or Paleozoic rocks is inferred for this region of the scarp. The shallow reflectors for shotpoints 80-98 are generally broken, discontinuous, and difficult to follow across the record. This reflection character may be the result of shallow faulting or of inadequate static corrections. The time intervals between the shallow reflectors at 130 and $180 \mathrm{~ms}$ remain essentially constant between shotpoints 1 and 90 but appear to increase slightly between shotpoints 90 and 100 .

A similar shallow feature exists on line JL- 1 between shotpoints 45 and 55; however, no time-interval change is observed (fig. 6) between the same shallow reflections. This feature can also be correlated with a disrupted shallow reflection $(130 \mathrm{~ms})$ on line LDC- 1 beginning at shotpoint 25 (fig. 7). A straight line connecting shotpoints 25 on LDC- 1,53 on JL-1, and 80 on AM-1 has a strike roughly parallel to the strike of the scarp and could possibly be a shallow fault zone (fig. 8) associated with the scarp. These features may or may not be related to each other and to a common, small- displacement (a few meters), shallow fault zone such as the one located at the base of the scarp by Russ (1978). The correlation is possible, but certainly open to question.

Between shotpoints 40 and 55 on line JL-1, the slope of the reflections decreases. Beginning at shotpoint 55 on line JL-1, the shallow reflections gradually bend upwards by a total of about $7 \mathrm{~ms}$ (one-way travel time) when compared to the same reflection between shotpoints 1 and 40 . This gradual rise is estimated to be about $39 \mathrm{ft}$ ( $12 \mathrm{~m}$ ) using a one-way travel time of $7 \mathrm{~ms}$ and a velocity (based on refraction and reflection data) 


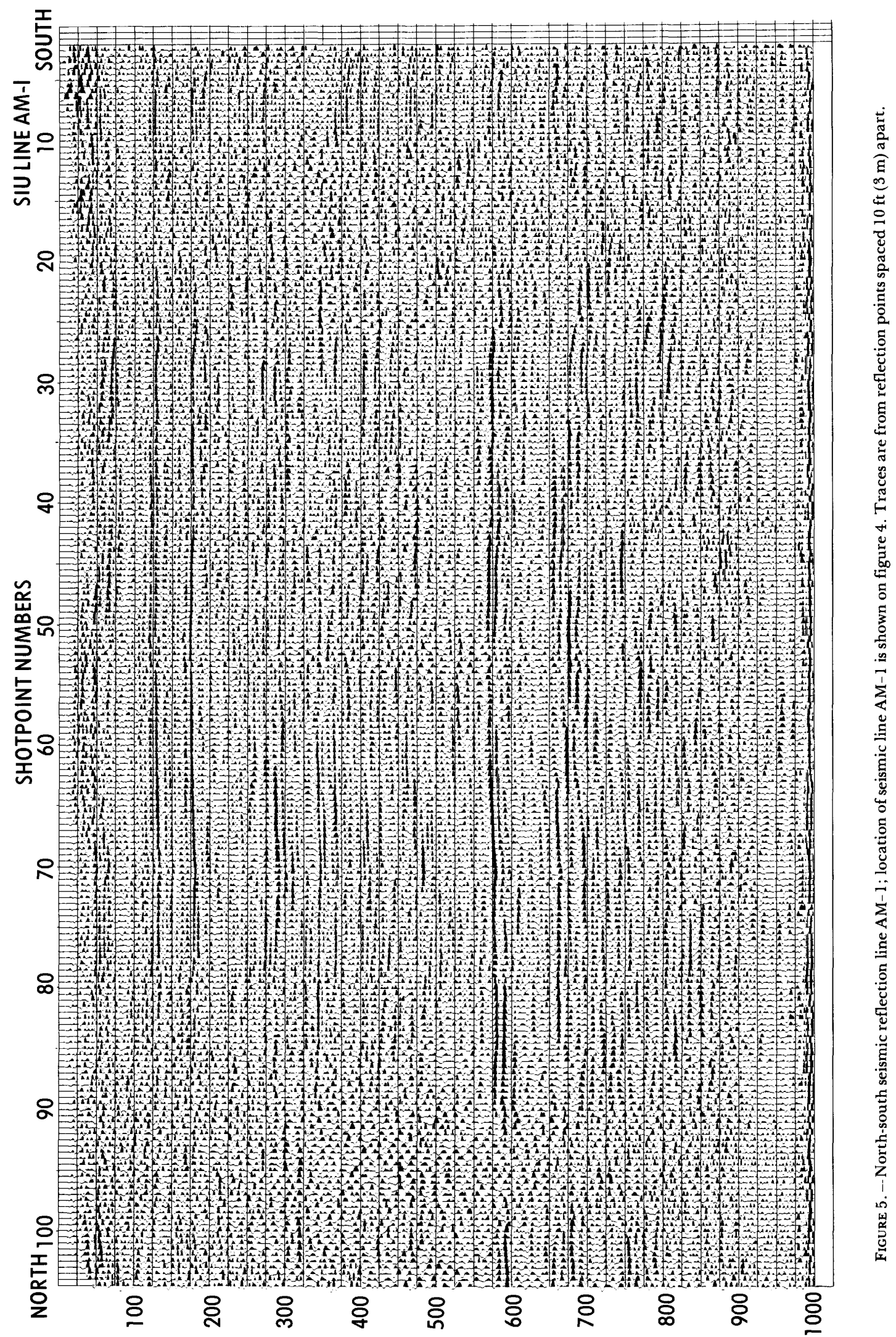




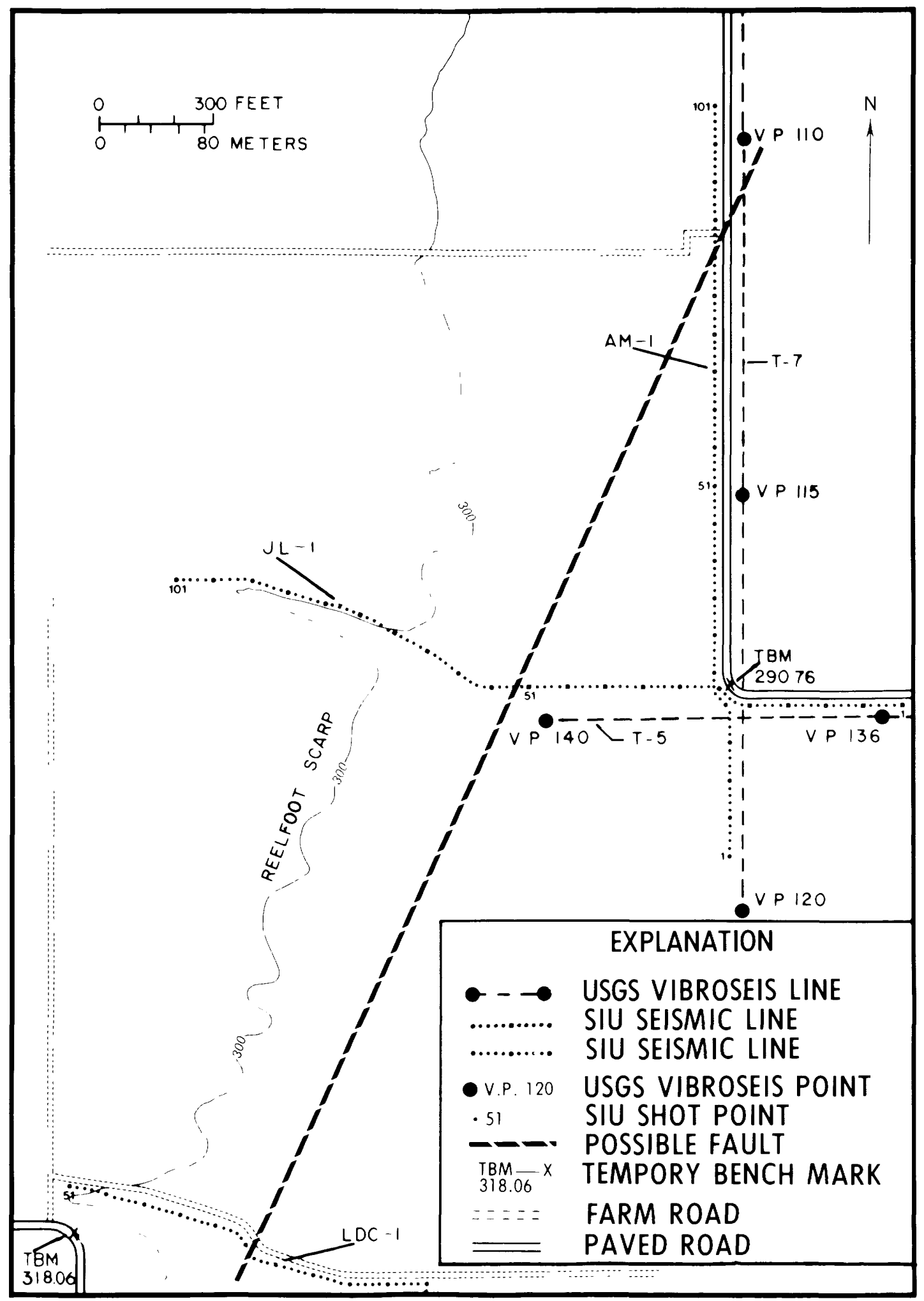

FIGURE 8. - Shotpoints on seismic lines LDC-1, JL-1, and AM- 1 at which similar features are noted are connected with heavy dashed line. 
USGS

REFLECTION LINE T-5

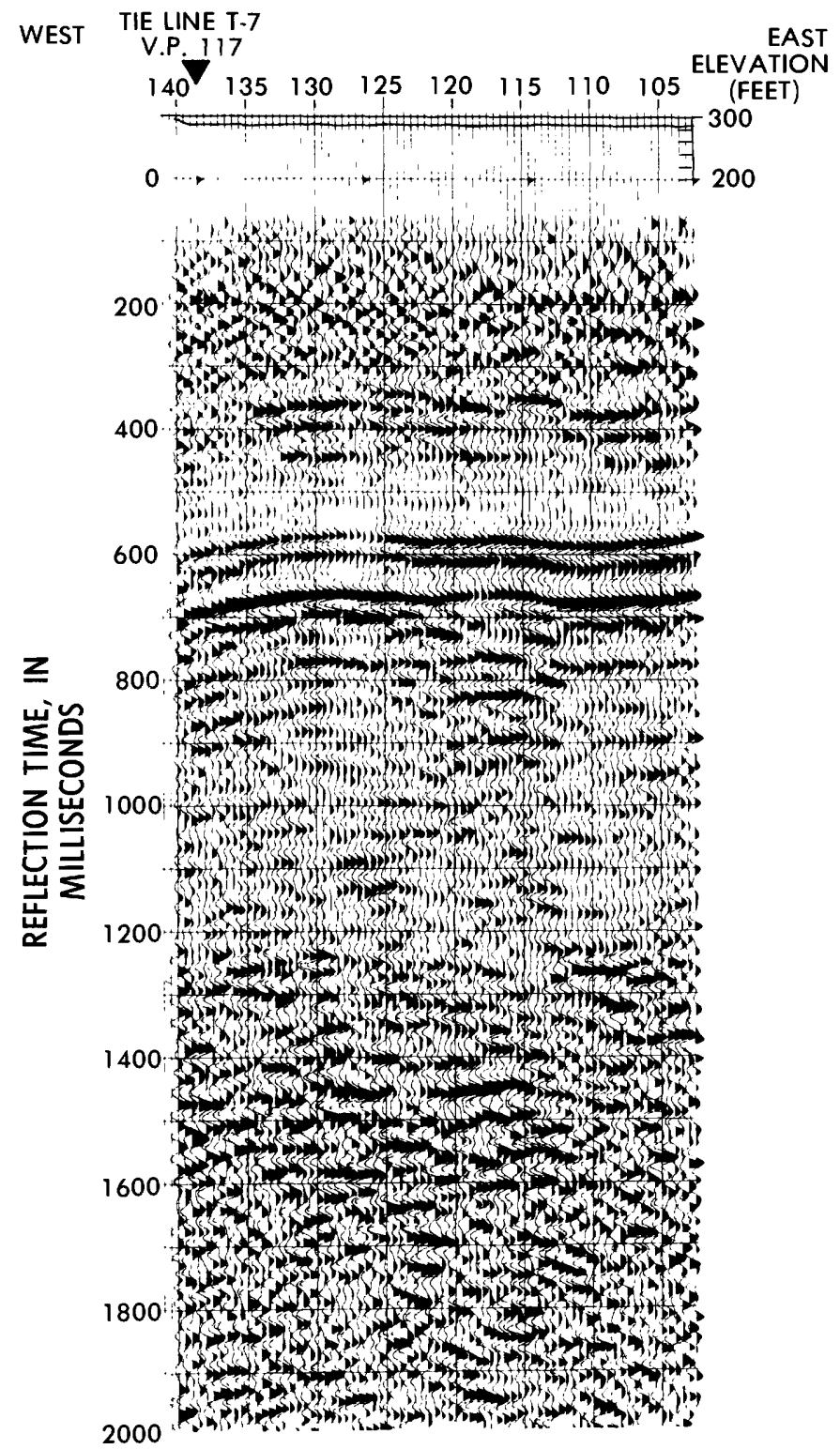

Figure 9.-- East-west USGS Vibroseis reflection record T-5. Seismic line $\mathrm{T}-5$ overlaps line $\mathrm{JL}-1$, and the location is shown in figure 3. Lines T-7 and $\mathrm{T}-5$ cross at vibration point (V.P.) 117.

face and water table, producing severe ground roll. This is observed as low-frequency noise on the reflection record, in contrast to the higher frequency content on that part of the record section where good reflections are recorded. Because most of the energy went into the generation of surface waves, little energy reached the subsurface reflectors. Therefore, the reflections were weak and difficult, if not impossible, to correlate across the record. Most of these reflections can, with difficulty, be followed across the record sections, except for those on the LDC-1 line.
USGS

REFLECTION LINE T-7

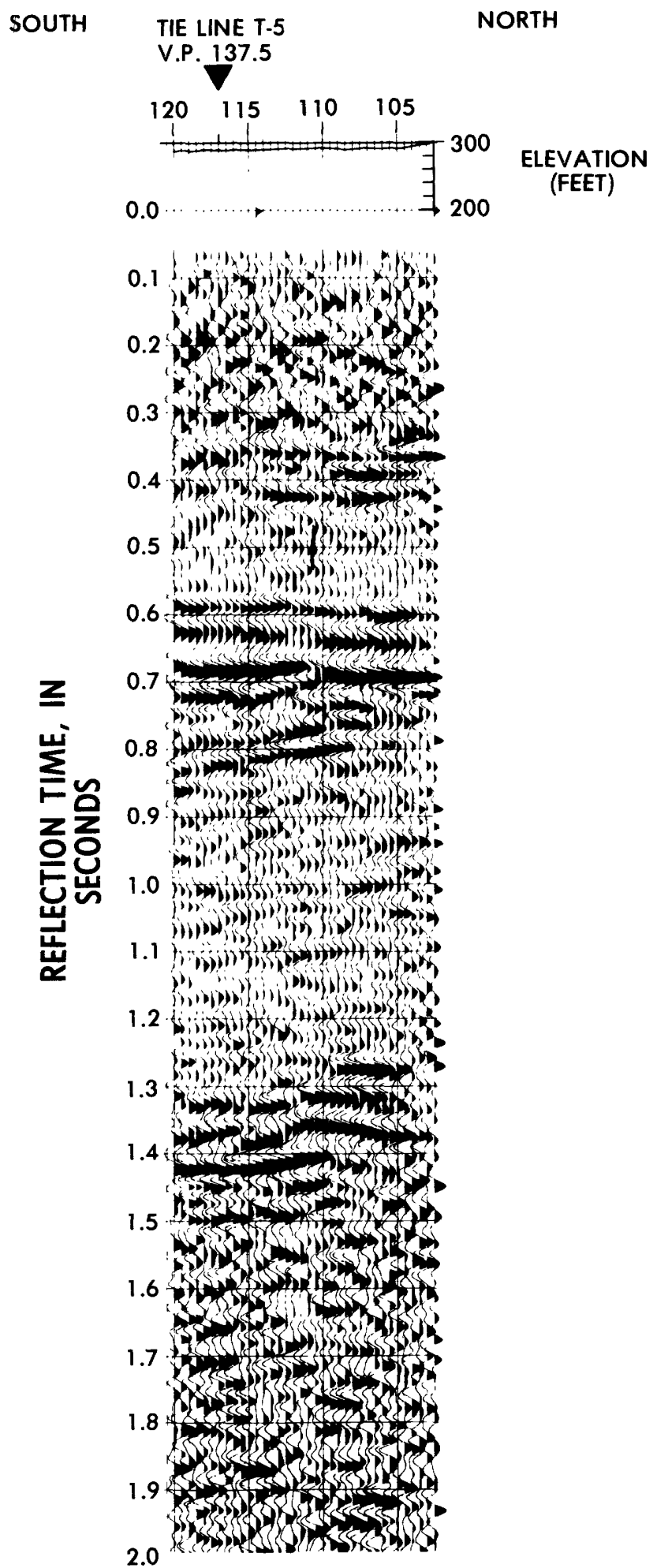

FIGURE 10.--North-south USGS Vibroseis reflection record T-7. Seismic line T- 7 overlaps line AM-1, and the location is shown in figure 3 . Lines $T-7$ and $T-5$ cross at vibration point (V.P.) 137.5 on line $T-7$. 


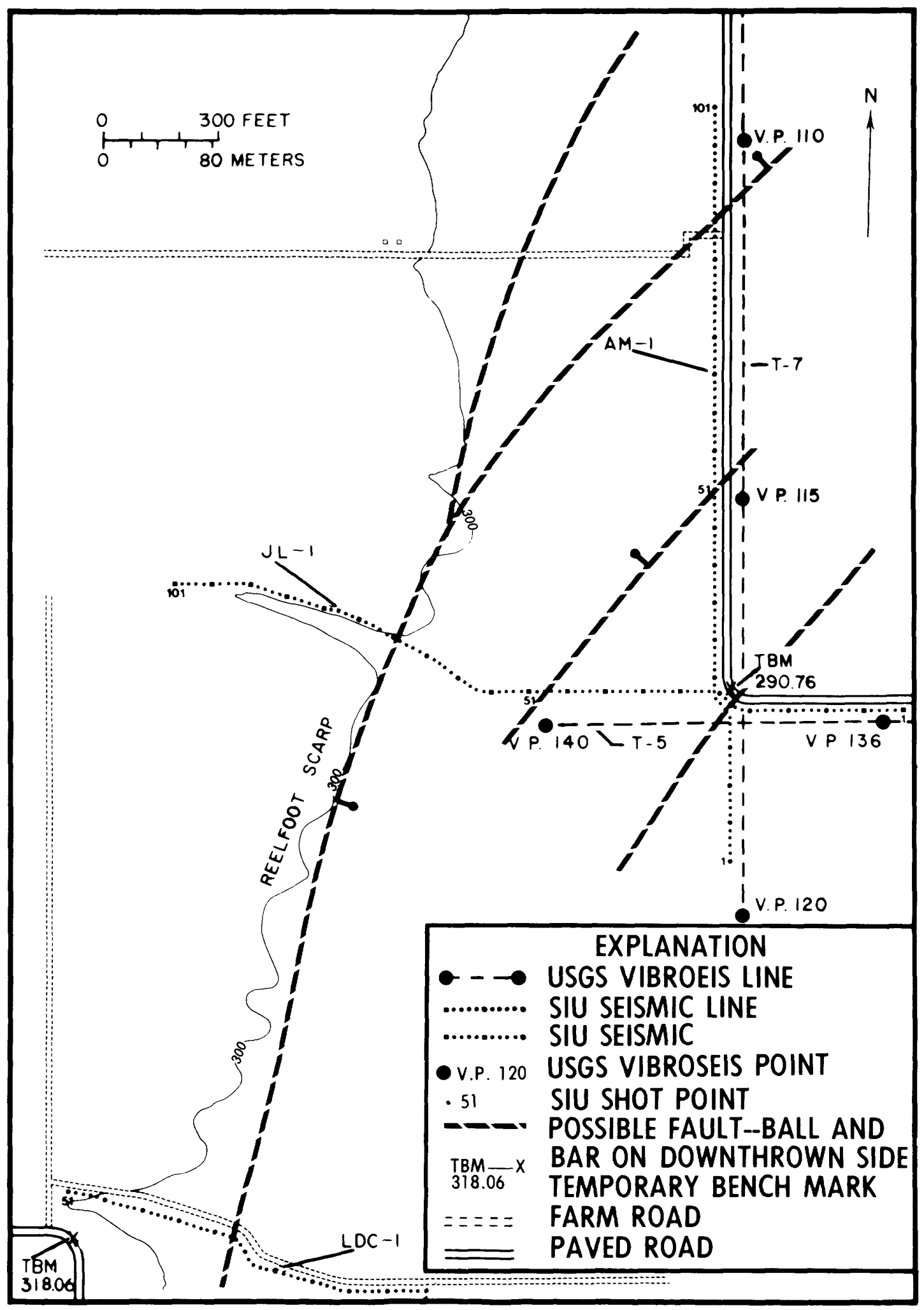

FIGURE 11.--Locations of faults suggested by Zoback (1979) based on Vibroseis reflection survey records. 


\section{COMPARISON TO VIBROSEIS RECORDS}

Vibroseis line $\mathrm{T}-5$ is an east-west line which overlaps seismic line JL-1 (fig. 9). T-5 extends much farther to the east than does JL-1. Line T-7 is a north-south line coincident with line AM-1, but $T-7$ extends farther to the north by about $2,000 \mathrm{ft}$ $(610 \mathrm{~m})$ (fig. 10). Seismic sections for $T-5$ and $T-7$ are presented in figures 9 and 10 . The time scale for the Vibroseis record is twice that for the JL-1, AM-1, and LDC- 1 records, which will be collectively called the SIU (Southern Illinois University) records.

Resolution, both in time and space, of shallow and deep reflectors is greater on the SIU records. Examination of the SIU field records shows a frequency of about $125 \mathrm{~Hz}$ for the reflection from the Paleocene Clayton Formation, whereas the Vibroseis reflections are about $30 \mathrm{~Hz}$ or less. Harmonic analysis of the SIU records for the shallower reflections reveals significant energy at $250-300 \mathrm{~Hz}$.

Several faults have been suggested (Zoback, 1979) for the scarp area on the basis of line $\mathrm{T}-4$, located several thousand feet north of the SIU lines, and also from line $T-3$, located several thousand feet west and extending south. Figure 11 gives the estimated location of possible faults, as discussed by Zoback. These suggested faults all cross one or more of the SIU lines. However, no fault with any significant displacement is observed on the SIU seismic records. Thus, if faulting is associated with Reelfoot scarp in the area of the SIU survey, it must be located west of the JL-1 line. Zoback (1979) has also commented on the questionable nature of the offsets observed on line $\mathrm{T}-4$ because of apparent errors in static corrections. Other Vibroseis lines not within the very localized area of investigation of this study have shown larger offsets in the Tertiary-Cretaceous and Cretaceous-Paleozoic contacts. On those lines, evidence for faulting is more positive than on line T-4 (Zoback, 1979).

\section{CONCLUSIONS}

Results of the high-resolution seismic-reflection feasibility study show that mapping shallow reflectors (60 to $400 \mathrm{~ms}$ ) in this region is possible if reflectors are continuous. The highresolution record sections also have excellent reflections from the Paleocene Clayton Formation $(580 \mathrm{~ms})$, which overlies the Cretaceous strata, and from the Paleozoic rocks (660 ms). Profiling across Reelfoot scarp has shown no significant vertical offset in Paleozoic and younger rocks directly beneath the scarp. If Reelfoot scarp is associated with faulting in the localized area of this investigation, then the fault must be located farther west. The scarp appears to be associated with a monoclinal flexure.

\section{REFERENCES CITED}

Heyl, A. V., and McKeown, F. A., 1978, Preliminary seismotectonic map of central Mississippi Valley and environs: U.S. Geological Survey Miscellaneous Field Studies Map MF-1011.

Russ, D. P., 1978, Recent surface faulting and earthquake recurrence in the Reelfoot Lake area, northwestern Tennessee [abs.]: American Geophysical Union, Midwestern Meeting, St. Louis, Mo., 1978, Program of Abstracts, St. Louis University, p. 8.

Stauder, William, 1977, Microearthquake-array studies of the seismicity in southeast Missouri: U.S. Geological Survey Earthquake Information Bulletin, v. 9, no. 1, p. 8-13.

Wells, F. G., and Foster, M. D., 1933, Ground-water resources of western Tennessee: U.S. Geological Survey Water-Supply Paper 656, 319 p.

Zoback, M. D., 1979, Recurrent faulting in the vicinity of Reelfoot Lake, northwestern Tennessee: Geological Society of America Bulletin, pt. 1, v. 90, p. 1019-1024.

Zoback, M. D., Healy, J., Roller, J., McKeown, F., and Russ, D., 1978, A geophysical assessment of suspected faults in the New Madrid seismic zone: EOS (American Geophysical Union Transactions), v. 59, no. 4, p. 229. 

Stratigraphy and Structure of Post-Paleozoic Sediments Above the Newport Pluton of Northeastern Arkansas By E. E. GLICK

INVESTIGATIONS OF THE NEW MADRID, MISSOURI, EARTHQUAKE REGION GEOLOGICAL SURVEY PROFESSIONAL PAPER $1236-\mathrm{K}$ 


\section{CONTENTS}

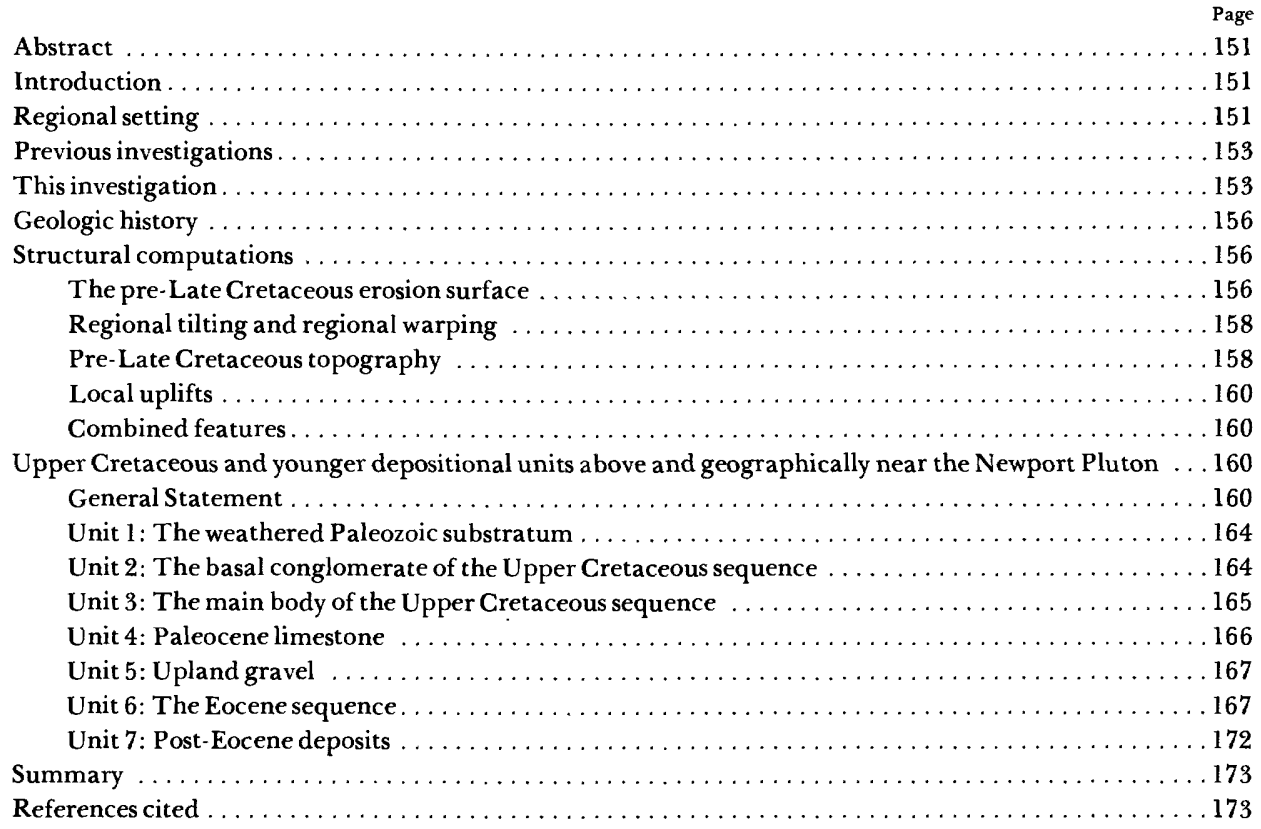

\section{ILLUSTRATIONS}

Page

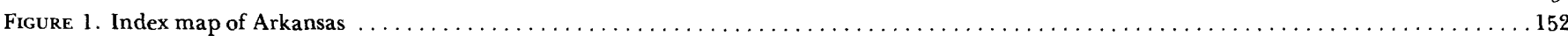

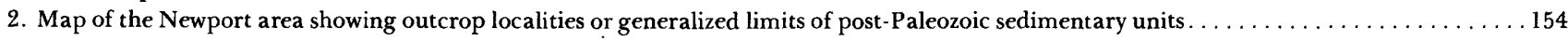

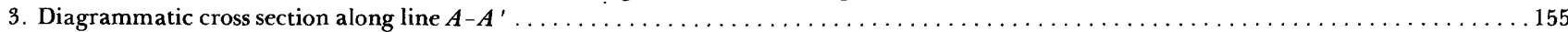

4. Map of three distinct parts of the Newport region with contours drawn on top of the reconstructed pre-Late Cretaceous erosion surface ..... 157

5. Map of the Newport region showing the cumulative effect of regional tilting and regional warping of the pre-Late Cretaceous erosion surface 159

6. Map of the Newport region showing an interpretation of the topography at the time of the advance of the Late Cretaceous sea $\ldots \ldots \ldots . .161$

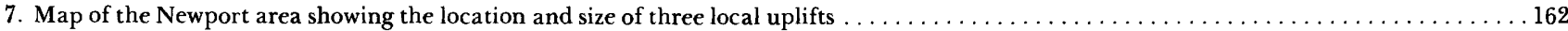

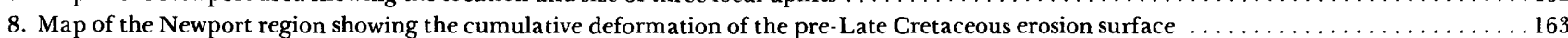

9. Map of the Newport area showing the middle Cretaceous topography as altered by the subsequent effect of local uplift $\ldots \ldots \ldots \ldots \ldots . \ldots 164$

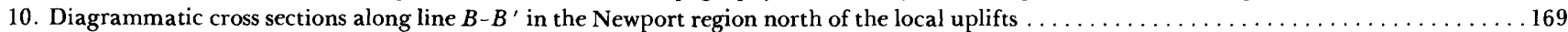

11. Diagrammatic cross sections along line $A-A^{\prime}$ in the Newport region through the area underlain by local uplifts $\ldots \ldots \ldots \ldots \ldots \ldots \ldots$ 


\section{STRATIGRAPHY AND STRUCTURE OF POST-PALEOZOIC SEDIMENTS ABOVE THE NEWPORT PLUTON OF NORTHEASTERN ARKANSAS}

By ERnest E. Glick

\section{ABSTRACT}

The Newport area, at the border of the Mississippi Embayment and the Ozark region of northeastern Arkansas, in part is underlain by the deeply buried Newport pluton of probable Late Cretaceous age. The area also contains three local uplifts that are closely associated geographically with the pluton. The uplifts developed during the time of deposition of Upper Cretaceous and lower Tertiary sediments in the embayment.

At about the end of Cretaceous time, the sea floor above the newly emplaced Newport pluton was arched slightly--just enough to allow marine erosion of a few meters of soft sediment and the formation of rounded pebbles from the underlying beds of Pennsylvanian sandstone. Some of those pebbles accumulated in slight depressions and became a foundation for Paleocene limestone; some were incorporated into the limestone.

At about the end of Paleocene time, three local areas within or near the geographic limit of the Newport pluton were uplifted well above their former level in the embayment. Apparently the uplifts resulted from the injection of magma into the lower part of the sedimentary sequence. If so, more than $50 \mathrm{~km}^{3}$ of material was emplaced at a depth of more than $1.76 \mathrm{~km}$ below sea level. The two uplifts near the edge of the embayment have been stripped of most of their post-Paleozoic cover; the southeastern uplift, about $25 \mathrm{~km}$ basinward from the Paleocene shoreline, still is covered by Quaternary alluvium and older sediments.

\section{INTRODUCTION}

Three local uplifts have been outlined by surface and subsurface geologic data in the vicinity of the Newport pluton along the edge of the Mississippi Embayment of northeastern Arkansas. This report discusses the general stratigraphy, structure, and depositional history of post-Paleozoic sediments in a broad area that includes the pluton and the uplifts, and indicates which stratigraphic and structural anomalies of the area are related to the local uplifts.

Geologic and geophysical data from the general area of the deeply buried pluton show that there is only a partial geographic correlation between the uplifts and the mass of dense and highly magnetic rock that makes up the main body of the pluton. No attempt is made herein to force the data to fit, or to blend the two sets of data, or even to present the raw geophysical data. However, because of the general agreement among various observations and concepts, one of the prime working hypotheses in this report is that the emplacement of the pluton - or the emplacement of local lenticular masses of igneous material stemming from the pluton-caused the dome-shaped uplifts.

\section{REGIONAL SETTING}

The rectangular Newport area, Arkansas (fig. 1), the principal geographic part of the region of interest in this report, extends from lat $35^{\circ} 15^{\prime}$ to $36^{\circ} 00^{\prime} \mathrm{N}$. and from long $91^{\circ} 15^{\prime}$ to $91^{\circ} 45^{\prime}$ W., a total of a little more than $3,600 \mathrm{~km}^{2}$. The three uplifts described in this report are within its borders, as are all but the easternmost and southernmost parts of the deeply buried Newport pluton. For completeness and in order to add a more regional perspective, areas to the east and south of the Newport study area are shown in many illustrations. The term Newport region, rather than Newport area, is used to designate this larger segment of northeastern Arkansas.

The northeast-trending boundary of the Mississippi Embayment of the Gulf Coastal Plain province extends along an ir- 


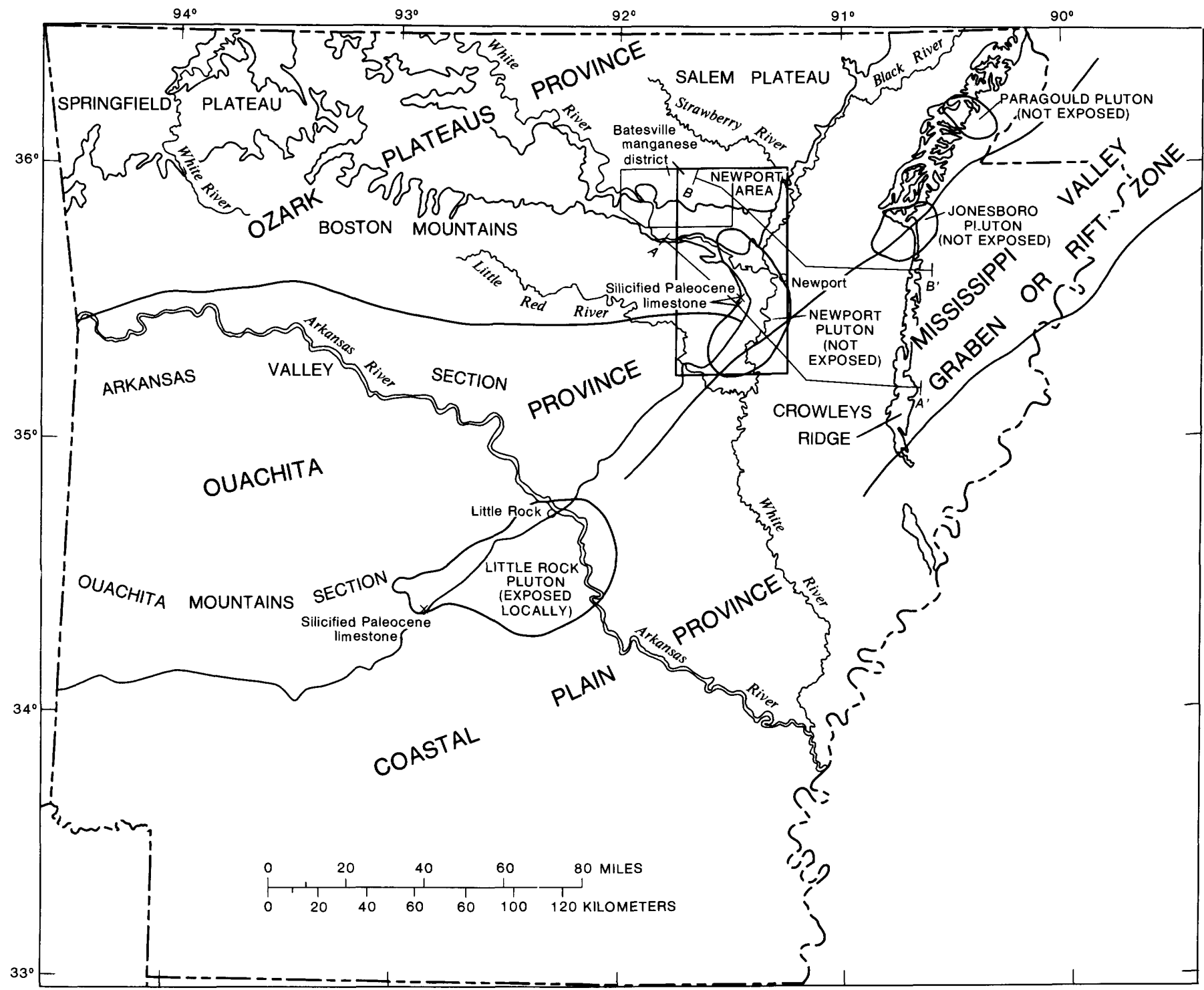

Figure 1.-- Index map of Arkansas showing the locations of the Newport area, the Batesville manganese district, Crowley Ridge, physiographic provinces and geologic phenomena discussed in text, the Mississippi valley graben or rift zone, and cross sections $A-A^{\prime}$ and $B-B^{\prime}$ shown on figures 3,10 , and 11 .

regular line from the southwest corner to the northeast corner of the Newport area. In general, this is the boundary at which rocks of Paleozoic age that crop out to the northwest dip beneath the Cretaceous and younger deposits of the embayment. This generally accepted position of the edge of the embayment, however, actually is the northwestern limit of a 30-m-thick layer of Quaternary clay, sand, and gravel. Cretaceous and Paleocene units crop out in a discontinuous band just northwest of the boundary and, farther northwest, in outliers throughout a zone several kilometers wide. No Paleozoic outcrops are found in the Arkansas part of the upper Mississippi Embayment, but many post-Paleozoic outliers occur in the eastern Ozark region.
The northwestern part of the Newport area, underlain by Paleozoic rocks, lies within the eastern ends of two principal physiographic provinces: the low-lying Arkansas Valley section of the Ouachita porvince on the south, and the relatively high Ozark Plateaus province on the north (fig. 1). The Ozark Plateaus province is in turn divisible into three distinct geomorphic units: (1) the Salem Plateau to the north (underlain by a variety of Ordovician units that are subject to truncation by the solution of their carbonate), (2) the Springfield Plateau (underlain by the highly resistant Boone Formation of Mississippian age), and (3) the Boston Mountains to the south (underlain by various siliceous sandstone beds of Early Pennsylvanian age). West of the Newport area, where these 
three geomorphic units are well delineated, the Boston Mountains stand nearly $400 \mathrm{~m}$ above the Springfield Plateau; and the Springfield Plateau, in turn, stands nearly $100 \mathrm{~m}$ above the Salem Plateau.

In the eastern Ozarks of the Newport area, facies changes all but eliminate any distinctive Boone-supported plateau along the edge of the embayment where Paleozoic units dip beneath younger deposits. The term Boston Mountains loses some of its usual significance when applied to topographic highs at the edge of the embayment, because the "mountains" there are uplifted areas that once were part of the embayment. Even though the standard concepts of Ozark geomorphic subdivisions are barely applicable at the eastern edge of the Ozark region, the terminology is retained to identify the distal ends of regionally meaningful geomorphic features. Furthermore, although the three geomorphic provinces of Arkansas (Ozark Plateaus, Ouachita, and Coastal Plain) theoretically join at a point within the Newport area (fig. 1), the effects of the emplacement of magma related to the Newport pluton have left the location of that junction quite vague.

\section{PREVIOUS INVESTIGATIONS}

In the Newport area, the geology of both the Paleozoic rocks to the northwest and the Cretaceous and younger sediments to the southeast have been investigated intermittently during the past century. The northwestern part of the Newport area includes the eastern half of the Batesville manganese district (fig. 1) which, along with the area to the south and east, has been extensively studied because it contains deposits of manganese ore, high-calcium limestone, agricultural limestone, building stone, glass sand, gravel and other roadmetal resources, important faunal zones, abundant ground water, and a trace of natural gas (Miser, 1922, 1941; Croneis, 1930; Easton, 1942; Gordon, 1944, 1964; Gordon and Kinney, 1944; Kinney and Straczek, 1950; Sheldon, 1954; Frezon and Glick, 1959; and Stroud and others, 1969).

The geology of the Arkansas portion of the Mississippi Embayment has been investigated in reference to ground water, gravel deposits, oil and gas possibilities, lignite deposits, and faunal zones (Stephenson and Crider, 1916; Spooner, 1935; Renfroe, 1949; Caplan, 1954; Sheldon, 1954; and Clardy, 1979).

Geophysical investigations of the Newport area have had a special impact on geologic concepts related to deeply buried sedimentary units and to underlying or possibly intruding igneous masses that have not yet been reached by the drill bit (Jespersen, 1964; Ouellette, 1970; Ervin and McGinnis, 1975; Hildenbrand and others, 1977; Cordell, 1977; Hendricks, 1979; Hendricks and Hildenbrand, 1979; and Hildenbrand and others, 1979). A recent map (Heyl and McKeown, 1978) summarizes the regional seismotectonic setting of the area.

\section{THIS INVESTIGATION}

The objective of this investigation of the Newport area was to reexamine on a regional basis many of the unresolved problems left by the local and topical geologic investigations of previous workers, and to organize and present both old and new data in various ways to depict the post-Paleozoic stratigraphic and structural development of the area. Previous workers left many geologic uncertainties in this particular part of the embayment area, because (1) some of the structural and depositional effects of the emplacement of the Newport pluton were recorded but not understood, and (2) remnants of postPaleozoic deposits west of the embayment lowlands are so widely scattered that they were largely ignored.

After this investigation was started, the discovery was made that the previously mapped rocks of Paleocene age which occur $70 \mathrm{~m}$ above sea level at the edge of the Mississippi Embayment have a counterpart of silicified limestone near the crest of the adjacent "mountain" $240 \mathrm{~m}$ above sea level (figs. 2 and 3). As the carbonate unit of the Paleocene sequence is less than $10 \mathrm{~m}$ thick in this immediate area and rests on or within $3 \mathrm{~m}$ of the Paleozoic surface, its distortion is unrelated to compaction of underlying material. Post-Paleocene uplift is involved and the mountain of Paleozoic rock is younger structurally than the Paleocene rock resting on it. With some local uplift accepted as a certainty, available data were plotted on a series of maps (figs. 4-9) to quantitatively show the structural displacement that has occurred in the Newport area since middle Cretaceous time.

Much of the material deposited in the Newport area since that time has remained relatively unconsolidated; a small percentage of it is limestone, silicified limestone, and sandstone cemented by iron oxide. As the term rock does not correctly apply to most of the material, the term sediment is used in this report to designate a general class of material that includes largely unconsolidated detritus and some slightly consolidated marl. When applicable, the terms clay, silt, sand, and gravel are used to designate specific classes of unconsolidated detritus. Specific types of sedimentary rock are noted if important to a concept.

The formal terms Late Cretaceous and pre-Late Cretaceous are in part too general for the purposes of this report. Technically, Late Cretaceous is a span of about $35 \mathrm{~m}$.y., whereas the Late Cretaceous sea probably did not reach the Newport area until about Maastrichtian time-probably not more than 5 m.y. before the end of the Cretaceous Period. Therefore, the Upper Cretaceous sequence of the Newport area probably was deposited during only the last $5 \mathrm{~m}$.y. of Cretaceous time. The informal term middle Cretaceous is used to indicate much of the first $30 \mathrm{~m}$.y. of Late Cretaceous time.

This study was supported by the National Earthquake Hazards Reduction Program and the Reactor Hazards Reduction Program of the U.S. Geological Survey. Cuttings and 


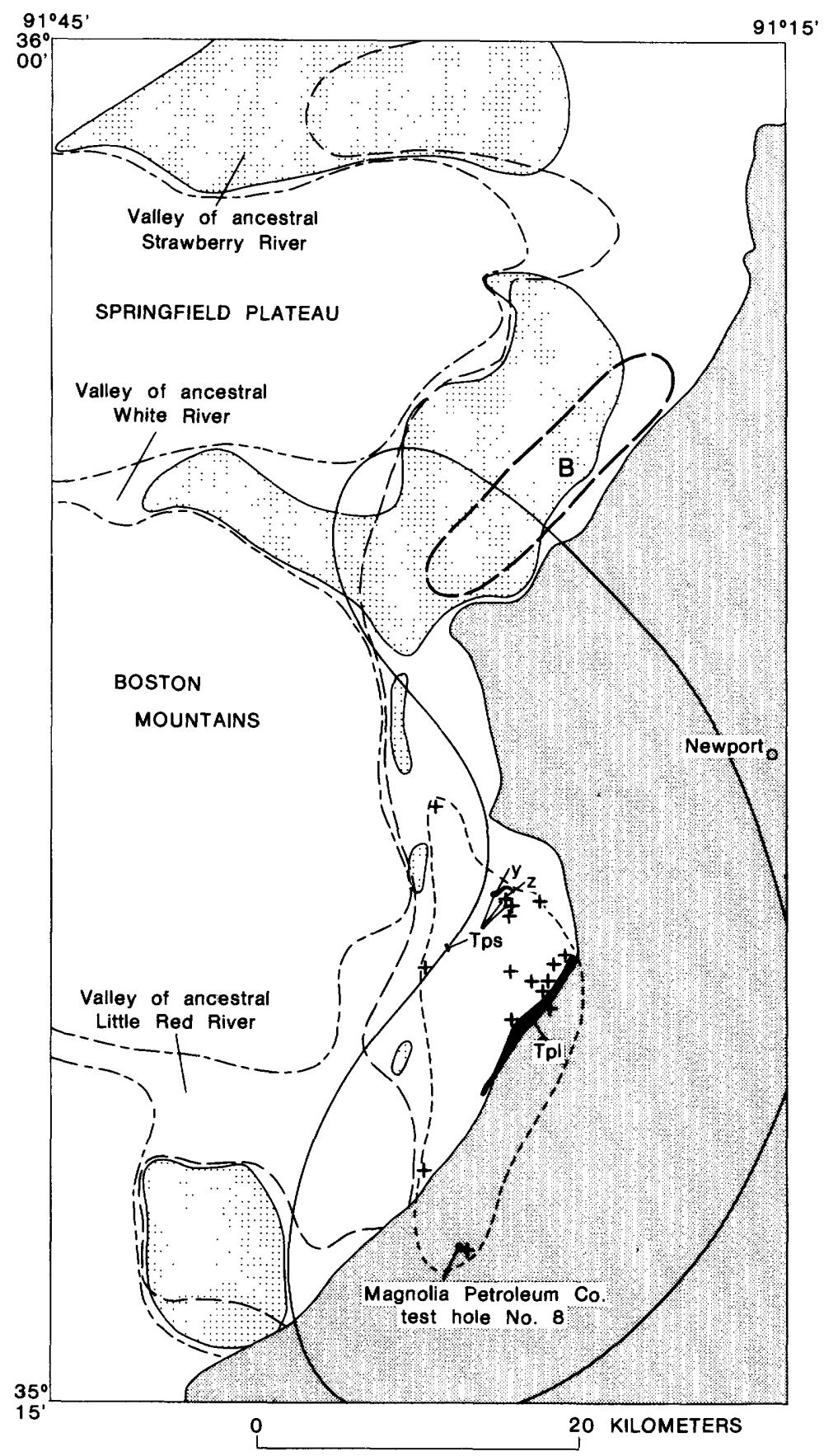

\section{EXPLANATION}

Main body of alluvium of Quaternary age in the Mississippi Embayment--Valleys of streams entering the embayment area contain alluvium not shown here

- - Western limit of scattered deposits of upland gravel; probably late Paleocene in age

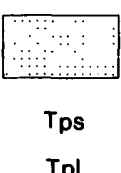

Areas that contain thicker, locally commercial, deposits of upland gravel

Outcrops of silicified Paleocene limestone
Paleocene limestone of the Grand Glaise terrace area, in part covered by loess and gravel

Generalized limit of sandstone-pebble gravel of Late Cretaceous and early Paleocene age. Widely scattered localities at which pebbles are abundant, locally in commercial quantities, indicated by cross

_ - Western limit of widely scattered remnants of Upper Cretaceous sand and clay

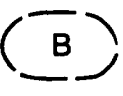

Offshore bar of Late Cretaceous age

Geographic limit of main body of deeply buried dense and highly magnetic rock of the Newport pluton, as determined from geophysical data

$z$ Manmade exposure in SW $1 / 4$ SE $1 / 4$ SE $1 / 4$ sec. 32 T. 11 N., R. 4 W., in which a layer of sandstone pebbles underlies a massive bed of silicified Paleocene limestone

y Outcrop in SW $1 / 4 N E 1 / 4$ sec. $32, T, 11 \mathrm{~N}$ R. $4 \mathrm{~W}$. in which pebbles of Ordovician and Mississippian chert and angular fragments of silicified Paleocene limestone occur together in an iron-rich sandy matrix

FiGURE 2. - Map of the Newport area showing outcrop localities or generalized limits of post-Paleozoic sedimentary units, and the geographic limit of the main body of the deeply buried Newport pluton.

cores from test holes drilled in and near the area of study were obtained with the cooperation of the Arkansas Geological Commission and the Mobil Oil Corporation. Norman F. Williams, Director of the Arkansas Geological Commission, and Elizabeth A. Elliot of the Mobil Oil Corporation were especially helpful. Donald R. Albin of the U.S. Geological Survey logged cuttings from the Newport Air Base test hole (fig. 10). 


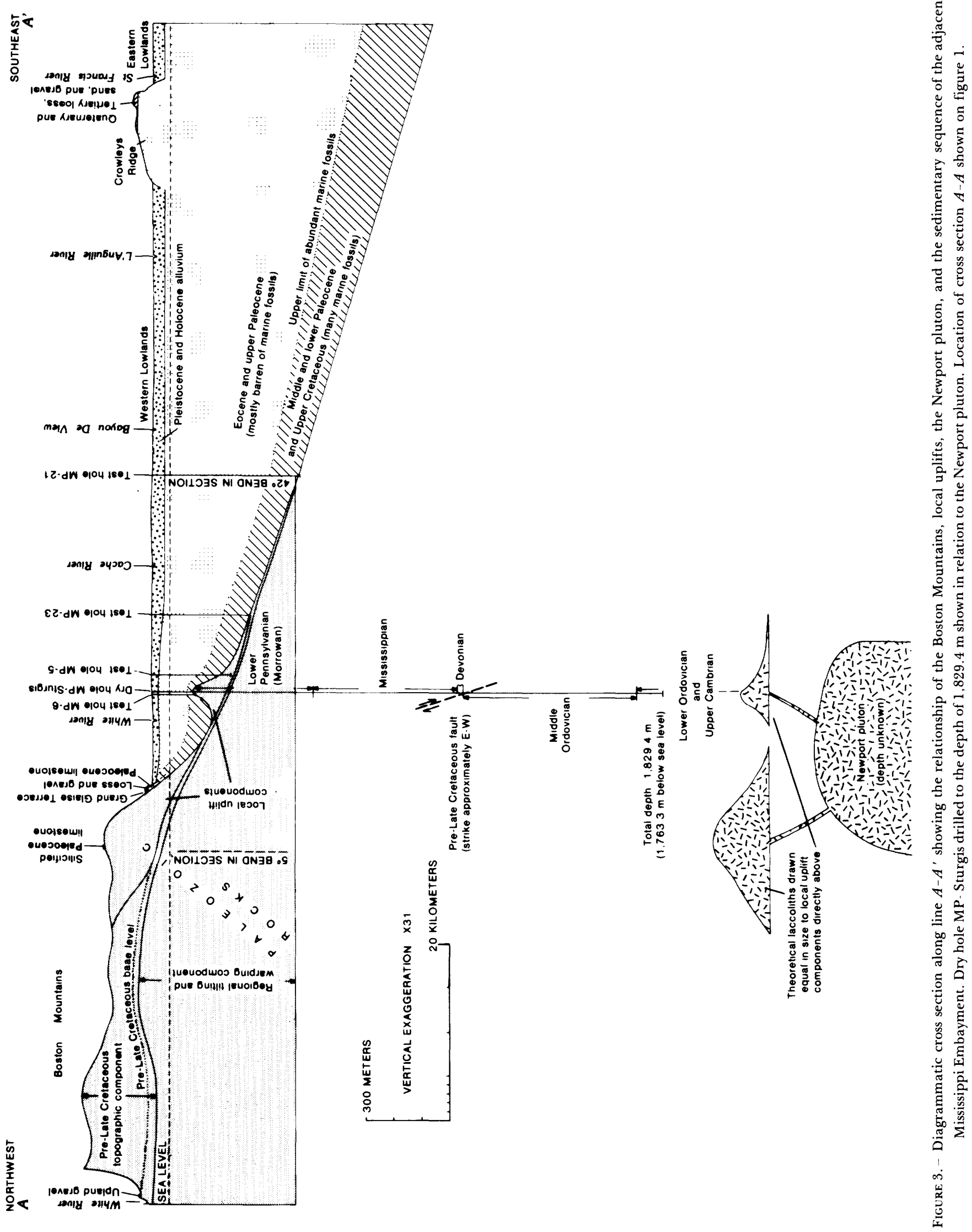




\section{GEOLOGIC HISTORY}

Based on current assumptions, the central part of the upper Mississippi Embayment area has been modeled as part of an ancient trough that may have been a rift valley or graben receiving deposits (volcanic, nonmarine, marine, or a mixture) during late Precambrian through Middle Cambrian time (Hildenbrand and others, 1977; and fig. 1). If so, deposition was effectively confined to the graben while drainage from the exposed igneous terrane of much of the upper midcontinent area was funneled into that trough. During Late Cambrian time the sea flooded the graben and spilled out across the adjacent lowlands. From then until Middle Pennsylvanian time, regional deposition and subsidence continued intermittently throughout the Ozark region and was nearly continuous in the trough. During early and middle Carboniferous time, a great quantity of detritus poured into at least the western part of the subsiding trough; much of the coarser detritus was reworked and swept westward by longshore currents while the central part of the trough received finer material.

An early phase of the Ouachita orogeny of Late Pennsylvanian time arched the trough or its outlet enough to block continental drainage and force the drainage to run around the north side of the Ozark region. No permanent deposits accumulated in the trough during the nearly $200 \mathrm{~m}$.y. from Middle Pennsylvanian to Late Cretaceous time, but through a process of erosion, or erosion and subsidence, midcontinent drainage was re-established there. Marine deposition was renewed during the latter part of Cretaceous time as mafic or ultramafic magma was emplaced to form plutons along the margins of the trough (Hildenbrand and others, 1977). A final retreat of the sea at the end of Eocene time, and a resultant extension of the major midcontinent river across the embayment area, established the modern aspect of the Mississippi Embayment. Pleistocene glaciation blocked the northern outlet of the Missouri River, which then began to flow into the Mississippi Valley and down the trough.

The pre-Late Cretaceous development of the broad embayment plain is a geologic enigma. Ample time - a substantial part of $200 \mathrm{~m}$.y. - was available for the widening of the valley once a channel was established, but a special sequence of events or circumstances seems to have been required to get a stream to cross the area. Apparently the post-Ouachitaorogeny route down the embayment and across the Ouachita Mountains was not as high topographically as geologic computations and projections seem to suggest, and this path was the best of several possible outlets for the ancestral Ohio River. Whatever the events may have been, a southward-flowing stream breached or circumvented the now-buried eastern end of the Ouachita Mountains during late Paleozoic or Mesozoic time. The Late Cretaceous sea advanced northward up a broad valley that had been cut directly across the structural grain of the Ouachita Mountains and across the ancient Mississippi Valley graben at an angle of about 20 .

\section{STRUCTURAL COMPUTATIONS}

\section{THE PRE-LATE CRETACEOUS EROSION SURFACE}

The surface that was shaped by $200 \mathrm{~m}$.y. of erosion prior to the advance of the Late Cretaceous sea is identifiable within broad limits over much of the Newport area. It is of critical importance in this study of subsidence and uplift during the past $70 \mathrm{~m}$.y. Two significant types of features - the Mississippi Embayment and the local uplifts in the vicinity of the Newport pluton-developed in this area after the Late Cretaceous sea began to flood the erosion surface; those features can be measured quantitatively by measuring the distortion of that surface. As no other applicable horizon is available, any disadvantages of using the erosion surface as a datum are recognized as unavoidable factors in the overall problem.

Contours showing the reconstructed pre-Late Cretaceous erosion surface (fig. 4) are based on data and assumptions that differ according to the state of preservation of the surface in each of three distinct parts of the Newport region: (1) the embayment area in which the erosion surface is preserved extensively beneath Cretaceous deposits, (2) adjacent parts of the Ozark region and Arkansas Valley in which a few Cretaceous and Tertiary remnants can be found in areas of mostly Paleozoic outcrop, and (3) parts of the Ozark region and Arkansas Valley in which no Cretaceous or Tertiary deposits are known. As the general altitude of the top of the embayment-lowland surface of this area is only slightly more than $60 \mathrm{~m}$ above sea level, the +60 -m contour on figure 4 is used as the generalized boundary of the embayment on this and on figures 2 and 7.

The erosion surface in the embayment segment of the Newport area now extends from the +60 - to the $-360-\mathrm{m}$ contours and has a relatively uniform southeast dip of less than $1^{\circ}$. Regionally, the southeast dip of the top of the undifferentiated Paleozoic beds remains relatively constant at less than $1^{\circ}$ through the outer $75 \mathrm{~km}$ of the northwest limb of the Mississippi Embayment and then decreases gradually through the next $45 \mathrm{~km}$ to the embayment axis near the present position of the Mississippi River (Caplan, 1954, pl. 2; and Cushing and others, 1964, fig. 4). As no significant pre-Late Cretaceous hills, ridges, or valleys have been identified in the embayment area of Arkansas, the erosion surface is assumed to have had little relief at the beginning of Late Cretaceous time-just enough southeast slope for drainage. The obvious distortion of the surface in the southeastern part of the Newport area is evidence of a post-Cretaceous uplift, which has been outlined by test drilling.

Where remnants of Late Cretaceous and Paleocene deposits are present on Paleozoic beds northwest of the embayment edge (northwest of the +60 - $\mathrm{m}$ contour, fig. 4 ), the pre-Late Cretaceous erosion surface is drawn to show as little undulation as possible while depicting a surface above all Paleozoic beds and below all Cretaceous and Paleocene deposits. The 


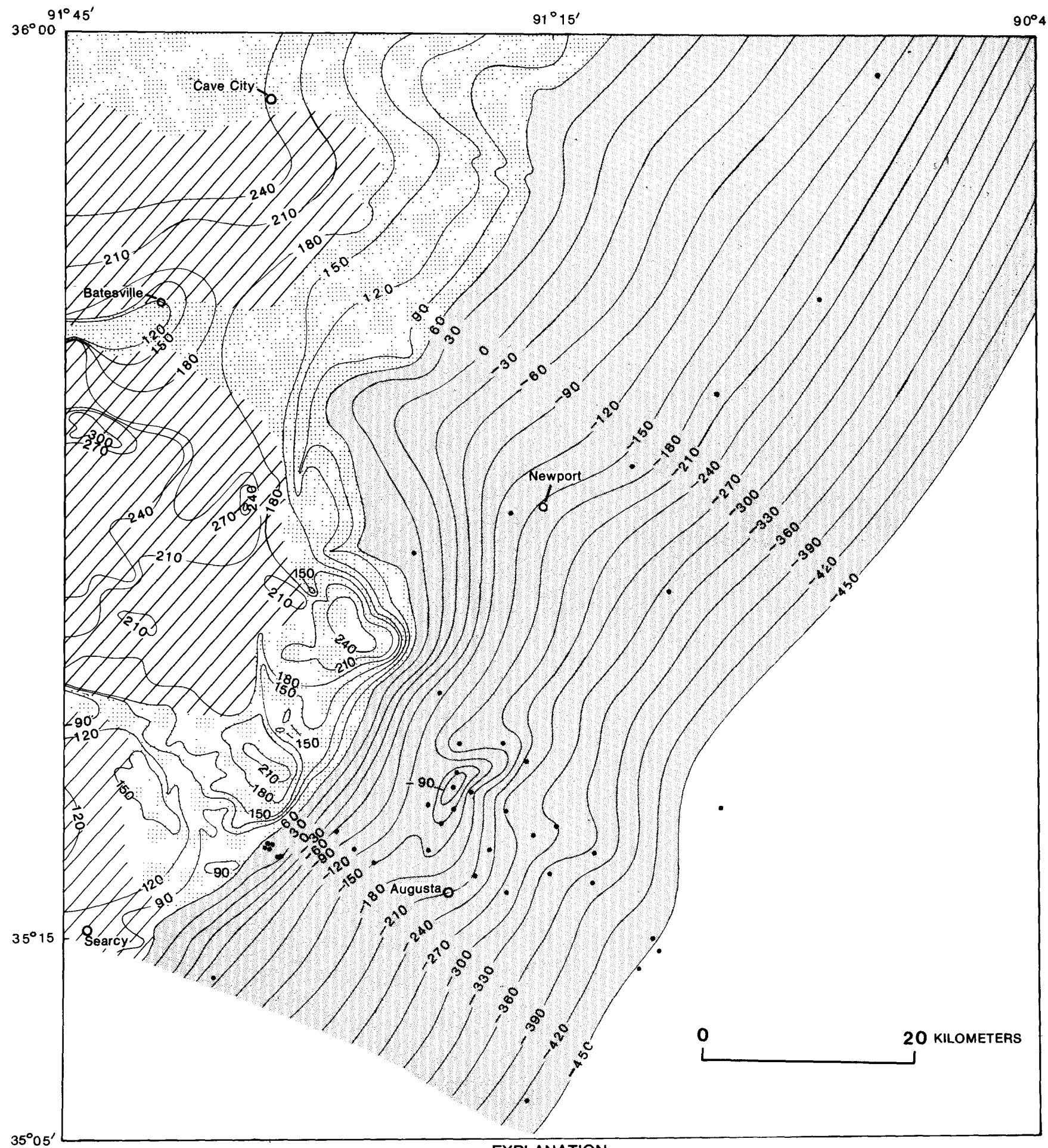

\section{EXPLANATION}

Embayment area in which the pre-Late Cretaceous erosion surface is preserved extensively beneath Cretaceous deposits

Eastern Ozark region in which a few Cretaceous and Tertiary remnants can be found in an area of mostly Paleozoic outcrops
Parts of the Ozark region and Arkansas Valley in which no Cretaceous of Tertiary deposits are known

- Drill hole

FiguRE 4-- Map of three distinct parts of the Newport region with contours drawn on top of the reconstructed pre-Late Cretaceous erosion surface. Contour interval, $30 \mathrm{~m}$; datum, mean sea level. The $+60 \cdot \mathrm{m}$ contour is the approximate boundary of the Mississippi Embayment. 
surface dips into valleys that contain Upper Cretaceous deposits but is drawn above valleys that appear to have been cut since Cretaceous time. The younger valleys tend to have high, steep walls, whereas the old valleys that contain deposits of Late Cretaceous age tend to be more open.

The dip of the erosion surface changes little in crossing the Mississippi Embayment boundary, remaining at a little less than $1^{\circ}$ to the southeast. Farther northwest in the Salem Plateau, the dip decreases. The largest local uplift of postPaleocene age in the Newport area (mentioned earlier in this report) distorts the surface in the south-central part of the area. A much smaller uplift is indicated by a closed $+90-\mathrm{m}$ contour just south of the southern lobe of the large uplift.

The most controversial of the three parts of the erosion surface is in the western part of the Newport area, where the Boston Mountains, the Springfield Plateau, and part of the Arkansas Valley stood above the Late Cretaceous sea floor; therefore, no post-Paleozoic marine remnants exist to mark the present position of the former upland surface (figs. 2, 4). In this area the erosion surface is drawn as a relatively smooth tentlike horizon slightly above the Paleozoic beds in such a way that only a small amount of erosion since middle Cretaceous time is accounted for. Any error caused by this procedure is a result of being too conservative in estimating erosion and is thought to be small. Long exposure prior to Late Cretaceous time must have resulted in a greatly decreased rate of erosion of these sandstone-capped and chert-residuum-capped uplands.

The reconstruction of the position of the pre-Late Cretaceous erosion surface, shown on figure 4 , involves using data from an actual surface whose position can be verified by drilling in the embayment or by mapping post-Paleozoic outcrops in all but the western part of the upland, where no Upper Cretaceous units were deposited. The two requirements of the surface, that it be above the present position of all Paleozoic beds and below the present position of all Upper Cretaceous and Tertiary deposits of the area, give it a great deal of constraint. The three derivative maps described below are interpretive, but only to the extent permitted by the objective control built into figure 4. By definition, these three maps (figs. 5-7) each show a separate component, and the fourth (fig. 4) is a combination of all components; any one of the maps can be reproduced from a proper combination of the other three.

\section{REGIONAL TILTING AND REGIONAL WARPING}

The three, largely unrelated components that define the surface shown on figure 4 are (1) regional tilting and regional warping, (2) pre-Late Cretaceous topography, and (3) local uplifts. Regional tilting and warping, as implied by its name, significantly involves the entire area (fig. 5), and for the most part, relates to the normal development of the Mississippi Em- bayment. It is shown by smooth contours that tend to parallel the trend of the embayment. The pre-Late Cretaceous land surface rose significantly above sea level only in the western part of the Newport area (fig. 6); local uplifts are anomalies that shaped the embayment only in limited areas (fig. 7).

The amount of regional tilting and warping (fig. 5) was determined by using control points from areas of outcrop and from the subsurface, but all the control points were outside of the limits of topographic and structural anomalies. Contours were projected through the anomalous areas and tied to control points on either side. Separating Cretaceous topography and local uplifts from regional tilting is not difficult. Tilt is relatively uniform and is the only factor involved in much of the area. Abrupt changes in the dip of the erosion surface at an uplift or at the edge of the middle Cretaceous upland clearly indicate the addition of another factor. The maximum amount of regional tilting and warping of the erosion surface shown on figure 5 is less than $1^{\circ}$; the maximum dip of the erosion surface in the vicinity of uplifts is as much as $4^{\circ}$.

As can be seen from figure 5 , the southeast corner of the Newport area (lat $35^{\circ} 15^{\prime}$; long $91^{\circ} 15^{\prime}$ ) has subsided more than $360 \mathrm{~m}$ and the northwest corner has risen more than 180 $m$ relative to sea level since the Late Cretaceous sea reached the area. Tilting toward the axis of the embayment is at a relatively uniform rate in the eastern part of the area but is reversed on the west side of the crest of a north-trending anticline that dominates the west-central and southwestern parts of the Newport area. This anticline is well outlined by field evidence along the south side of the White River valley and is extended southward from there on the basis of less positive evidence. The anticline may have been formed by the emplacement of an igneous body related to the Newport pluton, but probably it resulted from an entirely different stress. The structure is not similar to the more elliptical uplifts elsewhere in the area and is not a feature of middle Cretaceous topography. The anticline is present only in the area adjacent to and slightly east of the above-sea-level mass of the Boston Mountains. Apparently the Boston Mountains rose during the development of the Mississippi Embayment (as did the area directly to the north of them), but have since subsided. If so, the anticline was formed as a result of subsidence along the high side of a once uniformly tilted surface- not as a result of local uplift along an axis.

\section{PRE-LATE CRETACEOUS TOPOGRAPHY}

The second-largest component of the surface that represents the reconstructed position of the pre-Late Cretaceous erosion level is the topography of the area at the time of the advance of the Late Cretaceous sea (fig. 6). Even though that long-since-altered topographic surface is unknowable in detail, some of its general features can be outlined. In the west-central part of the Newport area, the eastern end of the Boston Mountains stood at least $240 \mathrm{~m}$ above the level of the 


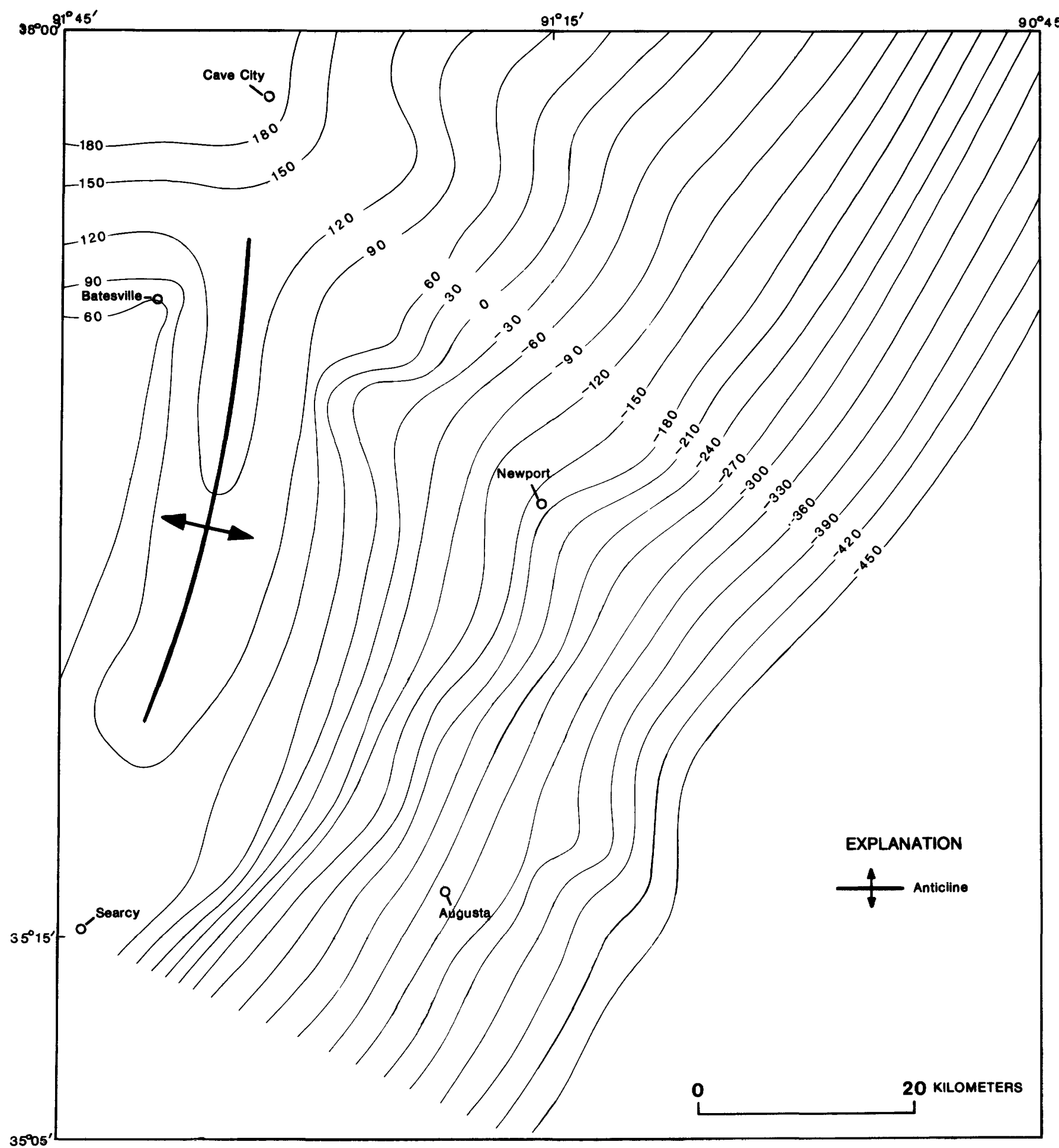

FigurE 5. --Map of the Newport region showing the cumulative effect of regional tilting and regional warping of the pre-Late Cretaceous erosion surface. Contour interval, $30 \mathrm{~m}$; datum, mean sea level.

advancing Late Cretaceous sea; today that part of the area is a little more than $300 \mathrm{~m}$ above present sea level. Just north of those mountains the eastern end of the Springfield Plateau sloped gently eastward from a level more than $90 \mathrm{~m}$ above the sea; today the highest hills there are more than $240 \mathrm{~m}$ above present sea level. These measurements of Late Cretaceous 
topography are made from the top of present-day topographic highs to the base of nearby post-Paleozoic deposits that accumulated at or near sea level. As such, they are conservative. Valleys of ancestral rivers also are marked by remnants of postPaleozoic deposits. Valleys of the ancestral Strawberry and Little Red Rivers (fig. 6) were respectively south and north of today's river valleys. The White River was then much as it is now, just north of the Boston Mountain escarpment. The proemial Mississippi Embayment lowlands sloped gently (perhaps even more gently than is shown on fig. 6) toward the advancing shoreline.

\section{LOCAL UPLIFTS}

The location and size of each of three local uplifts in the Newport area are shown on figure 7 , along with their geographic relationships to the Newport pluton and to the western edge of the Mississippi Embayment. These uplifts are shown quantitatively as the residuum in this series of computations; they are what is left after middle Cretaceous topography (fig. 6) and regional tilting and warping (fig. 5) are subtracted from the reconstructed pre-Late Cretaceous erosion surface (fig. 4). Subsurface and outcrop data also indicate the general geographic positions of the uplifts, which are anomalously high masses of Paleozoic rock overlain by structurally high post-Paleozoic deposits. Only the indirect computations used here, however, yield a clear indication of their true shape and size.

Collectively the three local uplifts cover an area of nearly $950 \mathrm{~km}^{2}$, which is only a little less than the area underlain by the Newport pluton. They and the pluton, however, are not totally within the same boundaries (fig. 7). Apparently the uplifts developed when magma associated with the pluton was injected into the lower part of the sedimentary sequence. If so, more than $50 \mathrm{~km}^{3}$ of magma was emplaced in order to effect the arching of the overlying rocks. No post-Paleozoic faults are known to be related to the uplifts, and no dip greater than $4^{\circ}$ has been measured on the flanks of the structures. Upper Cretaceous and younger depositional units above and geographically near the Newport pluton are discussed under that heading later in this report. The distribution of those units helps to identify the uplifts.

The locations of the two deepest holes that have been drilled on or near the uplifts are shown on figure 7. Both test holes reached total depth in rocks of Early Ordovician age, the northern one at $1,457 \mathrm{~m}$ below sea level and the southern one at $1,763 \mathrm{~m}$ below sea level (fig. 3). Neither test hole encountered igneous rock or unusually high temperatures.

The area occupied by the two northwestern uplifts is now generally included within the boundary of the Boston Mountains of the Ozark region, even though the uplifts are in areas once covered by embayment sediments. The southeasternmost uplift still is covered by embayment sediments because regional tilt exceeded uplift there. The "offset or reentrant" of the embayment boundary (Jespersen, 1964) just south of the White River valley (fig. 7) is a result of post-Eocene erosion that stripped most of the younger sediment from the large uplift but left nearly all of the associated Paleozoic rock standing well above the embayment level. Close examination of the regional trend of the embayment boundary, as shown on the geologic map of Arkansas (Haley and others, 1976), reveals that the anomaly in the trend is a protuberance or bulge into the embayment area and that the reentrant into the Ozark region is a complementary feature on the north side of the bulge which is accented by the broad valley of the White River.

\section{COMBINED FEATURES}

Even though the three features-middle Cretaceous topography, regional tilting and warping, and local upliftsappear to be unrelated genetically, selective combinations of them are informative. The combination of the effect of regional tilting and warping with the effect of local uplift (fig. 8) shows the total deformation of the Newport region since middle Cretaceous time. This view of the data reinforces the conclusion that the uplifts are local anomalies rather than a part of the regional tilting toward the axis of the embayment. No faults are known to have been involved in the formation of the uplifts or in the tilting.

A somewhat different aspect of the uplifts is shown by their combination with middle Cretaceous topography (fig. 9). Without the effect of regional tilting and warping, the crest of the highest uplift is on a level with the crest of the Boston Mountains. This was never their relative standing, however, because at least one-third of the tilting had been accomplished prior to the final uplifting. Again, the uplifts are seen as anomalies of the embayment area, slightly detached from the Ozark region. Even a cursory comparison of the distribution of post-Paleozoic deposits (fig. 2) and the combination of middle Cretaceous topography and local uplifts (fig. 9) indicate how readily the topography and the uplifts can be differentiated. None of the younger marine deposits overlies the remnants of middle Cretaceous hills, but three post-Paleozoic marine units extend onto or across the highest uplift.

\section{UPPER GRETACEOUS AND YOUNGER DEPOSITIONAL UNITS ABOVE AND GEOGRAPHICALLY NEAR THE NEWPORT PLUTON}

\section{GENERAL STATEMENT}

Beds of post-Paleozoic sand and clay in the area of outcrop of the Newport region have yielded no identifiable spore, pollen, or microfossils and only a few megafossils. The deposits that, in this report, are considered to be of Late Cretaceous 


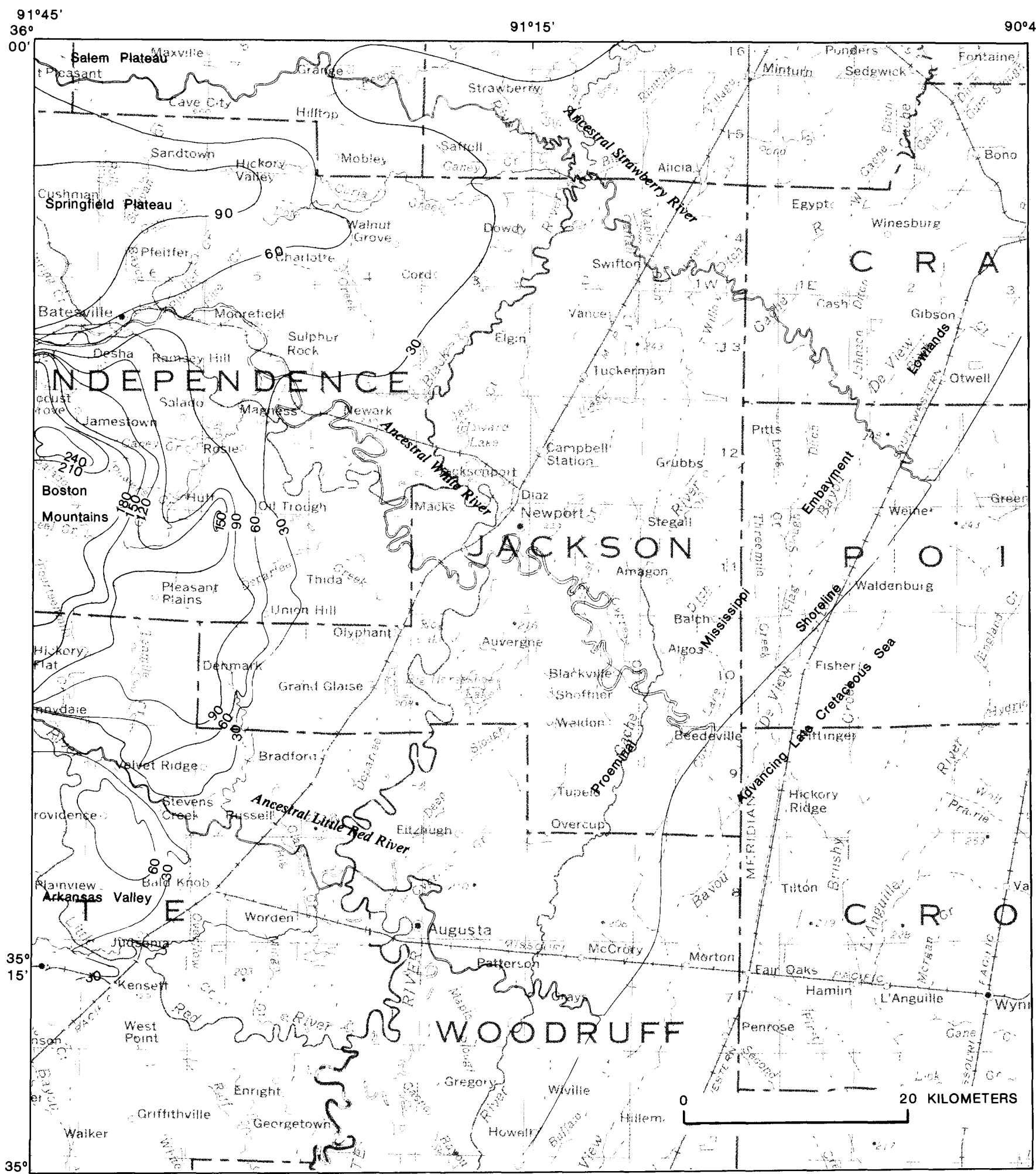

Figure 6. - Map of the Newport region showing an interpretation of the topography at the time of the advance of the Late Cretaceous sea. Contour interval, $30 \mathrm{~m}$; datum, mean sea level as of the time when the shoreline was as indicated on this map. 


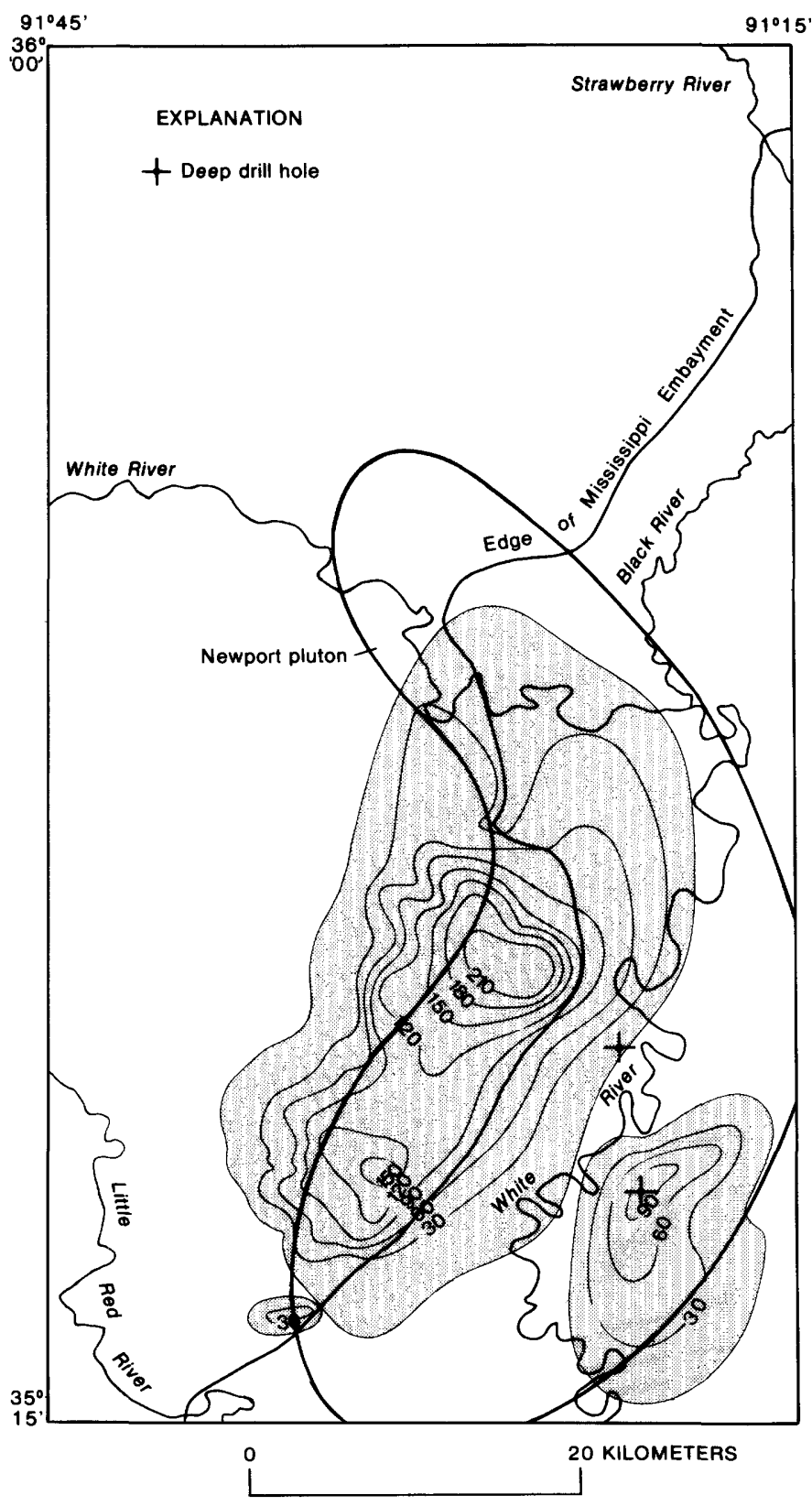

Figure 7. - Map of the Newport area showing the location and size of three local uplifts, all of probable pre-middle Eocene age, and their geographic relationship to the Newport pluton and to the western edge of the Mississippi Embayment. Contour interval, $30 \mathrm{~m}$; datum (outer limit of each uplift) arbitrarily assigned to a horizontal surface.

age are so classified on the basis of the work of Stephenson and Crider (1916), on stratigraphic position, on lithologic correlation, and on the lack of convincing evidence that the deposits are younger than Cretaceous. Outcrops of Paleocene limestone and silicified limestone are fossiliferous and easily recognizable but are restricted to the area of the largest of the three local uplifts, entirely south of the White River (fig. 2). No outcrops of Eocene deposits have been recognized in the Newport area, but Eocene deposits are present in the subsurface in the southeastern part of the area.

Rocks of Paleocene age that cap the Grand Glaise terrace along the edge of the embayment a few kilometers south of the White River (figs. 2, 3) yield an abundant fauna of Midway age. Stephenson and Crider (1916, p. 49-54) furnished details of the lithology, fauna, and stratigraphic relations of the Paleocene units in this area. (The Midway formation of Stephenson and Crider, 1916, and of earlier workers, originally was included in the Eocene Series.) Those authors also included two general comments in their report that, if accepted as stated, would counter some of the concepts of the present report:

1. p. 51 - "West of Bradford the Midway formation rests against the Paleozoic rocks along a steep eastward-sloping contact which probably represents an ancient sea cliff." Recent work (Glick, unpub. data, 1978) has shown that silicified limestone of Midway age caps the hills northwest of Bradford and that the "ancient sea cliff" is the unfaulted limb of a major post-Paleocene uplift.

2. p. 53 - "Independence County. - The Midway formation extends from Jackson County northward into the southern part of Independence County. Harris (1894, p. 24) says: In Arkansas the Midway stage forms a low, terracelike elevation on the northeast flank of the Paleozoic upland just to the south and southwest of Bayou Departe, Independence County."

Apparently Stephenson and Crider did not quite understand what Harris intended. The Midway does not extend along the edge of the embayment from Jackson County northward into Independence County, and Harris did not actually say that it does. At any rate, on their map (1916, pl. 2), Stephenson and Crider showed a narrow band of Midway and younger deposits extending along the edge of the embayment northward from Grand Glaise in Jackson County to Departee Creek (formerly Bayou Departe) in Independence County. Authors of the 1929 Geologic Map of Arkansas (Arkansas Geological Survey, 1929), Fisk (1944, pl. 10, sheet 1), Jespersen (1964), and numerous others have perpetuated the error. Only at the northernmost end of the band of outcrop shown on those maps do Cretaceous and possibly younger deposits form "a low, terrace-like elevation."

Seven lithologic units or stratigraphic sequences above the Paleozoic bedrock have been recognized in the outcrops and subsurface of the Newport area. Even though the units are not of equal stratigraphic rank, each is the product of a local or regional event that is important to the understanding of the structural and depositional history of the area. These units, listed below, are numbered from oldest to youngest and are discussed in that order in the following text: 


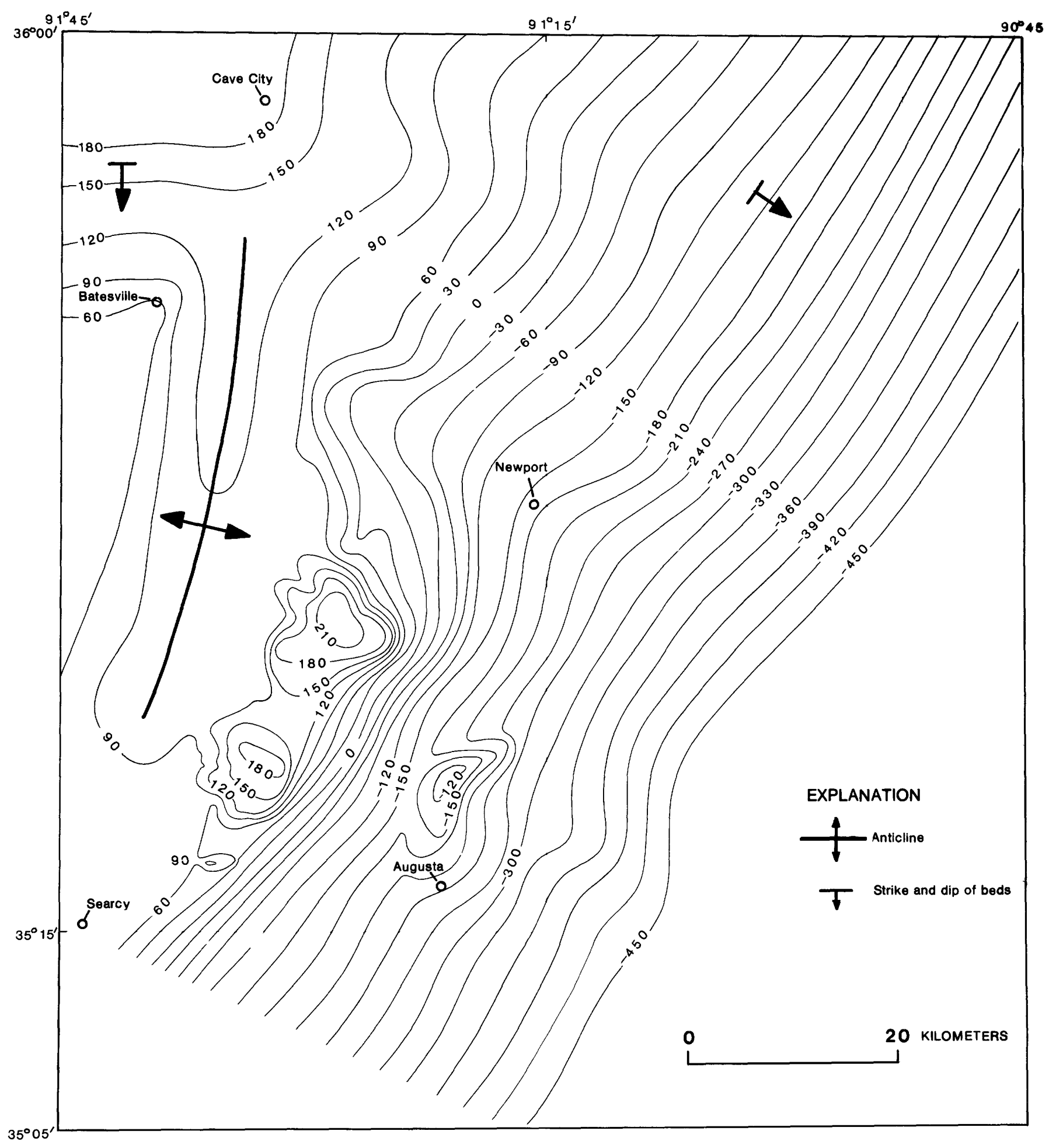

Figure 8. - Map of the Newport region showing the cumulative deformation of the pre-Late Cretaceous erosion surface (that is, regional tilting and warping plus local uplift). Contour interval, $30 \mathrm{~m}$; datum, mean sea level. 
(7) post-Eocene deposits of gravel, alluvium, and windblown material

(6) clay, silt, sand, and lignite of Eocene age (not known to crop out in this area)

(5) upland gravel, mostly chert pebbles

(4) the Paleocene limestone; found to be silicified in some locations; containing sandstone-pebble clasts in many locations

(3) the main body of the Upper Cretaceous sequence; mostly sand but partly clay, with local deposits of sandstone pebbles

(2) the basal conglomerate of the Upper Cretaceous sequence; scattered chert pebbles in locally derived residuum

(1) the weathered and leached upper layer of the Paleozoic substratum

\section{UNIT 1: THE WEATHERED PALEOZOIC SUBSTRATUM}

Outliers of post-Paleozoic deposits in the Newport area rest on a leached and weathered layer of Paleozoic material that, in many outcrops, may appear to be a depositional unit. The nature and significance of the weathered layer varies with the original character of the underlying rock, with the length of time of weathering, and with other more subtle factors. A correct interpretation of this leached zone in its various settings is helpful in appraising remnants of post-Paleozoic deposits.

Paleozoic limestone overlain by permeable Cretaceous deposits is especially susceptible to leaching; dolomite is a little less so. Shale is susceptible to the oxidation of its dark carbonaceous fraction and to other changes that make it plastic; sandstone and chert are less affected. The depth of weathering of the underlying Paleozoic rocks increases from east to west $35^{\circ} 15^{\prime \prime}$ across the Newport area. West of Cave City in the northern part of the Newport area, manganese ore is mined from a residual zone beneath gravel (Miser, 1922, p. 105-107); that zone is the product of the sub-gravel leaching of as much as 30 $\mathrm{m}$ of Ordovician limestone. To the east in the Newport area, the cover was thicker and more clayey, resulting in generally less sub-gravel solution and letdown.

All the weathering described here is of a type that is assumed to have taken place under a cover of permeable material. That cover absorbed rainwater, kept the substratum damp with slightly acid ground water, and prevented the mechanical erosion of the residue that resulted from leaching. The residue from Paleozoic carbonate is a layer of light-gray, plastic, clayey quartz silt or sand that, when wet, behaves like plastic clay. The clay fraction is illite, in contrast to the montmorillonitic clay of the overlying Cretaceous. The quartz content of the material generally is quite high in spite of the clayey appearance.

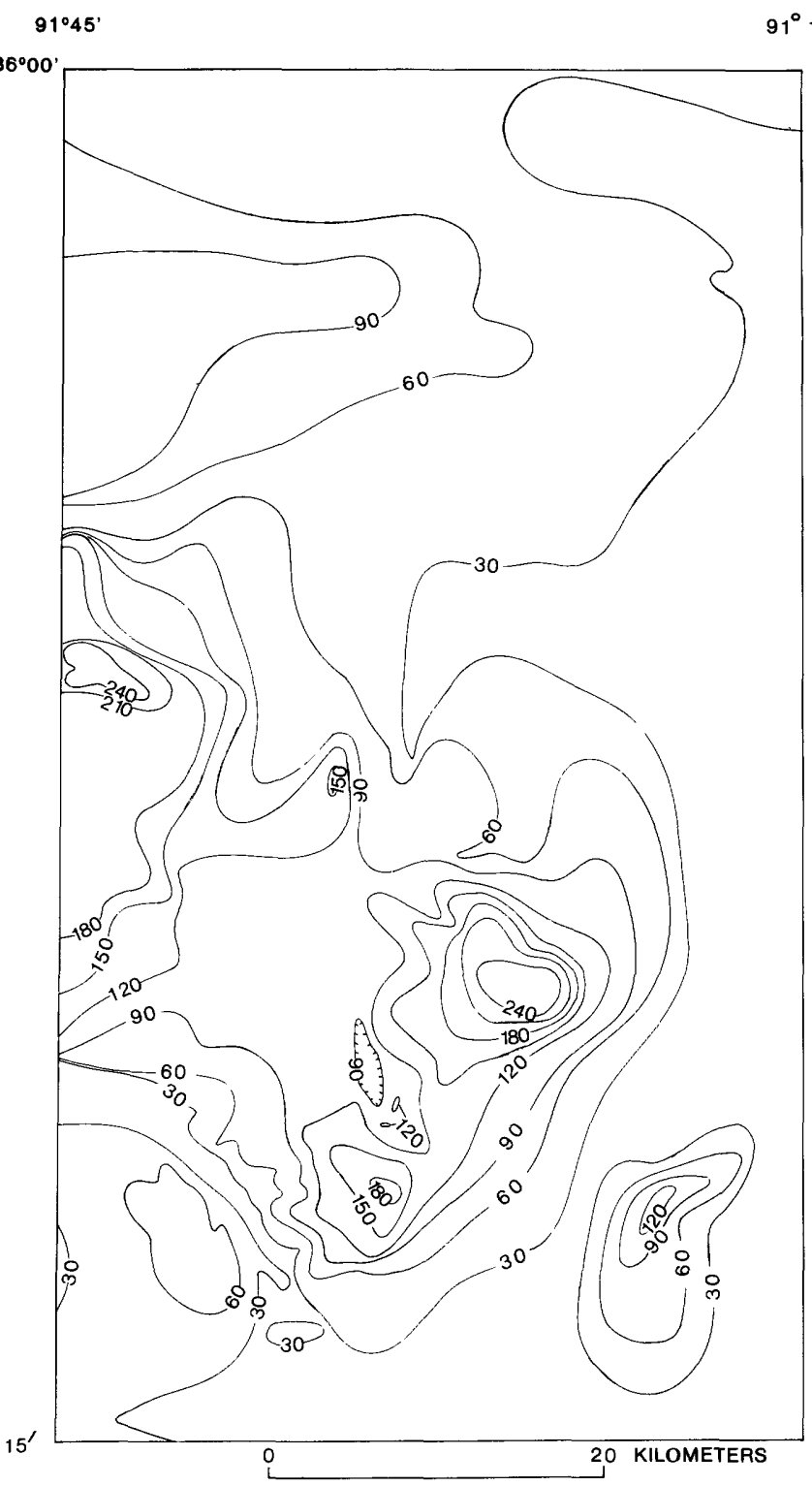

FigURE 9. - Map of the Newport area showing the cumulative effect of the reconstructed middle Cretaceous topography (Paleozoic surface) and the post- middle-Cretaceous distortion of the Paleozoic surface caused by local uplift. Contour interval, $30 \mathrm{~m}$; contour hachured where uplifting has closed the outlet of a middle Cretaceous valley; datum, arbitrary.

\section{UNIT 2: THE BASAL CONGLOMERATE OF THE UPPER CRETACEOUS SEQUENCE}

The surface of the truncated Paleozoic rocks in northeastern Arkansas was flooded in a gentle manner by the advancing low-energy sea of Late Cretaceous time (fig. 6). In the central part of the Newport area, the basal conglomerate of the resultant sequence is a thin layer of locally derived, poorly sorted residuum that may be largely what was left after a soil 
was washed away. There are, however, a few well-rounded pebbles of chert in most deposits, even where the substratum is not cherty.

In the area of outcrop along the edge of the embayment, and especially in the eastern outcrops north of the Newport area, the basal conglomerate of the Upper Cretaceous sequence is a little thicker and contains many well-rounded and polished chert pebbles, mostly less than $20 \mathrm{~mm}$ in longest dimension. These pebbles are found not only at the base of the unit but also as much as 2-3 $\mathrm{m}$ above the base, indicating that they were moved by a moderately energetic sea. In contrast, in the north-central part of the Newport area where the Cretaceous rests on St. Peter Sandstone (Middle Ordovician), the distinctive rounded and frosted sand grains of the St. Peter are reworked into only the lower several centimeters of the Cretaceous. In the subsurface of the embayment to the east, the base of the Cretaceous generally is marked by clay or sand, rather than by pebbles, suggesting that the valleys of pre-Late Cretaceous rivers of this area were paved with sand and clay.

\section{UNIT 3: THE MAIN BODY OF THE UPPER CRETACEOUS SEQUENCE}

For the purposes of this report, all sand and clay in the outcrop area that lies between the Paleozoic rocks below and the distinctive and extensive upland gravel unit above is included in the Upper Cretaceous sequence unless the material is a lens in the Paleocene limestone. The maximum thickness of material so included is about $30 \mathrm{~m}$; a common thickness in a representative outcrop is $5 \mathrm{~m}$. Part of the upper layer of this sand may be from decalcified sandy Paleocene limestone.

Small outliers of Upper Cretaceous sand commonly show little evidence of bedding or lamination because such features have been destroyed by extensive slump and creep. The total sequence-basal conglomerate, sand body, and overlying bed of Tertiary gravel-may drape over a hill and down a slope, partly because of dissolution of underlying rocks but primarily as a result of creep toward erosional lows. Where the sequence has been less disturbed, especially where the iron oxide cement is well developed, detailed bedding can be observed.

Outcrops of Upper Cretaceous sand are well exposed along the edge of the embayment north of the White River. Apparently these outcrops are remnants of an offshore bar that developed several kilometers seaward from the swampy shoreline (fig. 2). A typical outcrop on the northwestern side of the bar shows well-developed cross-laminations that dip westward or northwestward (shoreward) as much as $30^{\circ}$. Reinforced walls of vertical boreholes made by shallow-water marine animals stand out in sharp contrast to the laminae. The sand of the bar is medium to coarse, whereas that in the area shoreward from the bar is consistently fine. In the subsurface to the southeast of the bar, the Upper Cretaceous sequence consists of about $100 \mathrm{~m}$ of alternating, thick units of both limy shale and fine to medium sand, and a few local lenses of limestone. Most of the subsurface sequence is fossiliferous. Nearly all of the sand, silt, and clay deposited in the area during Late Cretaceous time was derived from a northern source.

During this investigation, locations of remnants of the Upper Cretaceous sand and clay were recorded on maps at a scale of 1:24,000 and were compiled on a small-scale regional map to show their general western limit (fig. 2). The difference between the present western limit of the remnants and the original depositional limit of the layer of Upper Cretaceous sand is unknowable but could be sizable. In the western part of the Newport area, the sand is preserved only where protected by a layer of gravel; it may have been washed away even in areas where some chert pebbles remain. Remnants of the original layer of Upper Cretaceous sand are found farther up the valleys of the ancestral Strawberry and Little Red Rivers than up the valley of the ancestral White River, but that probably is a function of preservation rather than of original extent.

Locally in the southern half of the Newport area, pebbles of sandstone are incorporated into the Upper Cretaceous deposits, primarily at the western shoreline and offshore on the largest of the three uplifts. The pebbles were derived from beds of Lower Pennsylvanian sandstone that were exposed to wave action along low sea cliffs and valley walls, as well as from beds exposed across the sea floor in the area of incipient uplift. Few if any of the pebbles were transported very far from their respective sources, but all were rounded. Those pebbles that were derived from valley walls and cliffs are in remnant deposits that now are deeply weathered and that have sustained at least a moderate amount of distortion through creep. The distribution of these deposits helps outline the middle Cretaceous topographic highs that limited the advance of the Late Cretaceous sea.

Widely scattered sandstone pebbles and several commercial deposits of sandstone-pebble gravel are found on the largest of the three uplifts (fig, 2). Those pebbles were formed under special conditions that existed on the budding uplift during Late Cretaceous or early Paleocene time. A relatively vigorous sea rolled across the slightly arched sea floor, removing any Cretaceous cover, rounding fragments of the underlying Pennsylvanian sandstone, and polishing the exposed faces of sandstone beds and sides of boulders too large to be moved. The best example of that is on the seaward (southeastern) side of the uplift where the sea spent most of its energy. There today, rock layers along the flank of the uplift and large boulders bypassed in gravel-pit operations display polished faces unlike those developed under normal subaerial weathering. No similar conditions are known to have been involved in the development of the two smaller uplifts.

The bulk of the sandstone pebbles in the area of outcrop across this uplift rests on the Pennsylvanian and is covered by soil or loess. At least one deposit of sandstone pebbles, a unit 
more than $2 \mathrm{~m}$ thick, is in a more definitive stratigraphic position near the crest of the uplift in the SW1/4 SE $1 / 4 \mathrm{SE} 1 / 4 \mathrm{sec}$. 32, T. 11 N., R. 4 W., Independence County, Ark. (fig. 2, locality Z). That layer of sandstone pebbles and sandy matrix rests on Pennsylvanian beds and is overlain by more than $1 \mathrm{~m}$ of friable fine sand that contains sandstone pebbles and a few lenses of silicified sandy limestone of Paleocene(?) age. The sequence is capped by a massive bed of silicified Paleocene limestone that contains widely scattered small clasts of sandstone. On the flank of the uplift, the Paleocene (Midway Group) limestone in the vicinity of the Grand Glaise terrace contains sandstone clasts - "small greenish pebbles of sandstone" (Stephenson and Crider, 1916, p. 52). The clasts there are much larger than those in the silicified limestone, some being as much as $10 \mathrm{~cm}$ long; they are present in varying abundance through at least the lower $3 \mathrm{~m}$ of the limestone unit at some localities. Presumably they are reworked from an older deposit.

The sandstone pebbles on the largest uplift were rounded prior to the beginning of the deposition of the closely associated Paleocene limestone; how long prior is unknown. Many of the pebbles underlie the Paleocene limestone; some are reworked into it. In this report, the pebbles are assumed to have been rounded during latest Cretaceous time and, in part, to have been transported a short distance during early Paleocene time.

\section{UNIT 4: PALEOCENE LIMESTONE}

Unconsolidated sediments and rocks of Paleocene age that crop out around the northern part of the Mississippi Embayment are assigned to the Midway Group, which is made up of the calcareous and sandy Clayton Formation below and the much thicker Porters Creek Clay above. The only outcrops of this group in the Newport area are the sandy limestone of the Grand Glaise terrace area on the flank of an uplift and the silicified limestone west of there on the crest of the uplift (fig. 2). Presumably all of those outcrops belong to the Clayton Formation, but herein they are assigned to the Midway Group, a broader classification. In the subsurface of the embayment in the southeastern part of the Newport area, the Paleocene sequence grades southeastward into clay, suggesting that the limestone of the outcrop area may be part of an upliftcontrolled facies. A slightly raised platform in an otherwise muddy sea may have favored a lime-producing fauna. No Paleocene limestone is known to have been encountered in the test holes drilled on the southeasternmost of the three uplifts. Apparently regional tilting kept that area well submerged throughout Paleocene time, in spite of any incipient uplifting.

The Paleocene outcrops of the Grand Glaise terrace extend about $10 \mathrm{~km}$ along the edge of the embayment, perched there on a platform of Paleozoic rock and partly protected by an intermittent cover of gravel and loess (fig. 2; and Stephenson and Crider, 1916, p. 44-45). The age of the overlying gravel is unknown. It is in the proper stratigraphic position to be either a facies of the upland gravel or one of the younger gravels of the embayment. Fossils, mainly mollusks, shark teeth, crustaceans, and echinoids, are abundant locally in the Paleocene limestone (Stephenson and Crider, 1916, p. 48). Fine sand is present in nearly all beds of the limestone, and layers of friable sand are interbedded locally with the well-indurated limestone. About $8 \mathrm{~m}$ of the unit is exposed in the thickest outcrops, which may represent most of the total sequence of the Grand Glaise area.

The Paleocene unit near the crest of the uplift northwest of the Grand Glaise terrace (fig. 2) is the product of nearly total silicification of massive-bedded, fossiliferous, slightly sandy limestone. A few fossils that were especially resistant to silicification were eventually dissolved, leaving open molds or irregular soft areas that, in turn, weathered and created voids. Of the two major remnants of the silicified limestone, the southwestern one is higher on the uplift; it is a massive elliptical outcrop $300 \mathrm{~m}$ long and $100 \mathrm{~m}$ wide that caps a nearly flat-topped hill. The northeastern and more extensive remnant of the unit caps a narrow ridge and dips about $90 \mathrm{~m}$ down the flank of the uplift in a distance of $1.3 \mathrm{~km}\left(4^{\circ}\right)$. The base of the unit there is exposed in a few places; but the top, being at the crest of the wooded ridge, is too distant from the base to allow a direct measurement of the thickness. The maximum thickness appears to be about $7 \mathrm{~m}$.

Periodically, both major outcrops of the silicified limestone yield a few durable pebbles that creep down the slope and into the channels of intermittent streams. The distinctive subrounded pebbles of silicified limestone, commonly associated with well-rounded sandstone pebbles from the basal unit of the sequence, are discernibly different from the remainder of the bedload of the short streams that drain the uplift. Some boulders have become separated from the massive beds of the outcrop but tend to remain close to their source. The silicified limestone is extremely durable, being subject to little small-scale shattering, exfoliation, or conchoidal fracturing. For the most part, it is weathered only by the chemical solution of silica, an extremely slow process. For that reason, the assumption is made that essentially all of the original areas of silicification are still represented by outcrops. The remainder of the uplifted area in which no trace of silicified limestone is found probably once was covered by Paleocene limestone that has long since been removed by chemical weathering, leaving only scattered sandstone clasts.

The time and cause of silicification of the Paleocene limestone in the Newport area are unknown. Only beds well up toward the crest of the uplift are known to have been altered. The other known outcrop of silicified Paleocene limestone in Arkansas is about $175 \mathrm{~km}$ to the southwest in the SE $1 / 4$ sec. 17, T. 4 S., R. 17 W., Hot Spring County (fig. 1), in the vicinity of the Cretaceous Magnet Cove Complex of the Little Rock pluton but only about $20 \mathrm{~m}$ above the embayment lowland (J. D. McFarland III, written commun., 1978).

In one small area near the crest of the uplift in the 
SW $1 / 4$ NE $1 / 4$ sec. 32 , T. 11 N., R. 4 W. (fig. 2, locality Y), rounded pebbles of Ordovician and Mississippian chert and angular fragments of the silicified Paleocene limestone are joined in an iron-rich sandy matrix. The conglomerate, resting on the massive beds of silicified Paleocene limestone, appears to be a typical iron-cemented lens of upland gravel (unit 5), except that here it also contains fragments of the underlying rock, which appears to have been silicified prior to brecciation. That suggests early silicification of the limestone because the chert gravel was deposited prior to the probable late Paleocene uplifting. Fractures in the massive bed of silicified limestone also suggest that the bed may have been broken into large blocks by post-silicification uplift.

\section{UNIT 5: UPLAND GRAVEL}

Many of the commercially important gravel pits in the Paleozoic outcrop area of the Newport region are in the layer of upland gravel that in most areas rests on the Upper Cretaceous sand and clay sequence. West of the limit of the layers of sand and clay, the gravel rests on the pre-Late Cretaceous erosion surface. In the northern part of the area, the upland gravel is made up primarily of pebbles and cobbles of Ordovician chert (Jefferson City and Cotter Formations); in the southern part of the area it is made up primarily of Mississippian chert (Boone Formation), but a mixture of the two types of chert is common. Isolated remnants of a once-regional layer of gravel now cap the highest hills in the northwestern part of the Newport area, extend up ancestral river valleys in the southwestern part, and dip regionally southeastward across the Newport area to the edge of the embayment. Some of the thicker deposits (as much as $10 \mathrm{~m}$ thick) are found just northwest of the present embayment edge.

The exact age of the upland gravel generally has been left to speculation, because the gravel contains few if any indigenous fossils and has no known inorganic fraction from which its age can be determined. It rests on rock as young as Paleocene limestone and is overlain by Pleistocene loess. In the Ozark region just north of the Newport area, the gravel rests on the crests of hills of Ordovician dolomite as much as $120 \mathrm{~m}$ above the stream level of the adjacent valley. It is found on the crest and flanks of the large uplift northwest of Grand Glaise- positions that it would have been unable to reach after the uplift had developed. All of the chert fraction, which is nearly 100 percent of the gravel, was derived from Ordovician and Mississippian outcrops north of the White River; some of it was carried southwestward $50 \mathrm{~km}$ into the estuary of the ancestral Little Red River along a path that did not drop in altitude (fig. 2). Such movement required strong marine currents that probably were characteristic of the late Paleocene sea but not of the Eocene sea. These bits of evidence suggest a late Paleocene age for the upland gravel. It is younger than the Paleocene limestone but probably not much younger.

\section{UNIT 6: THE EOCENE SEQUENCE}

No outcrops of sediment of Eocene age have been identified in the Newport area, but a thick sequence of Eocene deposits is present in the subsurface of the general embayrnent area. Regionally the Eocene is made up of thinner, predominantly continental units in the northern part of the Mississippi Embayment and of thicker, increasingly marine units to the south. An erosional wedge of the Wilcox Group (Eocene), consisting of clay, silt, sand, and lignite, extends into the southeastern part of the Newport area. There it is overlain by the Quaternary sand and gravel that blanket the embayment. A short distance farther southeast, outside of the Newport area, the Wilcox is overlain by the Claiborne Group, which in turn is overlain by the Jackson Group, both of Eocene age. The Jackson was deposited by the last sea that is known to have flooded the embayment northward beyond the vicinity of Memphis, Tenn.

The subcrop edge of the Eocene sequence is an erosional edge - the present limit of a once more extensive deposit. As the fine-grained and unconsolidated Eocene of this area is very easily eroded where not protected, no outliers have survived the $40 \mathrm{~m}$.y. of post-Eocene weathering to indicate the original extent of the unit. Indirect evidence, however, suggests that upper Paleocene and Eocene deposits did extend across a substantial part of the Newport area. Probably the best indication of that comes from Crowleys Ridge, about 60 $\mathrm{km}$ to the east (fig. 1). Sediments of Eocene age there, protected by a layer of gravel, stand at least $70 \mathrm{~m}$ above the embayment lowlands. The gravel rests on a truncated surface, indicating that the Eocene deposits once stood even higher than they do today. The assumption that Crowleys Ridge has not been uplifted relative to the Newport area forces the conclusion that the northern part of the embayment region, including a significant part of the Newport area, once was filled by Tertiary sediments to a level higher than that of any of the Eocene on Crowleys Ridge.

Superimposed valleys near the edge of the Ozark region indicate that Tertiary units younger than Paleocene limestone once extended northwestward into the Newport area. In much of the central and eastern part of the Arkansas Valley physiographic province, resistant beds of Pennsylvanian sandstone form dip slopes that dominate the drainage pattern. However, in the southwestern part of the Newport area (at the easternmost end of the Arkansas Valley), those resistant beds of sandstone have little effect on the courses of southeastward-flowing streams. The valleys of major and minor streams there are superimposed upon the folded Paleozoic rocks. After the beginning of the retreat of the Jackson sea, streams in the southern part of the Newport area flowed out of well-established valleys in the southern Ozarks and the Arkansas Valley onto the soft sediment of the embayment. These streams swung south around the end of the uplifted area but, otherwise, were free to choose a direct route toward the edge of the 

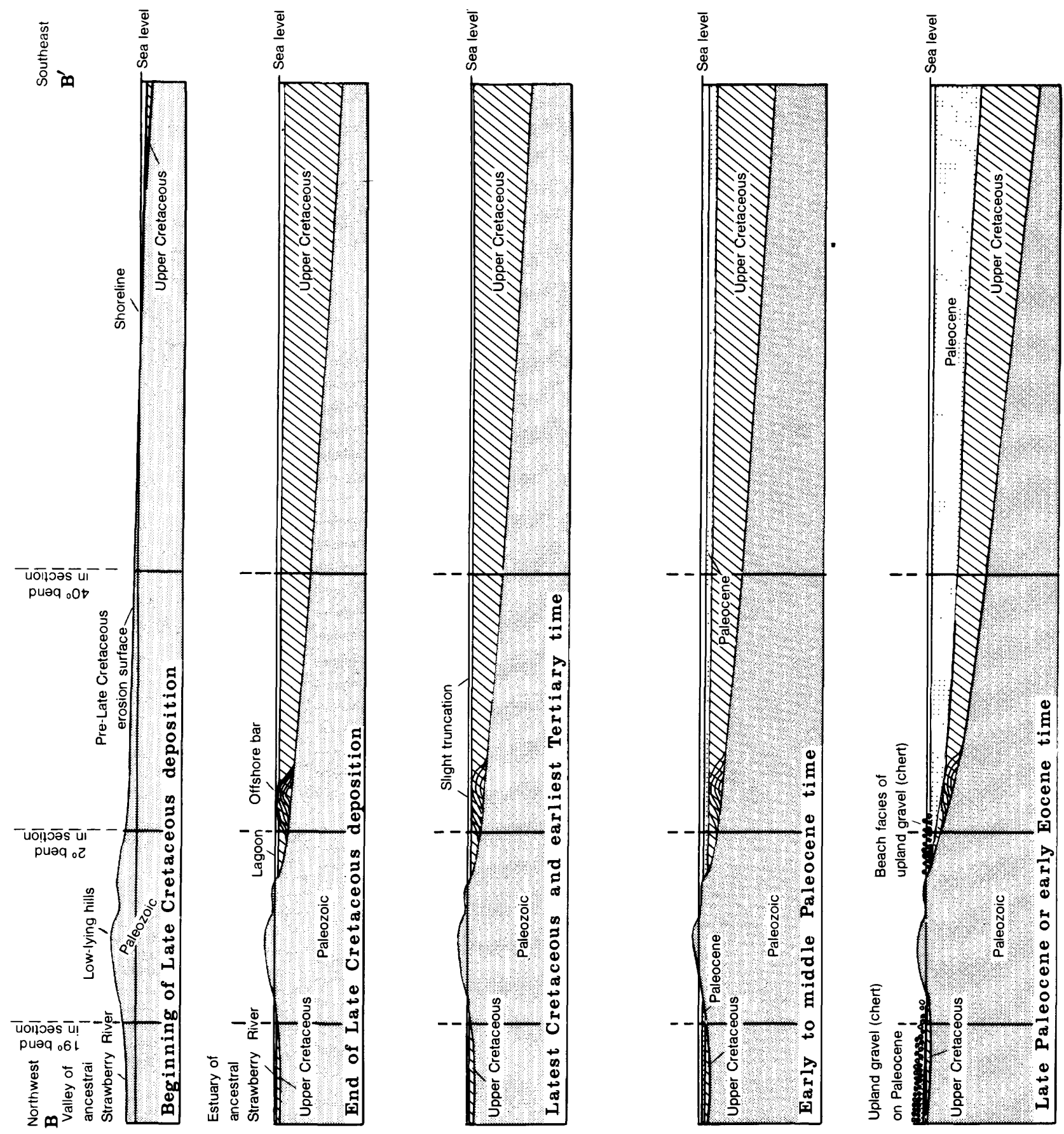

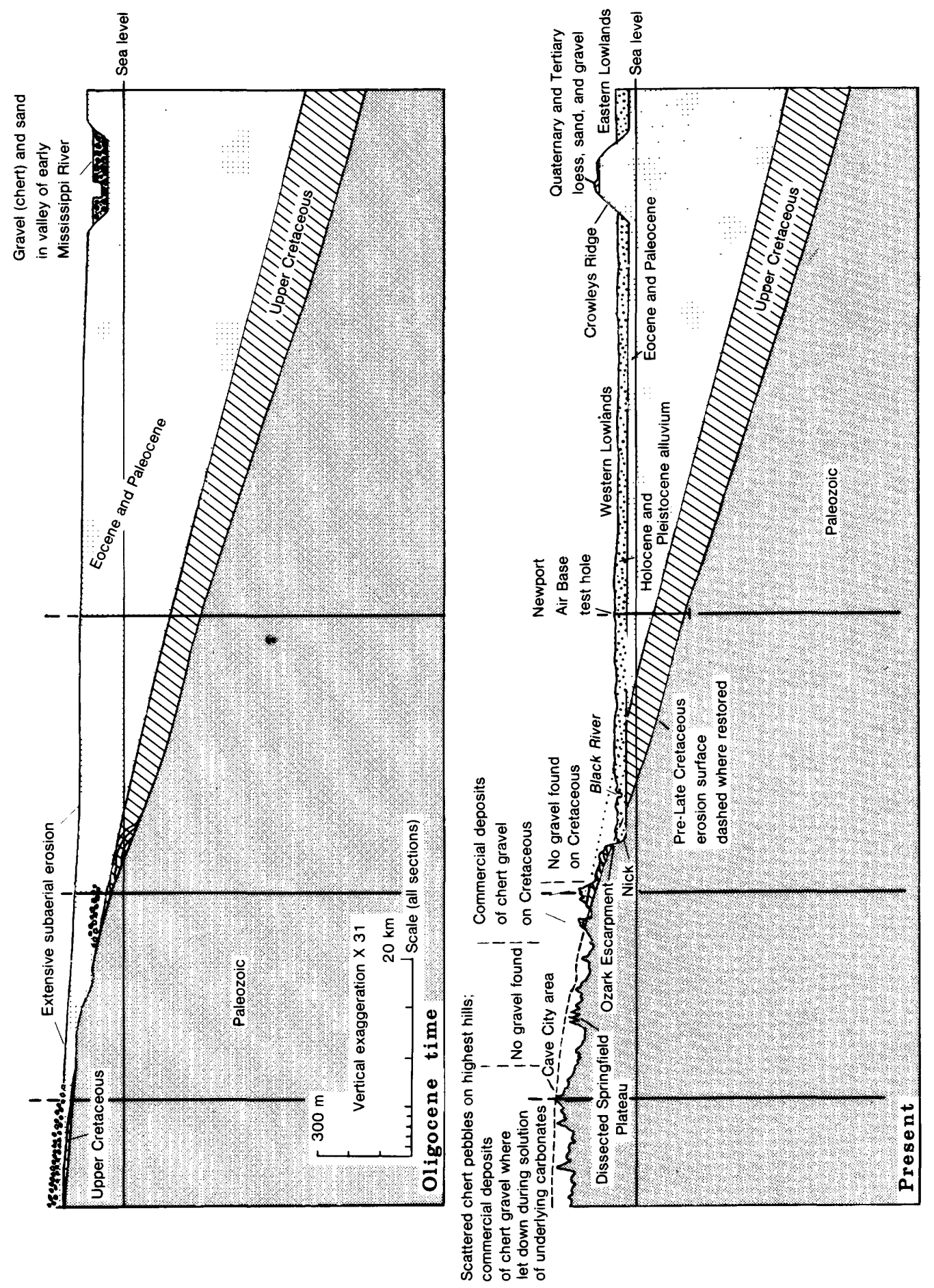

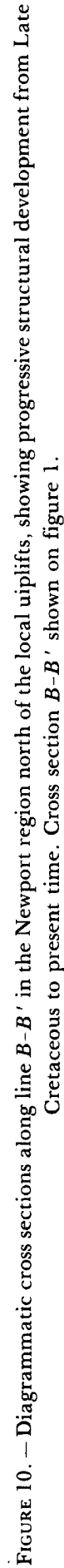



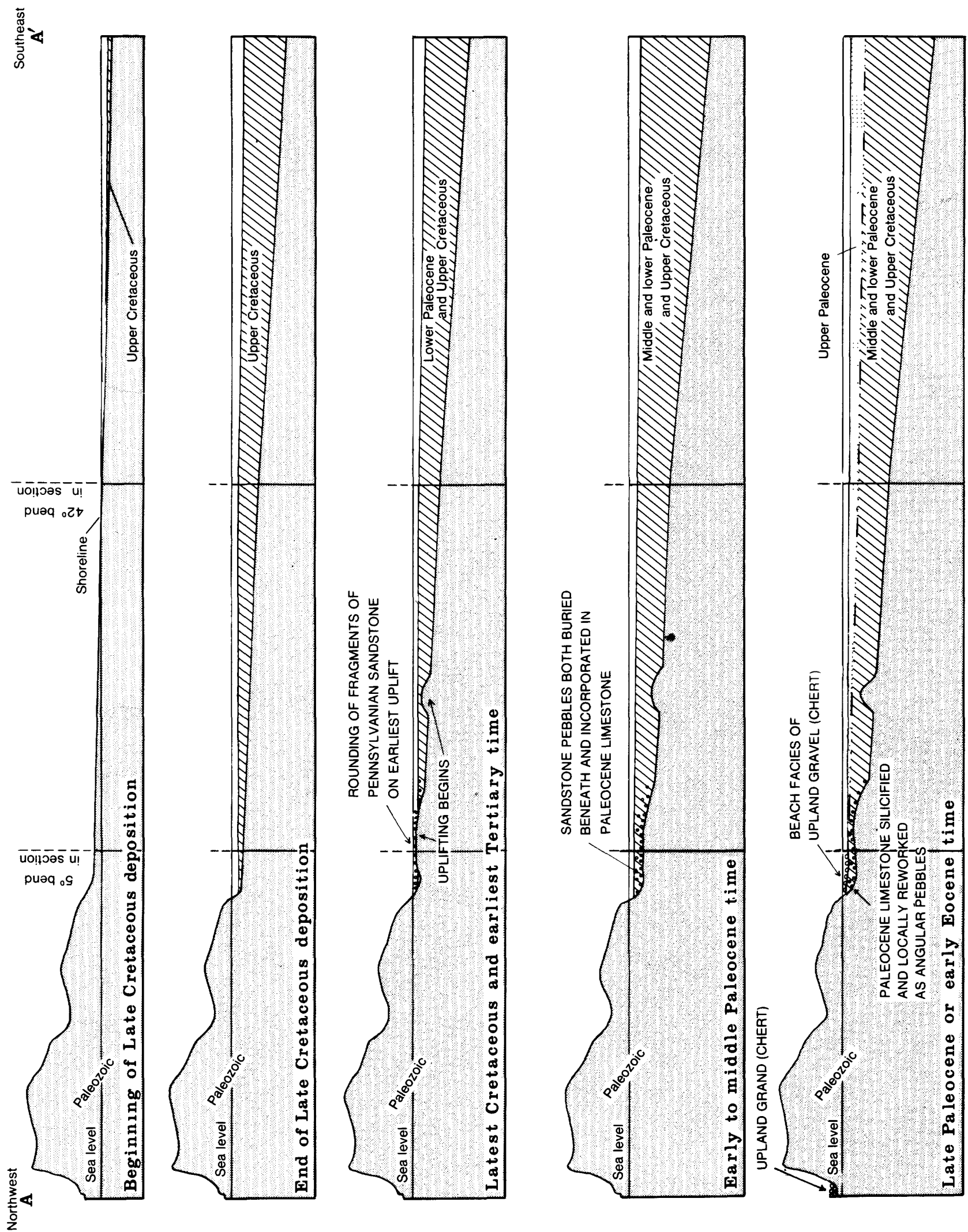

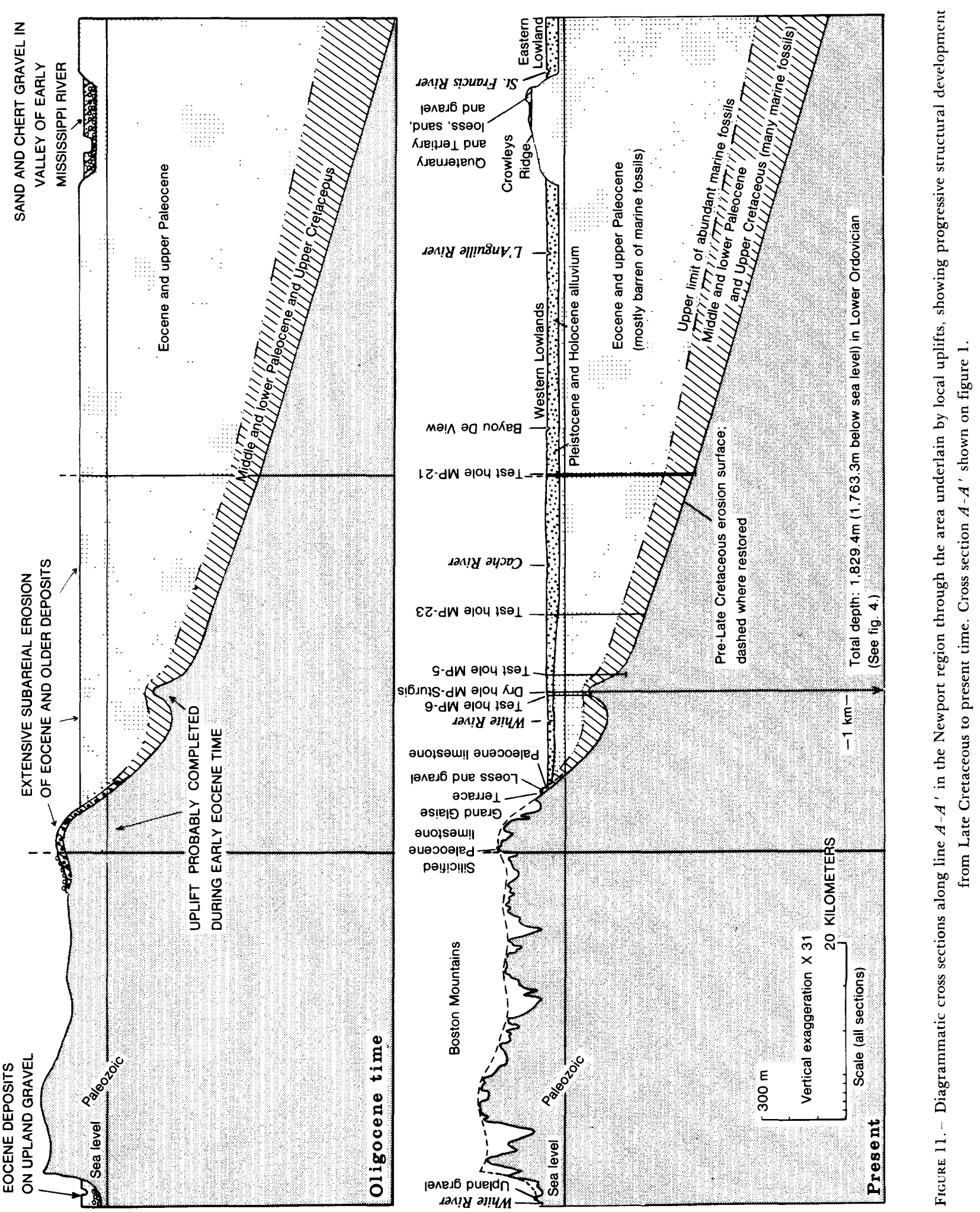
retreating sea. As base level lowered and valley bottoms reached the underlying resistant Paleozoic rocks, the streams did not deviate around obstacles; instead, they cut trenches through them.

The pre-Late Cretaceous channel of the Little Red River just north of the present site of Bald Knob was cut by a stream that followed the least resistant path around Paleozoic structures. The present channel of the Little Red River, probably established after Jackson time, cuts across Paleozoic structures and enters the present embayment just south of Judsonia. The nearly $10 \mathrm{~km}$ shift of the river may have been influenced in part by the uplift to the north. Overflow Creek flows southward from the uplift and directly across the valley of the ancestral Little Red River. Two km west of Bald Knob the creek has cut a channel $30 \mathrm{~m}$ deep through a resistant sandstone that caps a topographically high area herein considered to be a small local uplift that was buried by Eocene sediments. Both the Little Red River and Overflow Creek have classic superimposed valleys, cut in their present positions only because the path was established in overlying Tertiary sediments.

The White River also has cut a channel across resistant units in spite of the availability of a much easier path just to the south. The valley of that river was superimposed upon an anticline, which might have been a growing structure. Previously discussed local post-Cretaceous warping there must be considered in determining the Tertiary development of the White River valley. Some evidence suggests that the anticline crossed by the White River is continuous with the major anticline that is crossed by the Little Red River (figs. 5, 8). If so, post-Cretaceous warping was an additional factor in the development of nearly all the present drainage patterns in the Newport area.

\section{UNIT 7: POST-EOCENE DEPOSITS}

Two post-Eocene sequences that differ appreciably in age are present in the upper Mississippi Embayment: (1) highterrace gravel, such as that on Crowleys Ridge, locally at least $70 \mathrm{~m}$ above the adjacent lowlands; and (2) younger alluvium that underlies the Western and Eastern Lowlands on either side of Crowleys Ridge (fig. 3). For the most part, the alluvium of the lowlands accumulated during Pleistocene time; it is being reworked locally by streams of the area today. The highterrace gravel is much older and may have begun to accumulate not long after the Eocene sea retreated.

The gravel on Crowleys Ridge east of the Newport area is made up mostly of very resistant pebbles of Mississippian and Ordovician chert from the Ozark region and from other source areas to the north, northeast, and east. Most of the material may have been reworked from the formerly extensive deposits of upland gravel (unit 5 of this report). A few distinctive pebbles and cobbles that apparently were derived from as far north as the Lake Superior area are present in the gravel, but no suite of pebbles that might be indicative of glacial outwash has been found in these deposits (Salisbury, 1891, p. 240-243).

A blanket of Pleistocene and Holocene alluvium covers the $1,200-\mathrm{km}^{2}$ southeastern portion of the Newport area, leaving no exposures of the Paleozoic, Cretaceous, or Tertiary beds that underlie it (fig. 2). As the base of the unit is not exposed, thickness data are available only from test holes. The maximum thickness of the unit in the Newport area may be as much as $50 \mathrm{~m}$, but the more common thickness is about $30 \mathrm{~m}$. At no place in the Newport area is the base of the alluvium known to be as low as sea level. Apparently the unit thins slightly toward the edge of the embayment before it terminates abruptly against the erosional scarp that marks the northwestern edge of the embayment (figs. 3, 10, 11). Subsurface data suggest a slight thinning of the alluvium over the local southeastern uplift in the Newport area. Even if the thinning is as indicated in figures 3 and 11, various interpretations of its cause and significance are possible.

Several investigations of the alluvium have been made, including determinations of age, thickness, lithology, source areas, nature of contact with underlying sediments, environment of deposition, topographic features, ground-water resources, and tectonic features (Stephenson and Crider, 1916; Fisk, 1944; Boswell and others, 1968; Krinitzski and Wire, 1964; Smith and Saucier, 1971; Saucier, 1974, 1978).

Even though the alluvium of the Western Lowlands may be largely glacial outwash, a substantial fraction of it is made up of well-rounded grains, granules, and small pebbles of quartz. This fraction may be recycled nonglacial detritus from the Missouri River basin. Another significant constituent of the alluvium in the Newport area is chert gravel that the White River and other streams carried out of the Ozark region and deposited along the Ozark side of the embayment long before Pleistocene time. Because that gravel was readily available, its redeposition could have begun as soon as erosion established the present level of the embayment. Gravel is relatively near the surface in the Grand Glaise-Olyphant area, where it is dredged and pumped from extensive pits just inside the embayment. Most of the chert pebbles of this gravel are similar to those of the upland gravel to the northwest and appear to be reworked from it; some igneous pebbles from distant sources are included in at least part of the sequence. To the east, farther out in the embayment, the alluvium grades upward from gravel and sand to silt and clay; the gravel there has a high percentage of quartz pebbles. Some of the gravel on Crowleys Ridge may have been brought in by the ancestral Ohio River; but the alluvium of the Western Lowlands, except for a small fraction of gravel reworked from Crowleys Ridge, is thought to have been derived from areas west of the Ohio River basin.

The alluvial sequence is capped locally by sand dunes and deposits of loess, especially just east of the relict channel of a braided stream that once flowed along the northwestern edge of the embayment (Saucier, 1978, p. 30). The most recent and best preserved eolian deposits accumulated there just prior to 
the diversion of the ancestral Mississippi River to the eastern side of Crowleys Ridge.

During much of the past 20,000 years, major streams of the Western Lowlands have tended to flow at the extreme western edge of the embayment and rasp the exposed face of Paleozoic rocks. The braided ancestral Mississippi River conformed to that trend just prior to being diverted to the east about 18,000 years ago (Saucier, 1978, p. 30 and 34); the meandering rivers of today (Current, Black, and White) persist in following much the same pattern. In the process, some of those rivers have nicked the Paleozoic rocks and thereby formed the Ozark Escarpment (figs. 3, 10, 11). The fact that the surface of the Western Lowlands slopes slightly to the west could be either a cause or a result of the stream patterns. Braided-stream deposits of early Wisconsin age underlie most of the eastern and central part of the Western Lowlands; Holocene alluvium underlies much of the western part (Saucier, 1974, fig. 1). The nick is well developed where bordered by deposits of either age, and therefore may be entirely the result of abrasion by Pleistocene braided streams. The modern streams may be locked in an old channel.

The straightness of the Ozark Escarpment (the face of the nick) in some areas has been cited incorrectly as evidence of faulting at the edge of the embayment (Fisk, 1944, fig. 6). Actually, that lineation has developed at the line of intersection of the tilted pre-Late Cretaceous erosion surface and the horizontal surface at the working depth of the streams. Further cutting has modified the position of the face but has left a remarkably straight feature in many areas. Where the preLate Cretaceous erosion surface is distorted over local uplifts at the edge of the Ozark region, the nick is curved. Where the erosion surface is low, as in the area of the Late Cretaceous estuary of the ancestral Strawberry River, the nick was never developed. At no place did the rivers cut very far back into the Ozark region, because the Paleozoic rocks are resistant to erosion and the combined thickness of the geologic sequences that would have had to be cut increases rapidly northwestward from the embayment. In areas away from the uplifts where the exposed face of the nick is about $5 \mathrm{~m}$ high and the adjacent alluvium is $20-25 \mathrm{~m}$ thick, one can expect to find no Cretaceous deposits under the alluvium within 2-3 $\mathrm{km}$ of the edge of the embayment because the dip of the pre-Late Cretaceous erosion surface is less than $1^{\circ}$ (fig. 10).

\section{SUMMARY}

A series of structural, sedimentary, and erosional anomalies in the post-Paleozoic sequence above the deeply buried Newport pluton appears to have been caused by the emplacement of the pluton or by the emplacement of sills and laccoliths associated with the pluton. On the basis of evidence from the post-Paleozoic sedimentary sequence, uplifting over or near the pluton began during Late Cretaceous time and continued at least into middle Paleocene time. That tectonic activity was closely associated in time with the early development of the Mississippi Embayment.

A seven-step diagrammatic interpretation of the Late Cretaceous to Holocene evolution of a segment of the western margin area of the Mississippi Embayment is shown for each of two localities: (1) along line $A-A^{\prime}$ southeastward across uplifts associated with the Newport pluton (fig. 11), and (2) along line $B-B^{\prime}$ southeastward across the Newport area just north of the pluton (fig. 10). Those two figures illustrate the concepts developed in this report and show the effects of the local uplifts.

\section{REFERENCES CITED}

Arkansas Geological Survey, 1929, Geologic map of Arkansas: scale $1: 500,000$.

Boswell, E. H., Cushing, E. M., and Hosman, R. L., 1968, Quaternary aquifers in the Mississippi Embayment: U.S. Geological Survey Professional Paper 448-E, 15 p.

Caplan, W. M., 1954, Subsurface geology and related oil and gas possibilities of northeastern Arkansas: Arkansas Resources and Development Commission, Division of Geology Bulletin 20, $124 \mathrm{p}$.

Clardy, B. F., 1979, Arkansas lignite investigations: Arkansas Geological Commission Preliminary Report, 133 p.

Cordell, Lindrith, 1977, Regional positive gravity anomaly over the Mississippi Embayment: Geophysical Research Letters, v. 4, no. 7, p. 285-287.

Croneis, C. G., 1930, Geology of the Arkansas Paleozoic area, with especial reference to oil and gas possibilities: Arkansas Geological Survey Bulletin 3, $457 \mathrm{p}$.

Cushing, E. M., Boswell, E. H., and Hosman, R. L., 1964, General geology of the Mississippi embayment: U.S. Geological Survey Professional Paper 448-B, 28 p.

Easton, W.H., 1942, Pitkin limestone of northern Arkansas: Arkansas Geological Survey Bulletin 8, $115 \mathrm{p}$.

Ervin, C. P., and McGinnis, L. D., 1975, The Reelfoot Rift--Reactivated precursor to the Mississippi Embayment: Geological Society of America Bulletin, v. 86, no. 9, p. 1287-1295.

Fisk, H. N., 1944, Geological investigation of the alluvial valley of the lower Mississippi River: U.S. Army Corps of Engineers, Mississippi River Commission, $78 \mathrm{p}$.

Frezon, S. E., and Glick, E. E., 1959, Pre-Atoka rocks of northern Arkansas: U.S. Geological Survey Professional Paper 314-H, p. 171-189.

Gordon, Mackenzie, Jr., 1944, Moorefield formation and Ruddell shale, Batesville district, Arkansas: American Association of Petroleum Geologists Bulletin, v. 28, no. 11, p. 1626-1634

1964, Carboniferous cephalopods of Arkansas: U.S. Geological Survey Professional Paper 460, 322 p.

Gordon, Mackenzie, Jr., and Kinney, D. M., 1944, Geologic map and structure sections of the Batesville district, Independence County, Arkansas: U.S. Geological Survey Oil and Gas Investigations Preliminary Map 12, scale 1:20,000.

Haley, B. R., Glick, E. E., Bush, W. V., Clardy, B. F., Stone, C. G., Woodward, M. B., and Zachry, D. L., 1976, Geologic map of Arkansas: scale 1:500,000.

Harris, G. D., 1894, The Tertiary geology of southern Arkansas: Arkansas Geological Survey Annual Report for 1892, v. 2, 207 p.

Hendricks, J. D., 1979, Bouger gravity and geologic map of northeast Arkansas: U.S. Geological Survey Geophysical Investigations Map GP-925, scale 1:250,000. 
Hendricks, J. D., and Hildenbrand, T. G., 1979, Total field aeromagnetic map of northeast Arkansas: U.S. Geological Survey Open-File Report 79-1208, scale 1:250,000.

Heyl, A. V., and McKeown, F. A., 1978, Preliminary seismotectonic map of central Mississippi Valley and environs: U.S. Geological Survey Miscellaneous Field Studies Map MF-1011, scale 1:500,000

Hildenbrand, T. G., Kane, M. F., and Stauder, William, 1977, Magnetic and gravity anomalies in the northern Mississippi Embayment and their spatial relation to seismicity: U.S. Geological Survey Miscellaneous Field Studies Map MF-914, scale 1:100,000.

Hildenbrand, T. G., Kucks, R. P., Kane, M. F., and Hendricks, J. D., 1979 Aeromagnetic map and associated depth map of the upper Mississippi embayment region: U.S. Geological Survey Miscellaneous Field Studies Map MF-1158, scale 1:1,000,000.

Jespersen, Anna, 1964, Aeromagnetic prospecting for bauxite deposits in the Mississippi Embayment, Arkansas and Missouri: U.S. Geological Survey Geophysical lnvestigations Map GP-370, scale 1:125,000.

Kinney, D. M., and Straczek, J. A., 1950, Geologic map of the central part of the Batesville manganese district, Independence and Izard Counties, Arkansas: U.S. Geological Survey Mineral lnvestigations Field Studies Map MF-1, scale 1:31,680.

Krinitzsky, E. L., and Wire, J. C., 1964, Groundwater in alluvium of the lower Mississippi valley (upper and central areas): U.S Army Corps of Engineers, Waterways Experiment Station Technical Report 3-658, v. 2, $361 \mathrm{p}$.

Miser, H. D., 1922, Deposits of manganese ore in the Batesville district, Arkansas: U.S. Geological Survey Bulletin 734, 273 p.

1941, Manganese carbonate in the Batesville district, Arkansas: U.S. Geological Survey Bulletin 921-A, 97 p.
Ouellette, R. G., 1970, Upper crustal structure in the Newport, Arkansas area: St. Louis, Missouri, Washington University M.A. thesis, 58 p.

Renfroe, C. A., 1949, Petroleum exploration in eastern Arkansas with selected well logs: Arkansas Resources and Development Commission, Division of Geology, Bulletin 14, 159 p.

Salisbury, R. D., 1891, On the relationship of the Pleistocene to the pre Pleistocene formations of Crowleys Ridge, and adjacent areas south of the limit of glaciation: Arkansas Geological Survey Annual Report for 1889 , v. 2, p. 224-248.

Saucier, R. T., 1974, Quaternary geology of the lower Mississippi Valley: Arkansas Archaeological Survey Research Series 6, 26 p.

1978, Sand dunes and related eolian features of the lower Mississippi River alluvial valley: Geoscience and Man, v. 19, p. 23-40.

Sheldon, M. G., 1954, Sample descriptions and correlations for selected wells in northern Arkansas: Arkansas Resources and Development Commission, Division of Geology Information Circular 17, 222 p.

Smith F.L., and Saucier, R. T., 1971, Geological investigations of the Western Lowlands area, lower Mississippi valley: U.S. Army Corps of Engineers, Waterways Experiment Station Technical Report S-71-5, $47 \mathrm{p}$.

Spooner, W. C., 1935, Oil and gas geology of the Gulf Coastal Plain in Arkansas: Arkansas Geological Survey Bulletin 2, 474 p.

Stephenson, L. W., and Crider, A. F., 1916, Geology and ground waters of northeastern Arkansas: U.S. Geological Survey Water-Supply Paper $399,315 \mathrm{p}$.

Stroud, R. B., Arndt, R. H., Fulkerson, F. B., and Diamond, W. G., 1969, Mineral resources and industries of Arkansas: U.S. Bureau of Mines Bulletin 645, $418 \mathrm{p}$. 


\section{The Northeastern Extension of the New Madrid Seismic Zone}

By L. W. BRAILE, W. J. HINZE, G. R. KELLER, and E. G. LIDIAK

INVESTIGATIONS OF THE NEW MADRID, MISSOURI, EARTHQUAKE REGION

GE L O G I A L S U R V E Y PROFESS I N A L PA PER 1236 - L 


\section{CONTENTS}

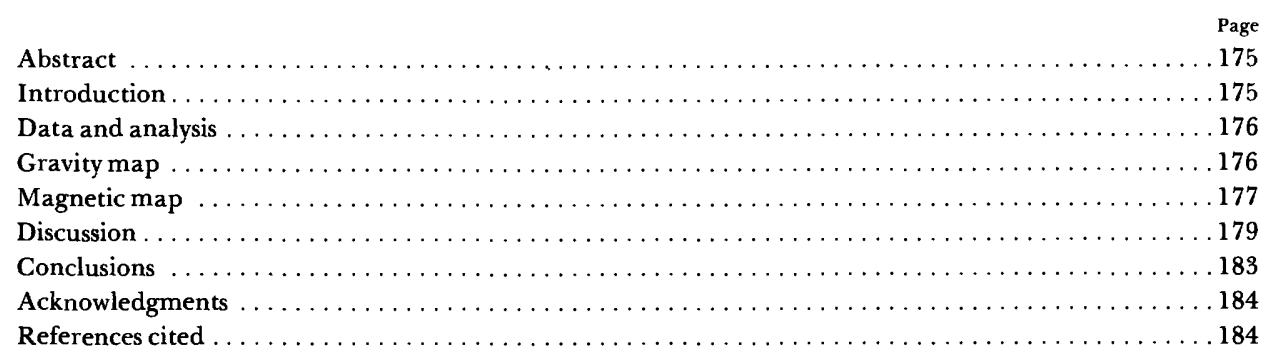

\section{ILLUSTRATIONS}

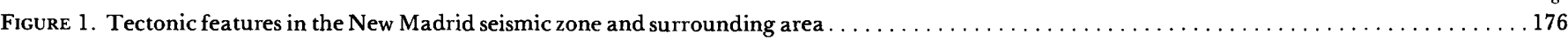

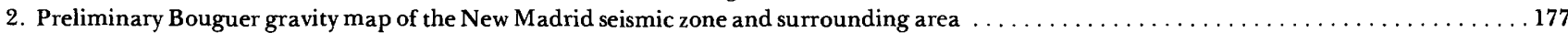

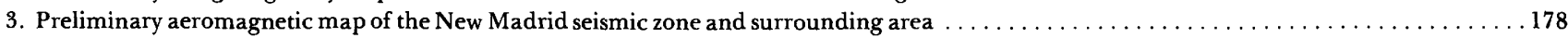

4. Shaded gravity-anomaly contour map showing inferred boundaries of the New Madrid linear tectonic feature . . . . . . . . . . . . . . 180

5. Shaded magnetic-anomaly contour map showing inferred boundaries of the New Madrid linear tectonic feature . . . . . . . . . . . . 181

6. Selected profiles of gravity and magnetic anomaly data across the New Madrid linear tectonic feature . . . . . . . . . . . . . . . 182

7. Contour map of number of earthquakes per $10^{4}-\mathrm{km}^{2}$ area with intensity greater or equal to three from 1800 to $1972 \ldots \ldots$ 


\title{
THE NORTHEASTERN EXTENSION OF THE NEW MADRID SEISMIC ZONE
}

\author{
By LaWrence W. Braile ${ }^{1}$, William J. Hinze ${ }^{1}$, \\ G. R. KELLER ${ }^{2}$, and EDWARD G. LIDIAK ${ }^{3}$
}

\section{ABSTRACT}

Linear trends of nearly circular, correlative, positive gravity and magnetic anomalies bound a central zone of low gravity and magnetic relief and are associated with the New Madrid seismic zone. These trends can be traced northeastward across the 38 th parallel lineament into southern Indiana at least to lat $39^{\circ} \mathrm{N}$. on regional gravity and magnetic anomaly maps. These anomalies, which are interpreted as having a source within the basement, are associated with the trend of earthquake epicenters in the New Madrid area and to the northeast. This association suggests that a linear basement structural feature is a primary control on the location of earthquake epicenters in the New Madrid region.

\section{INTRODUCTION}

The Mississippi Embayment is a major structural feature extending into the North American craton from the Gulf coast province. Geophysical data, subsurface geologic data, and the associated contemporary tectonism manifested in the New Madrid seismic zone suggest that both its paleotectonics and contemporary tectonics are complex. This complexity is especially evident in the region of the northern Mississippi Embayment, where the extension of the New Madrid seismic zone intersects the 38th parallel lineament. An understanding of this zone of intersection is of fundamental importance if we are to unravel the contemporary geodynamics and define the seismic regionalization of this region.

The major tectonic features of the upper Mississipp Embaymnet (fig. 1) have been described by Heyl (1972). Tectonic models that have been proposed to explain both the ancient and contemporary tectonic activity in the midcontinent have been reviewed by Hinze and others (1979). In an integrated

1Department of Geosciences, Purdue University, West Lafayette. IN 47907. 'Department of Geological Sciences, University of Texas, El Paso, TX 79968. ${ }^{3}$ Department of Earth and Planetary Sciences, University of Pittsburgh, PA 15260. analysis of existing geophysical and geologic data, Ervin and McGinnis (1975) postulated that the Mississippi Embayment is a reactivated Precambrian aulacogen. This tectonic model has received considerable acceptance as a working hypothesis for further study, and more recent data seem consistent with this interpretation.

A significant amount of geological and geophysical data has recently become available in the area of the northern Mississippi Embayment. The studies of Nuttli (1974), Varma (1975), and Kovacs and Murphy (1977) provided a thorough review of the historical record of seismic activity. Although limited in geographical extent, the seismograph array operated by Saint Louis University has for the first time provided detailed data about the extent and nature of seismicity in the New Madrid seismic zone (Stauder and others, 1976; Herrmann and Canas, 1978). The pattern of seismicity in the midcontinent of North America has long been the subject of controversy and speculation. Largely on the basis of straightline projection of regions of more intense seismicity, many investigators have suggested a structural connection between the New Madrid area; the Anna, Ohio, area; and the St. Lawrence River valley (Woollard, 1958; Kumarapeli and Saull, 1966). Regional analyses of gravity and aeromagnetic data have recently been completed by Lidiak and Zietz (1976) and Hildenbrand and others (1977).

In this paper we examine available regional geophysical data in the area of the New Madrid seismic zone and its possible northeastern extension. A correlation is seen to exist between regional basement structure, as evidenced by gravity and magnetic anomaly patterns, and contemporary tectonism, as evidenced by historical seismicity data. This correlation implies a structural control on the locations of earthquake activity and indicates that areas of potential seismic activity may be identified by delineating the extent of the controlling structural feature. This structure is interpreted as extending northeastward from the New Madrid area into southwestern Indiana at least to lat $39^{\circ} \mathrm{N}$. 


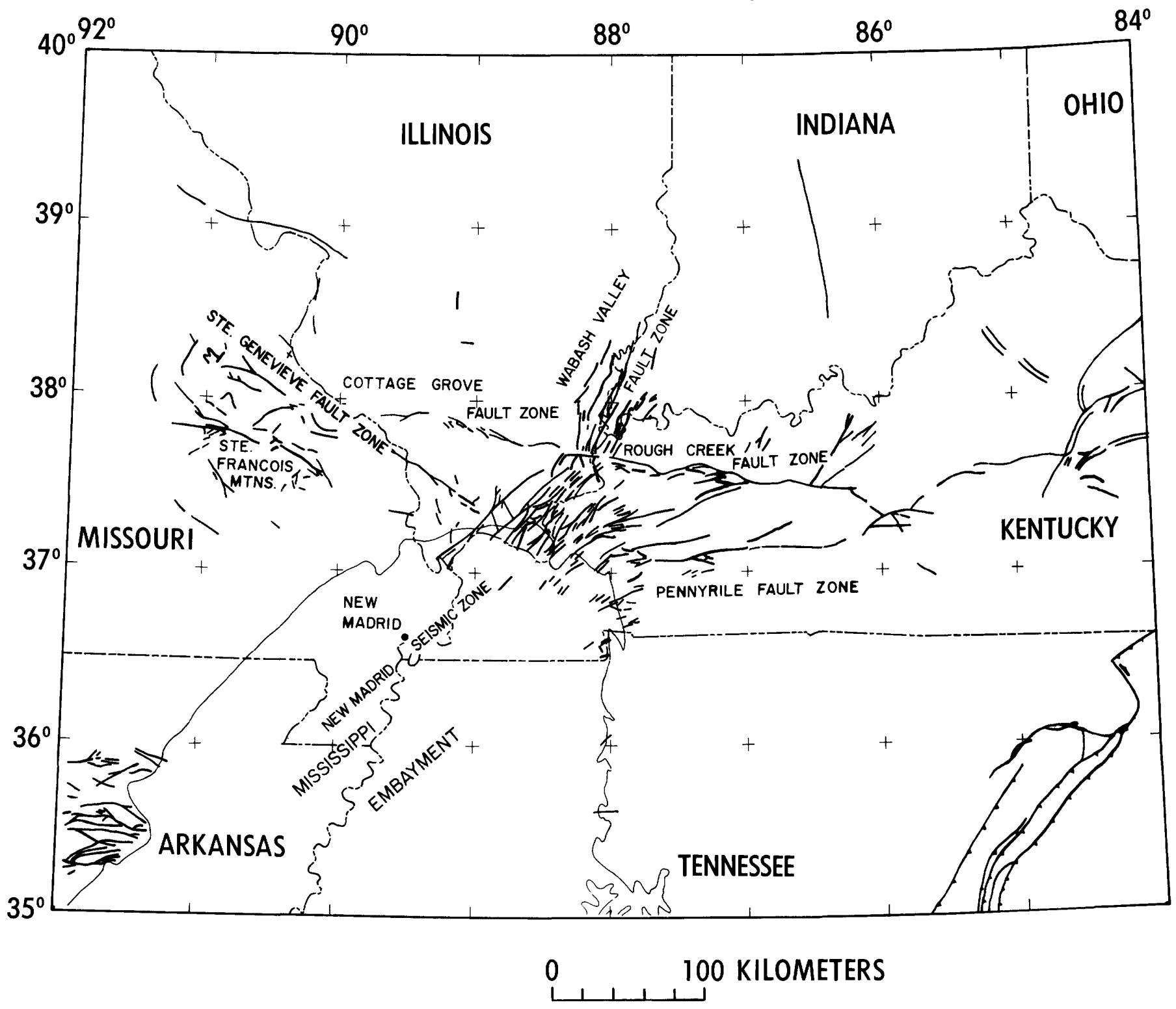

Figure 1. - Tectonic features in the New Madrid seismic zone and surrounding area (generalized from Heyl and McKeown, 1978; and Heyl, 1972). Faults are shown by thick solid lines. Thin solid line is outline of Mississippi Embayment.

\section{DATA AND ANALYSIS}

The data presented in this paper have been compiled from many sources and have been merged into a regional data set that is as consistent as current data and reduction procedures permit. The regional maps were prepared by compositing the data of individual surveys and adjusting levels to provide an adequate join at the boundaries. These data sets are currently undergoing further modifications and additional data are being added. Thus the maps presented here must be considered preliminary.

\section{GRAVITY MAP}

A regional gravity map of the northern Mississippi Embayment (fig. 2) was prepared from data reported by Hildenbrand and others (1977), McGinnis and others (1976), Keller and others (1978), and the National Geophysical and SolarTerrestrial Data Center, and from additional new gravity observations in southern Indiana. These data have been merged into a consistent data file and reduced using a sea-level datum, a Bouguer density of $2.67 \mathrm{~g} / \mathrm{cm}^{3}$, the 1967 international gravity formula and datum, and a curvature correction. The main 
body (six $1^{\circ} \times 2^{\circ}$ quadrangles) of the Bouguer gravity values was gridded on a $2-\mathrm{km}$ spacing using the technique of Braile (1978). Because new data are to be added to the file in southern Indiana, additional data from surrounding areas are to be gridded and included in the data file, and the data shown in figure 2 south of lat $36^{\circ} \mathrm{N}$. have not been gridded, this map must be considered as a preliminary gravity map of the area.

\section{MAGNETIC MAP}

Preparation of a consistent magnetic map of the area involves several difficult problems. Various aeromagnetic surveys have been observed at different times and elevations, and have been reduced using different geomagnetic field models. We are currently adjusting datum levels, survey eleva-
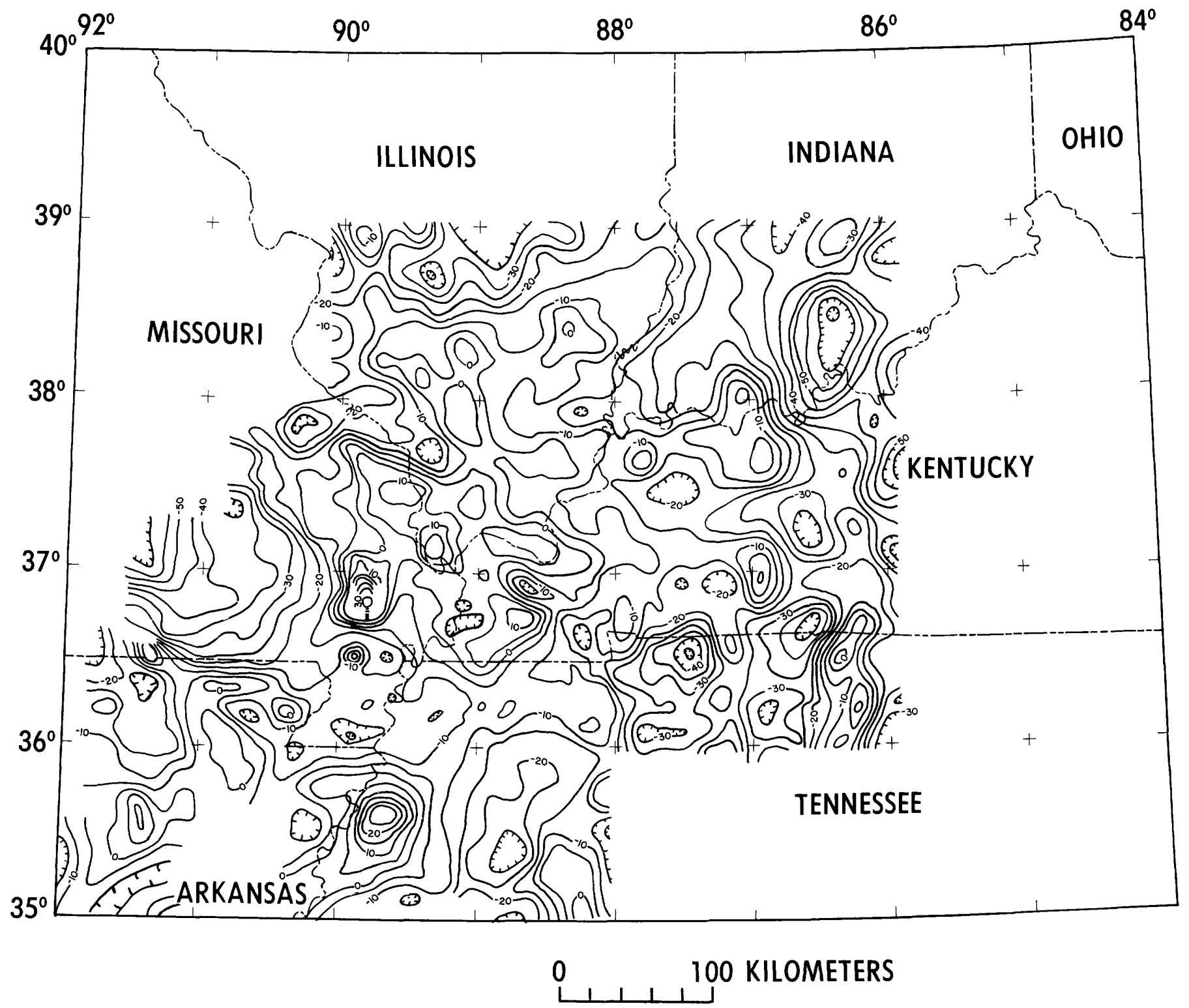

Figure 2. - Preliminary Bouguer gravity map of the New Madrid seismic zone and surrounding area. Hachured contours indicate closed lows. Contour interval is $5 \mathrm{mgal}$. The data are corrected using a Bouguer density of $2.67 \mathrm{~g} / \mathrm{cm}^{3}$ and a sea-level datum. 

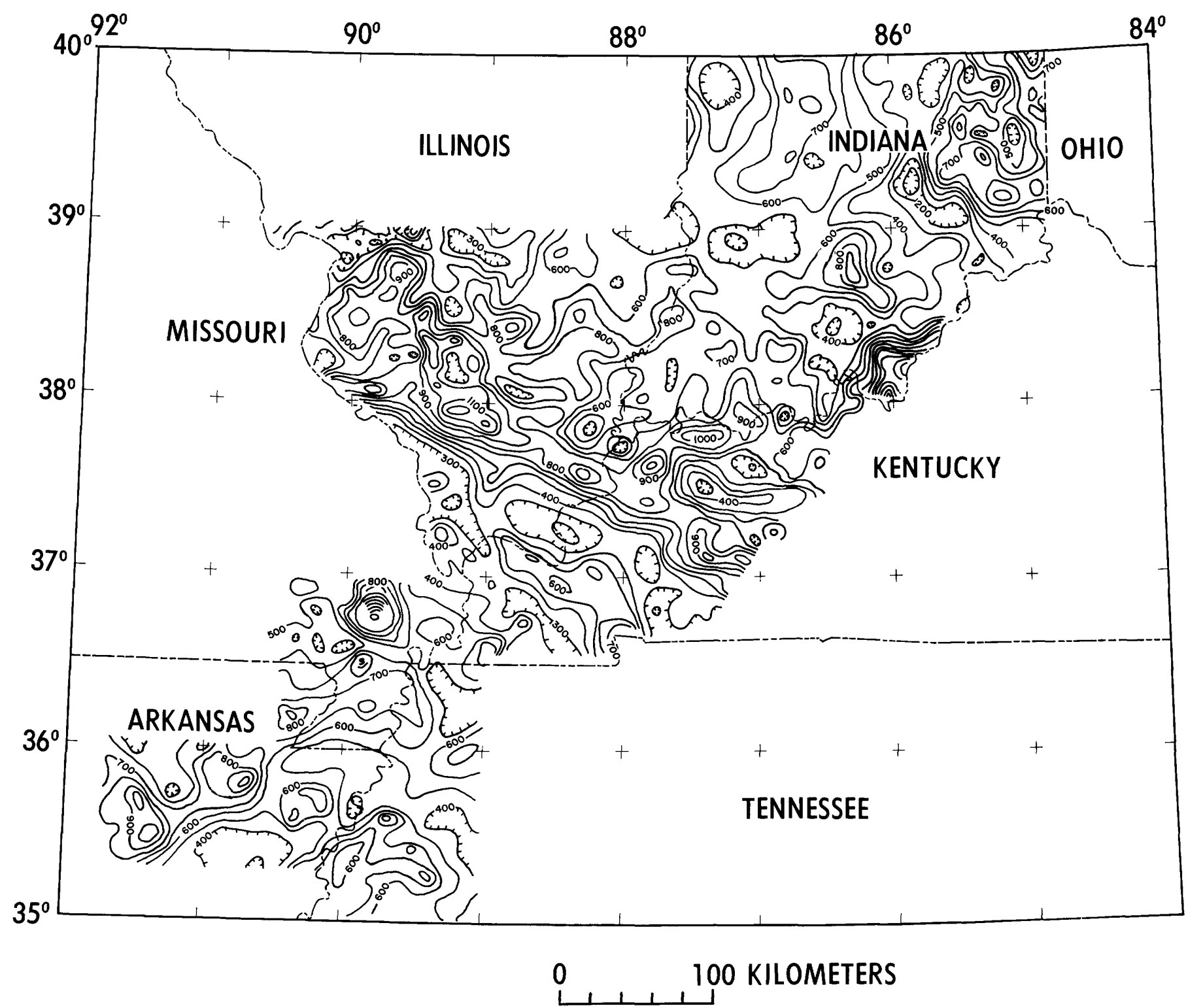

FIGURE 3. -- Preliminary aeromagnetic map of the New Madrid seismic zone and surrounding area. Hachured contours indicate closed lows. Contour interval is 100 gammas; survey elevation, $2 \mathrm{~km}$.

tions, and parameters for removal of geomagnetic-field effects to combine the existing and new aeromagnetic surveys of the area. The aeromagnetic map (fig. 3) was prepared by contouring the existing total-intensity anomaly maps of southern Illinois, Indiana, western Kentucky, and the northern Mississippi Embayment in a consistent manner. Until additional data are added and adjustment for variable survey parameters is completed, the magnetic map must be considered proliminary. The primary difference between this map (fig. 3) and the final magnetic map will be in regional base levels of individual surveys. The character of the magnetic field and the pattern of anomalies are correct as shown on the preliminary map. In preparation of the magnetic map, southwestern Il- linois aeromagnetic data (Heigold, 1976) were digitized and joined with new data observed in southeastern Illinois. These maps were joined to the geomagnetic-field-adjusted Indiana aeromagnetic map (Richardson, 1978). Western Kentucky data are from Johnson and others (1978), and the remainder of the data shown in figure 3 are from Hildenbrand and others (1977). Although the data for the various survey areas have not been completely adjusted, the map (fig. 3) is most consistent with a survey elevation of $2 \mathrm{~km}$. An arbitrary datum has been used. A magnetic anomaly map (Johnson and others, 1980) and a gravity anomaly map (Keller and others, 1980) covering the area of the maps in figures 2 and 3 at a scale of $1: 1,000,000$ will soon be available. 


\section{DISCUSSION}

Although many anomalous features are evident on the gravity and magnetic anomaly maps (figs. 2,3), our focus is the anomaly patterns associated with the New Madrid seismic zone and its possible extension to the northeast into the area of the Wabash Valley fault zone. The most prominent feature on the gravity and magnetic maps is a west-northwest-trending positive anomaly in southern Illinois and western Kentucky. This anomaly is particularly prominent on the magnetic map where the positive anomaly is flanked by a strong gradient and a parallel magnetic low to the southwest. Analysis of the gravity and magnetic data for this anomalous feature indicates a complex pattern of anomalous sources characterized by both correlative (positive- positive or negative-negative) and anticorrelative (positive-negative or negative-positive) gravity and magnetic anomalies. Preliminary modeling of the northwesttrending anomaly also indicates a considerable longwavelength character to the anomaly, suggesting that the depth of the causative bodies is significant. Although the northwest-trending anomaly closely parallels the Ste. Genevieve fault zone in southern Illinois and Missouri, the anomaly can be traced northwesterly across Missouri and southeasterly at least into central Tennessee. Furthermore, basement relief on the Ste. Genevieve fault zone is less than 1 $\mathrm{km}$, and so this fault zone is unlikely to be the source of the observed gravity and magnetic anomalies. Therefore, this northwest- trending anomaly is interpreted as being due to a major basement lithologic boundary. It appears likely, then, that faults associated with the 38th parallel lineament in southern Illinois and western Kentucky, which were active in late Precambrian and early Paleozoic time, may have been localized by the basement lithologic boundary. Although the northwest-trending gravity and magnetic anomaly is of considerable geologic significance, it appears to be unrelated to the possible northeastward extension of the New Madrid seismic zone. In addition as will be illustrated below, this basement lithologic boundary does not appear to affect the earthquake activity in the midcontinent area.

Another prominent feature on the gravity and magnetic maps is several nearly circular, positive gravity and magnetic anomalies. Hildenbrand and others (1977) described linear trends of positive magnetic and gravity anomalies that bound an area of low gravity and magnetic relief and delimit the seismicity patterns indicated by microearthquake epicenters in the New Madrid area. These anomalies are clearly seen on the maps (figs. 2, 3) in the northern Mississippi Embayment area (south of lat $37^{\circ} \mathrm{N}$.). The linear trends of these anomalies can be traced to the northeast at least to lat $39^{\circ} \mathrm{N}$. as shown on figures 4 and 5 . The signature of the anomalies composing the trends can best be seen on a series of profiles perpendicular to trends (fig. 6). The anomaly patterns are less pronounced to the northeast, possibly because this area is the deepest part of the Illinois Basin and because of the interference of the northwest-trending anomalies discussed previously. However, the trend (approximately northeast), the parallelism and width, and the correlative, positive, marginal character of the anomalies bounding the region of low gravity and magnetic relief continue to the northeast (fig. 6).

Hildenbrand and others (1977) have interpreted the generally circular, correlative, positive anomalies as originating from mafic plutons implaced within the crystalline basement and the structural feature defined by these anomalies as a buried rift. The earthquake activity associated with this feature is presumed by these authors to be due to reactivation of the rift structures or localization of stresses along this ancient zone of weakness. This interpretation rests heavily on the model of Ervin and McGinnis (1975), who postulated the existence of the Precambrian Reelfoot rift. Because the term "Rift' has a specific genetic meaning, or at least connotation, and because we have traced the structure associated with the New Madrid fault zone considerably to the northeast of where it has been described as a rift, we have chosen to term the structure evidenced by the marginal gravity and magnetic anomalies the New Madrid linear tectonic feature.

The New Madrid linear tectonic feature delineated by the gravity and magnetic anomalies (figs. 4,5) also approximately delimits an area of maximum seismicity. Seismicity data consisting of historical events (from approximately 1600 to 1975 exclusive of the 1811-12 New Madrid earthquake sequence) are shown compiled from Nuttli (1974), Varma (1975), and Kovacs and Murphy (1977) and from microearthquake epicenters recorded by the Saint Louis University seismic network (1974-76) (Hildenbrand and others, 1977). The correlation of seismicity with the New Madrid linear tectonic feature is clearly seen in a contour map of the numbers of epicenters per $10^{4}-\mathrm{km}^{2}$ area in the midcontinent region (Hadley and Devine, 1974), which is shown in figure 7. The New Madrid linear tectonic feature is seen to approximately bound an area of high seismicity trending northeast. The northern and southern extent of this trend are unclear from the available seismicity and the gravity and magnetic anomaly data, but it is interesting to note the fact that the Anna, Ohio, earthquake zone is directly in line with the trend of the New Madrid linear tectonic feature. This correlation of the gravity and magnetic anomaly patterns with contemporary seismicity attains added significance when one considers the earthquake focal mechanisms reported by Herrmann and Canas (1978). These mechanisms indicate right-lateral movement along the northeast-trending line of epicenters, indicated by the microearthquake epicenters (south of lat $36^{\circ} 15^{\prime} \mathrm{N}$.) and complex but probably dip-slip motion in the area of north-trending epicenters near lat $36^{\circ} 30^{\prime} \mathrm{N}$. These mechanisms are consistent with right-lateral strike-slip motion in a northeasttrending fault zone north of the cluster of microearthquake epicenters (lat $36^{\circ} 45^{\prime} \mathrm{N}$.). The northeast-trending gravity and magnetic anomaly patterns are direct evidence that the 

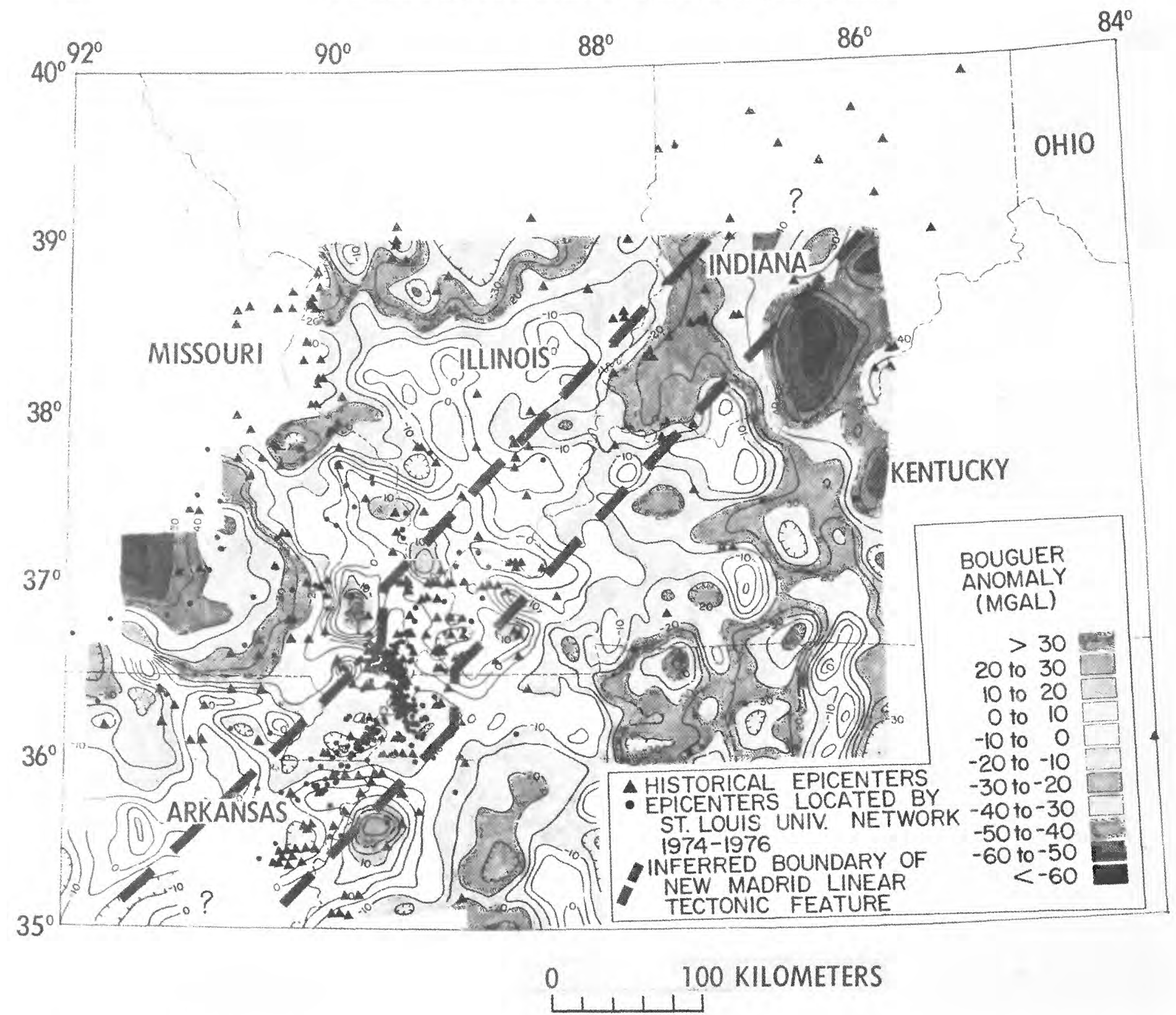

Figure 4.--Shaded gravity-anomaly contour map showing inferred boundaries of the New Madrid linear tectonic feature by the heavy dashed lines. South of lat $36^{\circ} \mathrm{N}$., the boundaries are identical to those inferred by Hildenbrand and others (1977). Queries at north and south ends of the New Madrid linear tectonic feature indicate that the extent of the feature is presently unknown.

New Madrid feature extends north of the 38th parallel lineament into southern Indiana at least to lat $39^{\circ} \mathrm{N}$. Although the seismicity north of lat $37^{\circ} \mathrm{N}$. is less intense and the patterns of epicenters more diffuse than the seismicity associated with the New Madrid seismic zone, the northeastern extension of the New Madrid linear tectonic feature bounds a majority of the epicenters in the southern Indiana area (figs. 4, 5). It should be noted that the seismicity pattern in southern Indiana and Illinois are not as well known as those in the New Madrid area owing to the limited number of seismographs operating in the area and the difficulties of discriminating between small earthquakes and strip-mine blasts, which are very frequent in the area. In fact, an excellent illustration of the inaccuracy of our knowledge of the epicentral patterns of the southern Indiana area from historical seismicity can be seen by analogy with the situation in the New Madrid area. The microearthquake data provided by the Saint Louis University seismograph array considerably refine the characteristics of the seismicity of the New Madrid seismic zone when compared with the historical data (figs. 4,5 ).

Several additional features are evident in the northern extension of the New Madrid linear tectonic feature. First, a 
deflection in the New Madrid linear tectonic feature appears to exist at about lat $36^{\circ} 30^{\prime} \mathrm{N}$. The deflection is suggested by the offset of the linear trends of the marginal gravity and magnetic anomalies when traced from the southwest (from Arkansas) and from the northeast (from Indiana) (figs. 4, 5). The deflection in the New Madrid linear tectonic feature occurs where the deflection in northeast-trending microearthquake epicenters occurs. The cluster of microearthquake epicenters located at the deflection of the New Madrid linear tectonic feature trends approximately N. $15^{\circ} \mathrm{W}$. This trend is in line with a linear but diffuse trend of epicenters which begins at the cluster and extends northward to near St. Louis,
Mo. This trend of epicenters is particularly evident on figure 7. Second, most of the seismicity associated with the northern extension of the New Madrid linear tectonic feature does not appear to be associated with the Wabash Valley fault zone (which is primarily to the west of the Indiana- Illinois border and trends approximately N. $20^{\circ} \mathrm{E}$.) but rather with the New Madrid linear tectonic feature (which trends N. $45^{\circ} \mathrm{E}$.) Third, the extension of the New Madrid feature into Indiana coincides with a basement trough superimposed on the Illinois Basin, as interpreted from magnetic anomaly data by Henderson and Zietz (1958). The precise limits and depth of this trough are unknown because of the paucity of deep drilling
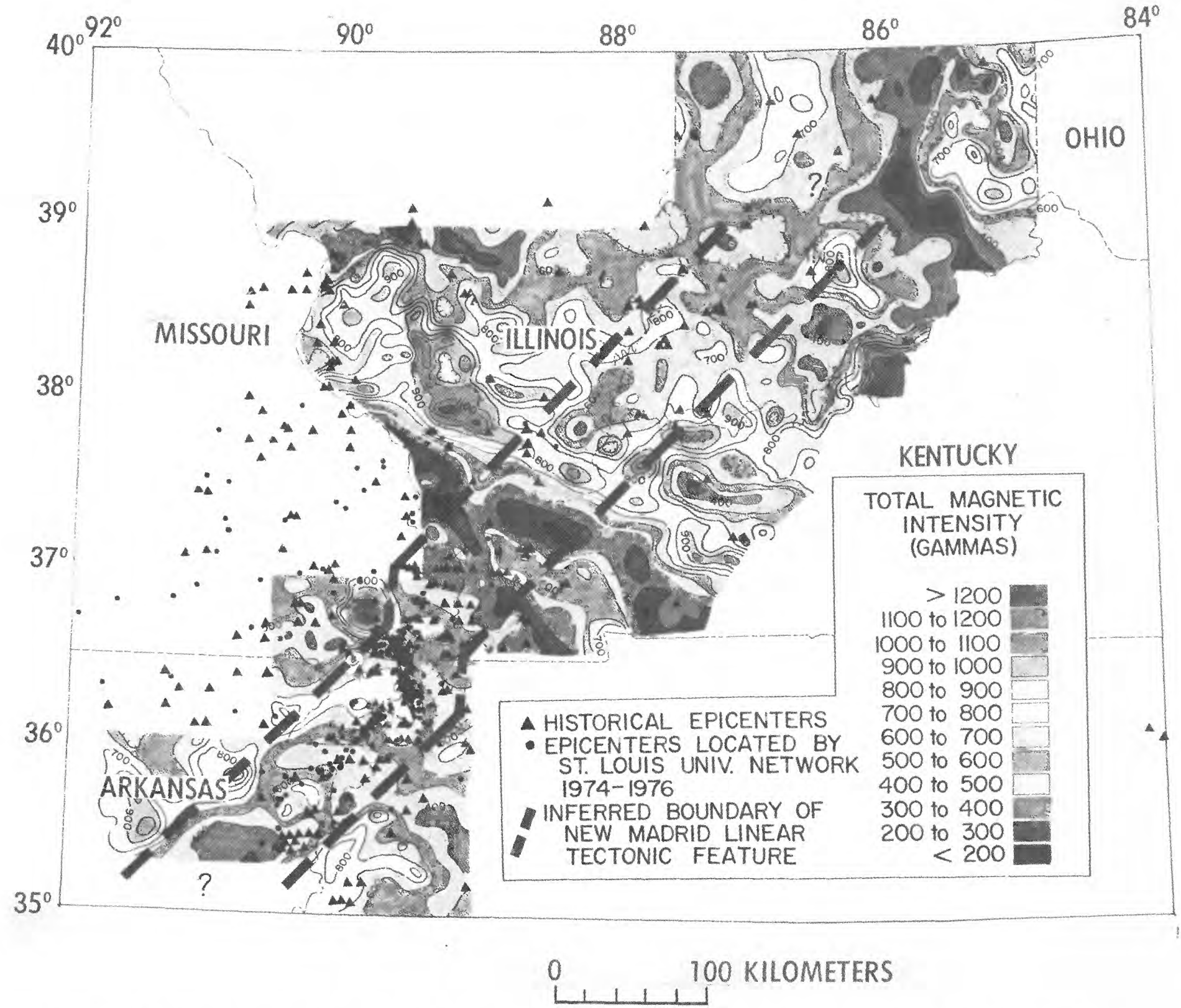

Figure 5. - Shaded magnetic-anomaly contour map showing inferred boundaries of the New Madrid linear tectonic feature by the heavy dashed lines. South of lat $36^{\circ} \mathrm{N}$., the boundaries are identical to those inferred by Hildenbrand and others (1977). Queries at north and south ends of the New Madrid linear tectonic feature indicate the extent of the feature is presently unknown. 


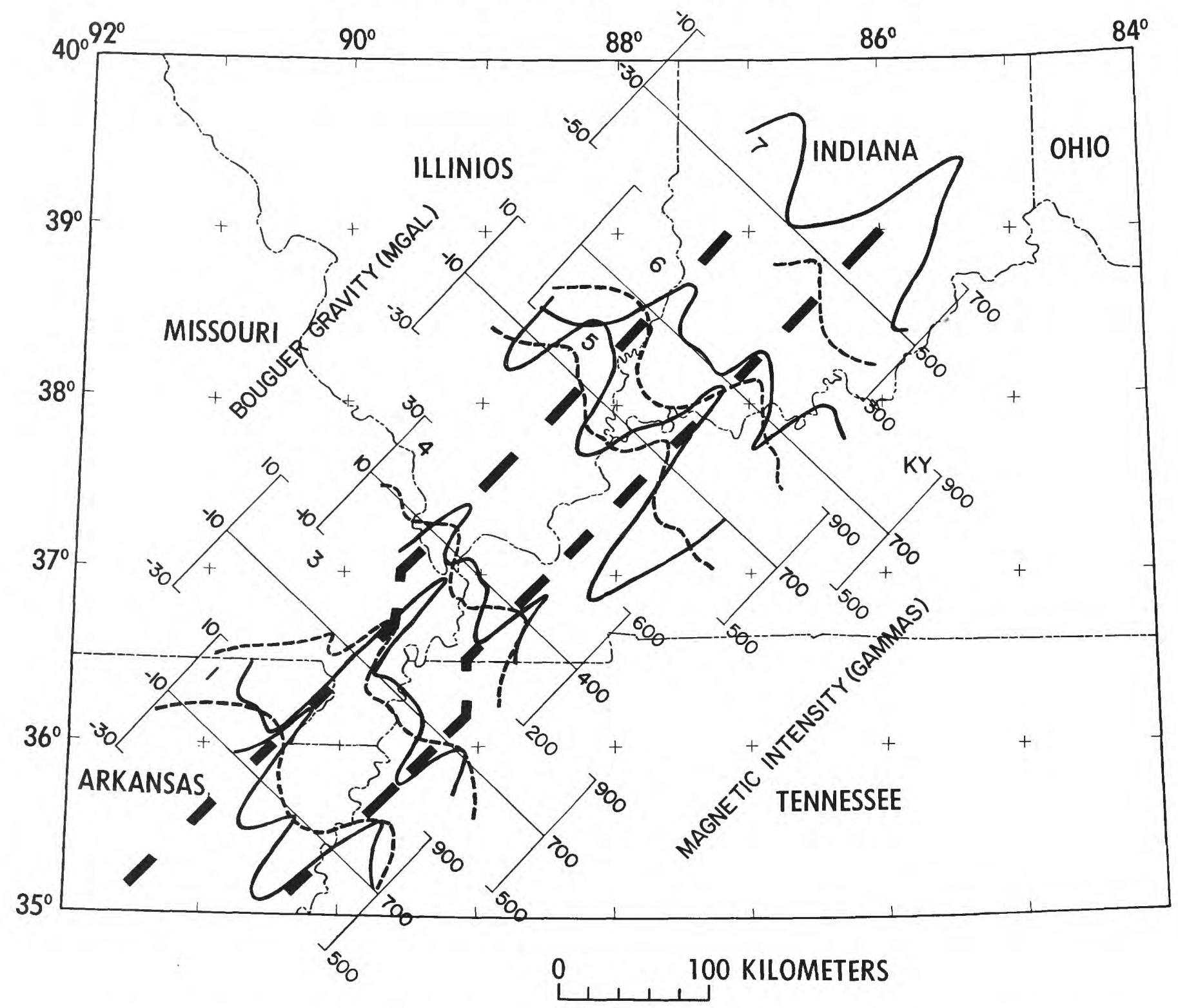

FIGURE 6. - Selected profiles of gravity (dashed lines) and magnetic (solid lines) anomaly data across the New Madrid linear tectonic feature (heavy dashed lines). Profiles are numbered $1,3,4,5,6$, and 7 for identification.

and the limited number and precision of the magnetically determined depths, but the feature is clearly evident in the deflection of the basement-configuration contours presented by Henderson and Zietz (1958).

The correlation of distinct gravity and magnetic anomaly patterns, including the deflection in those patterns, with earthquake epicenters suggests a basement structural control on contemporary seismicity. The gravity and magnetic anomalies are primarily an indication of an ancient basement geologic structure which extends from east-central Arkansas northeastward to southwestern Indiana. Simple linear continuation of this northeasterly trend extends to the Anna, Ohio, seismic area. However, it must be emphasized that, at present, available data only permit delineation of the New Madrid linear tectonic feature northeastward to lat $39^{\circ} \mathrm{N}$. In addition to the correlation of the seismicity with the New Madrid linear tectonic feature, it is significant that the inferred focal mechanisms indicate a fault-plane direction identical to the trend of the New Madrid linear tectonic feature and not an extensional pattern as anticipated in an active rift zone. That the number of historical earthquake epicenters decreases significantly north of lat $39^{\circ} \mathrm{N}$. and that their pattern is more diffuse should also be noted. Whether this observation is an artifact of an inaccurate and incomplete data set may be determined by future seismicity investigations.

Any model that is proposed to explain the contemporary 


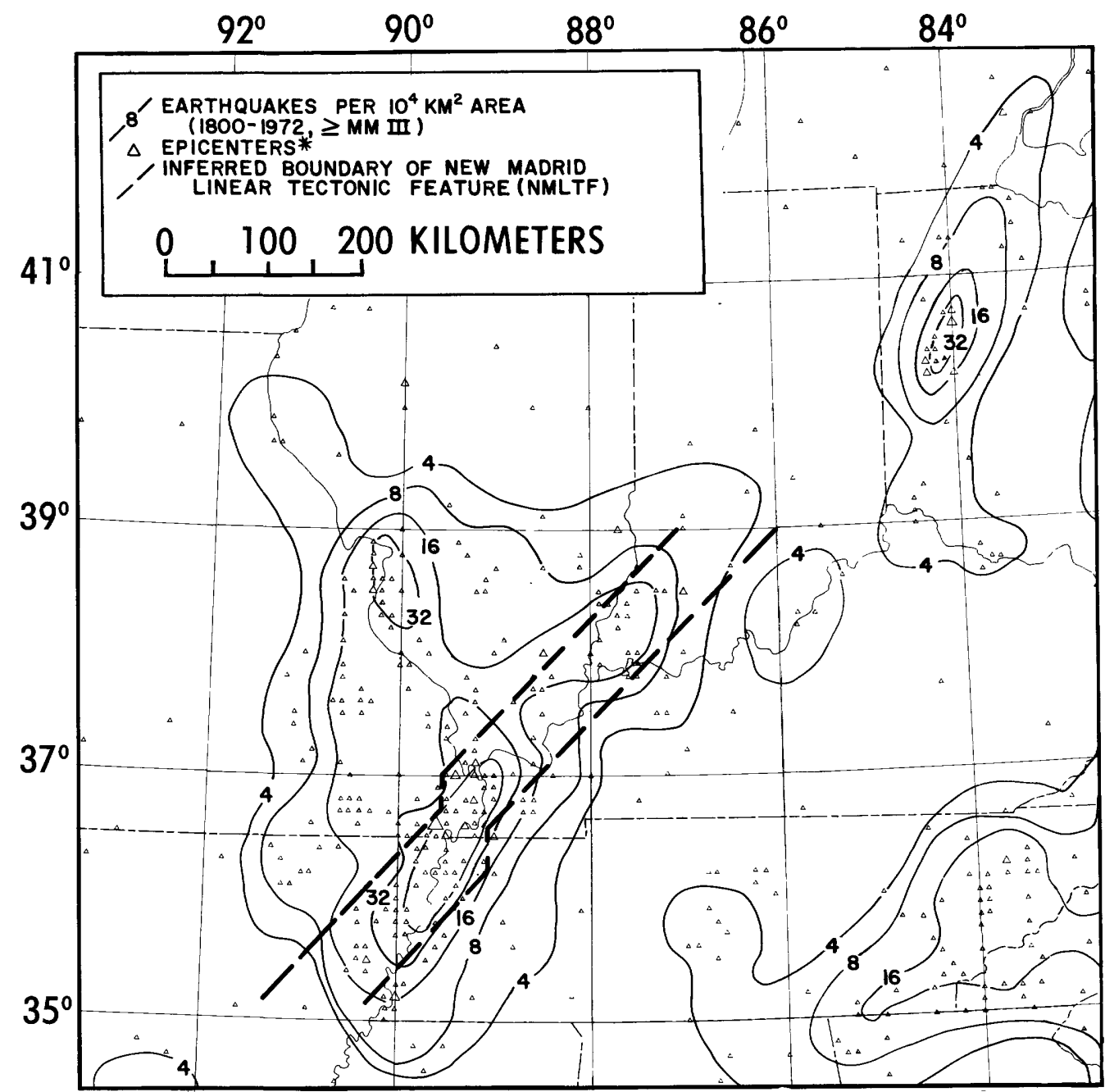

Figure 7. Contour map of number of earthquakes per $10^{4}-\mathrm{km}^{2}$ area with intensity greater than or equal to three from 1800 to 1972 (modified from Hadley and Devine, 1974). Inferred boundaries of the New Madrid linear tectonic feature shown by dashed lines. Size of triangles is proportional to intensity.

seismicity in the midcontinent area should account for the spatial correlation of the microseismicity in the New Madrid area and the New Madrid linear tectonic feature, and the coincidence of the trend of this feature with results of focalplane solutions and the predominant direction of maximum compressive stress in eastern North America (Sbar and Sykes, 1973; Haimson, 1977). These observations suggest that contemporary seismicity in the New Madrid area is derived from localization of stresses along an ancient crustal structure feature which is prone to reactivation by its orientation with respect to the current stress pattern and perhaps its general strength characteristics.

\section{CONGLUSIONS}

Interpretation of regional gravity and magnetic maps and the pattern of historical earthquake epicenters suggest that a basement structural feature is a primary control on seismicity in the midcontinent area. The New Madrid linear tectonic feature is characterized by marginal, correlative, positive gravity and magnetic anomalies that bound a zone of low gravity and magnetic relief and can be traced northeastward from the New Madrid area into southern Indiana at least to lat $39^{\circ} \mathrm{N}$. The extension of the New Madrid linear tectonic feature to the northeast does not necessarily imply that this feature is or will be seismically active along its entire length. The frequency of occurrence of earthquakes to the northeast of the New Madrid area is clearly lower than along the New Madrid seismic zone. Thus, although the entire length of the New Madrid linear tectonic feature (lat $35^{\circ}-39^{\circ} \mathrm{N}$.) is here interpreted as a structural unit, whether it must be considered as a single unit for seismic regionalization is unclear. However, the presently available evidence, including the continuity of the New Madrid linear tectonic feature, its definite correlation with seismicity, and the possibility that the historical record is a statistically poor indication of the true seismicity of the area, 
indicates to us that the entire structure (presently defined from lat $35^{\circ}$ to $39^{\circ}$ ) should be considered to be capable of significant earthquake activity.

We believe that the data and interpretations presented here demonstrate the importance of regional, integrated geological and geophysical studies in investigations of contemporary tectonics and seismicity in the midcontinent region. The data also provide striking evidence for basement structural control
Henderson, J. R., and Zietz, Isidore, 1958, Interpretation of an aeromagnetic survey of Indiana: U.S. Geological Survey Professional Paper 316-B, $37 \mathrm{p}$.

Herrmann, R. B., and Canas, J. A., 1978, Focal mechanism studies in the New Madrid seismic zone: Seismological Society of America Bulletin, v. 68, p. 1095-1102.

Heyl, A. V., 1972, The 38th parallel lineament and its relationship to ore deposits: Economic Geology, v. 67, p. 879-894.

Heyl, A. V., and McKeown, F. A., 1978, Preliminary seismotectonic map of

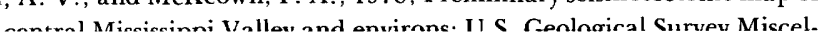

\section{CONTENTS}

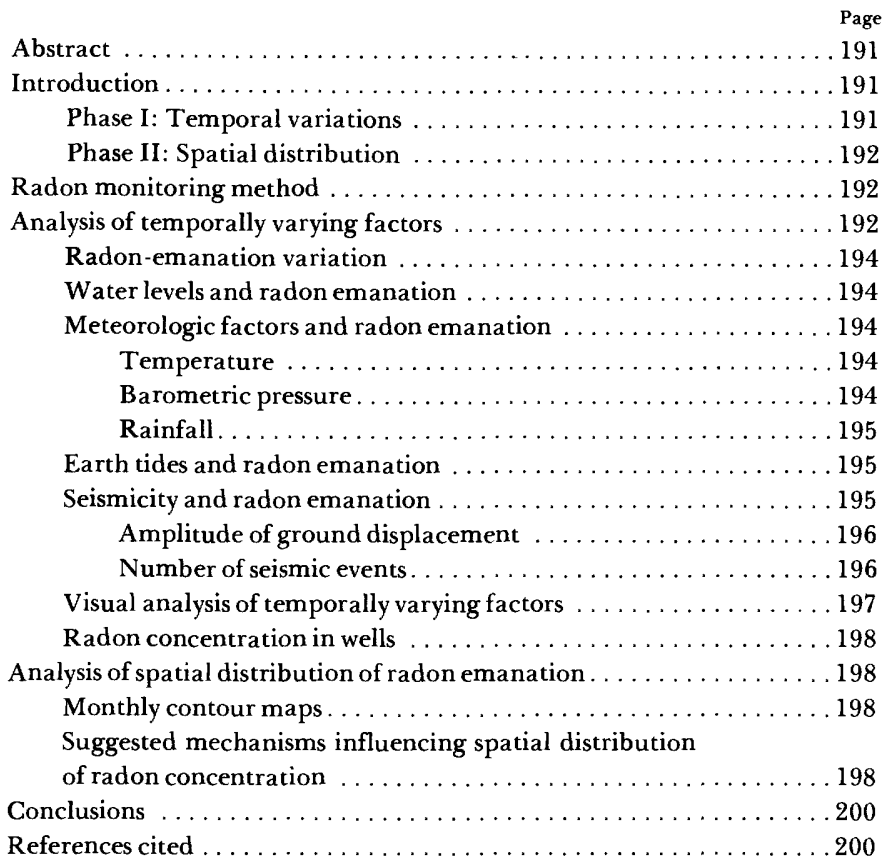

\section{ILLUSTRATIONS}

Figure 1. Map showing locations of seismographs and epicenters in the New Madrid seismic zone, July 1, 1974-March $31,1978 \ldots \ldots \ldots$. . . . . . . . . 192

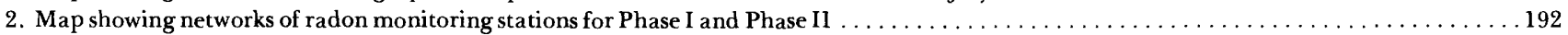

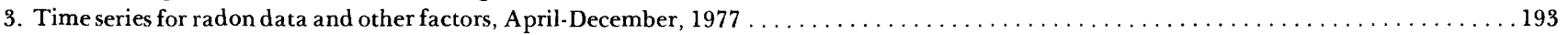

4. Time series and cross-correlation of radon data with wa ter-level data, September $1977-$ February $1978 \ldots \ldots \ldots \ldots$

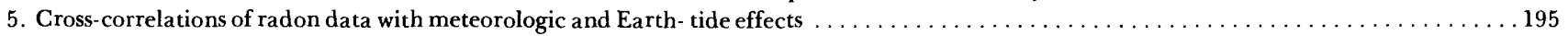

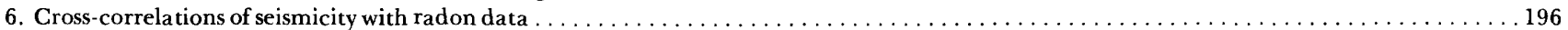

7. Time series and cross-correlation of smoothed seismic-events data with smoothed radon data . . . . . . . . . . . . . . . . . 197

8. Autocorrelation of smoothed radon-isotope data superimposed on autocorrela tion of smoothed seismic-events data . . . . . . . . . . . . . 197

9. Time series of factors exhibiting significant increase in the 37 th and 38 th weeks, early December $1977 \ldots \ldots \ldots \ldots$

10. Contour maps showing radon-isotope emanation survey data in the New Madrid seismic zone for months of June and November 1977,

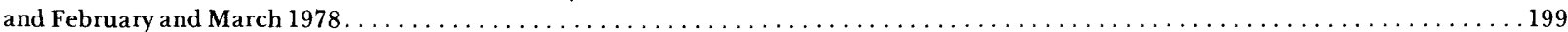

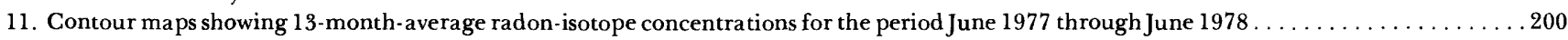

12. Map showing the 25 sites of greatest radon-isotope concentration $\ldots \ldots \ldots \ldots$ 


\title{
HEAT FLOW IN THE UPPER MISSISSIPPI EMBAYMENT
}

\author{
By C. A. Swanberg ${ }^{1}$, B. J. Mitchell ${ }^{2}$, R. L. Lohse ${ }^{1}$, and D. D. Blackwell ${ }^{3}$
}

\begin{abstract}
We have analyzed heat-flow data from the New Madrid seismic zone and adjacent areas in Missouri, Kentucky, Arkansas, Illinois, and Tennessee. These data consist of two traditional heat-flow determinations based on detailed temperature logs and laboratory measurements of thermal conductivity, two approximate heat-flow values based on detailed temperature logs and estimated thermal-conductivity values, and several hundred bottom hole temperature measurements. The bottom-hole temperature data show a small, but well-defined, thermal anomaly associated with the most seismically active area. The heat-flow values are slightly higher in the seismic zone relative to the rest of the stable interior, but the absolute values (1.3-1.6 heat flow units) are not sufficiently above the midcontinent mean to verify the existence of a major heat-flow anomaly. Although several explanations for the New Madrid thermal anomaly are possible, we favor a small convective heat flow component resulting from deep ground-water circulation along fractures in the upper crust associated with active faulting.
\end{abstract}

\section{INTRODUCTION}

The New Madrid seismic zone is characterized by a high level of earthquake activity occurring in a relatively small region surrounded by the more stable crust of the Central United States. It is a region of practical interest because of the relatively high probability that earthquakes occurring there could cause damage to manmade structures (Algermissen and Perkins, 1976), and because the concentration of numerous earthquakes makes it a convenient area in which to pursue earthquake-prediction research under intraplate conditions (Mitchell, Stauder, and Cheng, 1977).

Although the region can be characterized, to a first approximation, by plane-layered seismic models of the crust (McCamy and Meyer, 1966; Mitchell and Hashim, 1977), recent observations of teleseismic P-wave residuals have indicated that compressional-wave velocities in the crust and upper mantle can vary laterally by as much as 5 percent (Mitchell,

\footnotetext{
'Dept, of Physics. New Mexico State University, Las Cruces, NM 88003.

${ }^{2}$ Dept. of Earth and Atmospheric Sciences, Saint Louis University, St. Louis, MO 63156.

Institute for the Study of Earth and Man, Southern Methodist University, Dallas, TX 75275
}

Cheng, and Stauder, 1977). The lowest velocities occur beneath the most seismically active portion of the New Madrid seismic zone.

It is interesting to speculate whether these lateral variations in elastic properties of the crust and upper mantle are related to earthquake activity and whether other geophysical properties also exhibit lateral variations. Heat flow is one geophysical property which could vary laterally and which is easily determined if suitable boreholes are available.

During the summer and fall of 1976 , a search was conducted in the upper Mississippi Embayment for deep wells that might be suitable for heat-flow determinations. Most of the available wells turned out to be abandoned municipal water wells; they are adequate for temperature logging when in thermal equilibrium, but frequently lack the core material necessary for thermal-conductivity analysis. The one well logged for temperature in which a complete set of cuttings was preserved is a test well at Fort Pillow, Tenn. (Moore and Brown, 1969). We were also able to obtain cuttings from an oil test well near our well at Ridgely, Tenn., and from a test well located approximately $12 \mathrm{~km}$ north-northwest of the Ridgely well.

Two of the heat-flow values we obtained (Ridgely, Tenn., and Caruthersville, Mo.) are located within the zone of maximum seismicity as described by Stauder and others (1976). Two additional wells (Fort Pillow, Tenn., and Wilson, Ark.) are situated to the south of that zone. A fifth well, located at West Helena, Ark., yielded an unrealistically low heat-flow value and the data were rejected.

\section{HEAT-FLOW DATA}

The locations of the heat-flow sites are shown in figure 1 and the basic heat-flow data are summarized in table 1. The temperature gradients were obtained by making discrete temperature measurement $\left( \pm 0.01^{\circ} \mathrm{C}\right)$ at 5 -m intervals through the wells (fig. 2) and applying the method of least-squares to various sections of the wells. Conductivity measurements (table 1) were made using a standard divided-bar apparatus 


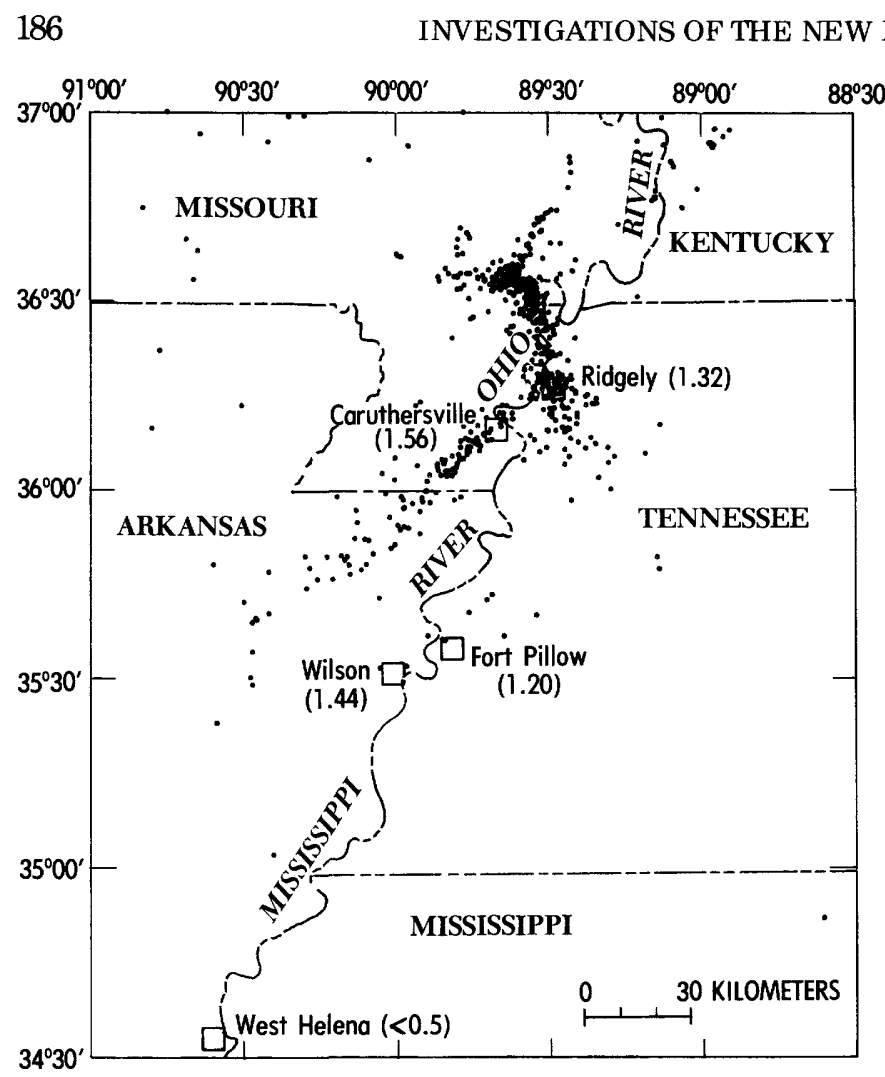

FigURE 1.-- Location of heat-flow sites. Heat-flow values are given in parentheses in units of $\mathrm{cal} / \mathrm{cm}^{2}$-sec. The small solid circles denote earth quakes located by the Saint Louis University seismograph network be tween June 29, 1974, and December 31, 1977.

and a cylindrical cell containing water-saturated rock fragments (Sass and others, 1971). The conductivity of the nonporous rock $\left(\mathrm{K}_{\mathrm{r}}\right)$ as determined in the laboratory has been converted to in situ conductivity $\left(\mathrm{K}_{\mathrm{pr}}\right)$ using the expression of Sass and others (1971):

$$
\mathrm{K}_{\mathrm{pr}}=\mathrm{K}_{\mathrm{w}}^{\phi_{0}} \mathrm{~K}_{\mathrm{r}}^{\mathrm{I}-\phi_{0}}
$$

where $\mathrm{K}_{\mathrm{W}}$ is the conductivity of water $\left(1.46 \mathrm{mcal} / \mathrm{cm}\right.$-sec- ${ }^{\circ} \mathrm{C}$ at $25^{\circ} \mathrm{C}$ ) and $\phi_{0}$ is the natural porosity of the rock. Porosity values of 30 percent and 40 percent have been taken for samples from Eocene and Pleistocene strata, respectively.

For the holes from which no cuttings were available, stratigraphic correlation was employed to estimate thermal conductivity. The Wilson, Ark., well was correlated with the Fort Pillow well (table 1). Because no lithologic logs were available for the Caruthersville well, a least-squares gradient was calculated for the bottom two-thirds of the well and combined with a conductivity value obtained by averaging 15 measured values representing the same depth interval in the Ridgely well and in a test well located $12 \mathrm{~km}$ northwest of the Ridgely well. This method yields only approximate conductivity values, however, because there is no guarantee that natural strati- graphic facies changes will not significantly alter the thermal conductivity even though the formations are the same. The heat-flow values given for the Wilson and Caruthersville wells must therefore be regarded as estimates. When they are interpreted in combination with the more reliable data for the Fort Pillow and Ridgely wells (table 1 ) and the voluminous bottomhole temperature data, however, they add appreciably to our overall understanding of the thermal state of the New Madrid seismic zone.

Figure 3 compares heat-flow values obtained in the present study with those compiled for the stable interior of the United States (Sass and others, 1976). All values obtained in the upper Mississippi Embayment, except that at Fort Pillow (1.20), are higher than the mean value (also 1.20) for the stable interior. The value at Ridgely (1.32) is only slightly higher, whereas the values at Wilson (1.44) and Caruthersville (1.56) appear to be significantly higher than the stable-interior mean. These values indicate that a modest, but not major, thermal anomaly occurs in the region of the New Madrid seismic zone.

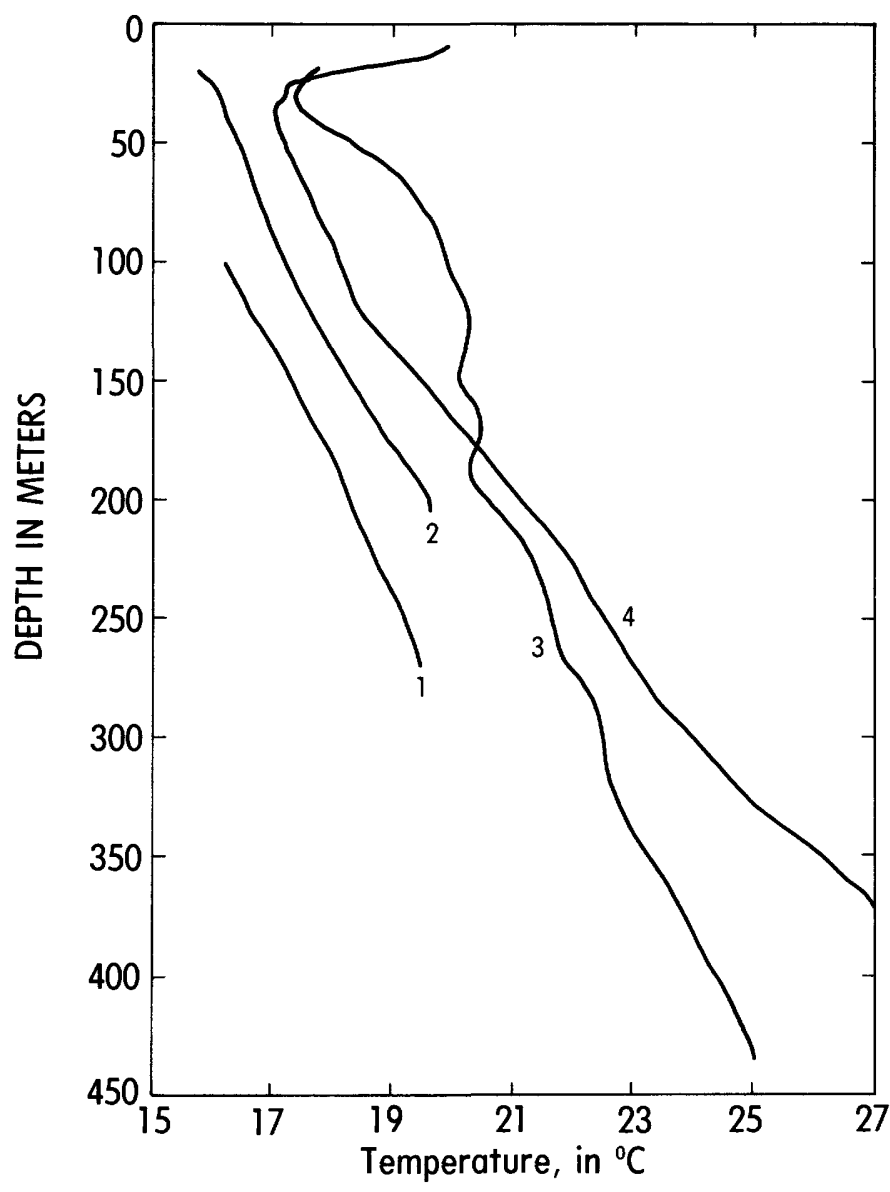

FIGURE 2.--Temperature profiles for the heat-flow sites located in figure 1: 1, Fort Pillow, Tenn.; (2) Ridgely, Tenn.; 3. Wilson, Ark.; and (4) Caruthersville, Mo. 
TABLE 1. - Heat flow using measured thermal conductivity

\begin{tabular}{|c|c|c|c|c|c|c|c|c|}
\hline Locality & Lat $\mathrm{N}$. & Long W. & $\begin{array}{l}\text { Elev } \\
(m)\end{array}$ & $\begin{array}{l}\text { Depth interval } \\
\qquad(\mathrm{m})\end{array}$ & $\begin{array}{l}\text { Stratigraphic } \\
\text { unit } \\
\text { (Eocene) }\end{array}$ & $\begin{array}{l}\text { Temperature } \\
\text { gradient } \\
\left({ }^{\circ} \mathrm{C} / \mathrm{km}\right)\end{array}$ & $\begin{array}{c}\text { Thermal } \\
\text { ffonductivity } \\
\left(10^{-3} \text { cal } / \mathrm{cm} \text { sec-deg }\right)\end{array}$ & $\begin{array}{l}\left(10^{-6} \text { Heat flow }{ }^{2}\right. \\
\mathrm{cal} / \mathrm{cm}^{2}\end{array}$ \\
\hline \multicolumn{9}{|c|}{ Wells for which cuttings were available } \\
\hline Fort Pillow & $35^{\circ} 38^{\prime} 39^{\prime \prime}$ & $80^{\circ} 49^{\prime} 35^{\prime \prime}$ & 135 & $\begin{array}{l}130-140 \\
140-190 \\
190-225 \\
225-240 \\
240-265 \\
275-284 \\
298-331 \\
349-386 \\
404 \\
414-423 \\
442-451 \\
469.488\end{array}$ & $\begin{array}{l}\text { Cook Mountain Fm. } \\
\text { Cook Mountain Fm. } \\
\text { Memphis Sand (upper) } \\
\text { Memphis Sand (upper) } \\
\text { Memphis Sand (lower) } \\
\text { Memphis Sand (lower) } \\
\text { Memphis Sand (lower)-- } \\
\text { Memphis Sand (lower) - } \\
\text { Flour Island Fm. (upper) } \\
\text { Flour Island Fr. (lower) } \\
\text { Transition zone-- } \\
\text { Fort Pillow Sand- }\end{array}$ & $\begin{array}{l}27.9 \pm 1.3 \\
20.6 \pm .1 \\
16.2 \pm .1 \\
21.3 \pm 1.8 \\
15.9 \pm .3 \\
\text { n.d. } \\
\text { n.d. } \\
\text { n.d. } \\
\text { n.d. } \\
\text { n.d. } \\
\text { n.d. } \\
\text { n.d. }\end{array}$ & $\begin{array}{l}4.89 \\
4.88 \\
6.45 \\
6.93 \\
7.12 \\
7.12 \\
7.29 \\
7.55 \\
5.40 \\
5.88 \\
5.19 \\
6.95\end{array}$ & $\begin{array}{l}1.36 \\
1.00 \\
1.04 \\
1.48 \\
1.13 \\
\text { n.a. } \\
\text { n.a. } \\
\text { n.a. } \\
\text { n.a. } \\
\text { n.a. } \\
\text { n.a. } \\
\text { n.a. } \\
\text { average } 1.20 \pm 0.21\end{array}$ \\
\hline Ridgely & $36^{\circ} 15^{\prime} 43^{\prime \prime}$ & $89^{\circ} 29^{\prime} 40^{\prime \prime}$ & 90 & $125-175$ & Memphis Sand (upper)---- & $23.6 \pm .1$ & 5.59 & 1.32 \\
\hline \multicolumn{9}{|c|}{ Wells for which no cuttings were available } \\
\hline wilson & $35^{\circ} 33^{\prime} 32^{\prime \prime}$ & $90^{\circ} 02^{\prime} 14^{\prime \prime}$ & 75 & $\begin{array}{l}320-345 \\
345-365 \\
365-405 \\
410-430\end{array}$ & 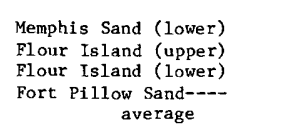 & $\begin{array}{l}18.4 \pm 0.4 \\
29.2 \pm .8 \\
21.2 \pm .4 \\
21.8 \pm 1.5 \\
1.44 \pm 0.15\end{array}$ & $\begin{array}{l}3.55 \\
5.40 \\
5.88 \\
6.95\end{array}$ & $\begin{array}{l}1.39 \\
1.58 \\
1.25 \\
1.52\end{array}$ \\
\hline Caruthersville & $36^{\circ} 11^{\prime} 38^{\prime \prime}$ & $89^{\circ} 39^{\circ} 30^{\prime \prime}$ & 75 & $125-370$ & Not quaflable--- & $31.9 \pm 0.4$ & ${ }^{4} 4.90$ & 1.56 \\
\hline
\end{tabular}

n.d. indicates no data.

n.a. indicates not applicable.

The conductivity for each stratigraphic unit in the wilson well is taken to be identical to the measured conductivity value for the same unit in the Fort Pillow well. Average of 5 values from Ridgely and 10 values from a test well located $12 \mathrm{~km}$ northwest of Ridgely, all from the $125-\mathrm{m}$ to $370-\mathrm{m}$ depth 1 interval.

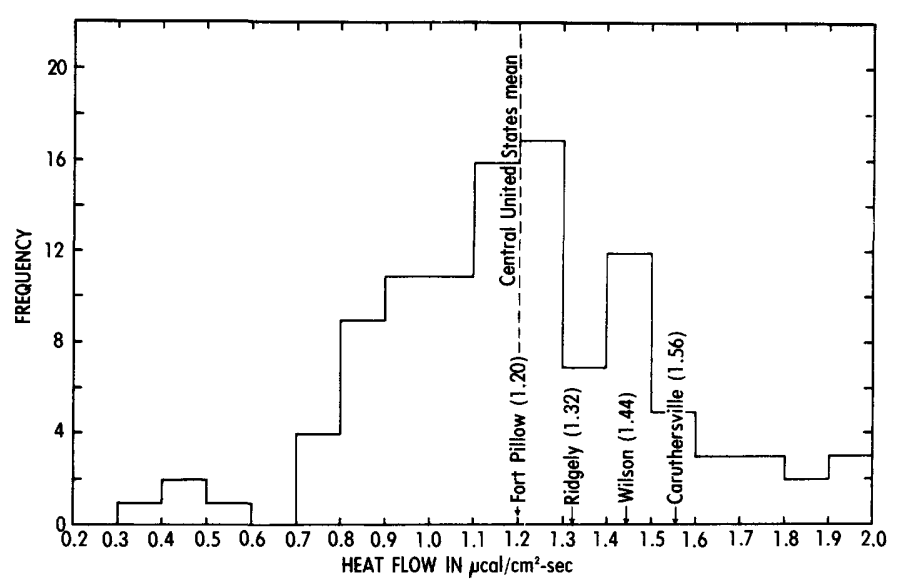

Figure 3.-Comparison of heat-flow values from the New Madrid region with a histogram of heat-flow values for the stable interior of the Central United States. Data from Sass and others, 1976.

\section{BOTTOM-HOLE TEMPERATURE DATA}

In addition to the heat-flow data described above, several hundred botton-hole temperature measurements have been obtained from the USGS WATSTORE file for the general area surrounding the New Madrid seismic zone. These temperatures, when combined with well depth and an assumed mean annual air temperature, can be used to calculate the geothermal gradient; this approach is commonly applied to deep-oil-well data (Geothermal Survey of North America Sub- committee of the American Association of Petroleum Geologists' Research Committee, 1976). In the present case, however, the wells are generally shallow $(50-500 \mathrm{~m})$, and rather large errors can occur in the calculated gradients. Thus, rather than contouring the calculated temperature gradients, we have isolated the wells having abnormally high gradients and plotted them in figure 4 along with the wells having normal gradients. We have designated the gradients as being abnormal if they are more than 1.5 standard deviations above the calculated mean gradient for the region. For the New Madrid area, the cutoff gradient is $30^{\circ} \mathrm{C} / \mathrm{km}$. The data in figure 4 show that nearly all of the abnormally high gradients are located within or adjacent to the zone of maximum seismicity.

A second approach in interpreting the bottom-hole temperature data is to group the wells according to depth and examine each group for the highest bottom-hole temperatures. Individual groups consist of all the wells having bottom-hole depths within a 16-m interval centered at 90, 120, 150, 180, $210,240,375$, and $525 \mathrm{~m}$. Figure 5 shows the locations of the hottest two or three wells from each group, along with the normal wells. This method of presentation has the advantage of not being dependent upon an assumed mean annual air temperature and avoiding the possibility that all of the high gradients may represent wells drilled into a particular aquifer that happens to be hot. The data in figure 5 clearly show that the hottest wells are consistently located within or adjacent to the zone of maximum seismicity. 


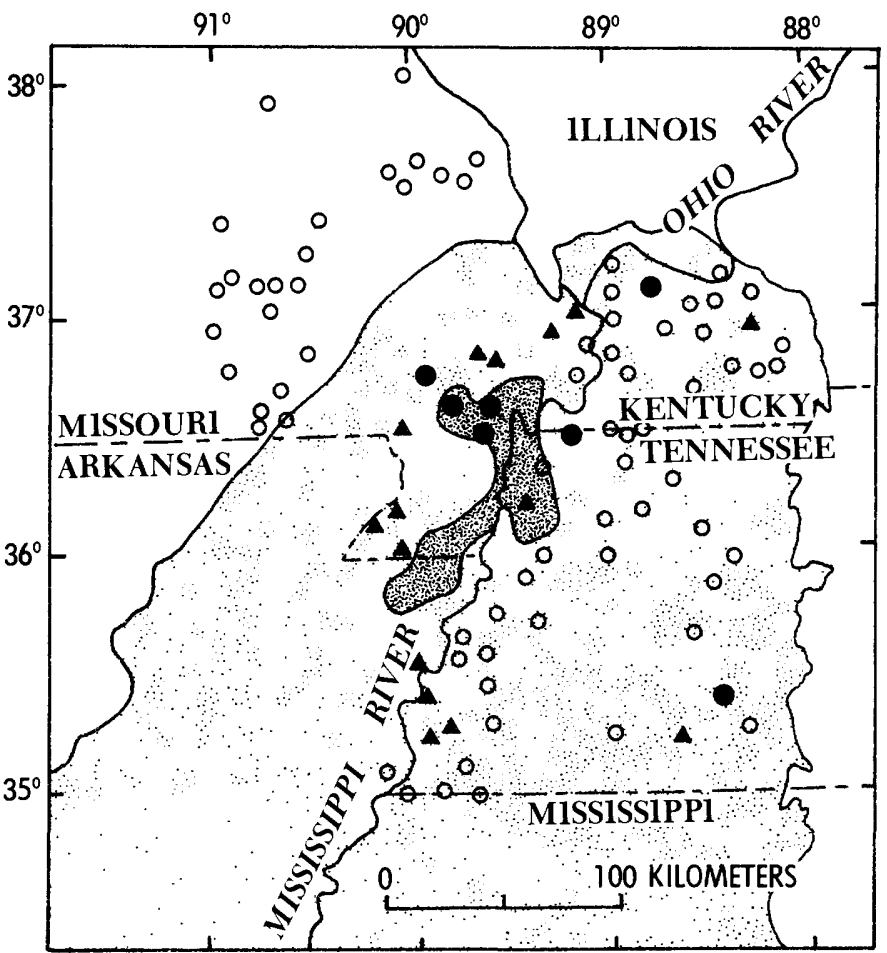

Figure 4.--Locations of wells having abnormally high temperature gradients as calculated from bottom-hole temperatures. Solid circles, triangles, and open circles denote gradients that are $>30^{\circ}, 24^{\circ}-30^{\circ}$, and $<24^{\circ} \mathrm{C} / \mathrm{km}$, respectively. The dark shading delineates the region of maximum seismicity (Stauder and others, 1976), and the light shading indicates the approximate extent of the Mississippi Embayment.

\section{CONCLUSIONS AND DISCUSSION}

All of our temperature data indicate the presence of a small but well- defined thermal anomaly associated with the New Madrid seismic zone. A new heat-flow map of the United States based on silica geothermometry also shows a small heatflow high located in the New Madrid region (Morgan and Swanberg, 1978).

Several possible origins exist for this thermal anomaly. The possibility of a mantle source is intriguing, because of the possible relationship of the thermal anomaly to the anomalously low velocities reported beneath the seismically active portion of the upper Mississippi embayment (Mitchell, Cheng, and Stauder, 1977). The limited spatial extent of the thermal anomaly, however, appears to argue against an upper mantle source.

The release of stored elastic strain or frictional heating during earthquake processes would lead to thermal anomalies of more limited extent than those produced by mantle sources. An evaluation of these possibilities will require a knowledge of the displacement along faults in the region, as well as of the seismic efficiency (the fraction of the total earthquake energy that goes into seismic waves), neither of which is known. The small magnitudes of most New Madrid region earthquakes (and consequent low-energy ralease) seem, however, to argue against this mechanism as a major cause of the New Madrid thermal anomaly.

A component of convective heat flow due to ground water ascending along active faults provides another possible explanation for the anomaly. This mechanism, although difficult to evaluate, would explain the limited spatial extent of the anomaly, and the close association between elevated heat flow and seismicity; it would also be capable of producing the observed heat-flow values. We tentatively favor this convective mechanism as the causative process for the New Madrid heatflow anomaly.

\section{ACKNOWLEDGMENTS}

We are grateful to A. T. Statler of the Tennessee Division of Geology for providing rock samples from wells in western Tennessee and to David P. Russ for providing samples from the New Madrid test well. James Kohsmann and Wing- wah Chan assisted in the field measurements. This research was partially supported by the National Science Foundation, Division of Earth Science, under Grant EAR 77-27096.

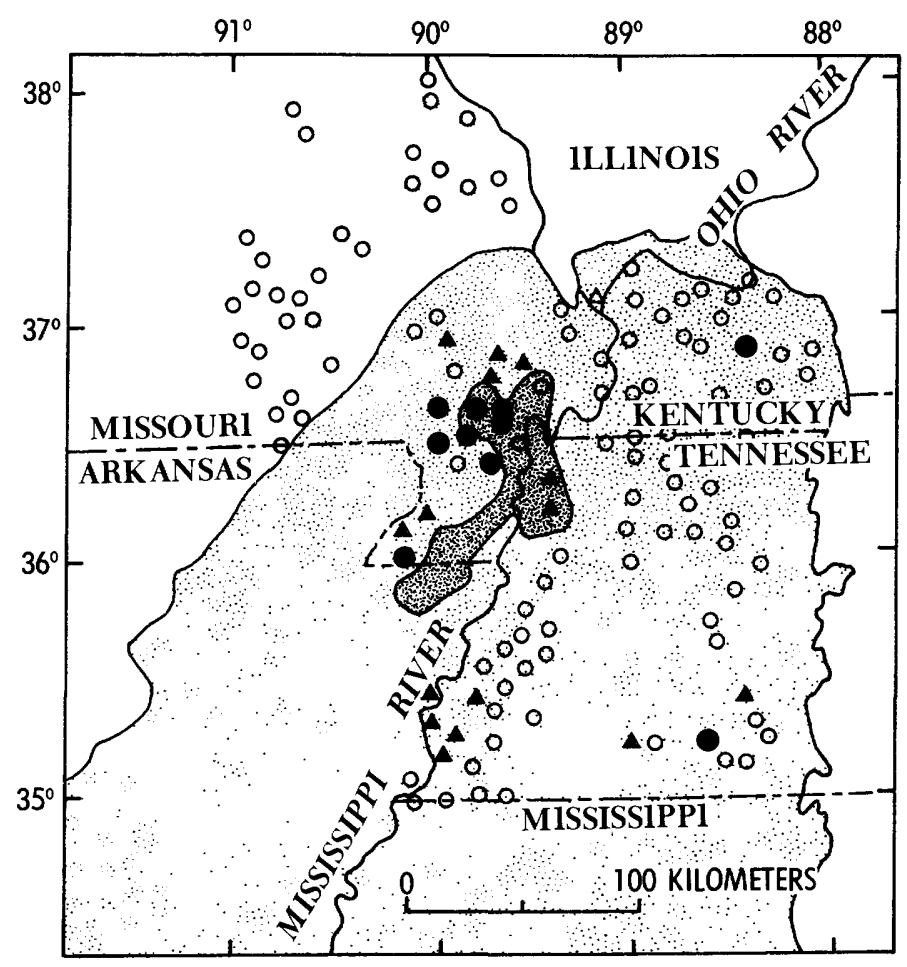

Figure 5.-- Locations of the hottest wells at depths of $90,120,150,180,210$, 240,375 and $525 \pm 16 \mathrm{~m}$. Solid circles, triangles, and open circles denote the hottest wells, marginally hot wells, and normal wells, respectively. The dark shading delineates the region of maximum seismicity (Stauder and others, 1976), and the light shading indicates the approximate extent of the Mississippi Embayment. 


\section{REFERENCES CITED}

Algermissen, S. T., and Perkins, D. M., 1976, A probabilistic estimate of maximum acceleration in rock in the conterminous United States: U.S. Geological Survey Open-File Report 76-416, 45 p.

Geothermal Survey of North America Subcommittee of the American Association of petroleum Geologists' Research Committee, 1976, Subsur face temperature map of North America: U.S. Geological Survey, scale $1: 5,000,000$ ( 1 inch $=80$ miles $)$.

McCamy, K., and Meyer, R. P., 1966, Crustal results of fixed multiple shots in the Mississippi embayment, in The earth beneath the continents: American Geophysical Union Monograph 10, p. 370-381.

Mitchell, B. J., and Hashim, B. M., 1977, Seismic velocity determinations in the New Madrid seismic zone--A new method using local earthquakes: Seis mological Society of America Bulletin, v. 67, p. 413-424.

Mitchell, B. J., Cheng, C. C., and Stauder, William, 1977, A three-dimensional velocity model of the lithosphere beneath the New Madrid seismic zone: Seismological Society of America Bulletin, v. 67, p. 1061-1074.

Mitchell, B. J., Stauder, William, and Cheng, C. C., 1977, The New Madrid seismic zone as a laboratory for earthquake prediction research: Journal of Physics of the Earth (Tokyo), v. 25, Supp., p. S43-S49.

Moore, G. K., and Brown, D. L., 1969, Stratigraphy of the Fort Pillow test well, Lauderdale County, Tennessee: Tennessee Division of Geology Report of Investigations 26, 1 sheet and tables.

Morgan, P., and Swanberg, C. A., 1978, Heat flow, topography, lithospheric thickness, and gravity anomalies in the United States: EOS (American Geo physical Union Transactions), v. 59, p. 120d.

Sass, J. H., Lachenbruch, A. H., and Munroe, R. J., 1971, Thermal conductivity of rocks from measurements on fragments and its application to heat-flow determinations: Journal of Geophysical Research, v. 76, p. 3391-3401.

Sass, J. H., Diment W. H., Lachenbruch, A. H., Marshall, B. V., Munroe, R. J., Moses, T. H., Jr., and Urban, T. C., 1976, A new heat flow contour map of the conterminous United States: U.S. Geological Survey Open-File Report 76-756, 24 p.

Stauder, William, Kramer, M., Fischer, S., Schaefer, S., and Morrissey, S. T., 1976, Seismic characteristics of southeast Missouri as indicated by a regional telemetered microearthquake array: Seismological Society of America Bulletin, v. 66, p. 1953-1964. 



\section{Radon Emanation in the New Madrid Seismic Zone}

By S. R. STEELE, W. C. HOOD, and J. L. SEXTON

INVESTIGATIONS OF THE NEW MADRID, MISSOURI, EARTHQUAKE REGION

GE L O G I A L S UR VEY PROFESSIONALA A P E R $1236-\mathrm{N}$ 


\section{CONTENTS}

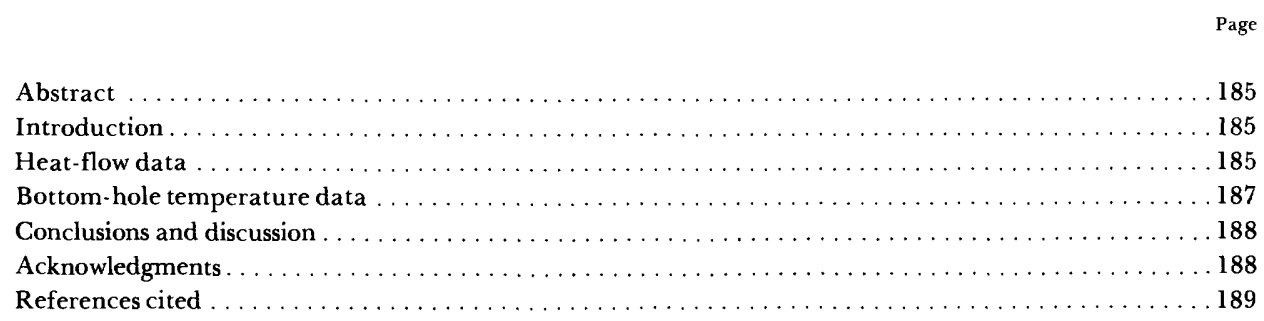

\section{ILLUSTRATIONS}

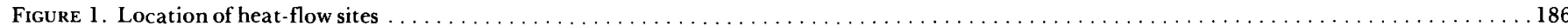

2. Temperature profiles for the heat-flow sites located in figure 1: (1) Fort Pillow, Tenn.; (2) Ridgely, Tenn.; (3) Wilson, Ark.;

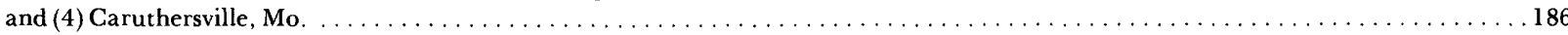

3. Comparison of heat-flow values from the New Madrid region with a histogram of heat-flow values for the stable interior of the

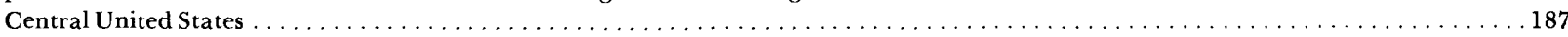

4. Locations of wells having abnormally high temperature gradients as calculated from bottom-hole temperatures

5. Locations of the hottest wells at depths of $90,120,150,180,210,240,375$, and $525 \pm 16 \mathrm{~m}$

TABLE

TABLE 1. Heat flow using measured thermal conductivity 


\title{
RADON EMANATION IN THE NEW MADRID SEISMIC ZONE
}

\author{
By S. R. STEele ${ }^{1}$, W. C. Hood ${ }^{2}$, and J. L. Sexton ${ }^{3}$
}

\begin{abstract}
A study of radon emanation in the New Madrid seismic zone and adjacent areas, inferred from alpha-particle activity of soil gas and wells, has revealed that radon activity varies in both time and space, and that this variation appears to be related to several physical mechanisms. Seasonal as well as short-term variations in radon emanation were observed. The method used to determine alpha-particle activity made no distinction among the radon $\mathrm{Rn}-222$ (radon), $\mathrm{Rn}-220$ (thoron), and $\mathrm{Rn}-219$ (actinon).

Using cross-correlation techniques and visual analyses, comparison of the temporal variations of the radon emanation with those of several other factors suggests that (1) periods of substantial variation in barometric pressure (undistinguished for positive and negative movements) are followed by increases in radon emanation; (2) periods of sharp increase in water levels are accompanied by similar increases in radon emanation, and periods in which water levels are signifiantly above the mean tend to be times of peak activity in radon emanation; (3) radon emanation increases significantly approximately 4-6 weeks prior to periods of increased seismicity (as defined by an increased number of events during a given weekly period); and (4) periods of increased ground motion are accompanied by relatively low concentrations of radon, which decrease further within 1-2 weeks after ground displacement occurs. Whereas a strong positive correlation was indicated from crosscorrelation of radon activity and temperature, visual analysis suggested that the observed high correlation may have resulted from the similar, though not identical, seasonal activity experienced by both factors.

Analysis of the spatial distribution of radon concentration revealed a linear zone of anomalously high radon emanation coinciding with the seismic trend, as well as a few isolated, small zones of high radon concentration that appeared to correspond to the peripheral regions of plutons. The spatial distribution of the near-surface radon concentration may be influenced by the following mechanisms: greater ease of emanation through existing fracture zones, increased fluid circulation enriching seismic-zone fractures in uranium and radium (precursors to radon), or increased outgassing of the thick sedimentary pile in the study area in response to tectonic stresses.
\end{abstract}

\section{INTRODUCTION}

A survey of radon emanation in the New Madrid seismic zone (fig. 1) and adjacent areas was initiated in February 1977 in an effort to detect fluctuations in radon concentration oc-

\footnotetext{
'Earth Science Research and Consulting, Union Hill, Carbondale, IL 62901. ${ }^{2}$ Geology Department, Southern Illinois University, Carbondale, IL 6290I

${ }^{\mathrm{s}}$ Department of Geosciences, Purdue University, W. Lafayette, IN 47907.
}

curring in both time and space, and to determine the physical mechanisms that might be influencing the variations. No distinction was made among the radon Rn-222 (radon), Rn-220 (thoron), and Rn-219 (actinon). This paper reports the results of the study for the period April 1977 through June 1978. Monitoring of certain areas in the seismic zone has continued.

Recent research involving radon measurements along active faults in central California indicates that anomalous radon emanation occurred a few weeks prior to several earthquakes of 4.0-4.6 magnitude (King, 1977). Although King found correlations of radon activity with seismicity in central California, a plate-boundary region of frequent intermediate-level tremors, the question remained whether seismically related variation in radon concentration existed in intraplate areas of lower level seismicity such as the New Madrid seismic zone. This zone is characterized by substantial thicknesses of unconsolidated sediments of the Mississippi Embayment, glacial outwash, and alluvial deposits (Buschbach, 1977).

Crustal microfracturing, a suggested mechanism of possible influence on deep-well radon activity in other seismic areas, was assumed to be an unlikely source of significant influence in the study area on the basis of the distance between the surface soil zone and the more competent rocks below the extensive embayment sediments. Numerous studies have shown that long-range migration of radon is not physically reasonable (A. B. Tanner, written commun., 1978), due in part to the relatively short half-life of 3.82 days for the longest lived isotope and to the slow process of diffusion. Thus consideration of other possible causes of the variation in radon emanation was a prime aspect of this study. The project was carried out in two separate phases: Phase I, which was an investigation of temporal variations; and Phase II, which was a study of spatial distribution.

\section{PHASE I: TEMPORAL VARIATIONS}

A nine-station network of radon monitoring stations was established in February 1977 within the zone of intense seismicity (fig. 2). These stations were located on significant geomorphic features such as lineaments, scarps, and sandblows, as it was felt that some of these features might relate to 


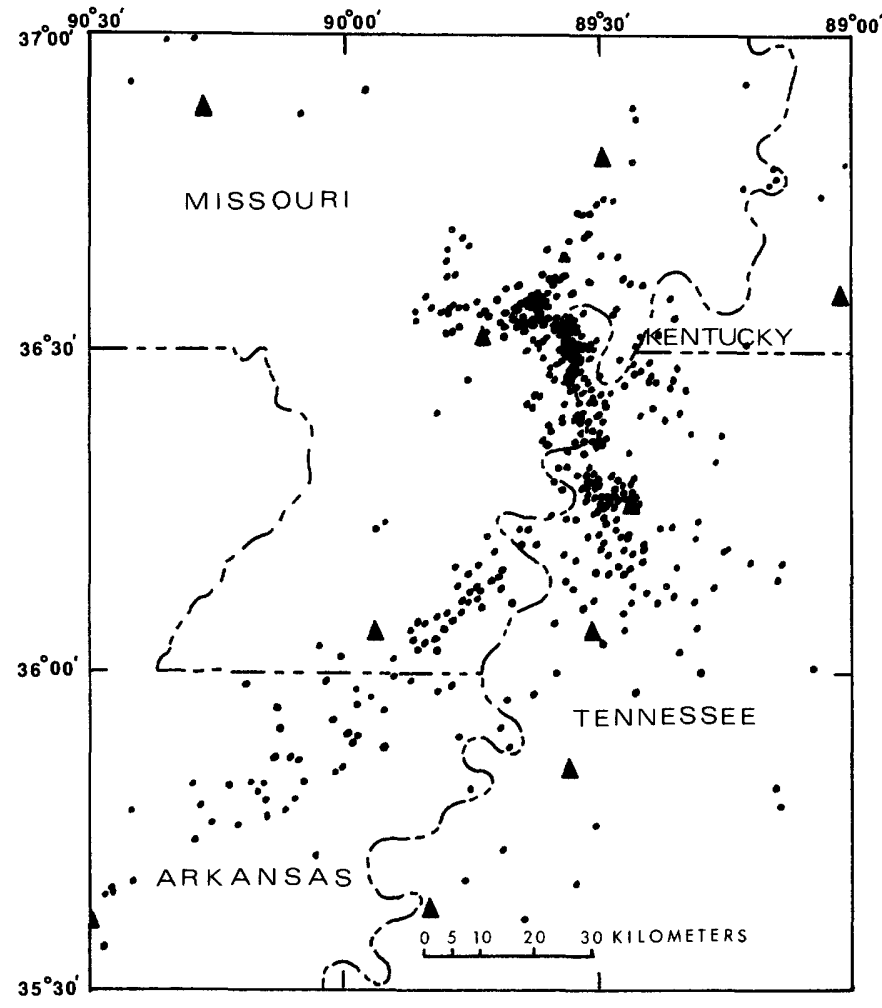

Figure 1.-- Locations of seismographs (triangles) and epicenters (dots) in the New Madrid seismic zone. Cumulative data of events from July 1, 1974, to March 31, 1978, modified from Stauder and others (1978).

faulting in the subsurface (F. A. McKeown, written commun., 1977) and, hence, offer the best chance to detect any seismically related variation in radon concentration that might exist.

The stations in this local network were monitored at 7-day intervals, providing data for analysis of temporal variations. Factors which were considered as possible influences on temporal variations in radon emanation were meteorologic effects (temperature, barometric pressure, and rainfall); Earth-tide effects; water-level changes; and seismic activity that occurred in the study area during the period of observation.

The radon concentrations of two water wells in the seismic zone that became available later in the study were also monitored weekly (fig. 2).

\section{PHASE II: SPATIAL DISTRIBUTION}

A regional network of 51 stations, which encompassed the seismic zone as well as adjacent areas, was established in an effort to determine whether obvious differences in radon distribution occurred between the seismic zone and areas of less frequent seismicity. As the Mississippi River bisects the seismic trend, approximately half of the monitoring stations were in Missouri and half were in Tennessee (fig. 2). These stations were monitored once every 28 days.

\section{RADON MONITORING METHOD}

Radon emanation at shallow levels in the soil was inferred from alpha- particle counts determined through the use of a commercially manufactured nitro-cellulose plastic film designed specifically for the detection of alpha radiation. Inverted plastic cups containing a strip of the film were put into shallow, plastic-lined holes, $0.31 \mathrm{~m}$ in depth, which were then covered for protection. Radon emanating from the soil entered the cup, giving off alpha radiation as it decayed. The film was removed at specified intervals and processed in a solution to enlarge the damaged zones, caused by alpha-particle interaction, to a size easily countable under low magnification. The number of enlarged tracks in a standard area of 14.5 $\mathrm{mm}^{2}$ was used to infer relative radon emanation for a given period.

\section{ANALYSIS OF TEMPORALLY VARYING FACTORS}

The time series for all of the factors considered in temporal analysis are shown in figures 3 and $4 A$. Data sets for each factor were normalized to 1.0 and subsequently centered about 0 mean by removing the long-term average from each of the weekly values. This procedure enabled comparisons between the variances from the mean for each factor. Specific data-

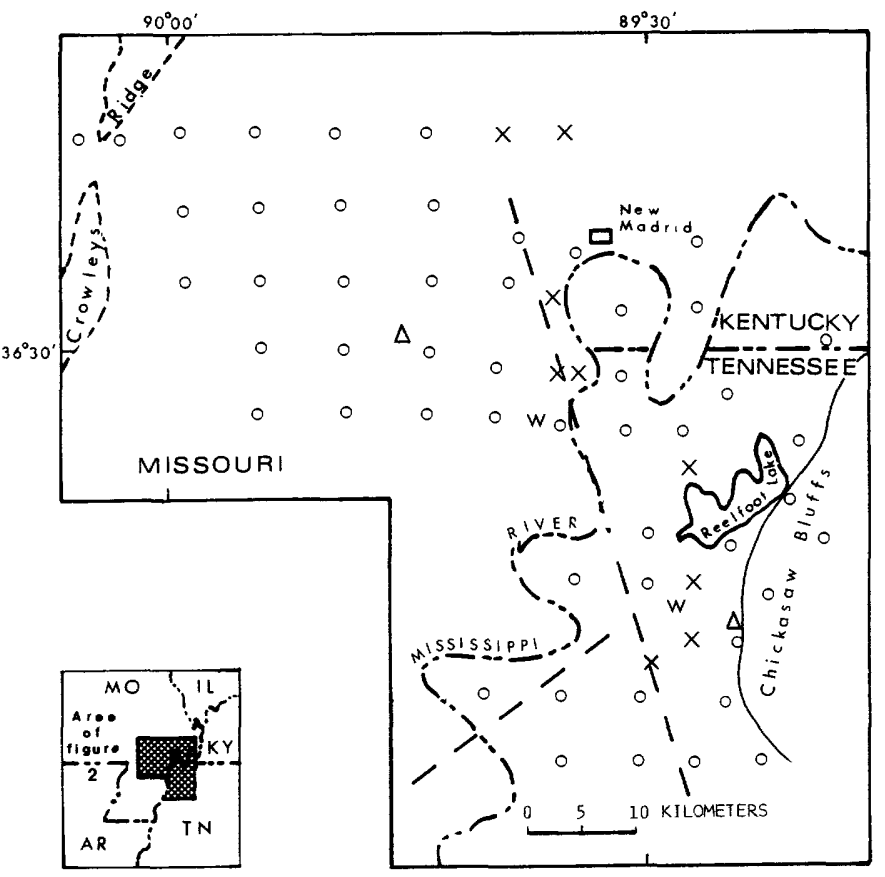

Figure 2. -- Networks of radon monitoring stations for phases 1 and 11 . Phase 1 stations (crosses) and wells (W) monitored weekly; Phase 11 stations ( 0 ) monitored monthly; $\Delta$, seismographs; and dashed lines indicate axes of seismic trends. 
MONTH OF 191

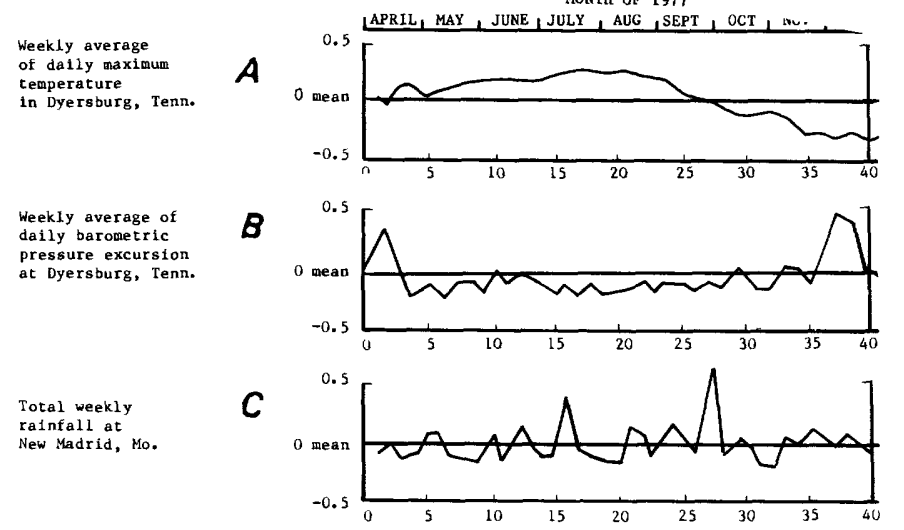

Earth-tide
excursion
Eccorded at

excursion
recorded

St. Louls

University, Mo.

Weekly average
inferred radon Inferred radon
concentration for concentration for
five Missourl tive Misso
stations

Number of seismic events per week in study area
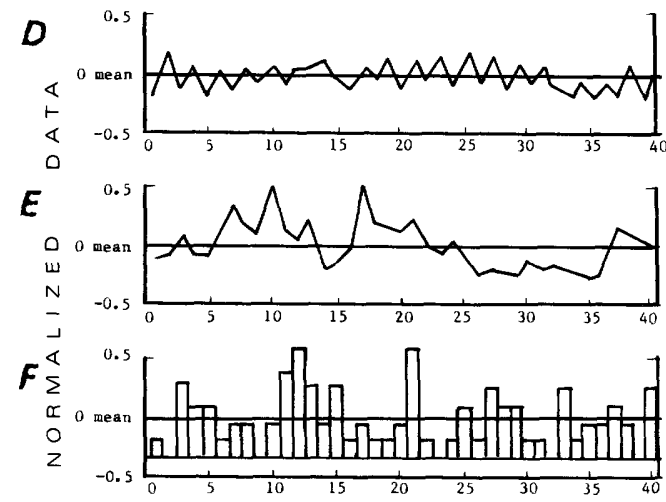

Total amplitude of ground displacement
at Lone Star, Mo.

G

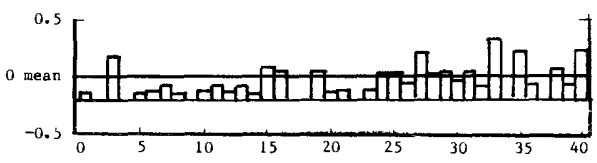

Total amplitude of ground displacement
at Gratio, Tenn.

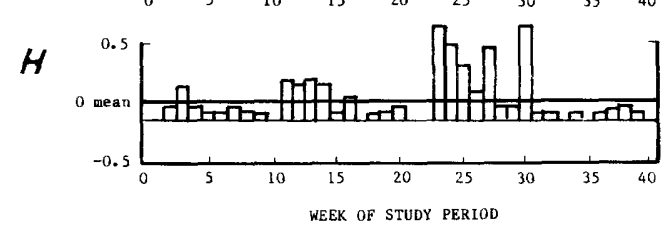

FIgURE 3. - Time series for radon data and other factors during the period April-December 1977. All data normalized to 1.0 and subsequently centered about 0 mean by removing the long-term average from weekly values. A, Temperature is weekly average of the daily maximum temperature in Dyersburg, Tenn. B, Barometric-pressure excursion is the weekly average of the total daily pressure range recorded at Dyersburg, Tenn. C., Rainfall is the total weekly rainfall recorded at New Madrid, Mo. D, Earth-tide excursion is the weekly average of the total amplitudes of the two daily earth-tide peaks recorded at Saint Louis University, St. Louis, Mo. $\mathrm{E}$, Missouri radon data is the total weekly radon concentration inferred from alpha-track count/standard area $\left(14.5 \mathrm{~mm}^{2}\right)$ based on a weekly average of the five Missouri stations. F, Number of seismic events is the total weekly number of significant events occurring in the study area. G, $\mathrm{H}$, Amplitude of ground displacement/week at the seismographs at the indicated locations: G, Lone Star, Mo.; H, Gratio, Tenn.

reduction methods for each of the factors are discussed in the individual sections relating to each factor.

The temporal variations of water levels, meteorologic effects, Earth tides, and seismicity were compared with the tem-

poral variation in randon emanatión using cross-correlation techniques, as well as visual analysis. Cross-correlation results are shown on correlograms (figs. 4-7). In the cross-correlation procedure, the time series for the first noted factor in each of the correlograms was held stationary while the series for the second factor was shifted past it; this procedure began with the second series completely offset to the left of the first. Shifting proceeded by 1 -week increments, with subsequent determination of a correlation coefficient for each shift. The coefficient provides a measure of the overall similarity between the two series for the overlapped portions of the sequences. The factor noted first on each correlogram was generally assumed to be the dependent variable.

Peaks that exceed the 0.05 or 0.01 lines indicate a statistically significant probability of a relationship existing between the two factors being compared. Only those peaks occurring within a 10-week lag limit were considered here, as there is some question of the validity of correlations at lags greater

Water levels
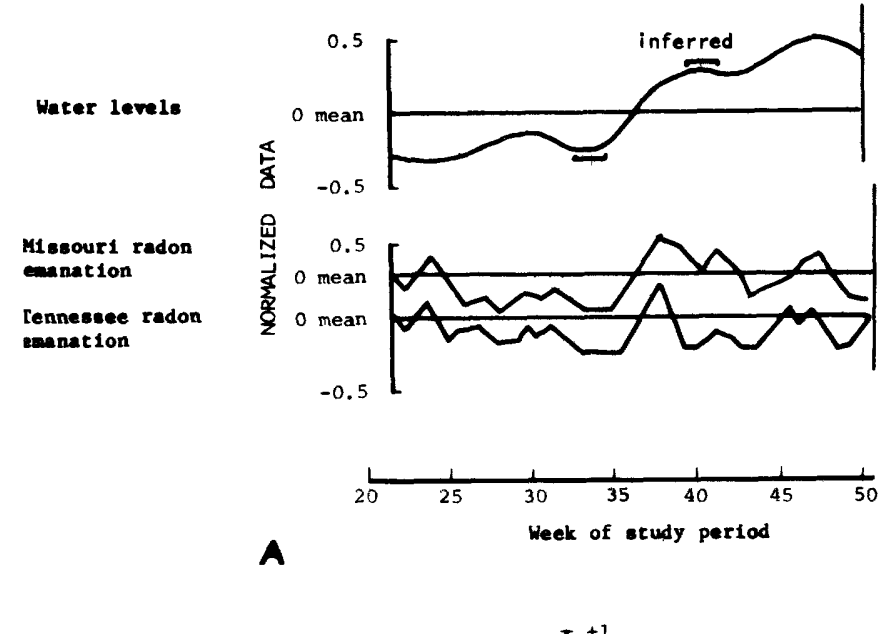

A

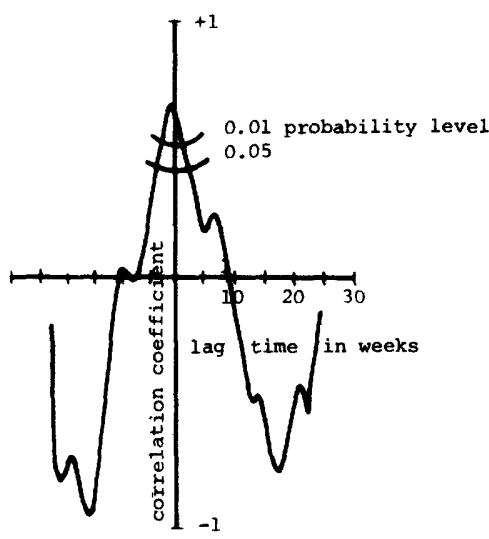

Figure 4. -- Comparison of radon-emanation data and water levels in a Ridge ly, Tenn., well, September 1977 to February 1978. A, Time-series data for water levels, Missouri radon emanation, and Tennessee radon emanation. Data for the time series were normalized to 1.0 and subsequently centered about 0 mean by removing long-term average from weekly values. B, Cross-correlation graph for radon emanation and water levels. 
than $n / 4$ (Davis, 1973), where $n$ is the number of weeks of observation. The amplitudes of peaks indicate the degree of similarity between the two time series; troughs represent corresponding dissimilarities.

To the left of the vertical axis, fluctuations in the first noted factor are precursory to those of the second by an amount of time indicated by the lag value. Conversely, to the right of the vertical axis, fluctuations in the second noted factor precede those of the first.

\section{RADON-EMANATION VARIATION}

In attempting to simplify the radon data collected from the nine stations monitored weekly, an average, weekly value of inferred radon emanation was computed for the Missouri stations and for the Tennessee stations. The range of the average values of radon concentration, expressed in terms of alpha track count per standard area of $14.5 \mathrm{~mm}^{2}$, was 21-643 tracks /standard area of the detector. The two average, weekly radon concentration curves, which exhibited striking similarity, were then used in subsequent cross- correlations. A long-term seasonal variation as well as short-term fluctuations was observed.

\section{WATER LEVELS AND RADON EMANATION}

Water levels in a 200-m-deep well in Ridgely, Tenn., situated in an active portion of the seismic zone, exhibited variations similar to those of radon emanation (fig. 4). The water levels fluctuated between 5 and $7 \mathrm{~m}$ below the ground surface during the 29-week period of observation. Both radon emanation and water levels were below the mean during the first half of this period. A simultaneous sharp increase above the mean occurred in both factors in the 37 th week. Water levels continued in a general upward trend that contained two periods of relatively greater increase, each of approximately 5 weeks' duration. Fluctuations in radon emanation were comparable in that two periods of increase above the mean were recorded for both Tennessee and Missouri. Current data for more than a year of observation suggest that sharp increases in water levels are generally accompanied by similar increases in radon emanation, and that periods in which water levels are significantly above the mean tend to be times of peak activity in radon emanation. Whereas water-level data reflect characteristically gradual changes a majority of the time, radon emanation is more sporadic.

If the relationship between water levels and radon emanation is real, it suggests that water levels may contribute to increased radon concentration at the surface. This increase may be due to outgassing of the sediments in response to rising water levels, or it may perhaps be due to upward transport of radon or their precursors from deeper levels by the rising water, causing an upward shift of the near-surface profile of radon concentration. Further investigation of the water levelradon emanation relationship is needed before definitive conclusions are made. Water-level data were provided by Brian Mitchell of Saint Louis University.

\section{METEOROLOGIC FACTORS AND RADON EMANATION}

\section{TEMPERATURE}

The average, weekly maximum temperature was determined from data supplied by the weather service in Dyersburg, Tenn. A strong positive correlation was observed in cross-correlations between radon emanation and temperature, as shown in figure $5 A$. However, visual analysis of the two series suggested that the strong correlation may have resulted from the similar, though not identical, seasonal variations exhibited by these two factors (Steele, 1978). The following observations seem to be evidence for a noncausal relationship between these factors: Both radon concentration and temperature values were relatively high in the first half of 1977 and dropped to significantly lower values in the latter half of the year, but the decrease in radon concentration preceded the seasonal decrease in temperature by several weeks and the radon emanation experienced a resurgence in early December (week 37) which was not accompanied by a corresponding temperature rise. As further evidence in favor of a noncausal relationship, a deep trough in the radon time series in July 1977 (weeks 14-16) was not accompanied by a corresponding temperature decrease.

It is noteworthy that King (1978) found an inverse relationship between radon emanation and temperature in the San Andreas region and that Gableman (1972) found a positive correlation between alpha-activity concentration and temperature.

\section{BAROMETRIC PRESSURE}

Reduction of barometric-pressure data involved determination of the maximum excursion of pressure for each daily period and subsequent determination of a weekly average of the daily pressure excursions. This provided a measure of the pumping effect which large changes in pressure may have initiated. In this treatment of the data, positive and negative pressure movements were not analyzed, only the relative range of the pressure from week to week. Earlier correlations using absolute, daily, noon pressure values to determine a weekly average pressure indicated no relationship between fluctuations in barometric pressure and radon emanation on a weekly basis.

Correlograms relating the weekly barometric-pressure excursions to variations in radon concentration indicated that large excursions in pressure bear some relationship to ensuing increases in radon emanation in the study area. The data shown in figure $5 B$, which indicate a significant correlation 

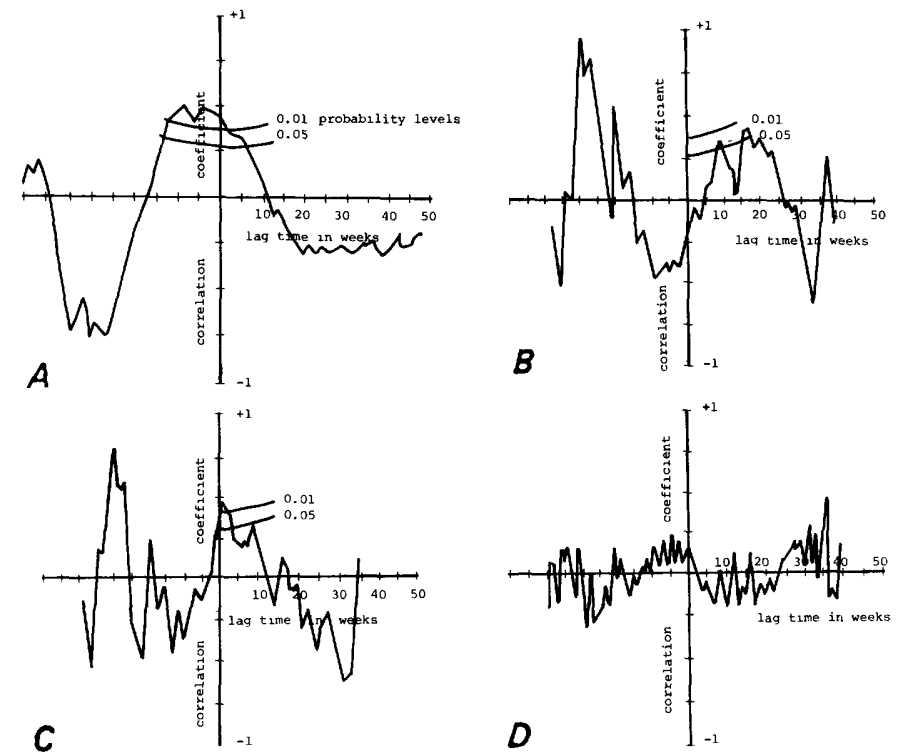

FIGURE 5.--Correlograms showing results of cross-correlations between radon data and meteorologic and Earth-tide factors. A, Correlogram for Missouri radon concentration (inferred from alpha-track count/standard area of $14.5 \mathrm{~mm}^{2}$, based on a weekly average of the five Missouri stations) and temperature (weekly average of daily maximum temperature recorded at Dyersburg, Tenn.) for the period Arpil 1977 to March 1978. B, Correlogram for Missouri radon data and barometric-pressure-excursion data recorded at Dyersburg, Tenn., April-December 1977. C, Correlogram for Missouri radon residual $1 \mathrm{~A}$ and barometric-pressureexcursion data, April-December 1977. Residual 1A is the original Missouri radon-emanation data minus the temperaturelike effect determined through a least-squares fitting procedure. D, Correlogram for Missouri radon-emanation data and Earth-tide excursion data (determined from the continuous gravity-tide profile recorded at Saint Louis University).

between the time series for Missouri radon activity and barometric-pressure excursions, suggested a relatively large lag of 8 weeks between pressure effects and radon increases. This seemed an excessive lag for a causal relationship.

A shorter lag of 1 week and a more pronounced relationship were exhibited on the correlogram relating the pressure excursions to a radon residual (fig. $5 C$ ). This residual $(1 A)$ was the original radon time series minus the temperaturelike effect, approximated through a least-squares fitting procedure (Robinson and Treitel, 1967). The residual was determined in an effort to see if removal of the indicated temperaturelike effect from the radon time series would result in a better assessment of the influence of pressure on radon emanation.

Tanner (1978) noted that an inverse relationship exists between atmospheric pressure and exhalation of Rn-222 and causes the concentration profile in soil gas to shift upward. Numerous studies have considered the effects of atmospheric pressure on the variation in concentration of radon: Geudalia and others (1970) concluded that the exhalation of Rn-220 was not influenced by variations in atmospheric pressure;
Gableman (1972) noted an inverse correlation between alpha activity of soil gas and pressure; Clements and Wilkening (1974) inferred that transport of Rn-222 at shallow depths only is influenced by daily changes in atmospheric pressure. Tanner further noted that Clements found, for sinusoidal pressure variations of 1- and 3-day periods, that the transport velocity at depths of $16.5 \mathrm{~m}$ and $28.5 \mathrm{~m}$, respectively, would decrease by a factor of $1 / \mathrm{e}$.

\section{RAINFALL}

Using local rainfall data for New Madrid, Mo., no relationship was found between total weekly rainfall and radon emanation. Using weekly data, King (1978) also found no correlation between rainfall and radon emanation in the central California region. However, Gableman (1972) found an inverse relationship beween rainfall and alpha activity of soil gas following a heavy rain; he noted a significant decrease in the concentration of alpha activity as downward percolation of the rain occurred.

\section{EARTH TIDES AND RADON EMANATION}

Earth-tide data were compiled from the continuous gravitytide profile produced by the tidal gravimeter at Saint Louis University. The average weekly tidal excursion was determined by measuring the amplitudes of the two daily Earth-tide peaks and calculating a weekly average of the daily tidal variation. This method of reducing the tidal data was felt to provide the most effective measurement of the biweekly Earthtide variation related to the lunar phases. A longer period, seasonal, Earth-tide component was also noticed.

The correlograms for Earth tides and radon emanation exhibited a nonrandom pattern of variation and an apparent biweekly fluctuation, although peaks did not exceed the 0.05 probability level. The bi-weekly pattern suggests that Earth tides may have a subtle influence on radon activity (fig. $5 D$ ). The use of residuals produced slightly greater peaks on the correlograms, but values still did not exceed the 0.05 probability level.

\section{SEISMICITY AND RADON EMANATION}

The two seismic parameters used in assessing the seismicity of the study area were (1) total weekly amplitude of ground displacement at two of the local seismographs, and (2) the number of significant events that occurred each week in the study area, as indicated in the quarterly reports of the 'Southeast Missouri Regional Seismic Network Bulletin" (Stauder and others, 1977a, b, c) and the "Central Mississippi Valley Earthquake Bulletin" (Stauder and others, 1978). The significant events were those events which were strong enough to be detected at more than one seismograph and, thus, more accurately located. 


\section{AMPLITUDE OF GROUND DISPLACEMENT}

A significant positive peak on the correlogram relating local New Madrid area values of radon concentration to the ground displacement at the Lone Star seismograph (near New Madrid) suggests that periods of increased radon emanation precede periods of increased ground displacement by several weeks (approximately 7-8 weeks, as indicated in fig. 6B). All correlograms relating ground displacement to radon emanation disclosed a characteristic pattern of inverse relationship at 0 time lag, with continued decline in the coefficient to the left of the ordinate suggesting that a drop in radon concentration occurs shortly after periods of increased ground motion (figs. $6 A, B)$. Visual comparison of the ground displacement and radon time series seemed to support this relationship. The use of residuals did not significantly alter the correlation results.
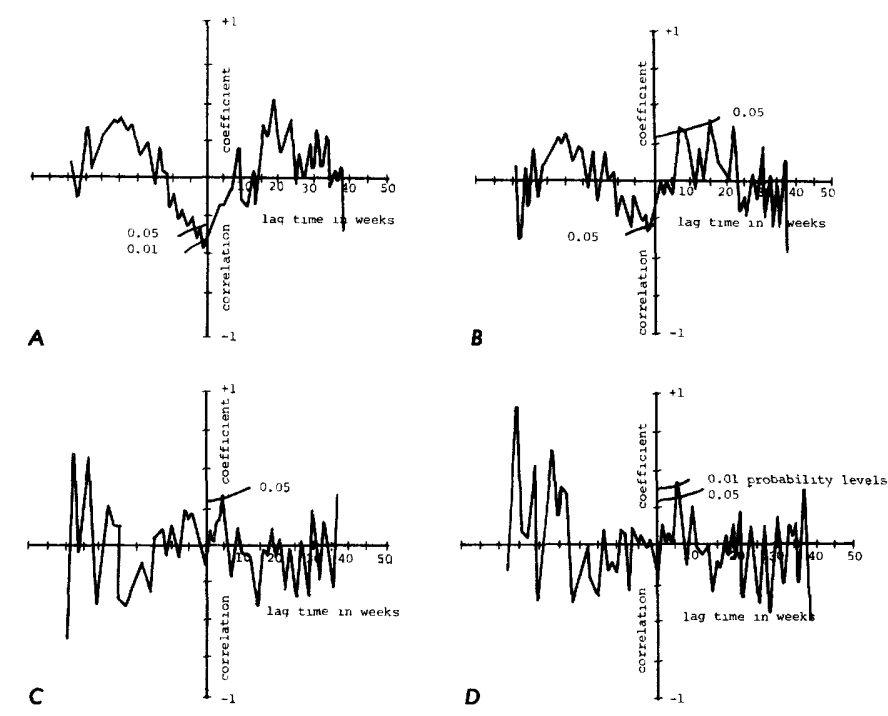

Figure 6. - Correlograms showing results of cross-correlations between seismicity parameters and radon data, April-December 1977. A, Correlogram for amplitude of ground displacement at the Lone Star, Mo., seismograph and Missouri radon data. Amplitude is the total weekly amplitude of ground displacement. Missouri radon data are the weekly radon concentration inferred from total alpha-track count/standard area of $14.5 \mathrm{~mm}^{2}$, based on an average of the five Missouri stations, $B$, Correlogram for amplitude of ground displacement at the Lone Star, Mo., seismograph and New Madrid radon data. New Madrid radon data are the weekly concentration for the New Madrid, Mo., station only. This is the radon monitoring station closest to the Lone Star, Mo., seismograph. C, Correlogram for number of weekly events and Missouri radon data. Events are those seismic events detected at more than one seismograph and considered significant. $D$, Correlogram for number of weekly events and Missouri radon residual 1B. Residual 1B is the original Missouri radon data minus temperaturelike and pressure effects, determined through a least-squares fitting procedure.
One suggested explanation of the relationship between radon emanation and ground displacement may be that strain accrual, which precedes strain release by several weeks, may be effectively influencing sediments as well as crust. Perhaps this occurs through subtle deformation of the thick sediments in the study area, causing an outgassing of the sediments from slight shifting, compaction, or compression related to tectonic stresses. The drop in radon concentration values accompanying or shortly following periods of strain release (ground displacement) may thus relate to the stress drop accompanying release of strain. Crustal compression is the mechanism proposed by King (1978) as a possible cause of increased radon emanation along faults in central California. He suggested that compression may cause an increased rate of outgassing and contribute radon brought up from deeper soil gas in which increased radon concentration exists.

\section{NUMBER OF SEISMIC EVENTS}

Cross-correlations indicated a positive correlation between radon activity and the periods of increased seismic activity (as defined by the increased number of weekly events) that occurred 4-5 weeks later. This positive correlation was also supported by visual analysis of the time series for radon emanation and seismic events. A significant positive relationship was observed in the majority of cross-correlations relating number of events to radon activity. Two graphs (figs. $6 C, D$ ) illustrate the significant increase in correlation which resulted when radon residual $1 \mathrm{~B}$ (original radon time series minus temperaturelike and pressure effects) was used.

Smoothing of the radon and events time series, by plotting only the periods of peak activity for both variables, resulted in signals that showed striking similarities when visually compared (fig. $7 A$ ). Subsequent cross- correlation of these two smoothed signals (fig. $7 B$ ) further substantiated the positive relationship found in the unsmoothed data, showing a strong positive correlation between radon emanation and periods of increased seismicity which occurred 4-5 weeks later. Of further interest on the correlogram of smoothed data is the periodic undulation and well-ordered decline of peaks. These may result from the periodic tendency exhibited by periods of peak seismic activity, combined (in the correlation procedure) with the seasonal periodic tendency exhibited by radon activity. Figure 8 shows the autocorrelation of the radon time series superimposed on the autocorrelation of the seismic- events data for comparison. The peaks on these graphs are an indication of the periodic tendencies of the two factors.

A similar mechanism to that given for the amplitude-radon relationship is suggested to explain the indicated positive relationship between radon emanation and ensuing seismic activi- 
Smoothed Missouri radon emanation

Smoothed Tennessee radon emanation

Smoothed events

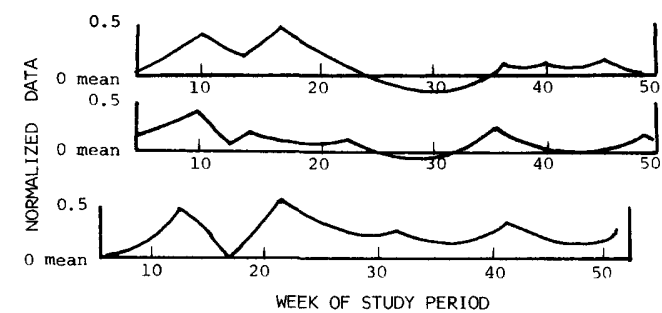

$A$

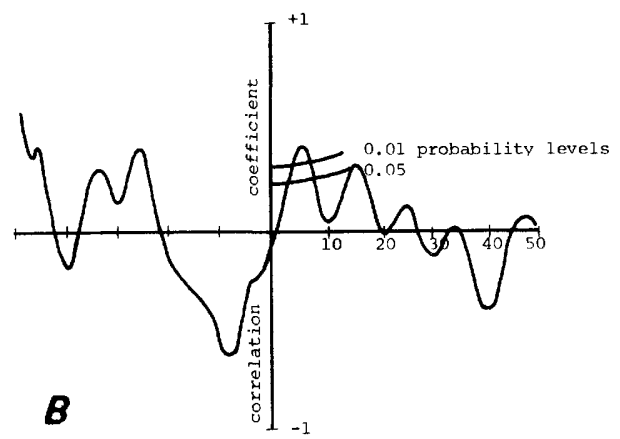

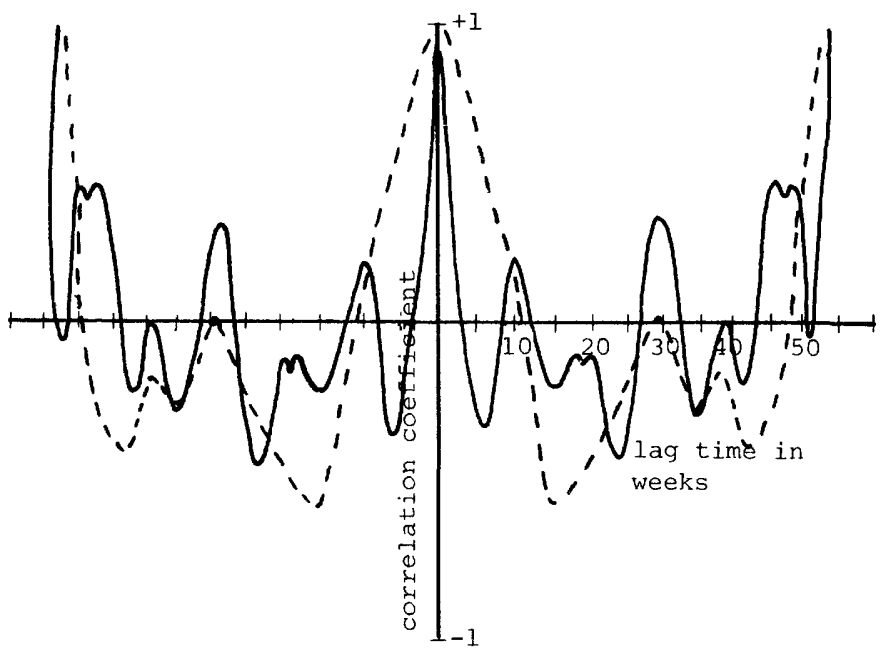

Figure 8. - Autocorrelations of smoothed seismicity (solid line) and smoothed radon emanation (dashed line) superimposed for comparision of periodic tendencies exhibited by both factors.
Figure 7.-Comparison of smoothed Missouri and Tennessee radonemanation data with smoothed seismic-events data, April 1977 to March 1978. $A$, Time-series data for smoothed Missouri and Tennessee radon concentration (inferred from alpha-track count/standard area of $14.5 \mathrm{~mm}^{2}$ ) and smoothed seismic events (number of events/week which occurred in the study area and were detected at more than one seismograph in the study area). Horizontal lines on time series are 0 mean lines for unsmoothed data. $B$, Correlogram for smoothed seismic events and smoothed radon data.

ty. Strain accrual several weeks before release of strain (in the form of increased number of seismic events) may impose an effect on the thick sediments in the study area through deformation of the sediments and subsequently increase the abundance of radon isotopes at the surface.

\section{VISUAL ANALYSIS OF TEMPORALLY VARYING FACTORS}

Viusal analysis of the time series for all factors being considered in this study revealed simultaneous sharp increases in several of these factors in the $37 \mathrm{th}-38$ th weeks, early December, of the study period (fig. 9).

The water levelin the Ridgely, Tenn., well exhibited the greatest increase in the 37 th week and continued to rise significantly in the 38th week. A sharp increase in the Earth-tide excursion in the 37 th week followed a 6 -week low. The barometric-pressure excursion increased drastically to a maximum peak for the study period. Following a period of several weeks in which radon activity was at the lowest levels of the entire study period, sharp increases in radon concentration were

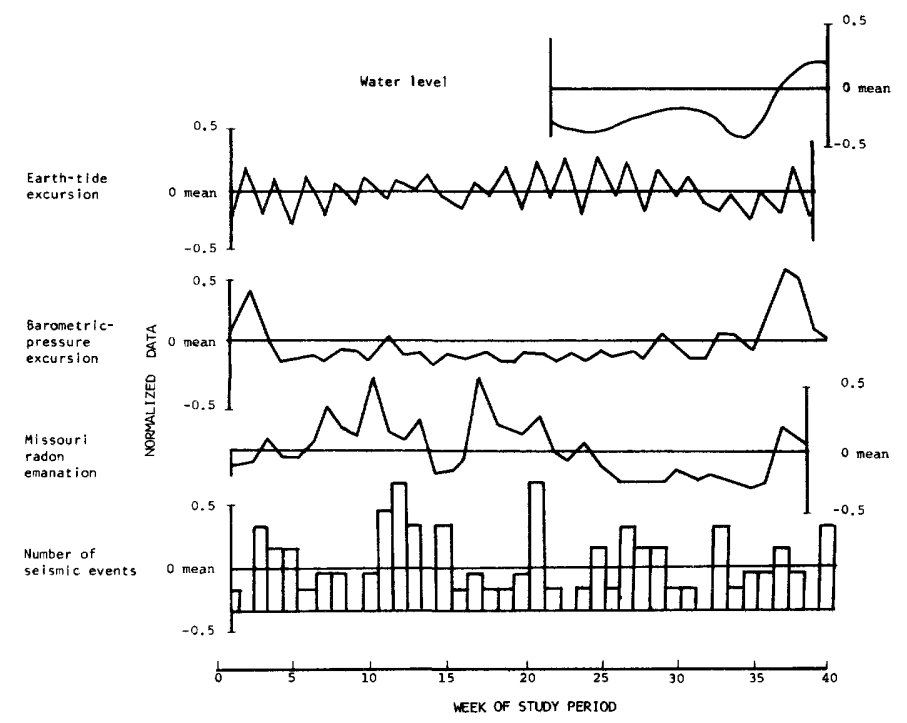

FIGURE 9. - Comparison of factors exhibiting significant increase in the 37 th and 38th weeks (early December) of the study period, April-December 1977. Data for each time series were normalized to 1.0 and subsequently centered about 0 mean by removing the long-term average from weekly values. Water-level data are for a well in Ridgely, Tenn., AugustDecember 1977. Earth-tide excursion is the weekly average of the total amplitudes of the two daily Earth-tide peaks. Barometric-pressure excursion is the weekly average of the daily pressure range recorded at Dyersburg, Tenn. Missouri radon emanation is the total weekly concentration inferred from alpha-track count/standard area of $14.5 \mathrm{~mm}^{2}$, based on a weekly average of the five Missouri stations. Seismic events are the number of events in the study area which are detected at more than one seismograph each week. 
noticed at every station in the seismic zone (including wells). The number of seismic events during the 37 th week also rose above the mean.

Although a causal relationship cannot be assumed from this one period of noticeable change in these numerous factors, the simultaneity of increased activity for all these factors would seem to be more than coincidental, and, therefore, suggestive of an interdependency. Perhaps the combined effects of these physical mechanisms served to initiate the rapid elevation of radon activity which occurred in the 37 th week (Steele, 1978).

\section{RADON CONGENTRATION IN WELLS}

Weekly radon activity was monitored in two wells having bottom depths of 7 and $10 \mathrm{~m}$. The radon concentration was measured at the bottom of the 7-m well and at a depth of $1 \mathrm{~m}$ in the 10-m well. The temporal fluctuations in radon activity in the wells exhibited close correspondence to the radon activity of soil gas, although the concentrations in the wells were, in general, slightly lower than simultaneous soil-gas concentrations.

\section{ANALYSIS OF SPATIAL DISTRIBUTION OF RADON EMANATION}

\section{MONTHLY CONTOUR MAPS}

Radon data from the regional network were collected monthly and plotted on maps to determine the spatial distribution of radon emanation. In general, individual monthly maps showed a characteristic pattern, with a linear zone of anomalous radon emanation coinciding with the seismic trend. This anomaly steadily diminished in size and intensity from June 1977 through November 1977 (figs. 10A, B). A significant resurgence was observed in February 1978 (fig. 10C). The anomaly then diminished again, and did not regain the size and intensity shown in June 1977 for the duration of the monthly monitoring, which continued through June 1978. Figure $10 D$ illustrates the linear configuration of the main anomaly, which was characteristic of the radon distribution during the spring and early summer of 1978.

A composite of the monthly maps is exhibited in a map showing the 13- month average for radon concentration; a strong spatial correlation is shown between the region of most intense radon emanation and the zone of most frequent epicenters (fig. 11). This map further illustrates the linear nature of the anomalous radon distribution $(>200)$ paralleling the seismic trend.

Sites of greatest radon concentration. - Of the 25 stations exhibiting the greatest radon concentration (fig. 12), 18 were in the seismic zone and 5 were located near the edges of igneous intrusions which are inferred from gravity and aero- magnetic surveys of the Mississippi Embayment (Hildenbrand and others, 1977). The numbers in figure 12 indicate the descending order of the sites as determined from the 13-month-average radon-concentration data. The duplication of several of the indicated order numbers resulted from identical 13-month-average values exhibited by a few of the sites.

\section{SUGGESTED MEGHANISMS INFLUENGING SPATIAL DISTRIBUTION OF RADON CONCENTRATION}

The spatial correlation between surface radon anomalies and certain subsurface features, both in the present study and in numerous other studies, suggests that the near-surface radon-concentration profile is related to subsurface structures. In attempting to explain the spatial distribution of anomalous zones of radon emanation in the study area, the following mechanisms are suggested as factors that may influence radon concentrations in the near surface:

1. Faults in the subsurface may provide paths of least resistance along which gases can migrate upward with greater ease. Near-surface faulting has been shown to exist in the study area (Russ and others, 1978), and geophysical studies indicate the existence of faulting at depth in several locations. Other studies relating $\mathrm{Rn}-222$ anomalies to faults have suggested migration over distances of $3 \mathrm{~m}$ or less (Israel and Bjornsson, 1967), and Gableman (1972) sug. gested migration from deep sources to account for $R n-222$ anomalies in soil gas over faults above a salt dome.

2. Deformation of the unconsolidated, thick sedimentary pile by imposed stresses may result in shifting and (or) compaction of sediments, causing outgassing and affecting a net upward shift of the near-surface profile of radon concentration.

3. Uranium localization in the seismic zone, due to increased fluid circulation facilitated by faults associated with the seismic zone, may be a source of radon enrichment. Accumulation of uranium and $\mathrm{Ra}-226$ in the soils of fault zones, due to ion exchange with clays, was shown by Vogler (1960) to be the primary source of emanometric anomalies over faults.

4. Penetrative mantle convection related to suggested active rifting in the study area (Kumarapeli and Saull, 1966) may be an alternative source of radon precursors through crustal remobilization and subsequent injection of radiogenic fluids and gases into the crust beneath the embayment. Thermal gradients and crustal microfracturing may perhaps augment the rate of flow of such fluids and gases. The net effect of such upwelling may possibly have 

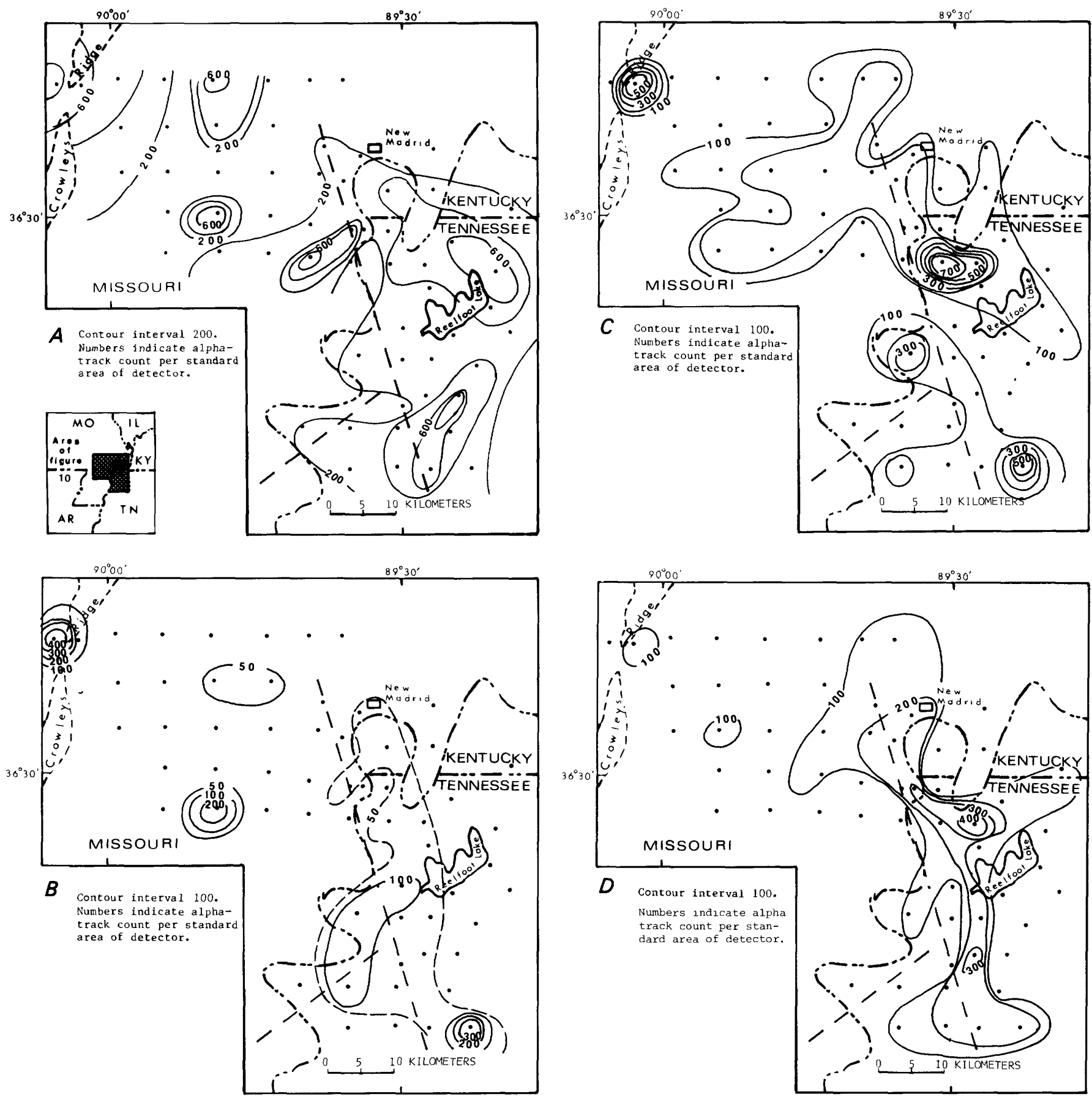

Figure 10. - Comparison of monthly radon-emanation-survey data for the New Madrid seismic zone. Radon monitoring stations (dots) and axes of seismic trends (dashed lines) shown. A, June 1977, contour interval, 200; B, November 1977, contour interval, 100 (the 50 isoline is also shown to illustrate the linear configuration of radon concentration at this lower level); C, February 1978, contour interval, 100; and D, March 1978, contour interval, 100

an ultimate influence on the surface profile of radon concentration. Long-range transport of radon itself is unlikely, but cannot be completely dismissed as a possible source. 5. Regarding the zones of anomalous radon emanation which appear to relate to igneous intrusive bodies in the study area, it is suggested that possible faulting on the periphery of the igneous bodies may provide zones of enrichment ist radon or their precursors through greater ease of emana- 


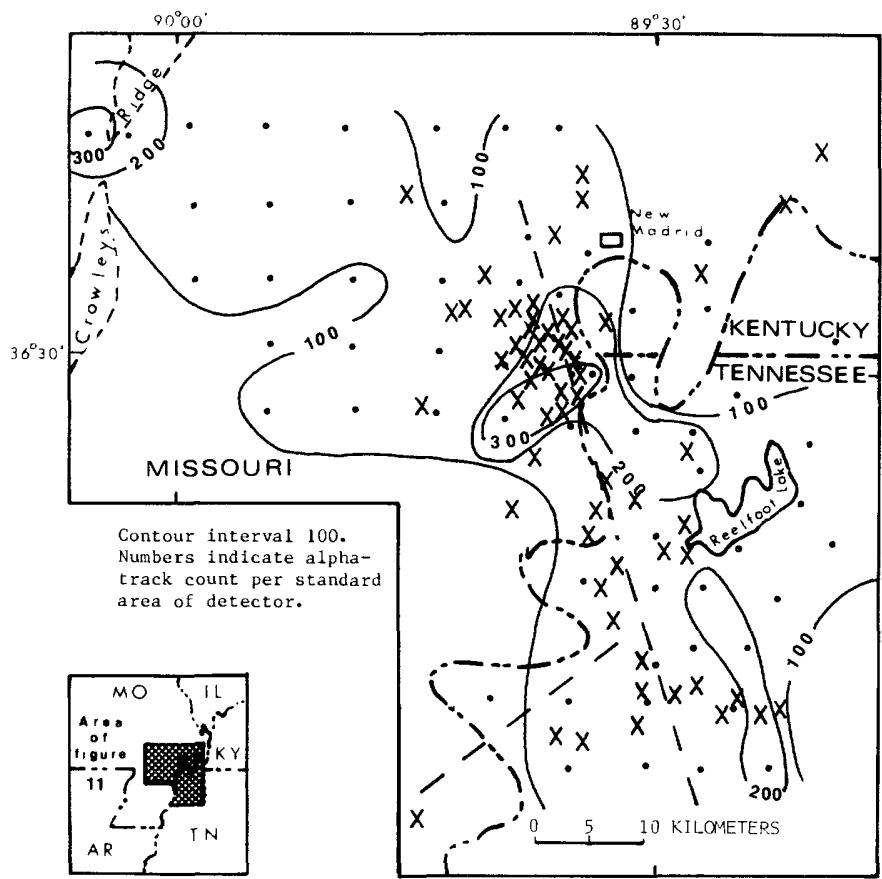

FIGURE 11. - Thirteen-month-average radon-emanation map of the New Madrid seismic zone. Radon monitoring stations (dots), axes of seismic trends (dashed lines), and epicenters (crosses) shown. Average alphatrack count/standard area of detector isolines shown; contour interval, 100.

tion and increased fluid migration, indirectly influencing the near- surface profile of radon concentration.

\section{CONCLUSIONS}

Analysis of the temporal variations in radon emanation in the New Madrid seismic zone suggests that radon activity in the soil gas is controlled by several physical mechanisms. The influences of barometric-pressure variations, water levels, and Earth tides were indicated, and a seasonal change in radon concentration was observed. However, the effects of these factors did not obscure an evident relationship between radon emanation and seismicity.

The fact that anomalous radon emanation was observed, which appeared to relate to ensuing seismicity of relatively low magnitudes (less than 3.0 in general), leads to the speculation that a proportionally larger increase in radon concentration might be expected to precede larger events. Continued monitoring of a few areas directly in the seismic zone could provide evidence to support this hypothesis (Steele, 1978).

Spatially, zones of anomalously high radon concentration coincide with the seismic zone and may result from a net upward shift of the near-surface profile of radon concentration, influenced by larger scale mechanisms originating at greater depths. Some of these larger scale mechanisms may be (1) enrichment in radon or their precursors in subsurface faults due to increased fluid circulation, (2) greater ease of emanation of gases along faults (this may be particularly significant where faults approach the surface in the study area), (3) outgassing of sediments in response to deformation by tectonic stresses, and (4) continuous generation of radiogenic fluids and gases derived from crustal remobilization due to mantle convection and associated rifting.

Zones of high radon concentration which appear to correspond to the locations of igneous intrusives may result from uranium enrichment in the faulted peripheral zones of the igneous bodies or increased emanation of gases along faults related to these intrusive bodies. Such mechanisms may affect the near-surface profile of radon concentration.

\section{REFERENGES CITED}

Buschbach, T. C., 1977, Geologic setting of the New Madrid area: American Geophysical Union Third Annual Midwest Meeting, Program and Abstracts, Purdue University, W. Lafayette, Indiana, abs. T12.

Clements, W. E., and Wilkening, M. H., 1974, Atmospheric pressure effects on radon-222 transport across the earth-air interface. Journal of Geophysical Research, v. 79, no. 33, p. 5025-5029.

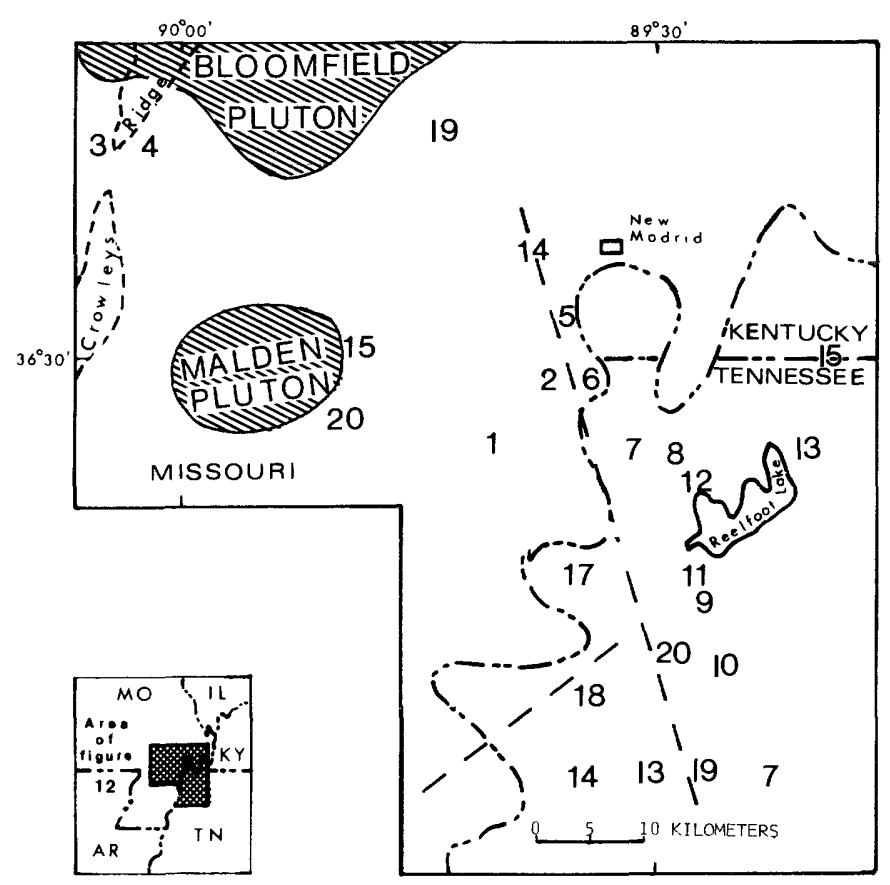

FIGURE 12. - Locations of 25 sites of greatest radon concentration. Axes of seismic trends (dashed lines) and igneous intrusives (triangles) shown. Numbers represent the descending order of the sites of greatest radon emanation based on the 13-month averages for all stations in the networks. Duplication of several of the nummbers resulted from identical 13-month-average values exhibited by some of the sites. 
Davis J. C., 1973, Statistics and data analysis in geology: New York, John Wiley and Sons, Inc.. 543 p.

Gableman, J. W., 1972, Radon emanometry of Starks Salt Dome, Calcasiey Parish, Louisiana: U.S. Atomic Energy Commission Report RME-414, $75 \mathrm{p}$.

Guedalia, D., Laurent, J. L., Fontan, J., Blanc, D., and Druilhet, A., 1970, A study of radon-220 emanation from soils: Journal of Geophysical Research, v. 75, no.2, p. 357-369.

Hildenbrand, T. G., Kane, M. F., and Stauder, William, 1977, Magnetic and gravity anomalies in the northern Mississippi Embayment and their spatial relation to seismicity: U.S. Geological Survey Miscellaneous Field Studies Map MF-914, scale 1:1,000,000.

Israel, H., and Bjornsson, S., 1967, Radon (Rn-222) and thoron (Rn-220) in soil air over faults: Zeitschrift fur Geophysik, v. 33, no. 1, p. 44-64.

King, C. Y., 1977, Temporal variations in radon emanation along active faults [abs.]: EOS (American geophysical Union Transactions), v. 58, no. 6, p. 434 .

1978, Radon emanation on the San Andreas fault: Earthquake Information Bulletin, v. 10, no. 4, p. 136-138.

Kumarapeli, P. S., and Saull, V. A., 1966, The St. Lawrence valley system, A North American equivalent of the East African rift valley system: Canadian Journal of Earth Science, v. 3, p. 639-658.

Robinson, E. A., and Treitel, S., 1967, Principles of digital Wiener filtering: Geophysical Prospecting, v. 15, no. 3, p. 311-353.

Russ, D. P., Stearns, R. G., and Herd, D. G., 1978, Map of exploratory trench across Reelfoot scarp, northwestern Tennessee: U.S. Geological Survey Miscellaneous Field Studies Map MF-985.

Stauder, William, Herrmann, R., Cheng, Sl, Nicholson, C., Singh, S., Woods, M., Chen, W., and Morrissey, S. T., 1977, Southeast Missouri Regional Seismic Network quarterly bulletin: St. Louis, Mo., Saint Louis University, Department of Earth and Atmospheric Sciences, no. $13,26 \mathrm{p}$.

Stauder, William, Herrmann, R., Nicholson, c., Cheng, S., and Morrissey, S. T., 1977, Southeast Missouri Regional Seismic Network quarterly bulletin: St. Louis, Mo., Saint Louis University, Department of Earth and Atmospheric Sciences, no. 12, $24 \mathrm{p}$.

Stauder, William, Herrmann, R., Nicholson, C., Singh, S., Woods, M. Haug, E., and Morrissey, S. T., 1978, Southeast Missouri Regional Seismic Network quarterly bulletin: St. Louis, Mo., Saint Louis University, Department of Earth and atmospheric Sciences, no. 14, 24 p.

Stauder, William, Herrmann, R., Nicholson, C., Singh, S., Woods, M., Haug, E., and Morrissey, S. T., 1978, Central Mississippi valley earthquake bulletin, quarterly report: St. Louis, Mo., Saint Louis University, Department of Earth and Atmospheric Sciences, no. 15, 28 p.

Steele, S. R., 1978, Spatial and temporal radon variation in the New Madrid seismic zone: Southern lllinois University M.S. thesis, 112 p.

Tanner, A. B., 1978, Kadon migration in the ground--A supplementary review: U.S. Geological Survey Open-File Report 78-1050, $61 \mathrm{p}$.

Vogler, G., 1960, Origins of emanometric anomalies; Zeitschrift fur Geophysik, v. 26, no. 2, p. 57-71. 